\title{
Atrakcyjność łódzkich centrów handlowych oraz zachowania nabywcze i przestrzenne ich klientów
}


$\frac{3}{40}$ 


\section{AGNIESZKA ROCHMIŃSKA}

\section{Atrakcyjność łódzkich centrów handlowych oraz zachowania nabywcze i przestrzenne ich klientów}


Agnieszka Rochmińska - Katedra Gospodarki Przestrzennej i Planowania Przestrzennego

Wydział Nauk Geograficznych, Uniwersytet Łódzki, 90-142 Łódź, ul. Kopcińskiego 31

RECENZENT

Franciszek Kłosowski

\author{
REDAKCJA TECHNICZNA I SKEAD KOMPUTEROWY \\ Andrzej Olejnik \\ OPRACOWANIE GRAFICZNE \\ Agnieszka Rochmińska, Karolina Dmochowska-Dudek
}

KOREKTOR

Bogusława Jędrasik

PROJEKT OKŁADKI

Karolina Dmochowska-Dudek

Wydrukowano z gotowych materiałów dostarczonych do Wydawnictwa UŁ

C Copyright by Uniwersytet Łódzki, Łódź 2013

Wydane przez Wydawnictwo Uniwersytetu Łódzkiego

Wydanie I. W.06212.13.0.H

ISBN (wersja drukowana) 978-83-7525-865-3

ISBN (ebook) 978-83-7969-327-6

Wydawnictwo Uniwersytetu Łódzkiego

90-131 Łódź, ul. Lindleya 8

www.wydawnictwo.uni.lodz.p1

e-mail: ksiegarnia@uni.lodz.pl

tel. (42) 66558 63, faks (42) 6655862 


\section{SPIS TREŚCI}

Wstęp......................................

Część I. Centra handlowe oraz zachowania nabywcze i przestrzenne w badaniach naukowych

1.1. Centra handlowe w badaniach naukowych ........... 13

1.2. Centra handlowe - problemy definicyjne i klasyfikacyjne... 25

1.3. Lokalizacje centrów handlowych i ich konsekwencje ...... 36

1.4. Atrakcyjność centrum handlowego jako produktu ........ 53

1.5. Konsument, nabywca, klient, użytkownik - trudności

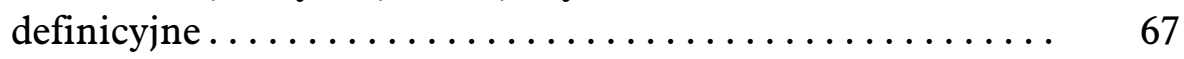

1.6. Badania nad zachowaniami nabywczymi i przestrzennymi... 72

Część II. Atrakcyjność łódzkich centrów handlowych $i$ ich otoczenia

2.1. Geneza i etapy rozwoju centrów handlowych .......... 95

2.2. Lokalizacja oraz dostępność przestrzenna centrów handlowych $w$ Łodzi ...................... 107

2.3. Oferta łódzkich centrów handlowych............. 121

2.3.1. Atrakcyjność oferty centrum handlowego - wymiar materialny i niematerialny................ 121

2.3.2. Struktura oferty handlowej............... 124

2.3.3. Pozostała działalność usługowa oraz kulturalno-

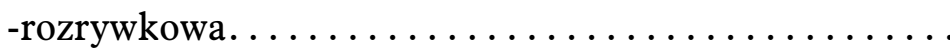


2.4. Zagospodarowanie otoczenia łódzkich centrów handlowych... 144

2.4.1. Podstawowy obszar handlowy .............. 144

2.4.2. Struktura funkcjonalno-przestrzenna.......... 150

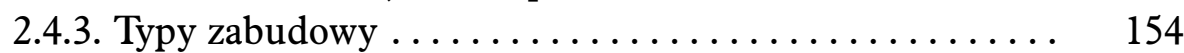

2.4.4. Potencjał ludnościowy $\ldots \ldots \ldots \ldots \ldots \ldots \ldots \ldots \ldots \ldots \ldots \ldots$

2.4.5. Oferta usługowa terenów przyległych.......... 175

2.5. Typy centrów handlowych oraz ich otoczenia ......... 188

Część III. Profile nabywcze oraz zachowania nabywcze i przestrzenne klientów łódzkich centrów handlowych

3.1. Technika badań ............................ 195

3.2. Łódzkie centra handlowe w oczach ich klientów ........ 200

3.2.1. Charakterystyka demograficzno-społeczna i ekonomiczna klientów ................. 200

3.2.2. Postrzeganie czynności zakupów w zależności od miejsca ich dokonywania ............... 203

3.2.3. Tygodniowy i dobowy cykl życia centrum

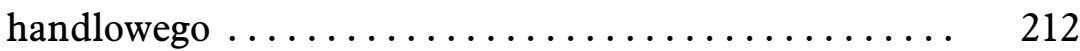

3.2.4. Korzystanie $z$ oferty centrów handlowych ........ 216

3.2.5. Postrzeganie łódzkich centrów handlowych i ich lokalizacji.

3.3. Profile klientów i ich zachowania nabywcze w zależności od typu centrum handlowego . . . . . . . . . . . . . 227

3.3.1. Profile klientów .................... 227

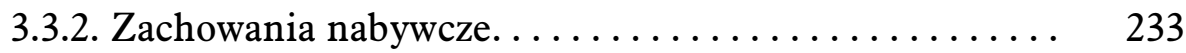

3.4. Zasięg oddziaływania centrów handlowych oraz zachowania przestrzenne ich klientów . ................. 250

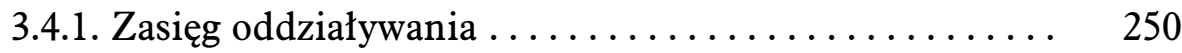

3.4.2. Zachowania przestrzenne klientów.......... 264

Zakończenie ................................ 279

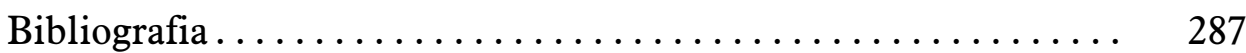

Alfabetyczny spis rysunków ................... 301

Alfabetyczny spis tabel $\ldots \ldots \ldots \ldots \ldots \ldots \ldots \ldots \ldots \ldots \ldots$ 


\section{WSTĘP}

Struktura polskiego handlu podlegała dynamicznym przemianom od końca lat 80 . XX wieku, kiedy to handel był jeszcze dziedziną silnie znacjonalizowaną. Początkowo zmiany te dotyczyły głównie własności (prywatyzacja) oraz dynamicznego rozwoju liczbowego. Od początku lat 90 . XX wieku na polski rynek zaczęły wkraczać zagraniczne sieci handlowe sklepów wielkopowierzchniowych, w tym obiektów handlowych $\mathrm{z}$ artykułami codziennego zakupu (FMCG): supermarketów (na przykład Billa, Champion, Rema 1000), dyskontów (między innymi Plus, Biedronka), oraz hipermarketów (choćby Geant, Tesco, Carrefour, E. Leclerc), a także hipermarketów specjalistycznych z artykułami nieżywnościowymi (IKEA, Praktiker, Nomi, Obi).

W związku z powyższymi procesami w strukturze polskich miast od lat 90. XX wieku zaczęły pojawiać się nowe obiekty oraz kompleksy handlowe związane głównie z napływem obcego kapitału. Zmiany w zagospodarowaniu spowodowały utworzenie w przestrzeni miast trwałych elementów strukturalnych, które odcisnęły piętno na współczesnym ich wizerunku. Kompleksy te wpływały, i nadal wpływają, na wartość niektórych terenów miejskich, doprowadzając do wykreowania nowych biegunów handlowo-usługowych, czy wręcz handlowo-usługowo-rozrywkowych. Nowo powstałe centra handlowe często wpływają też na zmianę roli historycznego centrum miasta, oraz przyczyniają się do rewitalizacji terenów, w tym głównie poprzemysłowych. Te nowe przestrzenie handlowe zmieniły również kierunki przepływu potoków „ludzkich”, wręcz można powiedzieć, że determinują obecnie zachowania nabywcze i przestrzenne osób będących klientami tych kompleksów.

W literaturze nowoczesne kompleksy handlowe ze względu na ofertę określa się mianem: centra handlowe, handlowo-usługowe, handlowo- 
-usługowo-rozrywkowe. Należy pamiętać, że handel należy do sektora usługowego, a zestawienie w nazwie „handlowo-usługowe” może sugerować, że handel stanowi osobną kategorię niż usługi. $Z$ drugiej strony ofertę centrów handlowych stanowią przede wszystkim usługi handlowe i przy określeniu „handlowo-usługowe” ich ofertowa specyfika jest lepiej eksponowana. Pozostałe usługi pod względem liczby placówek występują $\mathrm{w}$ mniejszym stopniu, dlatego $\mathrm{w}$ takim rozumieniu uprawnione wydaje się nazywanie ich centrami "handlowo-usługowymi”. W przypadku gdy oferta jest wzbogacona o elementy rozrywki i kultury można mówić o centrach handlowo-rozrywkowych, czy handlowo-usługowo-rozrywkowych.

Procesy, którym podlegały i podlegają miasta polskie, mają też swoje odzwierciedlenie $\mathrm{w}$ zachodzących zmianach $\mathrm{w}$ Łodzi. Kreowanie nowych „łódzkich” przestrzeni handlowych zaczęło następować już na początku lat 90. XX wieku, jednak dopiero na przełomie XX i XXI wieku duża dynamika zmian wpłynęła znacząco na tkankę miejską. W ostatnich latach największe przekształcenia są rezultatem realizacji wielu inwestycji, w tym inwestycji w nowoczesne centra handlowe (Tesco W., C.H. Guliwer i tym podobne), oraz handlowo-usługowe, na przykład C.H. Tulipan, Pasaż Łódzki, a także handlowo-usługowo-rozrywkowe (Manufaktura, Port Łódź, Galeria Łódzka). Przemiany jakie dokonują się w Łodzi pod tym względem mają również miejsce $w$ innych dużych miastach Polski, dlatego Łódź, jako trzecie co do liczebności miasto, jest dobrym przykładem do ukazania trendów w rozwoju tych nowoczesnych biegunów handlowo-usługowych.

Zmiany, jakie miały miejsce $\mathrm{w}$ rozwoju handlu szczególnie w okresie ostatnich lat doprowadziły do wykształcenia nowych dominant usługowo-handlowych w przestrzeni miasta. Dzięki tego typu inwestycjom niektóre zdegradowane tereny poprzemysłowe otrzymały nową jakość; przykładem wykorzystania inwestycji handlowych do rewitalizacji miasta jest Manufaktura w Łodzi. Realizacja tego projektu przyczyniła się do odnowy zabytkowego i zdewastowanego kompleksu fabrycznego oraz stworzenia z niego wizytówki miasta. Przy realizacji wielu obiektów handlowych zostały wykonane również różne inwestycje miejskie, na przykład wyremontowano drogi i chodniki, wytyczono ścieżki rowerowe, zainstalowano nowe oświetlenie, przeprowadzono reorganizację ruchu drogowego, powstały parkingi, które służą nie tylko klientom centrów handlowych.

Przekształcenia struktury przestrzennej miasta pod wpływem handlu wielkopowierzchniowego nie zostały jeszcze w Łodzi zakończone, o czym 
świadczą dalsze plany inwestycyjne. Łódź już zmieniła w znaczący sposób swój wizerunek pod wpływem rozwoju handlu szczególnie tego wielkopowierzchniowego i nadal będzie go zmieniać w wyniku postępujących prac realizacyjnych. Zaistniałe zmiany w zagospodarowaniu wielu części miasta, oddziałują na zachowania nabywcze i przestrzenne ich klientów, co wpłynęło na podjęcie badań nad tymi nowoczesnymi usługowo-handlowymi biegunami w przestrzeni miejskiej.

Głównymi podmiotami badań są łódzkie centra handlowe wraz z otoczeniem oraz ich indywidualni klienci (nabywcy). Za centrum handlowe (C.H.) uznano „nieruchomość handlową, która została zaplanowana, zbudowana oraz jest zarządzana jako jeden podmiot handlowy, składający się ze wspólnych części, o minimalnej powierzchni najmu brutto (GLA) 5 tys.

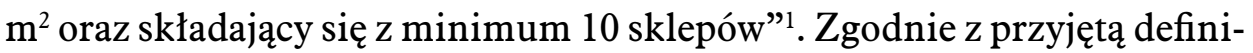
cją wyodrębniono w Łodzi dwanaście centrów handlowych: Manufaktura, Galeria Łódzka, Port Łódź, Pasaż Łódzki, C.H. Tulipan, C.H. Guliwer, C.H. M1, Carrefour Sz. (ul. Szparagowa), Carrefour P. (ul. Przybyszewskiego), Tesco W. (ul. Widzewska), Tesco P. (ul. Pojezierska) i E. Leclerc.

Przedmiotem badań jest atrakcyjność łódzkich centrów handlowych, rozpatrywana w wymiarze materialnym i niematerialnym oraz uwarunkowania zachowań nabywczych, rozumianych głównie jako zakup (korzystanie) $\mathrm{z}$ dóbr materialnych i usług oferowanych w poszczególnych centrach handlowych, oraz determinanty zachowań przestrzennych indywidualnych klientów łódzkich centrów handlowych. Problematyka badawcza tej pracy, uwzględniając uwarunkowania nabywcze i przestrzenne zachowań klientów łódzkich centrów handlowych, wchodzi w zakres nurtu badań geografii behawioralnej.

Teren badań obejmuje centra handlowe zlokalizowane w Łodzi oraz ich najbliższe otoczenie. W przypadku badań klientów zakres przestrzenny był poszerzony o tereny, z których te osoby pochodziły. Rozwój handlu w Łodzi przedstawiono w zarysie od zakończenia drugiej wojny światowej, natomiast centra handlowe od momentu ich powstania (pierwszy w 1997 roku). Zasadnicze badania inwentaryzacyjne i ankietowe przeprowadzono w 2011 roku.

Założono, że zachowania nabywcze i przestrzenne indywidualnych klientów łódzkich centrów handlowych są zdeterminowane różnymi

${ }^{1}$ Polska Rada Centrów Handlowych (PRCH), http://prch.org.pl/PL/BazaWiedzy/Definicje/ Default.aspx. 
czynnikami, między innymi zależą od typu ofertowego lub typu lokalizacyjnego centrum handlowego, dlatego postawiono następującą hipotezę badawczą:

Zachowania nabywcze indywidualnych klientów centrów handlowych zależa w gtównej mierze od oferty tychże kompleksów, zdeterminowanej ich wielkościa, natomiast zachowania przestrzenne uwarunkowane sq potożeniem centrów handlowych względem centrum miasta, sieci komunikacyjnej i terenów mieszkaniowych.

Głównym celem pracy była ocena atrakcyjności ofertowej centrów handlowych oraz identyfikacja uwarunkowań zachowań nabywczych i przestrzennych indywidualnych klientów oraz stworzenie profilów nabywczych klientów w zależności od typu kompleksu handlowego. W związku $\mathrm{z}$ tak sformułowaną hipotezą i celem głównym pojawiło się wiele problemów badawczych do rozwiązania oraz celów szczegółowych do zrealizowania (rys. 1):

- przedstawienie geograficznego dorobku naukowego z zakresu badań nad centrami handlowymi,

- doprecyzowanie zagadnień terminologicznych (między innymi centrum/ośrodek handlowy i jego atrakcyjność, konsument, klient, nabywca, użytkownik, zachowania nabywcze i przestrzenne),

- identyfikacja czynników lokalizacji łódzkich centrów handlowych,

- wydzielenie etapów rozwoju łódzkich centrów handlowych,

- ocena atrakcyjności ofertowej łódzkich centrów handlowych (obiektywna i subiektywna),

- dokonanie typologii ofertowej łódzkich centrów handlowych i identyfikacja zachowań nabywczych w zależności od ich typu,

- wyodrębnienie typów lokalizacyjnych łódzkich centrów handlowych i identyfikacja zachowań przestrzennych ich klientów,

- przedstawienie struktury użytkowania, zabudowy oraz potencjału ludnościowego otoczenia centrów handlowych oraz dokonanie wyodrębnienia ich typów,

- identyfikacja struktury placówek usługowych w bezpośrednim sąsiedztwie centrów handlowych,

- wyodrębnienie typów pulsujących biegunów nowoczesnej powierzchni handlowo-usługowej,

- wyznaczenie nowych kierunków badań nad centrami handlowymi i ich otoczeniem. 


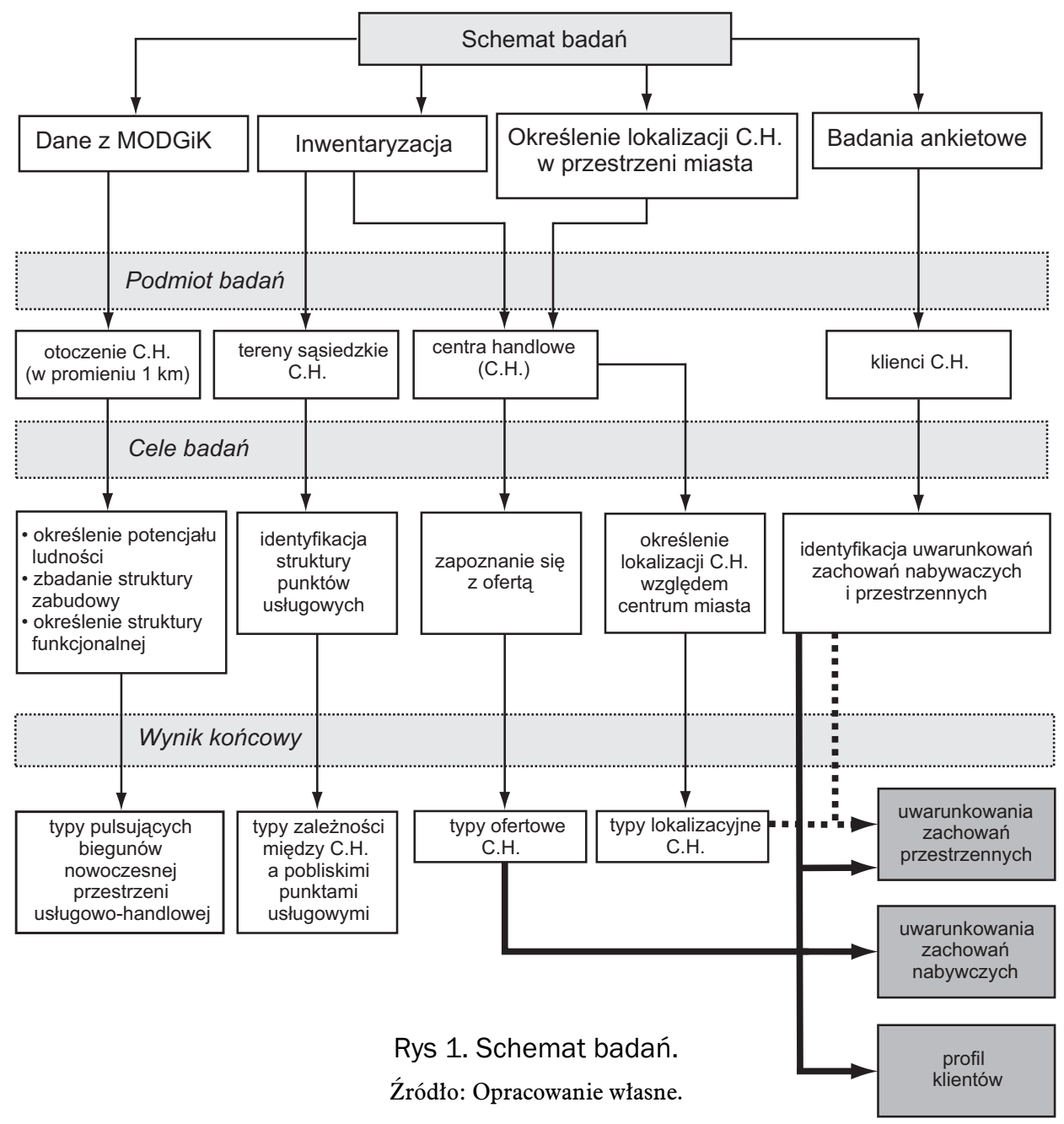

Opracowanie oparto głównie na literaturze geograficznej i ekonomicznej, stąd wiele terminów w pracy jest zaczerpnięte $\mathrm{z}$ zakresu nauk ekonomicznych, które adaptowano na potrzeby własnych badań. Należy też zaznaczyć, że większość typów placówek handlowych „została stworzona na rynku amerykańskim i wobec ich transferu - nazwy angielskie zostały wprowadzone do języka polskiego lub spolszczone (jak na przykład supermarket, sklep dyskontowy) lub występują w orginalej formie, jak na przykład factory outlet (Borusiak 2011, s. 179). W niektórych pracach pojawiają się tylko terminy anglojęzyczne bez tłumaczenia polskiego, w innych ich wersje spolszczone. Dodatkowym problemem było przedstawienie precyzyjnego określenia niektórych pojęć ze względu na ich różną interpretację i rozumienie. 
W niniejszej pracy zostały wykorzystane zebrane materiały inwentaryzacyjne $^{2}$ (inwentaryzacja dotyczyła głównie oferty handlowej i usługowej poszczególnych kompleksów handlowych i ich otoczenia), które posłużyły do wyodrębnienia różnych typów ofertowych centrów handlowych oraz do obiektywnej oceny ich atrakcyjności. W celu dokonania klasyfikacji badanych centrów handlowych pod względem ofertowym jak również wydzielenia typów pulsujących biegunów nowoczesnej powierzchni handlowo-usługowej zastosowano analizę skupień metodą k-średnich, wykorzystując program IBM SPSS ver. 20. Łódzkie centra handlowe oceniono również pod względem ich obiektywnej i subiektywnej atrakcyjności ofertowej. Dane wzięte do oceny poddano standaryzacji „Z”, następnie wartości zsumowano otrzymując wskaźniki syntetyczne, które poddano ocenie na podstawie wskaźnika jednorodności (rzetelności) skali $\alpha$-Cronbacha.

Wyznaczając strefy dostępności czasowej pieszej i komunikacyjnej wykorzystano narzędzia ArcGIS z grupy analiz Network Analysis. Do przeprowadzenia analizy struktury użytkowania terenu oraz określenia potencjału ludnościowego w tak zwanych podstawowych obszarach handlowych wyznaczono arbitralnie strefy jednokilometrowe od każdego centrum handlowego (10 min dojścia pieszego). Granice stref oparto o zewnętrzną granicę działek ewidencyjnych, których centroidy znalazły się w zasięgu $1 \mathrm{~km}$ od centrum handlowego. W wyniku przyjętej procedury wyznaczono dwanaście stref wokół wszystkich badanych centrów handlowych, jednak niektóre obszary handlowe nachodzą na siebie, dlatego nie dokonano bilansu użytkowania terenu, które nie było konieczne z punktu widzenia zakresu prowadzonych badań. Strefy wokół centrów handlowych pogrupowano ze względu na strukturę użytkowania terenu oraz ze względu na dominujący typ zabudowy. Najbliższe otoczenie (sąsiednie działki) są wykorzystywane również do prowadzenia działalności usługowej w związku z czym zidentyfikowano strukturę sąsiednich placówek usługowych i wydzielono typy zależności lokalizacyjnych między centrum handlowym a pobliskimi punktami usługowymi.

Dla wszystkich badanych centrów handlowych za pomocą narzędzi analiz przestrzennych GIS w aplikacji ArcMap wyznaczono również strefy zasięgu w Łodzi (dla 50\%, 70\% i 90\% klientów). Do tego celu zastosowano narzędzie selekcji obiektów na podstawie relacji przestrzennych, następnie

${ }^{2}$ Metody badań omówione są szczegółowo w częściach pracy w których są wykorzystane. 
wykreślając ekwidystanty o znalezionych promieniach. W wyznaczonych tak strefach nie dokonano porównania struktur ludności ze strukturami klientów (respondentów), ponieważ osoby, które wzięły udział w badaniu nie są grupą reprezentacyjną, szczególnie pod kątem przestrzennym, wyznaczone strefy nie mają charakteru modelu a są jedynie przykładem ukazującym pewną tendencję. Zidentyfikowane odległości (granice stref) uwarunkowane są specyficznymi dla każdego centrum handlowego warunkami przestrzennymi oraz jego otoczeniem (różne nasycenie obszarami mieszkaniowymi). Analiza struktur respondentów wokół konkretnych centrów handlowych w poszczególnych strefach nie ma większego sensu również ze względu na niewielką liczebność ankietowanych klientów w przypadku niektórych badanych kompleksów, na przykład dwadzieścia trzy osoby w strefie E. Leclerc. Określając profile nabywców (klientów) oraz uwarunkowań ich zachowań przestrzennych wykorzystano kwestionariusze badań ankietowych, które przeprowadzono w 2011 roku (2420 z czego 2335 z klientami badanych centrów handlowych).

Praca posiada charakter teoretyczno-empiryczny, w której można wyróżnić trzy części. W pierwszej części w oparciu o naukową literaturę polską i zagraniczną przedstawiono badania nad centrami handlowymi oraz nad zachowaniami nabywczymi i przestrzennymi. Ten fragment pracy poświęcono również wyjaśnieniu podstawowych terminów, np. centrum handlowe i jego atrakcyjność, konsument, nabywca, klient, użytkownik oraz zaprezentowano czynniki lokalizacji ogólnej i szczegółowej. W drugiej części zaprezentowano etapy rozwoju łódzkich centrów handlowych, ich czynniki lokalizacji, dostępność przestrzenną oraz ofertę. Ponadto w tym rozdziale przedstawiono strukturę użytkowania terenów, typy zabudowy, potencjał ludnościowy otoczenia centrów handlowych oraz zagospodarowanie pod względem usługowym terenów przyległych. Na podstawie danych inwentaryzacyjnych dokonano wyróżnienia typów ofertowych centrów handlowych, przedstawiono obiektywną ocenę ich atrakcyjności oraz typy pulsujących biegunów nowoczesnej przestrzeni handlowo-usługowej. Część trzecia w dużej mierze została oparta na badaniach ankietowych, dzięki którym opracowano profile nabywcze klientów poszczególnych typów centrów handlowych oraz zidentyfikowano czynniki warunkujące ich zachowania nabywcze i przestrzenne. 



\section{CZĘŚĆ I}

\section{CENTRA HANDLOWE ORAZ ZACHOWANIA NABYWCZE I PRZESTRZENNE W BADANIACH NAUKOWYCH}

\subsection{Centra handlowe w badaniach naukowych}

W polskich geograficznych badaniach naukowych tematyka rozwoju nowoczesnych przestrzeni handlowych (supermarketów, hipermarketów, sklepów dyskontowych, centrów handlowych i tym podobnych) pojawiła się dopiero w drugiej połowie lat 90 . XX wieku, kiedy to na polskim rynku zaczęły intensywnie się rozwijać te placówki będące elementem zagranicznych sieci handlowych. Nadal jednak wśród polskich geografów niewiele osób podejmuje ten problem badawczy w swoich rozważaniach naukowych. Często są to pojedyncze prace niestanowiące głównego nurtu zainteresowań badawczych poszczególnych naukowców (poboczne kierunki badań).

Podstawowe zainteresowania geografów w tym zakresie koncentrują się głównie na przedstawianiu etapów rozwoju tych nowych typów (formatów ${ }^{3}$ ) handlu detalicznego i ukazaniu rozmieszczenia placówek handlowych w strukturze danego miasta, na przykład Lublina (Kociuba 2006), Wrocławia (Namyślak 2006), Łodzi (Rochmińska 2005, 2010), Krakowa (Więcław 2000, 2003), aglomeracji katowickiej (Kłosowski 2002), Warszawy (Fuhrmann 2009, Dudek-Mańkowska, Fuhrmann 2009). Prace tego

\footnotetext{
${ }^{3}$ Pojęcie format oznacza określony sposób prowadzenia sprzedaży detalicznej w postaci stacjonarnej i niestacjonarnej (termin został zaczerpnięty z literatury anglosaskiej). Węższym pojęciem jest format sklepu, który definiuje i jednocześnie jest definiowany poprzez asortyment, wielkość powierzchni sprzedażowej, metodę obsługi, lokalizację, poziom cen, zakres świadczonych usług handlowych. W literaturze jest traktowany synonimicznie z pojęciem typ, rodzaj sklepu (Borusiak 2008, s. 171).
} 
typu mają głównie charakter „rejestrujący”, jak zauważają S. Ciok i D. Ilnicki $(2011)^{4}$. Rozwój handlu wielkopowierzchniowego w Poznaniu (między innymi Kaczmarek 2010, 2011) oraz Wrocławia (Ciok, Ilnicki 2011) został zaprezentowany na tle przemian $\mathrm{w}$ całym handlu detalicznym w tych miastach. Obok prac koncentrujących się na przestrzeni miejskiej podjęto również wśród geografów badania nad wkraczaniem handlowych sieci zagranicznych do poszczególnych regionów (Polska Wschodnia Gwosdz, Sobala-Gwosdz 2008; Sobala-Gwosdz, Gwosdz 2011; województwo dolnośląskie - Brezdeń, Spallek 2010) i całego kraju (na przykład Taylor 2000, Wilk 2005; Kaczmarek 2010) (tab. 1).

Wśród problemów badawczych rozwiązywanych na niwie nauk geograficznych dotyczących handlowych obiektów wielkopowierzchniowych (WOH), w tym głównie centrów handlowych, oprócz identyfikowania etapów wkraczania sieci handlowych do różnych miejsc w Polsce oraz czynników ich lokalizacji (ogólnych i szczegółowych) istotne i ciekawe wydają się szczególnie te wyznaczające nowe kierunki badań:

- miejsca miast w sieciach handlowych - zastosowanie koncepcji sieci do badania usług (Wilk 2005),

- centrów handlowych jako miejsc spędzania czasu wolnego (Wilk 2003; Rochmińska 2011) i jako nowych atrakcji turystycznych (Wilk 2003, Dudek-Mańkowska, Fuhrmann 2009; Fuhrmann 2009; Bosiacki, Rydlewski 2009, Majchrzak 2007),

- centrów handlowych jako „Zawłaszczonych” przestrzeni publicznych (Janiszewska, Klima, Rochmińska, 2011),

- mechanizmów oddziaływania pozytywnego i negatywnego sklepów wielkopowierzchniowych na ich otoczenie (Gwosdz, Sobala-Gwosdz 2008; Sobala-Gwosdz, Gwosdz 2011),

- wpływu sklepów wielkopowierzchniowych na strukturę placówek handlowych (na przykład Kaczmarek 2010, 2011; Ciok, Ilnicki 2011) (tab. 1). Należy podejść do badań geograficznych nad centrami handlowymi z jednej strony krytycznie, z drugiej zaś optymistycznie. Problem cen-

${ }^{4} \mathrm{~W}$ pracy S. Cioka, D. Ilnickiego, 2011, Handel detaliczny w przestrzeni dużego miasta na przyktadzie Wroctawia, Koncepcje i Problemy Badawcze Geografii, Wyższa Szkoła Gospodarki, Bydgoszcz, znajduje się dość dokładne przedstawienie geograficznych badań nad rozwojem handlu w Polsce. Natomiast w artykule J. Dzieciuchowicza, 2012, Nowa geografia handlu, „Acta Universitatis Lodziensis. Folia Oeconomica” nr 12, UŁ, Łódź, można zapoznać się z nurtami badawczymi w geografii handlu na świecie i w Polsce. 
Tabela 1

Badania geograficzne centrów handlowych według ośrodków i zagadnień badawczych

\begin{tabular}{|c|c|c|}
\hline Ośrodek & Nazwisko, data publikacji & $\begin{array}{c}\text { Główne zainteresowania badawcze } \\
\text { z zakresu handlu wielkopowierzchniowego }\end{array}$ \\
\hline \multirow[t]{3}{*}{ Warszawa } & Wilk $(2003,2004,2005)$ & $\begin{array}{l}\text { - } \text { C.H. - jako miejsce rozrywki i spędzania czasu } \\
\text { wolnego, } \\
\text { - } \text { C.H. - jako nowy produkt turystyczny, } \\
\text { - } \text { rozwój układów sieciowych w polskim handlu } \\
\text { detalicznym }\end{array}$ \\
\hline & $\begin{array}{l}\text { Dudek-Mańkowska }(2006,2010) \\
\text { Dudek-Mańkowska, } \\
\text { Fuhrmann, (2009) } \\
\text { Fuhrmann, Dudek- } \\
\text {-Mańkowska (2010) } \\
\text { Fuhrmann (2006a, b, 2007, 2009) }\end{array}$ & $\begin{array}{l}\text { - } \text { rozwój, lokalizacja i funkcje C.H. w Warszawie, } \\
\text { - C.H. - jako nowe produkty turystyczne i miejsca } \\
\text { spedzania czasu wolnego, } \\
\text { - wpływ C.H. na jakość życia }\end{array}$ \\
\hline & Taylor (2000) & $\begin{array}{l}\text { - zmiany w handlu detalicznym Polski, } \\
\text { - procesy koncentracji w handlu }\end{array}$ \\
\hline \multirow[t]{2}{*}{ Poznań } & Kaczmarek $(2010,2011)$ & $\begin{array}{l}\text { - usieciowienie handlu w skali międzynarodowej, } \\
\text { - rozwój i struktura przestrzenna handlu w Polsce, } \\
\text { - handel wielkopowierzchniowy na tle rozwoju } \\
\text { handlu detalicznego w Poznaniu (struktura } \\
\text { przestrzenno-funkcjonalna handlu w Poznaniu) }\end{array}$ \\
\hline & $\begin{array}{l}\text { Bednarek, Kaczmarek, } \\
\text { Kaczmarek (2004)Kaczmarek, } \\
\text { Kaczmarek (2006) } \\
\text { Kaczmarek, Szafrański (2008) }\end{array}$ & $\begin{array}{l}\text { - rozwój i struktura przestrzenna handlu detalicznego } \\
\text { w Poznaniu (stara i nowa przestrzeń handlowa) }\end{array}$ \\
\hline \multirow[t]{3}{*}{ Kraków } & $\begin{array}{l}\text { Więcław }(2000,2003) \\
\text { Więcław-Michniewska (2006) }\end{array}$ & $\begin{array}{l}\text { - rozwój i czynniki lokalizacji C.H. w Krakowie, } \\
\text { - } \text { wpływ C.H. na funkcjonowanie drobnego handlu, } \\
\text { - wpływ lokalizacji handlowego obiektu } \\
\text { wielkopowierzchniowego na realizację wybranych } \\
\text { zadań samorządu terytorialnego }\end{array}$ \\
\hline & $\begin{array}{l}\text { Gwosdz, Sobala-Gwosdz (2008) } \\
\text { Sobala-Gwosdz, Gwosdz (2011) }\end{array}$ & $\begin{array}{l}\text { - } \text { rozwój sieci hipermarketów w Polsce, prawidłowości } \\
\text { lokalizacji ogólnej, } \\
\text { - Polska Wschodnia w strategiach lokalizacji sieci } \\
\text { hipermarketów, } \\
\text { - wpływ rozwoju sieci handlowych na gospodarkę } \\
\text { lokalną i regionalną }\end{array}$ \\
\hline & Winiarczyk-Raźniak (2007) & $\begin{array}{l}\text { - badanie oferty krakowskich C.H. oraz struktury klientów } \\
\text { i ich celów wizyt }\end{array}$ \\
\hline
\end{tabular}


Tabela 1 (ciąg dalszy)

\begin{tabular}{|c|c|c|}
\hline Ośrodek & Nazwisko, data publikacji & $\begin{array}{c}\text { Główne zainteresowania badawcze } \\
\text { z zakresu handlu wielkopowierzchniowego }\end{array}$ \\
\hline \multirow[t]{3}{*}{ Wrocław } & Namyślak (2006) & $\begin{array}{l}\text { - rozmieszczenie obiektów we Wrocławiu, } \\
\text { - zmiany funkcjonalne terenów lokalizacji C.H. }\end{array}$ \\
\hline & Brezdeń, Spallek (2010) & $\begin{array}{l}\text { - uwarunkowania przestrzennego zróżnicowania } \\
\text { wielkopowierzchniowych sieci handlowych } \\
\text { w województwie dolnośląskim }\end{array}$ \\
\hline & Ciok, IInicki (2011) & $\begin{array}{l}\text { - zróżnicowanie przestrzenne placówek handlu } \\
\text { detalicznego we Wrocławiu }\end{array}$ \\
\hline \multirow[t]{4}{*}{ Łódźa $^{a}$} & $\begin{array}{l}\text { Rochmińska (2005, 2008, 2010) } \\
\text { Bratkowski, Klima, Rochmińska } \\
\text { (2005) } \\
\text { Janiszewska, Klima, Rochmińska } \\
\text { (2011) } \\
\text { Chrzanowska, Rochmińska (2012) }\end{array}$ & $\begin{array}{l}\text { - rozwój sklepów wielkopowierzchniowych w Łodzi i ich } \\
\text { oferta, } \\
\text { - } \text { C.H. jako miejsca spędzania czasu wolnego, } \\
\text { - } \text { C.H. - zawłaszczona przestrzeń publiczna, } \\
\text { - rozwój usług gastronomicznych w C.H. }\end{array}$ \\
\hline & Dzieciuchowicz (2012) & $\begin{array}{l}\text { - } \text { przedstawienie indywidualności, historii, kierunków } \\
\text { rozwoju, czynników lokalizacji, oferty, zasięgu } \\
\text { oddziaływania i tym podobnych centrów handlowych } \\
\text { Manufaktury w Łodzi i Ptaka w Rzgowie }\end{array}$ \\
\hline & Wójcik (2009) & $\begin{array}{l}\text { - znaczenie kompleksu Manufaktura w przestrzeni } \\
\text { społecznej Łodzi }\end{array}$ \\
\hline & Bińczyk (2006) & $\begin{array}{l}\text { - zmiany morfologiczno-funkcjonalne } \\
\text { na terenie kompleksu Manufaktura }\end{array}$ \\
\hline Lublin & Kociuba (2006) & $\begin{array}{l}\text { - rozmieszczenie nowych przestrzeni handlowych } \\
\text { w Lublinie }\end{array}$ \\
\hline Sosnowiec & Kłosowski (2002) & $\begin{array}{l}\text { - hipermarkety w przestrzeni handlowej miast } \\
\text { aglomeracji katowickiej, } \\
\text { - rozmieszczenie hipermarketów, zachowania ich klientów, } \\
\text { wpływ hipermarketów na pozostałe placówki handlowe }\end{array}$ \\
\hline
\end{tabular}

${ }^{a}$ W łódzkim ośrodku już wcześniej prowadzono badania nad handlem, głównie w aspekcie zasięgu oddziaływania miast, np. E. Dziegieć (1967, 1984), S. Pączka, F. Zając (1970), A. Suliborski, E. Dziegieć (1982). W latach 90 . XX wieku zajęto się przemianami transformacyjnymi w usługach w tym w handlu: A. Werwicki (1994, 1995), K. Rembowska (2000), handlem targowiskowym: A. Werwicki (2000, 2001), J. Jakóbczyk-Gryszkiewicz (2008) oraz hurtowym: A. Janiszewska, A. Rochmińska (2009).

Źródło: Opracowanie własne.

trów handlowych został zauważony, co owocuje podjęciem przez niektóre osoby tego zagadnienia w swoich rozważaniach, ale większość tych zainteresowań koncentruje się niestety tylko nad rejestrowaniem dynamicznych zmian lub na faktograficznym ukazaniu rozmieszczenia 
centrów handlowych bez dogłębnych poszukiwań czynników determinujących. Natomiast pojawianie się prac wskazujących na nowe role centrów handlowych (na przykład jako nowych atrakcji turystycznych, miejsc spędzania czasu wolnego), dyskusja nad jej „publicznym” charakterem, badanie ogólnych determinant rozmieszczenia, czynników lokalizacji stwarza nadzieję, że geografowie w przyszłości zajmą się bliżej tymi nowoczesnymi przestrzeniami handlowo-usługowymi, które przekształcają wizerunek nie tylko miast, ale zmieniają, tworzą nowe kierunki przemieszczeń potoków ludzkich.

Jednym z ciekawszych kierunków badań jest ten nad usieciowieniem miast polskich. W. Wilk (2005, s. 151) proponując zastosowanie koncepcji sieci do badań usług, przedstawił rozwój sieci handlowych w Polsce, uznając miasta jako węzły tych sieci. Jak pokazują jego wyniki badań, „handel wielkopowierzchniowy koncentruje się w miastach największych, chociaż tego rodzaju sieci rozszerzane są o coraz to nowe węzły w miastach niższych poziomów hierarchii systemu osadniczego (...). W wyniku dalszego nasilenia się integracji w polskim handlu detalicznym wzrośnie zapewne liczba miast (węzłów) w istniejących już sieciach handlowych”.

Nowi inwestorzy, jak i ci, którzy chcą rozszerzyć swoją działalność, toczą przysłowiową „bitwę o przestrzeń”. W strategiach lokalizacyjnych dużych sieci handlowych uwidacznia się prawidłowość, że im wyższa skala działalności handlowej, tym większego znaczenia nabierają nie pojedyncze czynniki, ale ich zespoły, działające zarówno w skali ogólnokrajowej, jak i lokalnej (Kaczmarek 2011, s. 76). Strategie lokalizacyjne firm wchodzących na rynek polski zależały między innymi od kryterium czasu rozpoczęcia działalności i ekspansji, można więc wyróżnić trzy grupy operatorów: pionierzy, główna fala, późni przybysze (Gwosdz, Sobala-Gwosdz 2008, s. 527). W badaniach rozwoju hipermarketów i ich prawidłowości w rozmieszczeniu przestrzennym na terenie Polski Wschodniej, nawiązując do relacji rdzeń-peryferie, okazało się że występują tak zwane „cienie usługowe”, czyli obszary nieatrakcyjne inwestycyjnie (Sobala-Gwosdz, Gwosdz, 2011). Rozważając rozmieszczenie nowoczesnych przestrzeni handlowych w skali regionu, warto zwrócić uwagę na zidentyfikowane uwarunkowania $\mathrm{w}$ województwie dolnośląskim, którymi są: gęstość zaludnienia, koncentracja ludności (aglomeracje, miasta), poziom rozwoju społeczno-gospodarczego i bliskość granicy polsko-niemieckiej (Brezdeń, Spallek 2010, s. 306). 
Ważna z punktu widzenia geografa jest identyfikacja szczegółowych czynników lokalizacji centrów handlowych, przede wszystkim w dużym i średniej wielkości mieście (tam głównie są lokalizowane) oraz hipermarketów i supermarketów, które są budowane również w mniejszych ośrodkach miejskich. Jak pokazują badania prowadzone w różnych miastach polskich (na przykład Kociuba 2006; Więcław 2000; Namyślak 2006, Rochmińska 2005, Kaczmarek 2011), kompleksy nowoczesnej przestrzeni handlowej lokalizowane były głównie na terenach magazynowo-składowych i poprzemysłowych (miedzy innymi tanie koszty zakupu gruntu pod nowe inwestycje, wyzbywanie się niepotrzebnych terenów przez nierentowne zakłady produkcyjne ${ }^{5}$ ). Istotnym czynnikiem lokalizacyjnym były i są również dostępność komunikacyjna, często przy trasach wylotowych z miasta (pozyskiwanie klientów spoza miasta) oraz bezpośrednie sąsiedztwo $z$ chłonnym rynkiem zbytu - w pobliżu dużych osiedli mieszkaniowych czy centrum miasta (gęsto zaludnione śródmieścia). Teoretyczne zagadnienia $\mathrm{z}$ zakresu lokalizacji centrów handlowych przedstawiali między innymi: W. Budner (2011), J. Mikołajczyk (2008b), M. Sullivan, D. Adcock (2003), M. Twardzik (2007), G. Chmielak (1999), P. Łukasik (2010) i A. Szromnik (2009).

A. Szromnik (2009, s. 18) uważa, że bardzo skromnie na tle krajowej literatury o problemach lokalizacji produkcji przedstawia się dorobek publikacyjny dotyczący lokalizacji szeroko rozumianych usług w tym placówek handlu detalicznego. O potrzebie, a nawet konieczności kontynuowania studiów i analiz z zakresu lokalizacji obiektów handlowo-usługowych decydują według niego następujące czynniki, fakty i okoliczności:

- lokalizacja obiektów handlowych zmienia strukturę funkcjonalną przestrzeni miast i wsi (zwłaszcza obszarów peryferyjnych),

- współczesne, nowe obiekty handlowe zajmują duże obszary ziemi,

- na terenach zurbanizowanych brakuje terenów pod nowe inwestycje handlowe,

${ }^{5} \mathrm{~W}$ okresie socjalistycznym zakłady produkcyjne często rozwijały się w sposób ekstensywny, właściwie cena gruntu w ogólnych kosztach była minimalna, stąd nadwyżki wolnych terenów wcale lub słabo wykorzystywanych. Po zmianach ustrojowych wiele zakładów wysprzedawało swoje tereny, żeby podreperować sytuację finansową i przetrwać jeszcze przez jakiś czas. Położenie tego typu obszarów w strukturze miasta, ich wielkość były nieraz bardzo atrakcyjne dla zagranicznych inwestorów z branży handlowej, na przykład kompleks byłych zakładów I.K. Poznańskiego (po drugiej wojnie światowej ZPB Poltex), dzisiaj Centrum Handlowe Manufaktura. 
- odczuwa się silny nacisk społeczny na wprowadzenie ograniczeń lokalizacyjnych dla obiektów wielkopowierzchniowych,

- obserwuje się wyraźny proces koncentracji powierzchni handlowych, rośnie średnia wielkość sklepów - nowe zwiększone potrzeby pozyskiwania terenów pod rozbudowę i modernizację techniczno-funkcjonalną obiektów,

- lokalizacja dużych punktów sprzedaży detalicznej narusza interesy wielu grup - osób fizycznych i organizacji,

- czynnik lokalizacyjny staje się głównym czynnikiem sukcesu sprzedażowego punktu sprzedaży lub całego centrum handlowego w związku ze wzrostem społecznej wyceny czasu traconego na zakupy,

- w wyścigu o dostęp (pozyskanie) atrakcyjnych lokalizacji dla nowych inwestycji handlowych uczestniczą przede wszystkim duże, globalne organizacje sieciowe, dysponujące ogromnymi środkami finansowymi na cele zakupu nieruchomości.

Do Polski od początku lat 90. XX wieku wkraczały sieci zagranicznych firm handlowych, najpierw badając rynek; pojawiały się wtedy głównie obiekty małe i średnie (supermarkety, sklepy dyskontowe), następnie zaczęły powstawać hipermarkety, centra handlowe, a od kilku lat intensywnie są budowane centra handlowo-usługowo-rozrywkowe. Szczególnie te ostatnie kompleksy zmieniły sposób postrzegania pobytów i czynności robienia zakupów, na co zwraca uwagę W. Wilk (2003, s. 208-210) w artykule o znamiennym tytule Między zakupami a rozrywkq nowe znaczenie centrum handlowego. Przytaczając badania E.L. Jacksona (1991), przedstawił relacje między wypoczynkiem i zakupami a wielkością obiektów handlowych oraz za U. Gerhardem (1998) zaprezentował koncepcję „Erlebniseinkauf”, w której zakupy są traktowane jako swoiste przeżycie, a „charakter ich polega na przechadzaniu się, najczęściej w towarzystwie rodziny lub znajomych po licznych sklepach bez wyraźnego celu, robieniu zakupów raczej spontanicznie (na zasadzie impulsu), przy czym kupuje się raczej towary, aby je mieć, a niekoniecznie, żeby ich używać”. W. Wilk (2003, s. 206-207) zwraca uwagę, że wśród determinant $\mathrm{w}$ wyborze zachowań rekreacyjnych w odniesieniu do związków między jedną z form obiektów handlowych i możliwościami spędzenia czasu wolnego w centrum handlowym szczególnego znaczenia nabierają 
czynniki czysto geograficzne (przestrzenne), chociażby miejsce zamieszkania i lokalizacja waloru turystycznego, jakim w tym przypadku jest właśnie centrum handlowe. Można jednak mówić o częściowym osłabieniu roli pokonywania odległości (przestrzeni) w przypadku tej formy spędzania czasu wolnego, ponieważ owa forma w przeważającym stopniu daje się sklasyfikować jako wypoczynek w pobliżu (w otoczeniu) miejsca zamieszkania bądź też (rzadziej) w granicach (w zasięgu) wyjazdów jednodniowych.

$\mathrm{Na}$ nowe postrzeganie przestrzeni centrum handlowego zwraca również uwagę socjolog B. Jałowiecki (2005, s. 11), nazywając ją „przestrzenią ludyczną”, czyli miejscem kultury i rozrywki. Jak zauważa, te „przybytki konsumpcji” stały się dla wielu nie tylko miejscem zakupów i spędzania wolnego czasu, ale wręcz ich elementem stylu życia. „Często spędzanie czasu wolnego $\mathrm{w}$ tych nowych komercyjnych przestrzeniach jest o wiele atrakcyjniejsze dla mieszkańców niż w przestrzeni publicznej miasta" (Dudek-Mańkowska 2006, s. 247).

S. Dudek-Mańkowska i M. Fuhrmann (2009, s. 278) zauważyły, że „bogata oferta nowoczesnych centrów handlowych sprawia, iż są one postrzegane przez turystów jako kolejna atrakcja turystyczna i stają się głównym celem podróży. Samo znaczenie turystyczne centrów handlowych może przejawiać się na dwa sposoby, otóż centrum handlowe (bądź obiekt zlokalizowany na jego terenie) i jego oferta mogą być celem wyjazdu turystycznego bądź stanowić jedynie uzupełnienie aktualnej oferty turystycznej miasta”6. „Centra handlowo-rozrywkowe, które chcą stać się lub pozostać poważną atrakcją turystyczną, muszą pilnie śledzić zmiany preferencji dotyczących spędzania czasu wolnego szczególnie grupy potencjalnych osób, dla których zakupy są głównym celem wyjazdu turystycznego"7 (Wilk 2003, s. 222).

W przypadku terenów centrów handlowych już od wielu lat trwa dyskusja, jak tego typu kompleksy klasyfikować w stosunku do przyjmowanych defini-

\footnotetext{
${ }^{6}$ „Centrum handlowe może nabrać znaczenia turystycznego także ze względu na swoją lokalizację”, jak również, „centra handlowe umożliwiają rozwój turystyki zakupowej” (Dudek-Mańkowska, Fuhrmann 2009, s. 278-279).

${ }^{7}$ Inną grupę turystów stanowią osoby które robią zakupy niejako przy okazji wyjazdu turystycznego (Wilk 2003).
} 
cji przestrzeni publicznej ${ }^{8}$. W literaturze przedmiotu określa się centra handlowe między innymi jako „przestrzenie prywatne udostępnione publicznie" (Chmielewski 2004), mówi się o "przestrzeniach quasi-publicznych” (Pancewicz 2010), „zawłaszczaniu przestrzeni publicznej (...) komercjalizacji przestrzeni” (Mironowicz 2010), „substytucie przestrzeni publicznej (...), które nie są przestrzenią publiczną, lecz terenem prywatnym, jedynie publicznie użytkowanym” (Ghirardo 1999), „hermetycznych atriach próbujących naśladować otwartą przestrzeń publiczną”, „o przekrytych przestrzeniach publicznych", „,prywatnych przestrzeniach publicznych” (Racon-Leja 2007), ,uzurpacji funkcjonalnej polegającej na zawłaszczaniu przestrzeni publicznych przez inwestorów prywatnych” (Kwiatkowski 2010), „prywatnych przestrzeniach konsumpcji” (Bauman 2000).

Z powyższych rozważań widać, że nie ma jednoznacznego stanowiska co do tego, jak traktować kompleksy handlowe: czy jako przestrzeń prywatną, czy raczej jako publiczną. Tego typu dywagacje wymagają dalszych doprecyzowań terminologicznych wśród naukowców różnych dyscyplin naukowych. Traktując centra handlowe jako przestrzeń prywatną, a nie publiczną, przytacza się różne argumenty:

- ograniczania, kontrola dostępu - nie każdy może się poruszać po wewnętrznych placach centrum handlowego (Krause 2010), ograniczenie dostępu do niej dla niektórych mieszkańców miasta zwłaszcza grup wykluczonych: osób ubogich, bezrobotnych, bezdomnych lub niebędących właścicielami terenu (Pancewicz 2010), zamknięty obszar i dostęp kontrolowany zarówno dla sprzedawców detalicznych, jak i klientów (Ghirardo 1999),

- ustalone odgórnie godziny otwarcia - dostępu (Racoń-Leja 2007),

\footnotetext{
${ }^{8}$ Przestrzeń publiczna definiowana w kategoriach społeczno-ekonomicznych jest dobrem wspólnie użytkowanym, celowo kształtowanym przez człowieka, zgodnie ze społecznymi zasadami i wartościami - służąca zaspokojeniu potrzeb społeczności lokalnych i ponadlokalnych. O publicznym charakterze przestrzeni decyduje zbiorowy sposób jej użytkowania (Karta Przestrzeni Publicznej, 2009, www.tup.org.pl). Ustawa o planowaniu i zagospodarowaniu przestrzennym z 2003 roku definiuje obszar przestrzeni publicznej jako teren „o szczególnym znaczeniu dla zaspokojenia potrzeb mieszkańców, poprawy jakości ich życia i sprzyjający nawiązywaniu kontaktów społecznych ze względu na jego położenie oraz cechy funkcjonalno-przestrzenne, określony w studium uwarunkowań i kierunków zagospodarowania przestrzennego gminy" (art. 2, pkt 6).

${ }^{9}$ Przestrzeń przekryta publiczna to przestrzeń wydzielona fizycznie od otoczenia co najmniej płaszczyzną dachu, w różnym stopniu izolowana od warunków zewnętrznych (Racoń-Leja 2007, s. 218).
} 
- prywatny nadzór oraz militaryzacja przestrzeni (wprowadzenie prywatnych służb bezpieczeństwa i monitoringu ${ }^{10}$ (Pancewicz 2010),

- nastawienie na zysk właściciela centrum handlowego (Krause 2010), organizacja terenu oraz dobór struktury podmiotów (oferty) przez pryzmat pieniądza (zysku), a nie przez zapotrzebowanie społeczne (zarządcy centrum handlowego odpowiadają na preferencje klientów, jednocześnie je kształtując),

- spłycenie relacji społecznych, zmniejszanie różnorodności użytkowników (Krause 2010), podporządkowanie roli przestrzeni wyłącznie celom komercyjnym przy ograniczeniu innych aktywności - działalności politycznej, religijnej, społecznej lub artystycznej (Pancewicz 2010),

- ograniczenia wynikające $z$ wewnętrznych ustaleń i związana z tym konieczność uzyskania specjalnych pozwoleń, choćby na fotografowanie czy prowadzenie badań naukowych na ich terenie.

Z powodu występujących licznych ograniczeń w zachowaniach, czasowych, ofertowych i personalnych trudno centra handlowe traktować jako przestrzenie publiczne ${ }^{11}$ (rys. 2).

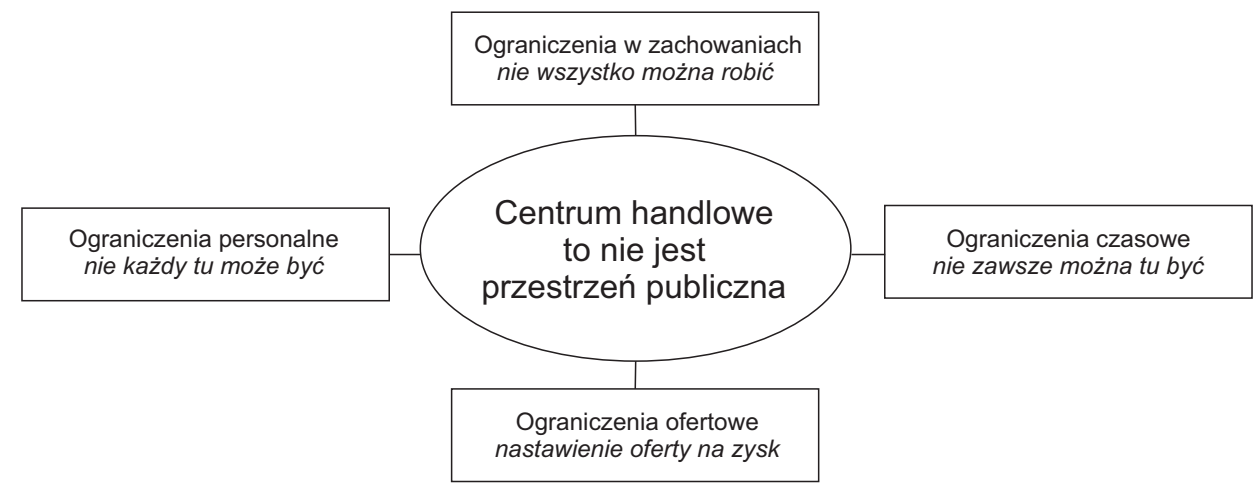

Rys 2. Główne ograniczenia eliminujące centra handlowe jako przestrzeń publiczną.

Źródło: Opracowanie własne.

${ }^{10}$ Więcej informacji na temat bezpieczeństwa w centrach handlowych można znaleźć [w:] Mordwa S., 2012, Poczucie bezpieczeństwa w centrach handlowych. Przyktad badań opinii klientów Galerii Łódzkiej i Manufaktury w Lodzi, [w:] Dzieciuchowicz J. (red.), Zróżnicowanie przestrzeni spoteczno-ekonomicznej - wybrane problemy, „Acta Universitatis Lodziensis. Folia Geographica Socio-Oeconomica”, nr 12, UŁ, Łódź, s. 163-185.

${ }^{11} \mathrm{Na}$ łamach tej pracy ze względu na jej zakres i cele nie badano postrzegania centrum handlowgo jako przestrzeni publicznej czy prywatnej. 
Zapoczątkowane przez ideę pasażu zamykanie pierwotnie otwartych przestrzeni publicznych doprowadziło do narodzin centrum handlowego i jego publicznego wnętrza - komercyjnego atrium. W tym momencie duże zespoły handlowe stały się niebezpieczną konkurencją dla otwartych przestrzeni publicznych (Racoń-Leja 2007, s. 216). Według K. Kwiatkowskiego (2010, s. 278): „funkcjonalne uzurpatorskie zawłaszczenie przestrzeni hipermarketów i galerii handlowych polega po pierwsze na zawłaszczeniu przez inwestora prywatnego przestrzeni publicznej; po drugie na wyznaczeniu reguł korzystania $z$ tej przestrzeni między innymi poprzez regułę $4 \mathrm{~F}^{12}$, zasadę kupowania impulsywnego i inne; po trzecie na ograniczaniu czasu korzystania; po czwarte na wprowadzeniu w pewnym sensie monotematyczności”. Zawłaszczanie przestrzeni publicznej przejawia się także jako przejmowanie kontroli nad przestrzenią pod pozorem zachowania jej „publiczności”, co jest nową, bardziej wyrafinowaną formą komercjalizacji, a tak wykreowana przestrzeń skomercjalizowana pozbawiona jest najbardziej immanentnego wyznacznika publiczności, czyli wolności dostępu (Mironowicz 2010, s. 47).

Obok badań geograficznych należy też zwrócić uwagę na dorobek ekonomistów, którzy częściej i bardziej dogłębnie podejmują tę tematykę $\mathrm{w}$ swoich rozważaniach ( $\mathrm{w}$ większości pod innym kątem niż geografowie). Badania nad centrami handlowymi najczęściej są prowadzone w ramach badań nad handlem, w tym głównie nad handlem detalicznym (Szumilak 2004; Sławińska 2008; Szulce 1998). Szczególnie tego typu zagadnienia są poruszane w literaturze ekonomicznej przy przedstawianiu procesów koncentracji i integracji w handlu: (Ciechomski 2006, 2010; Pokorska, Maleszyk 2002, 2006; Kucharska, Twardzik 2007; Komor 2011; Domański 2006; Tul-Krzyszczuk 2011; Kłosiewicz-Górecka 2006, 2009, 2010), przy omawianiu zagranicznych inwestycji w handlu detalicznym, przedstawianiu rozwoju sieci handlowych (E. Maleszyk 1998, 1999, 2001, 2004) czy przy strategiach marketingowych rozwoju dużych sieci handlowych (Domański 2001; Domański 2005; Pilarczyk, Sławińska, Mruk 2001; Mruk, Pilarczyk, Sojkin, Szulce 1998; Łukasik 2008, Marketing w handlu, pod redakcją G. Rosy 2009; Marketing w handlu pod redakcją L. Białoń 2007). Kompleksowym opracowaniem z zakresu mar-

${ }^{12}$ Forget your car, forget the street, forget services, forget yourself oznacza metaforyczne zamykanie się centrów na świat zewnętrzny (Makowski 2003, s. 46). 
ketingu jest praca M. Sullivana i D. Adcocka (2003) Marketing w handlu detalicznym, w której można znaleźć między innymi przegląd wielu koncepcji teoretycznych związanych z zachowaniami nabywców oraz lokalizacyjnych. $Z$ rolą samorządu terytorialnego $w$ rozwoju handlu w tym tego wielkopowierzchniowego, oraz jego wpływu na rozwój lokalny i regionalny możemy zapoznać się w pracach: U. Kłosiewicz-Góreckiej, B. Słomińskiej (2001) Samorzq̨ terytorialny a rozwój nowoczesnego handlu; U. Kłosiewicz-Górecka (2006) Globalizacja w sektorze handlu w Polsce - wyzwania dla krajowych przedsiębiorstw handlowych, Zagraniczne inwestycje w handlu na rynkach lokalnych pod redakcją U. Kłosiewicz-Góreckiej (2007); B. Słomińska (2009) Handel na rynkach regionalnych i lokalnych; J. Mikołajczyk (2008b) Przestrzenne aspekty funkcjonowania handlu.

O wpływie hipermarketów na rozwój społeczności lokalnych pisał między innymi B. Iwan (2007), roli centrów handlowych w kreowaniu wizerunku miast A. Kochaniec (2011), a o zmianie roli centrów miast śląskich T. Nawrocki (2010). Z punktu widzenia zakresu tej pracy na uwagę zasługuje artykuł M. Knecht-Tarczewskiej (2011), która zaprezentowała centrum handlowe jako nowoczesny produkt handlowo-usługowy, przedstawiając jego cechy i poziomy (wymiary). Należy też pamiętać, że decyzje zakupowe często wynikają ze stosowania przez sieci kompleksów wielkopowierzchniowych zaawansowanych technik wywierania wpływu na kupujących (manipulacje) o czym pisze między innymi K. Iwińska-Knop (2011), oddziaływanie na zmysły tworzenie obudowy kulturalno-handlowej dla tradycyjnych wydarzeń, czyli tak zwanego zjawiska rytualizacji konsumpcji (zanikanie różnic między strefą handlu, gastronomii i rozrywki) (Zatwarnicka-Madura 2011).

Prace ekonomistów pozwalają na zapoznanie się z rozwojem sklepów wielkopowierzchniowych na świecie, $\mathrm{z}$ etapami wkraczania zagranicznych sieci handlowych na polski rynek, $\mathrm{z}$ ich tempem, strategiami lokalizacyjnymi poszczególnych firm oraz z wpływem tego typu kompleksów na rozwój kraju, poszczególnych regionów czy dla Polski lokalnej (gmin, miast). Dorobek geografów i ekonomistów był bardzo przydatny dla rozważań teoretycznych prowadzonych na łamach tego opracowania, ale w wielu kwestiach niewystarczający, dlatego sięgano też do publikacji z zakresu socjologii (na przykład Jałowiecki 2005, 2011; Makowski 2003, 2010; Bauman 2000, Bierwiaczonek 2010, Kajdanek 2006), geomarketingu - powiązanie nauki o handlu z transportem (Zipser 2006, Fularz 2004, Dybicz 2001). 


\subsection{Centra handlowe - problemy definicyjne i klasyfikacyjne}

W Polsce za centrum handlowe (ang. shopping mall, shopping centre/shopping center) uznaje się zgodnie z definicją przyjętą przez Polską Radę Centrów Handlowych $(\mathrm{PRCH})^{13}$, a wcześniej doprecyzowaną przez Międzynarodową Radę Centrów Handlowych (International Council of Shopping Center - ICSC) „nieruchomość handlową, która została zaplanowana, zbudowana oraz jest zarządzana jako jeden podmiot handlowy, składający się ze wspólnych części, o minimalnej powierzchni najmu brutto (GLA - Gross Leasable Area $)^{14} 5$ tys. $\mathrm{m}^{2}$ oraz składający się z minimum 10 sklepów"15. W definicji tej główny nacisk został położony na fakt, że jest ono jednostką spójnie zarządzaną, wyodrębniającą się z otoczenia o odpowiedniej powierzchni najmu, posiadającą części wspólne służące wszystkim klientom.

Powstanie tej międzynarodowej definicji centrum handlowego jest wynikiem badań, jakie zleciła pod koniec 2005 roku Międzynarodowa Rada Centrów Handlowych (ICSC) w różnych krajach europejskich. W definicji położono nacisk na centralne zarządzanie takim obiektem, które pozwala utrzymać w nim porządek, czystość, uregulować godziny otwarcia wszystkich sklepów, zapewnić odpowiednią infrastrukturę (na przykład powierzchnie dodatkowe, toalety, parkingi). Centrum handlowe tworzy zazwyczaj fizycznie wyodrębnioną z otoczenia strukturę, budynek lub zespół budynków. Typowo jest to jeden budynek zawierający sklepy połączo-

\footnotetext{
${ }^{13}$ Polska Rada Centrów Handlowych (PRCH) powstała jako stowarzyszenie w 2003 roku i od samego początku jest wyłącznym narodowym partnerem International Council of Shopping Centers (ICSC). PRCH reprezentuje interesy branży nieruchomości handlowych w Polsce. Stowarzyszenie wydaje raporty rynkowe, organizuje szkolenia, konferencje, kwartalne miksery biznesowe. Misją jest wspieranie rozwoju firm i profesjonalistów działających na rynku nieruchomości handlowych $\mathrm{w}$ Polsce oraz promocja pozytywnego wizerunku branży centrów i ulic handlowych (http://prch.org.pl/PL/StronaGlowna/Default.aspx).

${ }^{14}$ Jest to całkowita powierzchnia, która jest przeznaczona do wyłącznego użytkowania przez najemcę. Należy do niej nie tylko powierzchnia sprzedaży, ale także pozostałe części sklepu, takie jak gastronomia, magazyny, zaplecze socjalne, ewentualne piwnice, antresole i tym podobne. Obszar powierzchni GLA jest mnożony przez stawkę najmu za $1 \mathrm{~m}^{2}$, co przekłada się na wysokość czynszu płaconego przez najemcę (Ledwoń 2009, s. 38).

${ }^{15} \mathrm{PRCH}$, http://prch.org.pl/PL/BazaWiedzy/Definicje/Default.aspx.
} 
ne ze sobą za pomocą tak zwanej galerii $\left(\right.$ mall $\left.^{16}\right)$, inaczej określanej jako powierzchnie wspólne, ponieważ służą one wszystkim użytkownikom centrum handlowego (Matysiak 2009, s. 27).

Mimo prób ujednolicenia definicji centrum handlowego wiele państw stosuje własne kryteria wydzielania tego typu kompleksów handlowych. Różnice polegają na uwzględnianiu powierzchni minimalnych najmu, liczby placówek oraz liczby i powierzchni, jaką zajmują główni najemcy (sklepy kotwicowe - tab. 2). Za sklepy kotwicowe w literaturze uznaje się $z$ jednej strony hipermarkety i supermarkety, ale też takimi punktami mogą być sklepy przyciągające pewne grupy klientów: firmowe sklepy z odzieżą, obuwiem, sprzętem komputerowym oraz inne sklepy specjalistyczne (Ciechomski 2010, s. 51), wszystko zależy od tak zwanego pozycjonowania ${ }^{17}$ (Borusiak 2010).

Centra handlowe zwane są również ośrodkami handlowymi, centrami samoobsługowymi lub galeriami handlowymi (Ciechomski 2010, s. 48). Jak zauważa W. Wilk (2003, s. 212) w literaturze polskiej możemy spotkać dwa równoważne określenia tej formy organizacyjnej handlu: centrum handlowe i ośrodek handlowy. Ten pierwszy termin jest częściej spotykany w literaturze geograficznej, na przykład Z. Taylor (2000), A. Jarosz (2002), a ten drugi rozpowszechniony jest bardziej w literaturze ekonomicznej, głównie marketingowej, zobacz E. Maleszyk (1998, 2001a), Olearczyk (1979), Strużycki (2000).

W literaturze naukowej również można spotkać wiele definicji centrów/ /ośrodków handlowych, w których to definicjach większą wagę zwraca się na kwestie organizacyjne, wizualne (architektoniczne), dostępnościowe (szczególnie pod względem komunikacyjnym) oraz ofertowe (tab. 3). Tak zróżnicowane podejście do wyodrębniania centrów handlowych z szero-

\footnotetext{
${ }^{16}$ Mall to po angielsku alejka, deptak, promenada, a w języku handlowym - skrzyżowanie domu towarowego, parku i centrum rozrywki (Makowski 2010, s. 45). Pierwsze centra handlowe typu shopping mall powstały w Ameryce Północnej. Określenie to oznacza układ sklepów po obu stronach pieszego przejścia. Podstawową cechą takiego obiektu jest przykrycie przestrzeni pieszej, jej wewnętrzne oświetlenie i kontrola środowiska za pomocą odpowiednich urządzeń technicznych - klimatyzacji, nawiewów, kurtyn powietrznych, świetlików i tym podobnych (Ledwoń 2009, s. 37).

${ }^{17}$ Pozycjonowanie - działania służące wysokiej ocenie, wyróżnieniu i zajęciu pożądanego miejsca produktu lub marki w świadomości docelowych konsumentów w porównaniu z produktami konkurentów (Kienzler, Romanowski 2009, s. 191).
} 
Tabela 2

Wybrane oficjalne krajowe definicje centrum handlowego

\begin{tabular}{|c|c|}
\hline Kraj & Definicje \\
\hline Łotwa & $\begin{array}{l}\text { Centrum handlowe jest celowo zaplanowane, zbudowane i zarządzane jako jeden podmiot } \\
\text { na rynku nieruchomości z co najmniej } 5 \text { oddzielnymi punktami najmu, o minimalnej } \\
\text { powierzchni najmu brutto (GLA) } 1500 \text { m² }^{2} \text { oraz z jednym najemcą, który nie zajmuje więcej } \\
\text { niż } 75 \% \text { GLA. }\end{array}$ \\
\hline Austria & $\begin{array}{l}\text { Centrum handlowe jest jednolicie zaprojektowane, zaplanowane i zarządzane, wynajęte przez } \\
\text { dużą liczbę niezależnych sprzedawców, dostawców usług i operatorów gastronomicznych } \\
0 \text { minimalnej powierzchni brutto najmu (GLA) } 4000 \text { m² z nie mniej niż } 20 \text { firmami lub } \\
\text { nie mniej niż 10, pod warunkiem że istnieją co najmniej dwa sklepy „kotwice” z różnych } \\
\text { sektorów. }\end{array}$ \\
\hline Finlandia & $\begin{array}{l}\text { Centrum handlowe składa się z komercyjnego budynku, w którym sklepy i punkty usługowe } \\
\text { otwierają się do wewnątrz na pasaż lub główną halę. Powierzchnia najmu brutto wynosi } \\
\text { zwykle co najmniej } 5000 \mathrm{~m}^{2} \text {. Kompleksy takie posiadają co najmniej } 10 \text { punktów sprzedaży } \\
\text { detalicznej jeden lub więcej sklepów „kotwic” oraz inne placówki usługowe. Usługi mogą } \\
\text { być zarówno komercyjne, jak i publiczne. Pojedynczy najemca nie może zajmować więcej } \\
\text { niż 50\% całkowitej powierzchni komercyjnej. Centra handlowe posiadają jednego zarządcę } \\
\text { i wspólny marketing. }\end{array}$ \\
\hline Francja & $\begin{array}{l}\text { Centrum handlowe jest zdefiniowane jako zestaw co najmniej } 20 \text { sklepów i punktów } \\
\text { usługowych, o łącznej powierzchni handlowej brutto (GLA) co najmniej } 5000 \text { m², }^{2} \\
\text { zaprojektowane, zbudowane i zarządzane jako całość. }\end{array}$ \\
\hline $\begin{array}{l}\text { Dania, } \\
\text { Islandia, } \\
\text { Łotwa, } \\
\text { Norwegia, } \\
\text { Szwecja }\end{array}$ & $\begin{array}{l}\text { Centrum handlowe jest to obiekt o minimalnej powierzchni handlowej } 5000 \text { m² (GLA) } \\
\text { z przynajmniej } 10 \text { sklepami, wspólnie zarządzany i z wspólnym marketingiem. }\end{array}$ \\
\hline Portugalia & $\begin{array}{l}\text { Centrum handlowe budynek lub sąsiadujące budynki handlowe, zaplanowane, zbudowane } \\
\text { i zarządzane jako pojedynczy podmiot, składający się z jednostek detalicznych, o minimalnej } \\
\text { powierzchni najmu brutto } 5000 \mathrm{~m}^{2} \text { (GLA) oraz } 12 \text { sklepach. }\end{array}$ \\
\hline Węgry & 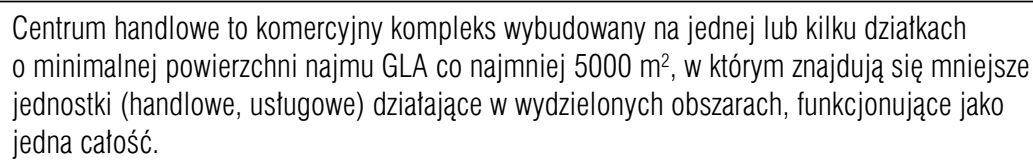 \\
\hline
\end{tabular}

Źródło: Opracowanie i tłumaczenie własne na podstawie: J.R. DeLisle, 2009, Towards global classification of shopping centers, http://www.icsc.org/srch/rsrch/wp/GlobalRetailClass_Feb2009.pdf; The Finnish Council of Shopping Centers, http://www.ncsc.se/images/finnishshoppingcenters.pdf, National Council of Shopping Centers of France (CNCC), http://www.cncc.com/index.php?rub=18\&srub=28, Nordic Council of Shopping Centers (NCSC), http://www.ncsc.se/index.php?option=com_content\&task=section\&id=15\&Itemid=66, Portuguese Association of Shopping Centres (A.P.C.C.), http://www.apcc.pt/tipologia.php, Hungarian Council of Shopping Centers, http://www.mbsz.hu/2011_08_06/MBSZ_eves_jenetes_A4_2010_FINAL.pdf. 
Tabela 3

Wybrane definicje centrum/ośrodka handlowego w literaturze naukowej

\begin{tabular}{|c|c|}
\hline Autor & Definicje \\
\hline $\begin{array}{l}\text { Chwałek } \\
\text { (2008) }\end{array}$ & $\begin{array}{l}\text { Ośrodek handlowy to zgrupowanie różnorodnych punktów sprzedaży detalicznej i punktów } \\
\text { usługowych (co najmniej 4-6 sklepów i } 1 \text { zakład usługowy), stanowiące całość pod } \\
\text { względem: } \\
\text { - oferty towarowej i usługowej (uzupełnianie się ofert poszczególnych placówek), } \\
\text { - formy budowlanej i architektonicznej (jeden projekt całości), } \\
\text { - organizacji zarządzania (jeden zarząd dla całości), } \\
\text { - klimatu handlowego (jeden styl całości). }\end{array}$ \\
\hline $\begin{array}{l}\text { Ciechomski } \\
(2010)\end{array}$ & $\begin{array}{l}\text { Centra handlowe, zwane również ośrodkami handlowymi, centrami samoobsługowymi lub } \\
\text { galeriami handlowymi to nowoczesne obiekty wielkopowierzchniowe o powierzchni kilku } \\
\text { lub kilkunastu tysięcy metrów. Największe z nich zajmują ponad } 100 \text { tys. m² powierzchni } \\
\text { i zlokalizowane są na obrzeżach miast. }\end{array}$ \\
\hline $\begin{array}{l}\text { Kaczmarek } \\
(2010)\end{array}$ & $\begin{array}{l}\text { Centra handlowe są to skupiska obiektów handlowych pod jednym dachem i na znacznej } \\
\text { powierzchni, na której działalność handlowa miesza się z innymi funkcjami usługowymi, } \\
\text { tworząc dominanty i kluczowe miejsca konsumpcji współczesnego świata (największa } \\
\text { forma koncentracji). }\end{array}$ \\
\hline $\begin{array}{l}\text { Maleszyk } \\
\text { (1998) }\end{array}$ & $\begin{array}{l}\text { Ośrodek handlowy - w jego skład musi wchodzić co najmniej 4-6 sklepów oraz zakład } \\
\text { gastronomiczny podstawowego żywienia. }\end{array}$ \\
\hline $\begin{array}{l}\text { Matysiak } \\
\text { (2009) }\end{array}$ & $\begin{array}{l}\text { Centrum handlowe to starannie zaprojektowany zespół detalicznych placówek } \\
\text { handlowo-usługowych, który jest planowany, budowany i zarządzany jako odrębna całość } \\
\text { wraz z powierzchniami wspólnymi, w tym z przyległym parkingiem. Centrum handlowe } \\
\text { reprezentuje wysoką jakość zakupów reprezentowaną przez odpowiedni dobór sklepów } \\
\text { i staranność zarządzania obiektem. Wielkość i charakter centrum są ogólnie determinowane } \\
\text { charakterystyką rynku i strefy zasięgu, którą obsługuje centrum handlowe. }\end{array}$ \\
\hline $\begin{array}{l}\text { Mikołajczyk } \\
\text { (2008) }\end{array}$ & $\begin{array}{l}\text { Centrum handlowe (ośrodek handlowy) - zgrupowanie różnorodnych detalicznych } \\
\text { jednostek handlowych i usługowych, prowadzonych zazwyczaj przez różne } \\
\text { przedsiębiorstwa, stanowiące całość pod względem handlowo-asortymentowo-usługowym, } \\
\text { budowlano-architektonicznym i organizacyjno-administracyjnym, przystosowane do } \\
\text { kompleksowej obsługi klientów. }\end{array}$ \\
\hline $\begin{array}{l}\text { Strużycki } \\
(2000)\end{array}$ & $\begin{array}{l}\text { Ośrodek handlowy potocznie zwany centrum handlowym jest nowoczesnym zgrupowaniem } \\
\text { sklepów, zakładów gastronomicznych i usługowych, w którego skład wchodzi co najmniej } \\
\text { kilka sklepów prowadzonych przez różne przedsiębiorstwa, w tym sklep magnes, którym } \\
\text { może być hipermarket, supermarket czy inny sklep typu „wygodny” (convenience) } \\
\text { i zakład gastronomiczny podstawowego żywienia. Stanowi całość pod względem } \\
\text { handlowo-asortymentowo-usługowym, budowlano-architektonicznym i organizacyjno- } \\
\text {-administracyjnym, przystosowany jest przy tym do obsługi zmotoryzowanych nabywców. } \\
\text { Ważnymi wymogami dla ośrodków handlowych są: wyłączenie ruchu kołowego wewnątrz } \\
\text { ośrodka, istnienie parkingu, łatwa dostępność komunikacyjna, klimat handlowy podkreślany } \\
\text { elementami i urządzeniami rekreacyjnymi. }\end{array}$ \\
\hline $\begin{array}{l}\text { Tarondeau, } \\
\text { Xardel (1999) }\end{array}$ & $\begin{array}{l}\text { Centrum handlowe to większa liczba sklepów detalicznych znajdujących się na terenie } \\
\text { specjalnie do tego przygotowanym, na wyznaczonym planie, w którego skład wchodzą } \\
\text { miejsca użytku publicznego (jak parking). }\end{array}$ \\
\hline
\end{tabular}


Tabela 3 (ciąg dalszy)

\begin{tabular}{|l|l|}
\hline Autor & \multicolumn{1}{c|}{ Definicje } \\
\hline $\begin{array}{l}\text { Olearczyk } \\
(1979)\end{array}$ & $\begin{array}{l}\text { Ośrodki (centra) handlowe to świadoma forma koncentracji przestrzennej placówek } \\
\text { handlu detalicznego. Pod względem asortymentowym, budowlanym, architektonicznym } \\
\text { i organizacyjno-administracyjnym stanowi ona całość przystosowaną do obsługi } \\
\text { zmotoryzowanych klientów }\end{array}$ \\
\hline
\end{tabular}

Źródło: Opracowanie własne.

kiej gamy formatów (rodzajów) handlu detalicznego utrudnia prowadzenie badań porównawczych i to nie tylko międzynarodowych, ale również krajowych.

Centra handlowe są jednym z przejawów koncentracji przestrzennej w handlu detalicznym. W. Ciechomski (2006, s. 90) pisząc o koncentracji w handlu, wyróżnia cztery jej typy: kapitałową, integracyjną, organizacyjną i przestrzenną. Tą ostatnią rozumie jako grupowanie placówek w danym miejscu, które mogą przyjmować różne formy i tworzyć wielofunkcyjne centra handlowe, wyspecjalizowane ośrodki handlowe czy też inne kompleksy handlowe, pasaże. Jak zauważa G. Śmigielska (2004, s. 60), w centrum handlowym zgrupowanie przestrzenne sklepów, punktów gastronomicznych oraz innych placówek usługowych jest tak dobrana, aby ośrodek stanowił całość pod względem handlowo-asortymentowo-usługowym, budowlano-architektonicznym, organizacyjno-administracyjnym oraz był przystosowany do obsługi nabywców zmotoryzowanych. Jeżeli ośrodek handlowy zlokalizowany jest pod jednym dachem, określa się go mianem kontrolowanego centrum handlowego.

Koncentracja przedsiębiorstw handlowych (rozpatrywana w różnych wymiarach) według W. Ciechomskiego (2006, s. 96) przynosi ewidentne plusy dla klientów:

- oferuje bogatą dostępność placówek handlowych,

- gwarantuje nabywcy bogaty asortyment w jednym miejscu i czasie,

- usprawnia obsługę i serwis dzięki nowoczesnym technologiom,

- przedstawia szeroką paletę usług poszerzonych dla klientów,

- wykazuje tendencję do obniżania cen,

- wzbogaca asortyment o innowacje,

- ułatwia bardziej przejrzyste zarządzanie kategoriami produktów,

- zapewnia lepszą komunikację marketingową w miejscu sprzedaży. 


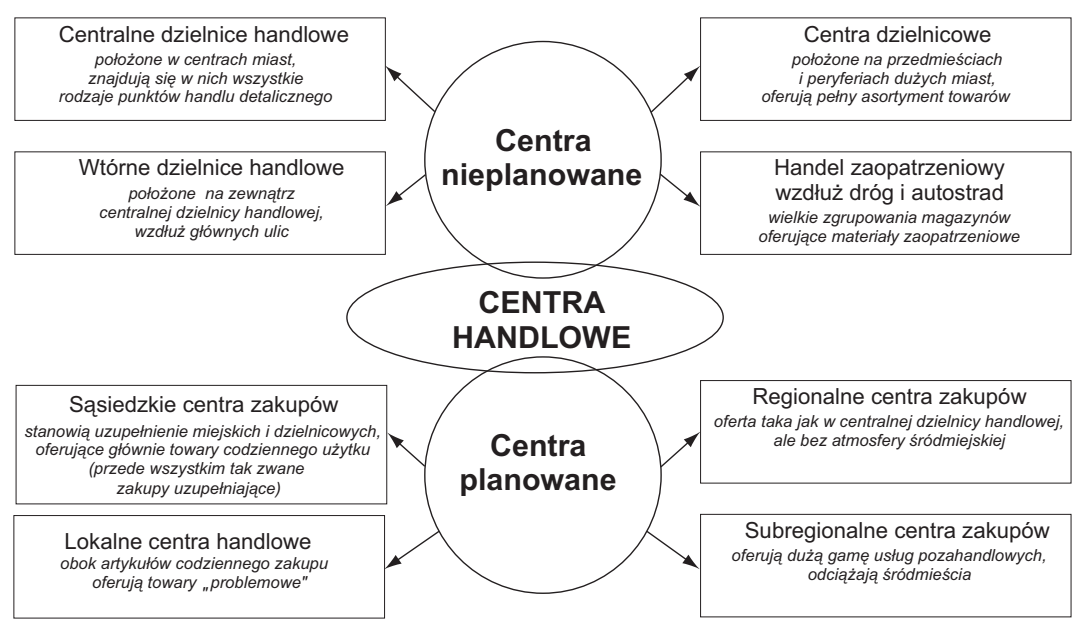

Rys 3. Typy centrów handlowych ze względu na ich formę koncentracji i rozmieszczenie.

Źródło: Opracowanie własne na podstawie H. Szulce, 1998, Struktury i strategie w handlu, PWE, Warszawa, s 220-222.

Centra (ośrodki) handlowe, jak już wcześniej wspomniano, są jednym z przejawów koncentracji przestrzennej. Ze względu na formę koncentracji oraz rozmieszczenie H. Szulce (1998, s. 85, 220) zalicza je do tak zwanej grupy placówek handlowych stowarzyszonych (obok wolno stojących), w ramach których tworzą się nieplanowane dzielnice handlowe (centralne dzielnice handlowe, wtórne dzielnice handlowe, sąsiedzkie okręgi handlowe, handel wzdłuż dróg i autostrad) oraz planowane centra handlowe (sąsiedzkie, lokalne, regionalne i superregionalne centra zakupów) (rys. 3).

W literaturze naukowej mamy do czynienia z różnymi typami centrów handlowych w zależności od przyjętego kryterium podziału. Najczęściej klasyfikuje się je ze względu na wielkość, ofertę oraz lokalizację względem centrum miasta, czasami biorąc pod uwagę złożone kryterium podziału, na przykład asortymentowo-lokalizacyjne.

Ważnym kryterium podziału ze względu na zakres tej pracy jest kryterium ofertowe. Generalnie Międzynarodowa Rada Centrów Handlowych (ICSC) wyróżnia centra handlowe tradycyjne i profilowane. „W tradycyjnym centrum handlowym oprócz supermarketu znajdują się sklepy odzieżowe, obuwnicze, z artykułami RTV i AGD, zabawkami, upominkami, artykułami dla zwierząt, a także apteka, kwiaciarnia itp. Centra profilowane oferują 
wąski i specjalistycznie rozbudowany asortyment towarów z jednej branży, np. meblarskiej" (Ciechomski 2010, s. 48).

W krajowych klasyfikacjach często dokonuje się podziału ze względu na wielkość poszczególnych kompleksów, głównie uwzględniając powierzchnię przeznaczoną pod wynajem dla różnych podmiotów. Ze względu na wielkość Międzynarodowa Rada Centrów Handlowych (ICSC) ${ }^{18}$ dzieli tradycyjne centra handlowe na bardzo duże ( $>80$ tys. $\mathrm{m}^{2} \mathrm{GLA}$ ), duże (40-79,999 tys. $\mathrm{m}^{2}$ GLA), średnie (20-39,999 tys. $\mathrm{m}^{2}$ GLA) i małe (5-19,999 tys. $\mathrm{m}^{2}$ GLA). Wśród profilowanych centrów handlowych wyróżniono: parki handlowe (retail park $)^{19}$ o powierzchni powyżej 5 tys. $\mathrm{m}^{2}$ GLA, centra/sklepy fabryczne $(\text { faktory outlet center })^{20}$ oraz centra/parki tematyczne (theme-oriented center $)^{21}$ o powierzchniach poniżej 5 tys. $\mathrm{m}^{2}$ GLA (Lambert 2005, s. 35).

Centra handlowe pod względem ofertowym są również klasyfikowane według pięciu generacji. Generacje to kategorie (typy) centrów handlowych wyróżniane głównie ze względu na funkcje, jakie pełnią oraz strukturę jego najemców, zwłaszcza proporcji między hipermarketem spożywczym, a galerią handlową (zobacz Matysiak 2009, s. 29). Kryteria podziału na generacje są nieostre, często autorzy podają różne cechy poszczególnych typów. W historii rozwoju poszczególnych generacji można zauważyć przechodzenie od najprostszych form głównie pełniących funkcje handlowe (generacja I) do tworzenia bardziej wyrafinowanych kompleksów handlowo-usługowo-rekreacyjnych z bogatą ofertą kulturalną (generacja V). Jak zauważa G. Makowski (2010), centrami handlowymi pierwszej generacji były hipermarkety, w których sąsiedztwie zbudowano kilkanaście butików. Kolejnym krokiem w rozwoju stał się wzrost liczby małych sklepów i dodanie restauracji i barów. W centrach handlowych trzeciej generacji hipermarket spożywczy nie jest już najważniejszy, staje się on po prostu jednym $\mathrm{z}$ wielu sklepów. Kiedy do centrów handlowych

\footnotetext{
${ }^{18}$ Kryteria wielkościowe są przyjmowane różnie w zależności od kraju.

${ }^{19}$ Park handlowy - ich koncepcja oparta jest na układzie obiektów wokół centralnie położonego parkingu, w którym do każdego z obiektów handlowych prowadzi oddzielne wejście, sklepy wielkopowierzchniowe, centra wyprzedaży, instytucje rozrywkowe (Sondej 2009, s. 26).

${ }^{20}$ Centra/sklepy fabryczne oferują przede wszystkim końcówki serii towarów markowych sprzedawanych pod koniec (lub po zakończeniu) sezonu. Cena towarów w nich sprzedawanych jest obniżona o około 25-70\% w stosunku do ceny wyjściowej (Borusiak 2008, s. 182).

${ }^{21} \mathrm{Centra}$ /parki tematyczne - zaplanowane kompleksy $\mathrm{z}$ lokalami handlowymi posiadającymi wąski, ale głęboki asortyment $z$ danej kategorii (Lambert 2005, s. 35).
} 
Tabela 4

Rodzaje (generacje) centrów handlowych ze względu na ich powierzchnię i funkcje

\begin{tabular}{|c|c|c|c|}
\hline \multirow[t]{2}{*}{ Typ } & \multirow{2}{*}{$\frac{\text { ŚWIAT }}{\text { Cechy charakterystyczne }}$} & \multicolumn{2}{|r|}{ POLSKA } \\
\hline & & $\begin{array}{c}\text { Okres } \\
\text { powstania }\end{array}$ & Cechy charakterystyczne \\
\hline I. & $\begin{array}{l}\text { - do } 20 \text { tys. m² o zasięgu } \\
\text { dzielnicowym } \\
\text { - gtówna funkcja handlowa } \\
\text { (hipermarket plus galeria } \\
\text { handlowa do } 50 \text { sklepów) - } \\
\text { nieliczne obiekty usługowe } \\
\text { (pralnia, punkt napraw, } \\
\text { punkt pocztowy, placówki } \\
\text { telekomunikacyjne), lokal } \\
\text { gastronomiczny (fast food) }\end{array}$ & $\begin{array}{l}\text { poł. lat } 90 . \\
X X \text { w. }\end{array}$ & $\begin{array}{l}\text { - } 5 \text {-20 tys. } \mathrm{m}^{2} \\
\text { - } \text { supermarket/hipermarket (około 75\% } \\
\text { pow.) oraz od kilkunastu do } 50 \text { placówek } \\
\text { handlowych, usługowych } \\
\text { - } \text { hipermarket i zakupy spożywcze są głównym } \\
\text { celem nabywców }\end{array}$ \\
\hline ॥. & $\begin{array}{l}\text { - 20-50 tys. m² o zasięgu } \\
\text { ogólnomiejskim } \\
\text { - } \text { hipermarket FMCG, 2-3 markety } \\
\text { specjalistyczne (na przykład dom } \\
\text { i ogród, elektroniczny), duże } \\
\text { sklepy odzieżowe, galeria małych } \\
\text { sklepów (do 100) } \\
\text { - placówki usługowe jak wyżej, } \\
\text { a także salony kosmetyczne, } \\
\text { fryzjer, biura podróży, plac } \\
\text { zabaw dla dzieci, kilka placówek } \\
\text { gastronomicznych (bary, } \\
\text { kawiarnie), salon gier, mała scena }\end{array}$ & $\begin{array}{l}\text { koniec lat } \\
\text { 90. XX w. }\end{array}$ & $\begin{array}{l}\text { - supermarket lub hipermarket } \\
\text { (około 30-40\% powierzchni) } \\
\text { - do kilku sklepów wielkopowierzchniowych } \\
\text { specjalistycznych (powyżej } 400 \mathrm{~m}^{2} \text { ) } \\
\text { - } \text { powyżej } 50 \text { placówek handlowych, } \\
\text { gastronomicznych (kawiarnie, restauracje) } \\
\text { - pojawienie się funkcji rozrywkowej (często } \\
\text { jeden, dwu operatorów, na przykład kino, } \\
\text { kręgielnia) }\end{array}$ \\
\hline III. & $\begin{array}{l}\text { - 50-200 tys. m² o zasięgu } \\
\text { regionalnym, krajowym } \\
\text { - } 2 \text {-3 hipermarkety FMCG, liczne } \\
\text { markety specjalistyczne, galerie } \\
\text { i sklepy wielopoziomowe } \\
\text { (100-500 sklepów) } \\
\text { - placówki usługowe jak wyżej, } \\
\text { wydzielona duża cześć } \\
\text { gastronomiczna (food court), } \\
\text { kino (multipleks), dyskoteka, } \\
\text { część rekreacyjna (salon gier, } \\
\text { bowling, ściana wspinaczkowa, } \\
\text { skatepark i tym podobne), kluby } \\
\text { fitness, park tematyczny dla } \\
\text { dzieci, kaplica, usługi medyczne. }\end{array}$ & po 2000 r. & $\begin{array}{l}\text { - } \text { supermarket staje się jednym z wielu } \\
\text { sklepów, często występuje sklep typu } \\
\text { DIY (do-it-yourself store) - z artykułami } \\
\text { budowlanymi i wyposażenia domu } \\
\text { - koncentracja placówek gastronomicznych } \\
\text { w formie „foodcourt” } \\
\text { - } \quad \text { rozwinięcie oferty rozrywkowo-rekreacyjnej } \\
\text { (na przykład powstaje kompleks kinowy } \\
\text { - centra handlowe przestają być tylko miejscem } \\
\text { robienia zakupów, ale zaczynają pełnić funkcję } \\
\text { miejsca spotkań, odpoczynku, relaksu } \\
\text { - większy komfort zakupów przez wzbogacenie } \\
\text { oferty markowych produktów w galerii } \\
\text { luksusowych sklepów }\end{array}$ \\
\hline
\end{tabular}


Tabela 4 (ciąg dalszy)

\begin{tabular}{|c|c|c|c|}
\hline \multirow[t]{2}{*}{ Typ } & \multirow{2}{*}{$\begin{array}{c}\text { ŚWIAT } \\
\text { Cechy charakterystyczne }\end{array}$} & \multicolumn{2}{|r|}{ POLSKA } \\
\hline & & $\begin{array}{c}\text { Okres } \\
\text { powstania }\end{array}$ & Cechy charakterystyczne \\
\hline IV. & $\begin{array}{l}\text { - } \text { powyżej } 200 \text { tys. m² o zasięgu } \\
\text { krajowym, międzynarodowym } \\
\text { - } \text { hipermarkety FMCG, } \\
\text { hipermarkety specjalistyczne, } \\
\text { domy towarowe, aleje zakupowe } \\
\text { (500-1000 sklepów), targowiska } \\
\text { i rynki, tematyczne malle, repliki } \\
\text { ulic i placów handlowych } \\
\text { - placówki usługowe jak wyżej, } \\
\text { czéśc biurowa, hotelowa, muzea, } \\
\text { galerie sztuki, sale widowiskowe, } \\
\text { rozrywkowe parki tematyczne, } \\
\text { kasyna, kompleks wypoczynkowy } \\
\text { (ogrody, fontanny, wodospady, } \\
\text { akwarium), discovery center, } \\
\text { obiekty rekreacyjno-sportowe } \\
\text { (boiska, aquapark, lodowisko) }\end{array}$ & $\begin{array}{l}\text { początek. } \\
\text { XX wieku }\end{array}$ & $\begin{array}{l}\text { - } \text { rozbudowane funkcje rozrywkowo- } \\
\text {-rekreacyjne (muzea, galerie sztuki, } \\
\text { amfiteatry - w których odbywają się } \\
\text { koncerty, studia do nagrań telewizyjnych, } \\
\text { ścianki wspinaczkowe, kluby SPA, hale } \\
\text { sportowe, centra medyczne, nawet centra } \\
\text { targowe) } \\
\text { - pojawiają się funkcje biurowe i hotelowe, } \\
\text { - charakteryzują się wyjątkowością rozwiązań } \\
\text { architektonicznych szczególnie ich } \\
\text { powiązaniem z historyczną tożsamością } \\
\text { miejsca } \\
\text { - możliwość wypoczynku }\end{array}$ \\
\hline V. & $\begin{array}{l}\text { - celem ich jest zaspokojenie } \\
\text { wszystkich potrzeb konsumentów, } \\
\text { są to miejsca w których ludzie } \\
\text { mogą spędzić cały swój czas } \\
\text { - mieszkając (poszerzenie } \\
\text { oferty o apartamenty, w których } \\
\text { mieszkają klienci), pracując, } \\
\text { bawiąc się, czyli po prostu żyjąc } \\
\text { (live-work-play mode/) } \\
\text { - około 40\% pow. zajmują sklepy, } \\
\text { 60\% punkty usługowe } \\
\text { (między innymi przychodnie, } \\
\text { salony piękności, siłownie, centra } \\
\text { wystawowe, biura, powierzchnie } \\
\text { udostępniane do organizacji } \\
\text { konferencji i bankietów) } \\
\text { - poszerzenie oferty rozrywkowej, } \\
\text { na przykład lunapark, zoo, stok } \\
\text { narciarski, wesołe miasteczko }\end{array}$ & brak & \\
\hline
\end{tabular}

Źródło: Opracowanie własne na podstawie T. Kaczmarek, 2010, Struktura przestrzenna handlu detalicznego. Od skali globalnej do lokalnej, Wydawnictwo Naukowe Bogucki, Poznań, s. 47; W. Ciechomski, 2010, Koncentracja handlu w Polsce $i$ jej implikacje dla strategii konkurowania przedsiębiorstw handlowych, UE, Poznań, s. 49-50; N. Matysiak, 2009, Wspótczesne centra handlowe w Polsce, „Handel wewnętrzny - rynek, przedsiębiorstwo, konsumpcja, marketing”, nr 6, IBRKiK, Warszawa, s. 29-30; DTZ Research, Rynek powierzchni handlowych Polska, 2009, www.detaldzisiaj.com.pl; A. Shiboleth, 2009, W Polsce powstanq centra V generacji. 
dołączono kina, centra rozrywki, biura, pojawiła się czwarta generacja. Piąta to centra $\mathrm{z}$ lunaparkiem, zoo, a nawet stokiem narciarskim i tym podobnymi. Jak szacuje W. Ciechomski (2010, s. 49) „jedna trzecia centrów handlowych w ogóle nie posiada hipermarketu, co burzy mit, że centrum/ ośrodek handlowy powstaje wraz z uruchomieniem hipermarketu, przy którym tworzona jest galeria sklepów i zakładów usługowych. W przyszłości owe tradycyjne centra handlowe $z$ dominującymi w nich supermarketami lub hipermarketami będą ewaluowały w kierunku wyspecjalizowanych centrów/ośrodków handlowych".

W Polsce centrum handlowe I generacji stanowi hipermarket/supermarket zajmujący około 75\% jej powierzchni (według DTZ Reaearch 2009, 40-50\% powierzchni najmu) z małą galerią handlową uzupełniającą jego ofertę. Centra II generacji na rynku to hipermarkety $\mathrm{z}$ większą galerią handlową (zajmującą blisko $70 \%$ powierzchni najmu całego obiektu. Generacja III charakteryzuje się większą galerią handlową oraz wprowadzeniem oferty rozrywkowej, a także ograniczonym udziałem operatora spożywczego. W IV generacji natomiast następuje rozbudowanie funkcji rozrywkowo-rekreacyjnej oraz pojawiają się funkcje biurowe i hotelowe. Piątej generacji centrów handlowych w Polsce jeszcze nie ma (tab. 4).

Podobnej klasyfikacji centrów handlowych dokonał A. Jarosz (2001, s. 254), który wziął w niej pod uwagę ich zagospodarowanie funkcjonalne. Podział ograniczył do centrów handlowych, w których wiodącą rolę odgrywają hipermarkety, wyróżniając: samodzielne hipermarkety, hipermarkety $z$ galeriami handlowymi, centra handlowe oraz centra handlowe ze sklepami wielkopowierzchniowymi.

Samodzielne hipermarkety to centra handlowe, gdzie główną rolę (zajmuje największą powierzchnię) odgrywa hipermarket, dodatkowo zwykle znajduje się tam kilka małych punktów handlowych i usługowych, zaspokajających najpilniejsze potrzeby. W hipermarketach z galeriami handlowymi, hipermarket zajmuje około dwóch trzecich powierzchni zabudowy, a pozostałą część stanowi pasaż handlowy ze specjalistycznymi sklepami i punktami usługowymi o zróżnicowanym asortymencie. Żeby hipermarket z galerią można było nazwać centrum handlowym, musi go charakteryzować duża liczba i różnorodność placówek handlowych i usługowych mieszczących się pod jednym dachem. Udział powierzchni hipermarketu i galerii handlowej jest w takim kompleksie porównywalny lub też przeważa na korzyść galerii. Istotnym elementem jest w nich rów- 
Tabela 5

Rodzaje lokalizacji hipermarketów i centrów handlowych

\begin{tabular}{|l|c|c|c|c|}
\hline Typy centrów handlowych & Lokalne & Komunikacyjne & Peryferyjne & Regionalne \\
\hline Samodzielne hipermarkety & + & & & \\
\hline $\begin{array}{l}\text { Hipermarkety z galeriami } \\
\text { handlowymi }\end{array}$ & + & + & $\begin{array}{c}+ \\
\text { (sporadycznie) }\end{array}$ & \\
\hline Centra handlowe & & + & + & \\
\hline $\begin{array}{l}\text { Centra handlowe ze sklepami } \\
\text { wielkopowierzchniowymi }\end{array}$ & & & + & + \\
\hline
\end{tabular}

Źródło: Opracowanie własne na podstawie A. Jarosz, 2001, Miejsce hipermarketów w przestrzeni miejskiej aglomeracji, [w:] Warszawa jako przedmiot badań w geografii spoteczno-ekonomicznej, „Prace Geograficzne”, nr 184, s. 253-254.

nież oferta gastronomiczna, a także rekreacyjna. Natomiast w centrach handlowych ze sklepami wielkopowierzchniowymi - następuje poszerzanie oferty handlowej o wprowadzenie wolno stojących, dużych specjalistycznych sklepów (na przykład sklepy meblowe, typu „dom i ogród”, z wyposażeniem elektrycznym i elektronicznym, artykułami odzieżowymi, sportowymi), a w niektórych również o część rozrywkową, na przykład kina wielkoekranowe (multipleksy) (Jarosz 2001, s. 254-255).

Centra handlowe są lokalizowane w różnych rejonach miasta, a czasami też poza jego granicami administracyjnymi. A. Jarosz (2001, s. 253-254) wyróżnił następujące ich typy lokalizacyjne: lokalne, komunikacyjne, peryferyjne, regionalne. Centra lokalne położone są zwykle wewnątrz lub na obrzeżach zwartych osiedli miejskich i nastawione są na zaspokojenie głównie potrzeb ludności mieszkającej na osiedlach sąsiednich. Centra komunikacyjne natomiast dobrze są powiązane $z$ układem drogowym, jak i z układem komunikacji publicznej, dzięki czemu klienci pochodzą z różnych części miasta, a ich pobyty są uwarunkowane dostępnością komunikacyjną. Peryferyjne centra handlowe są podobne do wcześniej omówionych, zlokalizowane są jednak przy głównych drogach wylotowych $\mathrm{z}$ miasta. Centra handlowe typu regionalnego położone są często w znacznej odległości od skupisk ludności, w niektórych przypadkach nawet poza funkcjonalnymi granicami aglomeracji.

A. Jarosz (2001, s. 253) zauważył zależności między obydwoma typologiami. Samodzielne hipermarkety najczęściej posiadają lokalizację lokalną, hipermarkety z galeriami handlowymi lokalną lub komunikacyjną 
(sporadycznie peryferyjną), centra handlowe natomiast komunikacyjną i peryferyjną, a centra handlowe ze sklepami wielkopowierzchniowymi peryferyjne i regionalne (tab. 5).

W literaturze, jak i w opracowaniach statystycznych można odnaleźć jeszcze wiele innych klasyfikacji centrów handlowych. Mimo przyjmowania podobnych kryteriów podziału zauważalna jest niekonsekwencja w zaliczaniu danych centrów handlowych do poszczególnych kategorii, zresztą kryteria podziału są często nieostre, co utrudnia prowadzenie badań porównawczych.

\subsection{Lokalizacje centrów handlowych i ich konsekwencje}

Znaczenie lokalizacji placówki handlowej nadal odgrywa dużą rolę, pomimo coraz większej mobilności klientów wynikającej z łatwości przemieszczeń (wzrost stopnia motoryzacji), rozwoju komunikacji miejskiej oraz zmian związanych $\mathrm{z}$ rozwojem Internetu (możliwość dokonywania zakupów, nie wychodząc z domu). Lokalizację powinniśmy traktować przynajmniej z trzech punktów widzenia, $z$ jednej strony jest to proces wyboru odpowiedniego miejsca przez przedsiębiorcę, gdzie główną przesłanką będzie $\mathrm{w}$ tym momencie dla niego odniesienie sukcesu i zapewnienie placówce odpowiedniej rentowności. Z drugiej strony jest to ocena lokalizacji przez klientów tych placówek, bo to właśnie ona może determinować zachowania przestrzenne nabywców. Nie można zapominać o roli władzy lokalnej, która posiada odpowiednie instrumentarium do wyznaczenia miejsca $\mathrm{w}$ przestrzeni na lokalizację, szczególnie dużych obiektów handlowych, wpływając $\mathrm{w}$ ten sposób na tworzenie i organizację odpowiednich struktur funkcjonalno-przestrzennych. W praktyce więc w przypadku lokalizacji dużych obiektów handlowych może mieć miejsce walka/gra o przestrzeń.

Głównymi decydentami w mieście w zakresie lokalizacji obiektów wielkopowierzchniowych należą władze miasta (ustalające tereny pod lokalizację działalności handlowej zgodnie $\mathrm{z}$ zapisami dokumentów planistycznych), inwestorzy (wywierający nacisk na władze w celu osiągnięcia jak najlepszej lokalizacji), drobni handlowcy (konkurujący z dużymi sieciami i mający wpływ na decyzje lokalizacyjne władz miasta) oraz mieszkańcy (aprobujący określone działania władz i inwestorów lub protestujący w przypadku lokalizacji pogarszających ich warunki życia) (rys. 4) (Kaczmarek 2011, s. 78-79). 


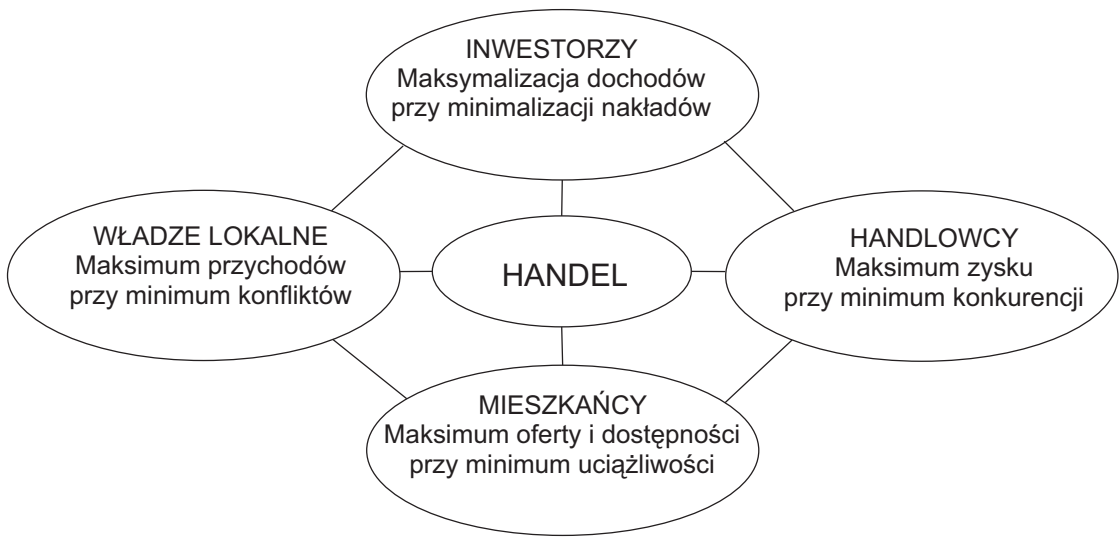

Rys 4. Główni uczestnicy „gry o przestrzeń” przy lokalizacji obiektów handlowych.

Źródło: T. Kaczmarek, 2011, Handel detaliczny w rozwoju funkcjonalnym i przestrzennym miast w Polsce, [w:] Wdowicka M., Mierzejewska L. (red.) Problemy rozwoju lokalnego i regionalnego na poczqtku XXI wieku, Biuletyn Instytutu Geografii Społeczno Ekonomicznej i Gospodarki Przestrzennej Uniwersytetu im. Adama Mickiewicza, Poznań, s. 78.

Pojęcie lokalizacji można rozpatrywać w dwóch ujęciach czynnościowym (dynamicznym) oraz rezultatowym (statycznym) ${ }^{22}$. W pierwszym aspekcie zawiera w sobie elementy decyzyjności, czyli odnosi się do procedury wyboru rodzaju inwestycji i jej miejsca, czyli lokalizację tu rozumiemy jako procedurę podejmowania decyzji lokalizacyjnej. W drugim ujęciu lokalizację traktujemy jako wynik przeprowadzonej procedury i rozpatrujemy ją poprzez już konkretną lokalizację, czyli poprzez miejsce prowadzenia działalności, będącej wynikiem wcześniej podjętej decyzji lokalizacyjnej (Budner 2003, s. 22; Godlewska 2001, s. 13). W pierwszym, dynamicznym, rozumieniu lokalizacji mamy do czynienia $z$ dwiema sytuacjami decyzyjnymi otóż dokonujemy tak zwanej lokalizacji ogólnej i szczegółowej. $Z$ punktu widzenia przedsiębiorcy najczęściej proces wyboru lokalizacji przebiega właśnie dwuetapowo, w pierwszym etapie dokonuje się lokalizacji ogólnej, w którym następuje wybór regionu, miasta czy obszaru podmiejskiego, w drugim etapie przeprowadza się wybór lokalizacji szczegółowej, czyli konkretnego miejsca usytuowania obiektu, terenu realizacji danego przedsięwzięcia (Budner 2003, Budner 2011, Śmigielska 2004, Szulce 1998, Pilarczyk 2001, Godlewska 2001).

${ }^{22}$ Definicję lokalizacji w znaczeniu ogólnym i szczegółowym proponuje J. Kaczmarek (2001, s. 77). 
W niektórych podejściach ekonomiści przy wyborze i ocenie lokalizacji wyróżniają trzy jej etapy. Pierwszy etap to ocena na poziomie makro (wybór kraju, regionu), po analizie zewnętrznych czynników marketingowych, makroekonomicznych, między innymi politycznych, ekonomicznych, społecznych, demograficznych i technicznych. Ocena na tym poziomie dotyczy w szcsególności liczby mieszkańców, struktury wieku, dochodów gospodarstw domowych, zmienności popytu, stylu życia i wzorców konsumpcji. W drugim etapie przeprowadza się ocenę na poziomie mikro (analiza konkretnego obszaru handlowego; znalezienie i ocena atrakcyjnych miejsc lokalizacji). Najlepsze miejsca handlowe wyszukuje się poprzez analizę klimatu biznesowego, natężenia konkurencji, zdolności do rozwoju sieci handlowej oraz zidentyfikowania lokalnych uwarunkowań demograficznych i stylu życia grupy docelowej obsługiwanej przez detalistę. Trzeci etap to wybór i ocena atrakcyjności konkretnego miejsca na nowy sklep. Analiza uwzględnia dostępność (miejsca parkingowe, łatwość dojazdu), architekturę budynku i wnętrza lokalu, koszt adaptacji i warunków najmu lokalu (Sullivan, Adcock 2003, s. 129; Otto, Olczak 2007, s. 204).

W fazie lokalizacji ogólnej „ważną rolę odgrywają zarówno tzw. czynniki miękkie (m.in. wiedza inwestora o regionie, doświadczenia innych firm), jak i czynniki twarde ${ }^{23}$ - kosztowe (np. popyt regionalny, analizy porównawcze nakładów i wyników w poszczególnych regionach, analiza lokalnych czynników kosztowych)”. W przypadku lokalizacji szczegółowej ,jest to wybór rozwiązania optymalnego w zbiorze rozwiązań dopuszczalnych i wiąże się on ze wskazaniem konkretnej działki, ze sporządzeniem projektu jej zagospodarowania i rozmieszczeniem poszczególnych elementów kompleksu, określeniem jego relacji do innych obiektów i infrastruktury. Aby inwestor wybrał określoną lokalizację, musi ona spełniać jego wymogi, tzn. charakteryzować się wysoką atrakcyjnością lokalizacyjną” (Budner 2011, s. 54).

Decyzje dotyczące lokalizacji placówek handlowych obejmują w pierwszej kolejności lokalizację ogólną rozumianą przez B. Pilarczyka (2001, s. 161) oraz J. Mikołajczyka (2008b, s. 292) jako „wyznaczenie liczby placówek handlowych w danej przestrzeni”. Wybór lokalizacji ogólnej (regio-

\footnotetext{
${ }^{23}$ Czynniki twarde mają charakter mierzalny (na przykład dostęp do infrastruktury, struktura rynku pracy, struktura branżowa), natomiast czynniki miękkie są niemierzalne (na przykład jakość środowiska antropogenicznego i naturalnego, klimat inwestycyjny, patriotyzm lokalny (Godlewska 2001, s. 17).
} 
nu, miasta czy obszaru podmiejskiego) ,wiąże się z potrzebą zbadania, jak w rejonie jej przyszłego działania kształtuje się zapotrzebowanie na planowany do zaoferowania asortyment towarów oraz jak przedstawiają się lokalne warunki konkurencji” (Śmigielska 2004, s. 59). Według W. Budnera (2011, s. 53) przy podejmowaniu decyzji o lokalizacji ogólnej obiektu handlowego należy rozpatrywać cztery grupy czynników:

- ekonomiczne (siła nabywcza, wielkość i struktura sprzedaży; chodzi o dochody ludności, wyposażenie gospodarstw w dobra trwałego użytku);

- ludnościowe (skala ich potrzeb; chodzi tu o liczbę ludności i jej cechy demograficzne, to znaczy struktura według wieku, płci, wykształcenia, aktywności zawodowej i tym podobnych);

- efektywności przedsiębiorstw handlowych (determinowane przez już istniejące placówki, ich dotychczasową lokalizację i urządzenie, wizerunek, poziom obsługi, jakość oraz różnorodność oferty handlowej);

- funkcjonalno-przestrzenne obszaru potencjalnej lokalizacji (struktura sieci osadniczej, poziom urbanizacji oraz w wymiarze miasta: układ urbanistyczno-architektoniczny i komunikacyjny, w tym infrastruktura techniczna miasta).

Rozszerzoną i pogrupowaną listę czynników lokalizacji placówek handlowych przedstawiła H. Szulce (1998, s. 216), wyróżniając sześć grup: demograficzne, ekonomiczne, urbanizacyjne, transportowe, związane z konkurencją i finansowe. Tę listę rozszerzył następnie J. Mikołajczyk (2008b, s. 294) o dwie grupy czynników - społeczno-kulturowe i prawne (tab. 6).

Tabela 6

Determinanty lokalizacji placówek handlowych

\begin{tabular}{|c|c|}
\hline Grupa czynników & Czynniki szczegółowe \\
\hline Demograficzne & $\begin{array}{l}\text { - liczba ludności } \\
\text { - gęstość zaludnienia } \\
\text { - zróżnicowanie ludności według płci i wieku } \\
\text { - liczba i wielkość gospodarstw domowych }\end{array}$ \\
\hline Ekonomiczne & $\begin{array}{l}\text { - poziom i dynamika wzrostu dochodów nabywców } \\
\text { - popyt potencjalny i efektywny } \\
\text { - styl życia i modele konsumpcji } \\
\text { - stabilność ekonomiczna regionu } \\
\text { - stopa bezrobocia }\end{array}$ \\
\hline
\end{tabular}


Tabela 6 (ciąg dalszy)

\begin{tabular}{|c|c|}
\hline Grupa czynników & Czynniki szczegółowe \\
\hline Społeczno-kulturowe & $\begin{array}{l}\text { - } \text { model konsumpcji } \\
\text { - ilość wolnego czasu } \\
\text { - mentalność społeczeństwa }\end{array}$ \\
\hline Urbanizacyjne & $\begin{array}{l}\text { - } \text { wielkość aglomeracji } \\
\text { - plan przestrzennego zagospodarowania terenu } \\
\text { - rodzaj zabudowy (gęstość, wiek, styl) }\end{array}$ \\
\hline Transportowe & $\begin{array}{l}\text { - } \text { poziom i dynamika rozwoju transportu publicznego } \\
\text { - } \text { stopień zmotoryzowania segmentu docelowego nabywców } \\
\text { - dogodna lokalizacja i dostępność parkingów } \\
\text { - dostępność środków transportu dla dostawców i personelu }\end{array}$ \\
\hline Związane z konkurencją & $\begin{array}{l}\text { - natężenie konkurencji bezpośredniej i pośredniej } \\
\text { - } \quad \text { szanse i zagrożenia (lokalizacja obok renomowanego konkurenta) } \\
\text { - } \text { strategie stosowane przez lokalnych konkurentów }\end{array}$ \\
\hline Finansowe & $\begin{array}{l}\text { - } \text { ceny gruntów i nieruchomości } \\
\text { - koszty leasingu, wykupu koncesji } \\
\text { - koszty budowy i modernizacji obiektów handlowych } \\
\text { - koszty ochrony jednostki handlowej }\end{array}$ \\
\hline Prawne $^{\mathrm{a}}$ & $\begin{array}{l}\text { - } \text { przepisy budowlane } \\
\text { - zezwolenia na otwarcie jednostki } \\
\text { - } \text { przepisy dotyczące czasu otwarcia sklepu }\end{array}$ \\
\hline
\end{tabular}

Źródło: H. Szulce, 1998, Struktury i strategie w handlu, PWE, Warszawa, s. 216; a J. Mikołajczyk, 2008b, Przestrzenne aspekty funkcjonowania handlu, [w:] M. Sławińska, Kompendium wiedzy o handlu, PWN, Warszawa, s. 294.

W przypadku lokalizacji szczegółowej, czyli wyboru konkretnego miejsca w przestrzeni, lokalizacja placówek sieci handlowej „związana jest ściśle z przestrzenną strukturą handlu, to znaczy rodzajem zabudowy, występowaniem dzielnic o określonych funkcjach społeczno-gospodarczych, ciągami ulic itp.” (Szulce 1998, s. 219), czyli głównymi czynnikami lokalizacji szczegółowej są rodzaj zabudowy terenu, istniejąca sieć handlowa oraz wielkość sklepu i branża, jaką reprezentuje (rys. 5). „Dokonując wyboru lokalizacji szczegółowej, detalista ocenia: dostępność danego miejsca (istnienie dróg dojazdowych, możliwość parkowania samochodów), atrakcyjność miejsca z uwagi na przebieg ciągów komunikacyjnych i ruchu pieszego (czynniki decydujące o natężeniu potoku nabywców), komplementarność oferty $\mathrm{z}$ asortymentem sklepów zlokalizowanych $\mathrm{w}$ pobliżu, oraz widoczność okna wystawowego, szyldu dla przechodzących bądź przejeżdżających konsumentów" (Śmigielska 2004, s. 59). 


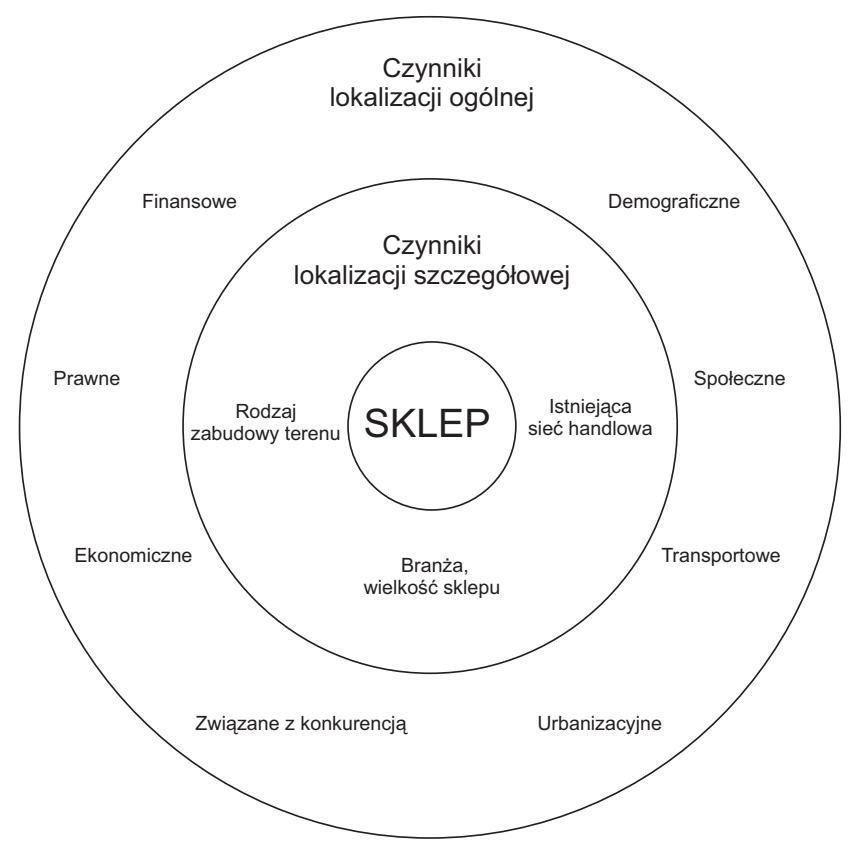

Rys 5. Czynniki lokalizacji ogólnej i szczegółowej placówek handlowych.

Źródło: J. Mikołajczyk, 2008b, Przestrzenne aspekty funkcjonowania handlu, [w:] M. Sławińska (red.), Kompendium wiedzy o handlu, PWN, Warszawa, s. 293.

Lokalizacja placówki handlowej w dużej mierze zależy od jej typu (formatu sklepu) i wielkości. Część placówek szczególnie o małych obszarach handlowych będzie lokalizować się w pobliżu miejsc zamieszkania, miejsc pracy klientów czy miejsc o dużym natężeniu potoków nabywców. Mogą to więc być centra miast, osiedla mieszkaniowe i/lub tereny przy głównych ciągach komunikacyjnych. Wraz z rozwojem motoryzacji i większą mobilnością ludności czynnik zamieszkania lub pracy nabywców zapewniający im wygodę zakupów, jak zauważa G. Śmigielska (2004, s. 59), obecnie odgrywa znaczenie już tylko w wypadku małych sklepów spożywczych, aptek i sklepów typu „wygodny sklep” (convenience store) (tab. 7).

"W strategiach lokalizacyjnych dużych firm (sieci) handlowych uwidacznia się prawidłowość, że im większa skala działalności handlowej, tym większego znaczenia nabierają nie pojedyncze czynniki, ale ich zespoły, oddziałujące zarówno w skali ogólnokrajowej, jak i lokalnej” (tab. 8) (Kaczmarek 2010, s. 149). 
Tabela 7

Podstawowe rodzaje/formaty handlu detalicznego i ich lokalizacje

\begin{tabular}{|c|c|c|}
\hline $\begin{array}{c}\text { Rodzaj/ } \\
\text { /format sklepu }\end{array}$ & $\begin{array}{c}\text { Charakterystyka } \\
\text { (powierzchnia, oferta) }\end{array}$ & Lokalizacja \\
\hline Sklep spożywczy & $\begin{array}{l}\text { Sklepy o powierzchni do } 100 \text { m². Głównie } \\
\text { z artykułami spożywczymi i drogeryjno- } \\
\text {-kosmetycznymi (około 20\%). }\end{array}$ & $\begin{array}{l}\text { W pobliżu miejsca zamieszkania } \\
\text { klientów. }\end{array}$ \\
\hline $\begin{array}{l}\text { Sklep } \\
\text { specjalistyczny }\end{array}$ & $\begin{array}{l}\text { Małe sklepy o powierzchni do } 50 \mathrm{~m}^{2} \text {, } \\
\text { z asortymentem należącym do jednej lub kilku } \\
\text { grup towarowych. }\end{array}$ & $\begin{array}{l}\text { W centrach handlowych, } \\
\text { centrach miast przy ulicach } \\
\text { handlowych. }\end{array}$ \\
\hline „Wygodny sklep”a & $\begin{array}{l}0 \text { powierzchni około } 100 \mathrm{~m}^{2}, \mathrm{z} \text { artykułami FMCG, } \\
\text { uzupełniony o towary będące w zainteresowaniu } \\
\text { klientów zmotoryzowanych. }\end{array}$ & $\begin{array}{l}\text { W pobliżu miejsca zamieszkania } \\
\text { klientów, przy stacjach } \\
\text { benzynowych, dworcach, } \\
\text { w sąsiedztwie placówek } \\
\text { gastronomicznych. }\end{array}$ \\
\hline Sklep powszechny & $\begin{array}{l}\text { Sklepy o powierzchni } 120-400 \mathrm{~m}^{2} \mathrm{z} \text { artykułami } \\
\text { FMCG (gdzie artykuły nieżywnościowe stanowią } \\
\text { około 15\%). }\end{array}$ & $\begin{array}{l}\text { Zazwyczaj w pobliżu miejsca } \\
\text { zamieszkania klientów. }\end{array}$ \\
\hline $\begin{array}{l}\text { Sklep } \\
\text { wyspecjalizowany }\end{array}$ & $\begin{array}{l}\text { Sklepy o powierzchni } 120-600 \mathrm{~m}^{2} \text { z szerokim } \\
\text { asortymentem towarów przeznaczonych do } \\
\text { kompleksowego zaspokojenia określonych } \\
\text { potrzeb. }\end{array}$ & $\begin{array}{l}\text { W centrach handlowych } \\
\text { i centrach miast. }\end{array}$ \\
\hline Sklep branżowy & $\begin{array}{l}\text { Sklepy o zróżnicowanej powierzchni z towarami } \\
\text { z wielu grup towarowych należących do jednej } \\
\text { branży. }\end{array}$ & $\begin{array}{l}\text { W centrach handlowych } \\
\text { i centrach miast. }\end{array}$ \\
\hline Supermarket & $\begin{array}{l}\text { Sklepy o powierzchni 400-2500 m² z artykułami } \\
\text { FMCG i nieżywnościowymi (około 30\%). }\end{array}$ & $\begin{array}{l}\text { Zazwyczaj w osiedlach } \\
\text { mieszkaniowych, poza ścisłymi } \\
\text { centrami miast. }\end{array}$ \\
\hline Hipermarket & $\begin{array}{l}\text { Sklepy o powierzchni powyżej } 2500 \mathrm{~m}^{2} \\
\text { z artykułami żywnościowymi wszystkich branż } \\
\text { i nieżywnościowymi (50\%). }\end{array}$ & $\begin{array}{l}\text { Poza obszarami ścisłego } \\
\text { centrum miasta, zazwyczaj } \\
\text { na peryferiach i przy drogach } \\
\text { szybkiego ruchu. }\end{array}$ \\
\hline Dom towarowy & $\begin{array}{l}\text { Sklep o powierzchni powyżej } 2000 \text { m² głównie } \text { z artykułami nieżywnościowymi, posiadający } \\
\text { często dział żywnościowy (centralne zaopatrywanie } \\
\text { u producentów). }\end{array}$ & W centrum miasta. \\
\hline „Zabójca kategorii”b & $\begin{array}{l}\text { Sklepy o powierzchni powyżej } 2500 \mathrm{~m}^{2} \\
\text { z artykułami wybranej branży. }\end{array}$ & $\begin{array}{l}\text { Poza obszarami ścisłego } \\
\text { centrum miasta, zazwyczaj } \\
\text { na obrzeżach i przy drogach } \\
\text { szybkiego ruchu. }\end{array}$ \\
\hline Sklep dyskontowy & $\begin{array}{l}\text { Sklep o powierzchni powyżej } 300 \text { m². Mogą } \\
\text { występować różne typy asortymentu w zależności } \\
\text { od rodzaju sklepu: art. FMCG, elektronika, AGD. }\end{array}$ & $\begin{array}{l}\text { Poza obszarami ścisłego } \\
\text { centrum miasta }\end{array}$ \\
\hline
\end{tabular}




\section{Tabela 7 (ciąg dalszy)}

${ }^{a}$ Wygodny sklep (convenience store) - podstawą tej koncepcji jest dogodność dla nabywców, jest to sklep oferujący produkty spożywcze i niespożywcze, ulokowany w miejscach o wysokim natężeniu potoków nabywców (blisko nabywców) tam gdzie mogą dotrzeć pieszo. Poziom cen jest w nich wyższy niż w innych oferujących artykuły spożywcze (Borusiak 2008, s. 190).

b Zabójca kategorii (category killer) - stanowi odmianę sklepu specjalistycznego. Sklepy tego typu charakteryzują się relatywnie dużą powierzchnią sprzedażową (do kilkunastu tys. $\mathrm{m}^{2}$ ), bardzo głębokim asortymentem w obrębie wybranych grup produktów (na przykład sprzęt elektroniczny, meble, sprzęt sportowy, zabawki), relatywnie niskim poziomem cen, dużym zakresem przestrzennego oddziaływania (Borusiak 2008, s. 181). Pojawienie się tego typu sklepów wielkopowierzchniowych oferujących szeroki i stosunkowo głęboki asortyment zaspokajający w sposób kompleksowy określone potrzeby nabywców „zabija” małe sklepy z jedną lub kilkoma kategoriami produktów (Śmigielska 2004, s. 50).

Źródło: Opracowanie własne na podstawie G. Śmigielska, Oferta ustugowa handlu detalicznego, [w:] J. Szumilak (red.), 2004, Handel detaliczny funkcjonowanie i kierunki rozwoju, Oficyna Ekonomiczna, Kraków, s. 67-69.

\section{Tabela 8}

\section{Czynniki lokalizacji dużych przedsiębiorstw (sieci handlowych) w zależności od skali przestrzennej}

\begin{tabular}{|c|c|c|c|}
\hline Czynnik lokalizacji & $\begin{array}{l}\text { Lokalizacja } \\
\text { ogólna w skali } \\
\text { krajowej } \\
\text { i regionalnej }\end{array}$ & $\begin{array}{l}\text { Lokalizacja } \\
\text { ogólna w skali } \\
\text { regionalnej }\end{array}$ & $\begin{array}{l}\text { Lokalizacja } \\
\text { szczegółowa } \\
\text { w skali } \\
\text { lokalnej } \\
\text { i miejscowej }\end{array}$ \\
\hline Polityka handlowa państwa & & & \\
\hline Stabilność polityczna & & & \\
\hline Stabilność gospodarcza & & & \\
\hline Stabilność prawna inwestowania & & & \\
\hline Koszty siły roboczej & & & \\
\hline Bliskość placówek otoczenia biznesu & & & \\
\hline Bliskość siedziby firmy & & & \\
\hline Lokalizacja centrów logistycznych & & & \\
\hline Bliskość granicy państwowej & & & \\
\hline Bliskość źródeł zaopatrzenia & & & \\
\hline Liczba (koncentracja) Iudności & & & \\
\hline Siła nabywcza konsumentów & & & \\
\hline Struktura demograficzna konsumentów & & & \\
\hline Preferencje zakupowe konsumentów & & & \\
\hline Bliskość szlaków transportowych & & & \\
\hline Bliskość innych, konkurencyjnych sieci & & & \\
\hline
\end{tabular}


Tabela 8 (ciąg dalszy)

\begin{tabular}{|l|l|l|l|}
\hline \multicolumn{1}{|c|}{ Czynnik lokalizacji } & $\begin{array}{l}\text { Lokalizacja } \\
\text { ogólna w skali } \\
\text { krajowej } \\
\text { i regionalnej }\end{array}$ & $\begin{array}{l}\text { Lokalizacja } \\
\text { ogólna w skali } \\
\text { regionalnej }\end{array}$ & $\begin{array}{l}\text { Lokalizacja } \\
\text { szczegółowa } \\
\text { w skali } \\
\text { lokalnej } \\
\text { i miejscowej }\end{array}$ \\
\hline Ceny gruntów, dzierżawy & & & \\
\hline Polityka władz samorządowych & & & \\
\hline Dostępność komunikacją publiczną & & & \\
\hline Dostępność komunikacją indywidualną & & & \\
\hline Nastawienie mieszkańców do lokalizacji & & & \\
\hline $\begin{array}{l}\text { Oddziaływanie na lokalny układ } \\
\text { komunikacyjny }\end{array}$ & & & \\
\hline Oddziaływanie na lokalny rynek pracy & & & \\
\hline $\begin{array}{l}\text { Oddziaływanie na lokalne środowisko } \\
\text { przyrodnicze }\end{array}$ & & & \\
\hline
\end{tabular}

Źródło: T. Kaczmarek, 2010, Struktura przestrzenna handlu detalicznego. Od skali globalnej do lokalnej, Wydawnictwo Naukowe Bogucki, Poznań, s. 150.

Pisząc o lokalizacji nowych placówek handlowych, należy również zwrócić uwagę, że często lokalizują się one w pobliżu już istniejących sklepów, nawet jeżeli reprezentują tę samą branżę handlową, można wtedy mówić o „przyrostowej” lokalizacji. W przypadku gdy powstają w nowych miejscach, pozbawionych placówek handlowych można ją wtedy określić mianem lokalizacji „na surowym korzeniu”. W obydwu sytuacjach może mieć to miejsce zarówno w śródmiejskiej części miasta, na osiedlach mieszkaniowych, jak i na miejskich peryferiach. Centralne części miasta, jak również osiedlowe jednostki mieszkaniowe są mocno zurbanizowane, dlatego tu mamy do czynienia częściej z lokalizacją przyrostową. W tych rejonach miasta mogą też powstawać placówki „na surowym korzeniu” warunkiem jest jednak znalezienie wolnej działki (lokalizacja czynna) lub zmiana funkcjonalna lokalu (lokalizacja bierna). W tym drugim przypadku może nastąpić zmiana przeznaczenia obiektu, na przykład z funkcji magazynowej na handlową. Lokalizacja może mieć również charakter „wtórnej”, to znaczy że lokal pełniący pierwotnie funkcje handlowe nadal takim pozostaje (zmienia się właściciel i/lub sprzedawany asortyment, branża). Taka 
często „przyrostowa” forma koncentracji przestrzenno-funkcjonalnej może powstać w sposób spontaniczny, symptomatyczny (wynika $\mathrm{z}$ historycznych uwarunkowań, ewolucyjnego rozwoju), może też być wykreowana przez odgórne decyzje planistów, którzy zaplanowali centrum „handlowo-usługowe" dla danego osiedla mieszkaniowego.

W przypadku centrum miasta jego ponadlokalny i prestiżowy charakter może być magnesem do lokalizacji nowych placówek handlowych. Zlokalizowanie sklepu w tym rejonie nie zawsze musi mieć charakter dochodowy, ale może być formą reklamy danej marki czy firmy (oczywiście to dotyczy firm, które mają więcej niż jedną placówkę i mogą sobie pozwolić, że jedna z nich mniej zarabia lub przynosi straty, co rekompensują zyski z pozostałych placówek). W takim przypadku liczy się wykreowanie w odbiorcach pozytywnego wizerunku, uzyskanie prestiżu, wpływ na zwiększoną rozpoznawalność marki/firmy, które to mogą procentować w innych punktach lokalizacyjnych zwiększonymi przychodami. Główny problem w lokalizacji tego typu placówek może stanowić odpowiedni zasób wolnej przestrzeni pod parkingi. Współcześnie większość klientów jest zmotoryzowanych, w związku z czym istotna dla nich jest możliwość łatwego parkowania samochodu i najlepiej bez uiszczania za to opłaty (na przykład Galeria Łódzka zlokalizowana w centrum miasta posiada parking płatny), tego typu wariant jest łatwiejszy do spełnienia na terenach słabiej zurbanizowanych.

W strefach peryferyjnych miasta oraz na innych terenach słabozurbanizowanych, gdzie można nadal znaleźć niezagospodarowane działki, częściej spotykamy lokalizacje „na surowym korzeniu”, czyli na nowo wykreowanych miejscach usług w tym handlowych. Tego typu lokalizacje są bardziej „swobodnymi” w zakresie rozplanowania obiektów i wizualizacji (w strefach śródmiejskich często wymuszone przepisami lub wymogami konserwatorskimi, na przykład Manufaktura w Łodzi) oraz prostszymi w uzyskaniu odpowiednich zezwoleń. Ze względu na wcześniejszą funkcję danego obszaru, na którym dochodzi do lokalizacji obiektów handlowych (lub innych), możemy mówić o lokalizacji greenfield (tereny rolnicze), brownfield (tereny poprzemysłowe) oraz o lokalizacji zastanej (tereny mieszkaniowo-usługowe) (rys. 6).

M. Pietraszewski (2000, s. 201-204) sformułował zasady racjonalnego rozmieszczenia jednostek handlowych, w które wpisuje się również lokalizacja centrów handlowych. Pierwsza $z$ zasad polega na maksymalnym 


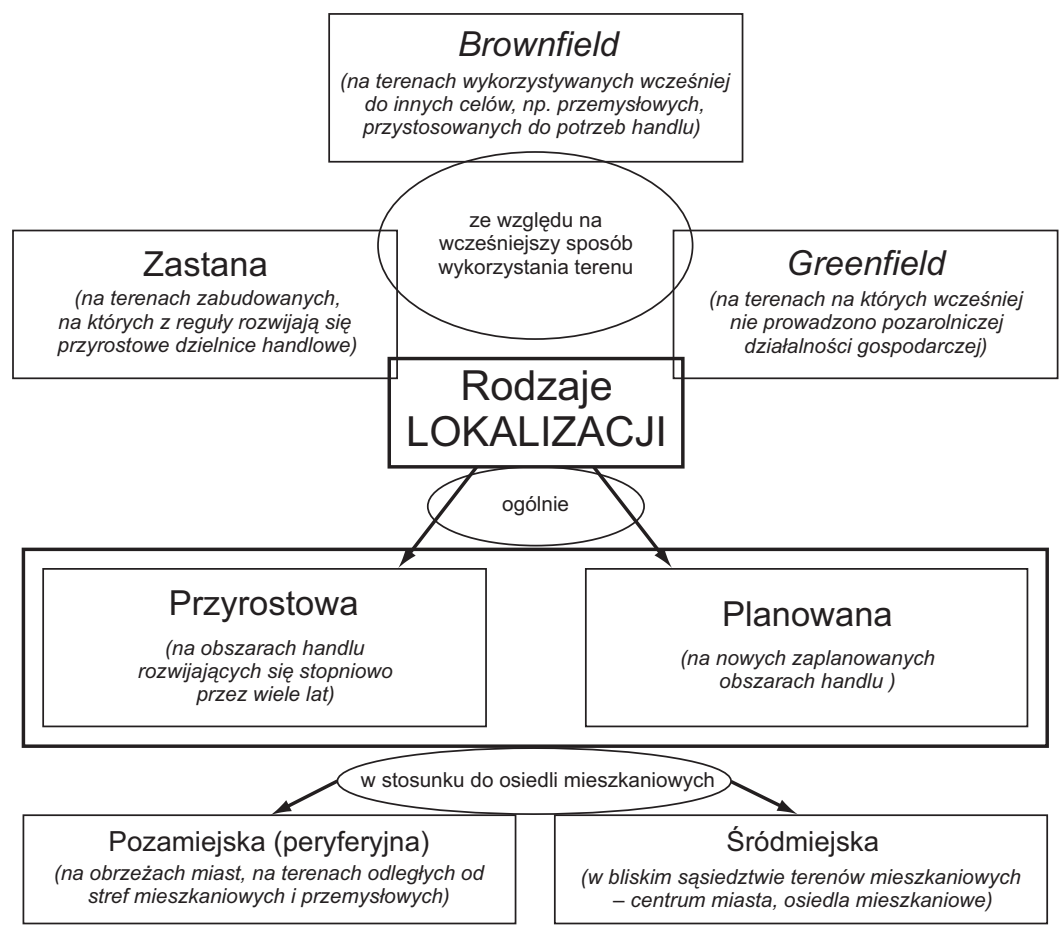

Rys 6. Rodzaje lokalizacji.

Źródło: Opracowanie własne na podstawie M. Sullivan, D. Adcock, 2003, Marketing w handlu detalicznym, Oficyna Wydawnicza, Kraków, s. 128.

zbliżeniu lokalizacji do miejsc występowania potrzeb (cel - skrócenie drogi nabywcy do towaru i usługi, opłacalny rynek zbytu). Druga zasada to grupowanie jednostek w miejscach sprzyjających lokalizacji. Wynika ona $\mathrm{z}$ faktu, że istnieją dobre przestrzenne lokalizacje oraz $\mathrm{z}$ tego, że klienci pragną kompleksowo zaspokoić kilka potrzeb, co wpływa na tworzenie się sieci skoncentrowanej w określonym miejscu (na przykład ulice handlowe, pasaże handlowe, zespoły pawilonów handlowo-usługowych, centra/ /ośrodki handlowe, hale targowe, targowiska, bazary). Następna zasada to dostosowanie lokalizacji do istniejącej infrastruktury społecznej $\mathrm{i}$ technicznej, co jest wynikiem szukania rynków zbytu i korzystnych warunków działania. Główne znaczenie ma tu dogodna komunikacja, związana z transportem towarów i dojazdem klientów oraz możliwością parkowa- 
nia, stąd wiele centrów handlowych powstaje na obrzeżach miast w miejscach dobrego dojazdu i z możliwością przeznaczenia dużych obszarów pod budowę parkingów. W rozmieszczeniu placówek handlowych duże znaczenie odgrywa również zasada przewagi konkurencyjnej (wybór lepszej lokalizacji, niż posiada konkurencja) oraz zasada tworzenia własnej sieci jednostek handlowych (obsługa większego terenu i możliwość rozwiązywania niektórych problemów w skali makro).

W. Budner (2011, s. 59) uważa, że przy lokalizacji jednostek handlowych powinno się uwzględniać regułę trzech stref (śródmieścia, stref osiedlowych, peryferii miasta) określającą proporcje udziału powierzchni handlowej w poszczególnych strefach $(40 \%, 20 \%, 40 \%)$. Centralna strefa śródmiejska to obszar szczególnej troski, wizytówka miasta, często określająca jego tożsamość, obszar „wspólny” mieszkańców, dający lokalizowanym obiektom prestiż, w której handel detaliczny odgrywa ważną rolę w rozwoju oraz w procesie jej ożywiania. Osiedla to domena handlu artykułami zapotrzebowania codziennego i aperiodycznego, więc odpowiednia polityka przestrzenna na tym obszarze powinna w największym stopniu uwzględniać interesy kupców i małych przedsiębiorstw handlowych. Peryferie $\mathrm{z}$ kolei to strefa dla lokalizacji przedsiębiorstw handlu wielkopowierzchniowego, gdzie powinien być oferowany asortyment, który wymaga większej powierzchni sprzedażowej, na przykład meble, materiały budowlane i tym podobne.

Analizując rozmieszczenie centrów i galerii handlowych w Polsce, stwierdzono, że mieszczą się one w zakresie czterech typów lokalizacji w śródmieściach miast, przy drogach krajowych i autostradach, na terenach i w obiektach poprzemysłowych, inne lokalizacje (na przykad na obrzeżu terenów zainwestowanych, na osi planowanego rozwoju miasta) (Dołhun 2011, s. 5). W pierwszym okresie dynamicznego rozwoju centrów handlowych lokalizacje najczęściej miay charakter peryferyjny w stosunku do centrów miast. Jak pisze jednak G. Makowski (2010, s. 52): „Z czasem zauważono, że budowanie centrów handlowych na przedmieściach przyczynia się do wyludniania centrów miast, w związku z czym pewnym rozwiązaniem okazało się przeniesienie galerii handlowych do ich serc (śródmieście)", również B. Pilarczyk (2001, s. 164) już wcześniej zauważył, że doświadczenia brytyjskie, niemieckie i francuskie wskazują na tendencję do lokalizacji ośrodków handlowych w centrum miasta. 
Każda lokalizacja pociąga za sobą różne konsekwencje, zarówno natury negatywnej, jak i pozytywnej. W przypadku centrów handlowych, które stanowią duże lub bardzo duże kompleksy koncentracji wielu placówek usługowych (w tym głównie handlowych), a często również kulturalnych i rozrywkowych, wpływ na otaczającą przestrzeń oraz ludzi jest znaczący i odbija swoje piętno zarówno w wymiarze materialnym jak i w wymiarze niematerialnym (społecznym).

Zlokalizowanie tego typu kompleksów (lub pojedynczych obiektów wielkopowierzchniowych typu hipermarkety) w obszarach śródmiejskich przyczynia się często do ożywienia centrum miasta, do wprowadzenia drugiego życia, reaktywowania lub uzupełnienia funkcji ogólnomiejskich tego fragmentu przestrzeni miejskiej lub wręcz przywrócenia albo wytworzenia nowych funkcji egzogenicznych. Centra handlowe przy lokalizacji śródmiejskiej zajmują często tereny zaniedbane, poprzemysłowe, nieużytki, które to dzięki tego typu inwestycjom odzyskują swój blask (przykład Manufaktury i Galerii Łódzkiej). W związku z tego typu realizacjami mają miejsce dwa główne sposoby przekształceń, z jednej strony może się dokonać proces tworzenia od podstaw nowych obiektów, najczęściej na nieużytkach (o te jednak trudno w centrach miast) lub częściej spotykany w strefach śródmiejskich proces rewitalizacji terenów najczęściej poprzemysłowych (co miało miejsce między innymi w Łodzi).

W przypadku przekształceń terenów już wcześniej zagospodarowanych mogą pojawić się liczne problemy, skala ich zależy od stopnia i formy zagospodarowania terenu. Obszary śródmiejskie charakteryzują się często dużym udziałem obiektów zabytkowych (wpisanych na listę konserwatora zabytków), podlegających wymaganiom stawianym między innymi przez ustawę o ochronie zabytków i opiece nad zabytkami ${ }^{24}$. W związku z tym to te obiekty stawiają największe wyzwania, ponieważ postępowanie z nimi (możliwości przekształceń adaptacyjnych) są determinowane przez ustawodawcę, jak również mogą podlegać przepisom i ustaleniom wewnętrznym (gminnym), na przykład wynikającym z prawa lokalnego, czyli z aktualnych zapisów zamieszczonych w miejscowym planie zagospodarowania przestrzennego. Tego typu przepisy posiadają wpływ na ostateczny wygląd nowo wykreowanego centrum handlowego, który może być również swego

${ }^{24}$ Ustawa o ochronie zabytków i opiece nad zabytkami z 23 lipca 2003 roku; Dz.U. z 2003 roku, Nr 162, poz. 1568, ze zm. 
rodzaju kompromisem między interesami władz miejskich, służb odpowiedzialnych za opiekę nad zabytkami, inwestorem i potrzebami społeczeństwa albo przestrzenią wykreowaną przez demiurga urbanistę. W przypadku obiektów wpisanych na listę zabytków największy wpływ mają osoby odpowiedzialne za zachowanie dziedzictwa kulturowego.

Handel odgrywał i odgrywa nadal ważną rolę w rozwoju miast. Szczególnie handel detaliczny, który pełni różne ważne funkcje: gospodarcze (tworzy miejsca pracy, dostarcza dochodów mieszkańcom, zasila budżet miasta i państwa), społeczno-kulturowe (jest miejscem wydarzeń kulturalnych, podnosi atrakcyjność miasta) również urbanistyczno-architektoniczne (zmiana krajobrazu, różnorodność zagospodarowania) (Budner 2011, s. 58). Wszystkie te funkcje szczególnie uwidaczniają się po wybudowaniu wielkopowierzchniowych obiektów handlowych (WOH), w tym oczywiście szczególnie dotyczy to dużych kompleksów handlowo-usługowych, jakimi są centra handlowe.

W zależności od lokalizacji centrum handlowego w przestrzeni miasta: w śródmieściu, na peryferiach przy drogach wylotowych lub na terenach poprzemysłowych pojawiają się różne korzyści i zagrożenia dla obszarów, na których są budowane, jak i dla ich otoczenia. Lokalizacja w śródmiejskiej części miasta doprowadza do rewitalizacji, poprawy infrastruktury technicznej (na przykład remonty dróg, lepsza organizacja ruchu drogowego), tym samym podnosi atrakcyjność terenów i wpływa na wzrost wartości nieruchomości w ich otoczeniu (podobnie jak na terenach poprzemysłowych). $\mathrm{Z}$ drugiej strony takie usytuowanie kompleksu handlowego może wpynąć na upadek drobnych handlowych firm detalicznych oraz wzrost trudności komunikacyjnych, na przykład bardziej zakorkowane drogi dojazdowe ${ }^{25}$. $\mathrm{Na}$ terenach peryferyjnych i poprzemysłowych duże znaczenie może odegrać aktywizacja gospodarcza tych terenów (powstawanie nowych firm), co może jednocześnie przełożyć się na niekorzystne zjawiska w śródmieściu (np. dekapitalizacja tkanki handlowej, zmniejszenie atrakcyjności centrum miasta jako celu wyjazdów, oraz jako terenu inwestycyjnego) (tab. 9).

\footnotetext{
${ }^{25}$ Im bliżej centrum miasta powstaje wielki sklep, tym mniejsze szanse mają tradycyjni handlowcy i bardziej jest ono zagrożone degradacją. Władze pozwalając na zbyt bliską lokalizację hipermarketu, bezpośrednio wpływają na obniżenie rangi centrum miasta, jego użyteczności handlowej i pozahandlowej (turystycznej, rekreacyjnej, wypoczynkowej i tym podobnej). Hipermarket działający dłużej w centrum miasta może (ale nie musi) zwiększyć bezrobocie i pauperyzację ludzi z inicjatywą, ale z małym kapitałem (Perenc, Rak, 2009, s. 53).
} 
Tabela 9

Korzyści i zagrożenia wynikające z lokalizacji wielkopowierzchniowych obiektów handlowych (WOH)

\begin{tabular}{|c|c|}
\hline Korzyści i sposobności & Zagrożenia i ograniczenia \\
\hline \multicolumn{2}{|c|}{ WOH w śródmieściu } \\
\hline $\begin{array}{l}\text { Synergizacja inwestycji: } \\
\text { - } \text { wzrost wartości nieruchomości w otoczeniu WOH } \\
\text { - } \text { napływ kapitału } \\
\text { - zdekteresowanitalizowaną (często zabytkową) zabudową } \\
\text { - impuls dla rewitalizacji śródmieścia } \\
\text { - umocnienie i doinwestowanie istniejącej miejskiej } \\
\text { - } \text { struktury funkcjonalno-przestrzennej } \\
\text { - } \text { nowniesienie atrakcyjności centrum miasta } \\
\end{array}$ & $\begin{array}{l}\text { - } \text { piętrzące się trudności komunikacyjne, w tym } \\
\text { pogłębienie deficytu miejsc parkingowych } \\
\text { - trudności realizacyjne } \\
\text { - „wypychanie” ze śródmieścia małych sklepów } \\
\text { rodzinnych }\end{array}$ \\
\hline \multicolumn{2}{|c|}{ WOH przy drogach wylotowych lub obwodnicach } \\
\hline $\begin{array}{l}\text { - } \text { napływ kapitału - Iokalizacja w sąsiedztwie WOH } \\
\text { - } \text { nśrodków biznesu, przemysłu i wytwórczości } \\
\text { - } \text { wzrost zapotrzebowania na tereny mieszkaniowe } \\
\text { - } \text { wyprowadzenie nadmiernego ruchu kołowego } \\
\text { ze śródmieścia } \\
\text { - } \text { dogodniejsze warunki parkowania }\end{array}$ & $\begin{array}{l}\text { - odpływ części firm handlowych ze śródmieścia } \\
\text { na obrzeże miasta } \\
\text { - } \text { zmniejszenie atrakcyjności „ulicy handlowej” } \\
\text { - } \text { spadek wartości nieruchomości } \\
\text { - zwiększenie podaży zdekapitalizowanych lokali } \\
\text { handlowych do wynajęcia } \\
\text { - obniżenie standardu otoczenia lokali handlowych } \\
\text { i gastronomicznych w śródmieściu }\end{array}$ \\
\hline \multicolumn{2}{|c|}{ WOH w obiektach i na terenach poprzemysłowych } \\
\hline $\begin{array}{l}\text { - } \text { rewitalizacja zdewastowanych terenów i obiektów } \\
\text { - napływ kapitału - lokalizacja w sąsiedztwie WOH } \\
\text { - } \text { ośrodków biznesu i przemysłu } \\
\text { charakterowi inwestycji } \\
\text { - możliwość uzyskania wsparcia funduszami } \\
\text { - } \text { celowymi programu rewitalizacji } \\
\text { nowe miejsca pracy }\end{array}$ & - wysokie koszty realizacji \\
\hline
\end{tabular}

Źródło: A. Dołhun, 2011, Regulacje czy nadregulacje w kwestii wielkopowierzchniowych obiektów handlowych (WOH), TUP, Katowice, s. 6.

Na zalety lokalizacji centrów handlowych w śródmieściu dla przedsiębiorców, nabywców i dla rozwoju miasta zwraca również uwagę B. Pilarczyk (2001, s. 164), zaliczając do nich: wzajemne powiązania w zakresie funkcjonowania sklepów i biznesu w centrum miasta, możliwość dokonywania zakupów szerokiej gamy produktów, łatwiejszy dostęp i obsługa 
klientów niedysponujących własnymi środkami transportu, możliwość wyposażenia tego rejonu miasta w dodatkową infrastrukturę, wzmocnienie potencjału ekonomicznego centrum miasta do przeprowadzenia konserwacji i modernizacji istniejących obiektów mieszkalno-usługowych.

Bardzo ważną kwestią, która się pojawia przy lokalizacji zagranicznych placówek handlowych - nie tylko centrów handlowych, ale i na przykład hipermarketów, supermarketów jest ich wpływ na funkcjonowanie lokalnych firm, szczególnie tych z branży handlowej. Wśród niekorzystnych zjawisk, jakie mogą zaistnieć, najczęściej wymienia się upadek firm lokalnych i w związku z tym utrata miejsc pracy oraz pogorszenie sytuacji dostawców. Lokalizacja dużych obiektów handlowych może też przyczyniać się do powstawania nowych form handlu, podnoszenia innowacyjności już działających placówek oraz lepszej jakości oferowanych usług (tab. 10).

\section{Tabela 10}

Niekorzystny i korzystny wpływ zagranicznych sieci handlowych na handel i lokalne rynki

\begin{tabular}{|l|l|}
\hline \multicolumn{1}{|c|}{ Niekorzystne zjawiska } & \multicolumn{1}{c|}{ Korzystny wpływ } \\
\hline - niewłaściwa lokalizacja WOH (na przykład & - zmiany podmiotowe w sferze handlu detalicznego, \\
w środowisku tradycyjnie zajętym przez niewielkie & gdyż krajowe firmy poddane silnej konkurencji \\
powierzchniowo sklepy), powodująca zbyt silną & konsolidują się i inwestują w coraz większe sklepy \\
konkurencję dla małych firm, często skutkiem jest & - rozwój nowych form handlu oraz przyśpieszenie \\
ich upadek & wprowadzania nowoczesnych technologii w detalu \\
- zmiana geografii zakupów ludności na lokalnym & i hurcie \\
rynku wskutek dużej inwestycji handlowej & - wzrost orientacji marketingowej wśród krajowych \\
(supermarket, hipermarket, centrum handlowe), & firm detalicznych i hurtowych, pozwalającej \\
która może niekorzystnie wpływać na handel & lepiej dostrzegać pojawiające się na rynku szanse \\
usytuowany w określonych miejscach lokalnego & i elastycznie dostosowywać się do oczekiwań \\
rynku & dobrze rozpoznanej grupy klientów \\
- utrata miejsc pracy, a niekiedy i podstaw & - podnoszenie poziomu obsługi klienta i tworzenie \\
materialnego utrzymania rodziny przez & zróżnicowanych warunków zakupu towarów \\
dotychczasowych właścicieli małych firm & - podnoszenie atrakcyjności rynku lokalnego \\
handlowych & i ściąganie siły nabywczej ludności \\
pogorszenie sytuacji dostawców, szczególnie & - wzrost znaczenia samorządu gospodarczego \\
małych, którzy nie są w stanie przyjąć warunków & i współpracy podmiotów na rynkach lokalnych \\
współpracy z siecią oraz podjąć konkurencji & \\
cenowej narzucanej przez sieci handlowe & \\
\hline
\end{tabular}

Źródło: U. Kłosiewicz-Górecka, Globalizacja w sektorze handlu w Polsce - wyzwania dla krajowych przedsiębiorstw handlowych, [w:] J. Mikołajczyk (red.), 2006, Handel znaczenie we wspótczesnej gospodarce, WSHiU, Poznań, s. 51-68. 
Prowadząc badania nad skutkami oddziaływania sklepów wielkopowierzchniowych na istniejącą sieć handlową i rynek pracy w Lesznie, W. Budner (2011a, s. 52) do pozytywnych aspektów takiego rozwoju zaliczył:

- podwyższenie atrakcyjności społeczno-gospodarczej miasta,

- rozwój funkcji miastotwórczych,

- podwyższenie jakości i egalitarności oferty handlowej (tym samym podwyższenie jakości życia mieszkańców),

- wzmocnienie procesów odnowy i rewitalizacji w obszarze centrum miasta oraz na terenach poprzemysłowych i pokolejowych,

- uatrakcyjnienie przestrzeni publicznej (unowocześnienie stylu życia),

- prawdopodobnie zwiększenie wartości rynkowej nieruchomości w centrum miasta oraz w obszarach sąsiadujących,

- obniżenie skłonności mieszkańców do zakupów poza miastem,

- wzrost danin publicznych na rzecz miasta (midzy innymi podatku od nieruchomości)

- stworzenie miejsc pracy.

Natomiast do niewątpliwie istotnych zagrożeń zaklasyfikował (Budner 2011a, s. 52):

- osłabienie tradycyjnych form prowadzenia handlu (małe sklepy, targowiska),

- utrata miejsc pracy w tradycyjnym handlu (upadłość drobnych kupców),

- dodatkowe obciążenia komunikacyjne w sąsiedztwie,

- konkurencja cenowa ze strony dużych obiektów handlowych,

- koncentracja przestrzenna handlu - może spowodować spadek zagęszczenia punktów handlowych w innych obszarach.

Niewątpliwie lokalizacja wielkopowierzchniowych obiektów handlowych może oddziaływać na otoczenie w sposób korzystny, jak również determinować zjawiska negatywne. Wpływ tych kompleksów może przejawiać się w sferze ekonomicznej, społecznej, kulturowej, przyrodniczej, komunikacyjnej, technicznej i tym podobnych. 


\subsection{Atrakcyjność centrum handlowego jako produktu}

„Produktem jest wszystko to, co można zaoferować klientom do konsumpcji, użytkowania lub dalszego przerobu. Oprócz rzeczy fizycznych do produktów zalicza się też usługi, czynności, umiejętności ludzi, miejsca, idee, pomysły, organizacje, projekty technologiczne i inne obiekty będące wytworem człowieka lub przyrody" (Rutkowski 2011, s. 17), organizacje, stowarzyszenia, widowiska, spotkania, projekty organizacyjne oraz inne wytwory potencjału intelektualnego, przyrodniczego, produkcyjnego i społecznego ludzkości (Sojkin 2003, s. 19). Produktem jest zatem wszystko to, co jest oferowane na rynku w celu zwrócenia uwagi, kupna, użytkowania lub konsumpcji i co może zaspokoić potrzebę lub pragnienie (Mruk, Rutkowski 1999, s. 19), co istnieje między pomysłem na zaspokojenie potrzeb a pojawieniem się określonej pozycji na liście zakupów klienta (Sojkin 2003, s. 19). Z produktem jest związane pojęcie dobra (lub usługi) ekonomicznego, czyli rzeczy (lub procesu) mającej wartość użytkową, zdolną do zaspokojenia potrzeb i będącą przedmiotem gospodarowania (Rutkowski 2011, s. 19).

Należy pamiętać, że w rzeczywistości wszystkie produkty (oferty), w tym również usługi, posiadają cechy zarówno materialne, jak i niematerialne. Zakup dóbr materialnych jest często połączony z usługami dodatkowymi, na przykład instalacją, montażem czy transportem. Podobnie zakup wielu usług wymaga produktów materialnych (na przykład potrawy w restauracji), lokalu lub urządzeń technicznych. Każdy zakup zawiera więc zestaw produktów i usług w różnych proporcjach. Poznając dokładnie strukturę poszczególnych produktów i przeprowadzając ocenę tych proporcji, można próbować dokonać klasyfikacji przedstawionych ofert rynkowych jako produktów rzeczywistych bądź usług (Styś 2003, s. 33).

W ofercie rynkowej wielu przedsiębiorstw produkujących dobra materialne mogą znajdować się również usługi, natomiast w ofertach usługodawców produkty materialne mogą stanowić większą lub mniejszą część całej propozycji firmy. Możemy mieć zatem do czynienia $z$ jedną $z$ kilku kategorii oferty wyróżnionej ze względu na udział w niej tak zwanego czystego produktu bądź czystej usługi (Kotler 1994, s. 426-428). G.L. Schostack (1982) ze względu na udział elementu materialnego i niematerialnego $\mathrm{w}$ ofercie wyróżnił produkt (ofertę) z dominacją składnika materialnego oraz produkt $z$ dominacją usługi. W środkowej części znajduje się produkt 
zrównoważony, w którym występuje równowaga między wkładem wyrobu materialnego i usługi (rys. 7).

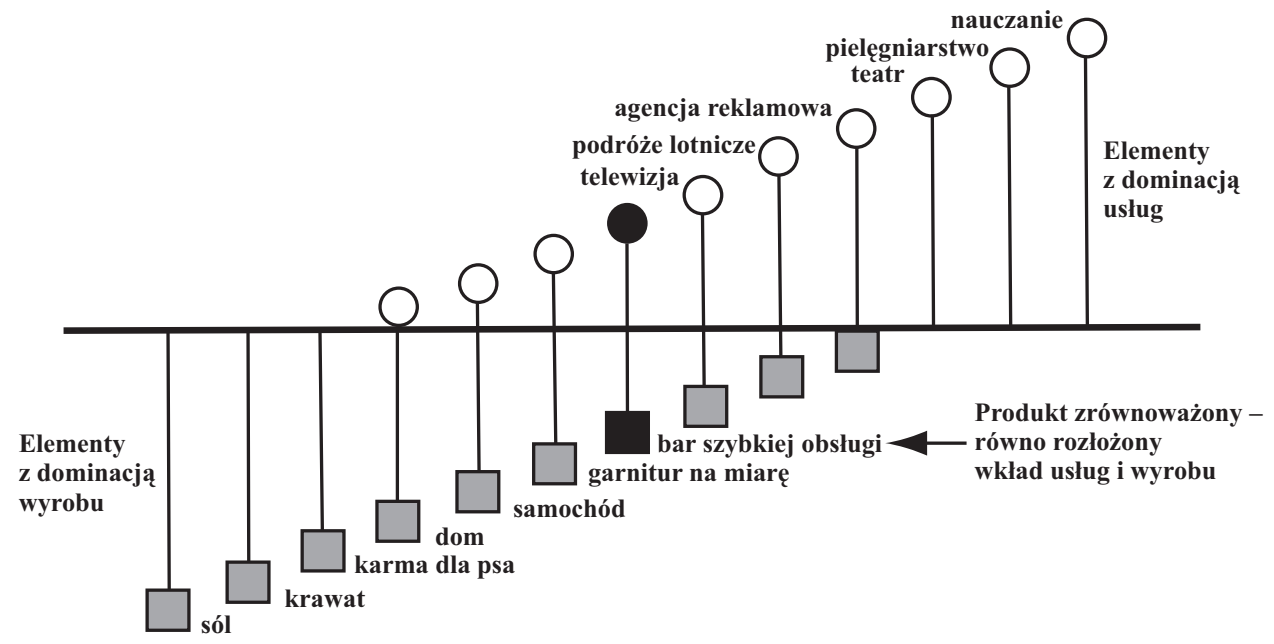

Rys. 7 Udział elementów materialnych i niematerialnych w ofercie rynkowej.

Źródło: G.L. Shostack, 1982, How to design a service, „European Journal of Marketing”, vol. 16(1), s. 49-64, za: P. Mudie, A. Cottam, 1998, Ustugi. Zarzadzanie i marketing, PWN, Warszawa, s. 15.

Nawiązując do koncepcji G.L. Schostacka, Ph. Kotler (1994, s. 426-428) zaproponował pięciostopniową klasyfikację produktów (ofert) opierającą się na natężeniu występowania w nich właściwości materialnych i niematerialnych (usługowych) (rys. 8).

1. Relatywnie czysty produkt (czyste produkty materialne). Oferta złożona jest wyłącznie $\mathrm{z}$ produktów materialnych, którym nie towarzyszą żadne dodatkowe usługi (mydło, pasta do zębów, sól, paczkowana żywność, cukier i tym podobne).

2. Produkt materialny $\mathrm{z}$ towarzyszącymi mu usługami (które podkreślają troskę o klienta); „są to produkty materialne oferowane wraz z dodatkowymi usługami, na przykład zaawansowane urządzenia sprzedawane wraz z usługami typu: doradztwo przy wyborze odpowiedniego modelu dla konkretnego użytkownika, szkolenia dotyczące obsługi sprzętu, dostawa, usługi serwisowe" (Smoleń 2006, s. 93). Przy bardziej zaawansowanych technologicznie produktach ich sprzedaż w dużym stopniu zależy od jakości i dostępności towarzyszących mu usług. 
3. Hybryda - jest to oferta charakteryzująca się równowagą cech materialnych i niematerialnych (na przykład lokale gastronomiczne) (Smoleń 2006, s. 93).

4. Usługa podstawowa $z$ towarzyszącymi jej produktami materialnymi i usługami o mniejszym znaczeniu. „Usługi, którym towarzyszą uzupełniające je produkty materialne lub inne składniki o charakterze usług dodatkowych (np. pasażer samolotu korzystający z usługi transportowej, który otrzymuje ponadto posiłek, możliwość słuchania muzyki, oglądania filmu czy lektury gazet" (Smoleń 2006, s. 94).

5. Relatywnie czysta usługa. Oferta taka składa się przede wszystkim z usługi, na przykład opieka nad dzieckiem, psychoterapia, masaże, wyprowadzanie psa na spacer, pilnowanie samochodów na strzeżonym parkingu.

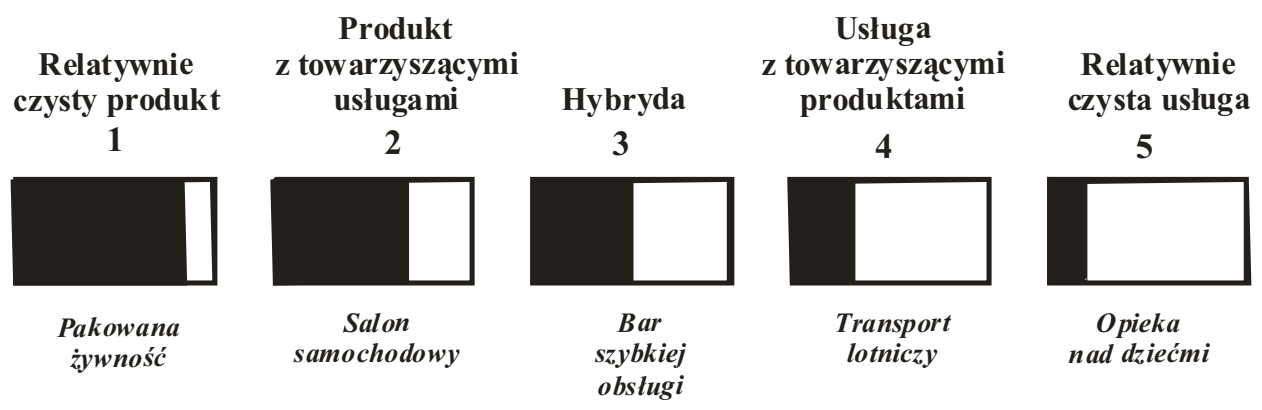

Rys. 8. Rodzaje oferty rynkowej ze względu na jej strukturę.

Źródło: L.L. Berry, A. Parasuraman, 1991, Marketing Services. Competing through Quality. The Free Press, New York, s. 9; za: A. Styś, 2003, Marketing ustug, PWE, Warszawa, s. 35.

W procesie planowania oferty firmy menedżer powinien uwzględniać tak zwane poziomy (wymiary) produktu oraz hierarchię produktu. Poziomy produktu odnoszą się do tych cech i funkcji, którymi klient kieruje się przy wyborze produktu i jego zakupie. Hierarchia produktu określa natomiast pewien sposób powiązania danego produktu z innymi produktami (Mruk, Rutkowski 1999, s. 19). Każdy produkt ma kilka poziomów (warstw), a ich suma składa się na całościową koncepcję produktu, która może być różnicowana. Koncepcję poziomów produktu pierwszy raz przedstawił T. Levitt w 1980 roku, kiedy poddał analizie przesłanki i motywy nabywców oraz postępowanie wytwórców $\mathrm{w}$ aspekcie postrzegania produktu (Sojkin 2003, s. 19). Zaproponował ogólną koncepcję poziomów produktu, w której wyróżnił trzy główne jego warstwy: rdzeń lub inaczej isto- 
tę produktu, produkt rzeczywisty oraz poszerzony (rys. 9). Jak zauważa M. Prymon (2008, s. 490), to co jest najbardziej wartościowe w idei T. Levitta, to wprowadzenie elementu dynamiki do interpretacji produktu, wynikającego $\mathrm{z}$ faktu, że poszczególne elementy nie stanowią odrębnych poziomów, a granice pomiędzy nimi są płynne (dla jednego klienta dany element może być produktem rzeczywistym, a dla innego poszerzonym).

Zgodnie z koncepcją struktury produktu, opisaną przez P. Kotlera (1994), obejmuje ona pięć poziomów (za: Rutkowski 2011, s. 28-29) (rys. 9):

1. Podstawowy pożytek - podstawowa potrzeba zaspokajana przez dany produkt (na przykład rozrywka w przypadku telewizora);

2. Produkt podstawowy - część produktu, która jest niezbędna do zaspokojenia potrzeby (na przykład telewizor);

3. Produkt oczekiwany - oczekiwania klienta wobec produktu (np. panoramiczny obraz wysokiej rozdzielczości);

4. Produkt rozszerzony - wszystko, co przewyższa oczekiwania klienta (na przykład dźwięk przestrzenny, interfejsy multimedialne);

5. Produkt potencjalny - wszystkie modernizacje, jakim może zostać poddany produkt w przyszłości (na przykład możliwość przeglądania stron WWW na telewizorze, 3D i tym podobne.).

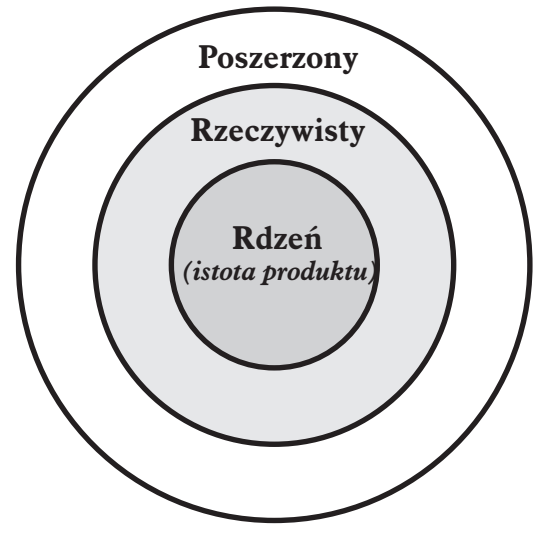

Poziomy produktu według T. Levitta (1980).

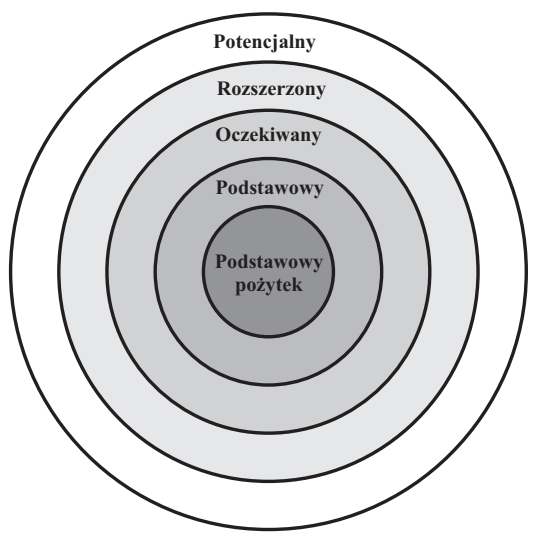

Poziomy produktu według P. Kotlera (1994).

Rys. 9. Poziomy produktu według T. Levitta (1980) i P. Kotlera (1994).

Źródło: I.P. Rutkowski, 2011, Strategie produktu. Koncepcje i metody zarzqdzania oferta produktowa, PWE, Warszawa, s. 28; P. Kotler, 1994 , Marketing. Analiza, planowanie, wdrażanie, kontrola, Gebethner \& S-ka, Warszawa, s. 401. 
W strukturze produktu najczęściej wyróżnia się trzy składniki (podzbiory/wartości/korzyści/warstwy): rdzeń produktu, produkt rzeczywisty i poszerzony. Rdzeń produktu zwany istotą produktu składa się z podstawowych korzyści, które klient otrzymuje, nabywając dane dobro lub usługę (Rutkowski 2011, s. 29). Koresponduje on z pierwotną potrzebą i może przybierać postać materialną (na przykład sprawne urządzenie, ubranie, fryzura) bądź niematerialną (na przykład nabyta wiedza, dobre samopoczucie i tym podobne) (Daszkowska 1998, s. 106). Struktura i jakość elementów tworzących produkt rzeczywisty decydują o sile postrzegania produktu przez nabywców, potencjalnych klientów, a także przez dostawców i konkurentów (polepszają wizerunek firmy i obraz produktu w oczach klientów). Na tę siłę wpływają takie cechy i elementy produktu jak: cena, jakość, opakowanie, styl, marka, znak handlowy, kontakt z konsumentem, wygląd i zachowania pracowników, materiał-surowiec, wzornictwo, części zamienne itp. Trzecią warstwę reprezentuje produkt poszerzony, a jego elementy i cechy zawierają dwie poprzednie warstwy, których kompozycja i zakres $w$ istotnym stopniu decydują o przewadze konkurencyjnej na rynku oraz oferują klientom dodatkowe korzyści. Produkt poszerzony tworzą także dostawa bezpłatna, usługi naprawcze, kredyty, usługi instalatorskie, możliwość składania reklamacji, empatia pracowników, terminowość dostaw, udzielane gwarancje i rękojmie (rys. 10) (Rutkowski 2011, s. 29-30).

Należy również mieć na uwadze warstwę produktu potencjalnego, który obejmuje wszystko, co potencjalnie może przyciągnąć i utrzymać klientów (Rutkowski 2011, s. 30); jest to poziom produktu, który powinien zawierać maksimum tego, co jest docelowo możliwe, aby zapewnić atrakcyjność całego produktu i utrzymać nabywcę (rys. 10) (Sojkin 2003, s. 20).

Kotlerowska koncepcja poziomów produktu, według M. Prymona (2008, s. 490-491), posiada ograniczoną wartość praktyczną i nie do końca jest obiektywna. Zwrócił on uwagę, że pomiędzy poziomem rdzenia produktu a poziomem produktu rzeczywistego jest istotna luka, a atrybuty ${ }^{26}$ produktu są ujęte statycznie. W związku z tym zaproponował „dynamiczną koncepcję produktu", w której zauważa, że w miarę rozwoju sprzedaży firmy nie koncentrują się tylko na wprowadzaniu nowych atrybutów, ale raczej na ich modyfikowaniu.

\footnotetext{
${ }^{26}$ Atrybut - powszechnie powtarzające się właściwości ogólne produktu, które mogą składać się z właściwości szczegółowych (Prymon 2008, s. 491, za: R.P. Bagozzi 1998).
} 


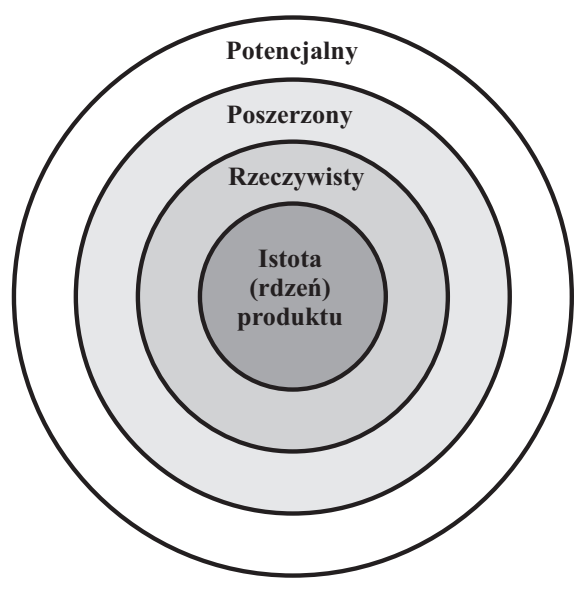

a. według A. Payne (1996).

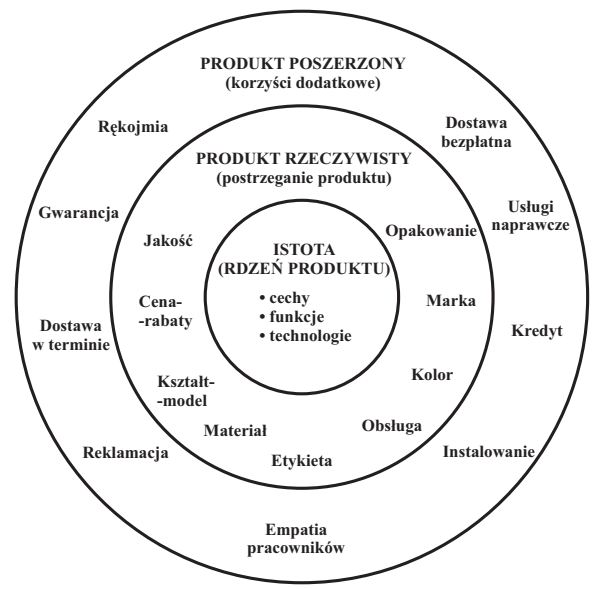

b. według T. Levitta (1980).

Rys. 10. Poziomy produktu (oferty).

Źródło: I.P. Rutkowski, 2011, Strategie produktu. Koncepcje i metody zarzqdzania oferta produktowq, PWE, Warszawa, s. 29; A. Payne, 1996, Marketing ustug, PWE, Warszawa, s. 161.

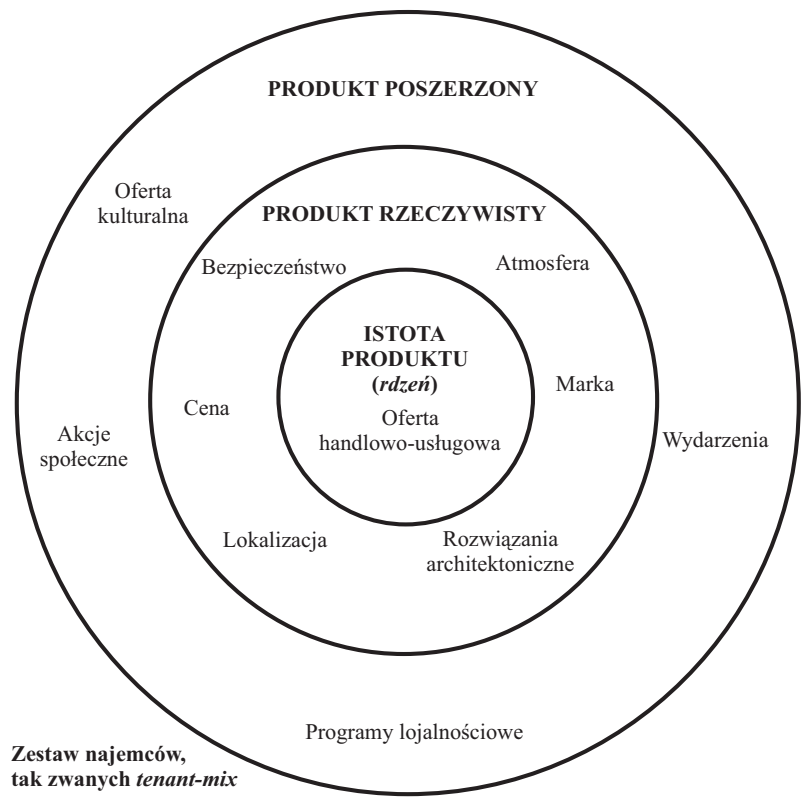

Rys. 11. Poziomy (wymiary) produktu na przykładzie centrum handlowego.

Źródło: M. Knecht-Tarczewska, 2011, Centrum handlowe jako nowoczesny produkt handlowo-ustugowy, „Zeszyty Naukowe”, nr 175, Uniwersytet Ekonomiczny, Poznań, s. 295. 
W literaturze można spotkać wiele opracowań, w których na bazie ogólnych założeń „teorii produktu” definiowano i konstruowano produkty branżowe. Produkt turystyczny można odnaleźć, między innymi w: J. Altkorn (1994), A. Rapacz (1994), S. Medlik (1995), V.T.C. Middleton (1996), J.C. Holloway, C. Robinson (1997), G. Gołembski (1998), L. Mazurkiewicz (2002), A. Nowakowska (2002), J. Kaczmarek, A. Stasiak, B. Włodarczyk (2005). Konstruowano również inne produkty branżowe, na przykład usługi edukacyjne E.S.K. Chan (2003); gastronomiczne M. Milewska, A. Prączko, A. Stasiak (2010), R. Zabrocki (2008); medyczne T. Smoleń (2006); produktu sportowego S. Kowalski, I. Sowier-Kasprzyk (2008), politycznego M. Rawski (2008), czy ogólnego produktu usługowego (Storey, Easingwood, 1998).

Produktem przedsiębiorstwa handlu detalicznego jest świadczenie polegające na dostarczaniu nabywcom pożądanego asortymentu towarów wraz z zestawem usług oferowanych łącznie lub dodatkowo (Śmigielska 2004, s. 49). M. Knecht-Tarczewska (2011, s. 295-301) wyznaczyła poziomy (wymiary) produktu dla centrum handlowego, wyróżniając w nim trzy warstwy: istotę produktu (rdzeń), produkt rzeczywisty i produkt poszerzony. Rdzeń produktu, jakim jest centrum handlowe, stanowi jego oferta usługowa, zarówno w wymiarze materialnym, jak i niematerialnym. Wartość dodatkową kształtuje produkt rzeczywisty, na który składają się: walor lokalizacji, architektura, atmosfera, poczucie bezpieczeństwa, marka placówki oraz poziom cen. Trzecią warstwę, tak zwanych dodatkowych korzyści dla nabywcy, tworzy produkt poszerzony, kształtowany przez programy lojalnościowe, imprezy, akcje społeczne i ofertę kulturalną (rys. 11; tab. 11).

Współczesne centra handlowe to złożone, zaplanowane przestrzennie kompleksy mające za zadanie realizację różnorodnych funkcji. Funkcja handlowa może być podstawowa (centra I i II generacji) bądź też równorzędna, a nawet tylko uzupełniająca w stosunku do innych funkcji (centra III, IV i V generacji). W wielu współczesnych centrach handlowych nastąpiło rozszerzenie funkcji handlowych o placówki i obiekty związane z usługami bytowymi, gastronomicznymi, kulturalnymi, rekreacyjnymi, rozrywkowymi, biurowymi i hotelarskimi (Kaczmarek 2010, s. 48). Cechą charakterystyczną centrów handlowych jest również skupienie sklepów oferujących produkty $z$ różnych branż, a także różnorodnych punktów usługowych (usługi fotograficzne, optyczne, pralnicze, finansowe i tym podobne). Zdywersyfikowanie oferty branżowo-usługowej powoduje, że jest ona kierowana do przedstawicieli wielu segmentów nabywców. 
Tabela 11

Poziomy (wymiary) produktu na przykładzie centrum handlowego

\begin{tabular}{|c|c|c|}
\hline & Poziomy & Cele \\
\hline I. & \multicolumn{2}{|c|}{$\begin{array}{c}\text { ISTOTA PRODUKTU - Rdzeń } \\
\text { - główne korzyści, których oczekują od produktu nabywcy }\end{array}$} \\
\hline 1. & $\begin{array}{l}\text { Oferta } \\
\text { handlowo-usługowa }\end{array}$ & $\begin{array}{l}\text { Zapewnienie realizacji zakupów oraz świadczenie usług dla nabywców } \\
\text { w jednym miejscu (sklepy, punkty usługowe, gastronomiczne, centra } \\
\text { rozrywki i tym podobne). }\end{array}$ \\
\hline II. & \multicolumn{2}{|r|}{$\begin{array}{c}\text { PRODUKT RZECZYWISTY } \\
\text { - kształtuje wartość dodatkową }\end{array}$} \\
\hline 1. & $\begin{array}{l}\text { Zestaw najemców } \\
\text { (tak zwany tenant- } \\
\text {-mix) }\end{array}$ & $\begin{array}{l}\text { Stworzenie niepowtarzalnego zestawu najemców w celu } \\
\text { wyróżnienia obiektu spośród konkurentów. Pozwala stymulować i kierować } \\
\text { ruchem nabywców, przedłużać ich pobyt w obiekcie, zwiększać szansę } \\
\text { na zakupy krzyżowe oraz kształtuje wizerunek centrum handlowego. }\end{array}$ \\
\hline 2. & Lokalizacja & $\begin{array}{l}\text { Zapewnienie dogodnej dostępności komunikacyjnej } \\
\text { (na przykład bliskość zamieszkania nabywców, dobry dojazd, odpowiednia } \\
\text { pojemność parkingów). }\end{array}$ \\
\hline 3. & $\begin{array}{l}\text { Rozwiązania } \\
\text { architektoniczne }\end{array}$ & $\begin{array}{l}\text { Atrakcyjność przestrzeni architektoniczno-urbanistycznej wpływa na } \\
\text { zatrzymanie klienta wewnątrz oraz na przedłużenie czasu spędzonego } \\
\text { w obiekcie (na przykład jakość, estetyka, innowacyjność rozwiązań). }\end{array}$ \\
\hline 4. & Atmosfera & $\begin{array}{l}\text { Ma na celu oddziaływanie na zmysły klientów, tak zwany marketing zmysłów } \\
\text { (na przykład zmysł wzroku, słuchu, dotyku). Atmosfera ma stymulować } \\
\text { klientów i umożliwiać im łączenie zakupów z rozrywką. }\end{array}$ \\
\hline 5. & Bezpieczeństwo & $\begin{array}{l}\text { Poczucie bezpieczeństwa dzięki zapobieganiu aktom wandalizmu } \\
\text { oraz kreowanie przez właścicieli wizerunku centrum jako „oazy spokoju” } \\
\text { pozwala na spokojne korzystanie z oferty centrum handlowego. }\end{array}$ \\
\hline 6. & Marka & $\begin{array}{l}\text { Marka wyróżnia daną placówkę od konkurencji, wywiera pozytywne wrażenie } \\
\text { na odwiedzających (co wpływa na chęć powrotu), oddaje istotę centrum } \\
\text { handlowego, buduje relacje z konsumentami, jest reklamą. }\end{array}$ \\
\hline 7. & Poziom cen & $\begin{array}{l}\text { Zarządcy pośrednio mogą wpływać na poziom cen w poszczególnych } \\
\text { placówkach, na przykład przez wybór najemców o różnych strategiach } \\
\text { cen (wysokich, średnich, niskich), przez wysokość kosztów najmu. } \\
\text { Dywersyfikacja lub specjalizacja najemców powoduje docieranie } \\
\text { do różnych segmentów klientów. }\end{array}$ \\
\hline III. & \multicolumn{2}{|c|}{$\begin{array}{c}\text { PRODUKT POSZERZONY } \\
\text { - zestaw dodatkowych korzyści, które czerpie z produktu nabywca }\end{array}$} \\
\hline 1. & $\begin{array}{l}\text { Program } \\
\text { Iojalnościowy }\end{array}$ & $\begin{array}{l}\text { Budowanie programów lojalnościowych dla klientów obiektu, ponieważ } \\
\text { tworzenie takich programów przez poszczególnych najemców nie gwarantuje } \\
\text { ich powrotu do centrum handlowego (najemcy mogą mieć placówki } \\
\text { w różnych miejscach), na przykład tworzenie systemu BIS (blackbox } \\
\text { inteligence system), oferującego w ramach tego jedną kartę rabatową } \\
\text { obowiązującą we wszystkich sklepach danego centrum handlowego. }\end{array}$ \\
\hline
\end{tabular}


Tabela 11 (ciąg dalszy)

\begin{tabular}{|c|l|l|}
\hline & \multicolumn{1}{|c|}{ Poziomy } & \multicolumn{1}{c|}{ Cele } \\
\hline 2. & Imprezy & $\begin{array}{l}\text { Organizowanie imprez ma na celu zwiększenie liczby klientów, przedłużenie } \\
\text { ich czasu przebywania na terenie centrum handlowego, co może wpłynąć } \\
\text { na zwiększenie sprzedaży. Tego typu okazjonalne wydarzenia (niebędące } \\
\text { integralną czę́cią oferty rozrywkowej centrum) kreują również wizerunek } \\
\text { obiektu, budują lojalność klientów, są też instrumentem osiągania przewagi } \\
\text { konkurencyjnej. }\end{array}$ \\
\hline 3. & Akcje społeczne & $\begin{array}{l}\text { Akcje tego typu tworzą więzi pomiędzy marką obiektu a lokalnymi } \\
\text { społecznościami, wpływając na kształtowanie jego pozytywnego wizerunku, } \\
\text { na przykład akcje charytatywne, edukacja najmłodszych. }\end{array}$ \\
\hline 4. & Oferta kulturalna & $\begin{array}{l}\text { Organizowanie wydarzeń kulturalnych na terenie centrum handlowego ma } \\
\text { na celu urozmaicenie oferty rozrywkowej i tym samym dotarcie do nowych } \\
\text { grup odbiorców (często ściśle wyselekcjonowanej grupy). Tego typu oferta } \\
\text { promuje centrum oraz zwiększa dostępność sztuki dla społeczeństwa, } \\
\text { na przykład wystawy, koncerty, pokazy filmowe. }\end{array}$ \\
\hline
\end{tabular}

Źródło: Opracowanie własne na podstawie: M. Knecht-Tarczewska, 2011, Centrum handlowe jako nowoczesny produkt handlowo-ustugowy, „Zeszyty Naukowe” nr 175, Uniwersytet Ekonomiczny, Poznań, s. 296-301.

Współczesne centra handlowe są swoistym produktem o zróżnicowanej ofercie, produktem, który ma za zadanie przyciągnąć jak największą liczbę klientów, dokonujących zakupu i zostawiąjących w nim jak najwięcej środków finansowych. W związku z powyższym celem zarządzających takimi kompleksami oraz ich podnajemców jest zainteresowanie nabywców swoją ofertą. Wraz z powstawaniem nowych centrów handlowych jest to coraz trudniejsze ze względu na wzrastającą konkurencję. Nie jest łatwo przygotować taki pakiet „ofertowy”, żeby wyróżnić się na tle innych tego typu kompleksów funkcjonujących na danym rynku „konsumenckim”. O atrakcyjności każdego centrum handlowego świadczą walory (materialne i niematerialne), zagospodarowanie oraz dostępność komunikacyjna (rys. 12).

R.M. Downs (1970) sformułował hipotezę, że „wyobrażenie badanego ośrodka kształtuje się pod wpływem dziewięciu czynników: ceny towarów, struktury, kompozycji ośrodka, łatwości poruszania się wewnątrz ośrodka i parkowania, wyglądu zewnętrznego, renomy, liczby typów różnych sklepów, jakości obsługi, godzin otwarcia i ogólnej atmosfery" (Walmsley, Lewis 1997, s. 139). „Atrakcyjność M. Cadwallader (1975, 1981) określił poprzez opinię konsumentów o każdym sklepie według 


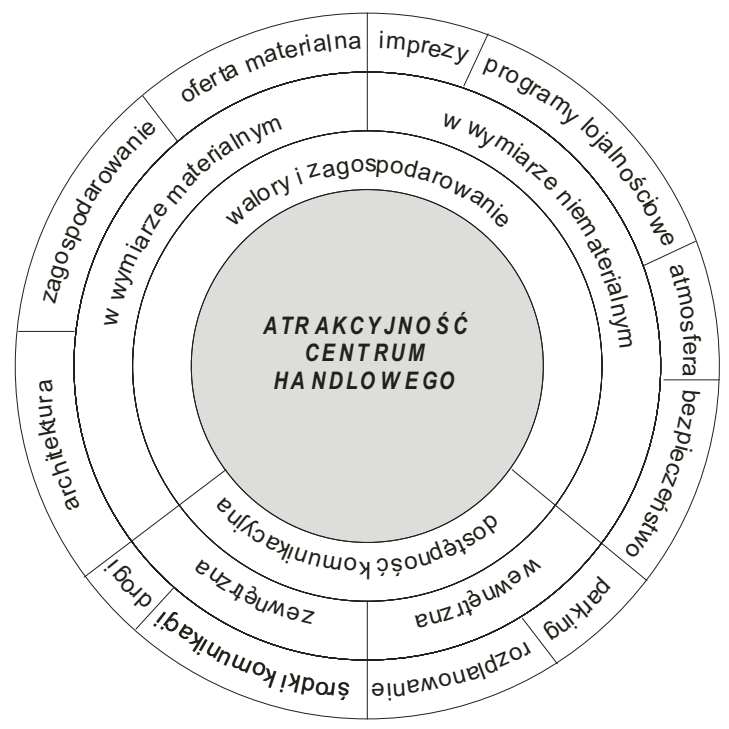

Rys. 12. Główne determinanty atrakcyjności centrum handlowego.

Źródło: Opracowanie własne.

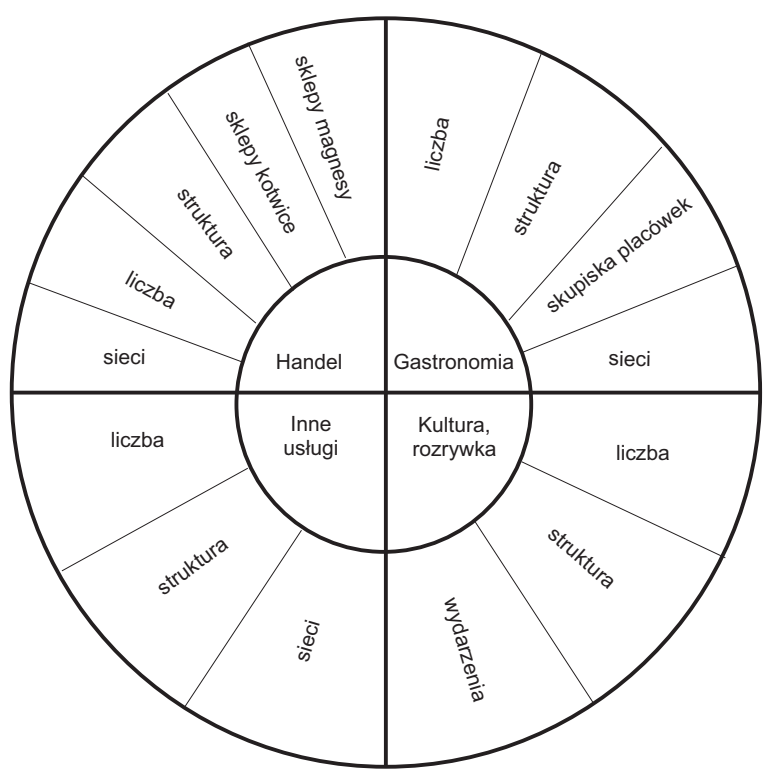

Rys. 13. Oferta rdzenia centrum handlowego.

Źródło: Opracowanie własne. 
czterech cech: szybkość obsługi kasowej, zakres oferty towarowej, ilość sprzedawanych dóbr oraz ceny. W tym samym badaniu podał też cechy atrakcyjności ośrodków handlowych: miejsca parkingowe, ceny, godziny otwarcia, zakres oferty towarowej, odległość według subiektywnej oceny konsumentów (w minutach); informację według skali dychotomicznej (odsetek konsumentów świadomych istnienia danego sklepu)" (Wilk 2001, s. 32).

Rdzeń centrum handlowego stanowią placówki usługowe, w tym głównie handlowe oraz miejsca oferujące rozrywkę i kulturę. $\mathrm{Z}$ punktu widzenia nabywcy istotna jest ich liczba oraz struktura. W przypadku usług handlowych na atrakcyjność oferty mają wpływ również sklepy „kotwicowe” i inne sklepy magnesy oraz występowanie sklepów znanych sieciowych marek. Korzystając $z$ usług gastronomicznych, klienci mogą być zainteresowani nie tylko ich liczbą, strukturą, ale również zgromadzeniem w jednym miejscu ${ }^{27} \mathrm{w}$ tak zwanych przestrzeniach gastronomicznych (food courtach), dziedzińcach lub pasażach gastronomicznych. Oferta kulturalna i rozrywkowa to nie tylko ta prezentowana w stałych placówkach, ale również organizowanie różnego rodzaju imprez na terenie centrum handlowego (rys. 13).

Wśród cech nowoczesnego centrum handlowego $\mathrm{z}$ punktu widzenia ich atrakcyjności można wymienić również (Domański 2005, s. 173):

- przestronne, ciepłe, suche i mocno oświetlone (jasne) - niezależnie od pory roku, dnia, od aury na zewnątrz (stanowi oazę w chłodnej i deszczowej przestrzeni miejskiej),

- ciepło, światło - kojarzą się podświadomie ze spokojem i bezpieczeństwem, izolują od otoczenia, pozwalają na skoncentrowanie się na robieniu zakupów - dzięki temu przestrzeń jest bardziej oswojona i przyjazna,

- czystość i porządek,

- oaza spokoju (zależy od dnia i pory dnia - szczególnie godziny przedpołudniowe w robocze dni tygodnia),

- gwarancja robienia zakupów w „swoim towarzystwie” (bez pojawiania się żebrzących, biednych, narkomanów, alkoholików itp. - jest więc „iluzją szczęśliwego świata bez biedy”).

${ }^{27}$ Więcej informacji o formach koncentracji placówek gastronomicznych w centrach handlowych $\mathrm{w}$ rozdziale II. 
W wymiarze niematerialnym duże znaczenie dla klientów ma poczucie bezpieczeństwa. Kompleksy tego typu są objęte systemem monitoringu pod opieką specjalnie przygotowanych służb ochroniarskich, dzięki czemu przebywające na terenie centrum handlowego osoby są spokojne o swoje zdrowie i życie oraz dobra materialne, na przykład pieniądze czy karty (przed kradzieżą). Centra handlowe, o których tu mówimy, są poddane pewnym regułom funkcjonowania, midzy innymi na ich teren nie są wpuszczani „niepowołani goście” - żebrzący, bezdomni, osoby pod wpływem alkoholu czy narkotyków, co dla wyselekcjonowanej grupy klientów stwarza komfort izolacji od niewygodnego dla nich „marginesu społecznego”. Daje im to poczucie bezpieczeństwa, wyalienowania z rzeczywistości w której obok bogactwa występuje również bieda. W takim centrum handlowym można zapomnieć o istnieniu tej drugiej „słabszej” strony świata, w dodatku klienci nie są zaczepiani przez osoby wykluczone społecznie, dzięki czemu nie przysłaniają im obrazu pięknego - bogatego świata „konsumpcji”. Można zatem mówić o realnym poczuciu bezpieczeństwa. Dodatkowo takie obiekty są zadaszone i odpowiednio izolowane od wpływu warunków atmosferycznych, w związku $\mathrm{z}$ czym osoby przebywające na ich terenie są zabezpieczone od ich negatywnego wpływu (chronią przed zimnem, gorącem, opadami).

Owe kompleksy są w porównaniu z otoczeniem sterylnie czystymi enklawami, w których nie zauważa się brzydoty miejskich zakamarków. Ład, czystość i porządek kreują oazę „spokojnego, uporządkowanego świata bez wad", w którym można poczuć się lepszym i zapomnieć o trudach dnia codziennego. Temu obrazowi sprzyjają dźwięk, kolor i zapach, których zadaniem jest spotęgowanie pozytywnych wrażeń, uprzyjemnienie i wydłużenie pobytów klientów oraz wykreowanie jak najlepszego wizerunku.

Jedną $z$ tendencji nowej konsumpcji jest jej dematerializacja, która $\mathrm{z}$ jednej strony jest rozumiana w kontekście przechodzenia na wyższe etapy rozwoju konsumpcji (związek $z$ humanizacją), a $z$ drugiej definiuje się ją w kontekście przedmiotów konsumpcji, którym nadawane są symboliczne, niematerialne znaczenia (związane jest to $\mathrm{z}$ tendencją hedonistyczną w zachowaniach konsumenckich, którą wyznacza przyjmowana przez konsumentów orientacja na przyjemność oraz orientacja na „tu i teraz”). W pierwszym podejściu następuje wzrost znaczenia dla konsumenta wartości niematerialnych, w tym także kultury, wiedzy, rekreacji, czego wy- 
razem jest wzrost udziału spożycia dóbr niematerialnych kosztem dóbr materialnych (Sobocińska 2011, s. 14).

Przedsiębiorstwa handlowe wdrażają strategię sensoryczną opierającą się na wywoływaniu wrażeń zmysłowych. Stosowanie marketingu sensorycznego wiąże się z prowadzeniem działań obejmujących wszystkie pięć zmysłów (Hultén, Broweus, van Dijk 2011 w: Sobocińska 2011, s. 14) „wzrok (kolor, światło, wielkość, kształt), słuch (muzyka, natężenie dźwięków), zapach (naturalne, sztuczne), dotyk (materiały, temperatura), smak (próbki). Stworzenie odpowiedniej atmosfery wymaga skoncentrowania się na wszystkich tych elementach i odpowiedniego zestawienia ich z pozostałymi. Według wielu naukowców, im więcej zmysłów zostanie zaangażowanych w doświadczenie produktu, usługi czy miejsca, tym silniejszy będzie wpływ na konsumenta" (Zatwarnicka-Madura 2011, s. 97).

Rozpatrując centrum handlowe jako produkt, nie należy zapominać, że jest ono zlokalizowane w pewnej przestrzeni funkcjonalnej, na którą w mniejszym lub większym wymiarze oddziałuje. Budowa samego kompleksu zmienia miejsce, na którym zostaje zlokalizowane, nie tylko pod względem funkcjonalnym (na przykład budowa na terenach poprzemysłowych), ale i wizualnym. Wpływając na otoczenie, centra handlowe kształtują pewną odmienioną i ciągle zmieniającą się nową przestrzeń miasta, nowoczesne pulsujące miejskie bieguny ${ }^{28}$ (jądro ${ }^{29}$ ) handlowo-usługowe.

Rdzeń produktu takiej przestrzeni stanowi samo centrum handlowe jako wielowymiarowy produkt ofertowy. W sąsiedztwie centrum handlowego w sposób, który można nazwać „przyrostowy”, mogą powstać lub powstają inne placówki handlowe, często są to duże sklepy, a wręcz centra profilowane, na przykład Obi, Castorama, Praktiker. Tego typu obiekty wpływają

\footnotetext{
${ }^{28}$ Sformułowana przez F. Perroux (1955) koncepcja bieguna wzrostu jest koncepcją sektorową (gałęziową). Wyjaśnia działanie wiodących jednostek gospodarki, pociągających za sobą rozwój innych jednostek; eksponuje i rozwija tezę, że motorem wzrostu są pewne dynamiczne dziedziny działalności. Termin „biegun”, w rozumieniu F. Perroux „oznacza raczej zjawisko wybijające się ponad przeciętny poziom niż jedną z przeciwstawnych skrajności” (Grzeszczak 1999, s. 11).

${ }^{29}$ Jądro - „wnętrze, środek czegoś”, „najważniejsza, zasadnicza, podstawowa część czegoś: istota rzeczy” „wewnętrzna część ciał niebieskich, np. Jądro Ziemi, „centralna część atomu” (Słownik języka polskiego 1978, s. 829). Termin „jądro” używa się przy badaniach rozwoju miast jako „jądro historyczne miast” (na przykład Koter 1969; Matlovič, Ira, Sýkora, Szczyrba 2001), ,jądro aglomeracji” - w znaczeniu ośrodka węzłowego, węzła, centrum, rdzenia aglomeracji (na przykład Parysek 2008) czy ,jądra metropolii” (na przykład Jałowiecki 2011).
} 
na atrakcyjność danych terenów, stanowiąc ich tak zwany produkt rzeczywisty. W niektórych przypadkach w niebezpośrednim sąsiedztwie, ale w niewielkiej odległości mogą zostać zlokalizowane inne placówki usługowe, których lokalizacja może być ściśle związana $\mathrm{z}$ centrum handlowym, w takim wypadku będą one stanowić produkt poszerzony danego obszaru (rys. 14).

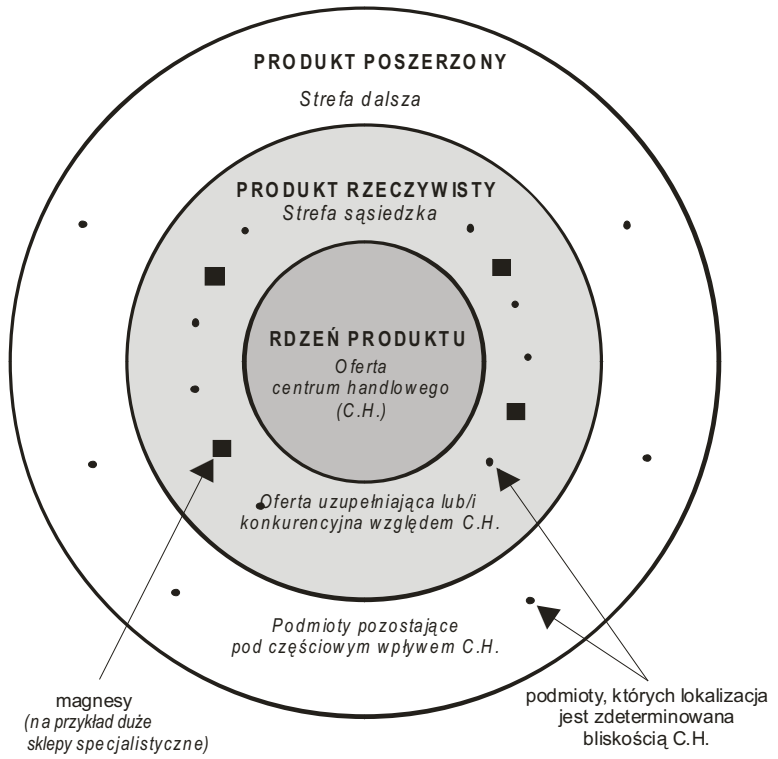

Rys. 14. Oferta nowoczesnych pulsujących miejskich biegunów handlowo-usługowych.

Źródło: Opracowanie własne.

W badaniach naukowych powinno się poświęcać więcej uwagi wpływowi centrum handlowego na otaczającą przestrzeń. Te wielkogabarytowe kompleksy są pulsującymi miejskimi biegunami nowoczesnej przestrzeni usługowej. To one generują potoki nabywców, którzy mogą być też klientami placówek sąsiednich, wpływając tym samym na atrakcyjność lokalizacyjną terenów położonych wokół centrum handlowego. Należy pamiętać że życie takiego kompleksu posiada swoje cykle roczne, tygodniowe i dobowe, co jest związane $\mathrm{z}$ terminami i godzinami ich otwierania, można więc powiedzieć, że pulsują. 


\subsection{Konsument, nabywca, klient, użytkownik - trudności definicyjne}

W literaturze osoby odwiedzające między innymi centra handlowe różnie się określa - konsumenci, nabywcy, klienci, czy użytkownicy. Wszystkie te terminy są niejednoznacznie używane i definiowane. Między nimi występują pewne zależności, a w niektórych przypadkach mogą funkcjonować nawet jako synonimy. Kategoria konsumenta, jak zauważa S. Smyczek (2005, s. 23), jest obiektem zainteresowań wielu dyscyplin naukowych, takich jak: biologia, psychologia, ergonomia, socjologia, ekonomia czy zarządzanie, co również stwarza wiele problemów natury metodologicznej. W związku z powyższym na potrzeby pracy należy doprecyzować, co będzie pod każdym $\mathrm{z}$ tych pojęć rozumiane ${ }^{30}$.

W Stowniku wyrazów obcych $i$ zwrotów obcojęzycznych konsumenta utożsamia się ze spożywcą, z nabywcą towarów na własny użytek (Kopaliński 1994, s. 276 ). W Kodeksie cywilnym za konsumenta natomiast uważa się „osobę fizyczną dokonującą czynności prawnej niezwiązanej bezpośrednio z jej działalnością gospodarczą lub zawodową" (art. 22) ) $^{31}$. Konsument jest to więc jednostka, która odczuwa i zaspokaja potrzeby konsumpcyjne poprzez dobra i usługi zakupione na rynku, wytworzone we własnym gospodarstwie domowym lub otrzymane w ramach świadczeń społecznych, a więc działa w sferze spożycia i czyni to zgodnie $z$ własnymi preferencjami, upodobaniami i tradycjami. Nie jest w tym przypadku ważne miejsce nabycia (pozyskania) środków zaspokajania potrzeb ani samo miejsce zaspokajania tych potrzeb. Konsument bowiem może funkcjonować (i funkcjonuje także) poza rynkiem, a w skrajnych przypadkach może całkowicie istnieć bez rynku (Smyczek 2005, s. 27). Przez pojęcie konsumenta najczęściej rozumie się podmiot ekonomiczny, który spożywa (zużywa) nabyte produkty (Kufel, Mruk 1998, s. 9).

Konsument to jednostka, odczuwająca i zaspokająca potrzeby konsumpcyjne, wykorzystując w tym celu (Rynkowe zachowania konsumentów, 2000, s. 59):

\footnotetext{
${ }^{30}$ Przy wyjaśnianiu pojęć skoncentrowano się na podejściu ekonomicznym. Celem tego podrozdziału nie było przedstawianie dywagacji na temat niejednoznaczności terminów, tylko doprecyzowanie na potrzeby pracy przede wszystkim, co będzie rozumiane pod pojęciem klient i nabywca.

${ }^{31}$ Ustawa z 23 kwietnia 1964 r. - Kodeks cywilny, Dz.U. z 1964 r., Nr 16, poz. 93 ze zm.; tekst jednolity.
} 
- dobra materialne oraz usługi zakupione na rynku (konsumpcja rynkowa),

- środki wytworzone we własnym gospodarstwie (jako element konsumpcji naturalnej),

- środki otrzymane całkowicie lub częściowo nieodpłatnie pod postacią świadczeń rzeczowych $\mathrm{z}$ funduszu spożycia społecznego (jako konsumpcja społeczna) lub innych gospodarstw domowych (jako element konsumpcji naturalnej).

Termin konsument może odnosić się nie tylko do indywidualnych podmiotów konsumpcji, ale także do instytucji społecznych oraz firm występujących na rynku dóbr konsumpcyjnych i reprezentujących tam określony popyt związany $\mathrm{z}$ ich działalnością; wtedy taki konsument jest zwany konsumentem zbiorowym (Smyczek 2005, s. 27). W takim ujęciu konsumentem może być: osoba, grupa osób, przedsiębiorstwo czy organizacja, która korzysta z wartości użytkowej produktów (Janoś-Kresło 2006, s. 15). A. Toffler (1974) na pokazanie odmienności konsumenta doby rewolucji informacyjnej wprowadził termin „prosument”, a jest nim taki konsument, który aktywnie uczestniczy w procesie tworzenia produktu.

Pod pojęciem nabywca rozumie się osobę, która „coś nabywa (nabyła) przez kupno, czyli inaczej kupującego" (Stownik języka polskiego, 1979, s. 240). To osoba faktycznie zakupująca dobra lub usługi w celu zaspokojenia własnych potrzeb osobistych lub osobistych i wspólnych potrzeb innych członków gospodarstwa domowego (Garbarski 1994, s. 105), kupując produkty, niekoniecznie musi uczestniczyć w procesie podejmowania decyzji dotyczącej zakupu, a dany towar nie musi być przeznaczony do użytkowania przez osobę go nabywającą (nie musi samodzielnie użytkować zakupionego produktu). Nabywca może być i często jest reprezentantem konsumenta na rynku (Janoś-Kresło 2006, s. 15). Konsument nie musi dokonywać zakupów w celu zaspokojenia potrzeb, robi to nabywca, który dokonując zakupu, może zaspokoić potrzeby wielu konsumentów (Łukasik 2008, s. 15). Nabywca jest więc osobą, która posiada formalne uprawnienia do dokonywania zamówień, negocjowania warunków transakcji oraz zbierania informacji i wyboru dostawcy (Kienzler, Romanowski 2009, s. 156). Nabywca może mieć charakter indywidualny lub instytucjonalny. W tym drugim przypadku może to być organizacja nabywająca dobra i usługi w celu zaspokojenia potrzeb wynikających z jej charakteru oraz przedmiotu działalności (na przykład przedsiębiorstwo produkcyjne, firmy handlowe, jednostki budżetowe, organizacje i instytucje niedochodowe) (Smyczek 
2005, s. 26). Termin konsument jest szerzej rozumiany, ponieważ nie jest on tylko nabywcą, ale kupione dobra i usługi (także darowane i wytworzone przez siebie) spożywa (zużywa) w różnych formach, w zróżnicowany sposób zaspokajając swoje potrzeby (Leksykon sfery spożycia... 1988, s. 121).

Klientem jest każdy podmiot ekonomiczny (osoba, gospodarstwo domowe, przedsiębiorstwo, instytucja), który jest lub może być potencjalnie zainteresowany zakupem produktu lub usługi (sam fakt istnienia oferty może być powodem traktowania go jako potencjalnego klienta) (Janoś-Kresło 2006, s. 15; Kufel, Mruk 1998, s. 8). Można zauważyć dwie zasadnicze różnice między klientem a konsumentem. Po pierwsze, klient jest nierozerwalnie związany z rynkiem (występuje na rynku), natomiast konsument może, ale nie musi, być uczestnikiem rynku, aby pozyskać dobra i usługi, które zaspokoją jego potrzeby konsumpcyjne. Po drugie, klient może być zarówno podmiotem sfery spożycia (zakupując na rynku dobra, usługi konsumpcyjne - zaspokaja potrzeby konsumpcyjne), jak i sfery produkcji (nabywając dobra, usługi przemysłowe - zaspokaja potrzeby produkcyjne), natomiast konsument jest wyłącznie uczestnikiem sfery spożycia i zaspokaja potrzeby konsumpcyjne (Smyczek 2005, s. 27).

Użytkownikiem (spożywcą) może być jednostka, grupa jednostek, przedsiębiorstwo lub organizacja, korzystająca $\mathrm{z}$ wartości użytkowej produktu (Leksykon sfery spożycia... 1988, s. 161). W literaturze przedmiotu często zawęża się pojęcie użytkownika do jednostki, która spożywa produkty zakupione na rynku. W szerszym ujęciu za użytkowników uznaje się również jednostki, które: w gospodarstwie domowym spożywają produkty wytworzone przez jej członków (spożycie naturalne), korzystają z dóbr lub usług przekazanych nieodpłatnie lub częściowo odpłatnie w ramach świadczeń społecznych (spożycie społeczne). Użytkownikiem jest więc każdy podmiot, który wykorzystuje wartości produktu niezależnie od źródła jego pochodzenia (Smyczek 2005, s. 26). Użytkownikiem może być zarówno osoba, jak i grupa osób niebiorąca bezpośredniego udziału w procesie zakupu, ale mogąca wywierać istotny wpływ na zakupy produktów (Janoś-Kresło 2006, s. 15).

Najszerszym terminem jest konsument, którym może być osoba kupująca (nabywająca) towary i usługi, czyli nabywca, oraz taka, która użytkuje produkty dla zaspokojenia osobistych lub organizacyjnych potrzeb. Konsumenci mogą być indywidualni (kupują na własny lub domowy użytek) lub organizacyjni (różne organizacje, agencje rządowe, instytucje - kupują produkty, wyposażenie i usługi na użytek organizacji) (Jachnis 2007, s. 20) (rys. 15). 


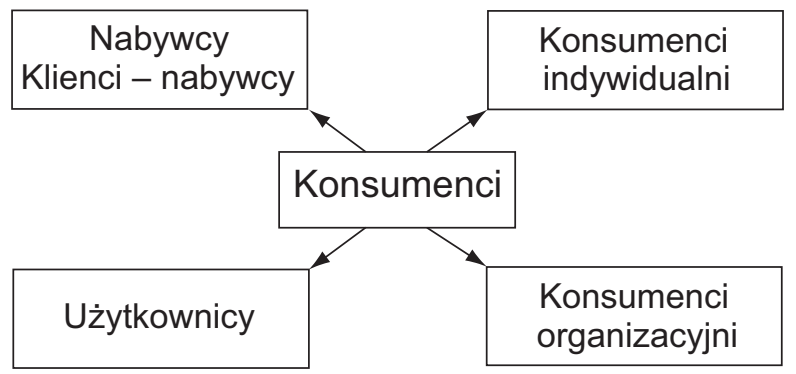

Rys. 15. Podział konsumentów na grupy.

Źródło: A. Jachnis, 2007, Psychologia konsumenta. Psychologiczne i socjologiczne uwarunkowania zachowań konsumenckich, Oficyna Wydawnicza Branta, Bydgoszcz-Warszawa, s. 21.

W procesie kupowania wyróżnić można trzy podstawowe funkcje: kupowanie, płacenie i konsumpcję. Nabywcą jest ten, kto dokonuje zakupu, płacącym - ten, kto finansuje zakup, konsumentem zaś - ten, kto korzysta $\mathrm{Z}$ wyrobu (lub konsumuje go) albo usługi. Wybór nabywcy zależy od jednej spośród pięciu wymienionych sytuacji. Konsument-płacący-nabywca nie będzie prawdopodobnie kierował się tymi samymi względami, co nabywca niebędący zarazem konsumentem albo nabywca niepłacący (tab. 12) (Bon, Pras 2001, s. 151-152).

Tabela 12

Przykłady możliwych zależności między uczestnikami procesu kupowania

\begin{tabular}{|c|c|c|c|}
\hline $\begin{array}{l}\text { Zróżnicowanie } \\
\text { funkcji }\end{array}$ & Rola nabywcy & Rola płacącego & $\begin{array}{c}\text { Rola } \\
\text { konsumenta }\end{array}$ \\
\hline $\begin{array}{l}\text { 1. Wszystkie trzy } \\
\text { funkcje pełni } \\
\text { ta sama osoba }\end{array}$ & \multicolumn{3}{|l|}{ Jednostkowy nabywca } \\
\hline $\begin{array}{l}\text { 2. Każdą funkcję } \\
\text { pełni inna osoba }\end{array}$ & Nabywca kupujący dla instytucji & Dyrektor finansowy instytucji & $\begin{array}{l}\text { Użytkownicy } \\
\text { lub konsumenci } \\
\text { w instytucji }\end{array}$ \\
\hline $\begin{array}{l}\text { 3. Jedna osoba } \\
\text { jest płacącym } \\
\text { i nabywcą. } \\
\text { Druga osoba jest } \\
\text { konsumentem }\end{array}$ & \multicolumn{2}{|l|}{$\begin{array}{ll}\text { - } & \text { nabywca kupujący } \\
& \text { dla rodziny } \\
\text { - } & \text { nabywca prezentu } \\
\text { - } & \text { nabywca pośrednik } \\
\text { - } & \text { gospodarz lub zapraszający }\end{array}$} & $\begin{array}{l}\text { - } \text { konsumenci } \\
\text { w rodzinie } \\
\text { - obdarowany } \\
\text { - gość }\end{array}$ \\
\hline
\end{tabular}


Tabela 12 (ciąg dalszy)

\begin{tabular}{|c|c|c|c|}
\hline $\begin{array}{l}\text { Zróżnicowanie } \\
\text { funkcji }\end{array}$ & Rola nabywcy & Rola płacącego & $\begin{array}{c}\text { Rola } \\
\text { konsumenta }\end{array}$ \\
\hline $\begin{array}{l}\text { 4. Jedna osoba } \\
\text { jest nabywcą } \\
\text { i konsumentem. } \\
\text { Druga osoba jest } \\
\text { płacącym }\end{array}$ & $\begin{array}{l}\text { - } \text { nabywca - konsument } \\
\text { usług bezpłatnych bądź } \\
\text { refinansowanych } \\
\text { - gość wybierający posiłek bez } \\
\text { płacenia }\end{array}$ & $\begin{array}{l}\text { - świadczący bezpłatne } \\
\text { - usługi } \\
\text { - refinansujący } \\
\text { - gospodarz lub } \\
\text { zapraszający }\end{array}$ & $\begin{array}{l}\text { - nabywca - } \\
\text { konsument } \\
\text { usług } \\
\text { bezpłatnych lub } \\
\text { refinansowanych } \\
\text { - zaproszony }\end{array}$ \\
\hline $\begin{array}{l}\text { 5. Jedna osoba } \\
\text { jest nabywcą } \\
\text { i konsumentem. } \\
\text { Druga osoba } \\
\text { jest płacącym } \\
\text { i konsumentem }\end{array}$ & - zobowiązany & - zobowiązujący & \\
\hline
\end{tabular}

Źródło: J. Bon, B. Pras, 2001, Rozdziat ról nabywcy, ptacacego i konsumenta, [w:] M. Lambkin, G. Foxall, F. van Raaij, B. Heilbrunn (red.), Zachowanie konsumenta. Koncepcje i badania europejskie, PWN Warszawa, s. 152.

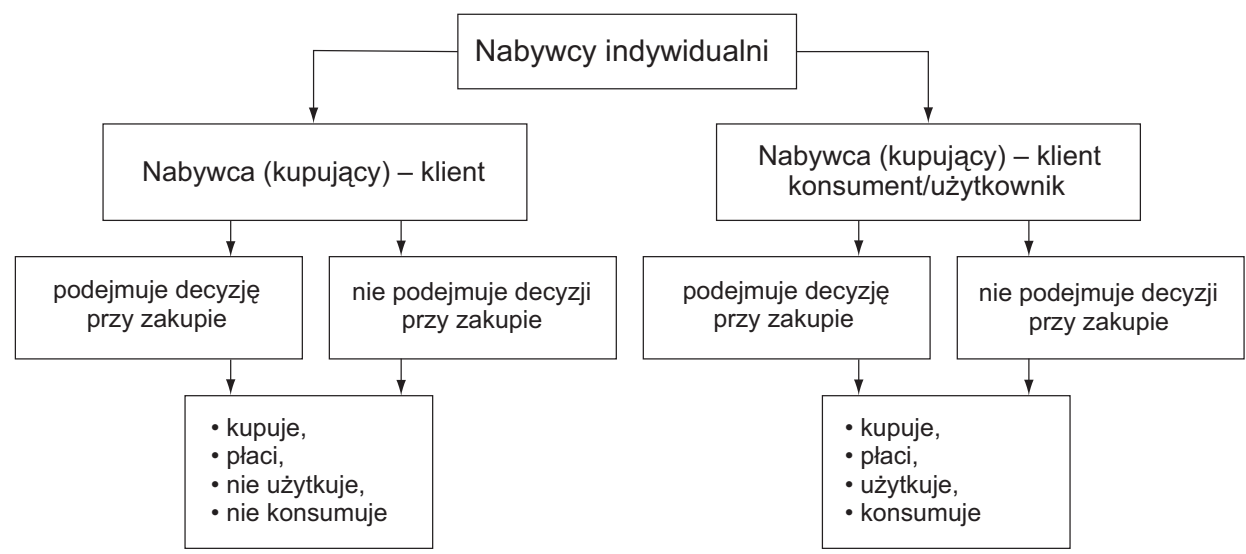

Rys. 16. Podstawowy podział nabywców indywidualnych.

Źródło: Opracowanie własne.

W badaniach skoncentrowano się głównie na zachowaniach nabywców indywidualnych, wizytujących i kupujących w łódzkich centrach handlowych. Termin nabywca $w$ pracy tej jest stosowany zamiennie $\mathrm{z}$ terminem klient, ale w kontekście bycia nabywcą - kupującym. Wśród nabywców 
można wyróżnić tych, co tylko kupują, ale nie użytkują, nie konsumują zakupionych dóbr i usług oraz tych, co nie tylko kupują, ale również są ich użytkownikami i konsumentami. W obu sytuacjach nabywca może być decydentem (współdecydentem) przy zakupie lub nie brać udziału w podejmowaniu decyzji, w takim wypadku jest tylko kupującym płacącym (rys. 16).

Wszystkie ankietowane osoby bywały w centrach handlowych i korzystały $z$ ich oferty, więc są nabywcami i jednocześnie klientami, ale nie każda wizyta musi być związana $\mathrm{z}$ zakupem, są więc w niektórych sytuacjach tylko klientami, potencjalnymi nabywcami. W pracy przyjęto, że każdy nabywca jest klientem, choć nie musi być użytkownikiem, konsumentem dóbr materialnych i usług przez siebie nabywanych ${ }^{32}$.

\subsection{Badania nad zachowaniami nabywczymi i przestrzennymi}

Badania nad zachowaniami konsumenckimi (consumer behavior) ${ }^{33}$ posiadają bardzo bogaty dorobek naukowy. W literaturze zachodniej, jak i polskiej można spotkać wiele modeli prezentujących różne podejścia do tego zagadnienia. Jak zaznacza S. Smyczek (2005b, s. 65), „zachowania konsumentów można badać w różnych wymiarach: podmiotowym, przedmiotowym, przestrzennym i czasowym, a tak szeroki zakres badań sprawia, że są one obiektem badań wielu dyscyplin naukowych, takich jak: psychologia, antropologia, socjologia czy ekonomia". W modelach prezentujących zachowania konsumenckie najczęściej pomijany jest aspekt przestrzenny, natomiast uwaga głównie zwracana jest na motywy podejmowania decyzji oraz determinanty zachowań i ich efekt końcowy, ale jak podkreśla S. Smyczek (2005, s. 64), „zachowania konsumenckie mają także swój wymiar przestrzenny i czasowy, a więc dokonują się w określonej sytuacji (układzie warunków), który ma zmienny charakter”. Aspekt przestrzenny pojawia się natomiast w badaniach behawioralnych, między innymi nad

\footnotetext{
${ }^{32} \mathrm{~W}$ pracy nie badano, kto jest użytkownikiem, konsumentem nabywanego asortymentu.

${ }^{33}$ „W literaturze marketingowej, zwłaszcza anglojęzycznej, oprócz najbardziej ogólnego terminu - zachowanie się konsumenta (consumer behavior), dla celów szczegółowych wyróżnia się na przykład zachowanie podczas zakupów (shopping behavior), zachowanie w procesie poszukiwania informacji (information search behavior), zachowanie podczas wyboru miejsc sprzedaży (in store choice behavior) i tym podobne. Wszystkie te rodzaje zachowań mieszczą się w kategorii zachowanie konsumenta, które jest pojęciem najszerszym" (Gajewski 1994, s. 9-10).
} 
zachowaniami turystycznymi, to tu w niektórych modelach eksponowana jest przestrzeń i jej pokonywanie. Szczególnie w grupie modeli „wyboru miejsc docelowych", jak je określa L. Mazurkiewicz (2007) ${ }^{34}$.

W literaturze zagranicznej, jak i w krajowej wiele miejsca poświęca się zachowaniom konsumentów. W drugiej połowie lat 60. XX wieku rozpoczął się okres tworzenia tak zwanych wielkich teorii, modeli, w których starano się przedstawić całościowo zachowania konsumentów. $\mathrm{Na}$ uwagę zasługują, między innymi modele: A.R. Andreasen (pierwszy ogólny model zachowania konsumenta - 1966), F.M. Nicosia (1966), J.A. Howard, J.N. Sheth (1969) i J.F. Engel, D.T. Kollat, R.D. Blackwell $(1968)^{35}$ (Smyczek 2005b, s. 69). W celu odzwierciedlenia zachowań konsumentów wykorzystuje się modele strukturalne (najczęściej), stochastyczne i symulacyjne (Światowy 2006, s. 46). „Modele te stanowią swego rodzaju schematy zjawisk i mechanizmów składających się na postępowanie nabywców i są podstawą do konstruowania teorii zachowań konsumentów" (Rudnicki 2004, s. 68).

J.A. Howard i J.N. Sheth $(1969)^{36}$ opracowali teorię zachowania nabywcy, w której wyróżnia się wejście (inputs), postrzeganie (perceptual constructs), uczenie się (learning constructs) oraz wyjście (outputs) (Smyczek 2005a, s. 130-131). Model ten składający się z czterech grup zmiennych jest próbą wyjaśnienia racjonalnego wyboru produktu w warunkach niepełnych informacji i ograniczonych możliwości ich przetwarzania przez konsumenta. Zmienne wejścia obejmują informacje, które stanowią podstawę podejmowania decyzji zakupu (produktu, na przykład jakość, cena, oryginalność; społeczne - rodzina, grupa odniesienia, grupa społeczna). Zmienne hipotetyczne to zmienne psychologiczne wpływające na przetwarzanie informacji płynących $z$ wejścia (percepcyjne i uczenia

\footnotetext{
${ }^{34} \mathrm{Z}$ kilkoma modelami tego typu można się zapoznać midzy innymi w książce: G. Dune, Motivation and decision making in city break travel. The case of Dublin, VDM Publishing, 2009, Saarbrucken, Niemcy.

${ }^{35}$ Przegląd modeli zachowań konsumentów na rynku można znaleźć w wielu opracowaniach, między innymi L. Rudnicki (2000, 2004, 2012), S. Smyczek, I. Sowa (2005), G. Światowy (2006), M. Sullivan, D. Adcock (2003).

${ }^{36}$ Celem pracy nie jest przedstawienie wszystkich modeli zachowań konsumenckich, tym bardziej że w opracowaniu tym skoncentrowano się głównie na zachowaniach nabywczych. Zaprezentowano przykładowe modele zachowań, które są zmodyfikowaną (rozszerzoną) formą wcześniejszych modeli w celu lepszego zrozumienia zachowań nabywczych, będących pojęciem węższym w stosunku do zachowań konsumenckich.
} 


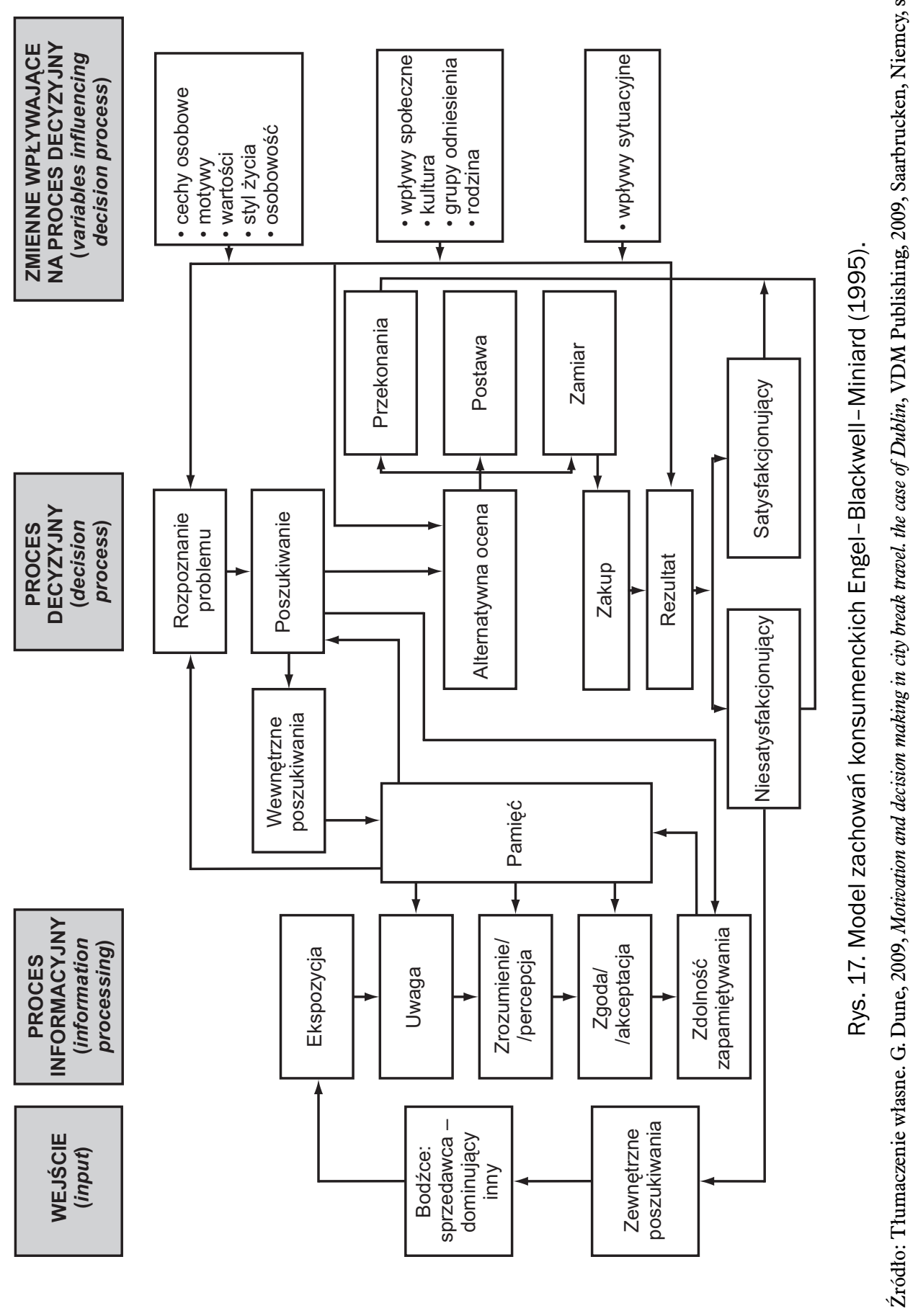


się). Natomiast zmienne wyjścia to: uwaga, zrozumienie, postawa, intencja i zakup (Gajewski 1994, s. 173; Rudnicki 2004, s. 72). Znaczną rolę $\mathrm{w}$ procesie nabywczym autorzy przypisują również zmiennym ograniczającym możliwości działania, do których zaliczają: ceny, dostępność produktu, ograniczenia czasowe, status finansowy nabywcy (Gajewski 1994, s. 174).

Model Engel-Blackwell-Miniard (1995), tzw. EKB ${ }^{37}$ jest jednym z najbardziej znanych w ekonomii modeli zachowania się nabywcy indywidualnego, odzwierciedlający proces podejmowania decyzji zakupu, który składa się z pięciu etapów: rozpoznanie problemu (zaistnienie potrzeby), poszukiwanie danych wewnętrznych i zewnętrznych (informacji, alternatywnych rozwiązań), ocenę wariantów wyboru (ocena informacji, alternatyw), decyzję zakupu (dobra lub usługi) oraz odczucia pozakupowe (skutki wyboru satysfakcjonujące lub niesatysfakcjonujące) (Rudnicki 2012, s. 22). Liczba etapów, przez które faktycznie przechodzi konsument, zależy od złożoności sytuacji (na przykład przy decyzji rutynowej najprawdopodobniej przejdzie od poszukiwań wewnętrznych do rzeczywistego zakupu) (Gajewski 1994, s. 176). W modelu tym zwrócono uwagę na czynniki wpływające na wszystkie pięć etapów procesu decyzyjnego. Do czynników wewnętrznych (indywidualnych) zaliczono: motywy, wartości, styl życia i osobowość, natomiast do czynników zewnętrznych: wpływy społeczne, kulturę, grupy odniesienia i rodzinę. Na proces decyzyjny obok tych dwóch grup czynników wpływają również czynniki sytuacyjne jak choćby sytuacja finansowa konsumenta (Smyczek 2005a, s. 134) (rys. 17).

W modelu zachowań konsumenckich D.L. Loudon i A.J. Della Bitta (1993), który w dużym stopniu opiera się na koncepcji uczenia, zwraca się uwagę między innymi na motywacje, które kierują zachowaniami nabywczymi, na ograniczenia czasowe i finansowe. Do czynników zewnętrznych, wpływających na proces decyzyjny zaliczono, między innymi wagę zakupu, cechy osobowe, klasę społeczną, kulturę, status finansowy (materialny). W modelu tym tak jak w omówionym powyżej dużą rolę przypisuje się informacji, jej poszukiwaniu, przetwarzaniu i wykorzystaniu (rys. 18).

\footnotetext{
${ }^{37}$ Model ten był wielokrotnie modyfikowany, modyfikacje z różnych lat można znaleźć w polskiej literaturze: z 1968 roku (Rudnicki 2004, s. 79), z 1973 roku (Gajewski 1994, s. 177), z 1986 roku (Smyczek, Sowa 2005, s. 132).
} 


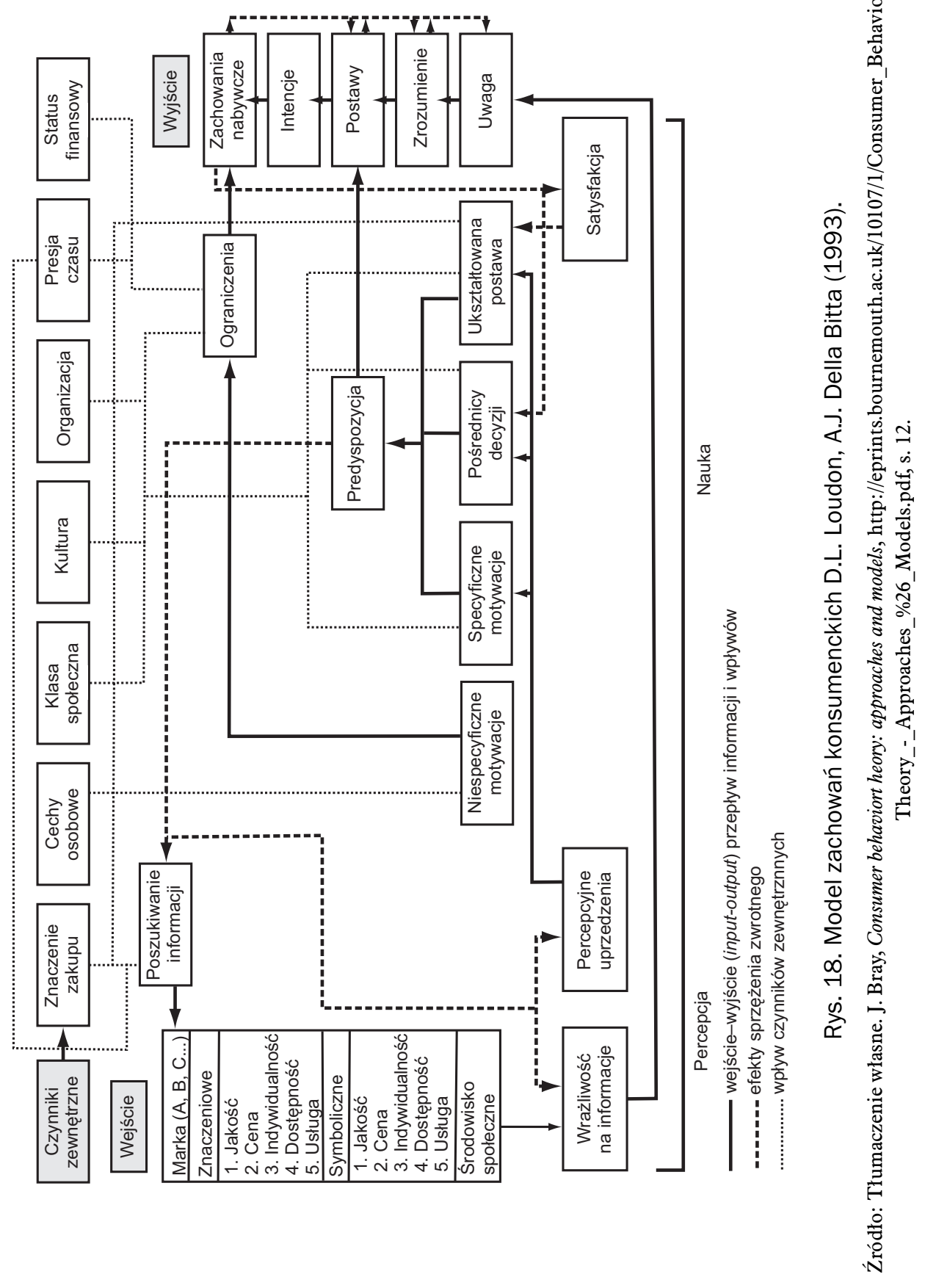


W wyżej omówionych modelach „proces nabywczy traktuje się jako serię występujących po sobie etapów, na których konsument musi rozwiązywać odmienne problemy" (Gajewski 1994, s. 178). Modele tego typu uzmysławiają, że proces zachowań konsumenckich, w tym nabywczych, jest złożony, a o jego przebiegu decyduje wiele zmiennych, zarówno wewnętrznych, jak i zewnętrznych.

W modelu trójstopniowym R. Hudson (1976), przedstawił etapy wyboru sklepu: w pierwszym konsumenci zdobywają wiedzę na temat miejsc zakupu i ustalają swoje preferencje (definiują idealny sklep), w drugim w związku z określoną potrzebą konsumenci oceniają pewien podzbiór sklepów znanych sobie (wyobrażenie odnoszące się do określonej potrzeby), w trzecim dokonują faktycznego wyboru jednego sklepu, najbliższego ideałowi (Walmsley, Lewis 1997, s. 140). Według L.P. Bucklina (1967) poszukiwanie nie jest procesem prostym, dlatego powstało wiele typów takiego zachowania. Wyróżnił on „pełne rozpoznanie” polegające na odwiedzaniu wielu sklepów, „rozpoznanie ukierunkowane”, w którym prowadzi się poszukiwanie ukierunkowane zwłaszcza przez cenę dobra, oraz „rozpoznanie przypadkowe”, gdy informacje uzyskuje się mimochodem” (Walmsley, Lewis 1997, s. 138).

Podejmowanie decyzji o zakupie konkretnego produktu (towaru, usługi) związane jest $\mathrm{z}$ wyborem miejsca realizacji tego zamierzenia. K.B. Monroe i J.P. Guiltinam (1975, za: Rudnicki 2000, s. 159-160), zauważyli, że na wybór placówki wpływa wiele czynników, a decydują o tym cztery grupy zmiennych: ogólna postawa konsumenta wobec uczęszczania do różnych punktów sprzedaży, planowanie zakupów i wydatków oraz znaczenie i postrzeganie atrybutów sklepu (rys. 19).

W metodzie opracowanej przez CCN (obecnie Experian) przedstawionej przez M. Davies, I. Clarke (1994) „założono, że głównymi zmiennymi wyjaśniającymi dokonywanie przez klientów wyboru miejsca zakupów są czas, którym dysponują oraz charakter zakupów”. „Klient preferujący bliskość wybiera sklepy położone w bezpośrednim sąsiedztwie miejsca zamieszkania lub pracy (pasaże handlowe), a klient preferujący wygodę szuka sklepów łatwo dostępnych, gdzie szybko może dokonać dużych zakupów (często są to samodzielne obiekty, wielkie i położone w znacznej odległości od innych obszarów handlowych)”. „Dla klienta mniej odczuwającego presję czasu zakupy są sposobem na spędzenie wolnego czasu czymś w rodzaju wypoczynku. Klienci tacy chętnie porównują oferty 


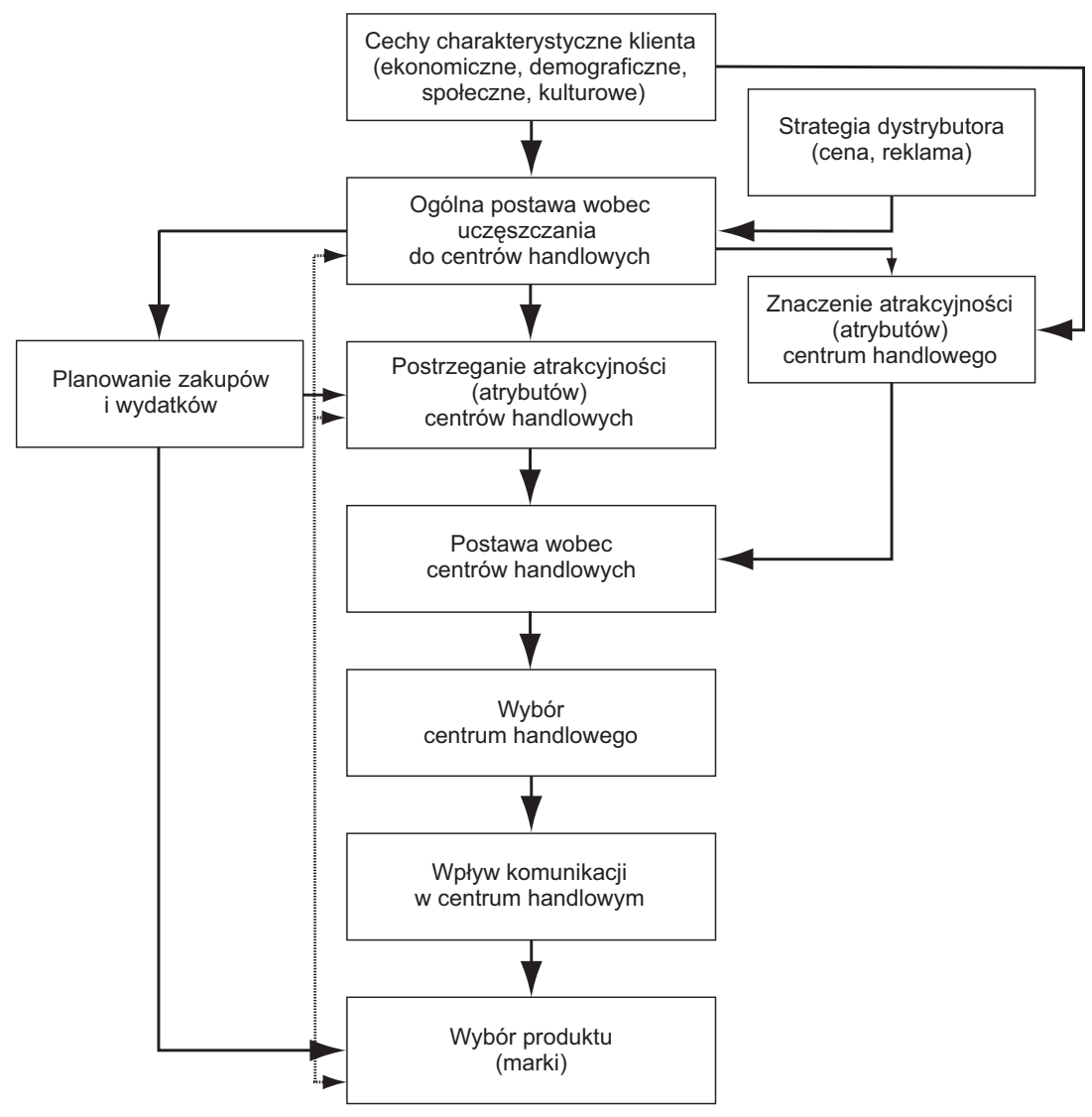

Rys. 19. Proces wyboru centrum handlowego.

Źródło: Monroe, Guiltinam J.P., A Path Analytic Exploration of Patronage Influences, Fournal of Consumer Research, vol. 2, 1975, [za:] Mazurek-Łopacińska K., Zachowania nabywców jako postawa strategii marketingowej, AE, Wrocław, 1997, s. 64; Mazurek-Łopacińska K., Zachowania nabywców i ich konsekwencje marketingowe, PWE, Warszawa, 2003, s. 129.

(„rozglądają się”) i faworyzują zamiejskie centra handlowe w wypadku zakupów dużych oraz tradycyjne miejskie centra handlowe w wypadku towarów łatwiejszych do przeniesienia” (Sullivan, Adcock 2003, s. 142-143).

L. Rudnicki (2000, s. 160-165) do czynników wpływających na zachowania konsumenta w procesie wyboru punktu sprzedaży zaliczył:

- charakter poszukiwanych produktów (częstego, okresowego lub epizodycznego zakupu),

- rolę zakupów (na czyj użytek jest kupowany), 
- postrzeganie ryzyka zakupu (obawy przed zakupem w Internecie),

- stosowaną politykę cenową (na przykład obniżki),

- jakość towarów (na przykład niezawodność działania),

- asortyment produktów (jego szerokość i głębokość),

- personel sklepu (na przykład kwalifikacje, sprawność obsługi),

- lokalizacja punktu sprzedaży względem domu i miejsca pracy (fizyczna odległość, dostępność komunikacyjna),

- dogodność zakupów (na przykład godziny otwarcia),

- usługi świadczone przez sklep (na przykład dostawa do domu),

- działania promocyjne (na przykład wyprzedaże, degustacje),

- reklama,

- atmosfera (na przykład wystrój wnętrza, układ stoisk, oświetlenie)

- opinia o punkcie sprzedaży,

- reputacja, opinia o uczciwości i sposób załatwiania reklamacji,

- stan psychiczny i fizyczny konsumenta (na przykład zmęczenie, uczucie głodu, senność).

Wybór konkretnego miejsca sprzedaży zależy więc od bardzo wielu czynników, ale nie zawsze wszystkie one łącznie o nim decydują. W przypadku dużych centrów handlowych, to o ich odwiedzeniu przez klientów decydują takie czynniki jak: wielkość centrum handlowego, czas podróży, lokalizacja przy trasie, możliwości parkingowe i tym podobne. Prawdopodobieństwo, że konsument uda się na zakupy do określonego centrum handlowego, jest wprost proporcjonalne do wielkości tego centrum i odwrotnie proporcjonalne do czasu podróży (Rudnicki 2000, s. 165). Często wielu konsumentów kumuluje zakupy w jednym, oddalonym punkcie sprzedaży (na przykład centrum handlowym, hipermarkecie) $\mathrm{z}$ powodu prowadzonej przez niego polityki niskich cen, uzyskiwane oszczędności finansowe przewyższają bowiem koszty dotarcia do tego punktu sprzedaży (Rudnicki 2000, s. 163).

"Zachowanie konsumenta obejmuje: nabywanie, posiadanie oraz użytkowanie środków zaspokajania potrzeb” (Rudnicki 2004, s. 22). Zachowania nabywcze „obejmują zespół działań związanych z dokonaniem wyborów mających na celu zakup dóbr i usług” (Smyczek 2005b, s. 62). „Jest to proces obejmujący całokształt działań związanych z podejmowaniem decyzji, rozpoczynający się od uświadomienia potrzeby, a kończący się na ocenie przez konsumenta-nabywcę trafności decyzji, włącznie z wymianą informacji. Decyzje konsumenta co do zakupu w warunkach istnienia swobody wyboru dotyczą: określonego dobra materialnego lub usługi, 
jego jakości, warunków zakupu (to znaczy miejsca zakupu, sposobu płatności)" (Kieżel 1998, s. 210).

Pierwsze badania nad zachowaniami przestrzennymi klientów sklepów pojawiły się pod koniec lat 20 . XX wieku. W 1929 roku H. Hotelling w teorii „minimum zróżnicowania” wprowadził zasadę, że „pewna liczba konkurencyjnych sklepów osiagga najlepsze wyniki, gdy wszystkie sklepy są zgrupowane”. Zgodnie $\mathrm{z}$ tą zasadą ,jeśli jakiś obszar w centrum staje się znany jako ośrodek pewnego rodzaju placówek (ofert), to nabywcy mogą maksymalnie zwiększyć swe możliwości wyboru, i zarazem zminimalizować koszty podróży pomiędzy sklepami, jeśli w poszukiwaniu odpowiedniego produktu czy usługi udadzą się właśnie na ten obszar"38 (Sullivan, Adcock 2003, s. 135-136). Zasada ta w pewnych względach jest adekwatna w dzisiejszych czasach w stosunku do centrów handlowych, które są właśnie takimi konglomeratami placówek o zróżnicowanej ofercie, gdzie nabywcy mogą się udać w celu zaspokojenia różnych potrzeb, mają większy wybór i mogą zminimalizować koszty przemieszczania się między sklepami.

Teoria interakcji przestrzennej określa „sposób oddziaływania konkurencyjnych obszarów handlowych na nabywców zamieszkałych w dzielnicach bezpośrednio sąsiadujących z nimi” (Sullivan, Adcock 2003, s. 136). Najstarszym modelem z tej grupy jest Prawo Reilly'ego (1931), które określa „granice między dwoma obszarami handlu detalicznego czy miastami, opierając się na populacji miast i ich odległości od linii granicznej”. Zgodnie z tym prawem „częstotliwość, z jaką mieszkańcy miejscowości znajdującej się między dwoma miastami odwiedzają je w celach handlowych, jest wprost proporcjonalna do liczby ludności tych miast i odwrotnie proporcjonalna do pierwiastka odległości między tą miejscowością a miastami. Granica wyznaczona przez to prawo nosi nazwę punktu brzegowego" (Sullivan, Adcock 2003, s. 137).

W. Wilk (2001, s. 29) zauważa, że „z punktu widzenia usługodawcy o podstawowym znaczeniu jest poznanie sposobów zachowań przestrzennych konsumentów oraz zasad i skłonności potencjalnych klientów do przemieszczeń w celu pozyskania danego dobra (usługi)”. W literaturze

\footnotetext{
${ }^{38}$ Teoria ta lepiej stosuje się do placówek detalicznych oferujących towary o wyższym progu, takich jak jubilerzy, antykwariaty, sklepy z odzieżą czy domy towarowe, niż do oferujących towary o progu niższym, jak lokalne sklepy wielobranżowe czy supermarkety (Sullivan, Adcock 2003, s. 136).
} 
geograficznej koncepcje behawioralne wyjaśniające zachowania konsumentów pojawiały się w latach 60. i 70. XX wieku. Pierwsze z nich nawiązywały do teorii „ośrodków centralnych” W. Christallera (1933) zgodnie z którą uznawano, że „postępujący w pełni racjonalnie konsument dąży do minimalizacji przemieszczeń, w konsekwencji nabywa potrzebne dobra (usługi) w najbliższym ośrodku, który je oferuje” (Wilk 2001, s. 30). „Konsekwencją przyjęcia w stosunku do konsumentów idealistycznego założenia racjonalności ekonomicznej było twierdzenie, że minimalizują oni przemieszczenia i kupują w najbliższym sklepie oferującym potrzebne dobra. Człowiek kierujący się tym założeniem będzie się jednak liczył z ceną dobra, a więc może udać się do sklepu dalej położonego, jeśli będzie móg1 tam taniej kupić"39 (Walmsley, Lewis 1997, s. 133). Założenia tej teorii poddano krytyce zwracając uwagę, że nie uwzględniono w niej pewnych faktów, między innymi: podróży wielocalowych (założono, że wyprawy podejmuje się wyłącznie w celu dokonania jednego rodzaju zakupu); pominięto takie zmienne jak wielkość i atrakcyjność ośrodka; błędnie założono, że wszyscy klienci są identyczni i zachowują się w całkowicie racjonalny sposób - część konsumentów lubi kierować się w wyborze miejsca zakupów jakością towarów, dobrą obsługą, życzliwością, a nie korzyściami natury ekonomicznej; nie udzielono pełnej odpowiedzi na zasadnicze pytanie ,jak daleko są gotowi się udać nabywcy, chcący dokonać zaplanowanego zakupu?"; część zakupów robi się ponadto łącząc je z innymi koniecznymi przemieszczeniami (Wilk 2001, s. 30, Walmsley, Lewis 1997, s. 133, Sullivan, Adcock 2003, s. 134).

Modele grawitacji operują prawdopodobieństwem wyboru miejsca zakupu. Jednym z pierwszych probabilistycznych modeli grawitacji była koncepcja D.L. Huffa $(1960,1963)$. Autor ten wśród podstawowych czynników wyboru miejsca zakupu dobra (usługi) uwzględnił powierzchnię sklepu oraz czas podróży do sklepu. Według niego „wiele zachowań przestrzennych konsumentów podejmowanych jest w warunkach niepewności dotyczącej możliwości spełnienia konkretnych wymagań przez dany ośrodek. Wybór konsumenta oparty jest wówczas na ocenie prawdopodobienstwa czy w danym ośrodku będzie mógł zaspokoić swoje potrzeby. To prawdopodobieństwo wzrasta ze zwiększeniem liczby rodzajów dóbr ofe-

\footnotetext{
${ }^{39}$ Teorię W. Christallera wykorzystywano, między innymi do ustalenia hierarchii ośrodków handlowych w obszarze dużego miasta, M. Proudfoot (1937), B.J.L. Berry (1963) (Wilk 2001, s. 24).
} 
rowanych w danym ośrodku handlowym”. Dokonał próby rozszerzenia modelu zachowań o większą liczbę zmiennych wyjaśniających, poza cechami opisującymi wielkość ośrodka oraz transport (sposób i koszt) uwzględnił także system wartości konsumenta. Wśród jego składowych wymieniał między innymi położenie geograficzne, zróżnicowanie społeczne (przynależność etniczną, zawód wykonywany, dochód, wykształcenie) $\mathrm{i}$ indywidualną ruchliwość (płeć, wiek) (Wilk 2001, 30-31).

W koncepcji ujawniania preferencji przestrzennych G. Rushtona (1969, 1976) założono, że „konsument porządkuje wszystkie możliwości dokonania zakupów według własnych preferencji i dokonuje systematycznie zakupu w ośrodku najbardziej preferowanym oraz że znając preferencje konsumenta można przewidzieć jego zachowanie”. Trudności obliczeniowe sprawiły, że w większości badań rozpatrywano dla uproszczenia tylko dwie zmienne: wielkość (atrakcyjność) ośrodka i odległość do niego (Walmsley, Lewis 1997, s. 134). Model zachowania się konsumentów H. Timmermansa $(1979,1982)$ „określał atrakcyjność ośrodka (strefy) nie poprzez liczbę ludności (jak G. Rushton) ale liczbę zatrudnionych (w handlu)" (Wilk 2001, s. 31) „próbował uogólnić preferencje i twierdził, że konsumenci kierują się często w wyborze ośrodka zakupów jego wielkością i dostępnością" (Walmsley, Lewis 1997, s. 135). Natomiast N.J. Williams $(1979,1981)$ dokonał próby powiązania zachowań przestrzennych konsumentów z rodzajem ich postawy wobec zakupów (Wilk 2001, s. 34).

W wielu podejściach dotyczących zachowań przestrzennych klientów zwracano uwagę na rolę informacji. F. Horton, D.R. Reynolds (1971) zauważyli, że „na sposób wykorzystania informacji mają wpływ cztery czynniki: rzeczywista struktura przestrzenna środowiska miejskiego, położenie miejsc zamieszkania, czas zamieszkania w tym samym miejscu oraz status społeczno-ekonomiczny konsumentów” (Walmsley, Lewis 1997, s. 137). W modelu behawioralnym zachowań przestrzennych konsumentów $M$. Cadwallader $(1975,1981)$, ,rozszerzył zestaw zmiennych opisujących obiekty handlowe (odległość i wielkość) o informację o sklepie”. Wyróżnił on trzy zmienne; atrakcyjność sklepów (wyrażającą się w zasięgu, jakości i cenie dóbr), odległość od sklepu - rzeczywistą i odległość oszacowaną przez konsumenta (odległość między domem klienta a sklepem) oraz liczbę informacji, którą konsument ma o sklepie (jaką generuje dany obiekt) (Walmsley, Lewis 1997, s. 136; Wilk 2001, s. 31). R.B. Potter (1976, 1977, 1979, 1982) w koncepcji pola informacji o środowisku handlowym zaproponował 
rozróżnienie między polem informacji konsumenckiej i polem wykorzystania. Pierwsze pojęcie odnosi się do ośrodków sklepowych, o których konsument ma informację (których istnienia konsument jest świadomy), a drugie - do ośrodków faktycznie odwiedzanych (z których oferty konsument korzysta dokonując zakupów). „Pole wykorzystania leży wewnątrz pola informacji” (Walmsley, Lewis 1997, s. 137, Wilk 2001, s. 32) ${ }^{40}$.

Niezależnie od tego, jak starano się wyjaśnić zachowania przestrzenne każda z propozycji teoretycznych zawierała pewne wady. Wśród najczęściej wymienianych zastrzeżeń wobec modeli zachowań wymieniano:

- uproszczenia sprowadzające się do uwzględniania zbyt małej liczby zmiennych mających wpływ na zachowania przestrzenne konsumentów,

- trudność ekstrapolacji uzyskanych wyników na możliwe inne sytuacje,

- częste stosowanie zmiennych trudnych do zoperacjonalizowania,

- brak możliwości przejścia z badań makroskalowych na mikroskalowe (określenia zachowań jednostek na podstawie zachowania grup),

- pomijanie istniejących, niezależnych od konsumenta, ograniczeń w wyborze ośrodka zakupów (Wilk 2001, s. 34).

Analizując modele turystycznych zachowań przestrzennych, można zauważyć pewne analogie do tego typu zachowań klientów centrów handlowych. W każdym takim zachowaniu następuje wykrystalizowanie się potrzeby, zgromadzenie informacji o możliwościach jej zaspokojenia, poszukiwanie miejsc mogących je zaspokoić, wybór konkretnego miejsca, podróż (dojazd) oraz wynik podróży. Taki uproszczony model podróży turystycznych zaprezentowali A. Mathieson i G. Wall (1982) (rys. 20).

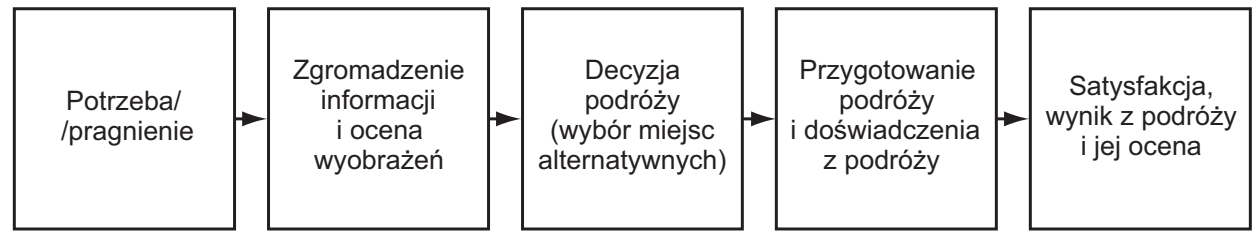

Rys. 20. Liniowy pięcioetapowy model turystycznych podróży według. A. Mathieson, G. Wall (1982).

Źródło: M.M.A. Abdallat, H.S. Emam, 2001, Consumer Behavior Models in Tourism. Analysis Study, Department of Tourism and Hospitality, King Saud University, s. 28.

40 Więcej informacji o zachowaniach przestrzennych można znaleźć w R.G. Golledge, R.J. Stimson, 1997, Spatial behavior. A geographic perspective, The Guilford Press, New York. 
Mechanizm ten jest $\mathrm{w}$ takim ujęciu oczywiście uproszczony, zgeneralizowany. W związku z pewnymi podobieństwami między zachowaniami turystów i klientów centrów handlowych poniżej będą prezentowane od razu modyfikacje modeli obrazujących „wybór miejsc docelowych” turystów na potrzeby zachowań przestrzennych klientów korzystających z oferty centrów handlowych. Należy w tym miejscu również podkreślić, że niektórzy klienci tego typu kompleksów mogą być turystami, ponieważ największe centra handlowe często wmontowane zostały w historyczną tkankę układów poprzemysłowych, na przykład Manufaktura w Łodzi, i stały się swego rodzaju atrakcją turystyczną miasta - atrakcją przyciągającą turystów, generującą ruch turystyczny.

Podobnie jak w przypadku podróży turystycznych, u potencjalnych klientów centrów handlowych pojawia się potrzeba, którą będą chcieli następnie zaspokoić. Potrzeby takie mogą mieć różny charakter, choć najczęściej utożsamiane są $\mathrm{w}$ tym przypadku $\mathrm{z}$ koniecznością zakupu dóbr materialnych lub/i niematerialnych. Ze względu na społeczny charakter centrów handlowych (o nim pisze między innymi G. Makowski 2003) w miejscach tych zaspokajane są też inne potrzeby, na przykład możliwość spędzania czasu wolnego czy kreowanie własnego prestiżu (eksponowanie przynależności do odpowiedniej klasy społecznej dzięki pojawianiu się w tego typu miejscach). Wizyta w centrum handlowym może być czasami wynikiem decyzji spontanicznej, która powstaje z racji pobytu w bliskiej odległości od takiego kompleksu, ale może być wywołana także przez zobaczoną, usłyszaną reklamę lub zaistnieć dzięki kontaktowi z innymi osobami (rodzina, przyjaciele, znajomi).

W momencie, gdy zapada decyzja odpowiednio wcześnie, a wyjazd przybiera charakter zaplanowany, wtedy poprzedza go analiza posiadanych informacji ( $\mathrm{z}$ różnych źródeł, w tym własne doświadczenia), co skutkuje wyborem odpowiedniego centrum handlowego i podjęciem decyzji o rozpoczęciu podróży. Wyjazd tego typu wiąże się z pokonaniem pewnej drogi (odległości czasowej i przestrzennej), odbywanej za pomocą różnych środków transportu. Pobyt w tego typu miejscu dostarcza odwiedzającej je osobie nowych doświadczeń i kończy się mniej lub bardziej satysfakcjonującym lub niesatysfakcjonującym rezultatem (rys. 21).

J. Kaczmarek (2005, s. 87) w swoich rozważaniach teoretycznych na temat działań przestrzennych i aktywności przestrzennej definiuje zachowania przestrzenne jako „obserwowalną aktywność człowieka związaną ze zmianą położenia w środowisku geograficznym, zawierającą świadomość, intencje, 


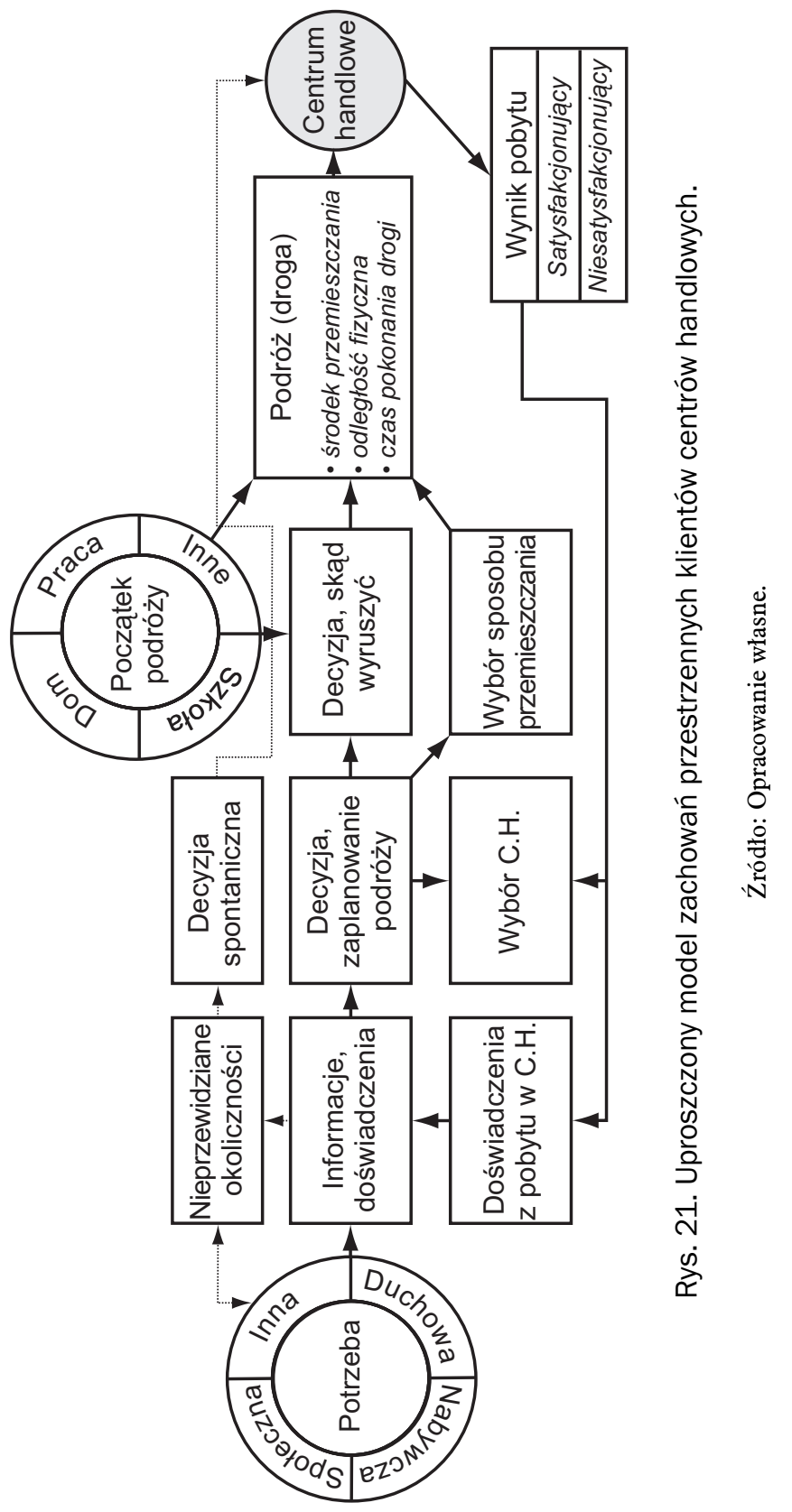


znaczenia”. W ramach aktywności przestrzennej zachowania przestrzenne związane $\mathrm{z}$ wyjazdami i odwiedzinami centrów handlowych można zaliczyć do jednej z form tak zwanej „dziennej ścieżki życia rozumianej jako dobowa aktywność człowieka, która dokonuje się w środowisku życia codziennego bez jego zmiany. Stanowi ona powtarzalny, rutynowy element szlaku życiowego. Składają się nań aktywności wykonywane poza domem w ciągu doby, zlokalizowane w konkretnym fragmencie przestrzeni i trwające określony czas” (rys. 22) (Kaczmarek 1996; 2003, 2005, s. 91).

\begin{tabular}{|l|}
\hline DZIAŁANIA PRZESTRZENNE \\
• złożony ciąg czynności, stanowiących pewna całość i ukierunkowanych \\
na wykonanie zadania przestrzennego (zrealizowania celu).
\end{tabular}

Rys. 22. Pola działań przestrzennych.

Źródło: J. Kaczmarek, 2005, Podejście geobiograficzne w eografii spotecznej. Zarys teorii i podstawy metodyczne, UŁ, Łódź, s. 87.

Wyjazdy do centrów handlowych dla niektórych klientów są rutynową czynnością, ale w różnych odstępach czasowych. Najczęściej nie mają charakteru codziennego, ale związane są $\mathrm{z}$,tygodniowym cyklem życia człowieka”. W związku z tym pobyty w centrach handlowych nie wpisują się idealnie w „dzienną ścieżkę życia człowieka”, chyba że będziemy rozpatrywać tylko wybrane dni tygodnia, szczególnie dni weekendowe. W takim wypadku dla wielu osób wizyta w centrum handlowego ma charakter 
rutynowy, schematyczny i jest integralną częścią organizacji szczególnie dni wolnych od pracy.

Zdefiniowania zachowań przestrzennych dokonał L. Mazurkiewicz (2007, s. 99), który podkreśla, że „zjawisko przestrzennego zachowania ludzi stanowi istotny składnik przedmiotu geografii społeczno-ekonomicznej, ponieważ łączy w sobie dwie najważniejsze dla tego przedmiotu kategorie: człowieka i przestrzeń". Autor w swoich rozważaniach skoncentrował się na zachowaniach przestrzennych indywidualnych turystów, konstruując model tego typu zachowań. Wzorując się na podanej przez niego definicji, można określić zachowania przestrzenne indywidualnego klienta centrów handlowych jako proces wyboru miejsca lub miejsc zakończenia podróży nabywczej (docelowej) z punktu widzenia ich odległości oraz atrakcyjności, w których spodziewa się on zaspokojenia swoich oczekiwań (potrzeb) oraz jako formę pokonania przestrzeni fizycznej w celu dotarcia do wybranych miejsc docelowych.

Podobnie jak w przypadku zachowań turystycznych, zachowania przestrzenne klientów centrów handlowych można rozpatrywać jako rezultat działania dwóch podstawowych grup czynników (przyczyn):

- czynników wypychających z miejsc pobytu (podejście typu push), między innymi „Model systemu atrakcji turystycznej” G. Richardsa (2002);

- czynników przyciągających ich do miejsc docelowych (podejście typu pull), proces wyboru uwzględniający wpływ atrakcyjności miejsc docelowych oraz odległości do nich, które wyjaśnia między innymi „Model wyboru miejsc docelowych” P.K. Ankomah i inni (1996) (rys. 23 i 24) ${ }^{41}$. Podstawą do skonstruowania modelu „zachowania przestrzennego turystów” dla L. Mazurkiewicza (2007) było uwzględnienie obydwu grup czynników odpowiedzialnych za zachowania turystów wypychających (push) oraz przyciągających (pull) oraz wykorzystanie modelu wyboru miejsc docelowych i modelu systemów atrakcyjności turystycznej do sformułowania modelu „zachowania przestrzennego turystów”. Model ten prezentuje „zachowanie ujawniane przez jednostkę pokonującą przestrzeń z zamiarem dotarcia do wybranego miejsca lub miejsc docelowych, w których spodziewa się zaspokojenia swoich turystycznych oczekiwań”. Warte podkreślenia jest, że autor w swoich rozważaniach zwraca uwagę na rolę

${ }^{41}$ Przegląd badań nad zachowaniami turystycznymi zamieszczony jest w pracy S.K. Burbidge, G. Goulias, 2009, Active travel behavior, "Annual Meeting of the Journal of the Transportation Research Board”, no 88, http://www.uctc.net/papers/873.pdf, (dostęp 2 maja 2011). 


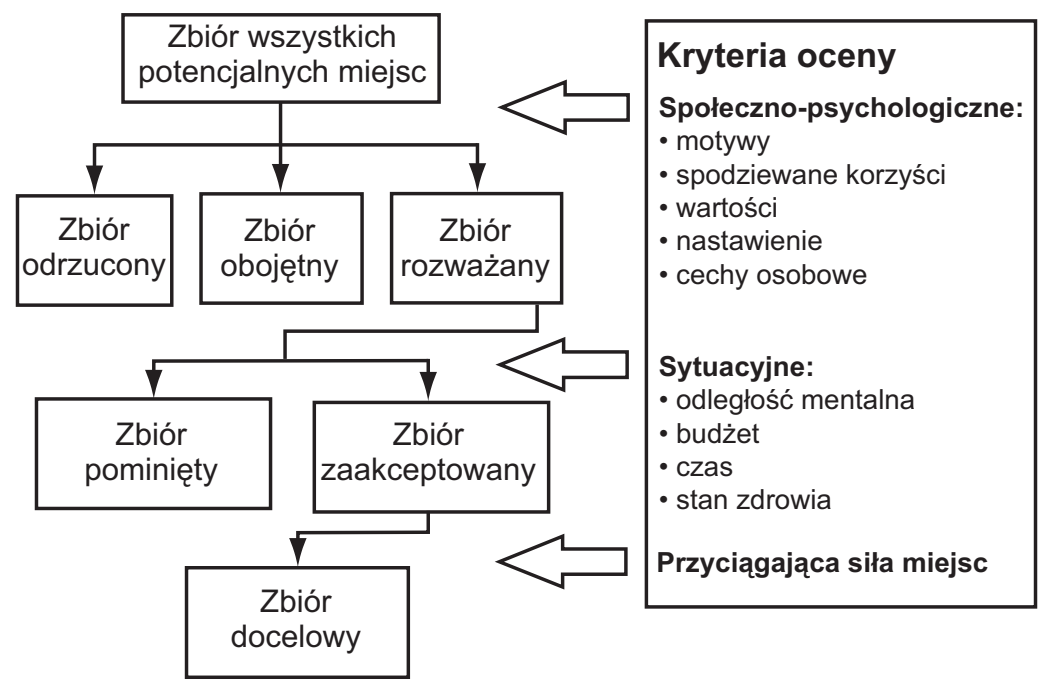

Rys. 23. Model wyboru miejsc docelowych w turystyce [P.K. Ankomah i in. 1996].

Źródło: P.K. Ankomah, J.L. Crompton, D. Baker, Influence of cognitive distance In vacatio choice, Annals of Tourism Research, 23, 1996, s. 138-150 oraz G. Richards, 2002, Tourism Attraction Systems, Annals of Tourism Research, 21, s. 1048-1064, zamieszczone [w:] L. Mazurkiewicz, 2007, Model przestrzennego zachowania turystów, „Przegląd Geograficzny” 79, s. 99-113.

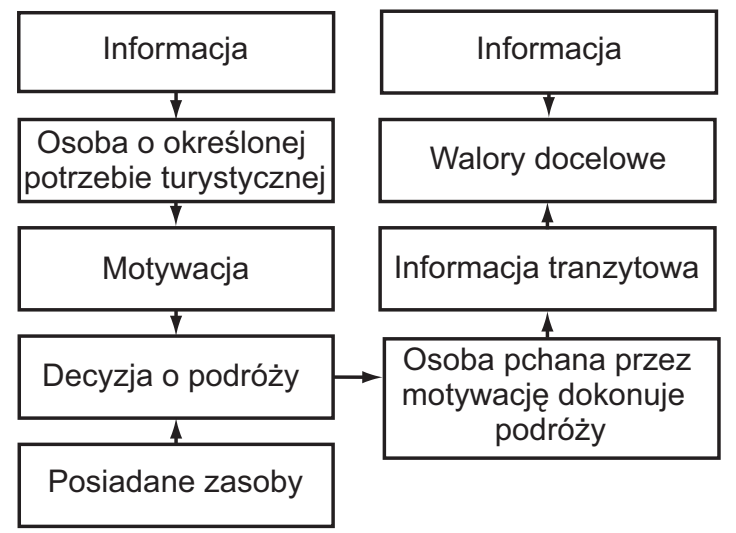

Rys. 24. Model systemów atrakcyjności turystycznej [G. Richards 2002].

Źródło: P.K. Ankomah, J.L. Crompton, D. Baker, 1996, Influence of cognitive distance In vacatio choice, Annals of Tourism Research, 23, s. 138-150 oraz G. Richards, 2002, Tourism Attraction Systems, Annals of Tourism Research, 21, s. 1048-1064, zamieszczone [w:] L. Mazurkiewicz, 2007, Model przestrzennego zachowania turystów, „Przegląd Geograficzny” 79, s. 99-113. 
odległości, która stawia opór i utrudnia dotarcie do celu (związane są z nią koszty). Odległość wpływa na wybór miejsc docelowych, eliminując niektóre ze zbioru potencjalnego ${ }^{42}$.

W przypadku klientów centrów handlowych również mogą odgrywać dużą rolę obydwie grupy czynników. $Z$ jednej strony oferta (materialna i niematerialna) centrów handlowych, klimat w nich wytwarzany mogą stanowić magnes przyciągający potencjalnych nabywców. $Z$ drugiej strony na przykład brak alternatywnych pomysłów na spędzenie czasu wolnego może determinować (wypychać) ludzi z domów w kierunku centrum handlowego. Podobnie jak w przypadku zachowań turystycznych podmiotem ich jest osoba o potencjalnej potrzebie nabywczej, która w celu zaspokojenia potrzeb własnych lub innych osób zbiera informacje o możliwych miejscach ich urzeczywistnienia, wykorzystując przy tym własne wcześniej zdobyte doświadczenia. Na ocenę i ostateczny wybór miejsca docelowego oraz czasu realizacji wpływ mają między innymi cechy osobowościowe, system wartości, spodziewane korzyści, jak również w niektórych przypadkach wpływ osób trzecich (rodzina, znajomi). $Z$ potencjalnego zbioru miejsc docelowych po całym procesie jego weryfikacji oraz po ocenie kosztów finansowych podróży oraz kosztów poświęconego czasu w zestawieniu $\mathrm{z}$ własnymi zasobami wolnego czasu wybiera miejsce realizacji potrzeby ${ }^{43}$. Czasem na zmianę tak zaplanowanego wyjazdu może mieć wpływ tak zwana ,informacja tranzytowa”, gdy dochodzi do pozyskania informacji w czasie przebiegu takiej podróży (na przykład reklama z bilboardów, radia, informacja od znajomych) (rys. 25).

W latach 70. XX wieku szwedzki socjolog $\mathrm{H}$. Aldskogius stworzył model zachowań turystycznych i rekreacyjnych w wyborze i kształtowaniu indywidualnej przestrzeni turystycznej ${ }^{44}$. Model ten można wykorzystać do wyboru

${ }^{42}$ L. Mazurkiewicz (2007, s. 109) posługuje się między innymi odległością krytyczną, która działa jak ograniczenie zabezpieczające przed nadmiernym wzrostem kosztów podróży, a miejsca znajdujące się w jej obrębie składają się na wyjściowy zbiór, od którego potencjalny turysta zaczyna proces selekcji.

${ }^{43} \mathrm{~W}$ przypadku podróży do centrów handlowych ponoszone koszty finansowe oraz czasowe są mniejsze niż w przypadku podróży turystycznych, odgrywają więc mniejsze znaczenie przy podejmowaniu decyzji i nie determinują w wielu wypadkach wyboru centrum handlowego. Większe znaczenie odgrywają oferta i korzyści wynikające z pobytu w wybranym, konkretnym centrum, w tym ceny, promocje - one pozwalają zaoszczędzić pieniądze wydawane na zakupy.

${ }^{44}$ Model ten został opisany w pracy B. Włodarczyk, 2009, Przestrzeń turystyczna. Istota, koncepcje, determinanty rozwoju, UŁ, Łódź, oraz w pracy D.J. Walmsley, G.J. Lewis, 1997, Geografia człowieka. Podejście behawioralne, PWN, Warszawa. 

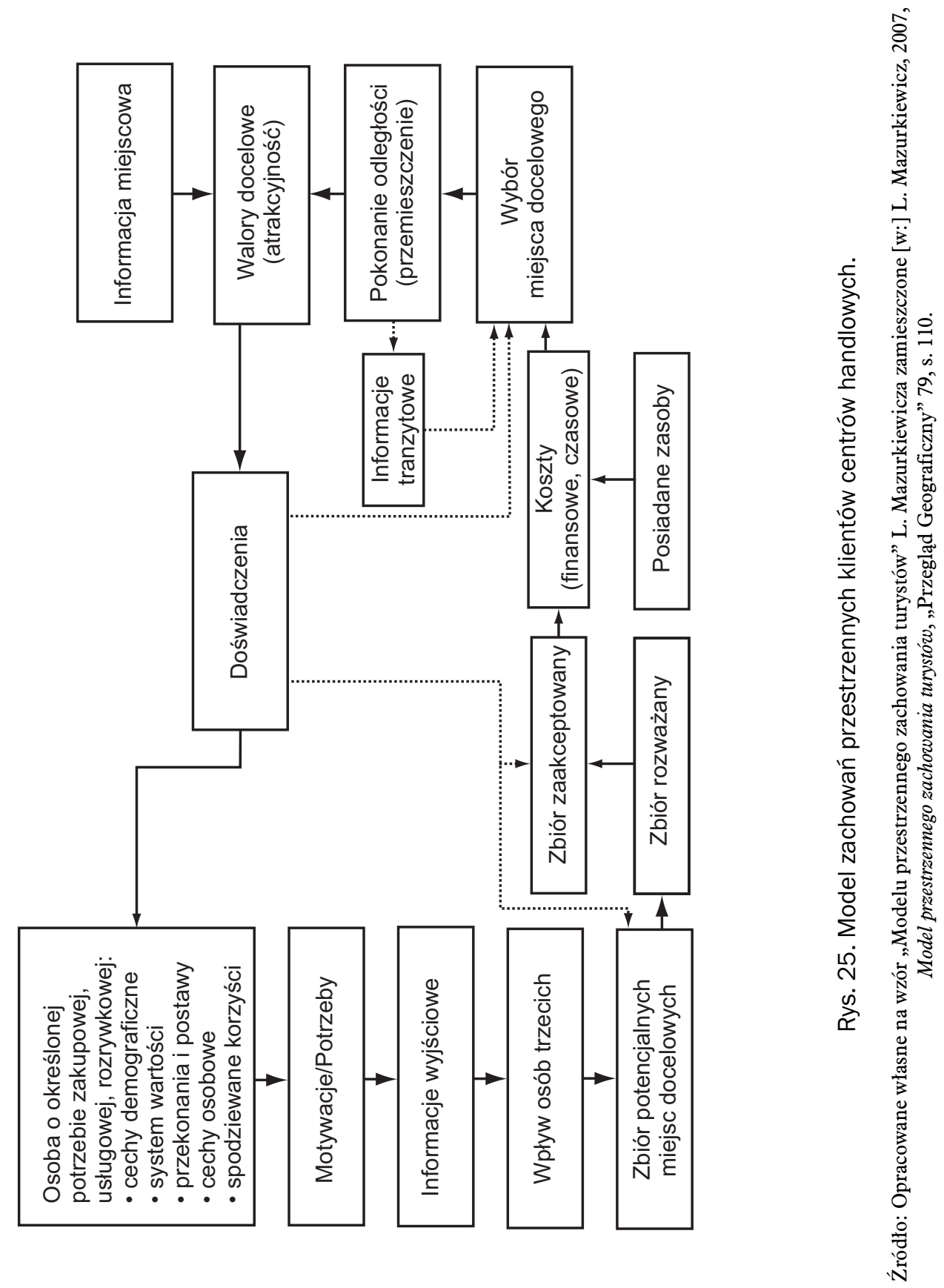
i wyznaczenia przestrzeni aktywności klientów centrów handlowych. W kontekście poprzedniego modelu należy zwrócić uwagę na rolę preferencji i wyobrażeń poznawczych, które potencjalny klient wytwarza pod wpływem różnych czynników, między innymi informacji, doświadczeń, środowiska społecznego. Te wszystkie elementy wpływają na wyznaczenie zbioru potencjalnych możliwości (wykreowanie przez daną osobę przestrzeni działania), z którego następuje wybór miejsca docelowego - będącego przestrzenią aktywności, w tym wypadku konkretnego centrum handlowego (rys. 26).

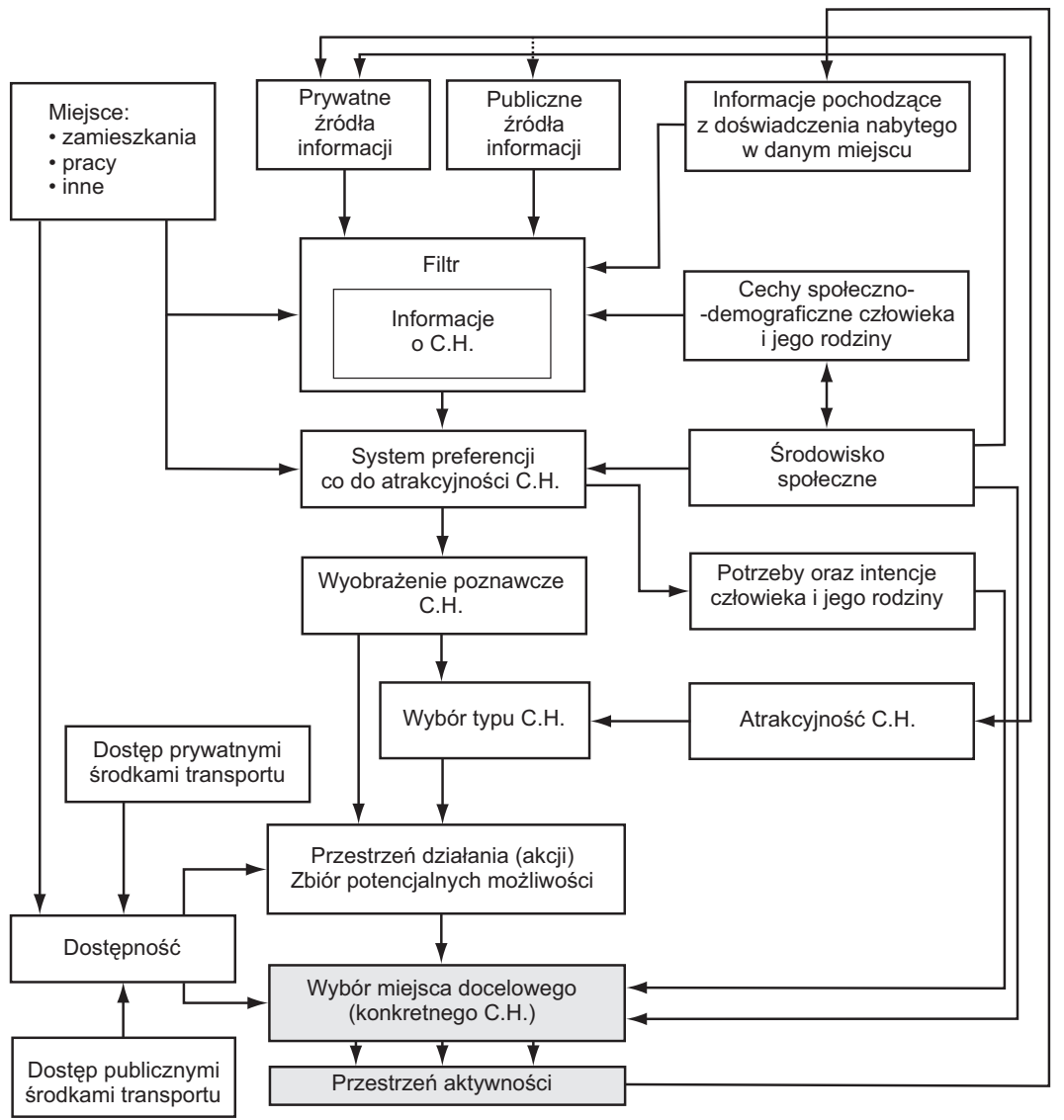

Rys. 26. Teoretyczny model zachowań przestrzennych klientów centrów handlowych.

Źródło: Opracowanie własne - model skonstruowany na podstawie teoretycznego modelu zachowań turystycznych i rekreacyjnych $\mathrm{H}$. Aldskogiusa (1977); H. Aldskogius, 1997, A conceptual framework and swedish case study of recreational behahavior and environmental cognition, „Economic Geography”, vol. 53 , nr 2. 
W zachowaniach przestrzennych duże znaczenie odgrywa lokalizacja centrum handlowego w stosunku do miejsc zamieszkania i pracy klientów, a co za tym idzie, odległość do niego. Z dystansem, który trzeba pokonać aby dostać się do wybranego miejsca, wiążą się koszty finansowe oraz poświęcenie odpowiedniej ilości czasu, dlatego w dużej mierze może ona wpływać na wybór miejsca docelowego realizacji swoich potrzeb. W tradycyjny sposób odległość postrzegamy najczęściej w wymiarze fizycznym. T. Domański (2005, s. 214-219) obok tego wymiaru fizycznego wyróżnia jeszcze odległość psychologiczną i wirtualną (rys. 27).

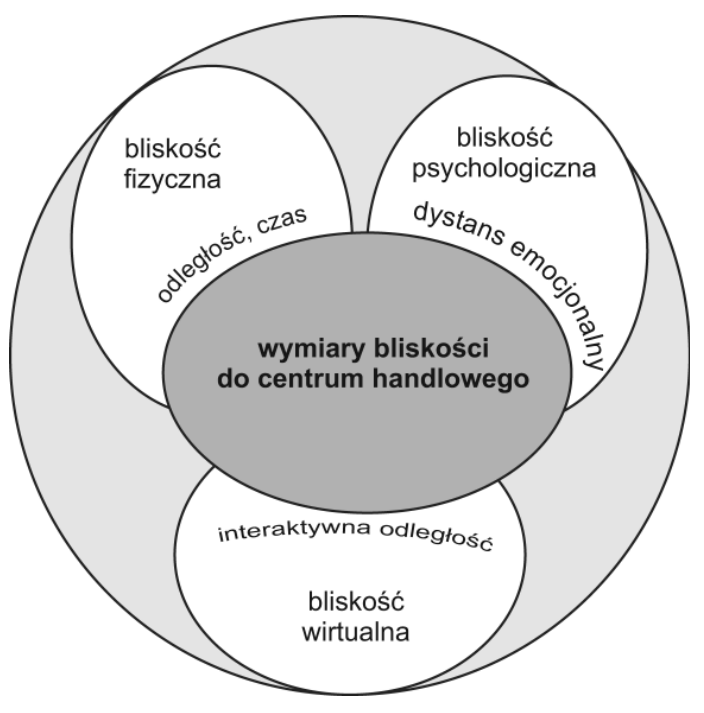

Rys. 27. Wymiary „bliskości sieci wobec klienta”.

Źródło: Opracowanie własne na podstawie T. Domański, 2005, Strategie rozwoju handlu, PWE, Warszawa, s. 214-219.

Wymiar bliskości w ujęciu fizycznym jest wymiarem obiektywnym i dotyczy czasu oraz przestrzeni, którą pokonuje nabywca, aby dotrzeć do określonego punktu sprzedaży. Kształtowanie przez przedsiębiorstwa handlowe poczucia tej bliskości polega na wyborze odpowiedniej lokalizacji, a także dostosowaniu godzin otwarcia do preferencji nabywców czy zapewnieniu transportu (Sobocińska 2011, s. 17). Według T. Domańskiego (2005, s. 216) ta fizyczna bliskość centrum handlowego powinna być uzupełniona fizyczną dostępnością usług handlowych. Źródłem przewagi 
konkurencyjnej, przy porównywalnym dystansie, jest większa dostępność sklepów dla klienta w czasie (dłuższe godziny otwarcia sklepów, funkcjonowanie sklepów w weekendy, całodobowe otwarcie placówek i tak dalej).

Bliskość w warstwie psychologicznej posiada natomiast subiektywny charakter i obrazuje stosunek emocjonalny oraz postawy nabywców wobec centrum handlowego (Sobocińska 2011, s. 17). Odległość w tym wymiarze zależy w dużym stopniu od stopnia akceptacji przez klienta wizerunku danego centrum handlowego oraz jego specyficznej formuły. Taka bliskość jest odzwierciedleniem między innymi wizerunku sieci (jego unikatowością), lojalności klienta wobec niej, jak również odbiciem osobistych doznań i wrażeń związanych z kontaktem z personelem. Więź emocjonalna klienta $\mathrm{z}$ danym centrum handlowym jest również wywołana między innymi „osobowością marki sieci”, która wynika z komunikacji reklamowej, poglądów kierownictwa, zachowań sprzedawców oraz tożsamości wizualnej sklepu (Domański 2005, s. 218).

Bliskość o charakterze wirtualnym związana jest z rozwojem technologii informatycznej. Stworzenie przez przedsiębiorstwa handlowe możliwości dokonywania zakupu przez Internet znosi ograniczenia dotyczące czasu dokonywania zakupów oraz redukuje dystans fizyczny, ponieważ nie wymaga od konsumenta przemieszczania się w przestrzeni fizycznej (niezależność, wygoda, oszczędność czasu «Domański 2005, s. 219»). 



\section{CZĘŚĆ II}

\section{ATRAKCYJNOŚĆ ŁÓDZKICH CENTRÓW HANDLOWYCH I ICH OTOCZENIA}

\subsection{Geneza i etapy rozwoju centrów handlowych}

Centra handlowe jako specyficzne formy usługowo-rozrywkowe $\mathrm{z}$ dominującą funkcją handlową zaczęły powstawać równolegle $\mathrm{z}$ rozwojem supermarketó $\mathrm{w}^{45} \mathrm{i}$ hipermarketów ${ }^{46}$ (typy sklepów o organizacji handlu na wielkich powierzchniach, tak zwany handel wielkopowierzchniowy), jednocześnie będąc wytworem ewolucji tego typu form handlu. Pierwsze centra handlowe powstawały w Stanach Zjednoczonych na początku XX wieku na bazie małych sklepów (które tworzyły własne wspólne parkingi), na wzór dzielnic mieszkaniowych. $\mathrm{Z}$ czasem przyjęto dla nich niezależne koncepcje architektoniczne. W skład nowoczesnych centrów handlowych zaczęto wkomponowywać markety (super-, hiper-), stanowiące główne „kotwice”/,magnesy” przyciągające klientów. To właśnie formuła centrum handlowego była formą łączącą różne rodzaje sklepów - form handlu pod jednym dachem.

\footnotetext{
${ }^{45}$ Supermarket - sklep o powierzchni sprzedażowej od $400 \mathrm{~m}^{2}$ do $2499 \mathrm{~m}^{2}$ prowadzący sprzedaż głównie w systemie samoobsługowym, oferujący szeroki asortyment artykułów żywnościowych oraz artykuły nieżywnościowe częstego zakupu (Rynek wewnętrzny... 2012, s. 13).

${ }^{46}$ Hipermarket - sklep o powierzchni sprzedażowej od $2500 \mathrm{~m}^{2}$ prowadzący sprzedaż głównie w systemie samoobsługowym, oferujący szeroki asortyment artykułów żywnościowych i nieżywnościowych częstego zakupu, zwykle z parkingiem samochodowym (Rynek wewnętrz$n y . . .2012$, s. 13). Sklep samoobsługowy o powierzchni sal sprzedażowych powyżej $2500 \mathrm{~m}^{2}$ prowadzący sprzedaż towarów żywnościowych wszystkich branż oraz towarów nieżywnościowych wielu branż, takich jak: AGD, RTV, meblowa, ogrodnicza, obuwnicza, komputerowa. Ma bardzo szeroki asortyment towarów oferowany po najniższych cenach rynkowych oraz bardzo dobrze rozwinięte działania promocyjne (Mikołajczyk 2008, s. 126).
} 
W procesie rozwoju centrów handlowych z punktu widzenia roli projektów architektonicznych, Ch. Maillet (2001) wyróżnia trzy etapy. W pierwszym etapie abstrahowano całkowicie od roli architektury; w Stanach Zjednoczonych i we Francji centrum takie określane jest mianem „pudło” (ang. box, fr. boîte). W drugim etapie projekty dużych centrów handlowych były sygnowane przez uznanych, światowej sławy architektów. Celem w tym wypadku było bardziej kreowanie określonej wizji architekta, niezależnej często od specyficznych funkcji i wymogów nowego obiektu handlowego. Natomiast w trzecim etapie oparto się na kontynuacji współpracy $z$ najbardziej znanymi i renomowanymi architektami, jednak przy założeniu, iż rola form architektonicznych ma pozostawać w ścisłej symbiozie $\mathrm{z}$ funkcją handlowo-usługową centrum nowej generacji (realizowany od 1998 roku) (za: Domańskim 2005, s. 172).

Pierwsze centrum handlowe powstało w Stanach Zjednoczonych w 1916 roku w Lake Forest niedaleko Chicago ${ }^{47}$. Market Square zaplanowany został na siatce istniejących już ulic i bardziej przypominał dzielnicę handlową niż dzisiejsze centrum handlowe $\left(\right.$ mall $\left.^{48}\right)$. Za protoplastę nowoczesnego centrum handlowego częściej uważany jest kompleks handlowo-biurowy Country Club Plaza, zbudowany na przedmieściach Kansas City w 1922 roku jako luźne zgrupowanie sklepów i budynków biurowych, otoczony parkingiem. Pierwsze w pełni zaplanowane, otwarte ${ }^{49}$ (open-air center) centrum handlowe Highland Park Shopping Village wybudowano w 1931 roku w Dallas, wtedy też nastąpiło zwrócenie ich „do wewnątrz" oraz wytyczenie specjalnych alejek między sklepami, co stało się od tego momentu standardem architektonicznym. W 1956 roku w Edina w stanie Minnesota zbudowano pierwsze w pełni zaprojektowane, zadaszone i klimatyzowane centrum handlowe Southdale Center (Makowski 2003, s. 44-45). Na dalszy szybki rozwój centrów handlowych w Stanach Zjednoczonych główny wpływ miały: migracja ludności na obrzeża wielkich

\footnotetext{
${ }^{47}$ Według S. Feinberga (1960) pierwsze centrum handlowe powstało w 1907 roku w Baltimore, gdzie grupa sklepów utworzyła wspólny parking (Feinberg, Meoli, 1991, s. 426).

${ }^{48} \mathrm{~W}$ Stanach Zjednoczonych centra handlowe są często określane mianem mall.

${ }^{49}$ Centrum otwarte - kompleks usytuowanych w rzędach sklepów i placówek usługowych, w którym ciągi piesze są otwarte i niezadaszone (ewentualnie tylko częściowo) zarządzany jako całość, zwykle posiadający parking umiejscowiony od frontu sklepów. Historycznie nazywany był strip center, a swoją nazwę zawdzięczał liniowej formie open-air center, gdzie sklepy były zlokalizowane obok siebie w długich i wąskich rzędach (ICSC Shopping Center... 2004).
} 
miast, wzrost zamożności obywateli oraz zmiany w prawie podatkowym, które zachęcały do inwestowania w duże i drogie centra (ośrodki) handlowe (Makowski 2003, s. 48) ${ }^{50}$.

W Europie Zachodniej centra handlowe na wzór amerykańskich „mallów" pojawiły się w połowie lat 60 . XX wieku, ale dopiero od lat 80 . XX wieku można obserwować ich bardziej dynamiczny rozwój (Makowski 2003, s. 52). Według W. Ciechomskiego (2010, s. 31) formuła organizacyjna centrum handlowego kształtowała się na kontynencie europejskim od 1950 roku przez 40 lat osiągając swoją dojrzałą formę w $1990 \mathrm{roku}^{51}$.

Po drugiej wojnie światowej w Polskiej Rzeczpospolitej Ludowej (PRL) zgodnie z zasadą, która uznała własność państwową za podstawę tworzonego w kraju nowego ustroju, w połowie 1947 roku zapoczątkowano tak zwaną bitwę o handel, która doprowadziła w znacznej mierze do jego upaństwowienia. W latach 50. i 60. XX wieku w Polsce jako jeden z instrumentó $\mathrm{w}^{52} \mathrm{w}$ walce o handel rozpowszechniło się budownictwo wielkopowierzchniowych domów towarowych: spółdzielcze domy handlowe $(\mathrm{SDH})$ oraz powszechne domy towarowe (PDT), w których istniały ceny państwowe (miały być one konkurencją dla placówek prywatnych). Jednak tego typu form wielkogabarytowych nie można porównywać z nowoczesnymi centrami handlowymi powstającymi wtedy $\mathrm{w}$ innych krajach (inna architektura, organizacja, zasady funkcjonowania, zdecydowanie mniejsze powierzchnie - największe $\mathrm{z}$ nich posiadały około 5 tys. $\mathrm{m}^{2}$ ).

Polski handel zaczął podlegać dynamicznym przemianom już od końca lat 80 . XX wieku, kiedy to był jeszcze dziedziną silnie znacjonalizowaną. Początkowo zmiany te dotyczyły głównie dynamicznego rozwoju liczbowego będącego wynikiem zakładania nowych niewielkich prywat-

${ }^{50} \mathrm{O}$ historii centrów handlowych w USA pisze na przykład M. Kavanagh (2008), D. Gwynn (2008), J. Goss (1993), L. Cohen (1996), T. Kinley, Y-K. Kim, J. Forney (2002).

${ }^{51}$ Można znaleźć wiele prac, w których przedstawiono rozwój centrów handlowych w poszczególnych państwach (na przykład w Czechach - Ptaček, Szczyrba 2007; Chinach - Wang, Zhang 2006; Turcji - Tuncer, Alkibay, Hoşgör 2008) i miastach (na przykład w Zagrzebiu i Ljublianie - Lukić, Jakovčić 2004; Budapeszcie - Sikos, Hoffman 2005; Singapurze - Ooi, Sim 2007; Izmirze - Kompil, Çelik 2006; Pradze, Bratysławie, Ołomuńcu, Preszowie - Ira, Matlovič, Sýkora, Szczyrba 2001).

${ }^{52}$ Głównymi instrumentami w walce o handel były między innymi koncesjonowanie firm, wprowadzenie cen maksymalnych, regulowanie cen i zysków, stosowanie różnych represji wobec prywatnych kupców, podporządkowanie spółdzielczości regułom państwowym (Jezierski, Leszczyńska 2001). 
nych placówek handlowych. Przełom polityczny w 1989 roku wpłynął na przemiany we wszystkich sektorach gospodarki narodowej, w tym również na znaczące zmiany w handlu. Nastąpiło wtedy między innymi otwarcie rynku polskiego na kapitał zagraniczny, w tym na ten, który inwestował w handel wielkopowierzchniowy. Słabe nasycenie placówkami handlowymi w Polsce, brak nowoczesnych form handlu wpłynęły na to, że nowe nieznane do tej pory na rynku obiekty handlowe (supermarkety, hipermarkety, sklepy dyskontowe, centra handlowe i tym podobne) szybko zjednały sobie wielu zwolenników wśród polskich konsumentów, co wzmacniało spiralę ich rozwoju. W latach 90 . XX wieku stopniowo następował również wzrost zamożności polskiego konsumenta, zmieniał się styl życia na tak zwany konsumencki, podnosił się wskaźnik zmotoryzowania (jak wiemy, ma to szczególny wpływ na wzrost dostępności komunikacyjnej sklepów wielkopowierzchniowych), co coraz mocniej zachęcało zagranicznych inwestorów do budowania następnych placówek. Te i inne czynniki determinowały również rozwój nowoczesnych form koncentracji handlowej, czyli centrów handlowych, głównie od drugiej połowy lat $90 \mathrm{XX}$ wieku (tab. 13).

Od początku lat 90. XX wieku, jak już wyżej wspomniano, na polski rynek zaczęły wkraczać zagraniczne sieci handlowe sklepów wielkopowierzchniowych, w tym obiektów handlowych $\mathrm{z}$ artykułami codziennego zakupu (FMCG): supermarketów (na przykład Billa, Champion, Rema 1000), sklepów dyskontowych (na przykład Plus, Biedronka) oraz hipermarketów (na przykład Geant, Tesco, Carrefour, E.Leclerc), a także hipermarketów specjalistycznych z artykułami nieżywnościowymi, tak zwanych profilowanych - IKEA, Nomi, Obi. W połowie lat 90. XX wieku w Polsce zaczęły też pojawiać się centra handlowe. „Pierwsze centra handlowe były poprzedzone ekspansją supermarketów i hipermarketów, jednak okres ich rozwoju nastąpił przed wyczerpaniem się formuły tych dwóch pierwszych typów obiektów wielkopowierzchniowych. W 1990 roku niemiecka firma Billa otworzyła pierwszy w Polsce supermarket, a pięć lat później skandynawski koncern IKEA wybudował w Jankach koło Warszawy pierwsze centrum handlowe" (Makowski 2003, 56-57) ${ }^{53}$.

Na współczesny obraz rozmieszczenia centrów handlowych i ich aktualny poziom rozwoju wpływ miały także bariery, które często decydo-

\footnotetext{
${ }^{53}$ Etapy ekspansji sklepów wielkopowierzchniowych w Polsce opisuje między innymi J. Wrzesińska (2008).
} 
wały o weryfikacji wcześniejszych założeń lokalizacyjnych. Szczególnie należy tu zwrócić uwagę na nieuregulowany status własnościowy wielu nieruchomości, w tym gruntowych, skomplikowane procedury administracyjne czy też brak planów miejscowych, głównie w dużych miastach, gdzie tego typu inwestycje miały i mają miejsce (tab. 13). $Z$ drugiej jednak strony brak planów miejscowych i bałagan administracyjny pozwalały na lokalizowanie tego typu obiektów w nie zawsze przemyślanych miejscach z punktu widzenia lokalnej społeczności, miejscowych przedsiębiorców handlowych czy też ogólnego zrównoważonego rozwoju miejscowości.

\section{Tabela 13}

\section{Czynniki i bariery rozwoju centrów handlowych w Polsce}

\begin{tabular}{|l|l|}
\hline \multicolumn{1}{|c|}{ Czynniki rozwoju } & \multicolumn{1}{|c|}{ Bariery hamujące rozwój } \\
\hline - wzrost zamożności polskiego konsumenta & • niski poziom infrastruktury \\
(większa liczba nabywców o dochodach wyższych & • nieuregulowany status własnościowy atrakcyjnych \\
niż przeciętne) & działek budowlanych \\
- rozwój motoryzacji (większa mobilność związana & - skomplikowane procedury administracyjne, w tym \\
z rozwojem komunikacji miejskiej oraz ze & związane z aktualizacją planów zagospodarowania \\
stopniem zmotoryzowania, lepsza przepustowośćc & przestrzennego oraz uzyskaniem pozwolenia na \\
infrastruktury drogowej) & budowę i realizację inwestycji \\
- zmiany w stylu i jakości życia konsumentów & - w wielu przypadkach brak planów miejscowych \\
(preferencje zakupowe) & - niechętny stosunek samorządowców do lokalizacji \\
- rozwój rynku nieruchomości handlowych & wielkopowierzchniowych obiektów handlowych \\
(ukierunkowanie na koncentrację) & konflikty między inwestorami centrów \\
- wzrost znaczenia sklepów wyspecjalizowanych & handlowych, władzami samorządowymi \\
z ofertą towarów markowych i korzystne warunki & a lokalnymi przedsiębiorstwami handlowymi \\
lokowania tych sklepów w centrach handlowych & \\
- rozszerzenie funkcji centrów handlowych & \\
i związana z tym integracja handlu z różnym & \\
wachlarzem usług & \\
- ożywienie (kreowanie) nowoczesnych centrów & \\
handlowych & \\
\hline
\end{tabular}

Źródło: Opracowanie własne na podstawie: E. Maleszyk, 2001, Ośrodki handlowe w Polsce-uwarunkowania i kierunki rozwoju, [w:] Rynek i konsumpcja, IRWiK, Warszawa; W. Ciechomski, 2010, Koncentracja handlu $w$ Polsce $i$ jej implikacje dla strategii konkurowania przedsiębiorstw handlowych, Wyd. Uniwersytetu Ekonomicznego, Poznań; E. Maleszyk, 2009, Procesy koncentracji $i$ integracji $w$ handlu detalicznym, [w:] M. Sławińska (red.), Handel wewnętrzny w Polsce 1989-2009, Wyd. IBRKiK, Warszawa.

Rozwój wielkopowierzchniowych obiektów handlowych (WOH) w Polsce i ich zasady lokalizacji starano się unormować w sposób ustawowy. „Wyrazem przekazania samorządom lokalnym uprawnień do decydowania o rozwoju handlu były zmiany ustawy o zagospodarowaniu przestrzen- 
nym, w rezultacie których władze gminy zostały zmuszone do wnikliwego rozpoznawania skutków budowy wielkopowierzchniowych obiektów handlowych dla całej społeczności lokalnej ${ }^{54}$ oraz obowiązkowego opracowywania planu miejscowego dla terenów, na których w studium uwarunkowań i kierunków zagospodarowania przestrzennego przewidziano budowę obiektów handlowych o powierzchni sprzedażowej powyżej $2000 \mathrm{~m}^{2 " 55}$ (Słomińska 2009, s. 67). W 2007 roku weszła w życie ustawa o tworzeniu i działaniu wielkopowierzchniowych obiektów handlowych ${ }^{56}$, która określała zasady i tryb wydawania zezwoleń na ich tworzenie i działanie. Zgodnie $z$ ustawą obiektami WOH były te o powierzchni sprzedaży przekraczającej $400 \mathrm{~m}^{2}$, w których prowadzona była działalność handlowa. Trybunał Konstytucyjny w dniu 8 lipca 2008 roku orzekł, że ustawa jest niezgodna $\mathrm{z}$ art. 2 (zasada prawidłowej legislacji) oraz z art. 20 i 22 (zasada wolności działalności gospodarczej) Konstytucji RP i ustawę uchyli1 ${ }^{57}$.

Pierwszej próby zidentyfikowania większości funkcjonujących i będących w budowie centrów (ośrodków) handlowych w Polsce dokonano w Instytucie Rynku Wewnętrznego i Konsumpcji (IRWiK) w roku $2000^{58}$. W połowie tego roku funkcjonowało i znajdowało się w fazie budowy około 140 wielofunkcyjnych ośrodków handlowych, zajmujących łączną powierzchnię blisko 1,7 mln $\mathrm{m}^{2}$ (Maleszyk 2009, s. 154). Według obliczeń dokonanych przez E. Maleszyka (2009, s. 155) w 2005 roku było ich już $221\left(4,4 \mathrm{mln} \mathrm{m}^{2}\right)$, a w 2008 roku - $330\left(6,3 \mathrm{mln} \mathrm{m}^{2}\right)$. Z Raportu - rynek powierzchni handlowych (2012, s. 302), przygotowanego przez firmę Cushman \& Wakefield wynika, że na koniec 2011 roku w Polsce działało 387 centrów handlowych o łącznej powierzchni najmu brutto (GLA) mniej więcej 7,7 $\mathrm{mln}^{2}$.

W statystyce GUS podaje się liczbę supermarketów, hipermarketów, domów handlowych i towarowych, ale brakuje klasyfikacji centrów handlo-

\footnotetext{
${ }^{54}$ Ustawa o zmianie ustawy o zagospodarowaniu przestrzennym z dnia 13 lipca 2000 roku, Dz.U. z 2001 roku, Nr 14, poz. 124.

${ }^{55}$ Ustawa o planowaniu i zagospodarowaniu przestrzennym z dnia 27 marca 2003 roku, Dz.U. z 2003 roku, $\mathrm{Nr} 80$, poz. 717

${ }^{56}$ Ustawa o tworzeniu i działaniu wielkopowierzchniowych obiektów handlowych $\mathrm{z}$ dnia 11 maja 2007 roku, Dz.U. z 2007 roku, Nr 127, poz. 880.

${ }^{57}$ Wyrok Trybunału Konstytucyinego z 8 lipca 2008 roku, Dz.U. z 2008 roku, Nr 123, poz.803, sygn. akt K 46/07.

${ }^{58}$ Według badań E. Maleszyk (2009, s. 154) niektóre firmy deweloperskie i zarządzające nieruchomościami zaczęły monitorować inwestycje związane z budową ośrodków handlowych pod koniec lat 90 . XX wieku.
} 
wych, w związku z tym trudno ustalić ich konkretną liczbę w Polsce ${ }^{59}$. Nawet $z$ tego nie do końca porównywalnego zestawienia informacji wynika, że w naszym kraju nadal powstają i rozwijają się nowoczesne centra handlowe. Według B. Pilarczyk (2001, s. 165) rozwojowi centrów (ośrodków) handlowych w Polsce sprzyjają następujące czynniki ${ }^{60}$ :

- dobra dostępność komunikacyjna, bezpłatne parkingi dla klientów centrum handlowego, uruchamianie specjalnych bezpłatnych linii autobusowych,

- wygląd centrum handlowego, usytuowanie w przestrzeni, kolorystyka, kształt, szczególne oznakowanie, niejednokrotnie oryginalne projekty architektoniczne,

- rosnący popyt na markowe produkty oferowane przez sklepy specjalistyczne lokowane w centrach handlowych,

- atrakcyjność ofert promocyjnych,

- struktura zlokalizowanych w nim sklepów, w tym przede wszystkim dostępność do obiektów - „lokomotyw”, którymi najczęściej są hipermarkety, ale także do sklepów przyciągających pewne grupy klientów, tak zwanych sklepów kotwicowych, najczęściej firmowych sklepów z odzieżą, obuwiem, sprzętem komputerowym oraz inne sklepy specjalistyczne.

W Łodzi tak jak w innych miastach Polski zaczęto po drugiej wojnie światowej w ramach bitwy o handel budować państwowe i spółdzielcze domy towarowe. W 1948 roku powstało przedsiębiorstwo „Powszechny Dom Towarowy w Łodzi” będące oddziałem Przedsiębiorstwa Domy Towarowe „Centrum” w Warszawie, którego przedmiotem działania było prowadzenie sprzedaży detalicznej towarów przemysłowych w ramach państwowych planów gospodarczych. W roku 1966 wybudowano Powszechny Dom Towarowy (PDT) „Uniwersal” o powierzchni sprzedaży około 5400 $\mathrm{m}^{2}$ (oficjalnie otwarty 30 września 1967 roku) (http://baza.archiwa.gov.pl). W 1975 roku został on przekształcony w Przedsiębiorstwo Domy Towarowe „Centrum”, a w 1993 roku w jednoosobową spółkę akcyjną Skarbu Państwa.

\footnotetext{
${ }^{59}$ Różne firmy, na przykad Pricewaterhouse Coopers, Cushman \& Wakefield, DTZ Management Polska, Ernst \& Young przygotowują raporty o nowoczesnej powierzchni handlowej, podając nieraz liczbę centrów handlowych. W związku z niejednoznacznym definiowaniem centrum (ośrodka) handlowego szacunki różnią się między sobą i nie są porównywalne. W pracy tej nie zajmowano się dokładną historią rozwoju centrów handlowych w Polsce, istotny jest tylko fakt, że istnieje ciągły trend wzrostowy, jeżeli chodzi o liczbę tego typu kompleksów handlowych.

${ }^{60}$ Zmodyfikowane przez W. Ciechomski (2010, s. 51).
} 
Pod koniec lat 90. XX wieku budynek „Uniwersalu” wynajęła sieć sklepów Galeria Centrum, ale z powodu niewielkiej liczby klientów szybko się wyprowadziła. W kwietniu 2006 roku budynek kupiła warszawska spółka specjalizująca się w przebudowie PRL-owskich gmachów na biurowce i centra usługowe (przygotowano projekt, otrzymano pozwolenie na budowę, planowano rozpoczęcie prac w 2008 roku), jednak wkrótce budynek sprzedano łódzkiej firmie, która przekształca go obecnie na nowy gmach tak zwany Unicity. Docelowo na trzech piętrach mają powstać nowoczesne biura, a na parterze butiki, sklepy i punkty usługowe (Nowe wcielenie Uniwersalu... 2009). Nadal trwają prace nad przekształceniami tego domu towarowego.

W lipcu 1972 roku otworzono Spółdzielczy Dom Handlowy (SDH) „Central” na działce o powierzchni $5285 \mathrm{~m}^{2}$. Na jego pięciu kondygnacjach, o łącznej powierzchni sprzedażowej $10500 \mathrm{~m}^{2}$ zlokalizowane zostały 34 stoiska, na których obowiązywała samoobsługowa ${ }^{61}$ lub preselekcyjna ${ }^{62}$ forma sprzedaży. Od końca 1989 roku rozpoczęto w „Centralu” wydzierżawianie powierzchni handlowej, co miało związek z podziałem PSS „Społem” i uzyskaniem rok później niezależności gospodarczej i organizacyjnej. W 1991 roku nastąpiło otwarcie domu handlowego pod nazwą "Central II” (budowę obiektu rozpoczęto $\mathrm{w}$ latach 70 . XX wieku, a pierwotnym przeznaczeniem jego miało być świadczenie usług gastronomicznych). Wspó1cześnie „Central” to dwa domy handlowe o łącznej powierzchni $24000 \mathrm{~m}^{2}$ (Plesińska 2003, s. 111-126). Obecnie w obu obiektach prowadzony jest handel na wydzierżawianych przez prywatne osoby stoiskach.

Dwa najbardziej charakterystyczne wielkopowierzchniowe łódzkie domy towarowe „starego typu” „Central” i „Uniwersal” pod względem wizualnym przetrwały do czasów współczesnych (dopiero w 2009 roku rozpoczęto prace nad zmianą wizerunku dawnego PDT „Uniwersal”). Obok tych dwóch największych wybudowano w mieście również dzielnicowe i osiedlowe domy towarowe, jak na przykład „Teofil” czy „Batory”.

W Łodzi rozwój zagranicznych sieci handlowych rozpoczął się w połowie lat 90. XX wieku od budowy dwóch supermarketów Szalony Max (ul. Wydawnicza 19, Duńska 3/5) należących do holendersko-niemieckiej fir-

${ }^{61}$ Samoobsługa to metoda obsługi, w której kontakt nabywcy z personelem jest ograniczony do przyjęcia zapłaty za towar (Śmigielska 2004, s. 64).

${ }^{62}$ Preselekcja, czyli dokonywanie przez sprzedawcę wyboru wstępnego, ułatwiającego klientom oglądanie towarów. Rola sprzedawcy jest tu ograniczona do asystowania nabywcy w wyborze towaru, a następnie do pobrania zapłaty za zakupiony towar (Śmigielska 2004, s. 64). 
my Ahold/Allkauf oraz hurtowni Makro Cash \& Carry (ul. Kasprzaka 8) holenderskiej firmy SHV - których europejska sieć od 1998 roku stała się własnością niemieckiej firmy Metro AG (Rochmińska 2005, s. 68). W tym pierwszym okresie na rynku łódzkim pojawiały się coraz liczniejsze supermarkety i sklepy dyskontowe. Pierwszym hipermarketem w Łodzi była wybudowana w 1997 roku Billa ${ }^{63}$ (kapitał austriacki), natomiast pierwszym łódzkim centrum handlowym - C.H. Guliwer (kapitał francuski).

Lata 1998-2000 były okresem najintensywniejszych inwestycji w nowe łódzkie centra handlowe, których najważniejszym elementem (częścią) były hipermarkety. W tym okresie powstało osiem takich kompleksów, które funkcjonują do dziś: E. Leclerc, C.H. M1, C.H. Tulipan, C.H. Pasaż Łódzki ${ }^{64}$, dwa centra handlowe Tesco (ul. Widzewska i ul. Pojezierska) oraz dwa Carrefoury przy ul. Przybyszewskiego ${ }^{65}$ i ul. Szparagowej ${ }^{66}$.

W 2003 roku istniały w Łodzi 23 hipermarkety zarządzane przez 11 firm reprezentujących zagraniczny kapitał z czterech krajów (Francji, Niemiec, Wielkiej Brytanii i Holandii) oraz gęsta sieć supermarketów i sklepów dyskontowych (Rochmińska 2005, s. 91). W przestrzeni miasta funkcjonowały sklepy takich sieci jak: Geant, Carrefour, Tesco, Hypernova, Castorama, Praktiker, Real, Nomi, Obi, Selgros Cash \& Carry, Makro Cash \& Carry, Biedronka, Leader Price, Globi, Albert, Lidl, Plus Discount, Rema $1000^{67}$. W wyniku międzynarodowych przekształceń własnościowych doszło w ostatnich latach do zmian właścicieli niektórych sieci handlowych, co pociągnęło za sobą zmiany w nazewnictwie, czyli tak zwany rebranding (w niektórych przypadkach był wynikiem zmiany dzierżawców). Szczególnie widoczne przemiany miały miejsce w latach 2006-2007, kiedy to z Łodzi znikły między innymi sklepy Leader Price, a na ich miejsce pojawiły się sklepy Tesco (11), hipermarkety Geant (2) przemianowano na Real, a supermarkety Albert (3) na Carrefour (Rochmińska 2010, s. 165).

${ }^{63}$ Sklep Billa pod względem prowadzonego typu działalności zaliczany był do supermarketów, jednak łódzki obiekt mający $4000 \mathrm{~m}^{2}$ odpowiada wielkością hipermarketowi. W 2003 roku została zakupiona przez francuską firmę Auchan i zmieniła swoją nazwę na Elea. Od 2008 roku w budynku działają głównie dwie polskie firmy: Alma i Intersport.

${ }^{64}$ W C.H. Tulipan i C.H. Pasaż Łódzki do 2006 roku działały hipermarkety francuskie Geant, teraz niemieckie Real.

${ }^{65}$ W latach 1999-2002 portugalskie Jumbo, a w latach 2002-2007 holenderska Hypernova.

${ }^{66} \mathrm{~W}$ latach 2000-2007 holenderska Hypernova.

${ }^{67}$ Norweska firma Rema 1000 posiadała w Łodzi cztery placówki, obecnie nie ma żadnej. 
Na początku XXI w. w Łodzi nastąpił etap budowy centrów handlowych nowej generacji. W 2002 roku otworzono Galerię Łódzką (inwestycja firmy ECE Projektmanagement) z najnowocześniejszą i najbardziej wtedy rozbudowaną galerią handlową w mieście $\left(40000 \mathrm{~m}^{2}\right.$, w 2008 roku rozbudowano ją o następne $5000 \mathrm{~m}^{2}$ ). W najbliższym czasie jest planowana jej dalsza rozbudowa (wydane zostały warunki zabudowy), docelowo ma ona być drugą co do wielkości galerią handlową w Łodzi (około 260 sklepów). Cztery lata później w 2006 roku na powierzchni 270 tys. m² firma Apsys Polska sp. z o.o. oddała do użytku pierwsze obiekty centrum handlowo-rozrywkowego Manufaktura ${ }^{68}$. Ostatnie z działających centrów handlowych w Łodzi rozpoczęło swoją działalność w 2009 roku od inauguracji sklepu IKEA w ramach wtedy jeszcze budowanego, a otwartego oficjalnie w 2010 roku Portu Łódź. „Od tego czasu zasób powierzchni handlowych w Łodzi powiększył się dodatkowo o rozbudowaną część Pasażu Łódzkiego (3500 $\mathrm{m}^{2}$ w 2010 roku - sklep Decathlon i $3000 \mathrm{~m}^{2} \mathrm{w} 2011$ roku - 3 sklepy w tym H \& M)" (Łódzki rynek nieruchomości... 2012, s. 9).

W Łodzi obok centrów handlowych, niezależnych hipermarketów $\mathrm{z}$ artykułami FMCG działają specjalistyczne (profilowane) obiekty handlowe - dwa Obi (ul. Szparagowa 3/5 i ul. Rokicińska 192), trzy Castoramy (ul. Wróblewskiego 31, ul. Sikorskiego 2/6, ul. Wydawnicza 13), Praktiker (ul. Wieniawskiego 3, plus jeden w ramach C.H. M1), Makro Cash \& Carry (ul. Kasprzaka 8, plus jeden przy granicy administracyjnej Łodzi w gminie Rzgów), dwa Selgrosy Cash \& Carry (ul. Rokicińska 190, ul. 3 Maja 4).

$\mathrm{Z}$ raportu firmy Ernst \& Young, opracowanego na zlecenie łódzkiej spółki „Fabryka Biznesu” wynika, że w Łodzi w 2010 roku było nadal zapotrzebowanie na nowe centra handlowe. Wskaźnik nowoczesnej powierzchni handlowej, przypadającej na 1000 mieszkańców był niższy niż w innych miastach. Łódź miała około 480 tys. $\mathrm{m}^{2}$ nowoczesnej powierzchni handlowej, z czego 360 tys. $\mathrm{m}^{2}$ przypadało na sześć największych centrów handlowych: Manufakturę, Galerię Łódzką, Port Łódź, C.H. Pasaż Łódzki, C.H. Tulipan i C.H. M1. O zapotrzebowaniu na nowoczesne lokale handlowe w Łodzi według wspomnianego raportu świadczyło ${ }^{69}$ :

${ }^{68}$ Szczegółowe informacje o budowie Manufaktury można uzyskać [w:] J. Dzieciuchowicz, 2012a, Wielkie centrum handlowe w przestrzeni miejskiej i podmiejskiej: Manfaktura w Eodzi i Ptak w Rzgowie, Wyd. UŁ, Łódź.

${ }^{69}$ Eódź: jest miejsce na nowe centra handlowe (http://www.bankier.pl/wiadomosc/Lodz-jest-miejsce-na-nowe-centra-handlowe-2181089.html. 
- duże zainteresowanie wynajmem nowoczesnej powierzchni handlowej, szczególnie ze strony zagranicznych sieci (stawki czynszu w łódzkich galeriach handlowych należały do najniższych wśród największych polskich miast),

- niski wskaźnik niewynajętej powierzchni w istniejących galeriach (w obiektach położonych $\mathrm{w}$ rejonie centrum miasta wynosił on około $5 \%)$

- niskie nasycenie nowoczesnymi obiektami handlowymi oraz potencjał miasta: trzeciego, co do wielkości w Polsce, silnego ośrodka akademickiego, położonego w pobliżu skrzyżowania autostrad A1 i A2.

W 2012 roku powierzchnia centrów handlowych w Łodzi szacowana była na około $460000 \mathrm{~m}^{2}$ i obejmowała dwanaście centrów handlowych. Wskaźnik nasycenia nowoczesną powierzchnią handlową kształtował się na poziomie $624 \mathrm{~m}^{2}$ na 1000 mieszkańców (wyłączając hipermarkety budowlane $)^{70}$ (Eódzki rynek nieruchomości... 2012, s. 9).

Proces inwestycyjny w nowoczesne powierzchnie handlowe nie jest jeszcze zakończony. Obecnie w Łodzi w budowie jest wielofunkcyine centrum handlowo-rozrywkowe „Sukcesja” przy Al. Politechniki 5 oraz C.H. Łódź Plaza zlokalizowane w rejonie ul. Rzgowskiej i Śląskiej, których otwarcie planowane jest na 2014 roku. Na etapie planowania są również mniejsze centra osiedlowe, na przykład Street Mall „Vis-à-Vis”71 ma powstać przy ul. Zgierskiej 211, w pobliżu Castoramy, zakończenie jego budowy przewidziane jest na grudzień 2013 roku.

Centrum handlowo-rozrywkowe "Sukcesja” będzie wielofunkcyjnym kompleksem, którego inwestorem jest łódzka spółka „Fabryka Biznesu”. Powierzchnia użytkowa obiektu wyniesie około $120000 \mathrm{~m}^{2}$, w tym najmu ponad $50000 \mathrm{~m}^{2}$. W obiekcie znajdą się: galeria handlowa $\mathrm{z}$ wydzieloną czę-

\footnotetext{
${ }^{70}$ Szacunki dotyczące nowoczesnej powierzchni handlowej oraz nasycenia tą powierzchnią na 1000 mieszkańców jest różnie szacowany, zależy to od firmy szacującej i od tego, które centra handlowe zostały wzięte pod uwagę w szacunkach. $Z$ punktu widzenia tej pracy nie jest istotne ustalenie dokładnej wielkości tej powierzchni. Po otwarciu w 2010 roku Portu Łódź do 2012 roku nie oddano żadnego nowego centrum handlowego, różnice w szacunkach wynikają więc $z$ przyjętej metodologii obliczeń.

${ }^{71}$ Street Mall „Vis-à-Vis” to sieć lokalnych centrów handlowych zlokalizowanych przy głównych ulicach miast. W łódzkim obiekcie na powierzchni handlowej około $5700 \mathrm{~m}^{2}$ (całkowita $7800 \mathrm{~m}^{2}$ ) znajdzie się supermarket i 17 lokali usługowo-handlowych. Przed budynkiem będzie parking na około 140 samochodów z bezpośrednim dostępem do marketu Castorama (http:// capitalpark.pl/news/169/87/lodz-Street-Mall-Vis-a-Vis.htm).
} 
ścią gastronomiczną tak zwanym food courtem (około 170 sklepów i punktów usługowych), hotel klasy biznesowej. Centrum to będzie też posiadać strefę rozrywkowo-rekreacyjną, w której zlokalizowane będą między innymi kino „Helios” (ponad 2100 miejsc, 9 sal, w tym premierowa i do projekcji 3D), klub fitness z 300-metrowym tarasem, park rozrywki z torem kręglarskim, bilardem i bogatą ofertą dla dzieci, ścianka wspinaczkowa oraz plac zabaw. Zaplanowano również dwupoziomowy parking na ponad 1000 miejsc $^{72}$.

Firma Plaza Centers realizuje projekt centrum handlowego „Łódź Plaza" na terenie dawnej fabryki Fakora. W nowym obiekcie na powierzchni handlowej około $42000 \mathrm{~m}^{2} \mathrm{z}$ nowoczesną galerią handlową powstanie około 120 sklepów, supermarket, strefa gastronomiczna i usługowa oraz rozbudowana część rozrywkowa, między innymi 10-salowe kino, park gier i rozrywek „Fantasy Park”. Obiekt ma łączyć w sobie elementy charakterystyczne dla fabrycznej architektury Łodzi z nowoczesnym stylem projektowania. Plaza Centers zachowa zabytkowe fragmenty konstrukcji żelbetowej w dawnej odlewni, komin, portiernię oraz wieżę ciśnień. Zaplanowano również parking na 1000 pojazdów (Wojnowski 2012).

Rozwój i przekształcenia łódzkiego handlu były zdeterminowane warunkami politycznymi i gospodarczymi kraju, dlatego w jego rozwoju od zakończenia drugiej wojny światowej można wyodrębnić kilka etapów.

1. Handel państwowo-spółdzielczy w gospodarce socjalistycznej 1945-1988 :

- odbudowana sieci handlu na wzór struktur przedwojennych (1945-1947), a następnie tak zwana bitwa o handel (1947-1949) i likwidacja większości placówek prywatnych w handlu detalicznym i hurtowym,

- budowa wielkopowierzchniowych domów towarowych typu SDH (spółdzielcze domy handlowe) oraz PDT (powszechne domy towarowe).

2. Okres przejściowy 1989-1997:

- wzrost liczby sklepów, prywatyzacja, pojawienie się pierwszych zagranicznych sieci supermarketów, sklepów dyskontowych (Szalony Max, Globi i Rema 1000) oraz budowa pierwszego hipermarketu (hurtowni Makro Cash \& Carry).

3. Okres intensywnego wkraczania handlowych sieci zagranicznych lata 1997-2000:

\footnotetext{
${ }^{72}$ Centrum handlowo-rozrywkowe Sukcesja Łódź, http://scf2012.retailnet.pl/projekty/centrum-handlowo-rozrywkowe-sukcesja-lodz/.
} 
- budowa hipermarketów z artykułami FMCG (Carrefour) i specjalistycznych (Praktiker, Castorama, Nomi, Obi), rozwój sieci supermarketów (Leader Price) i sieci dyskontowych (Biedronka),

- zmiany własnościowe i rebranding,

- budowa centrów handlowych średniej wielkości (C.H. Guliwer, C.H. Tulipan, C.H. Pasaż Łódzki) (Rochmińska 2010, s. 171).

4. Okres projektowania i budowy dużych centrów handlowych od 2002 roku.

- w latach 2002-2010 powstały Galeria Łódzka, Manufaktura, Port Łódź,

- w realizacji są dwa duże centra: Sukcesja i Plaza Łódź,

- dalszy rozwój supermarketów i sklepów dyskontowych firm już istniejących na rynku łódzkim, na przykład Biedronki, Lidla,

- pojawianie się nowych sieci handlowych - Intermarche, Kaufland.

Przekształcenia struktury przestrzennej miasta pod wpływem funkcji handlowej nie zostały jeszcze w Łodzi zakończone, o czym świadczą dalsze plany inwestycyjne. Łódź zmieniła w znaczący sposób swój wizerunek pod wpływem rozwoju handlu, szczególnie tego wielkopowierzchniowego i nadal będzie go zmieniać w wyniku postępujących prac koncepcyjnych i realizacyjnych.

\subsection{Lokalizacja oraz dostępność przestrzenna centrów handlowych w Łodzi}

Głównymi czynnikami lokalizacji szczegółowej centrów handlowych w Łodzi była istniejąca sieć drogowa, rozmieszczenie terenów mieszkaniowych oraz wolne tereny inwestycyjne, a szczególnie zdegradowane obszary poprzemysłowe. Kompleksy nowoczesnej przestrzeni handlowej znajdują się przy ważnych drogach o znaczeniu ponadlokalnym. W pobliżu drogi krajowej nr 1 (al. Włókniarzy, ul. Jana Pawła II, ul. Rzgowska) zlokalizowane są: Tesco P., Pasaż Łódzki, C.H. Guliwer, przy drodze nr 14 (ul. Pabianicka) Port Łódź, a przy nr 72 (ul. Brzezińska) C.H. M1. Natomiast przy drogach wojewódzkich położone są następujące centra handlowe: przy drodze nr 713 (al. Piłsudskiego, ul. Rokicińska) Galeria Łódzka, C.H. Tulipan, Tesco W., przy drodze nr 709 (ul. Aleksandrowska) Carrefour Sz. Pozostałe badane obiekty również zostały wybudowane w pobliżu głównych łódzkich arterii komunikacyjnych Manufaktura (ul. Zgierska), E. Leclerc (ul. Pojezierska) i Carrefour P. (ul. Przybyszewskiego) (rys. 28). 


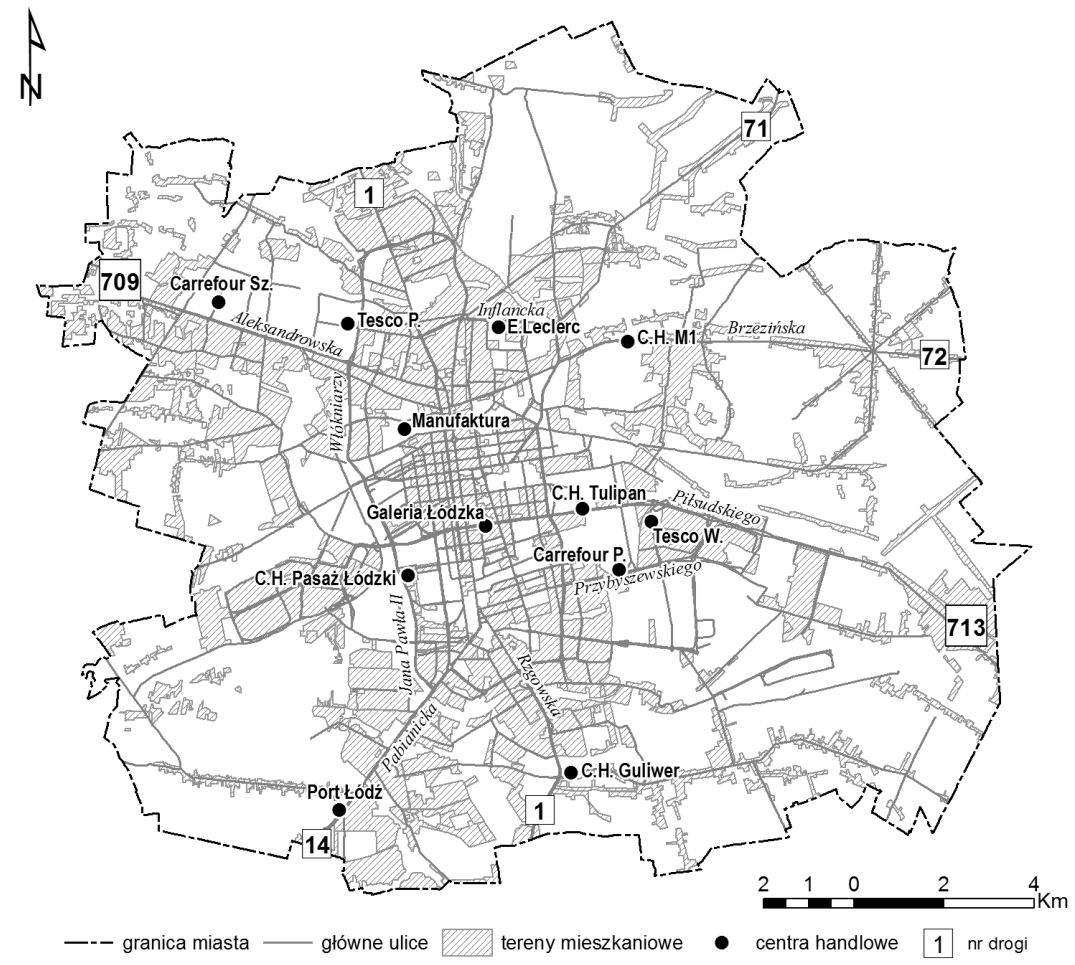

Rys. 28. Lokalizacja centrów handlowych w Łodzi w 2012 roku na tle sieci drogowej.

Źródło: Opracowanie własne.

Drugim istotnym czynnikiem lokalizacji centrów handlowych było rozmieszczenie w przestrzeni miasta terenów mieszkaniowych, szczególnie tych o największej gęstości zaludnienia. W związku z tym te badane kompleksy zostały wybudowane w/lub na obrzeżu osiedli mieszkaniowych, między innymi Widzewa, Retkini, Teofilowa i Bałut. Manufaktura i Galeria Łódzka zlokalizowane są w centrum ${ }^{73}$ miasta, w pobliźu głównej osi urbanistycznej Łodzi ul. Piotrkowskiej. Należy zauważyć, że większość centrów handlowych znajduje się w pobliżu dzielnic mieszkaniowych

${ }^{73}$ A. Wolaniuk (1994, s. 73-75) na podstawie badań rozmieszczenia instytucji wielkomiejskich oraz wyznaczonych środków grawitacji zauważyła przesuwanie się centrum Łodzi w kierunku południowym od skrzyżowania ul. Piotrkowskiej z ul. Jaracza w 1891 roku aż do skrzyżowania ul. Piotrkowskiej z ul. A. Struga i J. Tuwima w 1993 roku. W 1993 roku. centrum handlowo-usługowo-instytucjonalne obejmowało obszar zamknięty ulicami: Ogrodową - Północną - Kilińskiego - Wigury - Żwirki - Kościuszki - Mickiewicza - Żeromskiego. 
okalających Śródmieście ${ }^{74}$. Niedaleko granic administracyjnych miasta, czyli na jego peryferiach swoją lokalizację posiadają na południu miasta Port Łódź oraz C.H. Guliwer. Na północny-zachód najdalej odsuniętym centrum handlowym jest Carrefour przy ul. Szparagowej, położony jednak w pobliżu osiedla mieszkaniowego Teofilów. Natomiast na północnym wschodzie, w pewnym oddaleniu już od terenów intensywnej zabudowy mieszkaniowej znajduje się C.H. M1 (rys. 29).

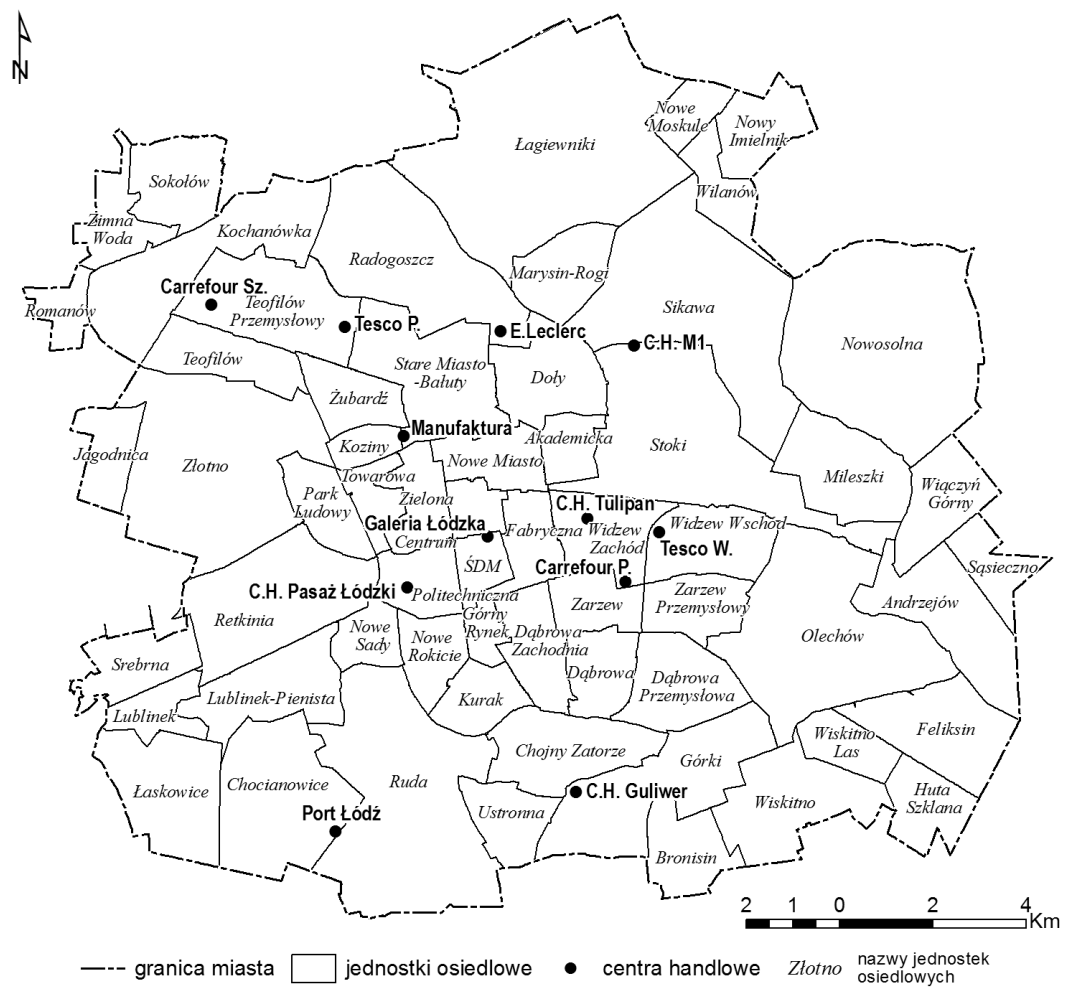

Rys. 29. Lokalizacja łódzkich centrów handlowych na tle jednostek osiedlowych.

Źródło: Opracowanie własne.

${ }^{74}$ J. Dzieciuchowicz (1984, s. 37) zauważa, że termin śródmieście często używa się jako synonimu centrum miasta. W swoim artykule pod pojęciem śródmieścia rozumiał centralnie położony obszar miasta, pełniący funkcje mieszane, z dominantą funkcji usługowych, o zasięgu ogólnomiejskim lub szerszym. Dzielnica administracyjna Śródmieście odpowiada w zasadzie urbanistycznemu śródmieściu Łodzi (dzielnica jest trochę większa). 
Przy wyborze miejsc pod nowe inwestycje istotną rolę odegrało również rozmieszczenie wolnych terenów inwestycyjnych oraz terenów poprzemysłowych przeznaczonych do rewitalizacji. Specyfiką łódzką jest lokalizacja typu brownfield, czyli na terenach wykorzystywanych wcześniej do innych celów, w tym przemysłowych czy magazynowych na przykład Manufaktura w byłych XIX-wiecznych zakładach I.K. Poznańskiego, CH. Tulipan, Carrefour Szparagowa, Tesco Pojezierska. Peryferyjne ośrodki, takie jak C.H. M1 i Port Łódź wybudowano na terenach pierwotnie niezainwestowanych, czyli na „surowym korzeniu” (lokalizacja typu greenfield ${ }^{75}$.

W przypadku lokalizacji centrum handlowego „Sukcesja”, które ma powstać między Galerią Łódzką a C.H. Pasażem Łódzkim, zwrócono uwagę na inne czynniki determinujące jego lokalizację. Obok podkreślania dobrego skomunikowania tego terenu $\mathrm{z}$ innymi dzielnicami łódzkimi i miejscowościami w aglomeracji (droga krajowa nr 1) wskazano na istniejące w pobliżu inwestycje: centrum Międzynarodowych Targów Łódzkich (MTŁ), kampus Politechniki Łódzkiej, Centrum Konferencyjno-Wystawiennicze MTŁ oraz na realizowane i planowane inwestycje osiedli mieszkaniowych (jedno docelowo z 2000 mieszkaniami i drugie na 800 mieszkań) oraz trwającą budowę Akademickiego Centrum Sportu (planowany termin otwarcia -2014 roku) ${ }^{76}$.

Można zauważyć, że rozmieszczenie łódzkich centrów handlowych (łącznie $z$ tymi planowanymi) jest zdeterminowane w dużej mierze przebiegiem głównych dróg o znaczeniu krajowym i wojewódzkim, a także położeniem osiedli mieszkaniowych, oraz wolnymi terenami inwestycyjnym (najczęściej uwolnionymi terenami poprzemysłowymi). W związku z tymi głównymi determinantami lokalizacyjnymi większość łódzkich centrów handlowych została zlokalizowana w pobliżu centrum miasta lub w strefie go okalającej między Śródmieściem a głównymi osiedlami mieszkaniowymi.

\footnotetext{
${ }^{75} \mathrm{Nie}$ jest celem tej pracy szczegółowa identyfikacja wcześniejszego zagospodarowania terenów na których zostały zlokalizowane poszczególne centra handlowe, ponieważ ten fakt nie wpływa na zachowania przestrzenne i nabywcze współczesnych klientów. Jedynie w przypadku zrewitalizowanego kompleksu takiego jak Manufaktura, gdzie zachowano wiele elementów architektonicznych i urbanistycznych z XIX-wiecznego kompleksu pałacowo-fabrycznego, ma to znaczenie ze względu na wykreowanie specyficznego klimatu, co podkreślali w swoich wypowiedziach niektórzy ankietowani. Manufaktura stała się „centrum” Łodzi, do którego podążają nie tylko mieszkańcy aglomeracji łódzkiej, ale również turyści, dla których jest ona atrakcją turystyczną.

${ }^{76}$ Centrum handlowo-rozrywkowe Sukcesja Łódź, http://scf2012.retailnet.pl/projekty/centrum-handlowo-rozrywkowe-sukcesja-lodz/.
} 
Dostępnośćc7 przestrzenna rozumiana jest jako „łatwość osiągnięcia miejsca lub funkcji z innego miejsca/miejsc wyrażona dystansem do pokonania, kosztem transportu bądź czasem podróży” (...). „W zależności od sposobu przedstawiania dostępności można mówić o dostępności fizycznej, jeśli określimy ją dystansem (metry, kilometry), dostępności czasowej, jeśli wyrazimy ją w minutach oraz o dostępności ekonomicznej, jeśli do jej określenia użyjemy kosztu” (Guzik 2003, s. 34). „Dostępność komunikacyjna (transportowa) jest pojęciem szerszym niż sama dostępność przestrzenna - oprócz dostępności komunikacyjnej określonego punktu czy miasta (wtedy jest zbieżna $\mathrm{z}$ dostępnością przestrzenną) obejmuje swoim znaczeniem dostępność komunikacyjną obszaru, rozumianą także jako jego drożność, a także dostępność sieci komunikacyjnej. Dostępność komunikacyjna obejmuje całokształt stosunków komunikacyjnych na danym obszarze" (Guzik 2003, s. 35).

Klienci centrów handlowych najczęściej przybywają do nich samochodami, część wykorzystuje środki komunikacji miejskiej lub linie autobusów bezpłatnych, jest też pewna grupa osób, która dociera do nich pieszo ${ }^{78}$. $\mathrm{Z}$ punktu widzenia atrakcyjności centrów handlowych duże znaczenie ma ich dostępność komunikacyjna zewnętrzna, jak i wewnętrzna ${ }^{79}$, zarówno dla klientów zmotoryzowanych, jak i tych niezmotoryzowanych. W przypadku dostępności zewnętrznej dla tej pierwszej grupy najważniejsze znaczenie będzie odgrywać możliwość szybkiego dojazdu (drogi dojazdu o dużej przepustowości, niezatłoczone) oraz możliwość łatwego zaparkowania. Dla tej drugiej grupy istotne będą szczególnie powiązania komunikacyjne komunikacją miejską danego centrum $\mathrm{z}$ innymi częściami miasta (między innymi częstotliwość kursów, położenie przystanków).

W celu określenia dostępności komunikacyjnej centrów handlowych określono liczbę linii autobusów i tramwajów MPK, linii bezpłatnych autobusów, liczbę miejsc parkingowych oraz wyznaczono strefy czasowe dla klientów zmotoryzowanych oraz tych niezmotoryzowanych.

\footnotetext{
${ }^{77}$ Geografowie wiążą dostępność z bliskością i możliwością przestrzennej interakcji, socjologowie patrzą przez pryzmat ograniczeń społecznych, a ekonomiści wiążą dostępność z kosztami (Guzik 2003, s. 33).

${ }^{78} \mathrm{O}$ tym bardziej szczegółowo w części III pracy.

${ }^{79}$ Dostępność komunikacyjna to wszelkie możliwości zarówno dojazdu do terenu będącego celem podróży (zewnętrzna), jak i poruszania się po nim (wewnętrzna) (Kaczmarek, Stasiak, Włodarczyk 2005, s. 54).
} 
Tabela 14

Dostępność komunikacyjna łódzkich centrów handlowych

\begin{tabular}{|c|l|l|c|c|}
\hline Lp. & \multicolumn{1}{|c|}{$\begin{array}{c}\text { Centrum } \\
\text { handlowe }\end{array}$} & $\begin{array}{c}\text { Liczba miejsc } \\
\text { parkingowych }\end{array}$ & $\begin{array}{c}\text { Liczba linii } \\
\text { komunikacji } \\
\text { miejskiej }\end{array}$ & $\begin{array}{c}\text { Liczba linii } \\
\text { bezpłatnych } \\
\text { autobusów }\end{array}$ \\
\hline 1. & Manufaktura & 3500 & 10 & 1 (tramwaj) \\
\hline 2. & Galeria $Ł$. & $\begin{array}{l}1400 \text { (zadaszony, } \\
\text { płatny) }\end{array}$ & 8 & 0 \\
\hline 3. & Port Łódź & 4500 & 3 & 2 (za 1 zł) \\
\hline 4. & C.H. M1 & 2400 & 7 & 4 \\
\hline 5. & C.H. Tulipan & 2000 & 8 & 3 \\
\hline 6. & Pasaż Łódzki & 1747 & 2 & 3 \\
\hline 7. & Tesco P. & 1800 & 5 & 2 \\
\hline 8. & C.H. Guliwer & 1200 & 7 & 2 \\
\hline 9. & Tesco W. & 1600 & 3 & 2 \\
\hline 10. & E. Leclerc & 400 & 9 & 2 \\
\hline 11. & Carrefour Sz. & 900 & 3 & \\
\hline 12. & Carrefour P. & $1000(300$ pod & dachem) & \\
\hline
\end{tabular}

Źródło: Opracowanie własne na podstawie pozyskanych informacji ze stron internetowych poszczególnych centrów handlowych, strony MPK oraz z badań inwentaryzacyjnych.

Wszystkie badane centra handlowe mają do dyspozycji duże bezpłatne parkingi (wyjątkiem jest Galeria Łódzka). Największymi parkingami dysponują: Port Łódź (4500 miejsc), Manufaktura (3500 miejsc), C.H. M1 (2400 miejsc) i C.H. Tulipan (2000 miejsc), natomiast najmniejsze znajdują się na terenie E. Leclerc (400 miejsc) i Carrefour Sz. (900 miejsc). Badane kompleksy są połączone $\mathrm{z}$ różnymi częściami miasta siecią komunikacji miejskiej. Najwięcej linii MPK przebiega w pobliżu Manufaktury (10), Carrefour Sz. (9), Galerii Łódzkiej i C.H. Tulipan - po osiem (tab. 14).

Wybrane centra handlowe kształtują również swoją przewagę konkurencyjną, organizując darmowe kursy autobusów dowożących klientów z głównych dzielnic mieszkaniowych. O dostępności komunikacyjnej poszczególnych centrów handlowych świadczyła również możliwość dotarcia do nich autobusami bezpłatnych linii zwanych frikobusami. $\mathrm{Z}$ badanych łódzkich centrów handlowych tylko Galeria Łódzka nie świadczyła i nie 
świadczy takiej usługi ${ }^{80}$. W przypadku Manufaktury był i jest to bezpłatny tramwaj jeżdżący po oklicznych ulicach wokół tego kompleksu handlowo-rozrywkowego. Natomiast Port Łódź oferował przejazd dwiema liniami autobusowymi, ale za przejazd należało uiścić opłatę w wysokości 1 zł. Najwięcej linii obsługiwało Pasaż Łódzki (4), C.H. M1 (4), C.H. Tulipan (3) i Tesco Pojezierska (3 - obecnie zlikwidowane). Pozostałe centra handlowe posiadały po dwie linie frikobusów. $Z$ poszczególnych centrów handlowych autobusy bezpłatnych linii obsługiwały najczęściej sąsiednie jednostki osiedlowe. Rejony miasta $\mathrm{z}$ intensywnym budownictwem mieszkaniowym często były połączone komunikacyjnie $z$ kilkoma centrami handlowymi:

- przez Widzew i Olechów przebiegały trasy bezpłatnych linii C.H. Tulipan, Carrefour P. i Tesco W.,

- przez dzielnicę mieszkaniową Retkinia z Portu Łódź i dwie linie z Pasażu Łódzkiego,

- przez Dąbrowę przebiegały trasy bezpłatnych linii z C.H. Tulipan, C.H. Guliwer, Carrefour P. i Tesco W.,

- Radogoszcz i Bałuty były obsługiwane nie tylko liniami E. Leclerc, ale również liniami Tesco P., które, jak wcześniej wspomniano w czerwcu 2011 roku zlikwidowano. Natomiast przez Bałuty przebiegała dodatkowo linia z Carrefoura na Szparagowej oraz z C.H. M1.

Oczywiście przez wiele innych jednostek łódzkich też wyznaczono linie bezpłatnych autobusów, ale najczęściej były to linie jednego centrum handlowego i to $\mathrm{z}$ tych najbliżej położonych. C.H. M1 jako jedyne centrum handlowe obok jednej lini miejskiej uruchomił trzy linie podmiejskie do Strykowa, Zgierza i Brzezin (rys. 30). Na trasach do tych miejscowości autobusy kursowały tylko w soboty i niedziele. Kursy weekendowe były jednak sporadyczne, bo do Brzezin i Zgierza to dwa, trzy połączenia na dobę, a do Strykowa tylko jeden kurs dobowy.

W związku z możliwością wyboru różnych wariantów docierania do badanych kompleksów ważne jest wyznaczenie stref dostępności czasowej. W przypadku dostępności pieszej wytyczono strefy w promieniu 15 minut

${ }^{80} \mathrm{~W}$ okresie kiedy były prowadzone badania terenowe, tylko Galeria Łódzka nie posiadała bezpłatnych połączeń. Od dnia 1 czerwca 2011 roku nie kursują trzy linie bezpłatnego autobusu do Tesco na Pojezierskiej, które zostały zlikwidowane. Od tego czasu również to centrum handlowe nie świadczy takiej usługi. W związku z terminem prowadzonych badań zostały jednak owe trzy linie uwzględnione w analizie, ponieważ mogły mieć wtedy wpływ na zachowania przestrzenne klientów tego centrum handlowego. 


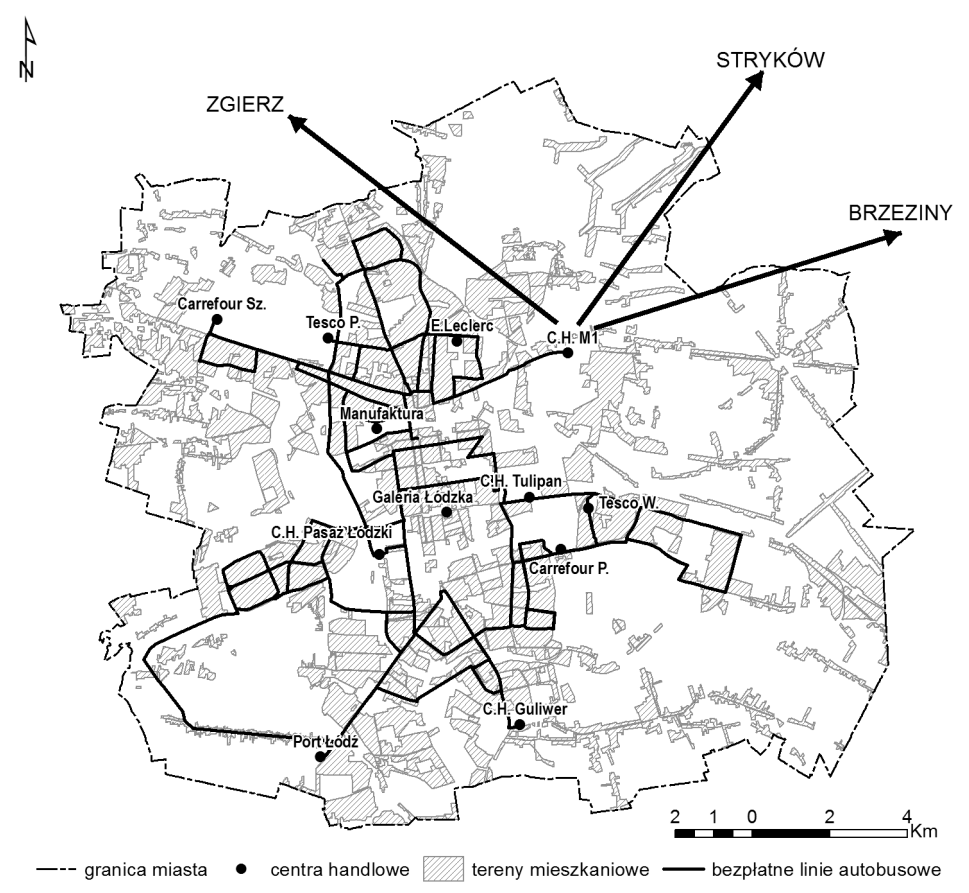

Rys. 30. Przebieg linii bezpłatnych autobusów z poszczególnych centrów handlowych na terenie Łodzi (stan na maj 2011 rok).

Źródło: Opracowanie własne.

od centrów handlowych dla pieszych poruszających się wzdłuż ciągów komunikacyjnych (ulice) z prędkością 5 kilometrów na godzinę (rys. 31).

W wyznaczonych piętnastominutowych strefach dojścia pieszego określono potencjał ludnościowy tych obszarów (liczbę ludności i gęstość zaludnienia). Okazuje się, że w tak bliskiej odległości mieszka 99 tysięcy łodzian, co stanowi około $13,4 \%$ ludności miasta. $Z$ tego wynika, że co ósmy mieszkaniec Łodzi może dotrzeć do najbliższego centrum handlowego pieszo w przeciągu 15 minut. Zdecydowanie najwięcej ludności mieszka w strefie wokół Galerii Łódzkiej (ponad 26 tys.), Manufaktury (prawie 16 tysięcy), Tesco W. (prawie 15 tysięcy) i C.H. Tulipan (około 9,6 tysiąca). W wyżej wymienionych strefach jest też najwyższa gęstość zaludnienia wynosząca ponad 5 tysięcy osób na km². Duży potencjał ludnościowy posiadają również strefy wokół Carrefoura na ul. Szparagowej (około 9 tysięcy) i E. Leclerca (ok. 8,5 tysięcy). Wyniki badań ankietowych wykazały, że właśnie w przypadku tych kompleksów największy odsetek osób przybywa do nich pieszo. Zdecydowanie najmniej 


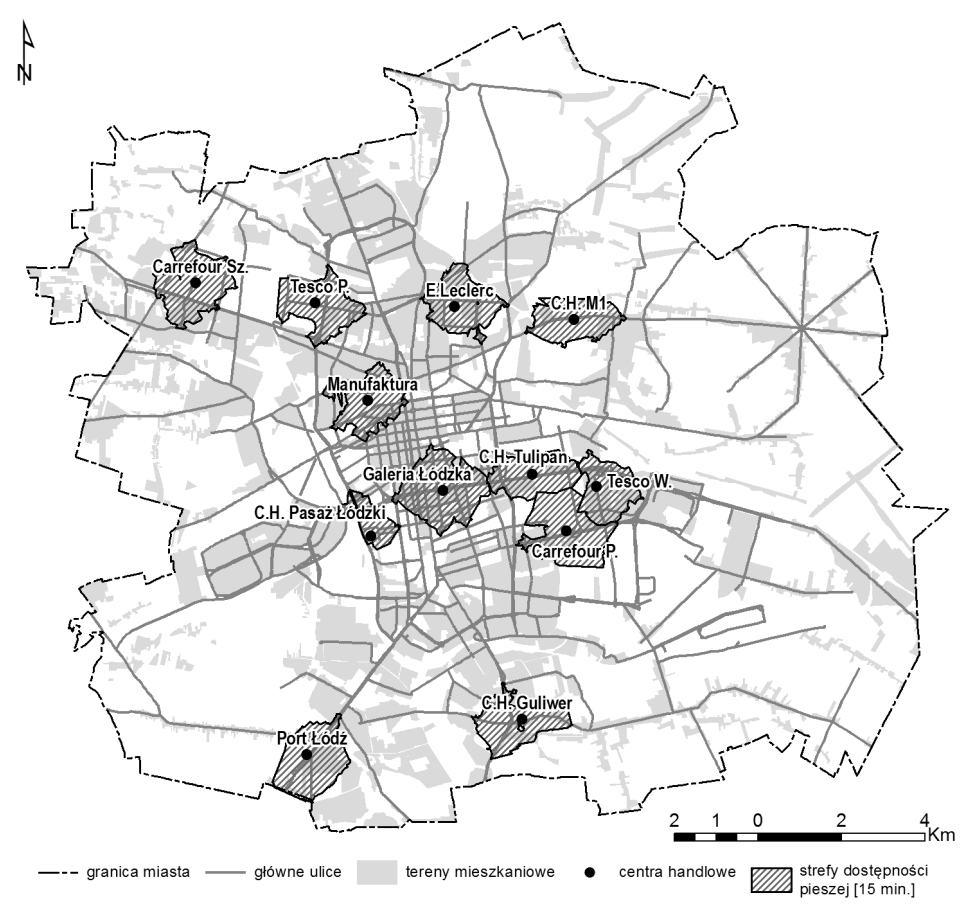

Rys. 31. Piętnastominutowe strefy dostępności pieszej do łódzkich centrów handlowych.

Źródło: Opracowanie własne.

osób może dostać się w taki sposób i w tak krótkim czasie do centrów handlowych położonych peryferyjnie w stosunku do centrum miasta - i tak do C.H. M1 tylko 641 osób, do C.H. Guliwer 1357 osób, a do Portu Łódź 1580 osób. Liczba ludności oraz gęstość zaludnienia w wyznaczonych strefach świadczy o tym, że centra handlowe zostały zlokalizowane w strefach zurbanizowanych. Ze wszystkich badanych obiektów wokół siedmiu gęstość zaludnienia kształtuje się powyżej 2 tysięcy osób na $\mathrm{km}^{2}$, a tylko w przypadku otoczenia C.H. M1 jest poniżej 500 osób na km² (rys. 31).

Dla lepszego zobrazowania dostępności pieszej do badanych centrów handlowych przedstawiono strefy 10 -minutowe (do 60 minut). Najdalej do centrów handlowych mają osoby mieszkające w trzech głównych łódzkich pasach peryferyjnych:

- we wschodniej części Łodzi - z obszaru rozciągającego się od Wiskitna (na południu) poprzez Feliksin, Olechów, Andrzejów, Wiączyń Górny, Mileszki po Nowosolną (na północy), 
- w rejonie północno-wschodnim - od Wilanowa (na wschodzie) poprzez Nowy Imielnik, Nowe Moskule, Modrzew po Łagiewniki (na zachodzie),

- w rejonie południowo-zachodnim - od Łaskowic (na południu) poprzez Lublinek, Nowy Józefów, Smulsko, Stare Złotno po Hutę Jagodnicę (na północy) $)^{81}$ (rys. 33).

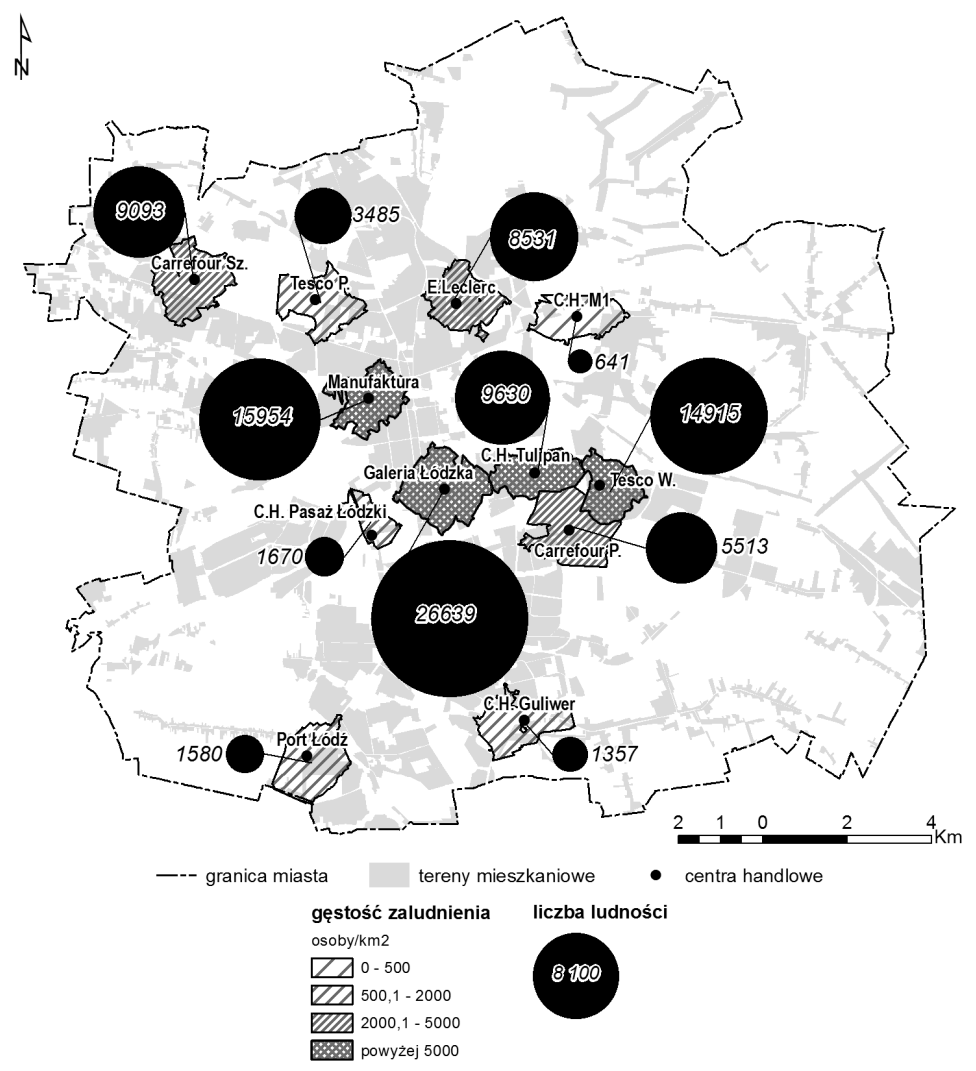

Rys. 32. Liczba ludności i gęstość zaludnienia w strefach piętnastominutowej dostępności pieszej.

Źródło: Opracowanie własne.

Następnym ważnym elementem było wyznaczenie stref dostępności komunikacyjnej centrów handlowych w Łodzi. Do sporządzenia map przed-

${ }^{81} \mathrm{~W}$ tym podrozdziale przy określaniu nazw terenów posługiwano się nazwami wynikającymi z podziału Łodzi na 56 osiedli widniejących w Systemie Informacji Miejskiej (SIM). 
stawiających taką dostępność wykorzystano narzędzia ArcGIS z grupy analiz Network Analysis, które pozwoliły wyznaczyć na obszarze miasta obszary leżące w zasięgu piętnastominutowej ${ }^{82}$ dostępności czasowej dla samochodów poruszających się z urealnionymi prędkościami wzdłuż szczegółowego układu ciągów komunikacyjnych w mieście. Dla dróg przyjęto następujące prędkości: krajowych $60 \mathrm{~km} / \mathrm{h}$, wojewódzkich $50 \mathrm{~km} / \mathrm{h}$, powiatowych $40 \mathrm{~km} / \mathrm{h}$, gminnych $30 \mathrm{~km} / \mathrm{h}$ i wewnętrznych $20 \mathrm{~km} / \mathrm{h}^{83}$. To narzędzie jest wykorzystywane również do wyznaczania obszarów handlowych, czyli podzielenia obszaru miasta na strefy obsługiwane przez poszczególne centra handlowe na podstawie kryterium dojazdu, w tym wypadku maksymalnie w ciągu 15 minut do poszczególnych kompleksów handlowych. Na obszarze miasta występuje kilka miejsc o dostępności komunikacyjnej większej niż kwadrans: rejon lotniska im. W. Reymonta (Lublinek), okolice Starego Złotna, Łaskowic, Nowego Józefowa, teren między Wiskitnem a Feliksinem i Hutą Szklaną oraz obszary położone w różnych częściach Łodzi przy granicy administracyjnej. Ze szczegółowej mapy prezentującej dostępność czasową do 15 minut widać, że tereny o słabszej dostępności komunikacyjnej są obszarami niezamieszkanymi, często $z$ brakiem dróg dojazdowych, stąd trudniejszy i dłuższy dojazd z tych rejonów (rys. 34).

Obok ukazania stref dostępności komunikacyjnej dla samochodów poruszających się z urealnionymi prędkościami po ciągach komunikacyjnych celowe byłoby zastosowanie ustawień Network Analysis pozwalających na uzyskanie obrazu zgeneralizowanego. Po generalizacji małe enklawy znikły, pokazując, że Łódź przy istniejącej „sieci” dwunastu centrów handlowych jest prawie w całości dostępna komunikacyjnie w przeciągu 15 minut. Jedynie z położonych obrzeżnie niektórych obszarach czas dojazdu samochodem jest dłuższy. Do takich terenów należą na południowym wschodzie głównie okolice Wiskitna i Feliksina (największy obszar), na południowym zachodzie obrzeża Łaskowic, na północy okolice Modrzewia (rys. 34).

W celu uszczegółowienia czasowej dostępności komunikacyjnej do badanych centrów handlowych $\mathrm{z}$ terenu całej Łodzi wyznaczono izochro-

\footnotetext{
${ }^{82}$ Przyjęto 15 minut, ponieważ dla ponad 44\% osób ankietowanych tyle zajmuje dotarcie do wskazanego centrum handlowego. Więcej informacji w części III.

${ }^{83}$ Prędkości zostały przyęte umownie, nie uwzględniono tu czasowych wyłączeń ciągów komunikacyjnych $\mathrm{z}$ ruchu samochodowego lub ograniczeń wynikających z prowadzonych robót drogowych. Tego typu utrudnienia mają charakter tymczasowy i nie wpływają na ogólną dostępność komunikacyjną poszczególnych terenów.
} 

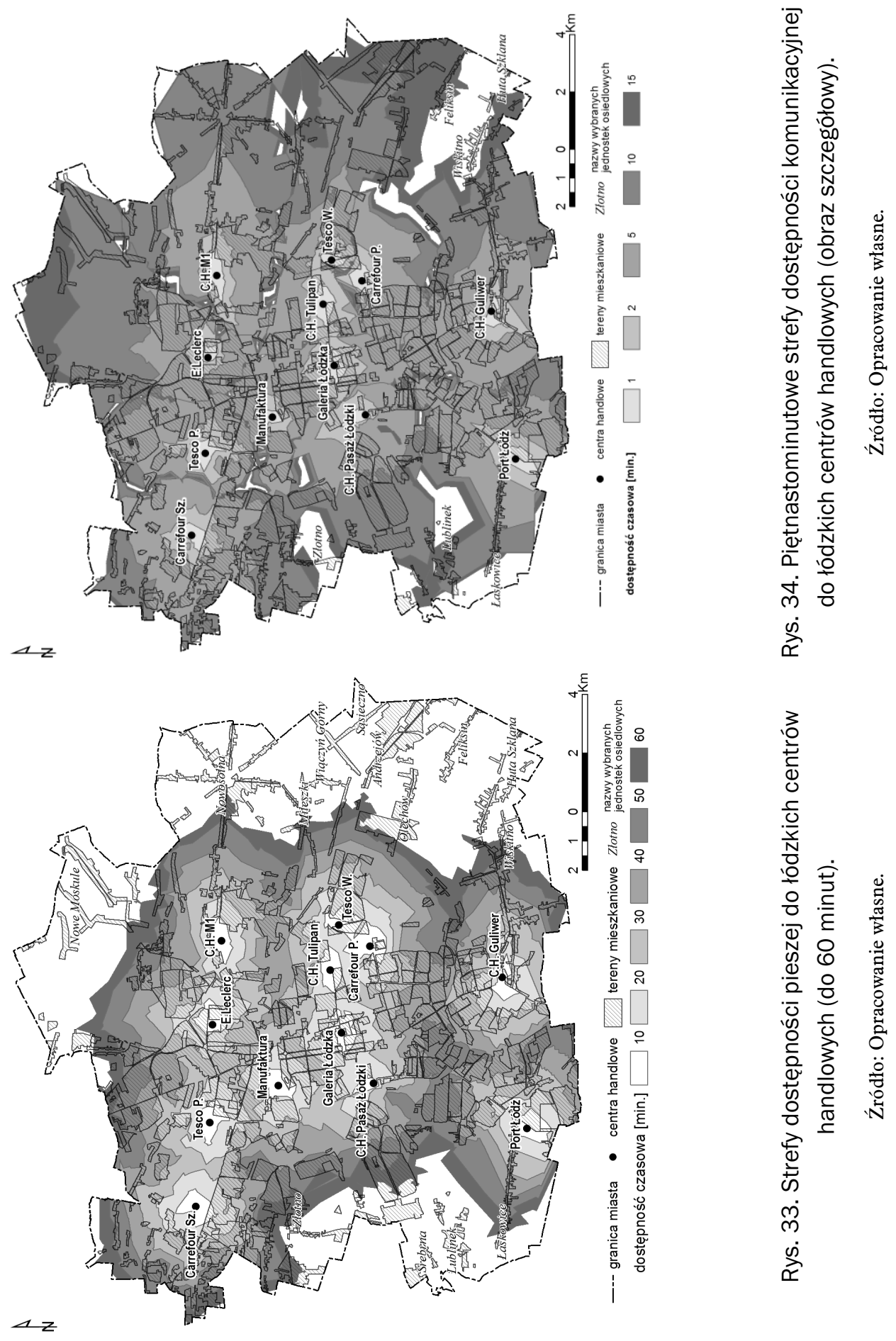
ny do 30 minut dojazdu samochodem. Należy zauważyć, że oprócz kilku fragmentów niezagospodarowanych, położonych na obrzeżach miasta do najbliższego centrum handlowego można dojechać w przeciągu półgodziny z każdego rejonu miasta (wyjątkiem jest Nowy Józefów, z którego należy poświęcić więcej czasu na dojazd). Komunikacyjna dostępność czasowa do łódzkich kompleksów handlowych jest bardzo dobra, a wynika to między innymi z dużej liczby centów handlowych dość równomiernie rozmieszczonych w przestrzeni miejskiej (mimo to dalsze są w budowie), stosunkowo małej powierzchni miasta oraz z kształtu miasta zbliżonego do koła (rys. 37).

Obok dostępności zewnętrznej ważna jest również dostępność wewnętrzna, na którą składają się, między innymi czytelność rozplanowania kompleksu, dobrze opracowane i w odpowiednich miejscach umieszczone tablice informacyine, dostępność materiałów promocyjnych wraz z planem centrum, przystosowanie obiektu do poruszania się osób niepełnosprawnych oraz funkcjonujące punkty informacyjne z profesjonalną obsługą.

Wcześniej wspomniano, że w Łodzi są realizowane nowe inwestycje - powstają dwa duże centra handlowe. W przypadku C.H. Łódź Plaza inwestor na lokalizację nowego projektu wybrał tereny osiedli mieszka-

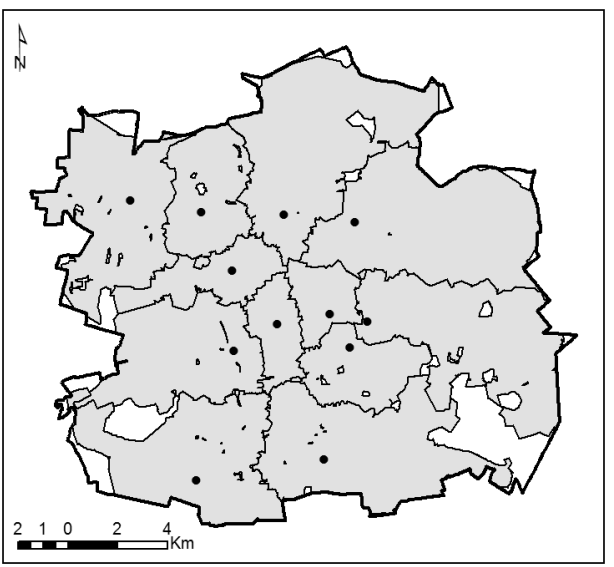

- centra handlowe

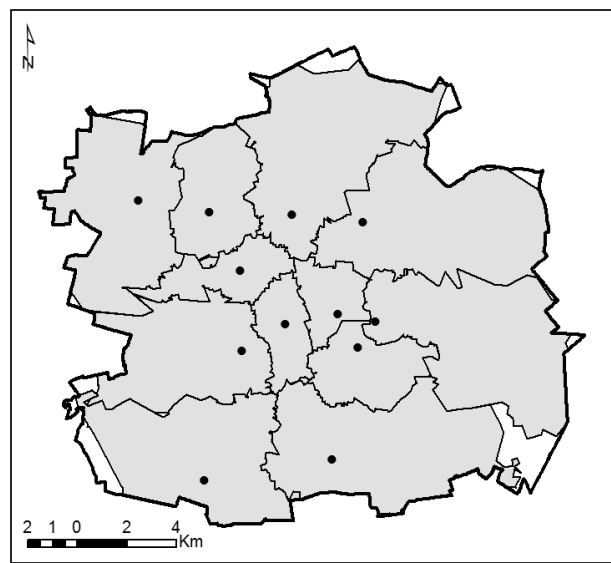

strefy dostępności [15 $\mathrm{min}$.

Rys. 36. Strefy dostępności komunikacyjnej w promieniu 15 minut - generalizacja.

Źródło: Opracowanie własne.

Źródło: Opracowanie własne. 


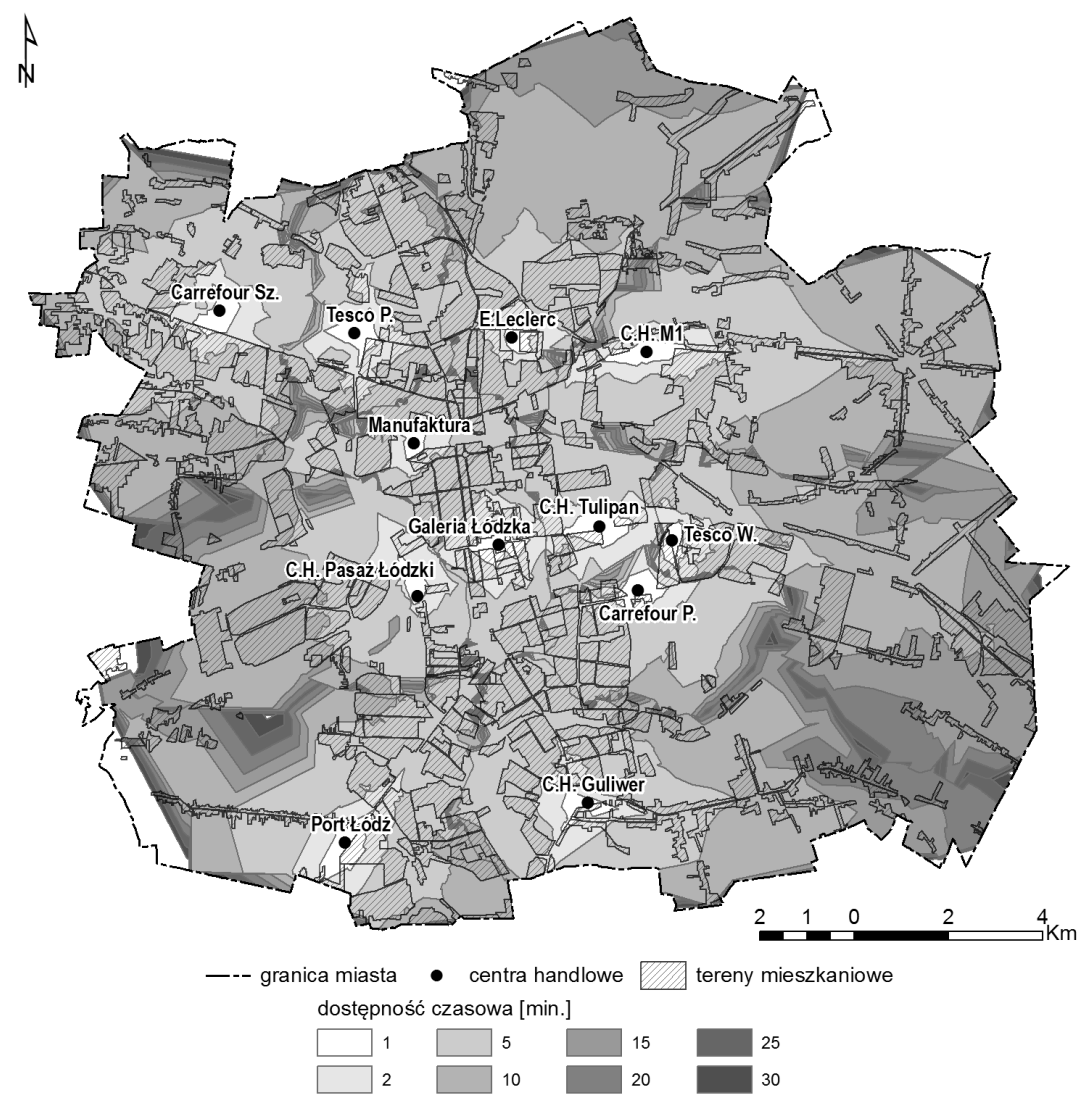

Rys. 37. Strefy dostępności komunikacyjnej w promieniu 30 minut - obraz szczegółowy.

Źródło: Opracowanie własne.

niowych południowej Łodzi, ponieważ, jak twierdzi: „dotychczasowe inwestycje handlowe $\mathrm{w}$ mieście omijały jego południową część z dużymi osiedlami mieszkaniowymi i bardzo dobrą infrastrukturą drogową. Ulica Rzgowska, przy której powstanie centrum handlowe, jest jedną z najważniejszych w mieście arterii komunikacyjnych łączących centrum miasta z wylotem w kierunku Katowic i Krakowa. W odległości 30 minut jazdy samochodem położony jest Piotrków Trybunalski, niewiele dalej Bełchatów i Tomaszów Mazowiecki, czyli miejscowości, z których mogą pochodzić potencjalni klienci. W ciągu ostatnich kilku lat południowe okolice Łodzi stały się gęsto zaludnionym przedmieściem, gdzie przeprowadza się coraz więcej zamożniejszych łodzian” (Wojnowski 2012). Na połu- 
dniowych obrzeżach Łodzi funkcjonują już dwa centra handlowe - Port Łódź i C.H. Guliwer nowa inwestycja - jest zlokalizowana jednak bliżej centrum miasta. Rozpatrując więc jego lokalizację w kontekście położenia w stosunku do Śródmieścia można się zgodzić, że istnieje tu luka w stosunku do obszarów położonych w innych kierunkach od centrum miasta.

\subsection{Oferta łódzkich centrów handlowych}

\subsubsection{Atrakcyjność oferty centrum handlowego - wymiar materialny i niematerialny}

Oferta rozumiana jest jako „wiążąca propozycja sprzedaży towarów zawierająca prawa oraz istotne warunki, na mocy których będzie realizowana dana transakcja i posiadająca charakter wiążący $\mathrm{z}$ punktu widzenia oferenta" (Kienzler, Romanowski 2009, s. 163) może być więc rozpatrywana $\mathrm{w}$ dwóch wymiarach, tym materialnym i tym niematerialnym. W łódzkich centrach handlowych w przeważającej części jest to oferta sprzedaży dóbr materialnych. Placówki handlowe zlokalizowane w badanych kompleksach oferują asortyment o zróżnicowanej szerokości ${ }^{84}$ i głębokości ${ }^{85}$. W zależności od centrum handlowego zachęcają one miejscami sprzedaży - ich liczbą, zróżnicowaną ofertą, prestiżem, pozycją na rynku i tym podobnymi. Punkty sprzedaży są fundamentem, na którym krystalizuje się oferta całościowa poszczególnych centrów handlowych.

Ważną składową produktu przedsiębiorstwa detalicznego są również usługi, których świadczenie może wywierać istotny wpływ na zachowanie nabywcy podejmującego decyzję o wyborze placówki handlowej. Wyróżnia się następujące rodzaje usług $\mathrm{z}$ uwzględnieniem ich związku z ofertą towarową (Borusiak 2008, s. 52):

- usługi bezpośrednio podnoszące wartość oferowanych towarów (na przykład usługa instalacyjna),

\footnotetext{
${ }^{84}$ Szerokość asortymentu - liczba grup towarowych wchodzących w skład asortymentu handlowego, może być wąski lub szeroki (Mikołajczyk 2008, s. 131).

${ }^{85}$ Głębokość asortymentu - liczba pozycji asortymentowych w ramach grupy towarowej; może być płytki lub głęboki (Mikołajczyk 2008, s. 131).
} 
- usługi wspierające proces wymiany (na przykład możliwość płacenia kartą, dowóz towaru do domu),

- usługi zwiększające wygodę zakupów i czyniące je bardziej przyjemnymi (na przykład miejsca zabaw dla dzieci),

- usługi mające zachęcić do zakupu określonych towarów (na przykład demonstracje posługiwania się sprzętem),

- usługi informacyjne (udzielanie informacji o towarach i usługach),

- usługi posprzedażowe, mające za zadanie utwierdzenie konsumenta w poczuciu dokonania prawidłowego wyboru miejsca zakupu (na przykład możliwość zwrotu towaru lub jego wymiany).

Centra handlowe stanowią więc multiusługowe kompleksy o zdywersyfikowanej ofercie usługowo-handlowej, czasami wzbogaconej ofertą kulturalno-rozrywkową. $\mathrm{Z}$ jednej strony każdy $\mathrm{z}$ takich jednolitych kompleksów, zarządzanych przez jednego zarządcę posiada własną specyficzną ofertę jako całość, z drugiej strony poszczególni usługodawcy prowadzący swoją działalność na jego terenie też przedstawiają zindywidualizowany koncepcyjnie i asortymentowo pakiet ofertowy. Według A. Panasiuka (2010, s. 75) „multiusługodawca poprzez swoje punkty dostępu umożliwia korzystanie z szerokiego zakresu usług, dostosowując placówkę usługową do możliwości świadczenia różnego rodzaju usług (...), a dzięki integracji oferty przedsiębiorstw sektora handlu i usług kształtowana jest przewaga konkurencyjna (...). Organizacyjną postacią zdywersyfikowanej formy działalności usługowej są centra handlowo-usługowe, gdzie w jednym miejscu, w zbliżonych warunkach kształtowania systemu obsługi ofertę przedstawiają różni handlowcy i usługodawcy”.

Dodatkowo multiusługodawca może działać w dwóch modelowych ujęciach organizacyjnych (Panasiuk 2010, s. 80):

- jako jeden podmiot gospodarczy, który świadczy poprzez placówkę usługową (sieć placówek) wiele usług własnych,

- jako jeden podmiot bezpośredniego kontaktu, oferujący usługi własne i jako pośrednik umożliwiający dostępność do usług wielu innych usługodawców, na przykład oferta biur podróży, agencji ubezpieczeniowych, doradztwa finansowego.

Z „multiusługowości” wynika po pierwsze, że w tego typu obiektach znajdują się placówki świadczące usługi różnego rodzaju, począwszy od szerokiego pakietu handlowego poprzez usługi gastronomiczne $\mathrm{i}$ inne usługi, aż po występującą w niektórych kompleksach ofertę kulturalno- 
-rozrywkową. Bogactwo i zróżnicowanie takiej oferty zależy w dużej mierze od wielkości kompleksu, przystosowania go do pełnienia różnych funkcji oraz, a może przede wszystkim, od polityki zarządcy. To zarządca często decyduje o charakterze danego kompleksu między innymi poprzez organizację struktury wewnętrznej placówek i stoisk, wydzielenie różnej liczby, pomieszczeń o zróżnicowanej powierzchni dostosowanych do świadczenia usług, oraz poprzez stosowaną politykę wynajmu, w którą wpisują się stosowane różnego rodzaju instrumenty zachęcające i zniechęcające najemców. To zarządca w dużej mierze może decydować o strukturze punktów usługowych, w tym handlowych, podpisując odpowiednie umowy z konkretnymi firmami.

Placówki często prowadzą działalność zarówno handlową, wystawiając różne towary do nabycia, jak i oferują niezależny pakiet usług uzupełniających związanych głównie z profilem danego punktu handlowego. Usługi mogą być $w$ nich sprzedawane również jako niezależna od prezentowanych produktów materialnych samodzielna oferta. Przykładem tego typu punktów usługowych może być na przykład stoisko z zegarami w którym można również skorzystać z usług zegarmistrzowskich, czy stoisko fotograficzne, gdzie można nabyć akcesoria fotograficzne i/lub skorzystać z możliwości wywołania zdjęć. Obok takich dwufunkcyjnych stoisk spotyka się również w centrach handlowych placówki ,wielofunkcyjne”, gdzie w jednym miejscu można nabyć usługi o zróżnicowanym charakterze, na przykład szewskie, zegarmistrzowskie, kserograficzne, ślusarskie (dorabianie kluczy). W takim przypadku często jest to niewielkich rozmiarów punkt, w którym dla świadczenia niektórych rodzajów usług stanowi on tylko punkt przyjęć i odbioru, a sama usługa jest realizowana w innym miejscu.

Ofertę placówek handlowych poszczególnych kompleksów wzbogacają punkty świadczące inne usługi, w wachlarzu których jedną z najważniejszych ról odgrywają usługi gastronomiczne. To one pozwalają na odpoczynek w trakcie czynności zakupowych, regenerują siły klientów, zatrzymują nabywców, przedłużają ich czas pobytu w poszczególnych centrach handlowych i często dzięki temu wpływają na wysokość wydatków ponoszonych przez klientów, a tym samym na sumę pozostawionych pieniędzy. Oferta usługowa (w tym głównie handlowa) jest podstawową we wszystkich łódzkich centrach handlowych, ale w niektórych ośrodkach wzbogacono ją ofertą kulturalno-rozrywkową, szczególnie w Manufakturze, gdzie punktów świadczących tego typu atrakcji jest najwięcej. 


\subsubsection{Struktura oferty handlowej}

Łódzkie centra handlowe w swojej ofercie mają placówki handlowe ${ }^{86}$, gastronomiczne i inne punkty usługowe, a niektóre $\mathrm{z}$ nich również miejsca, w których świadczona jest oferta rozrywkowa czy kulturowa. Zakres prowadzonej działalności w dużej mierze zależy od wielkości danego centrum handlowego oraz od specjalizacji, która często została wykreowana przez głównego zarządcę obiektu. W związku ze złożonością ofertową wybranych placówek zlokalizowanych w poszczególnych kompleksach pojawił się problem z zaklasyfikowaniem niektórych $\mathrm{z}$ nich do odpowiednich klas w PKD. W takich przypadkach brano pod uwagę podstawową działalność, za którą uznawano najczęściej handlową. Jest to częściowo uproszczenie, ale pozwoliło ono uniknąć wielokrotnego liczenia placówek.

Na łódzkim rynku centrów handlowych zdecydowanym liderem pod względem liczby placówek usługowych (w tym handlowych) oraz rozrywkowo-kulturalnych jest Manufaktura (łącznie 315). Bardzo rozbudowaną ofertę mają również Galeria Ł. (160 placówek) oraz Port Łódź (153). Najmniej placówek usługowych znajduje się w galeriach handlowych zlokalizowanych w E. Leclerc (23), Carrefour Sz. (21) i Carrefour P. (14). Pozostałe badane kompleksy stanowiły konglomeraty złożone od 45 jednostek - Tesco W. - do 92 w C.H. M1. W podobny sposób wygląda kolejność centrów handlowych pod względem liczby punktów sprzedaży detalicznej ${ }^{87}$ (głównie sklepów ${ }^{88}$ ) w nich zlokalizowanych. We wszystkich badanych centrach handlowych największy udział posiadają placówki zajmujące się

\footnotetext{
${ }^{86}$ Placówki handlowe to punkty sprzedaży detalicznej obejmujące obiekty wielkopowierzchniowe, sklepy łącznie z aptekami, stałe punkty sprzedaży drobnodetalicznej (kioski, „szczęki”, stragany), pozostałe punkty sprzedaży drobnodetalicznej o charakterze ruchomym, stacje paliw (Rynek wewnętrzny w 2011 r..., 2012, s. 12).

${ }^{87}$ Podczas inwentaryzacji zliczono i zaklasyfikowano nie tylko sklepy, ale również stoiska handlowe.

${ }^{88}$ Sklep jest to stały punkt sprzedaży detalicznej, posiadający specjalne pomieszczenie (to jest lokal sklepowy) z oknem wystawowym oraz wnętrzem dostępnym dla klientów. Jeżeli w dużych sklepach (na przykład w domach towarowych, domach handlowych) część powierzchni sprzedażowej została wydzierżawiona przez inną osobę prawną lub fizyczną, która na tej części prowadzi sprzedaż detaliczną na własny rachunek - to ta część stanowi odrębny sklep (Rynek wewnętrzny w 2011 r..., 2012, s. 12).
} 
handlem ${ }^{89}$. W większości udział ten wynosi 70\%-80\%, a największy jest w C.H. M1 (88\%) i Pasażu Ł. (85,1\%). Najmniejsze łódzkie centra handlowe charakteryzują się mniejszym udziałem punktów handlowych (około 50-60\%), przy większym innych placówek usługowych (tab. 15).

Tabela 15

Struktura placówek w łódzkich centrach handlowych w 2011 roku

\begin{tabular}{|l|c|c|c|c|c|c|}
\hline $\begin{array}{c}\text { Centrum } \\
\text { handlowe }\end{array}$ & $\begin{array}{c}\text { Liczba } \\
\text { placówek } \\
\text { handlowych }\end{array}$ & $\begin{array}{c}\text { Udział } \\
\text { placówek } \\
\text { handlowych } \\
\text { w ogólnej } \\
\text { liczbie } \\
\text { placówek } \\
\text { [\%] }\end{array}$ & $\begin{array}{c}\text { Liczba } \\
\text { placówek } \\
\text { gastrono- } \\
\text { micznych }\end{array}$ & $\begin{array}{c}\text { Liczba } \\
\text { punktów } \\
\text { usługowych }\end{array}$ & $\begin{array}{c}\text { Liczba } \\
\text { miejsc } \\
\text { rozrywki }\end{array}$ & $\begin{array}{c}\text { Ogólna } \\
\text { liczba } \\
\text { placówek }\end{array}$ \\
\hline Manufaktura & 228 & 72,4 & 50 & 19 & 18 & 315 \\
\hline Galeria Ł. & 130 & 81,3 & 19 & 11 & 0 & 160 \\
\hline Port Łódź & 127 & 83,0 & 18 & 8 & 0 & 153 \\
\hline C.H. M1 & 81 & 88,0 & 3 & 8 & 0 & 92 \\
\hline C.H. Tulipan & 67 & 82,7 & 5 & 9 & 0 & 81 \\
\hline Pasaż Łódzki & 57 & 85,1 & 4 & 6 & 0 & 67 \\
\hline Tesco P. & 44 & 71,0 & 3 & 14 & 1 & 62 \\
\hline C.H. Guliwer & 38 & 73,1 & 3 & 11 & 0 & 52 \\
\hline Tesco W. & 35 & 77,8 & 3 & 6 & 1 & 45 \\
\hline E.Leclerc & 13 & 56,5 & 1 & 9 & 0 & 23 \\
\hline Carrefour Sz. & 13 & 61,9 & 2 & 6 & 0 & 21 \\
\hline Carrefour P. & 8 & 57,1 & 1 & 4 & 1 & 14 \\
\hline
\end{tabular}

Źródło: Opracowanie własne na podstawie badań inwentaryzacyjnych.

W strukturze wyspecjalizowanych placówek detalicznej sprzedaży, według podziału $\mathrm{PKD}$, największy udział we wszystkich centrach handlowych posiadają te zaklasyfikowane w klasie 47.7, czyli „sprzedaż detaliczna pozostałych wyrobów prowadzona w wyspecjalizowanych sklepach”. Najwięcej placówek z tej grupy funkcjonuje w Manufakturze (178), Galerii Łódzkiej

${ }^{89}$ Sklasyfikowane według PKD (2007) w sekcji G „Handel hurtowy i detaliczny. Naprawa pojazdów samochodowych, włączając motocykle” w dziale 47 „Handel detaliczny, z wyłączeniem handlu detalicznego pojazdami samochodowymi”. 
(111) i Porcie Łódź (98). Praktycznie we wszystkich centrach handlowych (oprócz Carrefour Sz.) można spotkać również punkty oferujące narzędzia technologii informacyjnej i komunikacyjnej (47.4), są to przede wszystkim punkty przedstawicieli głównych operatorów komórkowych oraz telewizji cyfrowych. We wszystkich badanych centrach handlowych występuje przynajmniej jedna placówka zajmująca się sprzedażą asortymentu związanego z kulturą i rekreacją $(47.6)^{90}$, na przykład księgarnie, punkty prasowe czy sklepy ze sprzętem sportowym lub zabawkami. W mniejszych kompleksach najczęściej są to punkty z prasą, w większych pojawiają się reprezentanci sieci z innym asortymentem. Najwięcej placówek z tej klasy znajduje się w Manufakturze (15). Następną kategorią punktów sprzedażowych stanowią te sprzedające artykuły gospodarstwa domowego $(47.5)^{91}$, które działają tylko w największych centrach handlowych. W zdecydowanej większości badanych kompleksów swoją lokalizację znalazły również specjalistyczne placówki z żywnością, napojami i wyrobami alkoholowymi (47.2), których najwięcej jest w Manufakturze (9), Porcie Łódź (6) i C.H. M1 (5) (tab. 16).

\section{Tabela 16}

Liczba placówek handlu detalicznego wg grup PKD w łódzkich centrach handlowych w 2011 roku

\begin{tabular}{|l|c|c|c|c|c|c|c|}
\hline & \multicolumn{7}{|c|}{ Liczba placówek według grup PKD } \\
\hline Centrum handlowe & 47.1 & 47.2 & 47.4 & 47.5 & 47.6 & 47.7 & tącznie \\
\hline Manufaktura & 2 & 9 & 12 & 12 & 15 & 178 & $\mathbf{2 2 8}$ \\
\hline Galeria Ł. & 1 & 3 & 4 & 5 & 6 & 111 & $\mathbf{1 3 0}$ \\
\hline Port Łódź & 1 & 6 & 9 & 9 & 4 & 98 & $\mathbf{1 2 7}$ \\
\hline C.H. M1 & 1 & 5 & 8 & 10 & 2 & 55 & $\mathbf{8 1}$ \\
\hline C.H. Tulipan & 1 & 2 & 9 & 5 & 4 & 46 & $\mathbf{6 7}$ \\
\hline Pasaż Łódzki & 1 & 1 & 9 & 1 & 4 & 41 & $\mathbf{5 7}$ \\
\hline Tesco P. & 1 & 3 & 10 & 5 & 1 & 24 & $\mathbf{4 4}$ \\
\hline Tesco W. & 1 & 3 & 9 & 0 & 1 & 21 & $\mathbf{3 5}$ \\
\hline C.H. Guliwer & 1 & 3 & 12 & 0 & 2 & 20 & $\mathbf{3 8}$ \\
\hline
\end{tabular}

${ }^{90} 47.6$ - sprzedaż detaliczna wyrobów związanych z kulturą i rekreacją prowadzona w wyspecjalizowanych sklepach.

${ }^{91} 47.5$ - sprzedaż detaliczna artykułów użytku domowego prowadzona w wyspecjalizowanych sklepach. 


\section{Tabela 16 (ciąg dalszy)}

\begin{tabular}{|l|c|c|c|c|c|c|c|}
\hline & \multicolumn{7}{|c|}{ Liczba placówek wg grup PKD } \\
\hline Carrefour Sz. & 1 & 0 & 0 & 0 & 1 & 11 & $\mathbf{1 3}$ \\
\hline E.Leclerc & 1 & 1 & 3 & 0 & 1 & 7 & $\mathbf{1 3}$ \\
\hline Carrefour P. & 1 & 0 & 0 & 0 & 1 & 6 & $\mathbf{8}$ \\
\hline
\end{tabular}

47.1 - sprzedaż detaliczna prowadzona w niewyspecjalizowanych sklepach; 47.2 - żywności, napojów i wyrobów tytoniowych; 47.4 - narzędzi technologii informacyjnej i komunikacyjnej; 47.5 - artykułów użytku domowego; 47.6 - wyrobów związanych z kulturą i rekreacją; 47.7 pozostałych wyrobów.

Źródło: Opracowanie własne na podstawie badań inwentaryzacyjnych.

W strukturze detalicznych punktów handlowych dominują w centrach handlowych (powyżej 50\%) te sklasyfikowane w grupie 47.7. Największy udział tego typu podmiotów posiada Galeria Ł., Carrefour Sz., Manufaktura, Port Ł. i Carrefour P. Obok placówek sklasyfikowanych w powyższej grupie dużym udziałem w strukturze poszczególnych centrów handlowych charakteryzują się te $\mathrm{z}$,narzędziami technologii informacyjnej i komunikacyjnej" (47.4), szczególnie w C.H. Guliwer, Tesco W., Tesco P. i E. Leclerc oraz z artykułami gospodarstwa domowego w C.H. M1 i Tesco P. (rys. 38). Ze struktury podmiotów handlowych widać, że poszczególne łódzkie centra handlowe posiadają swoją specyfikę ofertową.

W dużych oraz średniej wielkości centrach handlowych w ramach klasy 47.7 dominują placówki handlowe z odzieżą (47.71), na przykład w Manufakturze, Porcie Łódź, Galerii Ł. i Pasażu Ł. punkty tego typu stanowią około $60 \%$ wszystkich, a w C.H. M1 - 45,5\% i C.H. Tulipan - 43,5\%. Największa liczba placówek handlowych z odzieżą znajduje się w Manufakturze (110), Galerii Ł. (63) i Porcie Łódź (61), wiele takich placówek działa również w C.H. M1 (25), Pasażu Ł. (24) i C.H. Tulipan (20). W pozostałych kompleksach można odwiedzić po kilka punktów handlowych z odzieżą (wyjątek stanowi E. Leclerc gdzie nie ma takiego punktu) (tab. 17).

Następną bardzo popularną kategorią placówek zlokalizowanych w centrach handlowych są te $z$ obuwiem i wyrobami skórzanymi (47.72), których pod względem liczbowym najwięcej jest w Manufakturze, Porcie Łódź i Galerii Ł. (po blisko 20 placówek). W badanych kompleksach handlowych popularnością lokalizacyjną cieszą się również inne wyspecjalizowane sklepy, szczególnie z kosmetykami i artykułami toaletowymi (47.75), których naj- 


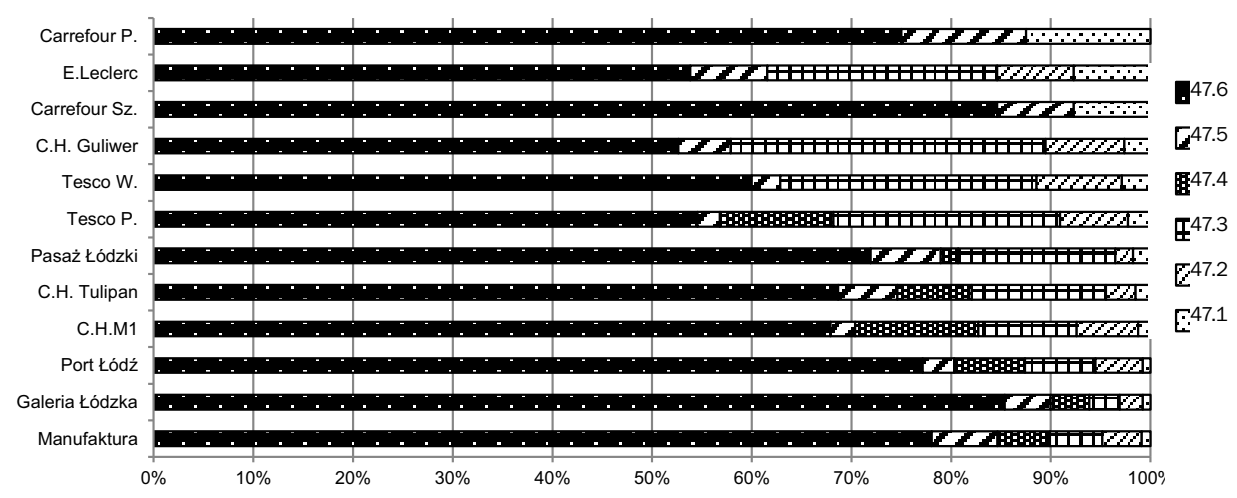

47.1 - sprzedaż detaliczna prowadzona w niewyspecjalizowanych sklepach; 47.2 - żywności, napojów i wyrobów tytoniowych; 47.3 - narzędzi technologii informacyjnej i komunikacyjnej; 47.4 - artykułów użytku domowego; 47.5 - wyrobów związanych z kulturą i rekreacją; 47.6 pozostałych wyrobów.

Rys. 38. Struktura sklepów wg grup PKD w łódzkich centrach handlowych w 2011 roku.

Źródło: Opracowanie własne na podstawie badań inwentaryzacyjnych.

więcej jest w Manufakturze (15), Galerii Ł. i C.H. M1. (po 9) oraz z zegarkami i biżuterią (47.77) (22 w Manufakturze, 12 w Galerii Ł., 6 w Porcie Łódź). Pozostałe kategorie placówek są najczęściej jednostkowymi punktami, do których można zaliczyć apteki (47.73), kwiaciarnie i sklepy zoologiczne (47.76), oraz z wyrobami ozdobnymi i optycznymi (47.78) (tab. 17).

\section{Tabela 17}

Struktura wyspecjalizowanych placówek handlu detalicznego w łódzkich centrach handlowych w 2011 roku

\begin{tabular}{|l|c|c|c|c|c|c|c|c|}
\hline & \multicolumn{7}{|c|}{ Liczba placówek według klas PKD } \\
\cline { 2 - 10 } Centra handlowe & 47.71 & 47.72 & 47.73 & 47.75 & 47.76 & 47.77 & 47.78 & Razem \\
\hline Manufaktura & 110 & 22 & 2 & 15 & 2 & 22 & 5 & $\mathbf{1 7 8}$ \\
\hline Galeria Ł. & 63 & 20 & 1 & 9 & 1 & 12 & 5 & $\mathbf{1 1 1}$ \\
\hline Port Łódź & 61 & 20 & 1 & 5 & 2 & 6 & 3 & 98 \\
\hline C.H. M1 & 25 & 9 & 1 & 9 & 2 & 4 & 5 & 55 \\
\hline C.H. Tulipan & 20 & 7 & 1 & 6 & 2 & 4 & 6 & $\mathbf{4 6}$ \\
\hline Pasaż Łódzki & 24 & 7 & 1 & 3 & 1 & 4 & 1 & $\mathbf{4 1}$ \\
\hline Tesco P. & 8 & 5 & 1 & 4 & 0 & 3 & 3 & $\mathbf{2 4}$ \\
\hline
\end{tabular}


Tabela 17 (ciąg dalszy)

\begin{tabular}{|l|c|c|c|c|c|c|c|c|}
\hline & \multicolumn{7}{|c|}{ Liczba placówek według klas PKD } \\
\cline { 2 - 10 } Centra handlowe & 47.71 & 47.72 & 47.73 & 47.75 & 47.76 & 47.77 & 47.78 & Razem \\
\hline C.H. Guliwer & 6 & 4 & 1 & 3 & 2 & 1 & 3 & 20 \\
\hline Carrefour Sz. & 4 & 1 & 1 & 1 & 0 & 1 & 3 & 11 \\
\hline E.Leclerc & 0 & 1 & 1 & 1 & 1 & 1 & 2 & 7 \\
\hline Carrefour P. & 2 & 3 & 1 & 0 & 0 & 0 & 0 & 6 \\
\hline
\end{tabular}

47.7 sprzedaż detaliczna pozostałych wyrobów prowadzona w wyspecjalizowanych sklepach: 47.71 - odzieży; 47.72 - obuwia i wyrobów skórzanych; 47.73 - wyrobów farmaceutycznych; 47.75 - kosmetyków i artykułów toaletowych; 47.76 - kwiatów, roślin, nasion, nawozów, żywych zwierząt domowych, karmy dla zwierząt domowych; 47.77 - zegarków, zegarów i biżuterii; 47.78 - pozostałych nowych wyrobów.

Źródło: Opracowanie własne na podstawie badań inwentaryzacyjnych.

We wszystkich badanych kompleksach występuje po jednym (tylko w Manufakturze dwa) sklepie „kotwicy"/"lokomotywie” z artykułami FMCG (Fast moving consumer foods) ${ }^{92}$. Hipermarkety z artykułami FMCG (47.1) oferują bardzo bogaty asortyment $\mathrm{w}$ relatywnie niskich cenach i mają za zadanie zaspokoić podstawowe potrzeby klientów przede wszystkim z zakresu artykułów żywnościowych i chemicznych. W każdym z łódzkich centrów handlowych swoją lokalizację znalazł jeden z tego typu hipermarketów, na przykład Real, Tesco, Carrefour, E. Leclerc. W Manufakturze do tego typu sklepów zaliczono Real i Almę, a w Porcie Łódź sklep „Piotr i Paweł” (tab. 18).

W największych centrach handlowych zlokalizowane zostały również duże sklepy specjalistyczne, RTV Euro AGD, Electro World, Leroy Mer-

${ }^{92}$ FMCG (Fast moving consumer foods) - Produkty szybko zbywalne, najczęściej codziennego użytku. Należą do nich przede wszystkim: artykuły spożywcze, kosmetyki, chemia gospodarcza, drobne artykuły gospodarstwa domowego, używki i tym podobne. Jako FMCG jest klasyfikowana większość produktów sprzedawanych w hipermarketach lub supermarketach (Kienzler, Romanowski 2009, 72). FMCG to tak zwane dobra szybko rotujące, co oznacza, że formaty te charakteryzują się relatywnie szerokim, ale raczej płytkim asortymentem i oferują przynajmniej produkty spożywcze, kosmetyczno-drogeryjne, papierosy, prasę. Do grupy tej należy zaliczyć przede wszystkim supermarket, convenience story, sklep dyskontowy, delikatesy i tym podobne (Borusiak 2008, s. 184). 
lin, Media Markt, IKEA, Saturn, Praktiker, Jysk czy Rossmann ${ }^{93}$, które stanowią swego rodzaju wyspecjalizowane „magnesy” - „sklepy kotwicowe”, które przyciągają swoją ofertą pewną grupę klientów i tym samym uatrakcyjniając samo centrum handlowe poprzez możliwość dokonania zróżnicowanych zakupów pod jednym dachem (tab. 18).

\section{Tabela 18}

Liczba placówek handlowych, w tym sklepów „kotwic”, w łódzkich centrach handlowych w 2011 roku

\begin{tabular}{|c|c|c|c|c|c|c|c|}
\hline 옴 & 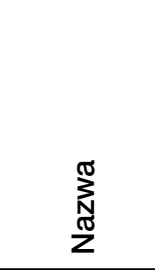 & 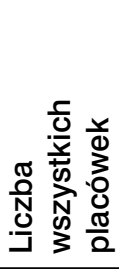 & 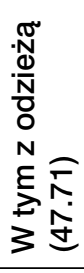 & 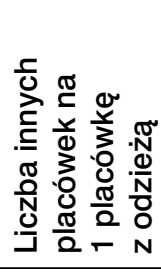 & 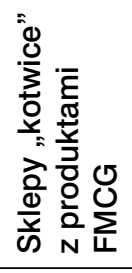 & 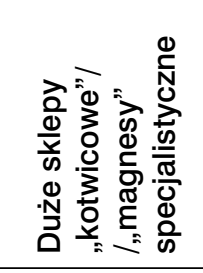 & 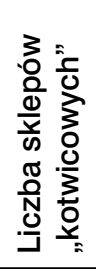 \\
\hline 1. & Manufaktura & 228 & 110 & 1,07 & $\begin{array}{l}\text { Real } \\
\text { Alma }\end{array}$ & $\begin{array}{l}\text { - Electro World } \\
\text { - Leroy Merlin } \\
\text { - RTV Euro AGD } \\
\text { - Rossman }\end{array}$ & 6 \\
\hline 2. & Galeria $Ł$. & 130 & 63 & 1,06 & Tesco & $\begin{array}{l}\text { - Media Markt } \\
\text { - Rossmann }\end{array}$ & 3 \\
\hline 3. & Port Łódź & 127 & 61 & 1,08 & $\begin{array}{l}\text { Piotr } \\
\text { i Paweł }\end{array}$ & $\begin{array}{ll}\text { - } & \text { IKEA } \\
\text { - } & \text { Saturn } \\
\text { - Leroy Merlin } \\
\text { - } \text { RTV Euro AGD } \\
\text { - Rossmann }\end{array}$ & 6 \\
\hline 4. & C.H. M1 & 81 & 25 & 2,24 & Real & $\begin{array}{l}\text { - Media Markt } \\
\text { - Praktiker } \\
\text { - Jysk } \\
\text { - Rossmann } \\
\end{array}$ & 5 \\
\hline 5. & C.H. Tulipan & 67 & 20 & 2,35 & Real & $\begin{array}{l}\text { - } \text { RTV Euro AGD } \\
\text { - Jysk } \\
\text { - Rossmann }\end{array}$ & 4 \\
\hline 6. & Pasaż Łódzki & 57 & 24 & 1,38 & Real & $\begin{array}{l}\text { - RTV Euro AGD } \\
\text { - Rossmann } \\
\end{array}$ & 3 \\
\hline 7. & Tesco P. & 44 & 8 & 4,5 & Tesco & - RTV Euro AGD & 2 \\
\hline 8. & C.H. Guliwer & 38 & 6 & 5,3 & Carrefour & - Rossmann & 2 \\
\hline
\end{tabular}

${ }^{93}$ Sklepami „kotwicowymi” mogą być różne jednostki, w tym opracowaniu zaliczono do nich tylko duże specjalistyczne sklepy o charakterze hipermarketu lub supermarketu. 


\begin{tabular}{|c|c|c|c|c|c|c|c|}
\hline$\dot{9}$ & $\begin{array}{l}\text { J } \\
\text { N్ } \\
\text { Z }\end{array}$ & 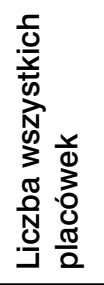 & 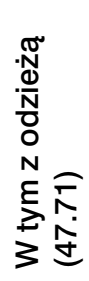 & 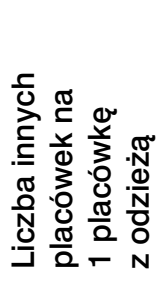 & 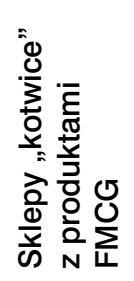 & 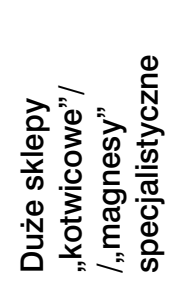 & 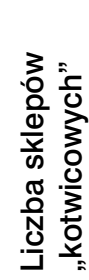 \\
\hline 9. & Tesco W. & 35 & 5 & 6,0 & Tesco & - & 1 \\
\hline 10. & Carrefour Sz. & 13 & 4 & 2,25 & Carrefour & - & 1 \\
\hline 11. & E. Leclerc & 13 & 0 & 0 & E. Leclerc & - & 1 \\
\hline 12. & Carrefour P. & 8 & 2 & 3,0 & Carrefour & - & 1 \\
\hline
\end{tabular}

Źródło: Opracowanie własne na podstawie badań inwentaryzacyjnych.

Podczas badań inwentaryzacyjnych zauważono, że wiele firm posiada swoje placówki w wielu centrach handlowych, tworząc sieć sklepów ${ }^{94}$. Największy odsetek placówek sieciowych znajduje się w Pasażu Łódzkim (86\%), Porcie Ł. (74,8\%) i Galerii Łódzkiej (72,3\%). Pozostałe centra handlowe posiadają około $50 \%$ placówek handlowych, które działają przynajmniej w dwóch kompleksach. Wyjątek stanowi tu tylko Tesco W. o najbardziej zindywidualizowanej strukturze placówek, ponieważ tylko co czwarta posiada również lokalizację $\mathrm{w}$ innym centrum handlowym (tab. 19).

Placówki niektórych marek z odzieżą i artykułami sportowymi działają aż w sześciu łódzkich centrach handlowych (Carry, Reserved, Triumph), inne w pięciu (Big Star, Lee Wrangler, Orsay). Dwanaście firm zlokalizowało swoje placówki handlowe w czterech kompleksach handlowych: 5.10.15., Bytom, Coyoco, H \& M, House, Kastor, Sizeer, New Yorker, Adidas, Diver-

${ }^{94}$ Sieć sklepów tworzą więcej niż dwa sklepy mające zbliżone parametry, jeżeli chodzi o asortyment, zasady lokalizacji, technologię i funkcjonujące pod jedną nazwą (Śmigielska 2004, s. 56). W niektórych krajach przedsiębiorstwo określa się jako sieciowe, gdy w jego strukturze występują przynajmniej dwa punkty sprzedaży detalicznej, w innych - pięć lub dziesięć (Kienzler, Romanowski 2009, s. 217). W pracy uwzględniono również placówki, które posiadają swoje lokalizacje w dwóch centrach handlowych, ponieważ firmy często umieszczają swoje placówki w centrach handlowych w innych miastach i/lub poza centrami handlowymi. Na potrzeby tej pracy wzięto pod uwagę tylko lokalizację w badanych centrach handlowych. 
Tabela 19

Liczba wyspecjalizowanych sieciowych placówek handlu detalicznego w łódzkich centrach handlowych według grup PKD w 2011 roku

\begin{tabular}{|l|c|c|c|c|c|c|c|}
\hline \multirow{2}{*}{$\begin{array}{l}\text { Centrum } \\
\text { handlowe }\end{array}$} & \multicolumn{3}{|c|}{$\begin{array}{c}\text { Liczba placówek ,sieciowych” } \\
\text { według grup PKD }\end{array}$} & Łącznie & $\begin{array}{c}\text { Liczba } \\
\text { sklepów } \\
\text { (ogółem) }\end{array}$ & $\begin{array}{c}\text { Udział } \\
\text { sieciowych } \\
\text { sklepów [\%] }\end{array}$ \\
\cline { 2 - 5 } Pasaż Łódzki & 47.7 & 47.6 & 47.4 & 47.5 & & 57 & $\mathbf{8 6 , 0}$ \\
\hline Port Łódź & 82 & 2 & 8 & 0 & 49 & 127 & $\mathbf{7 4 , 8}$ \\
\hline Galeria Ł. & 83 & 2 & 5 & 4 & 94 & 130 & $\mathbf{7 2 , 3}$ \\
\hline C.H. Tulipan & 29 & 2 & 6 & 3 & 40 & 67 & $\mathbf{5 9 , 7}$ \\
\hline C.H. M1 & 34 & 2 & 8 & 2 & 46 & 81 & $\mathbf{5 6 , 8}$ \\
\hline Carrefour Sz. & 6 & 1 & 0 & 0 & 7 & 13 & $\mathbf{5 3 , 8}$ \\
\hline Tesco P. & 10 & 1 & 9 & 2 & 22 & 44 & $\mathbf{5 0 , 0}$ \\
\hline Carrefour P. & 3 & 1 & 0 & 0 & 4 & 8 & $\mathbf{5 0 , 0}$ \\
\hline Manufaktura & 98 & 3 & 9 & 5 & 113 & 228 & $\mathbf{4 9 , 6}$ \\
\hline C.H. Guliwer & 8 & 1 & 9 & 0 & 18 & 39 & $\mathbf{4 6 , 2}$ \\
\hline E. Leclerc & 3 & 0 & 3 & 0 & 6 & 13 & $\mathbf{4 6 , 2}$ \\
\hline Tesco W. & 4 & 0 & 5 & 0 & 9 & 35 & $\mathbf{2 5 , 7}$ \\
\hline
\end{tabular}

Źródło: Opracowanie własne na podstawie badań inwentaryzacyjnych.

se, Nike, Puma. Firmy, które otworzyły najwięcej placówek handlowych w łódzkich centrach, posiadały najczęściej swoje sklepy w: Manufakturze, Porcie Łódź, Galerii Łódzkiej, Pasażu Ł. lub C.H.Tulipan (tab. 20).

W trzech centrach handlowych mają swoje sklepy takie firmy jak: Atlantic, Camaieu, Quisque, Takko, Monnari, Calzedonia, Cropp Town, Gatta, KappAhl, Levi's, Pierre Cardin, Promod, Smyk, Solar, Stradivarius, Tally Weijl, Tatuum, Tiffi, Vistula, Your New Style, Cross Jeanwear, Intimissimi, Hi Mounttains i Reebok. Dodatkowo 31 sieci handlowych znanych marek odzieżowych i sportowych otworzyło swoje sklepy w dwóch centrach handlowych.

Nie tylko sklepy odzieżowe i sportowe rozwinęły swoje sieci w łódzkich centrach handlowych, ale również jednostki reprezentujące inne branże posiadają w nich po kilka placówek. Najczęściej spotykanymi placówkami z obuwiem i wyrobami skórzanymi są: CCC, Deichmann, Lu Man, Botti i Wojas. Sieć swoich kwiaciarni aż w dziewięciu centrach posiada 
Tabela 20

Znane sieci handlowe z odzieżą oraz sportowe posiadające swoje placówki w przynajmniej czterech centrach handlowych

\begin{tabular}{|c|l|l|c|}
\hline Lp. & $\begin{array}{c}\text { Nazwa } \\
\text { sieci }\end{array}$ & \multicolumn{1}{|c|}{ Centra handlowe } & $\begin{array}{c}\text { Liczba } \\
\text { placówek } \\
\text { w centrach } \\
\text { handlowych }\end{array}$ \\
\hline 1. & Carry & Pasaż Ł., Galeria Ł., C.H. M1, Manufaktura, Port Łódź, C.H. Tulipan & 6 \\
\hline 2. & Reserved & Pasaż Ł., Galeria Ł., C.H. M1, Manufaktura, Port Łódź, C.H. Tulipan & 6 \\
\hline 3. & Triumph & Pasaż Ł., Galeria Ł., C.H. M1, Manufaktura, Port Łódź, C.H. Tulipan & 6 \\
\hline 4. & Big Star & Galeria Ł., C.H. M1, Manufaktura, Port Łódź, C.H. Tulipan & 5 \\
\hline 5. & Lee & Galeria Ł., C.H. M1, Manufaktura, Port Łódź, C.H. Tulipan & 5 \\
\hline 6. & Orsay & Galeria Ł., C.H. M1, Manufaktura, Port Łódź, C.H. Tulipan & 5 \\
\hline 7. & 5.10 .15 & Pasaż Ł., Galeria Ł., Manufaktura, Port Łódź & 4 \\
\hline 8. & Bytom & Pasaż Ł., C.H. M1, Manufaktura, Port Łódź & 4 \\
\hline 9. & Coyoco & Pasaż Ł., Manufaktura, Port Łódź, C.H. Tulipan & 4 \\
\hline 10. & H \& M & Pasaż Ł., Galeria Ł., Manufaktura, Port Łódź & 4 \\
\hline 11. & House & Pasaż Ł., Galeria Ł., Manufaktura, Port Łódź & 4 \\
\hline 12. & Kastor & Pasaż Ł., Galeria Ł., Port Łódź, Tesco P. & 4 \\
\hline 13. & Sizeer & Pasaż Ł., Galeria Ł., Manufaktura, Port Łódź & 4 \\
\hline 14. & New & Galeria Ł., Manufaktura, Port Łódź, Carrefour Sz. & 4 \\
\hline 15. & Yorker & & 4 \\
\hline 16. & Diverse & Pasaż Ł., Galeria Ł., Manufaktura, Port Łódź, C.H. Tulipan & 4 \\
\hline 17. & Nike & Pasaż Ł., Galeria Ł., Manufaktura, Port Łódź, C.H. Tulipan & 4 \\
\hline 18. & Puma & Pasaż Ł., Galeria Ł., Manufaktura, Port Łódź, C.H. Tulipan & 4 \\
\hline
\end{tabular}

Źródło: Opracowanie własne na podstawie badań inwentaryzacyjnych.

H. Skrzydlewska. Zegarki i biżuterię można kupić w wielu placówkach firm Apart, Yes i Swiss, natomiast wyroby optyczne w Vision Express i Pan Hilary. Sześć firm kosmetycznych rozwinęło swoją działalność na terenie centrów handlowych: Yves Rocher, Rossmann, Sephora, Golden Rose, Inglot i Douglas. Monopolistą w zakresie sprzedaży prasy w centrach handlowych jest In Medio. W czterech marketach działają duże sklepy RTV Euro AGD (tab. 21). 


\section{Tabela 21}

Znane sieci handlowe posiadające swoje placówki w przynajmniej czterech centrach handlowych w 2011 roku

\begin{tabular}{|c|c|c|c|c|}
\hline Lp. & Sieć & Asortyment & Centra handlowe & $\begin{array}{c}\text { Liczba } \\
\text { placówek } \\
\text { w centrach } \\
\text { handlowych }\end{array}$ \\
\hline 1. & $\mathrm{CCC}$ & $\begin{array}{l}\text { obuwie } \\
\text { i wyroby } \\
\text { skórzane }\end{array}$ & $\begin{array}{l}\text { Pasaż Ł., Galeria Ł., C.H. M1, Manufaktura, } \\
\text { Port Łódź, C.H. Tulipan, Tesco P., Carrefour P., } \\
\text { C.H. Guliwer }\end{array}$ & 9 \\
\hline 2. & Deichmann & $\begin{array}{l}\text { obuwie } \\
\text { i wyroby } \\
\text { skórzane }\end{array}$ & $\begin{array}{l}\text { Pasaż Ł., Galeria Ł., C.H. M1, Manufaktura, } \\
\text { Port Łódź, Tesco P., Tesco W. }\end{array}$ & 7 \\
\hline 3. & Lu Man & $\begin{array}{l}\text { obuwie } \\
\text { i wyroby } \\
\text { skórzane }\end{array}$ & Galeria Ł., C.H. M1, C.H. Tulipan, Carrefour P. & 4 \\
\hline 4. & Botti & $\begin{array}{l}\text { obuwie } \\
\text { i wyroby } \\
\text { skórzane }\end{array}$ & Pasaż Ł., C.H. M1, C.H. Tulipan, Tesco W. & 4 \\
\hline 5. & Wojas & $\begin{array}{l}\text { obuwie } \\
\text { i wyroby } \\
\text { skórzane }\end{array}$ & $\begin{array}{l}\text { Pasaż Ł., Manufaktura, Port Łódź, C.H. } \\
\text { Tulipan }\end{array}$ & 4 \\
\hline 6. & H. Skrzydlewska & $\begin{array}{l}\text { kwiaty, rośliny, } \\
\text { nasiona, } \\
\text { nawozy }\end{array}$ & $\begin{array}{l}\text { Pasaż Ł., Galeria Ł., C.H. M1, Manufaktura, } \\
\text { Port Łódź, C.H. Tulipan, Tesco W., E.Leclerc, } \\
\text { C.H. Guliwer }\end{array}$ & 9 \\
\hline 7. & Apart & $\begin{array}{l}\text { zegarki, zegary, } \\
\text { biżuteria }\end{array}$ & $\begin{array}{l}\text { Pasaż Ł., Galeria Ł., C.H. M1, Manufaktura, } \\
\text { Port Łódź, C.H. Tulipan, }\end{array}$ & 6 \\
\hline 8. & Yes & $\begin{array}{l}\text { zegarki, zegary, } \\
\text { biżuteria }\end{array}$ & $\begin{array}{l}\text { Pasaż Ł., Galeria Ł., Manufaktura, Port Łódź, } \\
\text { Tesco P. }\end{array}$ & 5 \\
\hline 9. & Swiss & $\begin{array}{l}\text { zegarki, zegary, } \\
\text { biżuteria }\end{array}$ & $\begin{array}{l}\text { Pasaż Ł., Galeria Ł., Manufaktura, Port Łódź, } \\
\text { Tesco P. }\end{array}$ & 5 \\
\hline 10. & Vision Express & $\begin{array}{l}\text { wyroby } \\
\text { optyczne }\end{array}$ & $\begin{array}{l}\text { Galeria Ł., C.H. M1, Manufaktura, Port Łódź, } \\
\text { C.H. Tulipan, C.H. Guliwer }\end{array}$ & 6 \\
\hline 11. & Pan Hilary & $\begin{array}{l}\text { wyroby } \\
\text { optyczne }\end{array}$ & Galeria Ł., Tesco P., Tesco W., E.Leclerc & 4 \\
\hline 12. & $\begin{array}{l}\text { Apteka „Dbam } \\
\text { o zdrowie” }\end{array}$ & $\begin{array}{l}\text { wyroby farma- } \\
\text { ceutyczne }\end{array}$ & $\begin{array}{l}\text { Pasaż Ł., Galeria Ł., C.H.Tulipan, Tesco P., } \\
\text { Carrefour P., Carrefour Sz. }\end{array}$ & 6 \\
\hline 13. & Yves Rocher & $\begin{array}{l}\text { kosmetyki } \\
\text { i artykuły } \\
\text { toaletowe }\end{array}$ & $\begin{array}{l}\text { Pasaż Ł., Galeria Ł., C.H. M1, Manufaktura, } \\
\text { Port Łódź, C.H. Tulipan, C.H. Guliwer }\end{array}$ & 7 \\
\hline
\end{tabular}


Tabela 21 (ciąg dalszy)

\begin{tabular}{|c|c|c|c|c|}
\hline Lp. & Sieć & Asortyment & Centra handlowe & $\begin{array}{c}\text { Liczba } \\
\text { placówek } \\
\text { w centrach } \\
\text { handlowych }\end{array}$ \\
\hline 14 & Rossmann & \begin{tabular}{|l} 
kosmetyki \\
i artykuty \\
toaletowe \\
\end{tabular} & $\begin{array}{l}\text { Pasaż Ł., Galeria Ł., C.H. M1, Manufaktura, } \\
\text { Port Łódż, C.H. Tulipan, C.H. Guliwer }\end{array}$ & 7 \\
\hline 15. & Sephora & \begin{tabular}{|l} 
kosmetyki \\
i artykuty \\
toaletowe
\end{tabular} & $\begin{array}{l}\text { Pasaż Ł., Galeria Ł., C.H. M1, Manufaktura, } \\
\text { Port Łódź, C.H. Tulipan }\end{array}$ & 6 \\
\hline 16. & Golden Rose & \begin{tabular}{|l} 
kosmetyki \\
i artykuty \\
toaletowe \\
\end{tabular} & $\begin{array}{l}\text { Manufaktura, C.H.Tulipan, Tesco P., C.H. } \\
\text { Guliwer }\end{array}$ & 4 \\
\hline 17. & Inglot & \begin{tabular}{|l} 
kosmetyki \\
i artykuty \\
toaletowe \\
\end{tabular} & $\begin{array}{l}\text { Galeria Ł., C.H. M1, Manufaktura, } \\
\text { C.H. Tulipan }\end{array}$ & 4 \\
\hline 18 & Douglas & \begin{tabular}{|l} 
kosmetyki \\
i artykuty \\
toaletowe \\
\end{tabular} & Galeria Ł., C.H. M1, Manufaktura, Port Łódź & 4 \\
\hline 19 & In Medio & prasa, książki & $\begin{array}{l}\text { Pasaż Ł., Galeria Ł., C.H. M1, Manufaktura, } \\
\text { Port Łódź, Tesco P., Carrefour P., Carrefour Sz., } \\
\text { C.H. Guliwer }\end{array}$ & 9 \\
\hline 20 & RTV Euro AGD & \begin{tabular}{|l} 
sprzęt RTV \\
i AGD
\end{tabular} & Manufaktura, Port Łódź, C.H.Tulipan, Tesco P. & 4 \\
\hline
\end{tabular}

Źródło: Opracowanie własne na podstawie badań inwentaryzacyjnych.

Niektóre firmy posiadają po dwie lub trzy placówki w łódzkich centrach handlowych. Przykładowo, do takich, które zlokalizowane są w trzech centrach, można zaliczyć obuwnicze: Bata, Vip Collection, Bartek, Ecco, Humanic, Ochnik, Ryłko, Venezia, Buty na czasie. Z placówek jubilerskich warto wspomnieć o 77. Jubistyl, W. Kruk, z zoologicznych Kakadu, a z prasowo-książkowych Empik. W sumie osiemnaście firm posiada po trzy placówki handlowe, a trzydzieści sześć po dwie w łódzkich centrach handlowych.

$\mathrm{Z}$ powyższego przeglądu firm handlowych zlokalizowanych w łódzkich centrach handlowych widać, że po pierwsze przyciągane są do nich znane marki światowe i polskie. Po drugie wiele firm otwiera po kilka placówek w takich kompleksach. Sklepy najbardziej znanych marek funkcjonują najczęściej w największych łódzkich centrach handlowych: Manufakturze, Galerii Łódzkiej, Porcie Łódź oraz w Pasażu Łódzkim. i C.H. Tulipan. 


\subsubsection{Pozostała działalność usługowa oraz kulturalno-rozrywkowa}

Centra handlowe oferują głównie usługi handlowe wzbogacone ofertą innych placówek usługowych, przede wszystkim usługami gastronomicznymi. Według M. Milewskiej, A. Prączko i A. Stasiaka (2010, s. 52) usługa gastronomiczna zaspokaja potrzeby człowieka poprzez prowadzoną działalność produkcyjną (przetwarza surowce spożywcze na posiłki) oraz dzięki działalności handlowej (dostarcza posiłki konsumentom). Usługa tego typu zawiera „obsługę osobistą" klienta (sprzedaż potraw, napojów i innych towarów), a także oferuje mu działalność kulturalno-rozrywkowo-rekreacyjną. Działalność placówek gastronomicznych ${ }^{95}$ więc ma charakter produkcyjny, handlowy oraz usługowy (organizacja i uprzyjemnianie konsumpcji na miejscu).

Lokalizacja placówek gastronomicznych w mieście tradycyjnie wiąże się z rozmieszczeniem mieszkańców i tak zwanych usług centralnych (są to takie, które służą nie tylko mieszkańcom), więc od dawna obiekty gastronomiczne są lokalizowane w miejscach o dobrej dostępności przestrzennej (Kaczorek, Kowalczyk 2003, s. 192). Można więc powiedzieć, że lokalizacja placówek gastronomicznych związana jest w głównej mierze z terenami mieszkaniowymi i miejscami przebywania ludzi, a takimi miejscami są między innymi centra handlowe. Jak zauważają A. Kaczorek i A. Kowalczyk (2003, s. 192) współcześnie nastąpiły zmiany w rozmieszczeniu usług gastronomicznych w miastach, a jedną ze zmian jest pojawienie się takich placówek w nowo powstających centrach handlowych ${ }^{96}$, które stały się dla nich nowym czynnikiem lokalizacji. Koncentracja punktów gastronomicznych w centrach handlowych wpisuje się w koncentryczno-radialny (złożony) model lokalizacji usług gastronomicznych w miastach ${ }^{97}$.

\footnotetext{
${ }^{95}$ Placówki gastronomiczne są to zakłady i punkty gastronomiczne stałe i sezonowe, których przedmiotem działalności jest przygotowanie oraz sprzedaż posiłków i napojów do spożycia na miejscu i na wynos. Do placówek gastronomicznych nie zalicza się tak zwanych punktów sprzedaży ruchomej i automatów sprzedażowych (Rynek wewnętrzny w 2011 r..., 2012, s. 15).

${ }^{96}$ Obecnie miejscami lokalizacji placówek gastronomicznych są również skrzyżowania autostrad, drogi wylotowe, okolice dworców kolejowych, lotniska, tereny wystawienniczo-targowe, hipermarkety itp. (Kaczorek, Kowalczyk 2003, s. 192).

${ }^{97}$ Model koncentryczno-radialny występuje przede wszystkim w większych ośrodkach miejskich, przy czym im ośrodek (aglomeracja miejska) jest większy, tym większy jest stopień złożoności. W najbardziej złożonej postaci modelu na peryferiach miast pojawiają się obszary o dużej koncentracji usług gastronomicznych, na przykład przy centrach handlowych, lotniskach, parkach rozrywki, terenach wystawienniczych i tym podobnych (Kaczorek, Kowalczyk 2003, s. 194).
} 
W dobie konsumpcyjnego stylu życia, gdy centra handlowe starają się przyciągnąć i jak najdłużej zatrzymać klientów w swoim wnętrzu, to między innymi usługi gastronomiczne odgrywają znaczącą rolę. Zaspokojenie elementarnych potrzeb, w tym żywnościowych, wpływa na wzrost stopnia samozadowolenia niektórych klientów, wzmacniając ich chęć dłuższego oraz częstszego przebywania w danym centrum handlowym. Odpowiednio duża dywersyfikacja ofertowa, jakościowa i cenowa placówek gastronomicznych wzmacnia „magnetyzm” tego typu kompleksów. W zależności od stopnia rozwoju centrum handlowego (jego generacji) placówki gastronomiczne mogą w takich kompleksach występować w formie pojedynczych punktów gastronomicznych (zlokalizowanych $\mathrm{w}$ różnych miejscach centrum handlowego), jak również tworzyć skupiska $\mathrm{z}$ bogatą ofertą gastronomiczną.

Ze względu na usytuowanie placówek gastronomicznych w centrach handlowych można wydzielić następujące miejsca ich lokalizacji: food court, dziedzińce gastronomiczne, lokalizacje w sklepie, między placówkami centrum handlowego, pośrodku alejek i deptaków oraz food malle (Levytska 2011, s. 125) (rys. 37).

Według G. Levtytskej (2003, s. 129) zgromadzenie kilku lokali gastronomicznych w jednym miejscu przyciąga więcej klientów niż pojedynczo funkcjonujące placówki. Działania efektu synergetycznego obserwuje się $\mathrm{w}$ dziedzińcach gastronomicznych (zgromadzenie obok siebie kil$\mathrm{ku}$ samodzielnie funkcjonujących lokali gastronomicznych) oraz $\mathrm{w}$ food courtach - „przestrzeniach (strefach) gastronomicznych, oferujących na całym poziomie zróżnicowany wybór restauracji i fast foodów" (Kaczmarek 2010, s. 48).

Szczególnie ten drugi typ koncentracji placówek gastronomicznych jest ważnym elementem dużych nowoczesnych centrów handlowych. Food court stanowi wydzieloną $\mathrm{w}$ galeriach handlowych przestrzeń przeznaczoną na działalność lokali gastronomicznych, w której znajduje się od kilku do kilkunastu lokali gastronomicznych z samoobsługą lub półobsługą (danie zamawiane przy ladzie, ale donoszone do stolika) i ze wspólną salą konsumencką. Do głównych zalet tego typu przestrzeni można zaliczyć: dużą liczbę potencjalnych klientów, niższe koszty operacyjne (wspólna infrastruktura i dzielenie kosztów jej utrzymania), natomiast podstawową wadą jest brak intymności gości lokalu, hałas i tłok (http://gastrowiedza.pl). O atrakcyjności tego typu stref dla klientów decyduje obok możliwości spożywania posiłków między innymi różnorodność asortymentowa i cenowa. 


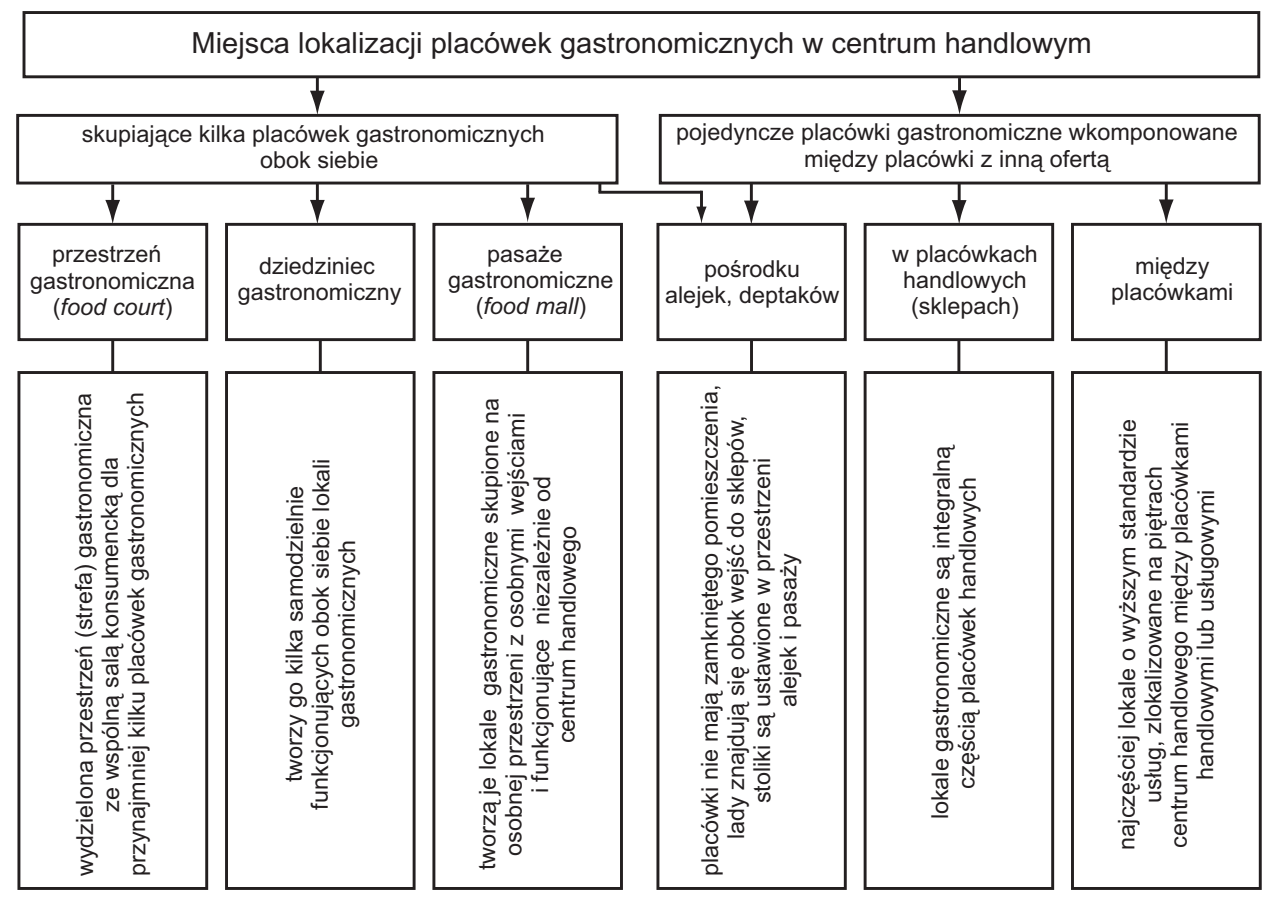

Rys. 39. Lokalizacja placówek gastronomicznych w centrum handlowym.

Źródło: Opracowanie własne na podstawie G. Levytska, 2011, Ustugi gastronomiczne-znaczenie i tendencje rozwoju, SGGW, Warszawa, s. 125-130.

Inną formą koncentracji placówek gastronomicznych występującą w niektórych centrach handlowych są pasaże gastronomiczne (food malle), które są tworzone przez lokale gastronomiczne skupione na wydzielonej przestrzeni z osobnymi wejściami niezależnymi od głównego budynku centrum handlowego. Tego typu placówki czynne są zazwyczaj dłużej niż centra handlowe. W pasażach takich mieszczą się zwykle placówki, których szczyt odwiedzania przypada na godziny wieczorowe, na przykład kluby, puby, bary, restauracje, dyskoteki. Ich lokalizacja jest zdeterminowana często lokalizacją placówek rozrywkowych (np. kin, teatrów, muzeów, klubów fitness) (Levytska 2011, s. 130).

Pośrodku alejek i deptaków centrum handlowego często funkcjonują również pojedyncze lub w grupach punkty gastronomiczne nieposiadające zamkniętego pomieszczenia, których lady znajdują się obok wejść do sklepów, a stoliki są ustawione w przestrzeni alejek i pasaży, na przykład 
bary kawowe, lodziarnie. W niektórych centrach handlowych można skorzystać $\mathrm{z}$ oferty pojedynczych lokali gastronomicznych zlokalizowanych między innymi placówkami usługowymi i/lub handlowymi, na przykład restauracje, placówki typu fast casual ${ }^{98}$, kawiarnie. Tego typu placówki świadczą usługi o wyższym standardzie, posiadają bardziej urozmaiconą ofertę i zapewniają większy komfort konsumpcji (zindywidualizowany wystrój placówki i przyjazna atmosfera) od tych zlokalizowanych w food courtach. W niektórych placówkach handlowych (sklepach) zaaranżowana jest również powierzchnia gastronomiczna, stanowiąca ich integralną część, np. kąciki gastronomiczne w supermarketach i hipermarketach (oferujące gotowe dania gorące do spożycia na miejscu lub na wynos), kawiarnie w sieci sklepów kawowych „Pożegnanie z Afryką”, w sklepach z kawą i artykułami do domu „Tchibo”, czy w niektórych winiarniach, itp. (Levytska 2011, s. 129).

Placówki gastronomiczne zlokalizowane w centrach handlowych pełnią nie tylko funkcję żywieniową, ale również często stają się immamentną częścią rozrywkowo-rekreacyjną. Dla konsumentów jest to nie tylko miejsce konsumpcji żywności w przerwie między zakupami, ale również miejscem spotkań towarzyskich i biznesowych, a wręcz dla niektórych docelowym miejscem pobytu w centrum handlowym.

Łódzkie centra handlowe posiadają zróżnicowaną ofertę gastronomiczną. Zdecydowanie najwięcej placówek gastronomicznych znajduje się w największych centrach handlowych w Manufakturze (50) ${ }^{99}$, w Galerii Łódzkiej (19) i Porcie Łódź (18). W pozostałych badanych obiektach funkcjonuje od jednego punktu (Carrefour P., E. Leclerc) do pięciu w C.H. Tulipan. W łódzkich centrach handlowych skoncentrowane przestrzenie konsumpcji żywności występują w Manufakturze (typowy food court - 13 placówek gastronomicznych) oraz dziedzińce gastronomiczne w Porcie Łódź

${ }^{98}$ Fast casual lub quick $\mathcal{E}$ casual („szybko i wygodnie”); obecnie tego typu placówki są samodzielnym typem przedsiębiorstw gastronomicznych, formą pośrednią między barem szybkiej obsługi (fast food) a restauracją tradycyjną (casual dining). Restauracje te oferują lepszą żywność niż placówki fast food, jednocześnie ceny są niższe w porównaniu do restauracji tradycyjnych (Levytska 2011, s. 46). Więcej informacji na temat tego typu placówek gastronomicznych można znaleźć [w:] B. Kowrygo, G. Levytska, 2006, Zmiany na rynku ustug gastronomicznych (na przyktadzie restauracji Quick $\mathcal{E}$ Casual), Handel Wewnętrzny, numer specjalny, czerwiec.

${ }^{99}$ Łącznie z tymi zlokalizowanymi w różnych formach koncentracji, np. food courtcie, pasażu gastronomicznym. 
(dwa jeden z nich skupia 7 placówek, drugi 4 placówki), Galerii Łódzkiej (9 placówek), C.H. Tulipan (5 placówek), C.H. Pasaż Łódzki (3 placówki). W największych łódzkich centrach handlowych o bogatej ofercie gastronomicznej występują wszystkie lub prawie wszystkie formy lokalizacji np. Manufaktura, Port Łódź. W przypadku Manufaktury występują pasaże gastronomiczne, których godziny otwarcia nie są uzależnione od funkcjonowania głównego centrum handlowego (tab. 22).

Tabela 22

Liczba placówek gastronomicznych ${ }^{\mathrm{a}}$ w łódzkich centrach handlowych w 2011 roku

\begin{tabular}{|c|l|c|c|c|}
\hline Lp. & \multicolumn{1}{|c|}{$\begin{array}{c}\text { Centrum } \\
\text { handlowe }\end{array}$} & $\begin{array}{c}\text { Liczba placówek } \\
\text { gastronomicznych }\end{array}$ & $\begin{array}{c}\text { Liczba głównych } \\
\text { form koncentracji }\end{array}$ & $\begin{array}{c}\text { Liczba placówek } \\
\text { w skupiskach }\end{array}$ \\
\hline 1. & Manufaktura & 50 & 1 & 13 \\
\hline 2. & Galeria Ł. & 19 & 1 & 9 \\
\hline 3. & Port Łódź & 18 & 2 & 7 i 4 \\
\hline 4. & C.H.Tulipan & 5 & 1 & 5 \\
\hline 5 & Pasaż Łódzki & 4 & 1 & 3 \\
\hline 6. & C.H. Guliwer & 3 & - & - \\
\hline 7. & Tesco P. & 3 & 1 & 2 \\
\hline 8. & Tesco W. & 3 & - & - \\
\hline 9. & C.H. M1 & 3 & - & - \\
\hline 10. & Carrefour Sz. & 2 & - & - \\
\hline 11. & Carrefour P. & 1 & - & - \\
\hline 12. & E.Leclerc & 1 & & \\
\hline
\end{tabular}

a Podmioty sklasyfikowane do działu 56. „działalność usługowa związana z wyżywieniem”, grupy 56.1 „restauracje i pozostałe placówki gastronomiczne”.

Źródło: Opracowanie własne na podstawie badań inwentaryzacyjnych.

W badanych łódzkich kompleksach mamy do czynienia z różnymi rodzajami działalności gastronomicznej: restauracje, bary, pizzerie, cukiernie, lodziarnie, kawiarnie, herbaciarnie i tym podobne. Niektóre z firm zlokalizowały w nich po kilka swoich placówek. W pięciu kompleksach otworzone zostały cukiernie Sowa Patisserie, w trzech bar Cofeeheaven, kawiarnie/sklepy Tchibo oraz restauracje KFC, McDonald's, Sphinx i Raz na wozie (tab. 23). 
Tabela 23

Sieci placówek gastronomicznych w łódzkich centrach handlowych w 2011 roku

\begin{tabular}{|c|c|c|c|c|}
\hline Lp. & Nazwa sieci & $\begin{array}{l}\text { Rodzaj placówki } \\
\text { gastronomicznej }\end{array}$ & Centra handlowe & $\begin{array}{c}\text { Liczba } \\
\text { placówek } \\
\text { w centrach } \\
\text { handlowych }\end{array}$ \\
\hline 1. & Coffeeheaven & bar kawowy & Manufaktura (2), Port Ł., Galeria Ł. & 4 \\
\hline 2. & Cube Cafe & kawiarnia & Manufaktura (2), Port Ł. & 3 \\
\hline 3. & Green Way & bar wegetariański & Manufaktura, Galeria Ł. & 2 \\
\hline 4. & Grycan & Iodziarnia & Manufaktura, Port Ł. (2) & 3 \\
\hline 5. & KFC & restauracja fast food & Manufaktura, Port Ł., Galeria Ł. & 3 \\
\hline 6. & McDonald`s & restauracja fast food & Manufaktura, Galeria Ł., C.H. Tulipan & 3 \\
\hline 7. & North Fish & restauracja & Manufaktura, Galeria Ł. & 2 \\
\hline 8. & Pizzeria Solo & pizzeria & Manufaktura, Port Ł., Galeria Ł. & 3 \\
\hline 9. & Sowa Patisserie & cukiernia & $\begin{array}{l}\text { Manufaktura, Port Ł., Galeria Ł., } \\
\text { Pasaż Ł., Tesco W. }\end{array}$ & 5 \\
\hline 10. & Sphinx & $\begin{array}{l}\text { restauracja fast } \\
\text { casual }\end{array}$ & Manufaktura, Port Ł., Pasaż Ł. & 3 \\
\hline 11. & Tchibo & kawiarnia & Manufaktura, Port Ł., Galeria Ł. & 3 \\
\hline 12. & $\begin{array}{l}\text { W Biegu Café by } \\
\text { Jacobs Krönung }\end{array}$ & kawiarnia & Manufaktura, Pasaż Ł. & 2 \\
\hline 13. & Rajskie jadło & restauracja & Port Ł., Galeria Ł. & 2 \\
\hline 14 & Raz na wozie & restauracja & Galeria Ł., C.H. M1, Carrefour P. & 3 \\
\hline 15. & Sushi Beneto & $\begin{array}{l}\text { restauracja fast } \\
\text { casual }\end{array}$ & C.H. Guliwer, Carrefour Sz. & 2 \\
\hline 16. & Cukiernia Filipiak & cukiernia & C.H. Guliwer, C.H. Tulipan & 2 \\
\hline 17. & Ha-long & $\begin{array}{l}\text { restauracja fast } \\
\text { casual }\end{array}$ & C.H. M1, Carrefour P. & 2 \\
\hline
\end{tabular}

Źródło: Opracowanie własne na podstawie badań inwentaryzacyjnych.

Centra handlowe są jak już wcześniej zauważono, kompleksami multiusługowymi, dlatego obok usług handlowych i gastronomicznych są świadczone też inne rodzaje usług, na przykład bankowe, pralnicze, ubezpieczeniowe.

Do najczęściej spotykanych punktów usługowych w łódzkich centrach handlowych należą:

- usługi pralnicze (12 C.H.) - reprezentowane przez trzy firmy, 5aSec (6), Panda (4) i Pralnie Paryskie (2), 
- usługi kosmetyczno-fryzjerskie(12 C.H.)-w Porcie Łódźi Galerii Łódzkiej występują po dwa takie punkty usługowe. Są to różne firmy, tylko zakład fryzjerski „Lauffer” zlokalizowany jest w trzech centrach handlowych (Tesco P., Tesco W., Carrefour P.),

- usługi naprawcze (11 C.H., brakuje w Porcie Łódź) - w tej szerokiej grupie znajdują się różne działalności, między innymi naprawa zegarków, dorabianie kluczy, usługi szewskie, krawieckie. Usługi tego typu często są świadczone w jednym punkcie (czasami jest to tylko punkt przyjęć). W czterech centrach handlowych występuje punkt naprawczy Cezar,

- usługi turystyczne (10 C.H., nie ma w Tesco W., Carrefour Sz.) w Manufakturze trzy placówki, po dwa biura znajdują się w Porcie Łódź i Pasażu Łódzkim,

- usługi bankowe (12 C.H.) - świadczone są z jednej strony przez bankomaty, z drugiej strony przez otwarte oddziały banków, na przykład mBank, Eurobank, PKO BP, ING Bank Śląski. Najwięcej oddziałów znajduje się w Manufakturze (4) i C.H. Guliwer (3),

- usługi pocztowe (8 C.H.) - świadczone przez placówki Poczty Polskiej. W niektórych centrach handlowych można spotkać też inne usługi, na przykład biura ogłoszeń prasowych (4), kantory (7), punkty usług fotograficznych często powiązane z punktami sprzedaży sprzętu fotograficznego, wypożyczalnie samochodów (Manufaktura, C.H. M1). W Manufakturze i Tesco P. można skorzystać również z usług weterynaryjnych. Placówki medyczne znalazły swoje miejsce w Manufakturze (EnelMed) i centrum dietetyczne Natur House, które posiada swoją placówkę również w Tesco P. Usługi edukacyjne są realizowane przez szkoły językowe w Manufakturze (Alliance Française) i w Tesco P. (British Centre) oraz dzięki działającym przedszkolom w Porcie Łódź (Port Łódź Junior) oraz w C.H. Ml (Kraina Dzieci).

Wraz z rozwojem formuły centrów handlowych, pojawianiem się nowych ich generacji zaczęto wzbogacać ofertę o elementy kultury i rozrywki. Jak pisze J. Szumilak (2004, s. 34): „łączenie handlu z rozrywką jest odpowiedzią handlu detalicznego na zmiany w otoczeniu, przejawiające się: stagnacją popytu na towary, wzrostem zapotrzebowania na usługi (w tym rozrywkę), wzrostem uciążliwości i związanym $z$ tym zmęczeniem konsumentów zakupami, nasileniem konkurencji ze strony niestacjonarnych form handlu". Czynniki te wpływają między innymi na powiększanie w centrach handlowych powierzchni przeznaczonej dla przedsiębiorstw z branży kulturalno-rozrywkowej. Te nowoczesne kompleksy handlowe 
dzięki lokalizowaniu w nich obiektów rozrywkowych, takich jak: kina, teatry, kluby taneczne i muzyczne, sceny koncertowe stają się ośrodkami kultury. Istotne są tu także argumenty ekonomiczne, albowiem większa powierzchnia centrum handlowego i jego bardziej zróżnicowane funkcje korespondują $\mathrm{z}$ rozszerzeniem zasięgu oddziaływania obiektu handlowego (rozszerzenie rynku docelowego) (Grzesiuk 2011, s. 140).

W Łodzi jedynym centrum handlowym o bogatej ofercie kulturalno-rozrywkowej jest Manufaktura. W tym najbardziej zróżnicowanym kompleksie można odnaleźć wiele propozycji spędzania czasu wolnego, skierowanych zarówno dla osób dorosłych, jak i dla dzieci, dla osób indywidualnych, jak i dla zorganizowanych grup. W pozostałych łódzkich centrach handlowych występują jedynie place zabaw dla dzieci, z największymi w Tesco P. i C.H. M1. W Manufakturze ofertę rozrywkową proponują:

- 3-poziomowy klub Elektrownia RP z możliwością zabawy w trzech klimatach muzycznych,

- Experymentarium - ośrodek typu „discovery center” (centrum odkrywców), w którym, między innymi organizowane są wystawy, umożliwiające samodzielne poznawanie zagadnień $\mathrm{z}$ wielu dziedzin nauki, techniki, kultury oraz warsztaty i wykłady,

- Jazda Park - centrum rozrywki, między innymi ze stołami bilardowymi, automatami, symulatorami wyścigów samochodowych,

- Kinderplaneta - park zabaw i rozrywki dla dzieci,

- kręgielnia Grakula,

- Stratosfera - centrum wspinaczkowe,

- Pure Fitness - centrum fitness ze strefą relaksacyjną (jacuzzi, sauna),

- Arena Laser Games - laserowe gry komputerowe,

- Kasyno - działa od 1 sierpnia 2012 roku $^{100}$,

- place zabaw dla dzieci zlokalizowane w pobliżu kawiarni „W biegu cafe" oraz przy Leroy Merlin.

Obok oferty typowo rozrywkowej w Manufakturze można również skorzystać z propozycji kulturowej, na którą składa się działalność kin (Cinema City z pierwszą w Łodzi salą Imax, gdzie wyświetlane są filmy w 3D oraz kino 5D), teatru (Teatr Mały na 144 miejsc) oraz trzech muzeów (Muzeum Fabryki związane z historią kompleksu, MS2 - muzeum sztuki XX i XXI wieku i Muzeum Miasta Łodzi w pałacu Poznańskiego).

${ }^{100}$ Podczas inwentaryzacji w terenie, która miała miejsce wcześniej, nie zostało uwzględnione. 
W wielu z wyżej wymienionych obiektach kulturalno-rozrywkowych można skorzystać z usług gastronomicznych, edukacyjnych (warsztaty, wykłady, spotkania ze znanymi osobami) czy uczestniczyć w specjalistycznych sekcjach, na przykład wspinaczkowej. Należy dodać, że w kompleksie Manufaktury znajduje się czterogwiazdkowy hotel Andel's i tym samym to centrum handlowe jest jedynym w Łodzi świadczącym usługi noclegowe.

Ofertę kulturalno-rozrywkową niektórych centrów handlowych uzupełniają różnego rodzaju imprezy, wydarzenia (eventy) organizowane na ich terenie. Najwięcej tego typu rozrywki dostarczanych jest w kompleksie Manufaktury. Imprezy tu organizowane są różnej rangi i posiadają zróżnicowany charakter. Wiele imprez nawiązuje do kalendarza świątecznego, inne do tradycji związanych z Łodzią (pokazy mody), jeszcze inne mają charakter okazjonalny (Dzień Dziecka, Dzień Matki, Walentynki). Tego typu akcje wpływają na zainteresowanie danym kompleksem handlowym, są elementem podnoszącym atrakcyjność centrum handlowego, ale jak pokazują badania ankietowe, nie są dla zdecydowanej większości respondentów głównym magnesem przyciągającym do danego centrum handlowego.

\subsection{Zagospodarowanie otoczenia łódzkich centrów handlowych}

\subsubsection{Podstawowy obszar handlowy}

W literaturze przedmiotu zwraca się uwagę na występowanie obszaru handlowego (trading area), przestrzeni handlowej, czyli mówiąc w sposób uproszczony - obszaru, z którego pochodzą klienci danej placówki handlowej. Według H. Szulce (1998, s. 217) „przestrzeń handlowa jest to obszar przyciągania konsumentów przez jednostkę handlową którą wyznaczają następujące determinanty: liczba i struktura ludności, efektywny popyt, struktura sieci osadniczej, stopień zurbanizowania terenu, infrastruktura transportowa, wielkość centrum handlowego". Określając krótko i ogólnie, jest to „geograficzny obszar obejmujący klientów poszczególnych firm lub grup firm konkretnych towarów lub usług” (Berman, Evans 2010). W wyniku decyzji lokalizacyjnych następuje podział przestrzeni na obszary handlowe. „Przez wybór lokalizacji, a więc rozmieszczenia placówek handlowych w przestrzeni zostaje określony dla każdego podmiotu rynek sprzedaży w sensie przestrzennym" (Pilarczyk 2001, s. 160). M. Sullivan, D. Adcock 
(2003, s. 132) $)^{101}$ określają proces analizy nabywców jako „sporządzanie mapy obszaru handlowego", który polega na określeniu jego obszaru (wyznaczenie granic działalności handlowej detalisty), jego analizie (szczegółowe przebadanie populacji) oraz dokonanie oceny potencjalnego popytu.

W zależności od udziału procentowego klientów wyróżnia się różne rodzaje takiej przestrzeni handlowej (obszaru handlowego). Według B. Bermana i J.R. Evansa (2010) ${ }^{102}$ każdy obszar handlowy składa się $\mathrm{z}$ trzech segmentów: podstawowego (primary), dodatkowego (secondary) i peryferyjnego (fringe). Podstawowy obszar handlowy znajduje się najbliżej sklepu i charakteryzuje się największą liczbą (zagęszczeniem) kupujących (stąd pochodzi 50-80\% klientów sklepu) oraz najwyższą sprzedażą na jednego mieszkańca. Dodatkowy obszar handlowy obejmuje kolejne 15-25\% nabywców, którzy są bardziej rozproszeni niż w obszarze podstawowym. Natomiast z obszaru peryferyjnego pochodzą pozostali, najbardziej rozproszeni geograficznie klienci, którzy są skłonni pokonywać dalsze odległości w celu dotarcia do punktu sprzedaży. Wielkość poszczególnych segmentów obszaru handlowego zależy między innymi od takich czynników jak rodzaj i rozmiar sklepu (w tym przypadku centrum handlowego), lokalizacji firm konkurencyjnych, od ewentualnych problemów, na jakie napotykają klienci w dotarciu do wybranej placówki. Na maksymalny zasięg obszaru oddziaływania (handlowego) ma wpływ w dużej mierze rozmiar samego punktu sprzedaży, ponieważ zazwyczaj związana jest $\mathrm{z}$ tym liczba i różnorodność oferowanych towarów i usług.

W przypadku centrów handlowych G. Chmielak (1999) wyróżnił dwie strefy handlowe podstawową i drugą. Zasięg stref według niego jest uzależniony od rodzaju centrum handlowego (sąsiedzkie, lokalne, regionalne,

${ }^{101}$ Autorzy przedstawili najczęściej wykorzystywane teorie do wyznaczania obszarów handlowych wraz z ich modyfikacjami: teorię miejsca centralnego (Christaller 1935), teorie wartości gruntu (Haig 1926), teorię minimum zróżnicowania (Hotelling 1929), teorie interakcji przestrzennej prawo Reilly'ego (1931), prawo Huffa (1964), model Lakshmanana-Hansena (1965), multiplikatywne modele interakcji z konkurencją, wielonominalne modele logitowe, oraz metodę stref współśrodkowych czy macierz mobilności nabywcy i ograniczeń czasowych. Ciekawy przegląd modeli i metod stosowanych do projektowania detalicznych powierzchni handlowych zaproponowali, a niektórzy zastosowali: C.C. Yrigoyen, J.V. Otero (1997), G. Kiel, G. Haberkern (1998), D. Huff, B.M. McCallum (2008), Z. Szczyrba (2002).

${ }^{102}$ Podejście B. Bermana i J.R. Evansa zaprezentowane jest również w pracy P. Łukasik, Lokalizacja miejsca sprzedaży, [w:] Zarzqdzanie sprzedaża w przedsiębiorstwie handlowym, (red.) G. Sobczyk, 2010, PWE, Warszawa, s. 60-67. 
ponadregionalne) oraz od ich dostępności komunikacyjnej. Uważa on, że z podstawowego obszaru handlowego pochodzi około $60-80 \%$ klientów, a zasięg przestrzenny tego obszaru zależy od typu centrum handlowego. W przypadku centrum handlowego „sąsiedzkiego" granica podstawowej strefy handlowej przebiega do 5 minut dostępności komunikacyinej, w „lokalnym” od 5 do 15 minut, „regionalnym” 15-30 minut, a „ponadregionalnym” powyżej 30 minut. Zasięg poszczególnych stref jest uzależniony od funkcji centrum handlowego, im bardziej posiada ono charakter ponadlokalny, tym klienci są skłonni poświęcić więcej czasu na dotarcie do niego (tab. 24).

\section{Tabela 24}

\section{Zasięg komunikacyjny obszarów handlowych zależny od rodzaju centrum handlowego}

\begin{tabular}{|c|c|c|}
\hline \multirow[t]{3}{*}{ Rodzaj centrum handlowego } & \multicolumn{2}{|c|}{ Rodzaj strefy (obszaru) handlowej } \\
\hline & podstawowa & druga \\
\hline & \multicolumn{2}{|c|}{ dostępność komunikacyjna (min.) } \\
\hline Centrum handlowe „w sąsiedztwie” & poniżej 5 minut & $5-15$ minut \\
\hline Centrum handlowe lokalne & $5-15$ minut & 15-30 minut \\
\hline Centrum handlowe regionalne & 15-30 minut & 30-60 minut \\
\hline \multirow[t]{3}{*}{ Centrum handlowe ponadregionalne } & powyżej 30 minut plus & \\
\hline & \multicolumn{2}{|c|}{ udział w sprzedaży oraz klientów [\%] } \\
\hline & $60 \%-80 \%$ & $20 \%-40 \%$ \\
\hline
\end{tabular}

Źródło: Chmielak G., Centra handlowe - analiza lokalizacji, „Nieruchomości”, nr 6, C.H. Beck, 1999.

W Łodzi mamy do czynienia $z$ różnymi typami centrów handlowych, jeżeli chodzi o ich zasięg oddziaływania ${ }^{103}$, w związku $\mathrm{z}$ tym ich obszary handlowe różnią się między sobą wielkością. W celu ujednolicenia analizy przestrzennej i uzyskania w jak największym stopniu porównywalności danych przy charakterystyce otoczenia centrów handlowych wyznaczono arbitralnie strefy o promieniu 1 kilometra od każdego centrum handlowego (10 minut dojścia pieszego) ${ }^{104}$ (rys. 40). Granice stref wokół centrów handlowych, w których badano zagospodarowanie terenów i potencjał ludnościo-

\footnotetext{
${ }^{103}$ Więcej informacji na temat zasięgu oddziaływania w części III pracy.

${ }^{104}$ Celem pracy nie było wyznaczanie obszarów handlowych oraz ich analiza. Dla lepszego zobrazowania miejsc lokalizacji poszczególnych centrów handlowych dokonano tylko charakterystyki ich bezpośredniego otoczenia, określając je mianem „podstawowego obszaru handlowego”.
} 


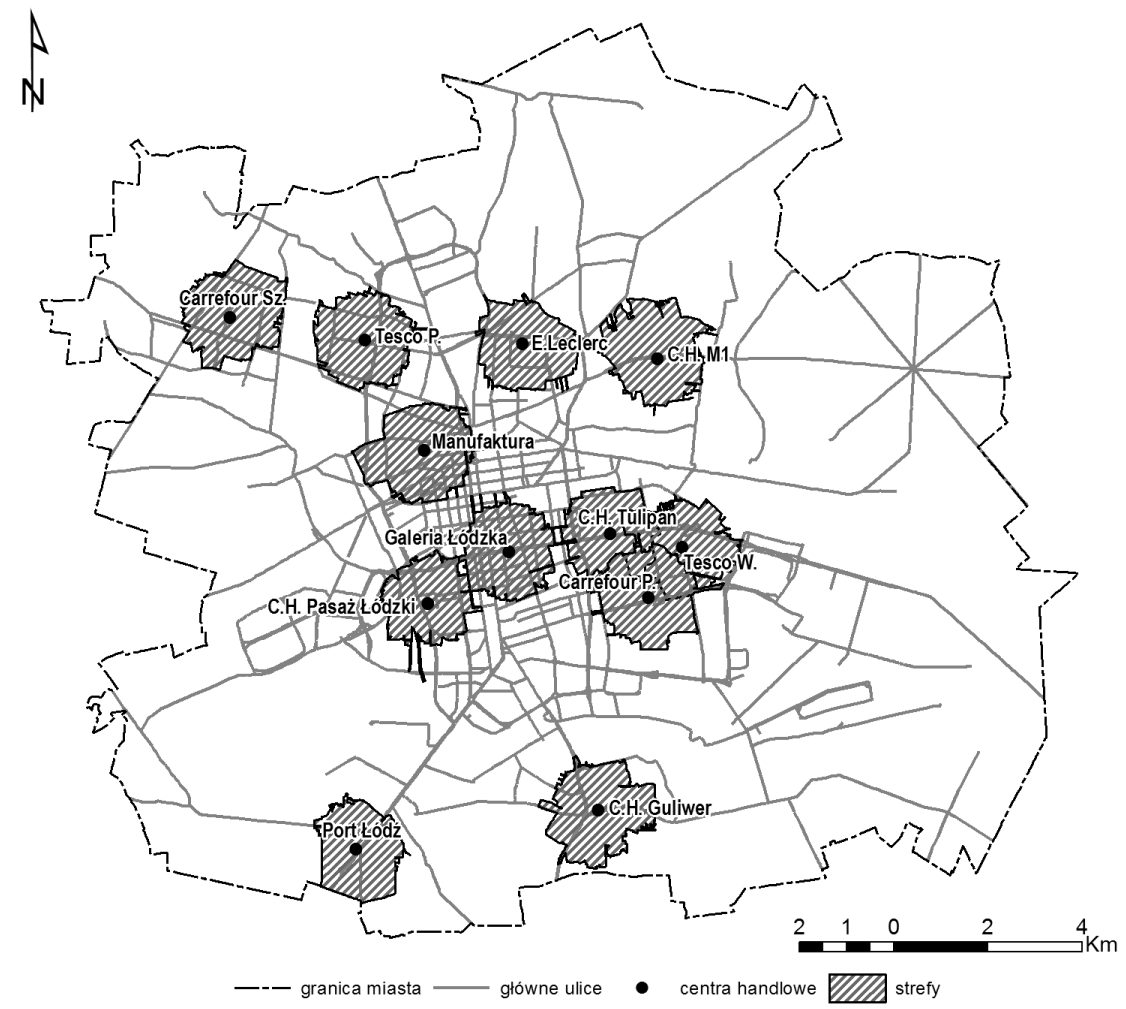

Rys. 40. Jednokilometrowe strefy badań wokół łódzkich centrów handlowych.

Źródło: Opracowanie własne.

wy, oparto na zewnętrznej granicy działek ewidencyjnych. Ich centroidy znalazły się w zasięgu 1 kilometra od centrum handlowego. Nieregularny przebieg granic wynika ze zróżnicowania kształtu działek, najczęściej działki komunikacyjne i pod wodami mają wydłużony kształt, w związku z tym w niektórych przypadkach konieczne było wyłączenie ich fragmentów $\mathrm{z}$ analizy.

Tego typu modyfikacja i uproszczenie pozwoliło wyznaczyć porównywalne wielkościowo obszary badań w przypadku wszystkich analizowanych centrów handlowych. Jest do bardzo uproszczony sposób potraktowania podstawowego obszaru handlowego ze względu na różne typy centrów handlowych (różna wielkość, zróżnicowana oferta i tym podobne), ale dzięki analizie takiego obszaru można bliżej określić położenie danego centrum handlowego w strukturze funkcjonalnej miasta oraz zidentyfikować szczegółowe czynni- 

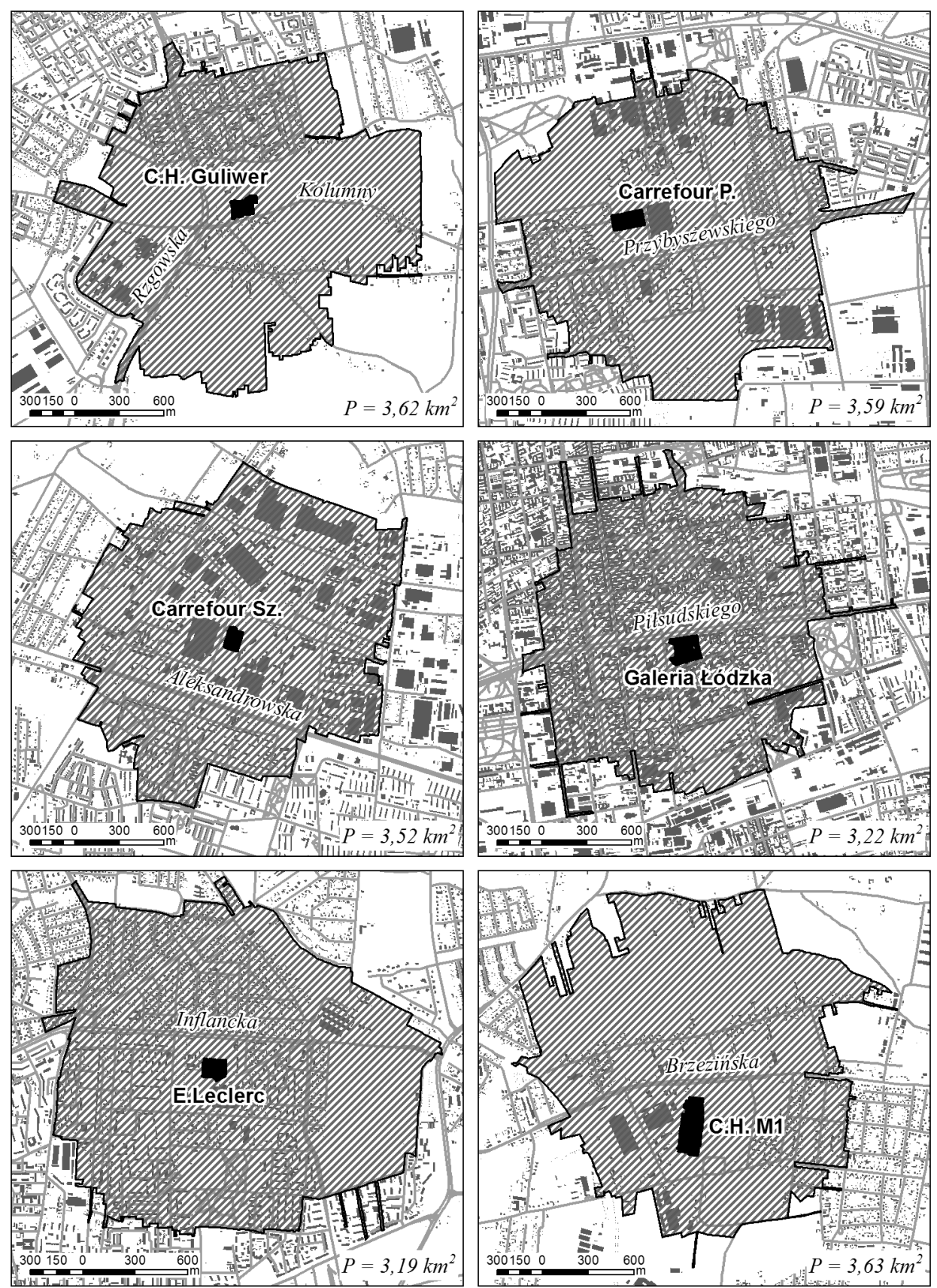

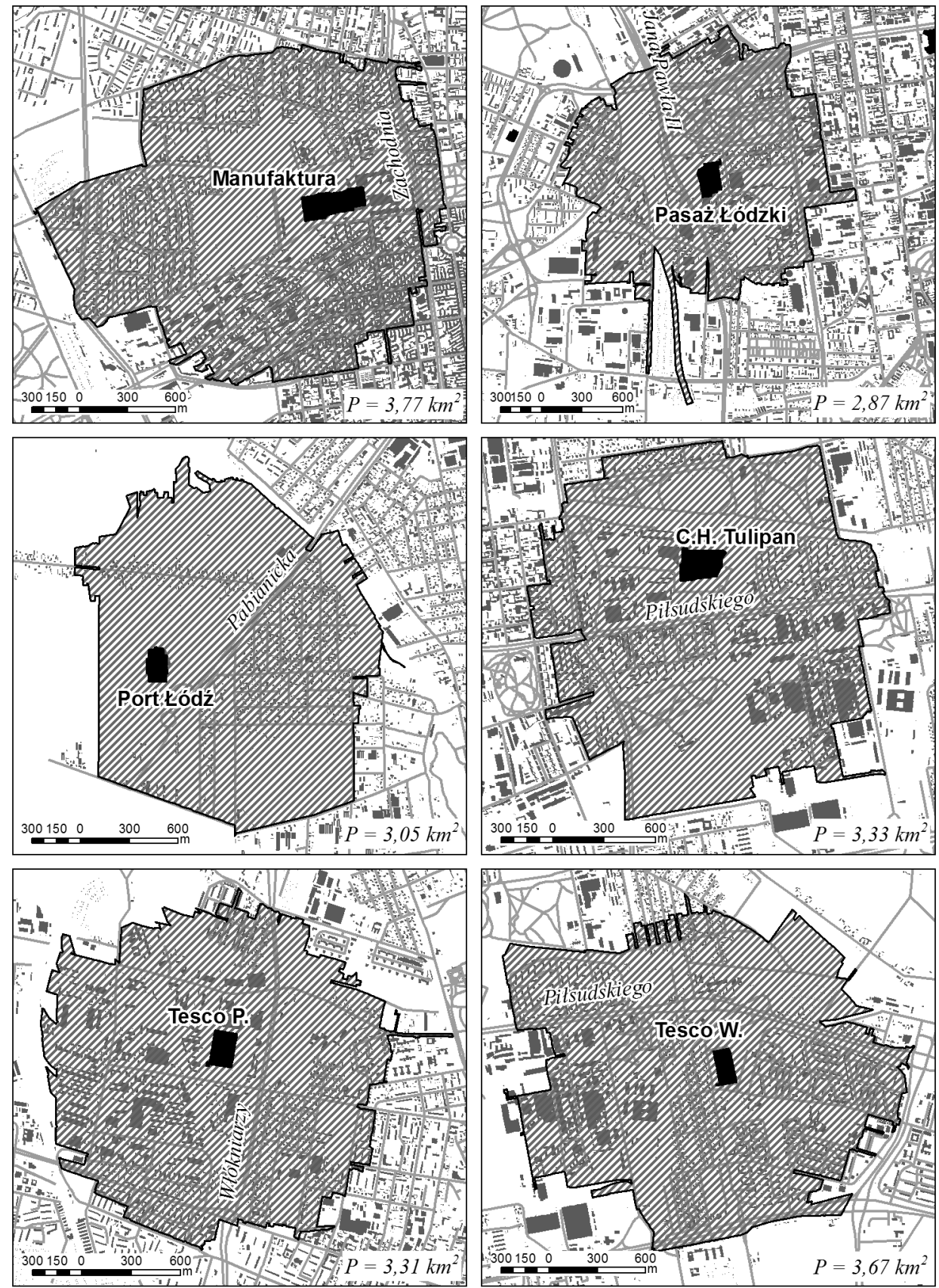

Rys. 41. Zasięg i powierzchnia jednokilometrowych stref handlowych wyznaczonych wokół poszczególnych łódzkich centrów handlowych.

Źródło: Opracowanie własne. 
ki ich lokalizacji. Należy jednak pamiętać, że duża część klientów poszczególnych centrów handlowych jest zmotoryzowanych i w związku z tym nie odgrywa dla nich większej roli, iż mieszkają w bezpośredniej strefie oddziaływania centrum handlowego. Zamieszkanie w jego sąsiedztwie nie jest też jednoznaczne $z$ byciem klientem danego centrum (bariera finansowa, psychologiczna, społeczna i tym podobne), można też zamieszkiwać w pobliżu jednego centrum handlowego, a korzystać $z$ oferty innego.

W wyniku przyjętej procedury wyznaczono dwanaście stref wokół wszystkich badanych centrów handlowych. W przypadku trzech centrów handlowych, to jest Tesco W., C.H. Tulipan i Carrefour P., ze względu na ich bliskie położenie względem siebie ich bezpośrednie obszary handlowe nachodzą na siebie (rys. 40).

Wokół każdego badanego łódzkiego centrum handlowego wyznaczono jednokilometrowe strefy, dzięki czemu ich umownie nazywane „podstawowe obszary handlowe” przyjęły kształty zbliżone do kół. Starano się $\mathrm{w}$ ten sposób otrzymać podobne wielkościowo tereny do dalszych analiz. Średnia powierzchnia podstawowego obszaru handlowego wziętego do analizy wyniosła $3,4 \mathrm{~km}^{2}$. Najmniejszą strefą jest ta wyznaczona wokół Pasażu Łódzkiego $\left(2,87 \mathrm{~km}^{2}\right)$, a największa w otoczeniu Manufaktury (3,77 $\mathrm{km}^{2}$ ) (rys. 41).

Strefy oddziaływania bezpośredniego w uproszczeniu nazywanymi „podstawowymi obszarami handlowymi” przeanalizowano pod względem struktury funkcjonalnej (użytkowania) terenu, typu zabudowy i struktur ludności (potencjalnych nabywców).

\subsubsection{Struktura funkcjonalno-przestrzenna}

„Funkcjonalno-przestrzenna struktura miasta opisuje rozmieszczenie terenów zajętych przez określony rodzaj działalności (funkcje miasta) oraz udział tych terenów w ogólnej powierzchni miasta. Oznacza to, że badania struktury funkcjonalno-przestrzennej koncentrują się na analizowaniu użytkowania terenów w mieście. Wiedza na temat użytkowania ziemi pozwala między innymi ocenić aktualny stan zagospodarowania terenu oraz intensywność działalności człowieka na określonym obszarze” (Słodczyk 2001, s. 102). „Badania struktury funkcjonalno-przestrzennej miasta obejmują analizę rozmieszczenia i wzajemnego oddziaływania działalności miejskich. 
Podstawową metodą prowadzenia w tym zakresie jest zdjęcie użytkowania przestrzeni miejskiej. Zawiera ono rozmieszczenie głównych typów użytków (a tym samym działalności miejskich) oraz ich wzajemne proporcje (w postaci bilansu) (...). Studiami nad użytkowaniem terenów miejskich zajmują się geografowie, geodeci i urbaniści. Prace geografów koncentrują się na wydzieleniu typów użytków miejskich (problem klasyfikacji), ich lokalizacji i wzajemnych powiązań oraz typologii przestrzeni miejskiej. Na tej bazie możliwa jest ocena racjonalności istniejącej struktury funkcjonalno-przestrzennej badanego miasta" (Matczak, Szymańska 1997, s. 45).

S. Liszewski (1978) dokonał klasyfikacji terenów miejskich ze względu na funkcje, jaką pełnią w organizmie miejskim. W zaproponowanej klasyfikacji wydzielił dziesięć głównych grup obejmujących podstawowe funkcje (mieszkaniowe, produkcyjne, usługowe, komunikacyjne, zieleni i rekreacji, inne tereny zainwestowane, intensywne uprawy podmiejskie, użytki rolne, wody, nieużytki) oraz jedenaście podgrup zróżnicowanych hierarchicznie.

$\mathrm{Z}$ punktu widzenia lokalizacji centrów handlowych w przestrzeni miejskiej istotne jest przybliżenie struktury użytkowania terenów w ich otoczeniu. Informacje o powierzchni konkretnych form zagospodarowania uzyskano z Miejskiego Ośrodka Dokumentacji Geodezyjnej i Kartograficznej (MODGiK) w Łodzi. Wydzielone formy zagospodarowania na podstawie ewidencji gruntów i budynków zestawiono w osiem grup funkcjonalnych. Wyróżniono tereny mieszkaniowe, usługowe, przemysłowe, komunikacyjne, rolnicze, rekreacyjno-leśne, pod wodami i pozostałe.

$\mathrm{Z}$ analizy struktury użytkowania terenu $\mathrm{w}$ strefach wyznaczonych w umownym promieniu 1 kilometra od poszczególnych centrów handlowych wynika, że ich lokalizacja jest związana z terenami mieszkaniowymi. Największy udział terenów mieszkaniowych posiadają strefy wokół centrów handlowych: Manufaktura (38,7\%), E. Leclerc (37\%), Galerii Łódzkiej (28\%) oraz Tesco W. (23,7\%).

Specyfiką łódzką jest lokalizacja nowoczesnych kompleksów handlowych na terenach poprzemysłowych i/oraz w obrębie obszarów przemysłowych. Największym udziałem terenów przemysłowych charakteryzują się strefy wokół położonych w północnej części Łodzi dwóch centrów handlowych Carrefour Sz., gdzie tereny przemysłowe zajmują 42,6\% oraz Tesco P. - 35,8\% (w obrębie tej strefy znalazła się między innymi elektrociepłownia). Znaczące obszary przemysłowe znajdują się również w okolicy Carrefoura P. (16,7\%), C.H. Tulipana (10,8\%), Tesco W. (10,7\%) i Galerii Ł. (10,5\%) (tab. 25). 
Położone peryferyjnie w stosunku do centrum Łodzi kompleksy handlowe są otoczone terenami użytkowanymi rolniczo, z jedną główną wielopasmową arterią komunikacyjną doprowadzającą do ośrodka, co wpływa na niski udział terenów komunikacyjnych w strukturze użytkowania terenu. Takim użytkowaniem charakteryzują się głównie strefy trzech peryferyjnych łódzkich centrów handlowych: C.H. M1 (55,9\% rolnicze; 7,3\% komunikacyjne), Port Łódź (55,2\% rolnicze; 9,6\% komunikacyjne), C.H. Guliwer (42,9\% rolnicze; 11,9\% komunikacyjne) (tab. 25).

W strefie Carrefour P., mimo położenia w stosunkowo niedalekiej odległości od centrum Łodzi, występuje duży udział terenów rolniczych (21,3\%), jak również komunikacyjnych (24,0\%). Dwa centra handlowe zostały zlokalizowane w pobliżu parków miejskich, dlatego w strefach ich otaczających duży udział posiadają tereny rekreacyjne i leśne. Pasaż Łódzki sąsiaduje od północy bezpośrednio z parkiem im. ks. Józefa Poniatowskiego (tereny rekreacyjne i leśne 16\%). Natomiast w obrębie strefy C.H. Tulipan znalazł się częściowo Park 3 Maja i Park nad Jasieniem, stąd 13,9\% zajmują tutaj tereny rekreacyjne i leśne (tab. 25).

Tabela 25

Struktura użytkowania terenu wokół łódzkich centrów handlowych ${ }^{105}$

\begin{tabular}{|l|c|c|c|c|c|c|c|c|}
\hline & \multicolumn{7}{|c|}{ Udział terenów o określonej funkcji [\%] } \\
\cline { 2 - 9 } Centrum \\
handlowe & $\begin{array}{c}\text { miesz- } \\
\text { kanio- } \\
\text { we (B) }\end{array}$ & $\begin{array}{c}\text { usłu- } \\
\text { gowe } \\
\text { (Bi) }\end{array}$ & $\begin{array}{c}\text { prze- } \\
\text { my- } \\
\text { słowe } \\
\text { (Ba) }\end{array}$ & $\begin{array}{c}\text { komu- } \\
\text { nika- } \\
\text { cyjne } \\
\text { (dr, Tk, } \\
\text { Ti, Tr) }\end{array}$ & $\begin{array}{c}\text { rolnicze } \\
\text { (R, Ps, } \\
\text { Ł, S) }\end{array}$ & $\begin{array}{c}\text { rekre- } \\
\text { acyjne } \\
\text { i leśne } \\
\text { (Bz, } \\
\text { Ls, Lz) }\end{array}$ & $\begin{array}{c}\text { wody } \\
\text { (Wsr, } \\
\text { Wp, } \\
\text { Ws, W) }\end{array}$ & $\begin{array}{c}\text { pozo- } \\
\text { stałe } \\
\text { (Bp, } \\
\text { N) }\end{array}$ \\
\hline Manufaktura & 38,7 & 28,5 & 1,3 & 18,9 & 1,1 & 6,0 & 0,0 & 5,5 \\
\hline Galeria Ł. & 28,0 & 27,5 & 10,5 & 21,2 & 0,0 & 6,3 & 0,0 & 6,5 \\
\hline Port Łódź & 18,0 & 11,7 & 0,0 & 9,6 & 55,2 & 1,3 & 0,2 & 4,0 \\
\hline C.H. M1 & 10,7 & 16,0 & 1,0 & 7,3 & 55,9 & 0,6 & 0,8 & 7,8 \\
\hline C.H. Tulipan & 13,1 & 25,2 & 10,8 & 19,4 & 8,2 & 13,9 & 0,4 & 9,1 \\
\hline Pasaż Łódzki & 9,0 & 32,5 & 3,0 & 32,1 & 0,1 & 16,0 & 0,0 & 7,4 \\
\hline
\end{tabular}

${ }^{105} \mathrm{Nie}$ dokonano bilansu użytkowania terenu dla wszystkich stref łącznie, gdyż jak wcześniej wspomniano, strefy niektórych centrów handlowych nakładają się na siebie i przy zbilansowaniu doszłoby do podwójnego liczenia tych terenów. Ważniejsze z punktu widzenia tej pracy było dokonanie pogrupowania stref. 
Tabela 25 (ciąg dalszy)

\begin{tabular}{|l|c|c|c|c|c|c|c|r|}
\hline & \multicolumn{7}{|c|}{ Udział terenów o określonej funkcji [\%] } \\
\cline { 2 - 9 } $\begin{array}{l}\text { Centrum } \\
\text { handlowe }\end{array}$ & $\begin{array}{c}\text { miesz- } \\
\text { kanio- } \\
\text { we (B) }\end{array}$ & $\begin{array}{c}\text { usłu- } \\
\text { gowe } \\
\text { (Bi) }\end{array}$ & $\begin{array}{c}\text { prze- } \\
\text { my- } \\
\text { stowe } \\
\text { (Ba) }\end{array}$ & $\begin{array}{c}\text { komu- } \\
\text { nika- } \\
\text { cyjne } \\
\text { (dr, Tk, } \\
\text { Ti, Tr) }\end{array}$ & $\begin{array}{c}\text { rolnicze } \\
\text { (R, Ps, } \\
\text { Ł, S) }\end{array}$ & $\begin{array}{c}\text { rekre- } \\
\text { acyjne } \\
\text { i leśne } \\
\text { (Bz, } \\
\text { Ls, Lz) }\end{array}$ & $\begin{array}{c}\text { wody } \\
\text { (Wsr, } \\
\text { Wp, } \\
\text { Ws, W) }\end{array}$ & $\begin{array}{c}\text { pozo- } \\
\text { stałe } \\
\text { (Bp, } \\
\text { N) }\end{array}$ \\
\hline Tesco W. & 23,7 & 15,6 & 10,7 & 27,9 & 8,6 & 4,6 & 0,1 & 8,9 \\
\hline E.Leclerc & 37,0 & 22,9 & 2,0 & 23,2 & 1,6 & 5,6 & 0,0 & 7,6 \\
\hline $\begin{array}{l}\text { Carrefour } \\
\text { Sz. }\end{array}$ & 14,9 & 12,1 & 42,6 & 15,4 & 5,8 & 1,9 & 0,1 & 7,1 \\
\hline Carrefour P. & 12,5 & 13,9 & 16,7 & 24,0 & 21,3 & 0,8 & 0,0 & 10,7 \\
\hline
\end{tabular}

$\mathrm{B}$ - tereny mieszkaniowe; $\mathrm{Bi}$ - inne tereny zabudowane; $\mathrm{Ba}$ - tereny przemysłowe; $\mathrm{dr}$ - drogi; $\mathrm{Tk}$ - tereny kolejowe; $\mathrm{Ti}$ - inne tereny komunikacyjne; $\mathrm{Tr}$ - tereny różne; $\mathrm{R}$ - grunty orne, Ps - pastwiska trwałe; $€$ - łąki; S - sady; Bz - tereny rekreacyjno-wypoczynkowe; Ls - lasy; $\mathrm{Lz}$ - grunty zadrzewione i zakrzewione; Wsr - grunty pod stawami; Wp - grunty pod wodami powierzchniowymi płynącymi; Ws - grunty pod wodami powierzchniowymi stojącymi; $\mathrm{W}$ - rowy; $\mathrm{Bp}$ - zurbanizowane tereny niezabudowane; $\mathrm{N}$ - nieużytki (rozporządzenie ministra rozwoju regionalnego i budownictwa w sprawie ewidencji gruntów i budynków z 29 marca 2001 roku, Dz.U. z 2001 roku, Nr 38, poz. 454).

Źródło: Opracowanie własne na podstawie danych z MODGiK.

W zależności od omawianej strefy zagospodarowanie terenu jest różne, $\mathrm{w}$ dużej mierze jest to związane $\mathrm{z}$ położeniem centrum handlowego w stosunku do Śródmieścia, osiedli mieszkaniowych i ciągów komunikacyjnych. W związku ze zróżnicowaną strukturą użytkowania terenu wokół poszczególnych centrów handlowych można badane strefy pogrupować w kilka typów.

Pierwszy typ tworzą strefy o charakterze rolniczym (typ rolniczy), w których tereny rolnicze, rekreacyjne i leśne oraz pod wodami zajmują pond 50\% terenu. Do tego typu można zaliczyć więc tereny położone wokół trzech położonych peryferyjne w stosunku do centrum miasta centrów handlowych: C.H. Guliwer (rys. 42), C.H. M1 (rys. 43) oraz Portu Łódź (rys. 44).

Drugi typ można nazwać przemysłowym, ponieważ w strefach przeważają tereny przemysłowe, $\mathrm{z}$ dużym udziałem komunikacyjnych. Do grupy tej można zaliczyć strefy wokół Carrefour Sz. (42,6\%; 15,4\%) (rys. 45) oraz Tesco P. $(35,8 \% ; 18,8 \%)$ (rys. 46). 
Trzeci typ mieszkaniowo-usługowy tworzą strefy wokół Galerii Łódzkiej (rys. 47), Manufaktury (rys. 48), E. Leclerca (rys. 49) i Tesco W. (rys. 50). Tego rodzaju obszary charakteryzują się dużym udziałem terenów pełniących funkcje mieszkaniowe (od 23,7\% wokół Tesco W. do 38,7\% wokół Manufaktury) oraz usługowe (od od 15,6\% wokół Tesco W. do 28,5\% wokół Manufaktury). Czwarty typ usługowy tworzą strefy te przy Pasażu Łódzkim (32,5\%) (rys. 51) i przy C.H. Tulipan (25,2\%) (rys. 52), w których obok funkcji usługowej duży udział posiadają również tereny komunikacyjne (Pasaż Łódzki - 32,1\%; C.H. Tulipan - 19,4\%). W ostatnim typie stref, tak zwanym wielofunkcyjnym, znalazły się tereny wokół Carrefour P. (rys. 53). W jej strukturze użytkowania terenu nie dominuje żadna funkcja, a duży udział posiadają obszary: komunikacyjne (24\%), rolnicze $(21,3 \%)$, przemysłowe $(16,7 \%)$, usługowe $(13,9 \%)$ oraz mieszkaniowe $(12,5 \%)$.

Łódzkie centra handlowe, jak już wcześniej wielokrotnie wspominano, są położone przy głównych arteriach komunikacyjnych przebiegających przez miasto (drogi krajowe i wojewódzkie), w związku z tym w strukturze użytkowania terenów wokół nich duży udział posiadają tereny komunikacyjne (od 7,3\% do 32,1\%). Następną cechą jest fakt lokalizacji wielu centrów handlowych w pobliżu centrum miasta, w sąsiedztwie osiedli mieszkaniowych, dlatego w wielu strefach otaczających centra duży odsetek stanowią tereny mieszkaniowe (od 9\% do 38,7\%) i usługowe (od 11,7\% do 32,5\%). Trzy z badanych kompleksów zostały zlokalizowane peryferyjnie w stosunku do centrum miasta (Port Łódź, C.H. M1, C.H. Guliwer), na obszarach słabiej zagospodarowanych, stąd w ich strefach dominują tereny rolnicze (około 50\%). Natomiast dwa centra handlowe Carrefour Sz. i Tesco P. zostały zlokalizowane w dzielnicy przemysłowej, stąd duży udział terenów o funkcji przemysłowej $(42,6 \%, 35,8 \%)$. 

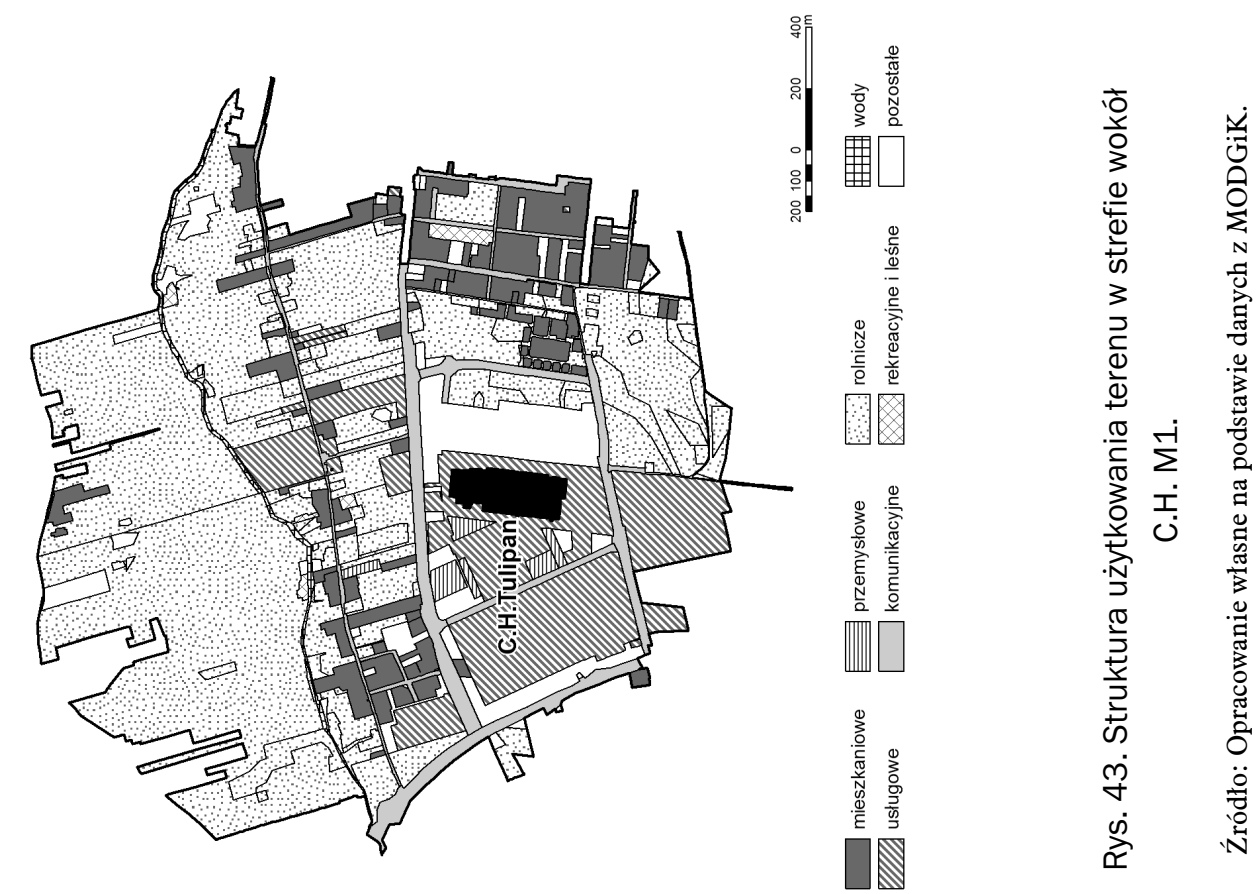

$A z$
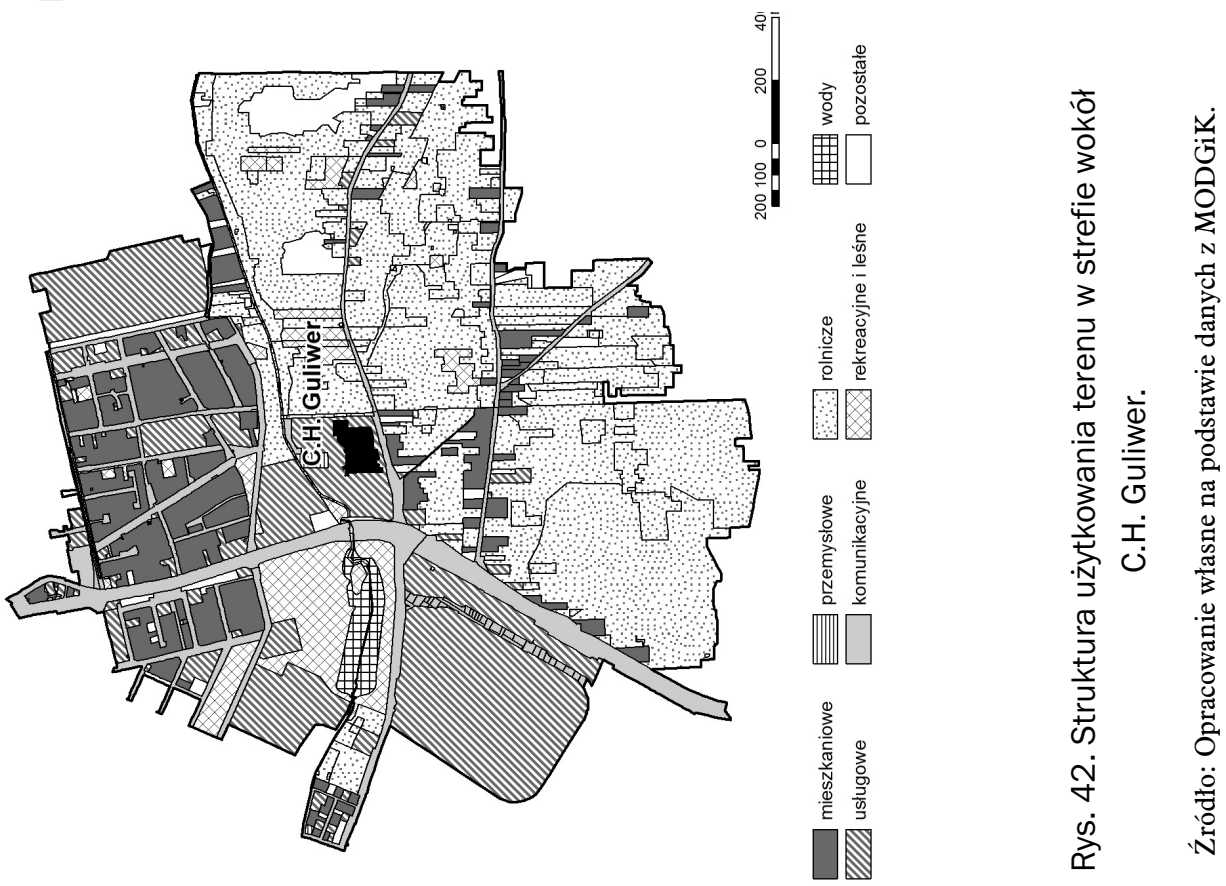


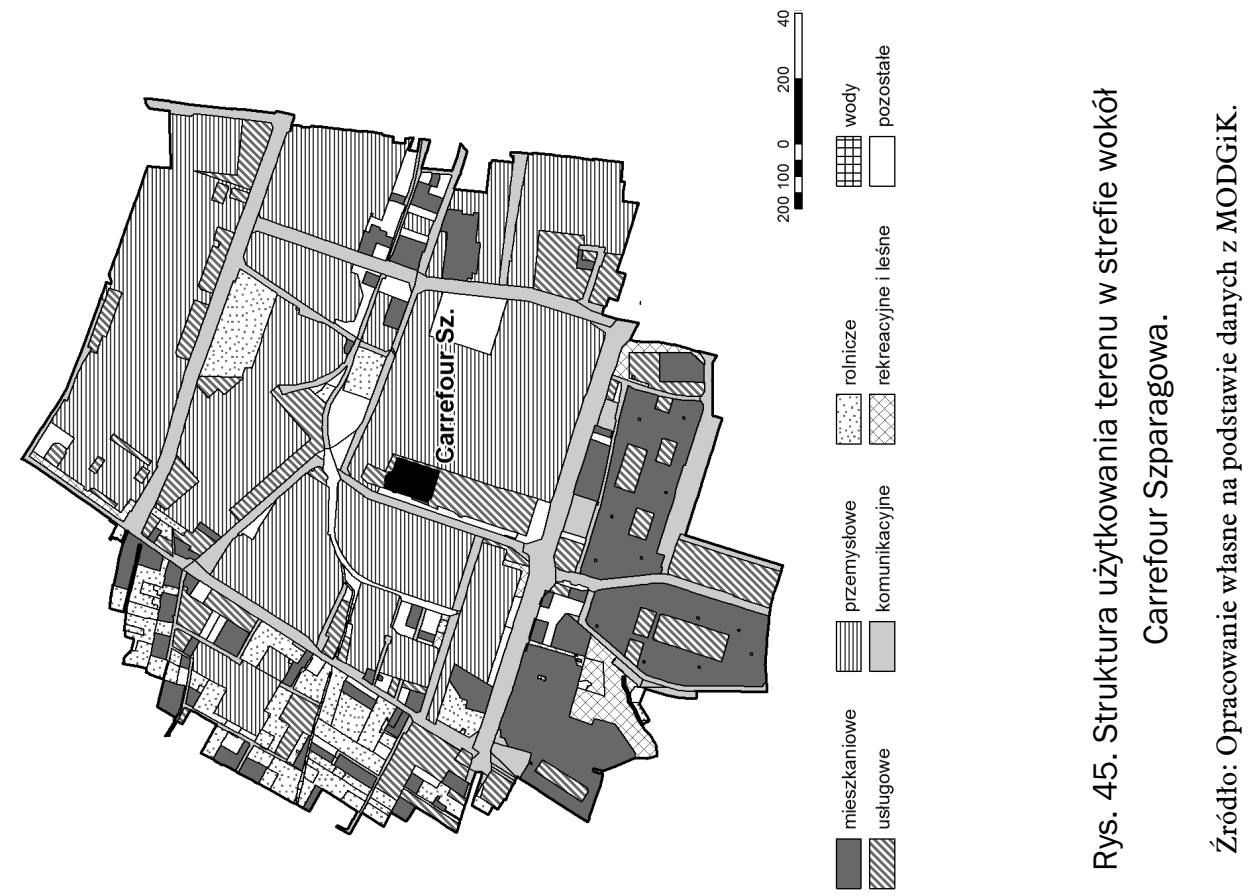

$A z$
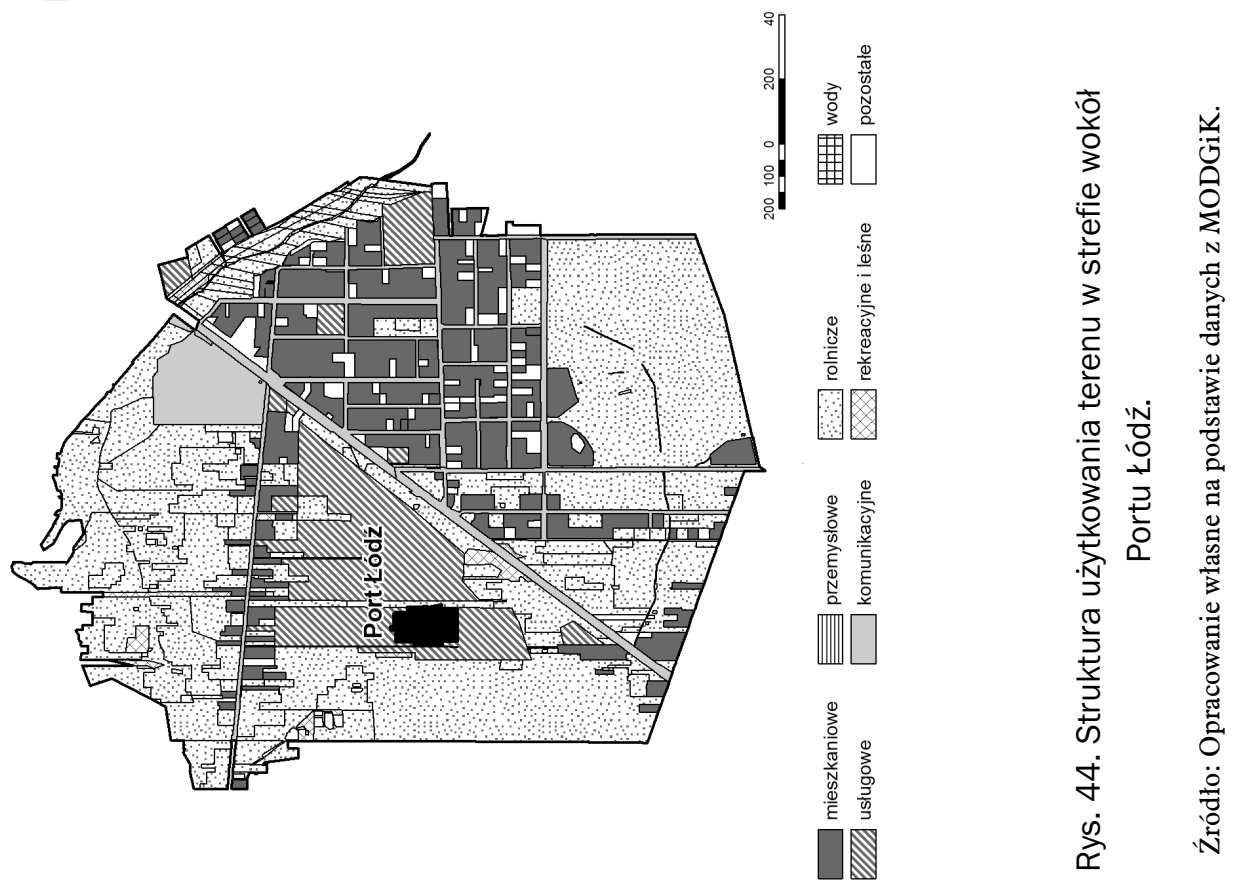


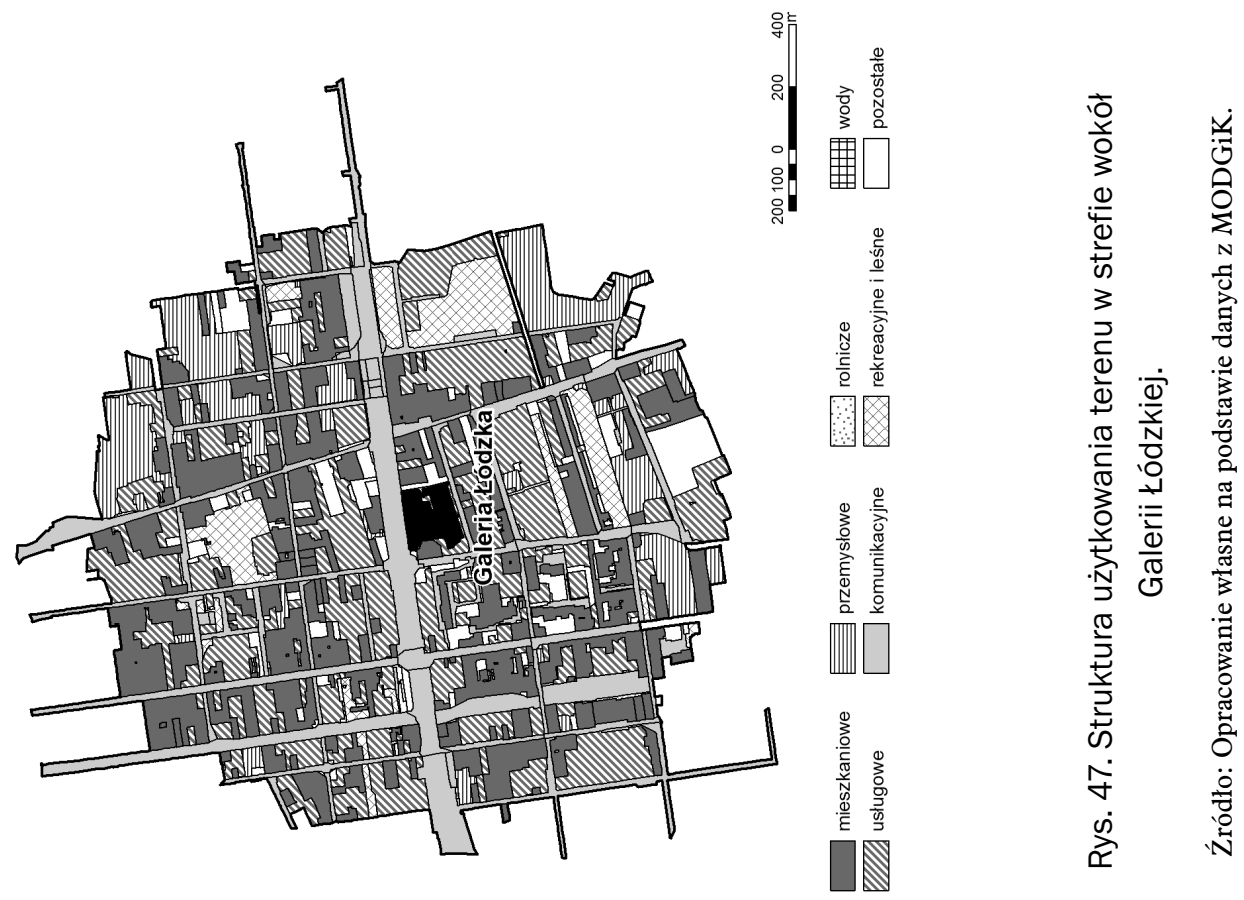

$A z$
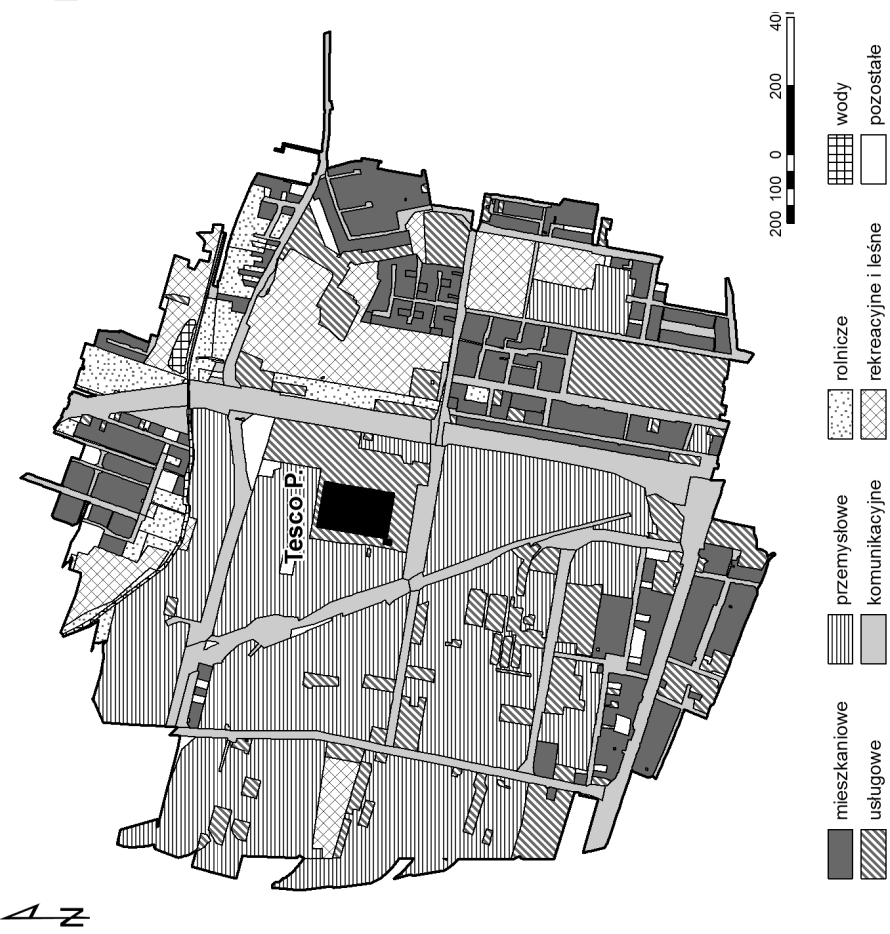

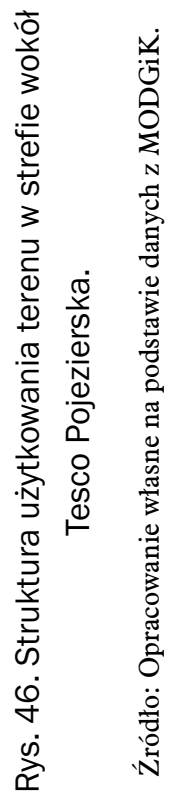




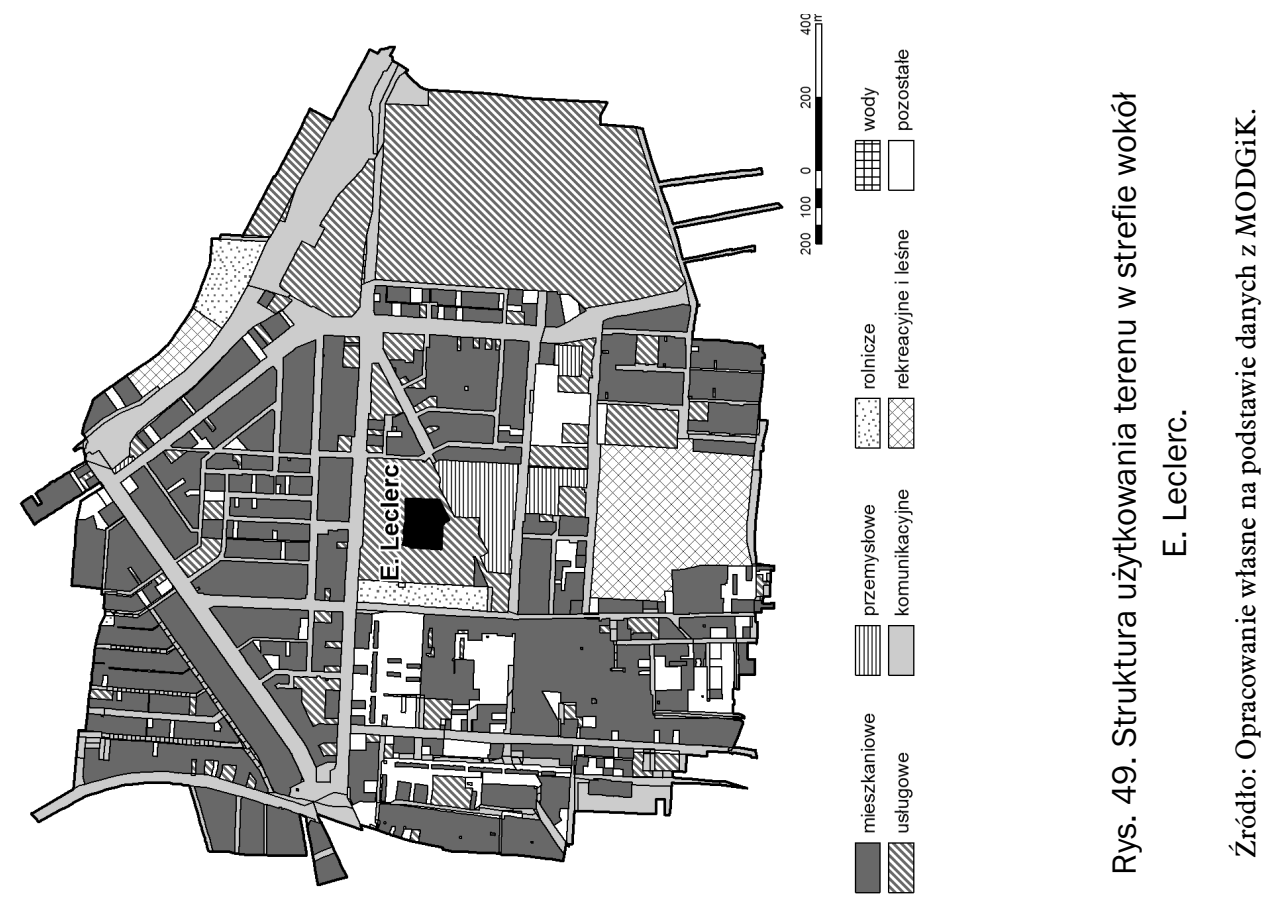

$\Delta z$



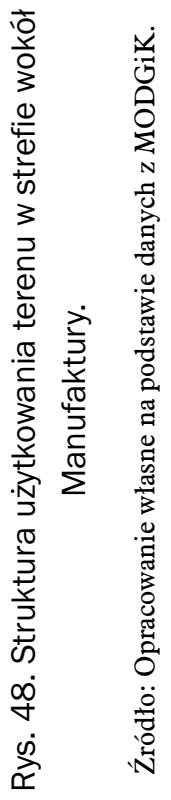



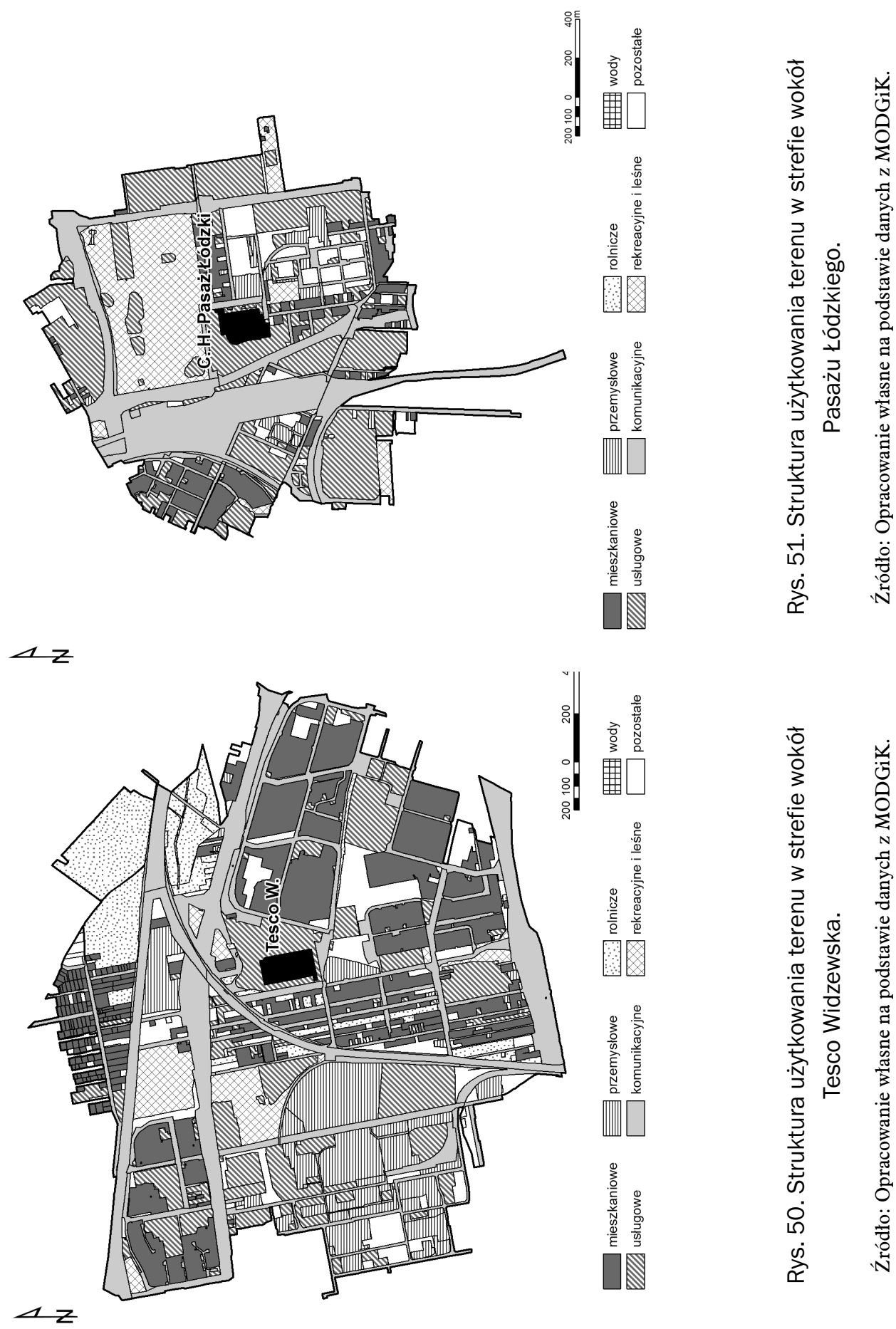

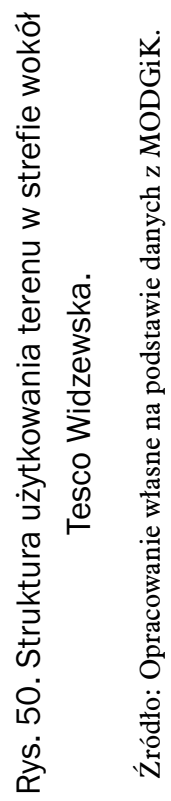





$A z$ 


\subsubsection{Typy zabudowy}

$\mathrm{Z}$ punktu widzenia funkcjonowania centrów handlowych bardzo istotne znaczenie odgrywa położenie ich względem terenów mieszkaniowych. Strefą z największą powierzchnią takiej zabudowy, wynoszącą znacznie ponad 7000 tys. $\mathrm{m}^{2}$, jest obszar wokół Manufaktury. Pięć z badanych obszarów posiada powierzchnie zajęte pod budownictwo mieszkaniowe od 1000 do 2000 tys. $\mathrm{m}^{2}$ (E. Leclerc, Galeria Łódzka, Tesco W., C.H. Guliwer, Carrefour P.), w pozostałych strefach powierzchnie te wynoszą poniżej 1000 tys. $\mathrm{m}^{2}$. Najmniej terenów $\mathrm{z}$ powierzchnią mieszkaniową znajduje się w okolicy Pasażu Łódzkiego, bo tylko 240,5 tys. m² (rys. 53).

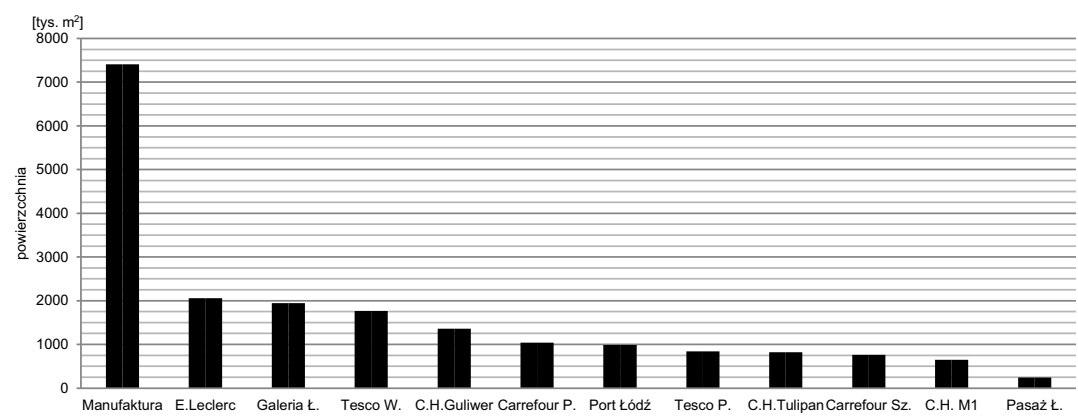

Rys. 54. Powierzchnia terenów zajętych pod zabudowę mieszkaniową w strefach wokół tódzkich centrów handlowych.

Źródło: Opracowanie własne na podstawie danych z MODGiK.

Łódzkie centra handlowe położone są w różnych rejonach Łodzi, co przekłada się na zróżnicowaną strukturę zabudowy mieszkaniowej terenów sąsiedzkich. S. Liszewski (1978) dokonując klasyfikacji terenów miejskich w ramach terenów mieszkaniowych (klasyfikacja funkcjonalna), wyróżnił tereny zabudowy wiejskiej, podmiejskiej, miejskiej i śródmiejskiej ${ }^{106}$. Ba-

${ }^{106}$ Zabudowa wiejska jest związana z gospodarką polową lub hodowlaną o znacznym współudziale zabudowy mieszkaniowej i gospodarczej występującej często na jednej działce. Zabudowa podmiejska odznacza się zdecydowaną przewagą zabudowy niskiej występującej w rozluźnieniu, z dużym udziałem ogrodów kwiatowych i warzywnych. Zabudowa miejska - głównie zabudowa skupiona, średnio wysoka, zmniejsza się lub zanika w niej udział budynków gospodarczych i zieleni przydomowej, dolne kondygnacje budynków mieszkalnych często zajmowane są przez usługi (zwłaszcza handel). Zabudowa śródmiejska - zabudowa wysoka lub średnio wysoka, brak zieleni przydomowej oraz zabudowań gospodarczych, cechą takich terenów jest mieszany mieszkaniowo-usługowy charakter (Liszewski 1978, s. 17). 
daniami różnych typów łódzkiej zabudowy zajmowali się, między innymi zabudową rezydencjonalną (Groeger 2011), nowym budownictwem mieszkaniowym w tym osiedlami grodzonymi (Milewska-Osiecka 2011; Tobiasz-Lis 2011), społecznym budownictwem mieszkaniowym (Dzieciuchowicz 2011), typologią przestrzenną standardu mieszkaniowego (Dzieciuchowicz 2002), przemianami struktury społecznej, przestrzennej i funkcjonalnej wielkich osiedli mieszkaniowych na przykładzie osiedla Widzew Wschód (Szafrańska 2012). W poniższej pracy przyjęto typologię zabudowy mieszkaniowej stosowaną w polskich dokumentach planistycznych, co wynikało z posiadanych danych pozyskanych z MODGiK-u. $\mathrm{Na}$ badanych obszarach występują różne typy zespołów urbanistycznych: obszary zabudowy śródmiejskiej, wielorodzinnej, jednorodzinnej (luźnej i zwartej) oraz wiejskiej (luźnej i zwartej) ${ }^{107}$.

Przez zabudowę śródmiejską „rozumie się zgrupowanie intensywnej zabudowy na obszarze funkcjonalnego Śródmieścia, który to obszar stanowi faktyczne lub przewidziane w planie miejscowym centrum miasta lub dzielnicy miasta" (art. 3.1.) ${ }^{108}$. W bazie danych CORINE Land Cover $(\mathrm{CLC})^{109} \mathrm{~W}$ ramach pierwszej klasy użytkowania i pokrycia terenu - strefy zurbanizowanej - wyróżnia się tereny o zabudowie zwartej i luźnej. Zabudowa zwarta obejmuje tereny zabudowane budynkami stykającymi się ze sobą, w której powierzchnia zabudowana zajmuje przynajmniej $80 \%$ obszaru. W jej ramach można wyróżnić zabudowę zwartą niską (od 1 do 2 kondygnacji) oraz zabudowę zwartą wysoką (od 3 kondygnacji wzwyż) $)^{110}$. Zabudowa wysoka występuje najczęściej w centrach miast, natomiast za-

${ }^{107} \mathrm{~W}$ „Studium uwarunkowań i kierunków zagospodarowania przestrzennego miasta Łodzi”, które zostało przyjęte uchwałą nr XCIX/1826/10 Rady Miejskiej w Łodzi z 27 października 2010 roku nie ma podanych definicji poszczególnych typów zabudowy, dlatego w pracy posłużono się definicjami z innych źródeł.

${ }^{108}$ Rozporządzenie ministra infrastruktury z 12 kwietnia 2002 roku w sprawie warunków technicznych, jakim powinny odpowiadać budynki i ich usytuowanie, Dz.U., Nr 75, poz. 690, z późn. zm.

${ }^{109}$ Jedna $\mathrm{z}$ metod kontrolowania stanu zagospodarowania przestrzennego na poziomie całej Unii Europejskiej. Program został powołany w 1985 roku w celu dostarczenia informacji o pokryciu i użytkowaniu ziemi we wszystkich krajach wchodzących w jej skład. Źródłem danych dla tego programu są zdjęcia satelitarne.

${ }^{110}$ S. Liszewski (1978) ze względu na intensywność pionową wyróżnił zabudowę niską (do 2,5 kondygnacji), średnią (do 6 kondygnacji) oraz wysoką (powyżej 6 kondygnacji naziemnych), natomiast ze względu na intensywność poziomą: zabudowę zwartą (pokrycie terenu budynkami i budowlami powyżej 75\%), luźną (50-75\%) oraz rozproszoną (poniżej 50\%). 
budowę niską spotykamy na przedmieściach oraz w niewielkich miastach. Zabudowa luźna obejmuje natomiast tereny o strukturze wskazującej na obecność budynków, w tym przypadku budynki, drogi i obszary o sztucznym pokryciu występują wraz z terenami o pokryciu roślinnym i odsłoniętej glebie, zajmujące $\mathrm{w}$ sposób nieciągły znaczące powierzchnie ${ }^{111}$. Do zabudowy luźnej wysokiej zalicza się tereny zajęte przez bloki mieszkalne stojące w otoczeniu terenów zieleni, a do luźnej niskiej osiedla domów jednorodzinnych, otoczonych niewielkimi ogrodami przydomowymi (Pawlak 1999).

Dominujący typ zabudowy w otoczeniu poszczególnych centrów handlowych w dużej mierze zależy od jego położenia w stosunku do centrum miasta. Najbardziej centralnie położone kompleksy posiadają w strukturze zabudowy mieszkaniowej w bezpośrednim ich sąsiedztwie głównie zabudowę typu śródmiejskiego; są to strefy wokół Manufaktury $(81,3$ \%) oraz Galerii Łódzkiej (79,7\%). Wszystkie badane kompleksy zlokalizowane zostały w granicach administracyjnych trzeciego co do liczebności miasta Polski - Łodzi. Specyfiką miast jest duży udział terenów o zabudowie wielorodzinnej, która związana jest szczególnie z „blokowymi” osiedlami mieszkaniowymi. Łódzkie centra handlowe w większości przypadków są „przyklejone” do osiedli mieszkaniowych, stąd duży udział terenów mieszkaniowych budownictwa wielorodzinnego w strukturze użytkowania terenu w ich sąsiedztwie, szczególnie w okolicach Carrefour Sz. (80,6\%), C.H. Tulipan (78,5\%) i Carrefour P. (67,7\%) (tab. 26).

W sąsiedztwie centrów handlowych zlokalizowanych na obrzeżach miasta dominuje zabudowa jednorodzinna zwarta C.H. M1 (99,7\%) i Port Łódź (66,9\%). W okolicach C.H. Guliwer obok terenów budownictwa wielorodzinnego (37,8\%) duży udział posiadają tereny o zabudowie wiejskiej luźnej (34,7\%). W kilku przypadkach centra handlowe są otoczone terenami o zabudowie mieszanej wielorodzinnej i jednorodzinnej zwartej. Do tego typu obszarów można zaklasyfikować otoczenie: E. Leclerc $(56,6 \%$ wielorodzinna, 43,4\% jednorodzinna), Pasaż Ł. (43,2\% i 56,6\%) i Tesco P. (35,8\% i 57,4\%) oraz Tesco W. (63,1\% i 36,9\%) (tab. 26).

${ }^{111}$ Definicje typów zabudowy poziomu trzeciego pochodzą z zestawienia definicji wydzieleń użytkowania ziemi na potrzeby programu Corine opracowanego przez D. Dukaczewskiego na podstawie Corine, Land Cover Project Nomenclature, CORINE, Technical Guide, Part One, Commision of the European Commities, Directorate-General, Environment, Nuclear Safert and Civil Protection, Brussels (17 lutego 1989 roku). 
Tabela 26

Struktura zabudowy w strefach wokół łódzkich centrów handlowych

\begin{tabular}{|c|c|c|c|c|c|c|}
\hline \multirow{3}{*}{$\begin{array}{c}\text { Nazwa centrum } \\
\text { handlowego }\end{array}$} & \multicolumn{6}{|c|}{ Typ zabudowy [\%] } \\
\hline & \multicolumn{2}{|c|}{ jednorodzinna } & \multirow{2}{*}{$\begin{array}{l}\text { wielo- } \\
\text { rodzinna } \\
(\mathrm{WLR})\end{array}$} & \multirow{2}{*}{$\begin{array}{c}\text { śród- } \\
\text { miejska } \\
\text { (SRD) }\end{array}$} & \multicolumn{2}{|c|}{ wiejska } \\
\hline & $\begin{array}{l}\text { luźna } \\
\text { (JRL) }\end{array}$ & $\begin{array}{c}\text { zwarta } \\
\text { (JRZ) }\end{array}$ & & & $\begin{array}{l}\text { luźna } \\
\text { (WSL) }\end{array}$ & $\begin{array}{l}\text { zwarta } \\
\text { (WSZ) }\end{array}$ \\
\hline Manufaktura & 0,0 & 0,3 & 18,4 & 81,3 & 0,0 & 0,0 \\
\hline Galeria $Ł$. & 0,0 & 0,0 & 20,3 & 79,7 & 0,0 & 0,0 \\
\hline Port Łódź & 12,1 & 66,9 & 0,0 & 0,0 & 2,8 & 18,2 \\
\hline C.H. M1 & 0,3 & 99,7 & 0,0 & 0,0 & 0,0 & 0,0 \\
\hline C.H. Tulipan & 0,0 & 10,0 & 78,5 & 11,5 & 0,0 & 0,0 \\
\hline Pasaż Łódzki & 0,0 & 56,6 & 43,2 & 0,2 & 0,0 & 0,0 \\
\hline Tesco P. & 6,8 & 57,4 & 35,8 & 0,0 & 0,0 & 0,0 \\
\hline C.H. Guliwer & 4,8 & 5,8 & 37,8 & 0,0 & 34,7 & 16,9 \\
\hline Tesco W. & 0,0 & 36,9 & 63,1 & 0,0 & 0,0 & 0,0 \\
\hline E. Leclerc & 0,0 & 43,4 & 56,6 & 0,0 & 0,0 & 0,0 \\
\hline Carrefour Sz. & 12,3 & 7,1 & 80,6 & 0,0 & 0,0 & 0,0 \\
\hline Carrefour P. & 0,0 & 32,3 & 67,7 & 0,0 & 0,0 & 0,0 \\
\hline
\end{tabular}

Źródło: Opracowanie własne na podstawie danych z MODGiK.

Ze względu na dominujący typ zabudowy w strefach wokół centrów handlowych wyróżniamy cztery typy takich stref. Pierwszy tworzą strefy z przewagą zabudowy śródmiejskiej wokół Manufaktury (rys. 55) i Galerii Łódzkiej (rys. 56) (około 80\%). Do drugiego typu z przewagą zabudowy wielorodzinnej zaliczamy strefy wokół Carrefour Sz. (rys. 57), C.H. Tulipan (rys. 58), Carrefour P. (rys. 59), Tesco W. (rys. 60) i E. Leclerc (rys. 61) (od 56,6\% wokół E. Leclerc do $86,6 \%$ wokół Carrefour Sz.). W tej grupie udział mają także tereny z zabudową jednorodzinną (od 10\% w pobliżu C.H. Tulipan do 43,4\% w strefie wokół E. Leclerc). W typie trzecim największy udział ma zabudowa jednorodzinna występująca na terenach wokół: C.H. M1 (rys. 62), Tesco P. (rys. 63), Port Łódź (rys. 64) i Pasaż Ł. (rys. 65) (od 56,6\% wokół Pasażu Ł. do 100\% wokół C.H. M1). W tej grupie wokół Pasażu Ł. oraz Tesco P. duży udział mają tereny z zabudową wielorodzinną (43,2\%; 35,8\%), a wokół Portu Łódź obszary z zabudową wiejską (21\%). Strefa wokół C.H. Guliwer reprezentuje czwarty typ ze względu na przewagę zabudowy wiejskiej (51,6\%), której towarzyszy zabudowa wielorodzinna (37,8\%) oraz jednorodzinna (10,6\%) (rys. 65). 


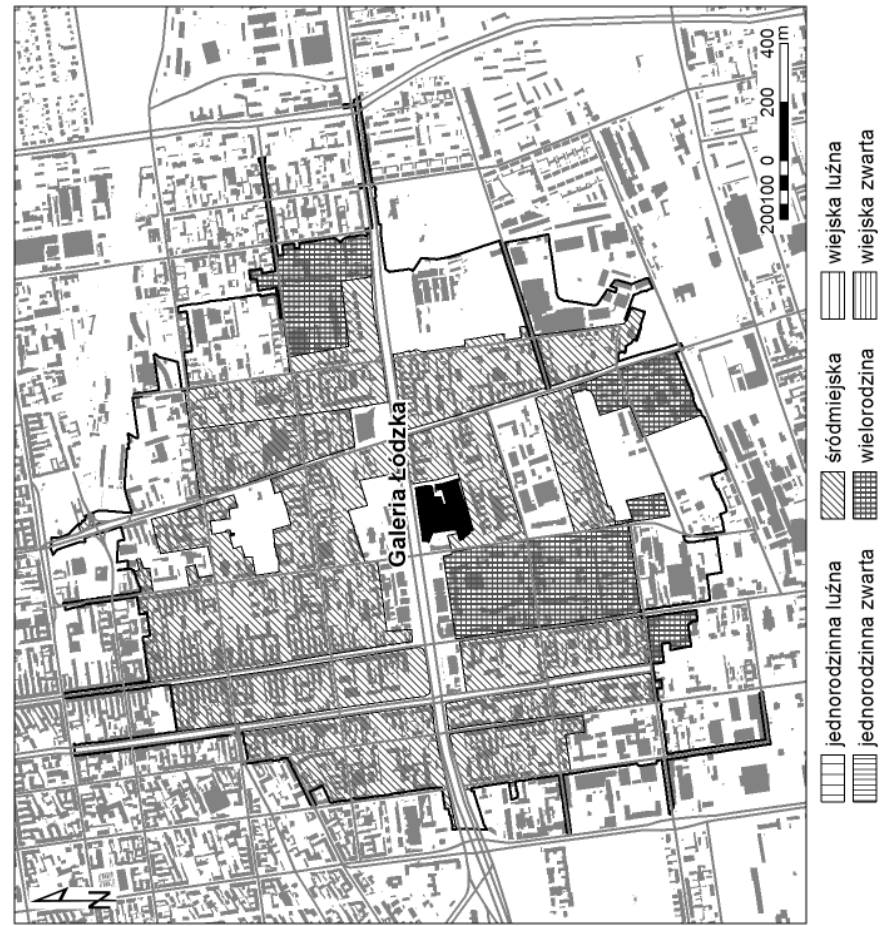

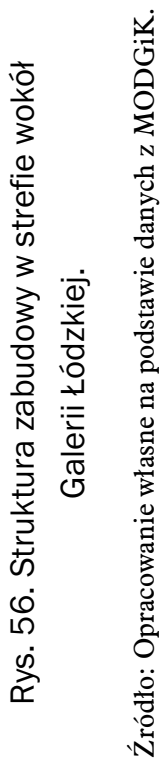

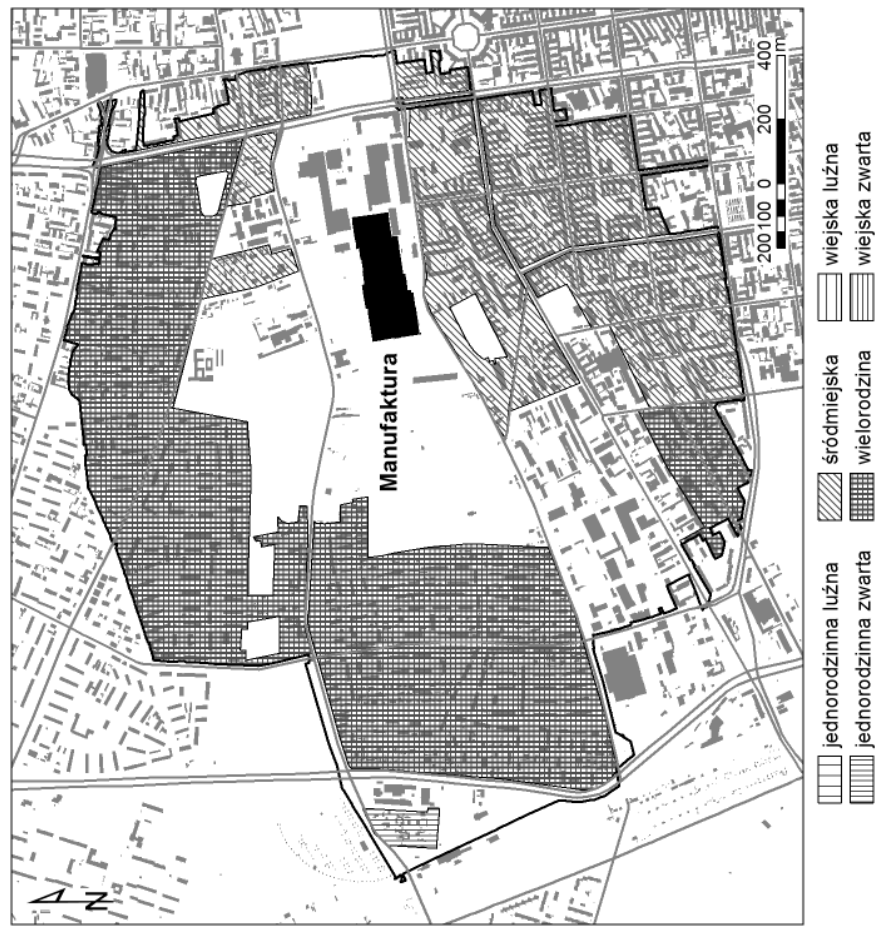

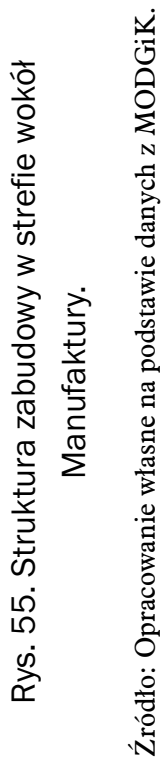




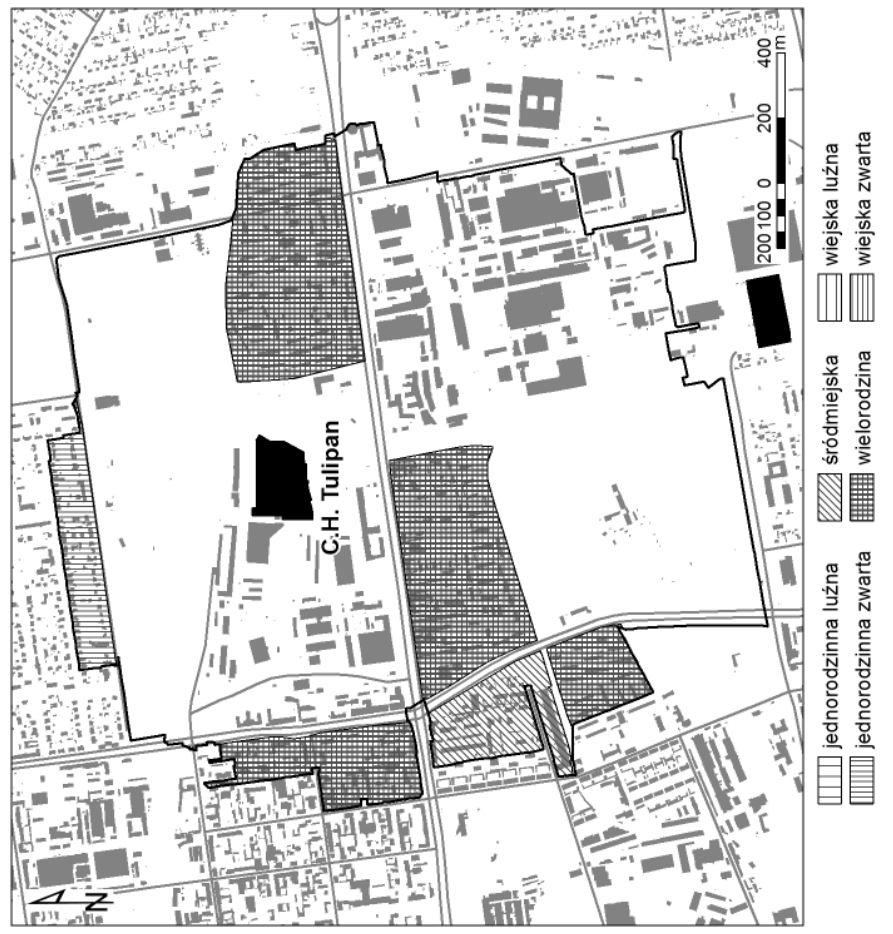

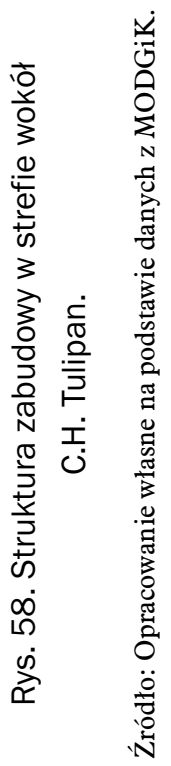

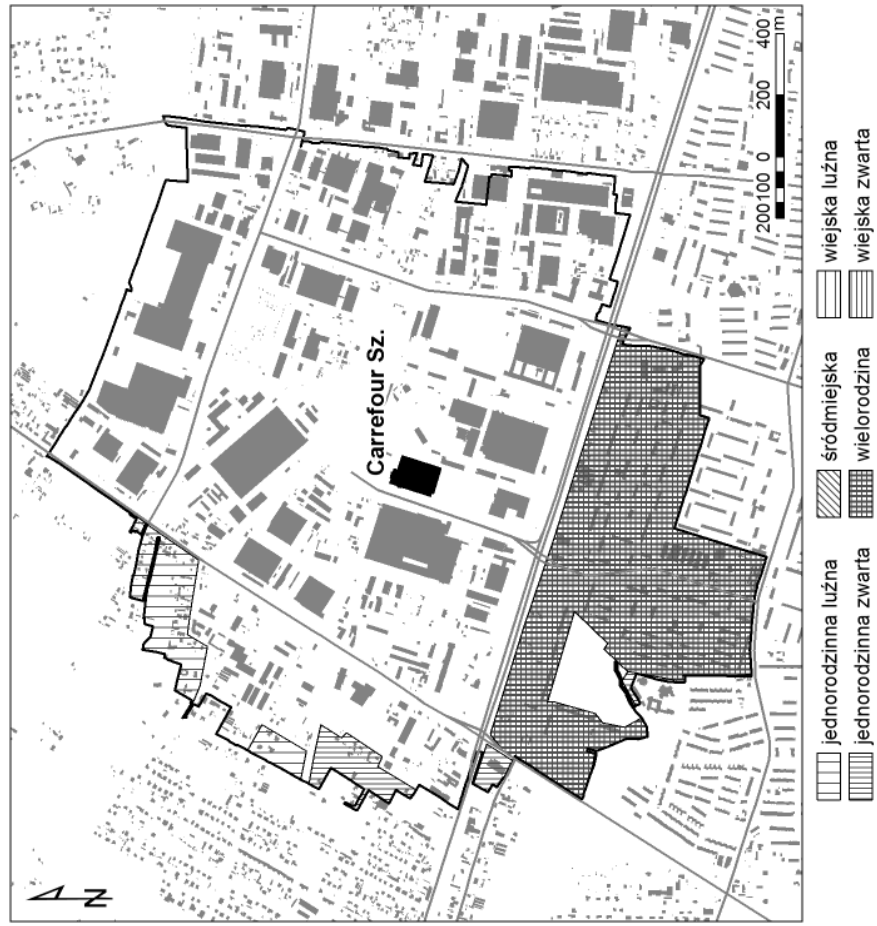

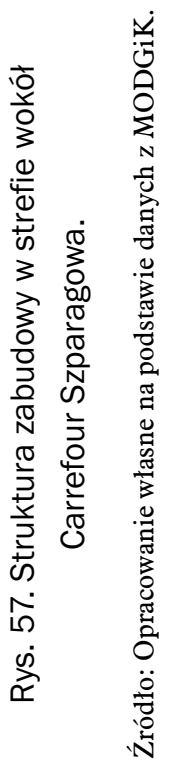




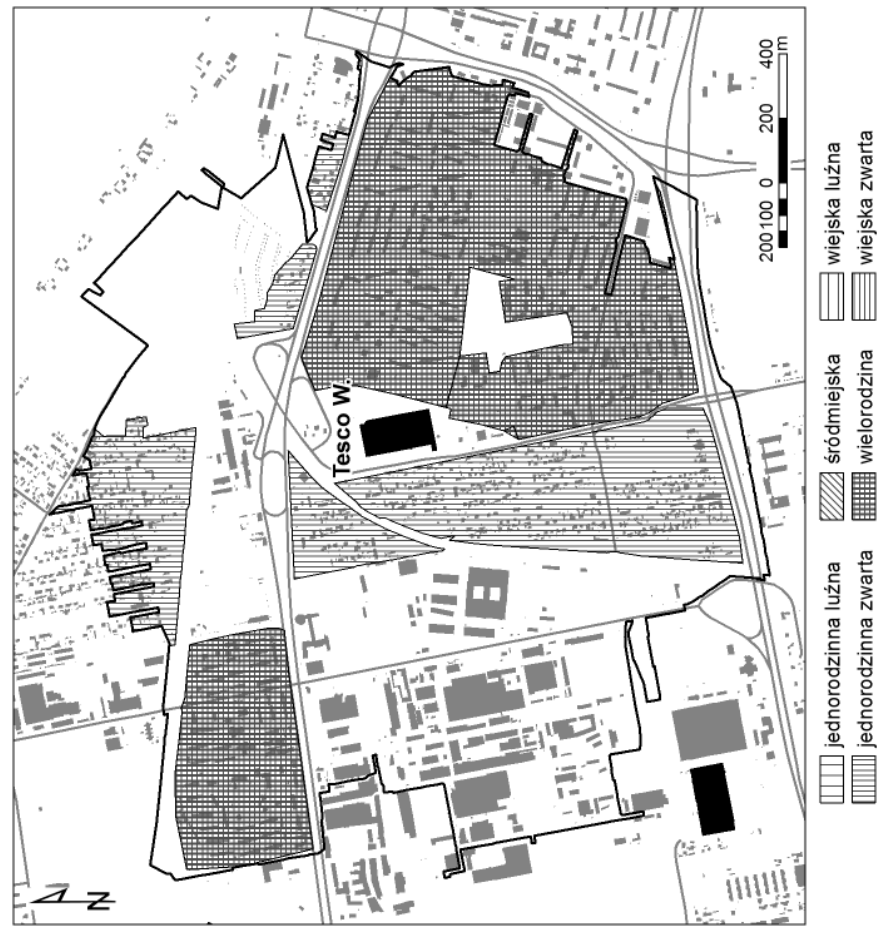

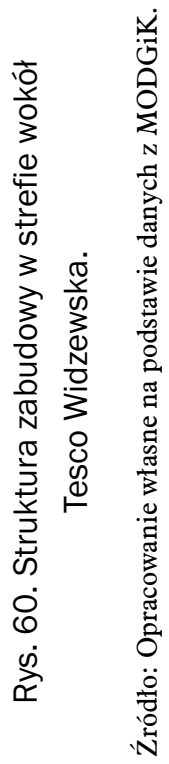



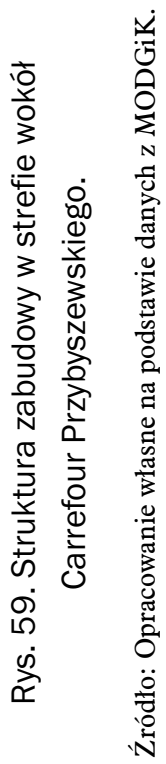




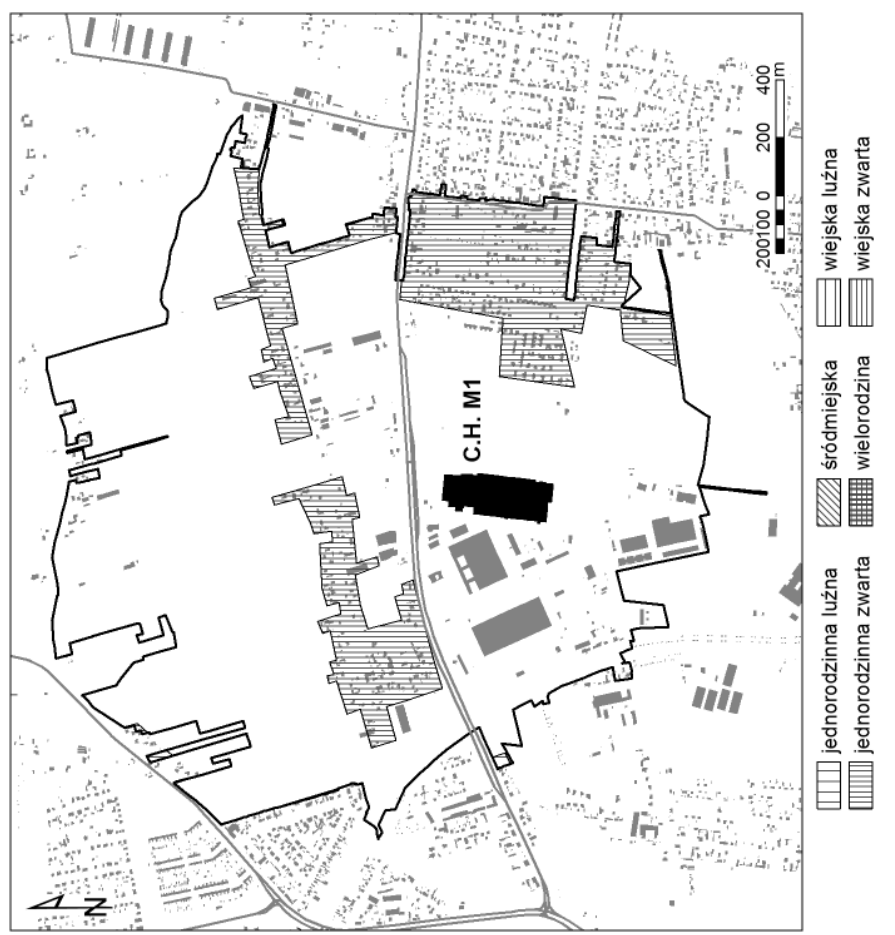

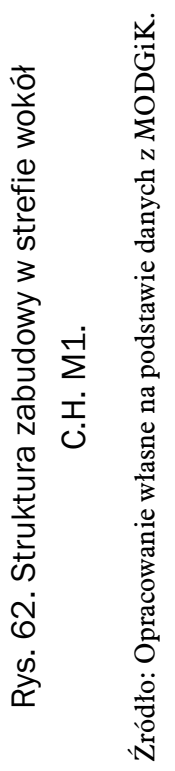

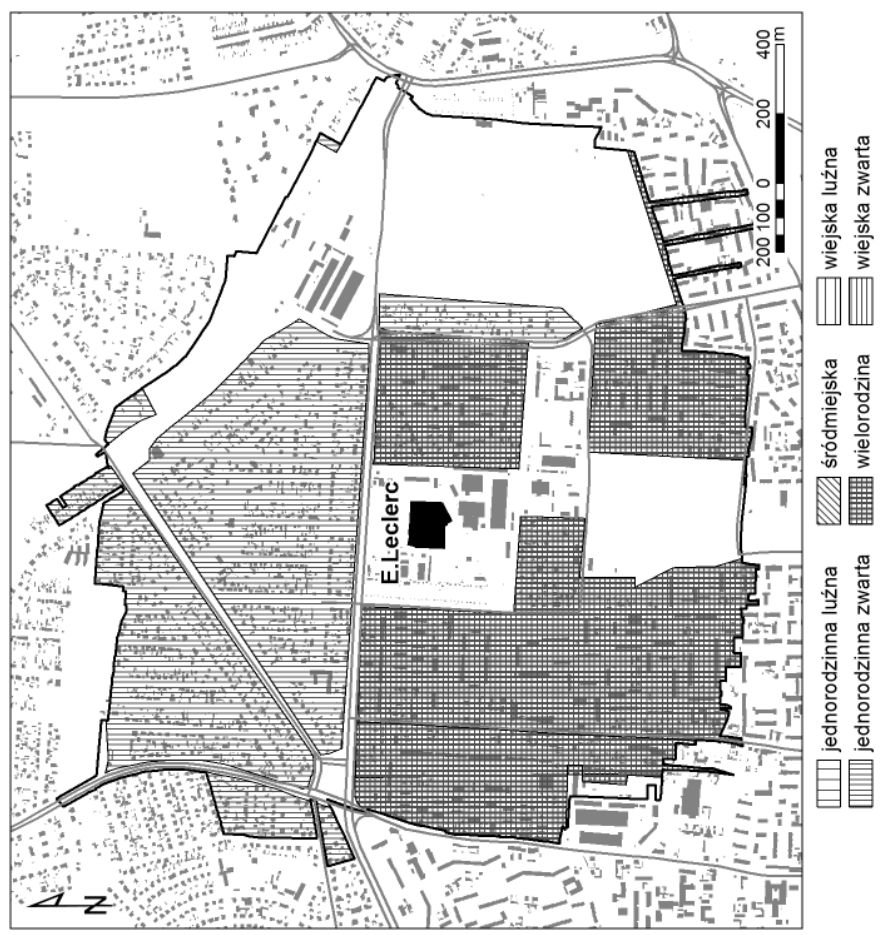

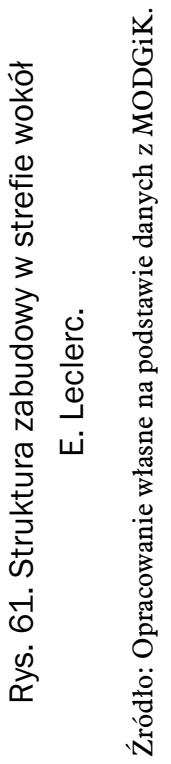




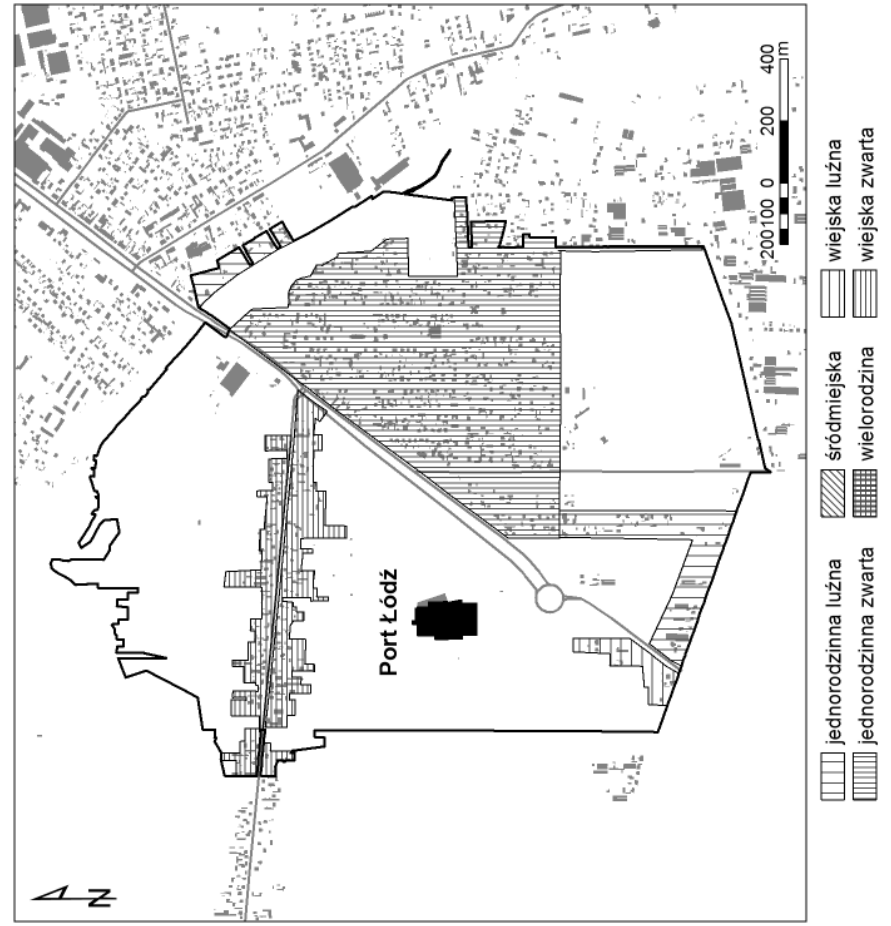

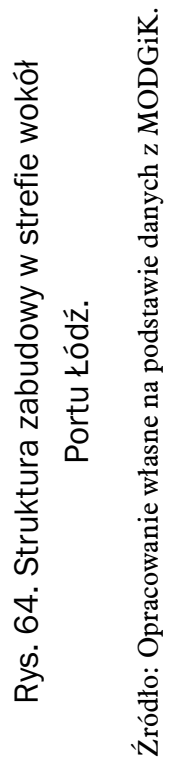

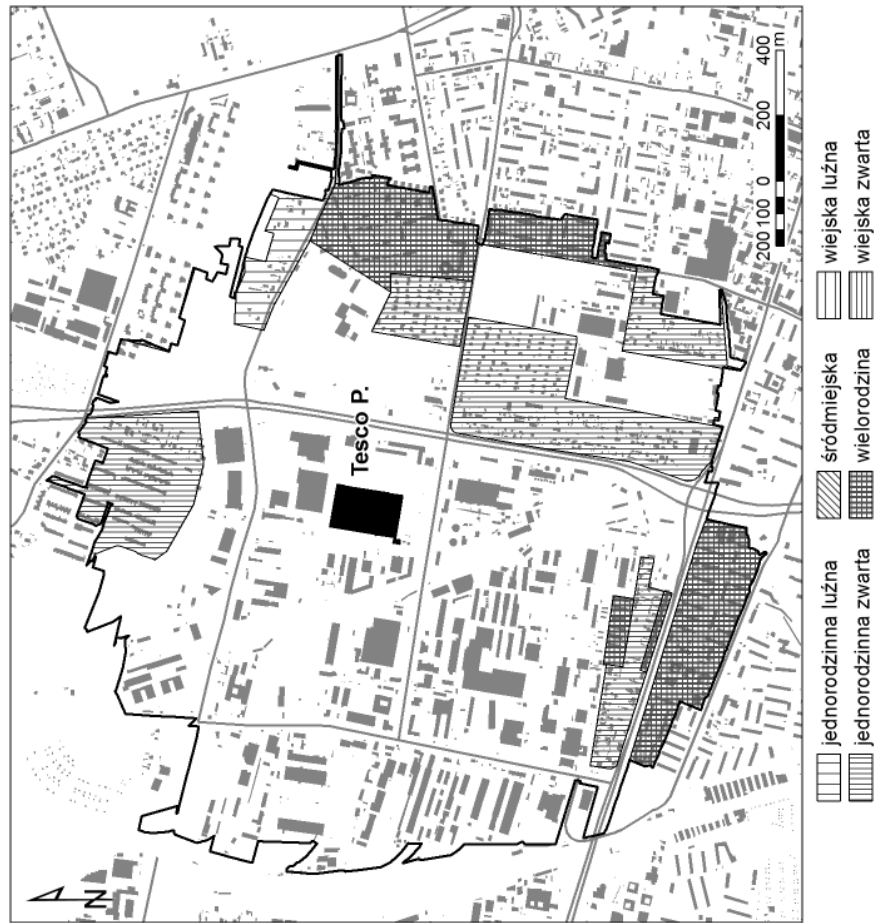

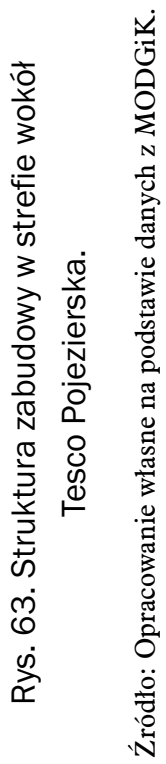



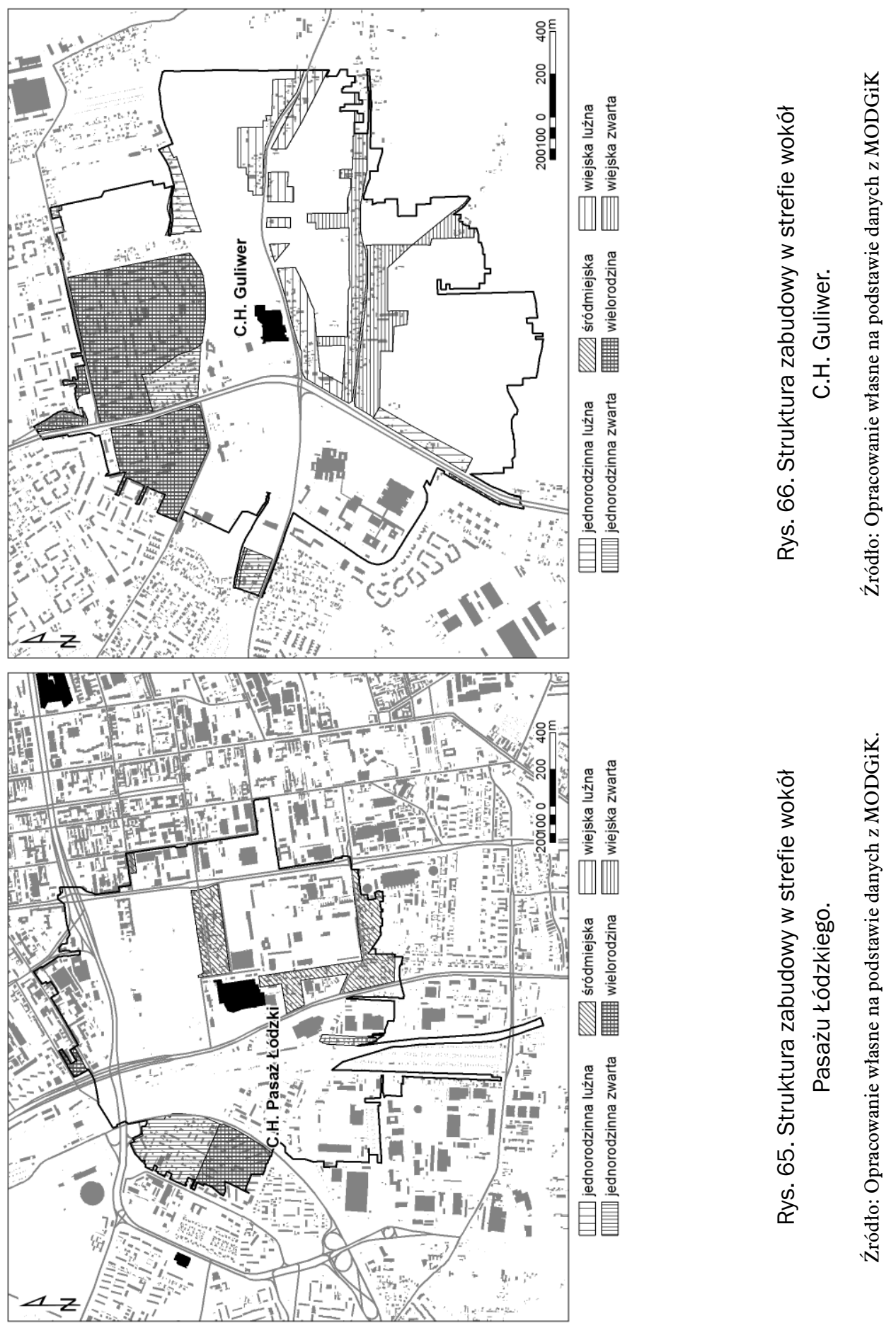

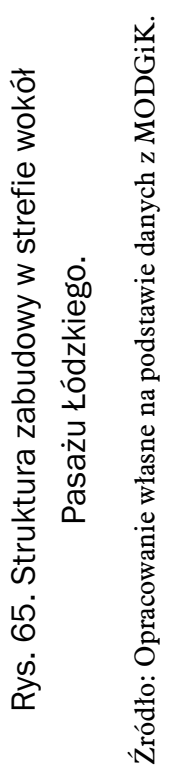


Struktura typów zabudowy w „podstawowych” obszarach handlowych uzależniona jest od położenia danego centrum handlowego w stosunku do centrum miasta i w stosunku do głównych osiedli mieszkaniowych. Dlatego można mówić o kilku rodzajach stref otoczenia ze względu na dominujący typ zabudowy: śródmiejskim, wielorodzinnym, jednorodzinnym i wiejskim.

\subsubsection{Potencjał ludnościowy}

W wyznaczonych strefach wyróżnionych na potrzeby niniejszych badań na podstawie danych z MODGiK określono potencjał ludnościowy. W promieniu 1 kilometra od badanych obiektów najbardziej zurbanizowanymi obszarami są te położone w pobliżu Śródmieścia oraz dużych osiedli mieszkaniowych. Najwięcej potencjalnych klientów mieszka w związku z powyższym w rejonie Manufaktury (ponad 45 tys. osób) i Galerii Łódzkiej (prawie 30 tys.) oraz Tesco W. (ponad 23 tys.) zlokalizowane w jednej z największych dzielnic Łodzi - Widzewie i E. Leclerc (ponad 19 tys.) - w dzielnicy Bałuty. Duży potencjał ludnościowy posiada również strefa wokół C.H. Tulipan położonego na pograniczu Śródmieścia i dzielnicy Widzew (prawie 13 tys.). W tym wypadku niższy potencjał ludnościowy wynika $\mathrm{z}$ faktu, że w okolicy znajdują się tereny poprzemysłowe, komunikacyjne oraz rekreacyjne i leśne (Park 3 Maja). Podobnie wygląda sytuacja strefy wokół Pasażu Ł. (prawie 6 tys.), w której duży udział posiadają tereny komunikacyjne i rekreacyjne (park im. ks. J. Poniatowskiego). Wielofunkcyjną strefę w sąsiedztwie Carrefour P. zamieszkuje prawie 9 tys. osób, w niej znaczny udział posiadają tereny komunikacyjne, rolnicze i przemysłowe (po około 20\%). Podobnym potencjałem ludnościowym dysponują w znacznej mierze przemysłowe strefy wokół Carrefour Sz. (ponad 9,5 tys.) i Tesco P. (prawie 7 tys.) oraz rolnicza strefa C.H. Guliwer (ponad 8,5 tys.). Dwa $z$ badanych kompleksów są zlokalizowane na obrzeżu miasta, wśród terenów rolniczych z przeważającą zabudową jednorodzinną, z czego wynika dużo mniejszy potencjał ludnościowy w ich strefach Port Łódź (ponad 1,6 tys.) oraz C.H. M1 (prawie 0,8 tys.). W tych dwóch przypadkach potencjał ludnościowy najbliższych okolic jest niewielki w porównaniu ze strefami wokół pozostałych centrów handlowych (rys. 67). Z powyższej analizy widać, że przy lokalizacji centrów handlowych znaczenie odgrywała bliskość zamieszkania potencjalnych nabywców. 


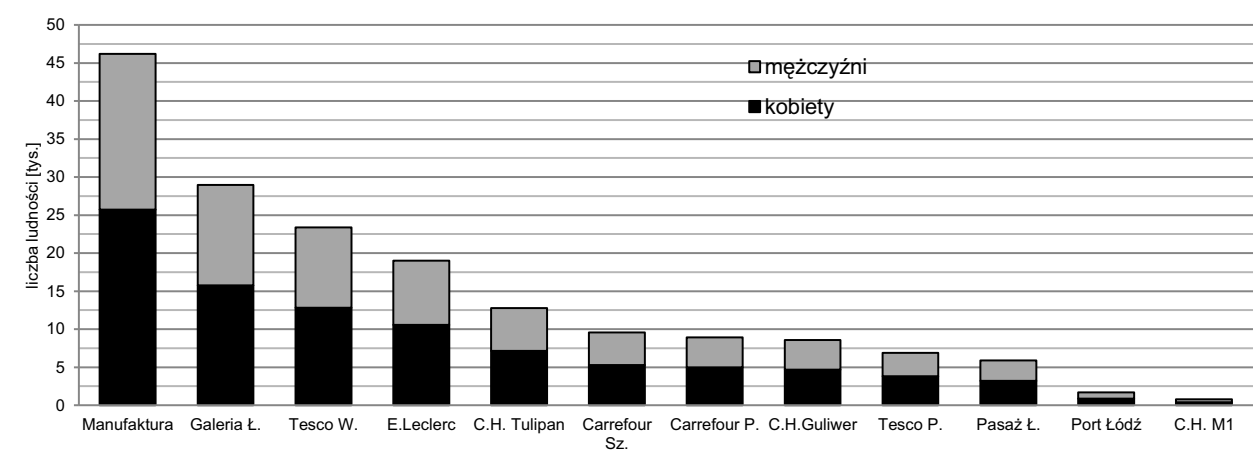

Rys. 67. Liczba ludności według płci w strefach wokół centrów handlowych w 2009 roku.

Źródło: Opracowanie własne na podstawie danych z MODGiK.

Takie same zależności zauważymy, przyglądając się gęstości zaludnienia w badanych strefach. W przypadku sześciu kompleksów Manufaktura, Galeria Łódzka, Tesco W., E. Leclerc, C.H. Tulipan i Carrefour Sz. wskaźnik ten przyjmuje wartości wyższe niż średnia liczona dla miasta Łodzi (ponad 2,5 tys. osób $/ \mathrm{km}^{2}$ ). Najwyższą wartość indykator posiada w otoczeniu Manufaktury (ponad 12 tys. osób $/ \mathrm{km}^{2}$ ) oraz Galerii Łódzkiej (ponad 9 tys. osób/ $\mathrm{km}^{2}$ ). Zdecydowanie najniższą gęstość zaludnienia posiadają tereny sąsiadujące z Portem Łódź (niecałe 500 osób $/ \mathrm{km}^{2}$ ) oraz C.H. M1 (tylko niecałe $218 \mathrm{osób} / \mathrm{km}^{2}$ ) (rys. 68), czyli te położone peryferyjnie w stosunku do głównych obszarów mieszkaniowych miasta.

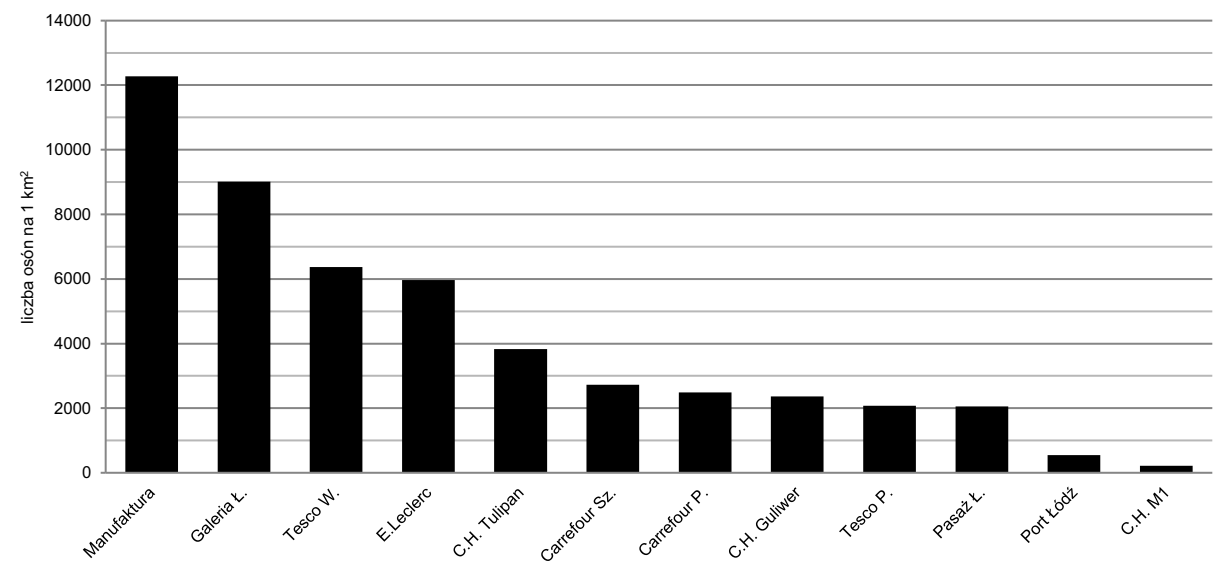

Rys. 68. Gęstość zaludnienia w strefach wokół centrów handlowych w 2009 roku. Źródło: Opracowanie własne na podstawie danych z MODGiK. 
We wszystkich badanych strefach zauważalna jest przewaga liczebna kobiet nad mężczyznami, co wyraża współczynnik feminizacji. W Łodzi indykator ten przyjmuje wartość około 120 kobiet na 100 mężczyzn. Większość badanych „sąsiedzkich" stref (7) posiada ten wskaźnik wyższy od średniej dla miasta. Najwyższymi wskaźnikami charakteryzują się obszary w okolicach: C.H. Tulipan (127,2), Carrefour P. (126,8), Manufaktura (125,4), E. Leclerc (124,9), Tesco P. (123,1), Carrefour Sz. (122,7) i Tesco W. (121,4). W trzech następnych strefach współczynnik feminizacji przyjmuje wartości zbliżone do średniej liczonej dla całego miasta: Pasaż Łódzki (119,6), Galeria Łódzka $(119,4)$ i C.H. Guliwer $(119,4)$. Najbardziej wyrównane proporcje między płciami występują w strefie Portu Łódź $(111,1)$ oraz C.H. M1 $(105,7)$.

W Łodzi dzieci i młodzieży w wieku do 19. roku życia mieszka około $16 \%$, w wieku produkcyjnym (20-64 lat) jest prawie 64\% osób, a powyżej 65. roku życia 20\%. Największym udziałem najmłodszej grupy wiekowej charakteryzują się strefy wokół: C.H. M1 (20,1\%), Galerii Łódzkiej (18,3\%), Manufaktury (17,9\%), Pasażu Ł. (17,5\%) oraz Portu Łódź (16,6\%). Natomiast odsetek osób w najstarszych rocznikach jest najwyższy w strefach: Carrefour P. (23,6\%), Carrefour Sz. (22,8\%), Tesco P. (22,3\%) i C.H. Tulipan (21,8\%). Natomiast największym udziałem ludności w wieku produkcyjnym, zdecydowanie powyżej średniej łódzkiej, charakteryzują się tereny w pobliżu: C.H. Guliwer (75,4\%), Tesco W. (72,3\%), Galerii Łódzkiej (68,9\%) oraz Portu Łódź (67,1\%) (rys. 69).

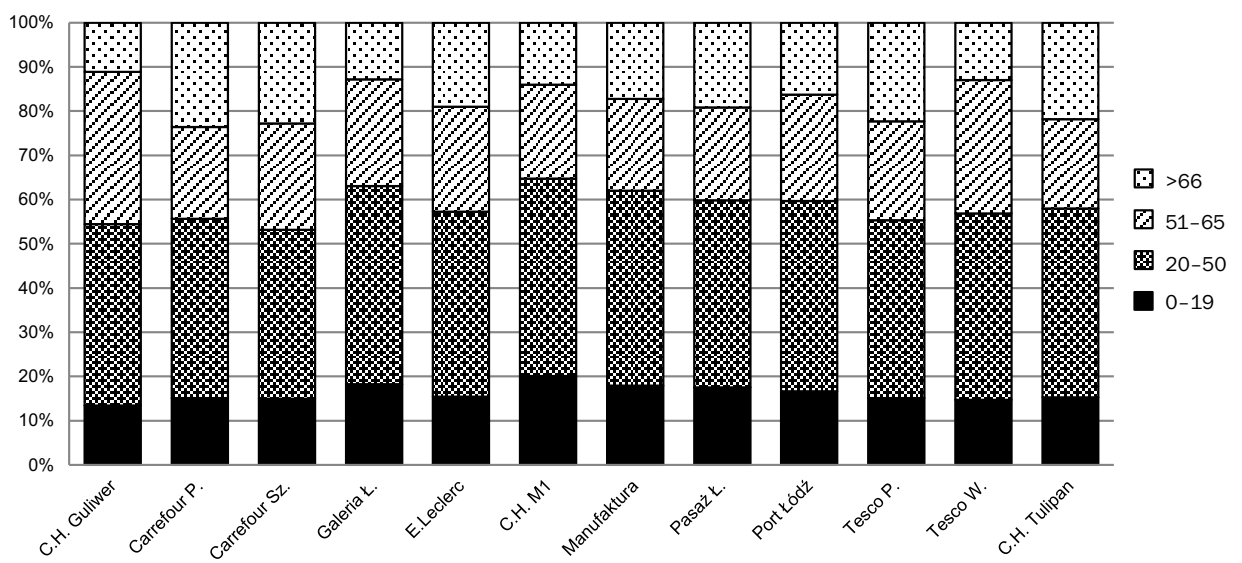

Rys. 69. Struktura ludności według wieku w strefach wokół centrów handlowych w 2009 roku.

Źródło: Opracowanie własne na podstawie danych z MODGiK. 
Najkorzystniejsza sytuacja pod względem demograficznym występuje na obszarach wokół C.H. M1 (na 100 osób w wieku $66<$ przypada tam 143,2 dzieci i młodzieży poniżej 19. roku życia), Galerii Łódzkiej (142,3), C.H. Guliwer (121,2), Tesco W. (113,7) i Portu Łódź (102,2). Na pozostałych terenach mieszka więcej osób w starszych rocznikach i w tych wypadkach indykator przyjmuje wartości poniżej 100. Najniższe odnotowuje się w sąsiedztwie Carrefour P. (63,9), Carrefour Sz. $(65,5)$, Tesco P. $(67,6)$, C.H. Tulipan (69,9), E. Leclerc (81,3) oraz Pasażu Łódzkim $(91,6)$ (rys. 70).

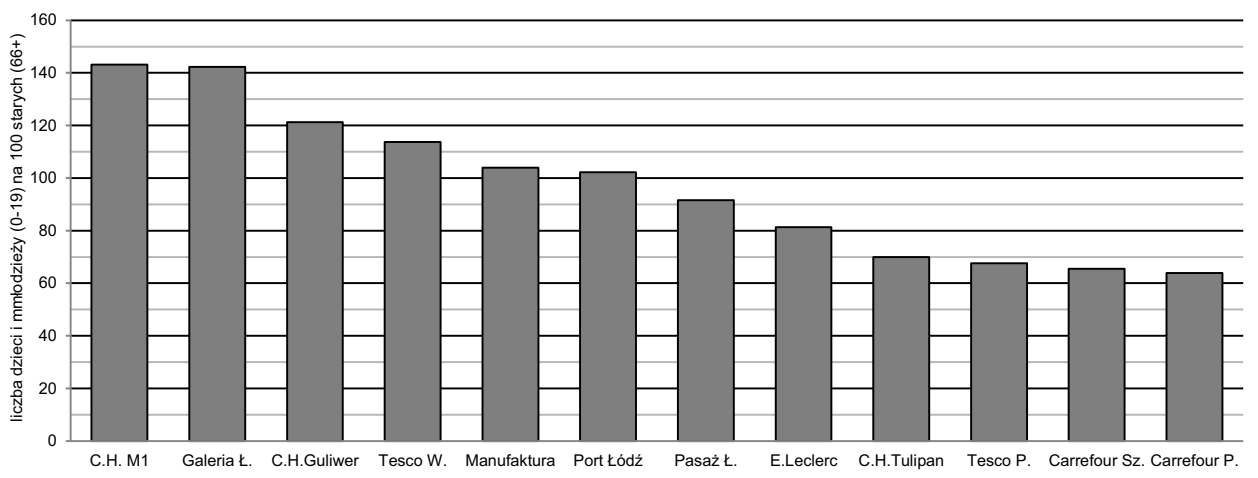

Rys. 70. Wartość współczynnika starości w strefach wokół centrów handlowych w 2009 roku.

Źródło: Opracowanie własne na podstawie danych z MODGiK.

Analiza potencjału ludnościowego w strefach otaczających łódzkie centra handlowe wykazała, że najwięcej potencjalnych nabywców mieszkających w pobliżu badanych kompleksów posiadają te centra handlowe, które zostały zlokalizowane w Śródmieściu i jego okolicach oraz w pobliżu osiedli mieszkaniowych z zabudową wielorodzinną. Natomiast najmniejszym potencjałem ludnościowym charakteryzują się strefy Portu Łódź i C.H. M1, w których otoczeniu dominują obszary niezamieszkane lub te z zabudową jednorodzinną. We wszystkich strefach tak jak w całej Łodzi przeważają liczbowo kobiety, zdecydowanie najmniejsze dysproporcje występują w okolicach Portu Łódź i C.H. M1 położonych peryferyjnie. Najmłodsze społeczeństwo ze sporym odsetkiem dzieci i młodzieży poniżej 19. roku życia mieszka w okolicach C.H. M1 i Galerii Łódzkiej. Najmniej korzystna sytuacja demograficzna występuje w okolicach: Carrefour P., Carrefour Sz., Tesco P. i C.H. Tulipan. 


\subsubsection{Oferta usługowa terenów przyległych}

Centra handlowe jako duże powierzchniowo kompleksy ze zróżnicowaną ofertą generują potoki ludzkie, wśród których duży udział stanowią klienci zmotoryzowani. Ze względu na przemieszczanie się osób po głównych „drogach przepływu” mogą oni stać się potencjalnymi klientami innych placówek usługowych zlokalizowanych w pobliżu takich centrów handlowych, w takim przypadku centra handlowe mogą stać się swego rodzaju czynnikiem lokalizacji dla niektórych firm usługowych. Położenie firmy w bezpośrednim sąsiedztwie centrum handlowego może wpłynąć na umocnienie jej pozycji na rynku i lepszy punkt wyjścia w walce o klienta.

A. Sobala-Gwosdz, K. Gwosdz (2011, s. 284) zauważają, że oddziaływanie hipermarketów na ich otoczenie gospodarcze nie doczekało się w Polsce kompleksowych badań. Wskazali oni na pewne mechanizmy oddziaływania pozytywnego i negatywnego sklepów wielkopowierzchniowych na ich otoczenie (w kontekście obszaru Polski Wschodniej). Przeprowadzone przez tych autorów badania w 2001 roku wśród przedsiębiorców (województwo śląskie i dolnośląskie) pokazały, że „po otwarciu hipermarketu $\mathrm{w}$ okolicy obroty $\mathrm{w}$ istniejących sklepach natychmiast spadły, następnie znacznie już wolniej nastąpiło odrobienie części strat i ukształtowanie się ich na nowym poziomie, wyższym niż w kilka tygodni po otwarciu hipermarketu, ale niższym niż przed wejściem placówki wielkopowierzchniowej na rynek" (rys. 71).

W bezpośrednim sąsiedztwie centrów handlowych lokalizują się inne podmioty gospodarcze, szczególnie punkty świadczące usługi ${ }^{112}$. W celu identyfikacji rodzajów punktów usługowych w pobliżu badanych centrów handlowych dokonano szczegółowej inwentaryzacji terenów ich otaczających. Zgodnie z przyjętymi założeniami i w celu uzyskania porównywalnych wyników zinwentaryzowano wszystkie działki stykające się $\mathrm{z}$ terenem zarządzanym przez zarządcę danego kompleksu handlowego. W przypadku gdy taki teren był oddzielony drogą kilkupasmową, uznano ją jako barierę i nie przeprowadzono badań obszarów po drugiej jej stronie.

${ }^{112} \mathrm{~W}$ tym rozdziale zwrócono uwagę tylko na punkty usługowe, ponieważ w centrach handlowych świadczy się głównie szeroki wachlarz usług (w tym oczywiście głównie usługi handlowe). Chodziło o przyjrzenie się bliżej, w jakim stopniu placówki usługowe zlokalizowane w otoczeniu centrów handlowych są komplementarne w stosunku do oferty centrów handlowych. 


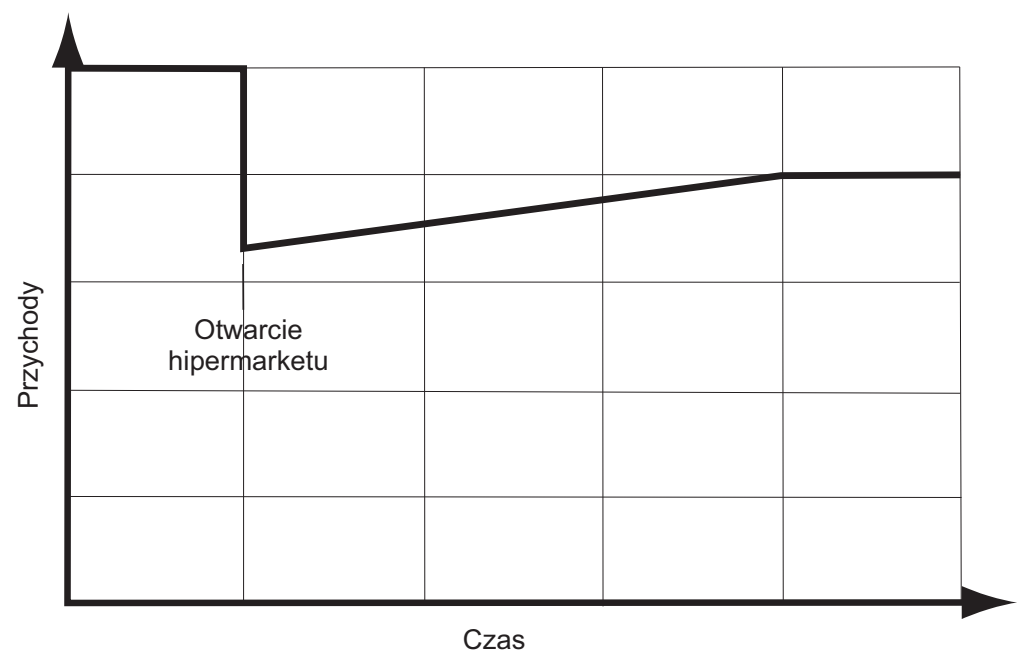

Rys. 71. Model oddziaływania hipermarketu na sklepy zlokalizowane w jego sąsiedztwie.

Źródło: A. Sobala-Gwosdz, K. Gwosdz, 2011, Polska Wschodnia w strategiach lokalizacji sieci hipermarketów, [w:] Nierówności spoteczne a wzrost gospodarczy. Uwarunkowania sprawnego dziatania w przedsiębiorstwie i regionie, z. 20, Uniwersytet Rzeszowski, s. 285.

W ramach strefy, której zarządcą i właścicielem jest podmiot zarządzający głównym obiektem, znajdują się parking samochodowy oraz często kilka podmiotów gospodarczych, którymi najczęściej są stacje benzynowe, automyjnie oraz placówki serwisowe i stacje kontroli pojazdów (tylko przy Galerii Łódzkiej nie świadczone są tego typu usługi). Stacje benzynowe zlokalizowane są przy siedmiu badanych kompleksach, niektóre $z$ nich są firmowane marką głównego hipermarketu i zarządzane przez te firmy (na przykład Carrefour, Tesco i E. Leclerc), a obok niektórych funkcjonują również stacje innych firm, na przykład przy C.H. Guliwer stacja BP, przy C.H. M1 PKN Orlen, a przy E. Leclerc stacja paliw Lukoil. Przy większości (10) centrów handlowych znajdują się automyjnie, a w niektórych przypadkach nawet po dwie, na przykład przy C.H. Guliwer, Carrefour P. i Pasażu Łódzkim.

W bezpośrednim otoczeniu łódzkich centrów handlowych zidentyfikowano 186 placówek usługowych. Z przeprowadzonych badań wynika, że w pobliżu badanych obiektów zlokalizowane są głównie podmioty rejestrowane w sekcji $\mathrm{G}$ (handel hurtowy i detaliczny; naprawa pojazdów samochodowych, włączając motocykle), których zidentyfikowano 97 - co stanowi 52,2\% wszystkich placówek. Po kilkanaście placówek zaklasyfiko- 
wano do sekcji S (pozostała działalność usługowa), M (działalność profesjonalna, naukowa i techniczna) oraz $\mathrm{H}$ (transport i gospodarka magazynowa) (tab. 27).

\section{Tabela 27}

Struktura placówek usługowych zlokalizowanych w bezpośrednim sąsiedztwie centrów handlowych według sekcji PKD

\begin{tabular}{|c|c|c|c|c|c|c|c|c|c|c|c|c|c|c|c|c|c|}
\hline \multirow{2}{*}{$\begin{array}{l}\text { Centrum } \\
\text { handlowe }\end{array}$} & \multicolumn{16}{|c|}{ Sekcje PKD } & \multirow{2}{*}{$\begin{array}{c}\text { Łącz- } \\
\text { nie }\end{array}$} \\
\hline & $D$ & $E$ & $F$ & $G$ & $\mathrm{H}$ & $\mathrm{I}$ & $\mathrm{J}$ & $\mathrm{K}$ & $\mathrm{L}$ & $M$ & $\mathrm{~N}$ & 0 & $P$ & $\mathbf{Q}$ & $\mathbf{R}$ & $S$ & \\
\hline Galeria Łódzka & - & - & - & 9 & 1 & 3 & - & 3 & 1 & 2 & 5 & - & 5 & - & - & 7 & 36 \\
\hline Pasaż Łódzki & - & - & 3 & 8 & 2 & - & 1 & 2 & - & 6 & 1 & - & 1 & 1 & - & - & 26 \\
\hline Manufaktura & 1 & - & - & 7 & 1 & 1 & - & - & - & - & 3 & - & 1 & 1 & 3 & 6 & 24 \\
\hline C.H. Tulipan & - & - & - & 14 & 1 & - & - & 1 & - & 1 & 1 & - & - & 1 & - & 2 & 21 \\
\hline C.H. M1 & - & - & 1 & 10 & 5 & - & - & 1 & - & 1 & - & 1 & - & - & - & - & 19 \\
\hline Tesco P. & - & - & - & 17 & 1 & - & - & - & - & 1 & - & - & - & - & - & - & 19 \\
\hline C.H. Guliwer & - & 1 & - & 12 & - & - & - & - & - & - & - & - & - & - & - & - & 13 \\
\hline Carrefour P. & - & - & 1 & 5 & - & - & - & - & - & 2 & - & - & - & - & - & - & 8 \\
\hline E. Leclerc & - & - & - & 6 & - & 1 & - & - & - & - & - & - & - & - & 1 & - & 8 \\
\hline Carrefour Sz. & - & - & - & 5 & - & - & - & - & - & - & - & - & - & 1 & - & - & 6 \\
\hline Tesco W. & - & - & 2 & 4 & - & - & - & - & - & - & - & - & - & - & - & - & 6 \\
\hline Port Łódź & - & - & 1 & - & - & - & - & - & - & - & - & - & - & - & - & - & 1 \\
\hline Łącznie & 1 & 1 & 8 & 97 & 11 & 5 & 1 & 7 & 1 & 13 & 10 & 1 & 7 & 4 & 4 & 15 & 186 \\
\hline
\end{tabular}

D - wytwarzanie i zaopatrywanie w energię elektryczną, gaz, parę wodną, gorącą wodę i powietrze do układów klimatyzacyjnych; E - dostawa wody; gospodarowanie ściekami i odpadami oraz działalność związana z rekultywacją; F - budownictwo; G - handel hurtowy i detaliczny; naprawa pojazdów samochodowych, włączając motocykle; $\mathrm{H}$ - transport i gospodarka magazynowa; I - działalność związana z zakwaterowaniem i usługami gastronomicznymi; J - informacja i komunikacja; $\mathrm{K}$ - działalność finansowa i ubezpieczeniowa; L - działalność związana $\mathrm{z}$ obsługą rynku nieruchomości; $\mathrm{M}$ - działalność profesjonalna, naukowa i techniczna; N działalność w zakresie usług administrowania i działalność wspierająca; - administracja publiczna i obrona narodowa; obowiązkowe zabezpieczenia społeczne; P - edukacja; Q - opieka zdrowotna i pomoc społeczna; $\mathrm{R}$ - działalność związana z kulturą, rozrywką i rekreacją; $\mathrm{S}$ - pozostała działalność usługowa.

Źródło: Opracowanie własne na podstawie badań inwentaryzacyjnych.

Najwięcej placówek usługowych znajduje się w bezpośrednim sąsiedztwie: Galerii Łódzkiej (36), Pasażu Ł. (26), Manufaktury (24), C.H. Tulipan (21), C.H. M1, (19) i Tesco P. (19). Tylko po kilka punktów usługo- 
wych działa w bezpośrednim sąsiedztwie E. Leclerca (8), Carrefoura Sz. (6), Tesco W. (6) i Portu Łódź (1). W strukturze placówek usługowych przy ośmiu obiektach zdecydowanie przeważają punkty zajmujące się handlem (rys. 72).

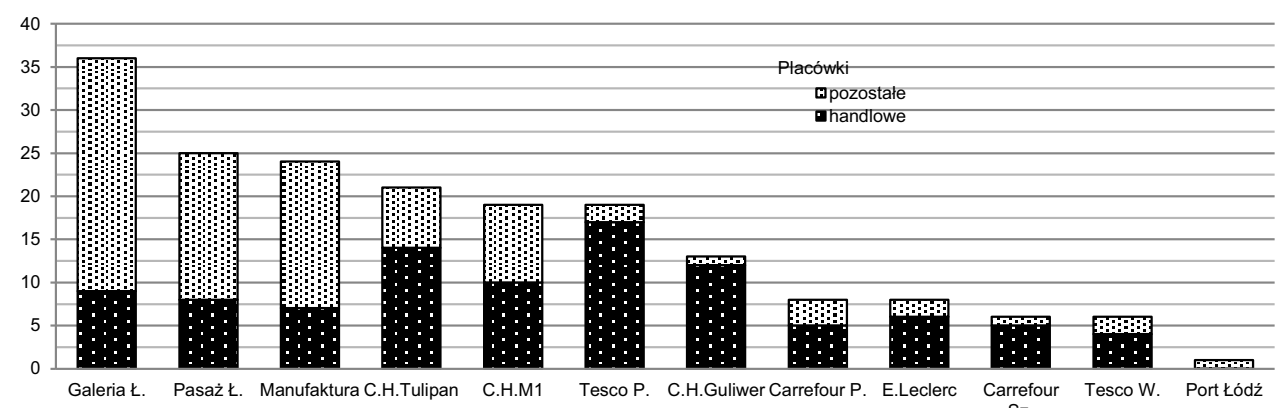

Rys. 72. Liczba placówek usługowych zlokalizowanych w bezpośrednim sąsiedztwie centrów handlowych.

Źródło: Opracowanie własne na podstawie badań inwentaryzacyjnych.

Najwięcej sklepów i hurtowni zlokalizowanych jest w pobliżu Tesco P. (17), C.H. Tulipan (14), C.H. Guliwer (12) i C.H. M1 (10). Należy zauważyć, że w otoczeniu dziewięciu centrów handlowych przeważają placówki handlu detalicznego. W bezpośrednim sąsiedztwie C.H. Guliwer (8) i Pasażu Ł. (6) można skorzystać z oferty największej liczby hurtowni (rys. 73).

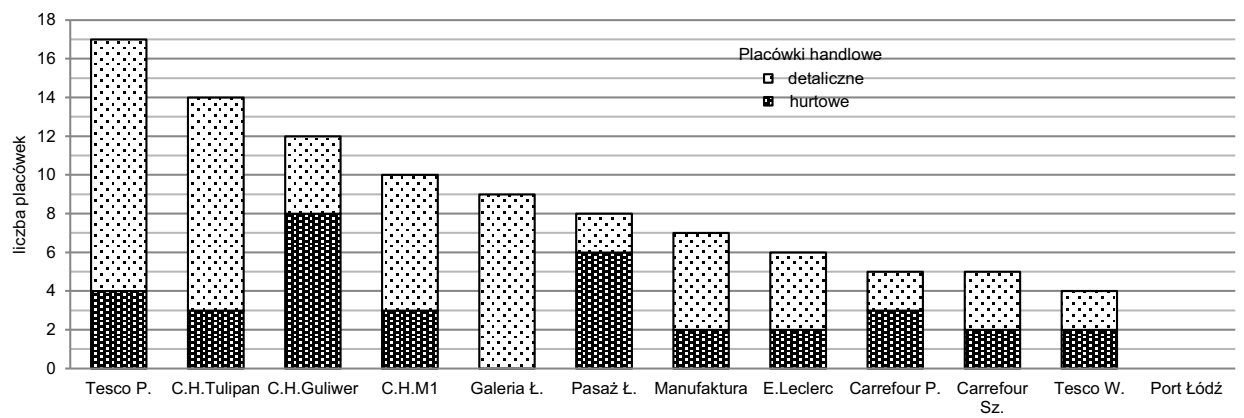

Rys. 73. Liczba placówek handlowych zlokalizowanych w bezpośrednim sąsiedztwie centrów handlowych.

Źródło: Opracowanie własne na podstawie badań inwentaryzacyjnych. 
Lokalizacja zinwentaryzowanych podmiotów gospodarczych wynika zapewne nie tylko z bliskości centrum handlowego, ale może również być uwarunkowana przebiegiem ciągów komunikacyjnych czy sąsiedztwem terenów mieszkaniowych. Niektóre z nich działały jeszcze przed powstaniem centrum, inne rozwinęły swoją działalność przypuszczalnie pod wpływem rozwoju centrum handlowego ${ }^{113}$. Otwarcie centrum handlowego może wpływać na likwidację pewnych podmiotów gospodarczych, lub ich relokacje. $Z$ drugiej strony kompleksy handlowe mogą być magnesem przyciągającym nowe inwestycje, a wręcz stać się czynnikiem ich lokalizacji ${ }^{114}$.

W bezpośrednim sąsiedztwie łódzkich centrów handlowych występują podmioty usługowe, których liczba, struktura i związki lokalizacyjne z tym głównym obiektem mogą pozostawać na różnym poziomie. W sumie w Łodzi można wydzielić pięć typów sytuacyjnych, pokazujących zależności między położeniem centrum handlowego a lokalizacją pobliskich punktów usługowych. Wydzielone typy ukazują jedynie w sposób poglądowy rozmieszczenie placówek usługowych i ich strukturę oraz ewentualne związki lokalizacyjne $\mathrm{z}$ centrum handlowym ${ }^{115}$.

W pierwszym typie wokół centrum handlowego działają tylko pojedyncze punkty usługowe, których działalność nie jest uwarunkowana funkcjonowaniem kompleksu handlowego. W typie drugim w otoczeniu centrum handlowego znajdują się małe i średniej wielkości podmioty usługowe, z których część nie ma żadnych związków z centrum handlowym, ale loka-

\footnotetext{
${ }^{113} \mathrm{~W}$ pracy ze względu na jej zakres nie analizowano szczegółowo czasu powstania poszczególnych podmiotów gospodarczych i nie ustalano wpływu centrum handlowego na ich funkcjonowanie.

${ }^{114} \mathrm{~W} 2010$ roku przeprowadzono wywiady niestandaryzowane z przedsiębiorcami działającymi na obszarze wokół Galerii Łódzkiej. Z 59 osób 45 rozpoczęło w tym miejscu działalność po otwarciu Galerii Łódzkiej (po 2002 roku). Więcej informacji uzyskano jednak tylko od 28 respondentów. $Z$ odpowiedzi przez nich udzielanych wynika, że głównymi czynnikami lokalizacji ich firm były między innymi położenie w centrum miasta i dobry dojazd. Tylko dwie osoby podały za główny czynnik lokalizacji bliskość centrum handlowego. Dla 16 osób Galeria Łódzka wpływa korzystnie na funkcjonowanie ich firm (więcej klientów, lepszy wizerunek dzięki lokalizacji), dwie osoby zauważyły niekorzystny wpływ (zmniejszenie liczby klientów) (Chrzanowska 2011, s. 158-159).

${ }^{115}$ Wyróżnienie tych schematycznych typów powinno dać asumpt do dalszych bardziej pogłębionych badań nad związkami między lokalizacją i funkcjonowaniem placówek usługowych w pobliżu centrów handlowych.
} 
lizacja i działalność niektórych z nich może być w większym lub mniejszym stopniu zdeterminowana istnieniem w ich pobliżu kompleksu handlowego. W typie trzecim obok licznych niewielkich punktów usługowych zostaje zlokalizowane centrum specjalistyczne (profilowane), na przykład Obi, Praktiker, Castorama. Czwarty typ jest podobny do trzeciego, z tą tylko różnicą, że centrum profilowane jest oddzielone od głównego kompleksu handlowego barierą komunikacyjną, na przykład wielopasmową drogą. W związku z tym korzystanie $\mathrm{z}$ oferty obu obiektów w tym samym dniu może być utrudnione (szczególnie dla osób niezmotoryzowanych) lub zachęcić niektórych klientów do zrealizowania swoich zróżnicowanych potrzeb w pobliskich kompleksach (dotyczy to głównie osób zmotoryzowanych). Ostatni piąty typ charakteryzuje się funkcjonowaniem obok centrum handlowego małych punktów handlowych również występowaniem dużych sklepów branżowych na przykład z odzieżą dziecięcą, materiałami budowlanymi (rys. 74).
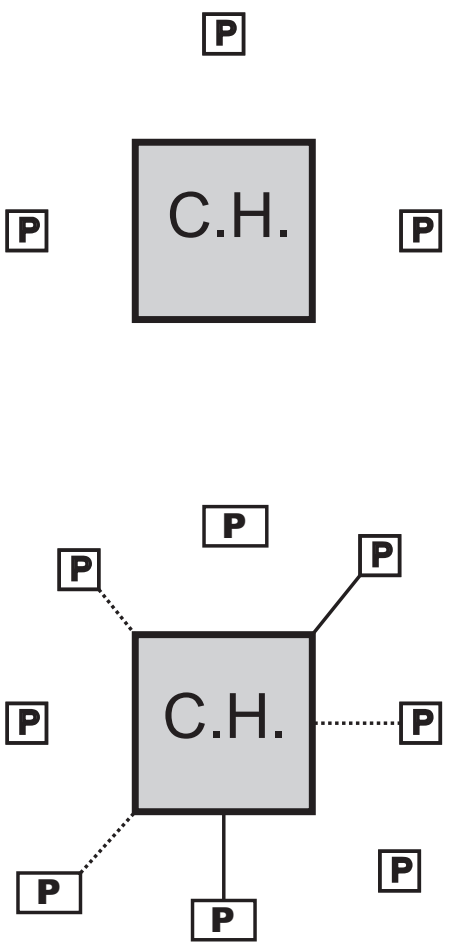

Typ I:

- Port Łódź
Typ II:

- Carrefour P.

- C.H. M1

- Manufaktura

- Tesco W.

- Galeria Łódzka

- C.H. Guliwer

- E. Leclerc 

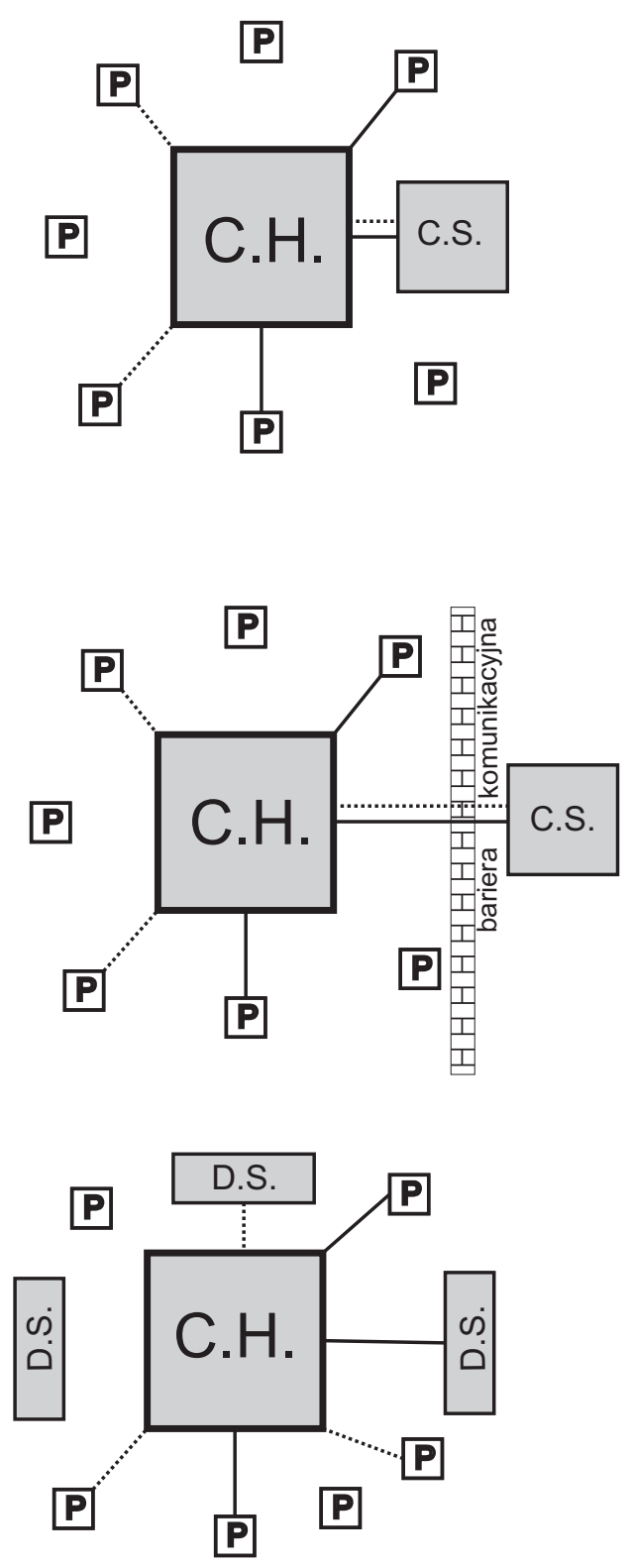

C.H. - centrum handlowe; P - punkty usługowe; C.S. - centrum specjalistyczne; D.S. - duży sklep Rys. 74. Typy zależności lokalizacyjnych między centrum handlowym a pobliskimi punktami usługowymi.

Źródło: Opracowanie własne.
Typ III:

- Carrefour Sz.

- C.H. Tulipan
Typ IV:

- Pasaż Łódzki
Typ V:

- Tesco P. 
Typ 1: Do pierwszego typu zaklasyfikowano Port Łódź i jego okolice (rys. 75), który jest położony na obrzeżach miasta wśród terenów wykorzystywanych głównie rolniczo, słabo zurbanizowanych, w związku z czym brak w tym miejscu placówek usługowych (tylko firma budowlana Dom-Tom). Należy pamiętać, że jest to stosunkowo nowe centrum handlowe w Łodzi, które nie wywarło jeszcze większego wpływu na rozwój gospodarczy terenów sąsiednich. Dodatkowo parkingi wokół centrum zajmują duży teren, a jego klientami są głównie osoby zmotoryzowane. Placówki usługowe natomiast można znaleźć za barierą komunikacyjną, jaką jest w tym przypadku ulica Pabianicka, ale są to głównie punkty usługowe obsługujące lokalnych mieszkańców, niezwiązane z kompleksem handlowym, jakim jest Port Łódź.

Typ 2: Drugi typ reprezentuje w Łodzi największa liczba centrów handlowych, a zaliczono do niego: Carrefour P., C.H. M1, Manufakturę, Tesco W., Galerię Łódzką, C.H. Guliwer i E. Leclerc. W bezpośrednim sąsiedztwie wszystkich wymienionych centrów handlowych działalność prowadzą liczne punkty usługowe, których obecność w tym miejscu w różnym stopniu może być związana $\mathrm{z}$ istnieniem danego kompleksu.

Kompleks Manufaktury położony jest wśród terenów mieszkaniowych, w związku z czym w rejonie tym funkcjonuje wiele placówek usługowych. Podmioty gospodarcze są głównie zlokalizowane przy ulicy Ogrodowej i Drewnowskiej, często są to usługi niezwiązane z funkcjonowaniem centrum, na przykład Biblioteka Publiczna, Wojewódzkie Centrum Ortopedii i Rehabilitacji Narządów Ruchu, Zespół Szkół Ponadgimnazjalnych, Urząd Miasta. Przy ulicy Drewnowskiej swoje siedziby mają ponadto takie firmy usługowe jak fryzjerskie, kosmetyczne, Robokop (wulkanizacja opon i sprzedaż części samochodowych), SPS Electronics (biuro handlowe zajmujące się systemami zabezpieczeń) oraz kompleks budynków fabrycznych, magazynowych i administracyjnych firmy Polfa Łódź. Naprzeciwko wejścia na teren kompleksu od ulicy Drewnowskiej działa supermarket Biedronka.

Galeria Łódzka tak jak Manufaktura zlokalizowana została niedaleko ulicy Piotrkowskiej. W przypadku Manufaktury hotel wchodzi w skład kompleksu, stanowiąc jego integralną część, natomiast Galeria Łódzka nie ma w swojej ofercie tego typu usług. Uzupełnieniem jednak pakietu usługowego są dwa hotele Ambasador i Campanille (oraz Ibis położony też niedaleko). Większość placówek usługowych zlokalizowanych w pobliżu 


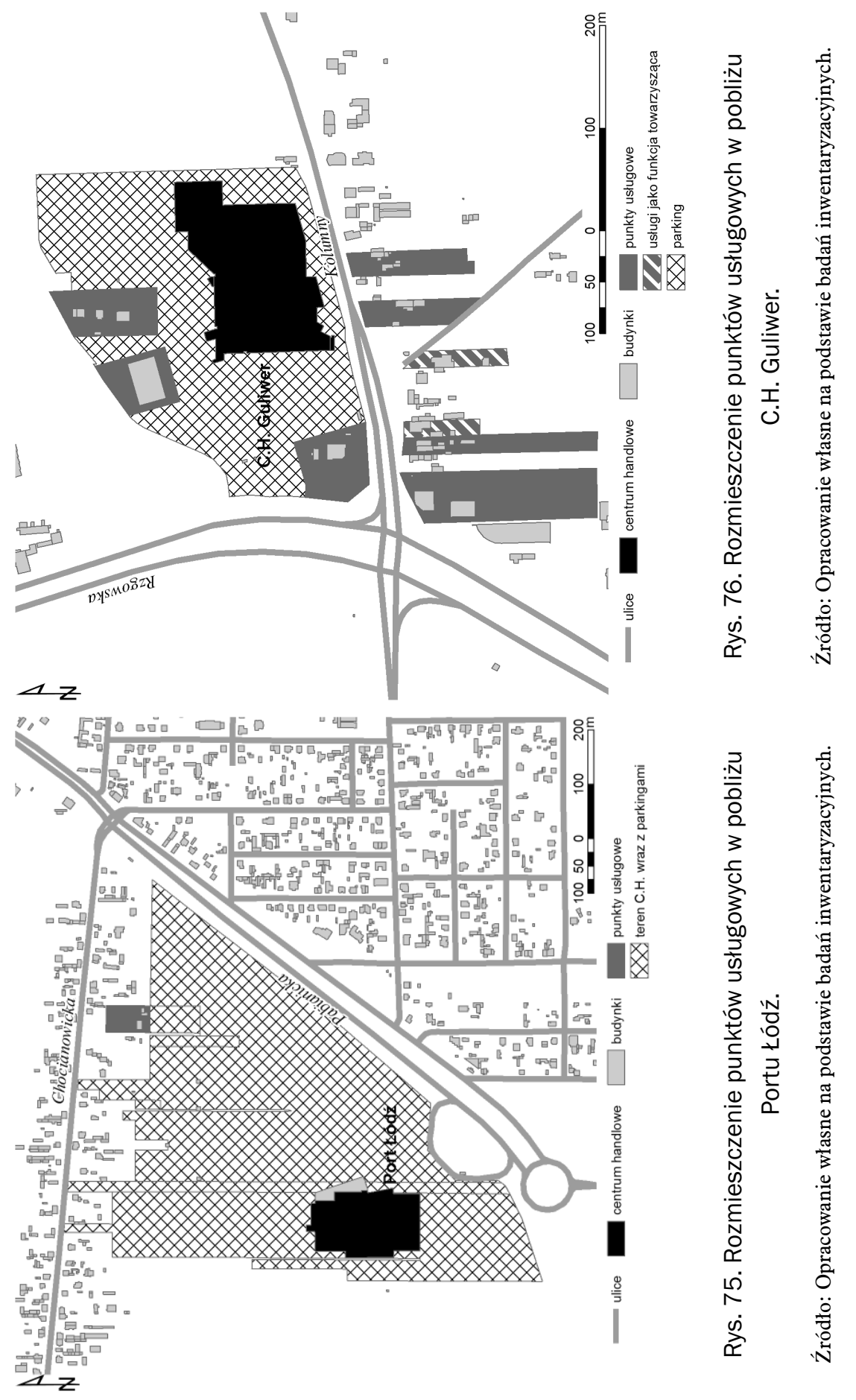


to małe punkty mieszczące się w parterach kamienic $\mathrm{z}$ usługami dla ludności, na przykład cztery biura podróży, salony kosmetyczne (4), sklepy w tym specjalistyczne (salon ślubny, zdrowa żywność, ubranka dla dzieci, alkoholowy, z akcesoriami myśliwskimi), usługi ubezpieczeniowe czy punkty serwisowe komputerów.

Centrum handlowe Tesco W. położone w dzielnicy Widzew znajduje się na obszarze o przeważającej funkcji mieszkaniowej. W jej sąsiedztwie działa więc tylko kilka niewielkich firm, na przykład „Bomar_com” (instalacja wideo domofonów), „Osiecka ZTRMO” (usługi w zakresie elektronicznej ochrony). Jedyną większą placówką handlową jest zlokalizowany naprzeciwko supermarket Biedronka.

W dzielnicy Łódź Bałuty przy ulicy Inflanckiej znajduje się E. Leclerc, otoczony ze wszystkich stron terenami mieszkaniowymi i usługowymi. W bezpośrednim sąsiedztwie tego centrum handlowego swoje lokalizacje znalazły między innymi: firma Ice Full zajmująca się dystrybucją napojów alkoholowych, Saunopol (hurtownia artykułów sanitarnych), sklep sieciowy Pepco, sklep z artykułami do fitness, sklep Tanagram (sprzedaż mebli kuchennych), Psotna Kraina (bajkoland), fryzjer czy hostel Molo.

W sąsiedztwie Carrefour P. pod względem wyposażenia go w tereny usługowe zwracają uwagę dwie rzeczy. Po pierwsze przy ulicy Przybyszewskiego (wjazd do Carrefoura) znajdują się duże salony samochodowe: Jaguar, Idczak i Przyguccy Inter-Car. Po drugie od strony wschodniej w dużym budynku magazynowym swoje siedziby mają różne firmy usługowe - pracownia protetyki, agencja reklamowa, biuro rachunkowe oraz magazyny.

C.H. M1 od zachodu sąsiaduje z terenami przemysłowo-usługowymi i to właśnie na tych terenach oraz przy ulicy Brzezińskiej zlokalizowały się placówki usługowe. $Z$ bardziej znanych firm należy wymienić sklep meblowy „Meble Bodzio”, salon płytek ceramicznych „Inspiro by Paradyż”, firmę produkcyjno-handlową „Chin-tex” (dzianiny), ZUS, Instytut Włókiennictwa. W strefie tej działają również magazyny, na przykład magazyn mebli „Rectiker”, oraz funkcjonują, podobnie jak w okolicach Carrefour P., salony samochodowe. Jeden $\mathrm{z}$ nich po tej samej stronie co centrum „Damis Motor Polska”, a dwa po drugiej stronie ulicy Brzezińskiej „Ford” i „Toyota” (następny jest w budowie).

C.H. Guliwer zlokalizowane jest na obrzeżach miasta. Funkcjonujące w pobliżu placówki usługowe związane są głównie z motoryzacją i są to sa- 
lony samochodowe „Dealer Mitsubishi” i „Norauto”, mieszalnia lakierów (w tym sprzedaż akcesoriów do samochodów), punkty serwisowe „Auto-Serwis” i „Mobile 1” oraz „Auto-Gaz” (sprzedaż gazu do samochodów) (rys. 76).

Typ 3: Do typu trzeciego zaklasyfikowano dwa centra handlowe: Carrefour przy ul. Szparagowej oraz C.H. Tulipan. W przypadku tych dwóch kompleksów w bezpośrednim ich sąsiedztwie obok małych punktów usługowych zlokalizowano również centra specjalistyczne (profilowane), które tworzą łącznie $z$ centrami handlowymi wizualną całość i są połączone ze sobą wspólnymi parkingami ${ }^{116}$. Naprzeciwko Carrefoura Sz. znajduje się OBI, natomiast z C.H. Tulipan sąsiaduje Castorama (rys. 77). Tak bliskie sąsiedztwo hipermarketów budowlanych ewidentnie wzbogaca ofertę miejsca (uatrakcyjnia je), umożliwia też klientom w tym samym czasie i prawie w tym samym miejscu zaspokajać różnorodne potrzeby zakupowe. Tego typu obiekty nie konkurują ze sobą, ponieważ są nastawione na sprzedaż innej kategorii asortymentu.

Typ 4: Centrum handlowe Pasaż Łódzki położone jest przy jednej z głównych arterii komunikacyjnych Łodzi, ulicy Jana Pawła II. Po drugiej stronie trasy znajduje się hipermarket specjalistyczny Castorama, który stanowi rozwinięcie oferty tego obszaru o asortyment budowlany i wyposażenie wnętrz (rys. 78). Bliskie położenie tych dwóch obiektów względem siebie może zachęcać klientów do zaspokajania swoich potrzeb $z$ różnego zakresu w tym samym czasie. Jednak przedzielenie ich barierą w postaci wielopasmowej trasy może stanowić poważne utrudnienie i dyskomfort szczególnie dla klientów pieszych, przemieszczających się miejskimi środkami transportu, lub przybywających do centrum liniami bezpłatnej komunikacji. W bezpośrednim otoczeniu Pasażu Łódzkiego znajduje się 26 punktów usługowych, głównie są to kancelarie prawnicze, firmy doradcze i promocyjne.

Typ 5: Piąty typ reprezentuje kompleks handlowy Tesco przy ulicy Pojezierskiej, otoczony wianuszkiem różnych firm usługowych, które nie tylko bezpośrednio sąsiadują z centrum, ale wejście do nich jest z parkingu należącego do centrum. Sztandarowymi dużymi placówkami handlowymi są tu: Komfort, Jysk, Agata Meble, multimarket Jula (sprzęt do majster-

${ }^{116}$ Kompleks C.H. Tulipan powstał wcześniej niż Castorama, natomiast centrum handlowe Carrefour Sz. wybudowano później niż market Obi. 

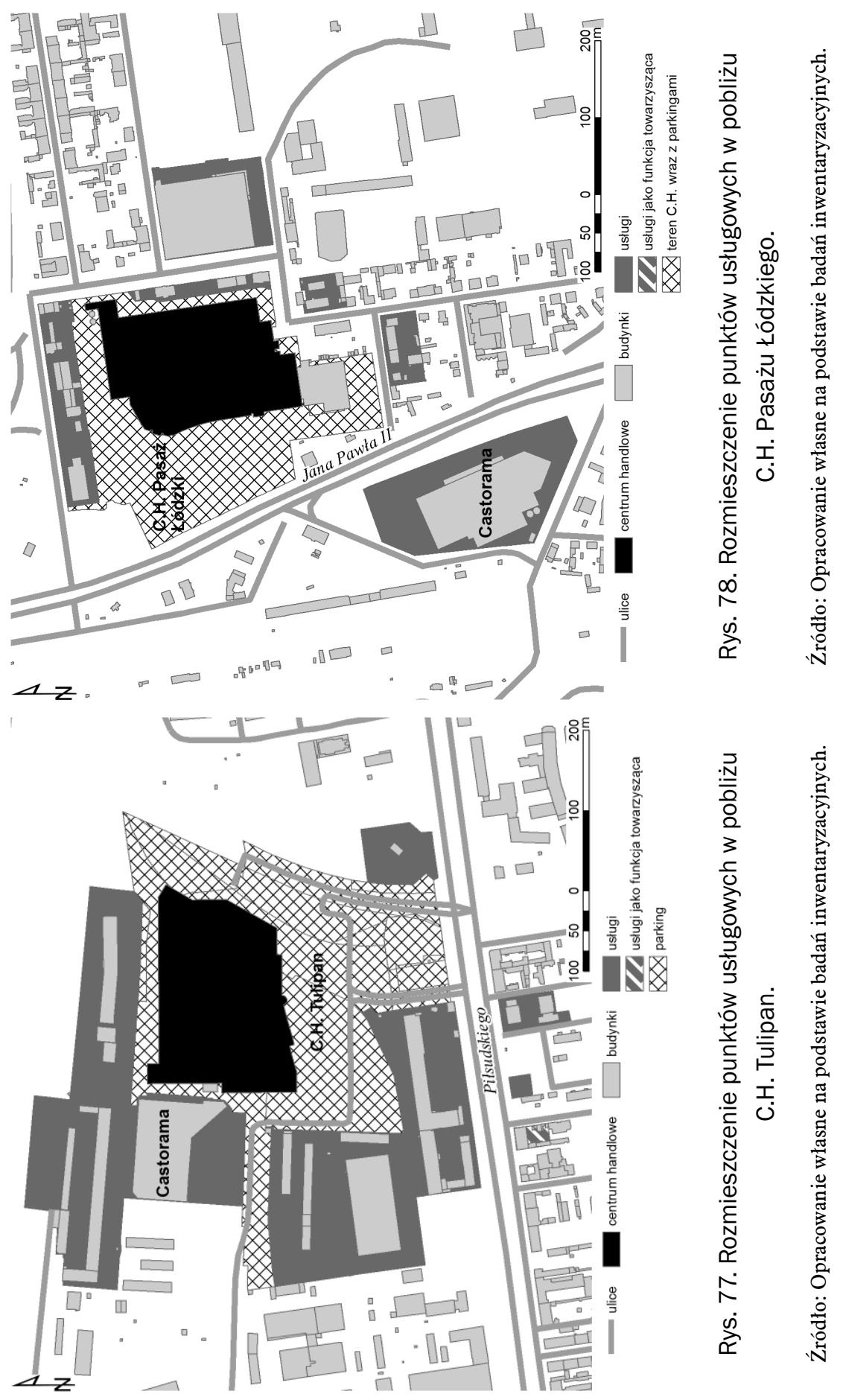
kowania, remontowania, budowania, AGD), Chińskie Centrum Handlowe (odzież, obuwie), sklep Słoń (wszystko dla dzieci), Komandor (meble, AGD). Wszystkie one mogą stanowić magnes przyciągający klientów do całego kompleksu. Przy ulicy Włókniarzy, na wprost wejścia do hipermarketu Tesco, znajdują się głównie wyspecjalizowane sklepy zajmujące się sprzedażą artykułów, takich jak drzwi, okna, kominki czy panele podłogowe. Większość $\mathrm{z}$ nich zajmuje niewielką powierzchnię, a w ich sąsiedztwie są magazyny. Na uwagę zasługuje również 4-kondygnacyjne, eleganckie biuro rachunkowe Centrum Teresy 100 (rys. 79).

Położenie i otoczenie kompleksu terenami o przewadze funkcji przemysłowej wpłynęło na powstanie tutaj kilku magazynów i hurtowni. Równolegle do ulicy Brukowej znajdują się magazyny należące do: Rudolf Chemie Polska, Skanska, hurtowni artykułów elektroinstalacyjnych i oświetleniowych Ins-el oraz maszyn szwalniczych Impall.

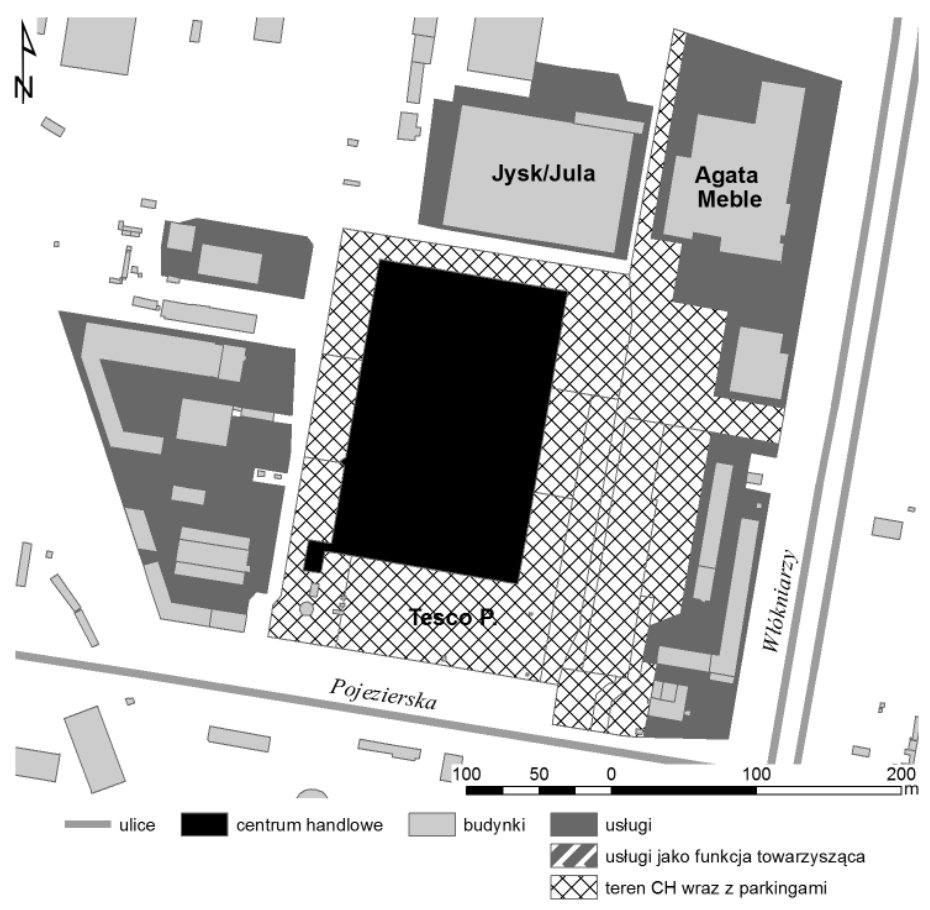

Rys. 79. Rozmieszczenie punktów usługowych w pobliżu Tesco Pojezierska. Źródło: Opracowanie własne na podstawie badań inwentaryzacyjnych. 
Centra handlowe są dużymi kompleksami, które mogą i wpływają na tereny sąsiednie. Ich oddziaływanie na rozwój podmiotów gospodarczych w bezpośrednim otoczeniu jest jednak zróżnicowany i w dużej mierze zależy od położenia danego centrum w mieście oraz od istniejących form zagospodarowania terenu (na przykład od tego, czy istnieją w pobliżu wolne tereny inwestycyjne). W pracy tej nie badano związków centrum handlowego $\mathrm{z}$ otoczeniem, przedstawiono jedynie stan istniejący, wydaje się to jednak bardzo interesujący kierunek dalszych badań. Należy nie tylko zidentyfikować wpływ samego obiektu na powstawanie w jego okolicach nowych firm, przedstawić zmiany w strukturze podmiotów gospodarczych, ale również spróbować ustalić korzyści i niekorzyści jakie daje tym podmiotom gospodarczym sąsiedztwo dynamicznie funkcjonującego centrum handlowego.

\subsection{Typy centrów handlowych oraz ich otoczenia}

W Łodzi zidentyfikowano dwanaście centrów handlowych, różniących się między innymi powierzchnią, wielkością i zróżnicowaniem oferty. W celu klasyfikacji badanych centrów handlowych pod względem ofertowym zastosowano analizę skupień metodą k-średnich, wykorzystując program IBM SPSS ver. 20.

Metoda k-średnich należąca do grupy metod aglomeracyjnych jest jedną $\mathrm{z}$ metod taksonomii numerycznej $\mathrm{z}$ grupy metod optymalizacyjno-iteracyjnej służącą do grupowania obiektów przestrzennych. W grupie tych metod przyjmuje się założenie, że każda jednostka zbioru stanowi odrębną klasę, które następnie stopniowo łączy się w sposób sekwencyjny w coraz większe grupy. W efekcie uzyskuje się hierarchiczny system skupień rozłączny na każdym z poziomów. Proces klasyfikacyjny kończy się w momencie uzyskania jednej grupy zawierającej wszystkie obiekty. Punktem wyjścia metody k-średnich jest określenie z góry liczby skupień, na który chcemy podzielić cały zbiór analizowanych obiektów ${ }^{117}$. Za pomocą tej metody zostaje utworzona założona liczba k skupień, w możliwie największym stopniu różniących się od siebie (Malina 2004 za: Suchecki, Lewandowska-Gwarda, 2010).

${ }^{117}$ Powinny w tym momencie być przetestowane różne warianty, tak aby otrzymać najbardziej różniące się grupy klasyfikowanych obiektów. 
Dokonując klasyfikacji łódzkich centrów handlowych pod względem ofertowym, uwzględniono następujące zmienne: liczbę placówek handlowych (sklepy), placówek gastronomicznych, innych punktów usługowych oraz liczbę miejsc świadczących usługi kulturalno-rozrywkowe ${ }^{118}$. Dane uprzednio poddano standaryzacji, wykorzystując standaryzację $\mathrm{Z}$ wyrażoną wzorem:

$$
\mathrm{Z}=(\mathrm{x}-\mathrm{x} \text { śr }) / \mathrm{x} \text { odch. standard }
$$

W prowadzonej analizie przyjęto liczbę skupień równą 4, co pozwoliło zaklasyfikować wszystkie badane centra handlowe do jednej z grup. $Z$ góry założono, że w przypadku badanego zbioru obiektów można wydzielić cztery grupy, które różnią się znacznie liczbą punktów usługowych (mając ich od kilkunastu do kilkuset), strukturą placówek (różny udział sklepów w stosunku do innych punktów usługowych) oraz posiadaniem lub nie placówek kulturowo-rozrywkowych. Przy zbiorze dwunastu obiektów bezzasadne było wydzielanie większej liczby grup, natomiast przy mniejszej obawiano się braku odróżnienia małych centrów od tych średniej wielkości.

W wyniku przeprowadzonej analizy zaklasyfikowano poszczególne centra handlowe do jednej z grup, wyznaczając odległości między poszczególnymi centrami w grupie. „Odległość” informuje o odległości euklidesowej pomiędzy każdą z obserwacji a jej centrum klasyfikacji. Wartość 0 w odległości oznacza, że dane centrum handlowe jest „typowe” dla danego skupienia. W skupieniu 1 znalazła się tylko Manufaktura ze zdecydowanie największą liczbą placówek usługowo-kulturowo-rozrywkowych i z największym zróżnicowaniem ofertowym (jako jedyna posiada dużą liczbę placówek kulturowo-rozrywkowych). Do skupienia 2 zaklasyfikowało się sześć centrów handlowych, z których najbardziej typowym dla tej grupy jest Carrefour P. Najbliżej położonymi centrami są Carrefour Sz. (odl. 0,528) i Tesco W. $(0,653)$, natomiast najdalej w tej grupie znalazły się C.H. M1 $(1,509)$ i E. Leclerc $(1,210)$. Do skupienia 3 przynależy Port Łódź i typowa dla tego skupienia Galeria Łódzka. W ostatniej grupie (skupienie 4) ulokowały się trzy centra handlowe: Tesco P., C.H. Tulipan i C.H. Guliwer. Dla tej grupy typowym reprezentantem jest Tesco P., w stosunku do którego bliżej pod względem ofertowym znajduje się C.H. Guliwer (odległość 0,748) niż C.H. Tulipan (1,268) (tab. 28).

\footnotetext{
${ }^{118} \mathrm{Nie}$ uwzględniono powierzchni centrów handlowych, ponieważ jest ona ściśle skorelowana $\mathrm{z}$ liczbą placówek, która jest w dużej mierze zdeterminowana wielkością centrum.
} 


\section{Tabela 28}

Przynależność do skupień łódzkich centrów handlowych

\begin{tabular}{|c|l|c|c|}
\hline $\begin{array}{c}\text { Numer } \\
\text { obserwacji }\end{array}$ & Centrum handlowe & Skupienie & $\begin{array}{c}\text { Odległość } \\
\text { euklidesowa }\end{array}$ \\
\hline 1. & Manufaktura & 1 & 0,000 \\
\hline 2. & Port Łódź & 3 & 0,719 \\
\hline 3. & Galeria Łódzka & 3 & 0,000 \\
\hline 4. & C.H. M1 & 2 & 1,509 \\
\hline 5. & C.H. Tulipan & 4 & 1,268 \\
\hline 6. & C.H. Guliwer & 4 & 0,748 \\
\hline 7. & Pasaż Łódzki & 2 & 0,951 \\
\hline 8. & Tesco P. & 4 & 0,000 \\
\hline 9. & Tesco W. & 2 & 0,653 \\
\hline 10. & Carrefour P. & 2 & 0,000 \\
\hline 11. & Carrefour Sz. & 2 & 0,528 \\
\hline 12. & E. Leclerc & 2 & 1,210 \\
\hline
\end{tabular}

Źródło: Opracowanie własne.

Wartości dla ostatecznych centrów skupień interpretuje się jako charakterystykę danego skupienia. W skupieniu numer 1 wszystkie wartości badanych zmiennych są wysokie (wartości zmiennych standaryzowanych dużo większe od 0), a w skupieniu numer 2 wszystkie wskaźniki nieco niższe od 0 - co oznacza, że w centrach handlowych należących do tego skupienia jest mniej placówek gastronomicznych, sklepów, punktów usługowych i rozrywkowych niż średnio we wszystkich badanych centrach handlowych (tab. 29).

Tabela 29

Ostateczne grupy centrów handlowych

\begin{tabular}{|l|c|c|c|c|}
\hline \multirow{2}{*}{ Punkty (stand.) } & \multicolumn{4}{c|}{ Skupienie } \\
\cline { 2 - 5 } & $\mathbf{1}$ & $\mathbf{2}$ & $\mathbf{3}$ & $\mathbf{4}$ \\
\hline Gastronomiczne & 2,99625 & $-0,46770$ & 0,70714 & $-0,37080$ \\
\hline Handlowe & 2,54765 & $-0,48243$ & 0,98955 & $-0,24493$ \\
\hline Usługowe & 2,41751 & $-0,55859$ & 0,15567 & 0,59217 \\
\hline Rozrywkowe & 3,31540 & $-0,25942$ & $-0,32687$ & $-0,25942$ \\
\hline
\end{tabular}

Źródło: Opracowanie własne. 
Ostatecznie do dalszej analizy wydzielono cztery typy centrów handlowych w Łodzi:

- I typ: Manufaktura - centrum z najbardziej rozbudowaną ofertą usługowo-kulturowo-rozrywkową (wszystkie wartości dodatnie, zdecydowanie powyżej średniej);

- II typ: Galeria Łódzka, Port Łódź - centra z rozbudowaną ofertą handlowo-gastronomiczną uzupełnioną przez inne placówki usługowe;

- III typ: Tesco P., C.H. Guliwer, C.H. Tulipan - centra handlowe z dużym udziałem punktów usługowych (powyżej średniej)

- IV typ: Carrefour P., Carrefour Sz., Tesco W., Pasaż Łódzki, E. Leclerc i C.H. M1. - grupa, w której jest najmniej punktów w każdej kategorii.

Łódzkie centra handlowe oceniono również pod względem ich atrakcyjności ofertowej. W pierwszej kolejności zmienne poddano standaryzacji „Z”. Następnie wartości zestandaryzowane zsumowano i dzięki temu otrzymano wskaźnik syntetyczny. Wskaźnik ten oceniono na podstawie wskaźnika jednorodności (rzetelności) skali $\alpha$-Cronbacha ${ }^{119}$, który w tym wypadku osiągnął wartość 0,961 . Najbardziej atrakcyjnymi, powyżej przeciętnej są trzy centra handlowe Manufaktura (13,5), Galeria Łódzka (2,52) oraz Port Łódź $(1,59)$. Pozostałe kompleksy uzyskały wartości poniżej przeciętnej, przy czym najbardziej zbliżonym do przeciętnego okazało się że jest Tesco P. Najmniej atrakcyjne pod względem ofertowym są: Carrefour P. $(-3,87)$, Carrefour Sz. $(-3,35)$, E. Leclerc $(-2,67)$ i Tesco W. $(-2,46)$ (tab. 30).

Tabela 30

Atrakcyjność ofertowa łódzkich centrów handlowych

\begin{tabular}{|l|l|l|l|l|l|l|}
\hline $\begin{array}{c}\text { Centrum } \\
\text { handlowe }\end{array}$ & $\begin{array}{c}\text { Z- liczba } \\
\text { placówek } \\
\text { handlo- } \\
\text { wych }\end{array}$ & $\begin{array}{c}\text { Z- liczba } \\
\text { placówek } \\
\text { gastrono- } \\
\text { micznych }\end{array}$ & $\begin{array}{c}\text { Z- liczba } \\
\text { punktów } \\
\text { usługo- } \\
\text { wych }\end{array}$ & $\begin{array}{c}\text { Z- liczba } \\
\text { miejsc } \\
\text { rozrywki }\end{array}$ & $\begin{array}{c}\text { Z-ogól- } \\
\text { na liczba } \\
\text { placówek }\end{array}$ & $\begin{array}{c}\text { Wskaźnik } \\
\text { syntetycz- } \\
\text { ny }\end{array}$ \\
\hline Manufaktura & 2,45865 & 2,86087 & 2,36948 & 3,16347 & 2,64366 & 13,50 \\
\hline Galeria Ł. & 0,93286 & 0,68004 & 0,42529 & $-0,34068$ & 0,81909 & 2,52 \\
\hline Port Łódź & 0,88615 & 0,60969 & $-0,30378$ & $-0,34068$ & 0,73669 & 1,59 \\
\hline
\end{tabular}

${ }^{119}$ Jedną z częściej stosowanych technik pomiaru homogeniczności skali jest współczynnik Cronbacha. Współczynnik ten przyjmuje wartości od 0 do 1 . Minimalną rzetelność skali wyznacza wartość współczynnika większa od 0,6 (Sagan 2003). 
Tabela 30 (ciąg dalszy)

\begin{tabular}{|l|l|l|l|l|l|l|}
\hline $\begin{array}{c}\text { Centrum } \\
\text { handlowe }\end{array}$ & $\begin{array}{c}\text { Z- liczba } \\
\text { placówek } \\
\text { handlo- } \\
\text { wych }\end{array}$ & $\begin{array}{c}\text { Z-liczba } \\
\text { placówek } \\
\text { gastrono- } \\
\text { micznych }\end{array}$ & $\begin{array}{c}\text { Z- liczba } \\
\text { punktów } \\
\text { usługo- } \\
\text { wych }\end{array}$ & $\begin{array}{c}\text { Z- liczba } \\
\text { miejsc } \\
\text { rozrywki }\end{array}$ & $\begin{array}{c}\text { Z-ogól- } \\
\text { na liczba } \\
\text { placówek }\end{array}$ & $\begin{array}{c}\text { Wskaźnik } \\
\text { syntetycz- } \\
\text { ny }\end{array}$ \\
\hline C.H. M1 & 0,16996 & $-0,44554$ & $-0,30378$ & $-0,34068$ & 0,01864 & $-0,90$ \\
\hline C.H. Tulipan & $-0,04801$ & $-0,30485$ & $-0,06076$ & $-0,34068$ & $-0,11085$ & $-0,87$ \\
\hline Pasaż Łódzki & $-0,20370$ & $-0,37520$ & $-0,78983$ & $-0,34068$ & $-0,27565$ & $-1,99$ \\
\hline Tesco P. & $-0,40610$ & $-0,44554$ & 1,15436 & $-0,14601$ & $-0,33450$ & $-0,18$ \\
\hline C.H. Guliwer & $-0,49952$ & $-0,44554$ & 0,42529 & $-0,34068$ & $-0,45222$ & $-1,31$ \\
\hline Tesco W. & $-0,54622$ & $-0,44554$ & $-0,78983$ & $-0,14601$ & $-0,53462$ & $-2,46$ \\
\hline E. Leclerc & $-0,88875$ & $-0,58624$ & $-0,06076$ & $-0,34068$ & $-0,79359$ & $-2,67$ \\
\hline Carrefour Sz. & $-0,88875$ & $-0,51589$ & $-0,78983$ & $-0,34068$ & $-0,81713$ & $-3,35$ \\
\hline Carrefour P. & $-0,96659$ & $-0,58624$ & $-1,27587$ & $-0,14601$ & $-0,89953$ & $-3,87$ \\
\hline
\end{tabular}

Źródło: Opracowanie własne.

Łódzkie centra handlowe położone są w otoczeniu różnych obszarów funkcjonalnych. We wcześniejszych rozdziałach wyznaczono umowne „podstawowe obszary handlowe" w promieniu 1 kilometra od centrum, gdzie samo centrum handlowe stanowi rdzeń takiego obszaru. Tereny wokół biegunów nowoczesnej przestrzeni usługowej sklasyfikowano pod względem struktury użytkowania terenu i potencjału ludnościowego, wykorzystując analizę skupień metodą k-średnich. Analizowano powierzchnię terenów mieszkaniowych i usługowych, liczbę ludności oraz liczbę „magnesów” - dużych detalicznych punktów handlowych. Tak jak w przypadku klasyfikacji centrów handlowych, dane poddano standaryzacji „Z” i przyjęto analogicznie liczbę skupien - 4, do których zaliczono każdy $\mathrm{z}$ badanych obszarów.

W skupieniu numer 1 znalazły się dwa obszary, położone wokół śródmiejskich centrów handlowych Manufaktury (typowy obszar dla tej grupy) i Galerii Łódzkiej. Dwa obszary zlokalizowane w dzielnicy Bałuty, wśród terenów przemysłowych (z mniejszym udziałem terenów mieszkaniowych) zostały sklasyfikowane w skupieniu numer 2 (Carrefour Sz. i Tesco P). Najwięcej, bo aż sześć umownych „podstawowych obszarów handlowych” znalazło się w grupie 3, dla której typowym obszarem jest ten położony wokół Tesco W., najbliżej niego według odległości euklidesowej znajduje się Carrefour P. (odległość 1,576), a najdalej C.H. M1 (2,145). W ostatnim 4 skupieniu sklasyfikowano obszary wokół C.H. Tulipan (typowy) oraz Pasaż Łódzki (odległość 1,655) (tab. 31). 
Tabela 31

Przynależność do skupień łódzkich biegunów nowoczesnej przestrzeni handlowo-usługowej

\begin{tabular}{|c|l|c|c|}
\hline $\begin{array}{c}\text { Numer } \\
\text { obserwacji }\end{array}$ & Centrum handlowe & Skupienie & $\begin{array}{c}\text { Odległość } \\
\text { euklidesowa }\end{array}$ \\
\hline 1. & Manufaktura & 1 & 0,000 \\
\hline 2. & Port Łódź & 3 & 1,831 \\
\hline 3. & Galeria Łódzka & 1 & 1,689 \\
\hline 4. & C.H. M1 & 3 & 2,145 \\
\hline 5. & C.H. Tulipan & 4 & 0,000 \\
\hline 6. & C.H. Guliwer & 3 & 1,747 \\
\hline 7. & Pasaż Łódzki & 4 & 1,655 \\
\hline 8. & Tesco P. & 2 & 0,473 \\
\hline 9. & Tesco W. & 3 & 0,000 \\
\hline 10. & Carrefour P. & 3 & 1,576 \\
\hline 11. & Carrefour Sz. & 2 & 0,000 \\
\hline 12. & E. Leclerc & 3 & 1,700 \\
\hline
\end{tabular}

Źródło: Opracowanie własne.

W skupieniu 1 wartości dotyczących terenów mieszkaniowych, usługowych i liczby ludności są wysokie (powyżej 1), natomiast mniej niż w pozostałych grupach jest „magnesów” (wartość ujemna). W skupieniu 2 duże znaczenie odgrywa lokalizacja w pobliżu dużych obiektów handlowych $(1,57)$, natomiast w grupie 4 obszary charakteryzują się obok występowania sklepów „magnesów” również największym udziałem terenów usługowych (tab. 32).

Tabela 32

Ostateczne grupy biegunów nowoczesnej przestrzeni handlowo-usługowej

\begin{tabular}{|l|c|c|c|c|}
\hline \multirow{2}{*}{\multicolumn{1}{|c|}{ Zmienne (stand.) }} & \multicolumn{4}{c|}{ Skupienie } \\
\cline { 2 - 5 } & $\mathbf{1}$ & $\mathbf{2}$ & $\mathbf{3}$ & $\mathbf{4}$ \\
\hline Tereny mieszkaniowe & 1,37111 & $-0,44338$ & $-0,03524$ & $-0,82201$ \\
\hline Liczba ludności & 1,76966 & $-0,46961$ & $-0,30480$ & $-0,38565$ \\
\hline Liczba „magnesów” & $-0,64791$ & 1,57349 & $-0,64791$ & 1,01814 \\
\hline Tereny usługowe & 1,11173 & $-0,92762$ & $-0,47207$ & 1,23210 \\
\hline
\end{tabular}

Źródło: Opracowanie własne. 
W wyniku przeprowadzenia powyższej klasyfikacji biegunów nowoczesnych przestrzeni usługowych wyróżniono następujące ich typy:

- I typ: Manufaktura, Galeria Łódzka - duży potencjał ludnościowy, ponadprzeciętny udział terenów mieszkaniowych i usługowych;

- II typ: Carrefour Sz., Tesco P. - duże znaczenie odgrywają tu „magnesy handlowe”, ich obszary mają duży udział terenów mieszkaniowych (-0,44 poniżej jednak średniej) oraz duży potencjał ludnościowy $(-0,46)$, najmniej ze wszystkich grup posiadają terenów usługowych $(-0,92)$;

- III typ: Tesco W., Carrefour P., E. Leclerc, C.H. Guliwer, Port Łódź, C.H. M1 - obszary o dużym znaczeniu terenów mieszkaniowych $(-0,03)$ oraz potencjale ludnościowym $(-0,47)$ i dość znaczącym udziale obszarów usługowych $(-0,47)$ (wszystkie zmienne poniżej średniej o wartościach ujemnych);

- IV typ: C.H. Tulipan, Pasaż Łódzki - wyróżniają się na tle innych grup liczbą „magnesów” $(1,0)$ i udziałem terenów usługowych $(1,2)$, natomiast zdecydowanie poniżej średniej jest tu udział terenów mieszkaniowych $(-0,82)$. 


\section{CZĘŚĆ III}

\section{PROFILE NABYWCZE ORAZ ZACHOWANIA NABYWCZE I PRZESTRZENNE KLIENTÓW ŁÓDZKICH CENTRÓW HANDLOWYCH}

\subsection{Technika badań}

Przemiany ustrojowe i gospodarcze w Polsce w latach 90. XX wieku wpłynęły na funkcjonowanie handlu w Polsce, w tym w Łodzi. Na rynku polskim pojawiły się nowe rodzaje placówek handlowych, w tym centra handlowe oraz możliwość dokonywania zakupów przez Internet. W związku z tymi zjawiskami w polu zainteresowań badawczych autorki pojawił się właśnie handel. Pierwsze badania dotyczyły handlu internetowego, następne związane były z rozwojem centrów handlowych, żeby ostatecznie skoncentrować się na określeniu profilów nabywczych oraz zachowań nabywczych i przestrzennych klientów łódzkich centrów handlowych. W celu uzyskania podstawowych informacji o cechach (demograficznych, społecznych, ekonomicznych) klientów oraz ich zachowaniach przeprowadzano kilkuetapowy proces doświadczalny.

Pierwsze prace badawcze dotyczące usług, w tym handlu, zostały przeprowadzone w 2007 roku w jednostce osiedlowej Olechów w Łodzi (209 respondentów $)^{120}$. W badaniach tych skoncentrowano się na zachowaniach zakupowych nabywców usług i dóbr materialnych zamieszkujących teren znacznie oddalony od centrum miasta i słabo wyposażony w punkty usługowe. Wyniki badań były zbliżone do tych prezentowanych w innych

\footnotetext{
${ }^{120}$ A. Rochmińska, 2008, Zachowania konsumenckie w handlu internetowym na przyktadzie mieszkańców jednostki osiedlowej Łodzi (Olechów), [w:] Theoretical and empirical researches on services turing socio-economic changes, UŁ, Łódź.
} 
pracach naukowych, w związku z czym zrezygnowano z pytań dotyczących handlu internetowego. W następnej kolejności zainteresowania badawcze skoncentrowano na rozwoju i funkcjonowaniu łódzkich centrów handlowych, dlatego w 2010 roku przeprowadzono badania ankietowe $\mathrm{z}$ ich klientami. Uświadomiły one, między innymi autorce, że wiele osób nie rozumie terminu centrum handlowe, często utożsamiając je nawet ze zwykłym supermarketem, dlatego $w$ dalszych badaniach wprowadzono do kwestionariusza listę centrów handlowych, znajdujących się w polu zainteresowań autorki ${ }^{121}$. W dalszej kolejności do doprecyzowania kwestionariusza ankiety poświęconego zachowaniom nabywczym i przestrzennym klientów centrów handlowych, posłużyły standaryzowane (ankietowe) badania pilotażowe z 25 respondentami (rys. 80).

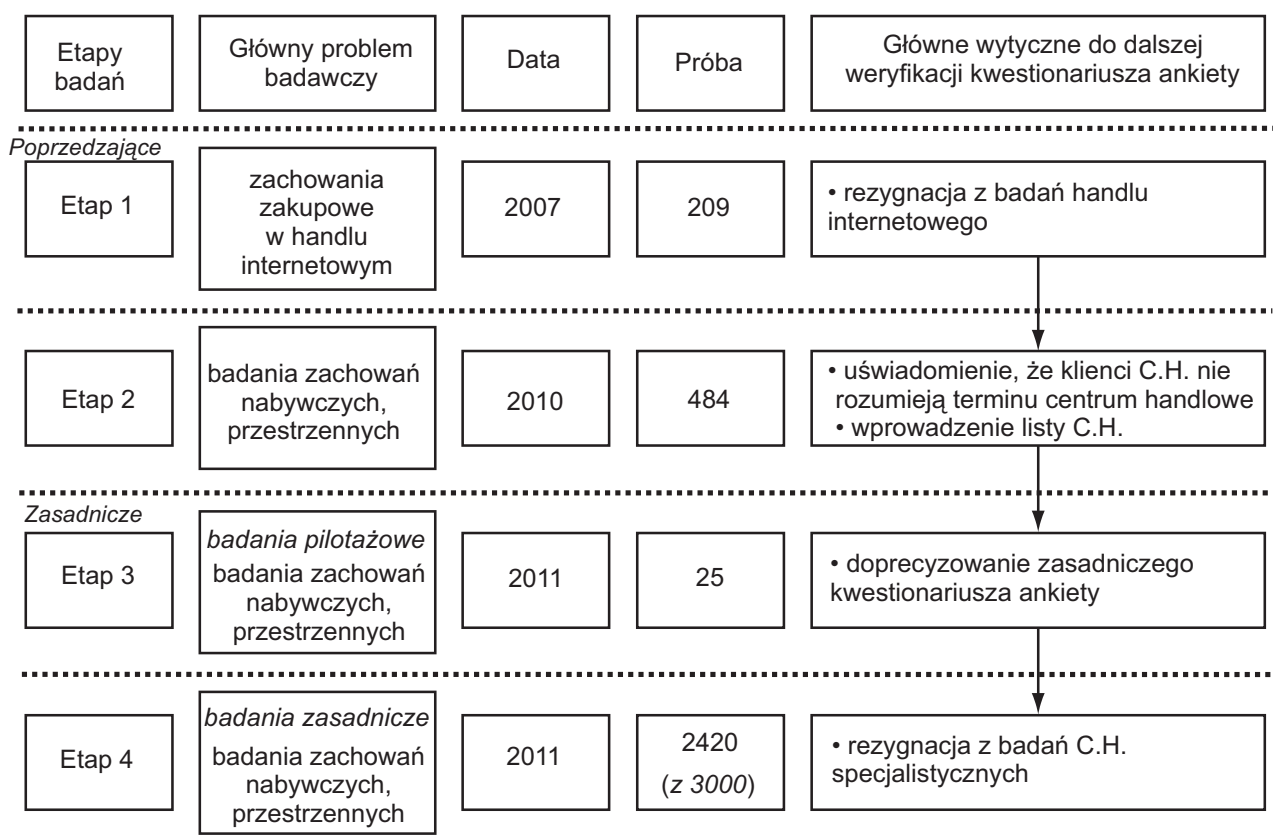

Rys. 80. Etapy badań ankietowych dotyczące łódzkiego handlu.

Źródło: Opracowanie własne.

${ }^{121}$ Badania te przeprowadzono z 484 respondentami, częściowe wyniki zamieszczono [w:] A. Janiszewska, E. Klima, A. Rochmińska, 2012, Centra handlowe w Łodzi-zawtaszczona, przestrzeń publiczna?, [w:] I. Jażdżewska (red.), Cztowiek w przestrzeni publicznej miasta, XXIV Konwersatorium Wiedzy o Mieście, UŁ, Łódź. 
W kwietniu i maju 2011 roku miały miejsce zasadnicze badania ankietowe $\mathrm{z}$ klientami łódzkich centrów handlowych ${ }^{122}$. Z uwagi na trudności z uzyskaniem pozwoleń na przeprowadzenie tego typu badań na terenie poszczególnych kompleksów (w przypadku gdy taką zgodę uzyskiwano, była ona obwarowana licznymi warunkami, na przykład brakiem zgody na publikowanie wyników), zastosowano nieprobabilistyczną technikę doboru próby, tak zwaną metodę kuli śnieżnej ${ }^{123}$. Odszukiwano klientów centrów handlowych, a następnie proszono ich o wypełnianie kwestionariuszy, ci następnie przekazywali niewypełnione formularze swoim znajomym, sąsiadom i rodzinie i tak dalej. W ten sposób starano się trafić do osób $\mathrm{z}$ rozmaitych grup społecznych i zamieszkujących w różnych rejonach Łodzi oraz poza miastem. Metoda ta pozwoliła na identyfikację klientów poszczególnych centrów handlowych.

Ostatecznie w 2011 roku przygotowano i rozdano 3000 kwestionariuszy ankiet, z czego część nie wróciła (307) lub została odrzucona i nieuwzględniona $\mathrm{w}$ analizach (273). Wyeliminowanie kwestionariuszy $\mathrm{z}$ dalszego procesu badawczego wynikało głównie $\mathrm{z}$ występowania wielu luk w odpowiedziach, oraz z faktu, że w niektórych ankietach jako główne centrum handlowe (lista była załączona) respondenci podawali sklepy, które były im najbliższe, ale nie zostały sklasyfikowane jako centrum handlowe, na przykład Biedronka, Lidl, Kaufland. Zgodnie z założeniem wstępnym kwestionariusz miały wypełniać osoby, które częściej lub rzadziej korzystają $\mathrm{z}$ oferty przynajmniej jednego $\mathrm{z}$ łódzkich centrów handlowych, dlatego ankiety, w których wypowiadano się na temat innych niewymienionych sklepów odrzucono ${ }^{124}$.

$\mathrm{Na}$ liście zamieszczonej w kwestionariuszu ankiety znalazły się również centra specjalistyczne (profilowane) Selgros Cash \& Carry (na ul. Rokicińskiej i 3 Maja) oraz Makro Cash \& Carry (na ul. Kasprzaka oraz w Rzgo-

${ }^{122}$ Badania w części przeprowadzili studenci I roku studiów magisterskich w ramach przedmiotu fakultatywnego „Geografia usług”. Ich zadaniem było wypełnienie kwestionariusza oraz przekazanie formularzy członkom rodziny, sąsiadom i znajomym.

${ }^{123}$ „W metodzie tej badacz zbiera dane o kilku członkach badanej populacji, których da się odszukać, a następnie prosi te osoby o dostarczenie informacji potrzebnych do znalezienia innych członków tej populacji, których akurat znają. Określenie „kula śnieżna” odnosi się do procesu akumulacji, gdyż każda odszukana osoba podaje inne osoby” (Babbie 2007, s. 205-206).

${ }^{124} \mathrm{Nie}$ wzięto ich pod uwagę również przy pytaniach ogólnych, uznając, że ci respondenci bez zrozumienia wypełniali kwestionariusze lub wypełniali je nierzetelnie. 
$w^{12}{ }^{125}$ ). Tego typu kompleksy posiadają ograniczoną dostępność, ponieważ żeby skorzystać $\mathrm{z}$ ich oferty, należy dysponować odpowiednią kartą wstępu. We wstępnym zamierzeniu chciano zbadać również zachowania (nabywcze, przestrzenne) klientów i tej kategorii obiektów handlowych, ale okazało się, że tylko 62 osoby wskazały je jako najczęściej odwiedzane lub najbardziej ulubione - zrezygnowano więc $z$ analizy zachowań nabywców w ramach tej kategorii obiektów.

$\mathrm{Na}$ liście centrów handlowych w kwestionariuszu umieszczono również do wyboru Carrefour przy ul. Bandurskiego ${ }^{126}$, mimo że nie spełniał kryterium powierzchniowego uwzględnianego przy definiowaniu centrum handlowego (poniżej $5000 \mathrm{~m}^{2}$ ). Obiekt ten spełniał natomiast drugie kryterium, czyli liczbę punktów usługowych w galerii (10). Umieszczenie go na liście wynikało $\mathrm{z}$ faktu, że był to jedyny kompleks tego typu w okolicach dużego osiedla mieszkaniowego Retkini (Galeria Retkińska posiada inny charakter), stąd założono, że wielu mieszkańców osiedla jest jego klientami. W badaniach obiekt ten wskazały jednak tylko 23 osoby, dlatego ostatecznie w celu ujednolicenia doboru próby badawczej nie analizowano zachowań klientów tego kompleksu. Wszystkie te kwestionariusze ankiet zostały uwzględnione w zakresie pytań ogólnych dotyczących zakupów i oceny centrów handlowych. W sumie do dalszej analizy zaklasyfikowano 2420 ankiet, z tego 2335 uwzględniono przy dokonywaniu typologii centrów handlowych oraz określaniu profilów nabywczych oraz zachowań nabywczych i przestrzennych klientów.

Kwestionariusz ankiety składał się z trzech bloków tematycznych oraz z metryczki. Pierwszy blok ogólny dotyczył głównie postrzegania czynności zakupu w zależności od miejsca jego dokonywania, na przykład centrum handlowe, duży sklep specjalistyczny, ryneczek, supermarket, sklep osiedlowy czy Internet. Zasadniczy (najobszerniejszy) blok dotyczył konkretnego łódzkiego centrum handlowego wybranego z zamieszczonej listy. Respondenci mieli odpowiedzieć na pytania dotyczące między innymi zachowań nabywczych i przestrzennych w najczęściej odwiedzanym kompleksie, a jeżeli takiego nie ma, to w ulubionym centrum handlowym.

${ }^{125}$ Makro Cash \& Carry w Rzgowie wpisano na listę, ponieważ obiekt ten znajduje się blisko granic administracyjnych Łodzi i zakładano, że część klientów jest mieszkańcami tego miasta.

${ }^{126} \mathrm{Na}$ wstępie założono, że ten obiekt handlowy może być w centrum zainteresowań nabywczych mieszkańców dużego osiedla, jakim jest Retkinia. 
W tej części skoncentrowano się na centrach handlowych $z$ artykułami FMCG (między innymi częstość, czas, główne powody wizyt) oraz ocenie lokalizacji centrum handlowego w zależności od odległości od miejsca zamieszkania. Odpowiedzi na pytania zawarte w tym bloku pozwoliły następnie zidentyfikować zachowania nabywcze i przestrzenne klientów C.H. w zależności od jego typu. Ostatnią częścią kwestionariusza była metryczka, która pozwoliła zidentyfikować podstawowe informacje o cechach demograficznych, społecznych i ekonomicznych respondentów.

Zdecydowanie najwięcej osób przedstawiło swoje zachowania nabywcze i przestrzenne w trzech największych centrach handlowych Łodzi: Manufakturze (810 osób), Galerii Łódzkiej (386) i Porcie Łódź (211). Natomiast najmniej wskazało i wypowiedziało się na temat zachowań w centrum handlowym Carrefour przy ul. Przybyszewskiego (58) oraz E. Leclerc (51) (rys. 81).

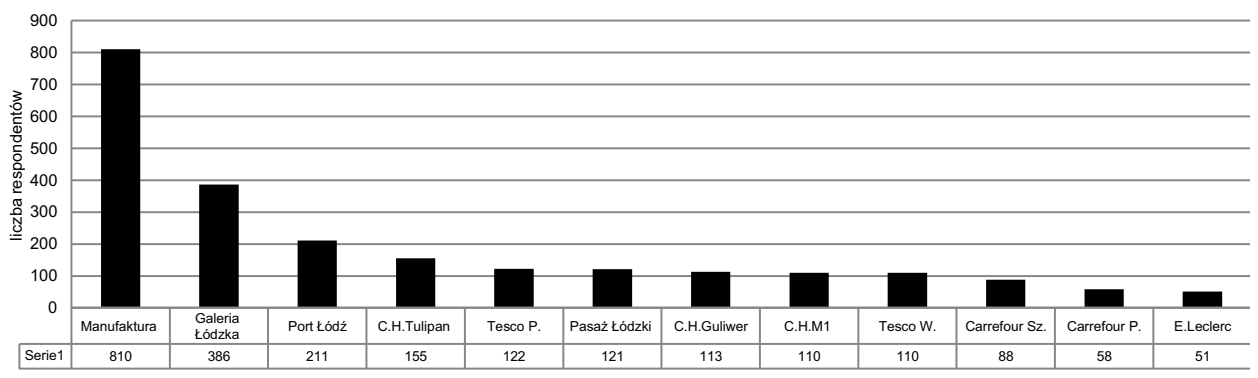

Rys. 81. Liczba respondentów wedługg łódzkich centrów handlowych

[N: 2335=100\%].

Źródło: Opracowanie własne na podstawie badań ankietowych. 


\section{2. Łódzkie centra handlowe w oczach ich klientów}

\subsubsection{Charakterystyka demograficzno-społeczna i ekonomiczna klientów}

W celu identyfikacji zachowań nabywczych i przestrzennych klientów łódzkich centrów handlowych przeprowadzono badania ankietowe z 2420 osobami. Wśród respondentów dominowały kobiety 66,4\% (1606) nad mężczyznami 33,6\% (814). Najwięcej osób biorących udział w badaniu było w wieku mobilnym 25-44 lata (51,3\%). Młodzież w wieku 19-24 oraz osoby $\mathrm{w}$ wieku niemobilnym 45-64 stanowiły podobny odsetek (20,5\% i $23,1 \%)$. Również porównywalne wielkościowo były grupy najmłodszych do 18 . roku życia $(2,4 \%)$ oraz najstarszych powyżej 64 . roku życia $(2,9 \%)$.

Największa liczba ankietowanych legitymowała się wykształceniem średnim $(34,5 \%)$ oraz wyższym magisterskim (31,5\%) i wyższym licencjac$\operatorname{kim}(15,4 \%)$. Kobiety przeważały szczególnie w grupie $\mathrm{z}$ wykształceniem wyższym magisterskim (34,1\% kobiet, 26,6\% mężczyzn), natomiast z wykształceniem zasadniczym zawodowym było zdecydowanie więcej mężczyzn niż kobiet (11,1\% mężczyzn, 5,5\% kobiet) (rys. 82).

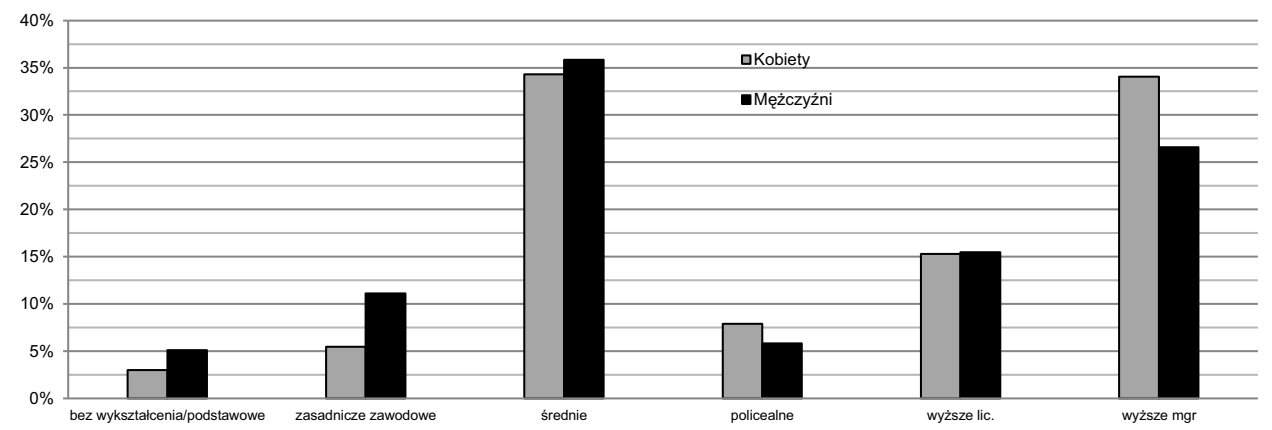

Rys. 82. Struktura respondentów według płci i wykształcenia [N: 2403=100\%].

Źródło: Opracowanie własne na podstawie badań ankietowych.

Z osób, które podały swój stan cywilny [N=2373], najwięcej było panien i kawalerów (47,7\%) oraz w związku małżeńskim (43\%). Część respondentów jest rozwiedziona $(5,4 \%)$, w stanie wdowim $(3,1 \%)$ lub w separacji 
(0,8\%). Respondenci mieszkają w 2-, 3- i 4-osobowych gospodarstwach domowych. Sporo osób mieszka samotnie (12,9\%) (rys. 83). Bardzo wielu ankietowanych $(66,1 \%)$ nie ma własnych potomków, a te osoby, które zadeklarowały posiadanie dzieci, to najczęściej mają jedno dziecko $(21,3 \%)$ lub dwójkę (10,6\%) (rys. 84).

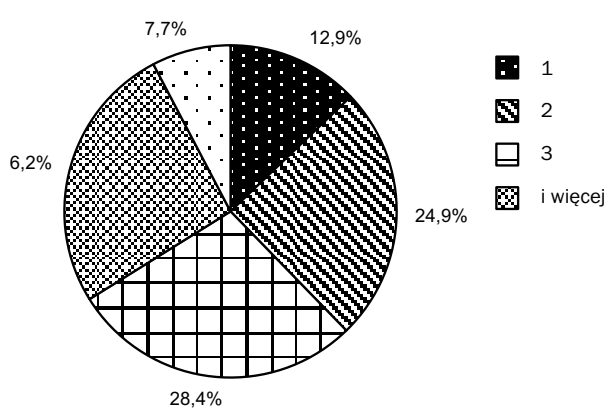

Rys. 83. Liczba osób w gospodarstwie domowym [N: 2277=100\%].

Źródło: Opracowanie własne na podstawie badań ankietowych.

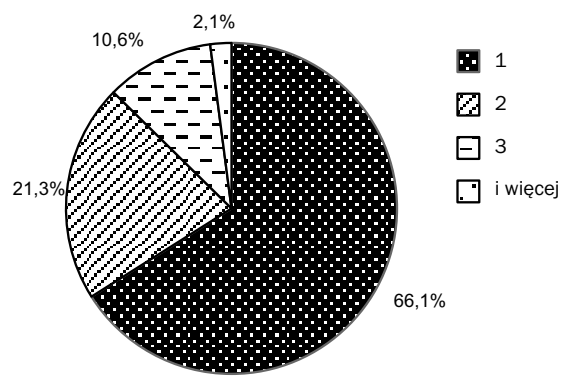

Rys. 84. Liczba dzieci w gospodarstwie domowym [N: 2280=100\%].

Źródło: Opracowanie własne na podstawie badań ankietowych.

Dla zdecydowanie największej grupy respondentów głównym źródłem utrzymania była praca najemna $(66 \% \mathrm{z} \mathrm{N}=2174)$, spora grupa osób czerpała swoje dochody z pracy na własny rachunek (8,7\%) lub z niezarobkowych źródeł dochodów (renty, emerytury, zasiłki) - 6,9\%. Znaczny odsetek w całej badanej populacji zajęły osoby pozostające na utrzymaniu innych osób, nie posiadające własnych źródeł dochodów (16,3\%). W tej ostatniej kategorii najwięcej, bo ponad $80 \%$ stanowili uczniowie i studenci, ale znalazły się tu również między innymi gospodynie domowe $(7,2 \%)$ oraz bezrobotni bez zasiłku (3,1\%). Osoby bezrobotne ogólnie stanowiły małą grupę badanych, tylko 33 osoby zadeklarowały się jako te $\mathrm{z}$ zasiłkiem, a 19 osób jako bezrobotne bez zasiłku.

Z 2398 badanych osób większość oceniła swój status materialny jako średni (54\%) lub dobry (33,4\%), z czego wynika, że przeciętny klient centrum handlowego we własnej ocenie jest dość dobrze sytuowany materialnie. Negatywną ocenę wystawiło 8,9\% respondentów (źle i bardzo źle), a tylko 3,7\% bardzo dobrą. Najlepszą opinię o własnym statusie mate- 
rialnym posiadają osoby pracujące na własny rachunek: średnio $(29,6 \%)$, dobrze (52,9\%) i bardzo dobrze (14,3\%). Na poziomie średnim i dobrym ocenia swoje położenie również przeważająca grupa pracowników najemnych (prawie 90\%) oraz będących na utrzymaniu innych (ponad 90\%). Najsłabiej swój status materialny postrzegają osoby korzystające $z$ niezarobkowych źródeł utrzymania, oceniając je jako zły (21,3\%) lub średni (60\%) oraz bezrobotni z zasiłkiem (źle - 33,3\%, średnio - 60,6\%) (rys. 85).

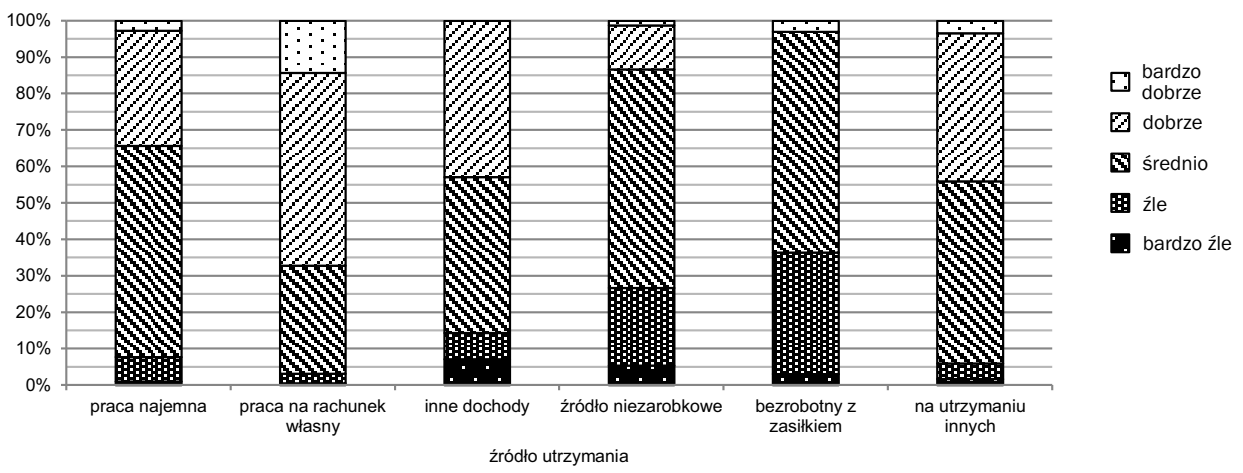

Rys. 85. Ocena statusu materialnego ze względu na źródło dochodów [N: 2398=100\%].

Źródło: Opracowanie własne na podstawie badań ankietowych.

Ocena własnego statusu materialnego zależy również od wykształcenia, im wyższe wykształcenie, tym ocena lepsza. Osoby z wykształceniem wyższym magisterskim $(95,5 \%)$ i wyższym licencjackim $(93,5 \%)$ ocenili go, w zdecydowanej większości, przynajmniej na poziomie średnim. Wśród respondentów legitymizujących się wykształceniem zasadniczym zawodowym odsetek ten był niższy i wyniósł 78,5\%.

Ponad połowa ankietowanych posiadała swoje mieszkanie w bloku, przy czym część mieszkała w bloku do 4 pięter (43,5\%), a część w bloku powyżej 4 pięter (18,9\%). Pozostali ankietowani zamieszkiwali w kamienicach (17\%), w zabudowie szeregowej (1,6\%) lub w domu jednorodzinnym (19\%). Najlepiej swój status materialny postrzegały osoby mieszkające w zabudowie szeregowej (54,1\% dobrze i bardzo dobrze) oraz w domach jednorodzinnych (41,1\% dobrze i bardzo dobrze). Najsłabiej natomiast oceniali go respondenci z kamienic (10,5\% bardzo źle i źle; 54,5\% średnio), bloków 
powyżej 4 pięter (11\% bardzo źle i źle; 52,5\% średnio) i z bloków do 4 pięter (7,9\% bardzo źle i źle; 55,8\% średnio) (rys. 86).

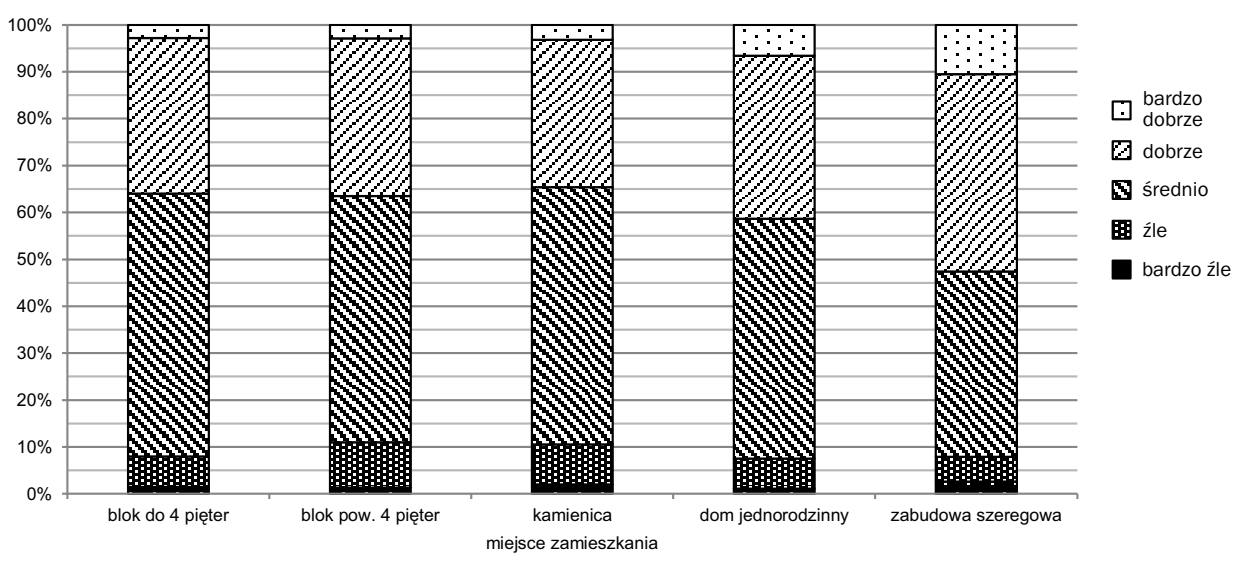

Rys. 86. Ocena statusu materialnego ze względu na miejsce zamieszkania

[N: 2398=100\%].

Źródło: Opracowanie własne na podstawie badań ankietowych.

O statusie materialnym badanych osób może też świadczyć posiadanie samochodu. Pytanie to okazało się jednym z problematycznych, ponieważ odpowiedzi na nie udzieliło $60,8 \%$ respondentów. $Z$ osób, które odpowiedziały na to pytanie, samochodem dysponowało $62,4 \%$ ankietowanych kobiet i 74,1\% mężczyzn, z czego wynika, że mężczyźni byli lepiej zmotoryzowani od kobiet.

\subsubsection{Postrzeganie czynności zakupów w zależności od miejsca ich dokonywania}

Dokonywanie zakupów jest jedną z podstawowych czynności w życiu człowieka. We współczesnym świecie wyróżniamy różne rodzaje jednostek handlowych, sprzedaż odbywa się w detalicznych punktach handlowych (na przykład centra handlowe, supermarkety, sklepiki, stragany i tym podobne), hurtowniach, czy też poprzez stosunkowo nowy kanał dystrybucji, jakim jest Internet, który z roku na rok zyskuje coraz większą popularność. $Z$ drugiej strony pojawianie się nowych rodzajów 
(formatów) sklepów, przeobrażenia w stylu życia wpływają na zmianę postrzegania czynności robienia zakupów, rozumianych jako „funkcja w przedsiębiorstwie handlowym, zapewniająca odpowiednie dostawy towarów pod względem rodzaju, ilości, czasu, miejsca, z punktu widzenia popytu nabywców, z uwzględnieniem polityki kształtowania zapasów” (Borusiak 2008a, s. 66). „W badaniach naukowych, jak również w tych prowadzonych przez instytucje badania opinii publicznej zakupy przestały być traktowane, tylko i wyłącznie jako obowiązek - czynność «robienia sprawunków» (w badaniach nad budżetem czasu Polaków zakupy były najczęściej zaliczane do czasu przeznaczonego na zajęcia domowe w ramach zajęć obowiązkowych), ale zaczęto zwracać uwagę na fakt, że dla coraz większej populacji stały się one obowiązkiem połączonym z przyjemnością, przyjemnością $\mathrm{w}$ ramach czasu wolnego, a nawet formą spędzania czasu wolnego" (Rochmińska 2011, s. 208).

Czas wolny ${ }^{127}$ według A. Kamińskiego (1965, s. 69) jest to czas nieprzeznaczony na pracę zarobkową (normalną i dodatkową), systematyczne kształcenie się, zaspokajanie elementarnych potrzeb fizjologicznych i stałe obowiązki domowe, który można wykorzystać na odpoczynek, życie rodzinne, pracę społeczną. Podobnie rozumie czas wolny B.H. Jung (1989, s. 6) jako czas pozostający do dyspozycji jednostki czy grupy społecznej po wypełnieniu przez nie swoich obowiązków zawodowych (czas pracy) i szeroko pojętych obowiązków życiowych (czas obowiązków). E. Wnuk-Lipiński (1981, s. 159) w sferze czasu wolnego wyróżnił trzy układy. Do pierwszego zaliczył wszystkie te jego formy wykorzystania, które są realizowane bez udziału instytucji i pojawiają się na płaszczyźnie nieformalnych kontaktów społecznych (na przykład życie towarzyskie, rozmowy z członkami rodziny, odpoczynek bierny, indywidualne hobby). W ramach drugiego układu znalazły się takie zajęcia, dla których realizacji niezbędne jest istnienie pewnych lokalnych, zinstytucjonalizowanych form

\footnotetext{
${ }^{127}$ M. Bombol (2003, s. 3) zauważa, że koncepcje wyodrębniania czasu wolnego są przedmiotem zainteresowań filozofii, antropologii, socjologii, psychologii, medycyny, ekonomii z czego wynika, między innymi „ogromna obfitość definicji”. W prezentowanych badaniach nad zachowaniami nabywczymi i przestrzennymi klientów łódzkich centrów handlowych nie koncentrowano się na czasie wolnym, tylko na postrzeganiu czynności zakupów oraz na uzyskaniu odpowiedzi na pytanie: „Czym dla respondentów były pobyty w badanych kompleksach?”. Pod pojęciem czasu wolnego rozumiano taki czas, kiedy można robić to, na co się ma ochotę, lub po prostu odpoczywać”.
} 
organizacyjnych (np. dom kultury, obiekt sportowo-rekreacyjny, kino, teatr). Natomiast w trzecim układzie sklasyfikowane zostały zajęcia, które wiążą się $z$ odbiorem treści transmitowanych przez prasę, radio i telewizję. Zgodnie $\mathrm{z}$ powyższym podziałem placówki handlowe, centra handlowe można zaklasyfikować do drugiego układu spędzania czasu wolnego.

Na nowe podejście do czynności robienia zakupów, w tym szczególnie w centrach handlowych zwraca uwagę W. Wilk (2003). W swoim artykule odwołuje się do badań J. Carra, który wyróżnił cztery rodzaje robienia zakupów: zakupy właściwe (czynność czysto funkcjonalna, nabywanie towarów pierwszej potrzeby), zakupy techniczne (nabywanie artykułów sporadycznego zakupu, na przykład sprzętu hi-fi), „na pokaz” (na przykład biżuterii, odzieży) oraz zakupy jako czynność typowo rekreacyjną. Przyporządkowania do jednego z rodzajów zakupów dokonano według rosnącej skali przyjemności z wykonywanej czynności. Inne ciekawe podejście do związków między zakupami a wypoczynkiem prezentuje E.L. Jackson (1991), który wyróżnił cztery kategorie relacji: wzajemna niezależność (zakupy jako konieczność, obowiązek), zakupy „wspomagające” wypoczynek (na przykład towary związane $z$ własnym hobby), zakupy i wypoczynek (między innymi charakterystyczne dla centrów handlowych, gdzie obok zakupów wiele osób korzysta też z oferty rozrywkowej), zakupy jako wypoczynek (oglądanie witryn, ludzi czy korzystanie z oferty rozrywkowej) (za: Wilk 2003, s. 208) (rys. 87).

Klienci łódzkich centrów handlowych w zdecydowanej większości nie robią zakupów w hurtowniach $(80,7 \%)$, nadal też prawie połowa nie deklaruje wykorzystania Internetu do takich celów (47,4\%). Placówki, z których korzystają respondenci, to supermarkety/sklepy samoobsługowe/dyskonty (95,9\%), C.H. z artykułami spożywczymi $(91,4 \%)^{128}$ i małe sklepy $(89,8 \%)$ (rys. 88). Większy odsetek kobiet niż mężczyzn nie robi zakupów drogą internetową $(51,7 \% ; 38,8 \%)$, w hurtowniach $(82,6 \%$; $77 \%)$ i specjalistycznych centrach handlowych $(36,9 \% ; 26,5 \%)$. Natomiast duży udział mężczyzn nie korzysta $z$ oferty ryneczku i tym podobnych $(32,6 \%)$ i jest on większy niż w grupie kobiet (18,4\%).

${ }^{128}$ Wszyscy wypełniający kwestionariusze ankiety byli klientami przynajmniej jednego centrum handlowego, które następnie opisywali. Wpisanie jednak „duże centrum handlowe $\mathrm{z}$ artykułami spożywczymi” niektórzy mogli powiązać z hipermarketem spożywczym w ramach centrum handlowego, stąd kilka procent osób zaznaczyło, że nie robi tam zakupów. 


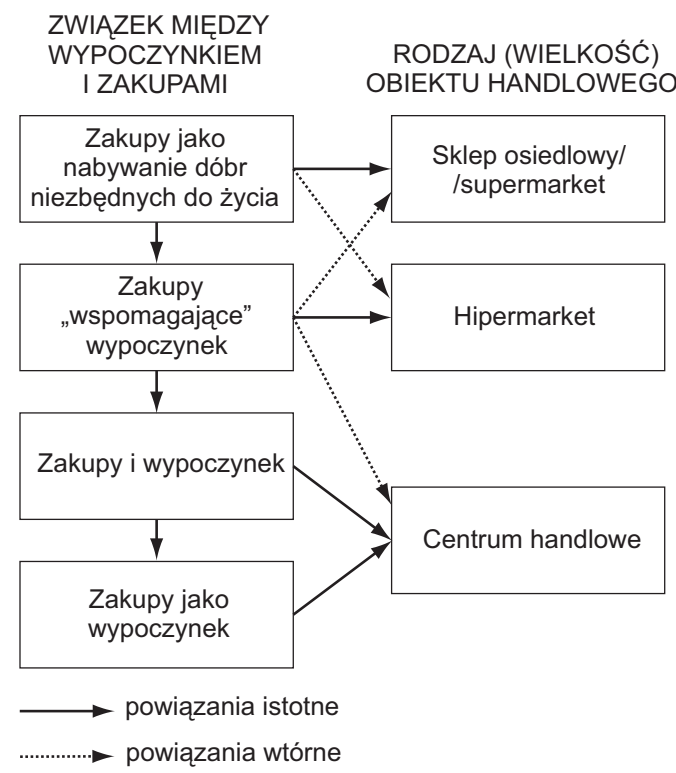

Rys. 87. Relacje między wypoczynkiem i zakupami a wielkością obiektów handlowych.

Źródło: E.L. Jackson, 1991, Shopping and leisure: implications of west Edmonton mall for leisure and for leisure research, „The Canadian Geographer” 35, s. 280-287, [za:] W. Wilk, 2003, Między zakupami a rozrywkq - nowe znaczenie centrum handlowego, „Prace i Studia Geograficzne”, t. 32, s. 209.

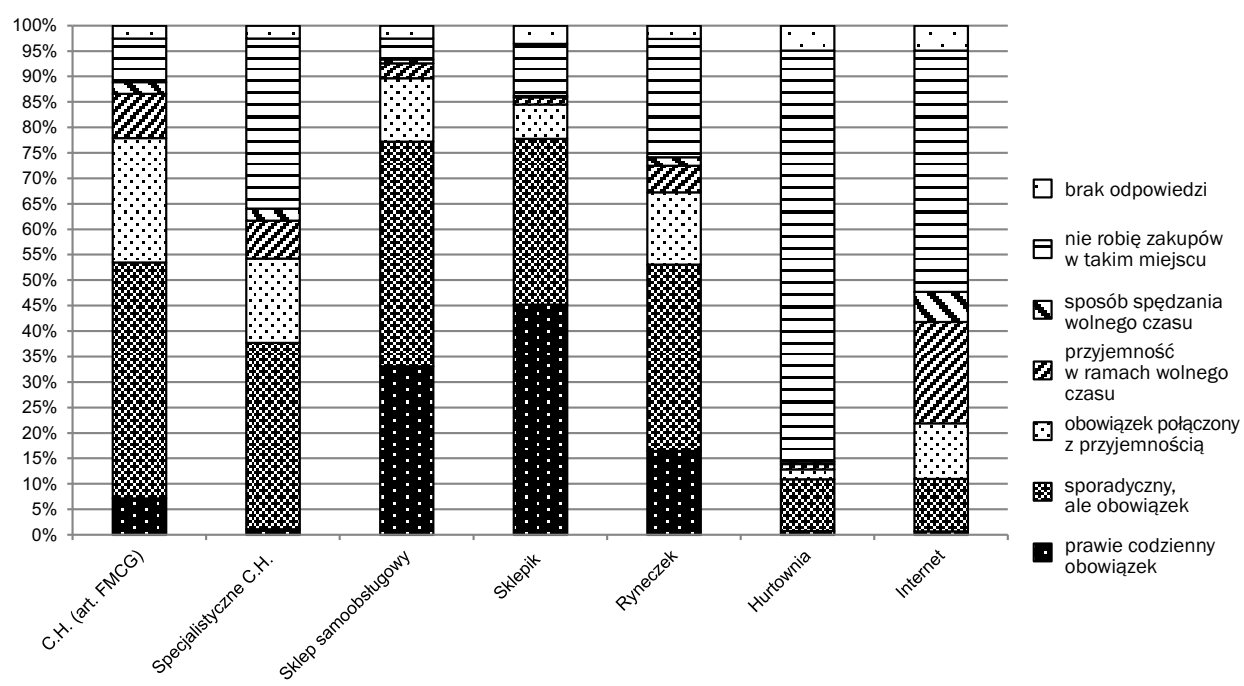

Rys. 88. Postrzeganie czynności zakupu ze względu na miejsce ich realizacji

$$
\text { [N: } 2420=100 \%] \text {. }
$$

Źródło: Opracowanie własne na podstawie badań ankietowych. 
Z przeprowadzonych badań ankietowych wynika, że postrzeganie czynności zakupów zależy, między innymi od miejsca, w którym ta czynność jest realizowana przez nabywcę. Dla większości osób dokonywanie zakupów kojarzy się głównie $\mathrm{z}$ obowiązkiem lub obowiązkiem połączonym z przyjemnością w: supermarketach (89,7\%), małych sklepach $(84,5 \%)$, centrach handlowych $\mathrm{z}$ artykułami spożywczymi (77,9\%), na bazarach/ryneczkach $(67,3 \%)$ i w specjalistycznych centrach handlowych $(54,3 \%)^{129}$ (rys. 88).

Jako „przyjemność w ramach czasu wolnego” lub „sposób jego spędzania” zakupy są postrzegane głównie te dokonywane drogą internetową (625 osób - 25,8\% respondentów). Dla ponad 200 osób miejscami, w których czynność zakupów kojarzy się z tymi dwoma wyżej wymienionymi kategoriami, są duże centra handlowe $z$ hipermarketem $z$ artykułami FMCG (267 osób - 11\%) oraz duże centra specjalistyczne, na przykład z materiałami budowlanymi lub ogrodniczymi (236 osób - 9,8\%). Należy też zwrócić uwagę na fakt, że bywanie na ryneczkach czy bazarach też może być formą przyjemności połączonej z czasem wolnym (166 osób - 6,9\%) (rys. 89).

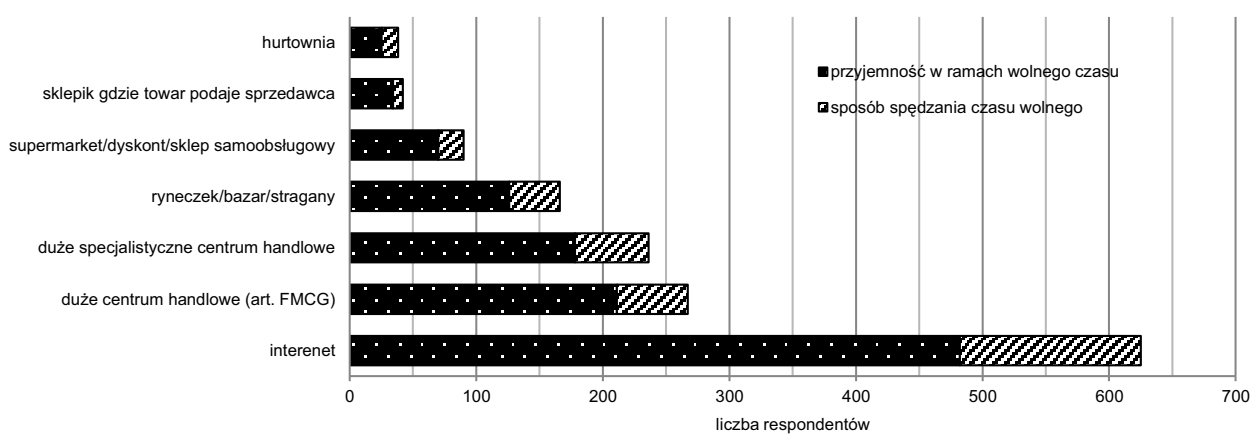

Rys. 89. Postrzeganie czynności zakupu jako przyjemności lub sposobu spędzania czasu wolnego ze względu na miejsce ich realizacji.

Źródło: Opracowanie własne na podstawie badań ankietowych.

${ }^{129}$ W badaniach CEBOS-u w 2008 roku okazało się, że dla 51\% Polaków zakupy były uciążliwym obowiązkiem i robili je tylko wtedy, gdy musieli. Jednak duża grupa respondentów (39\%) lubiła robić zakupy, spędzać czas, chodząc po sklepach, oglądając i wybierając produkty (odczuwała przyjemność płynącą ze spędzania czasu na zakupach). Kobiety częściej niż mężczyźni deklarowali, że lubią zakupy, ponadto im młodsi respondenci, tym częściej przyznawali, iż robienie zakupów sprawia im przyjemność (Feliksiak 2008). 
Współczesne centra handlowe oferują obok towarów i usług coraz częściej pakiet rozrywkowo-kulturalny, który zachęca do postrzegania wizyt w nich nie tylko jako obowiązek, ale swego rodzaju przyjemność, a nawet jako miejsca spędzania czasu wolnego. W związku z tym zaczyna krystalizować się grupa ludzi, która postrzega pobyt w tego typu kompleksach jako formę spędzania czasu wolnego ${ }^{130}$. W badaniach nad kulturą miejską w Polsce wyróżniono w ramach pozadomowych form spędzania czasu wolnego również wizyty w centrach handlowych ${ }^{131}$. Przy czym, jak zauważono: „odwiedzanie tego typu obiektów jest charakterystyczne dla mieszkańców dużych, a nie małych miast, co stanowi jedną z głównych różnic w sposobie spędzania czasu wolnego między ludnością w tych dwóch kategoriach miejscowości” (Fotyga 2009).

W przypadku wizyt w łódzkich centrach handlowych w dalszym ciągu większość ich klientów postrzega je jako obowiązek (60,1\%), ale już co trzeci traktuje je jako obowiązek połączony z przyjemnością (27,5\%). Co dziesiąty klient uważa pobyty w tego typu kompleksach za przyjemność w ramach czasu wolnego $(9,8 \%)$ lub wręcz jako sposób jego spędzania $(2,6 \%)$ (rys. 88$)$.

W grupie klientów centrów handlowych (267 osób - 12,4\%), które postrzegają robione w nich zakupy jako formę spędzania czasu wolnego, znalazło się 169 kobiet i 98 mężczyzn. Należy zwrócić uwagę, że w młodszych kategoriach wiekowych odsetek osób utożsamiających zakupy z czasem wolnym jest większy (18,2\% respondentów do 24 . roku życia) niż w starszych rocznikach (4\% ankietowanych $w$ wieku 65 . lat i powyżej). To wła-

${ }^{130}$ Badania CEBOS-u przeprowadzone w 2008 roku w Polsce wykazały jednak, że popularność spędzania wolnego czasu w centrach handlowych w skali kraju jest niewielka. Rezultat badań wynika $\mathrm{z}$ ograniczeń $\mathrm{w}$ dostępności do tego typu miejsc, które są charakterystyczne dla większych miast. Tylko co dziesiąty ankietowany (11\%) często lub czasami spędza wolne chwile w centrach handlowych. Pozostałym badanym albo wcale się to nie zdarza (64\%), albo robią to sporadycznie (24\%). Taka forma spędzania wolnego czasu jest bardziej charakterystyczna dla osób młodszych, mieszkańców największych miast, ale też dla ludzi o wyższym statusie materialnym (Feliksiak 2008).

${ }^{131} \mathrm{Nie}$ we wszystkich badaniach jednak zwraca się dostateczną uwagę na to nowe zjawisko występujące w Polsce. W badaniach CEBOS-u z 2006 roku (Lewandowska 2006) oraz z 2010 roku (Stasik 2010) dotyczącym czasu wolnego Polaków w ramach weekendowych zajęć nie pojawiła się kategoria wizyt w centrach handlowych jako sposobu spędzania czasu wolnego. Brak tej kategorii ewidentnie zubaża ocenę sytuacji, a wynika z przyjętej metodologii badań i narzucenia zamkniętej listy wyboru zajęć (brak kategorii zakupów i wizyt w centrach handlowych). 
śnie ludzie młodzi czerpią z czynności zakupowej przyjemność i to często w ramach czasu wolnego ${ }^{132}$ (rys. 91).
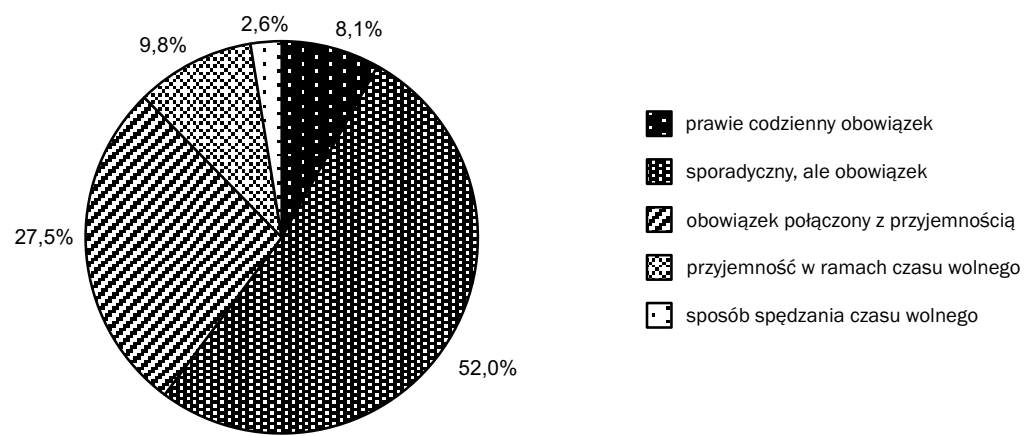

Rys. 90. Postrzeganie czynności zakupu w centrach handlowych [N: 2152=100\%].

Źródło: Opracowanie własne na podstawie badań ankietowych.

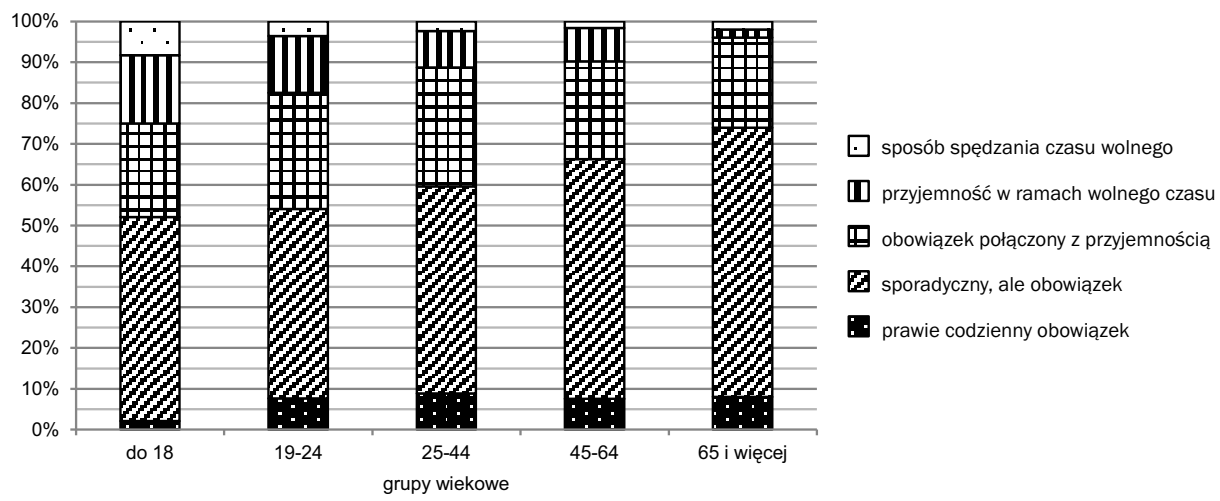

Rys. 91. Postrzeganie czynności zakupu w centrach handlowych według wieku

[N: 2152=100\%].

Źródło: Opracowanie własne na podstawie badań ankietowych.

${ }^{132} \mathrm{Z}$ badań socjologicznych przeprowadzonych z młodymi ludźmi w Galerii Krakowskiej wynika, że najczęściej wskazywanymi powodami pobytu w niej było: robienie zakupów (84\%), spotkania z rówieśnikami/znajomymi (82\%), kino (73\%), oglądanie i przymierzanie „ładnych rzeczy” (67\%), ze względu na to, że jest „czysto i ładnie” (66\%), jedzenie (65\%), bez żadnego celu (47\%), „nie mam co robić po lekcjach” (44\%), „ciągle się coś dzieje” (43\%). Z badań tych wynika również, że w centrum można spotkać sławnych ludzi (82\%), a nawet się zakochać (62\%) (Smagacz 2007). 
Osoby, dla których zakupy w centrach handlowych kojarzą się z przyjemnością, są najczęściej ludźmi oceniającymi swój status materialny średnio, dobrze lub bardzo dobrze (po około 28\%). W grupach oceniających położenie ekonomiczne źle (14,7\%) lub bardzo źle (19,4\%) odsetek takich osób spada, wzrasta natomiast odsetek osób kojarzących zakupy z obowiązkiem. Najmniejszy odsetek osób wiążący czynności zakupowe z czasem wolnym występuje wśród osób oceniających swój status materialny bardzo źle i średnio (po około 10\%), natomiast w pozostałych kategoriach jest porównywalny (po około 14\%) (rys. 92).

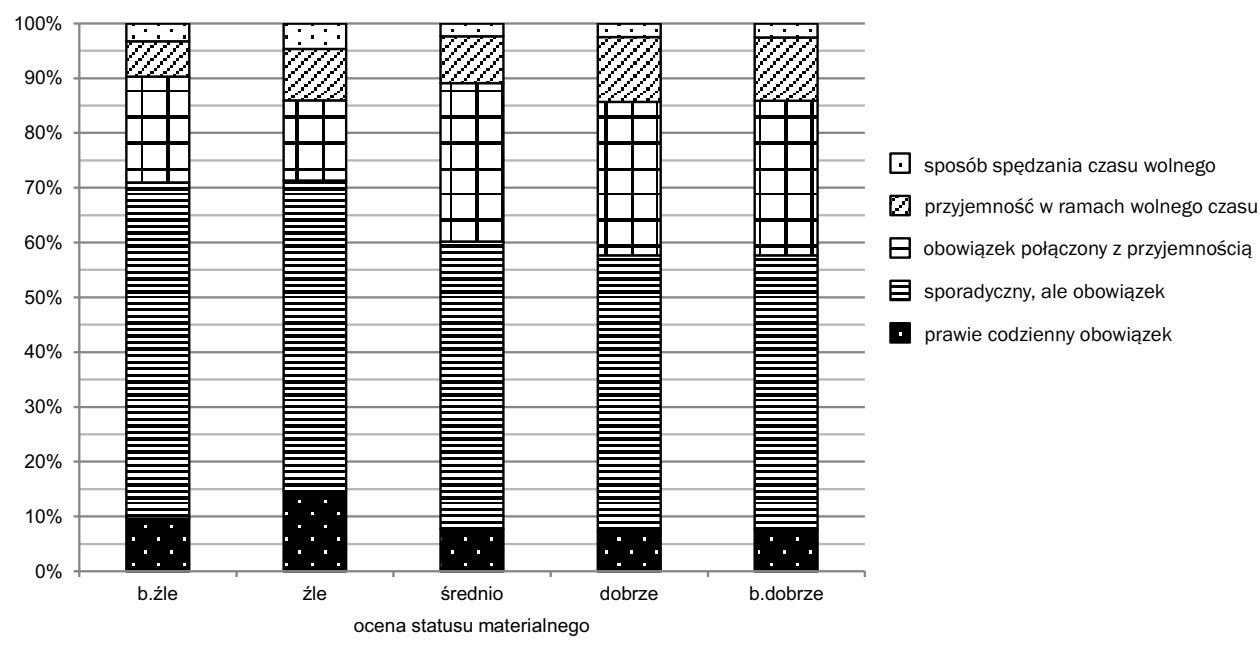

Rys. 92. Postrzeganie czynności zakupu w centrach handlowych według deklarowanego statusu materialnego [N: 2140=100\%].

Źródło: Opracowanie własne na podstawie badań ankietowych.

Podczas badań zapytano również respondentów o to, „czym jest dla nich pobyt w centrum handlowym?”. Okazało się, że wizyty w centrum handlowym są różnie odbierane przez odwiedzających je klientów i dla wielu nie są tylko miejscami nabywania dóbr materialnych czy „koniecznością robienia zakupów” (74,5\%), ale są też „obowiązkiem połączonym z przyjemnością” (55,6\%) oraz "przyjemnością w ramach czasu wolnego” $(42,8 \%)$. Dla co trzeciej osoby jest to również miejsce „spędzania czasu wolnego”, „załatwiania innych spraw niż zakupy”, miejscem „rozrywki” i „spotkań towarzyskich”. W związku z powyższym można powiedzieć, że tego typu kompleksy są wielofunkcyjne (rys. 93). 


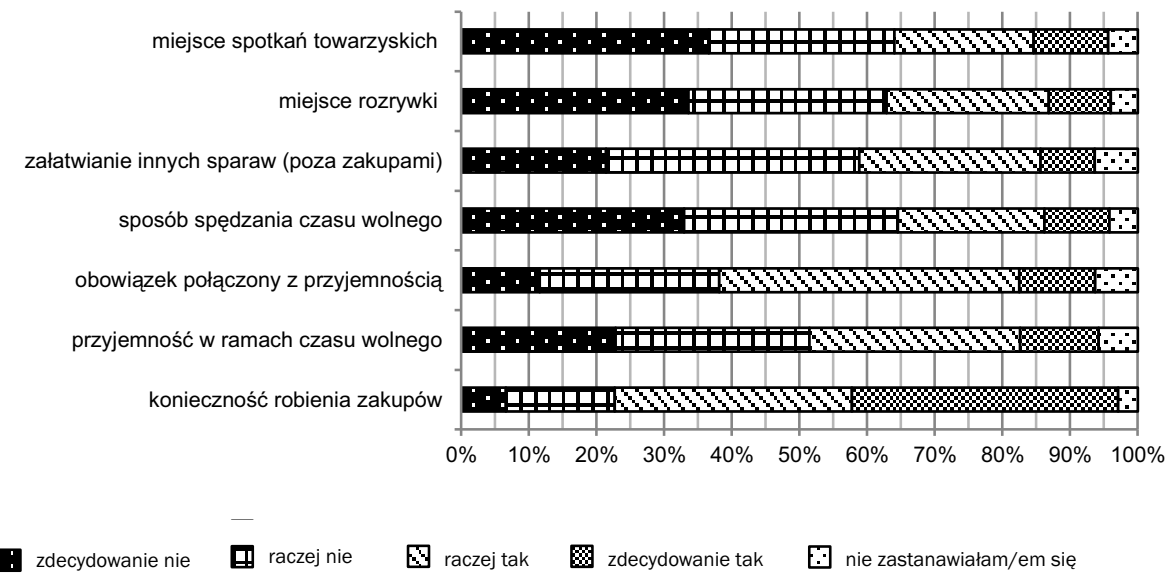

Rys. 93. Czym jest pobyt w centrum handlowym.

Źródło: Opracowanie własne na podstawie badań ankietowych.

Z powyższych rozważań wynika, że postrzeganie zakupów przez mieszkańców (przynajmniej dużych miast) w erze „konsumpcji” zaczyna się zmieniać. Z czynności obowiązkowych zaczyna nabierać charakteru przyjemności, a wręcz staje się formą zagospodarowania i spędzania czasu wolnego. W dużej mierze, jak wskazują badania, odbieranie czynności zakupowych zależy od miejsca dokonywania „sprawunków”. Szczególną rolę odgrywają dla mieszkańca dużego miasta wizyty w centrach handlowych, bo to one stały się generatorem zachowań „pozazakupowych” i wpisały się ewidentnie w budżet czasu wolnego wielu klientów (głównie są to ludzie młodzi i ci oceniający dobrze swój status materialny). To właśnie ludzie młodzi swoje wypady weekendowe do tych nowych "przybytków konsumpcji" postrzegają wielowymiarowo i nie utożsamiają ich tylko z zakupami, ale również z czasem wolnym. Postrzeganie centrów handlowych przez tych młodych ludzi pewnie dalej będzie się upowszechniał, należy więc zwrócić baczniejszą uwagę na te nowe zachowania, które są również przejawem nowego stylu życia wśród młodego pokolenia. 


\subsubsection{Tygodniowy i dobowy cykl życia centrum handlowego}

Centra handlowe żyją w pewnym rytmie rocznym ${ }^{133}$, tygodniowym i dobowym. W ciągu roku można zaobserwować wzmożony ruch klientów szczególnie w okresach poprzedzających dni świąteczne (przed Bożym Narodzeniem, Wielkanocą) lub okolicznościowe (Dzień Dziecka, Dzień Zmarłych) i związany jest on głównie z robieniem zakupów. Zarządcy zdając sobie $\mathrm{z}$ tego sprawę nasilają $\mathrm{w}$ tym czasie akcje promocyjne, co staje się dodatkowym impulsem odwiedzin.

Centra handlowe są odwiedzane najczęściej 2-3 razy w miesiącu (34,5\%) lub raz w tygodniu (24,8\%). Pewna grupa bywa w nich jednak zdecydowanie częściej nawet kilka razy w tygodniu (15,3\%). Część osób jest klientami tego typu kompleksów tylko raz w miesiącu $(13,8 \%)$ lub odwiedza je rzadziej niż raz w miesiącu (6\%) albo wręcz tylko kilka razy w roku (5\%). Nie uwidacznia się tu zależność między częstotliwością odwiedzin a płcią. Natomiast można zaobserwować pewną prawidłowość związaną $\mathrm{z}$ wiekiem respondentów. Najczęściej w centrach handlowych bywają osoby w wieku 19-44 lata, aż około 70\% tych respondentów odwiedza centra przynajmniej kilka razy w miesiącu. W starszych kategoriach wiekowych spada odsetek osób, które bywają często w takich placówkach, a wzrasta odsetek osób, które wizytują je raz w miesiącu lub rzadziej. W grupie wiekowej 45-64 odsetek takich osób wynosi blisko 35\%, a w wieku powyżej 65. roku życia stanowią już prawie $48 \%$ (rys. 94 ).

Istotne $\mathrm{z}$ punktu widzenia zachowań jest ustalenie, $\mathrm{w}$ jakich dniach tygodnia najczęściej bywają klienci w centrach handlowych. Okazuje się, że aż dla 36,5\% respondentów nie ma reguły. Dla osób, które odwiedzają tego typu kompleksy w sposób schematyczny i wskazały dni, w których najczęściej je odwiedzają, to pobyty w nich mają miejsce głównie w dni weekendowe, w sobotę i niedzielę (69,1\%). Szczególnie popularnym dniem odwiedzin jest sobota, w którym to prawie co drugi respondent przyznaje, że bywa w takim centrum handlowym $(47,6 \%)$, w piątki odwiedza je co czwarty ankietowany $(25,8 \%)$, a w niedzielę co piąty (21,5\%). W robocze dni tygodnia odsetek takich osób wynosi około $6 \%$, trochę większy jest w czwartek $(9,1 \%)$. Można zatem mówić o tygodniowym cyklu życia takiego centrum (rys. 95). Najczęściej w piątek w godzinach popołudniowych następuje wzrost natęże-

${ }^{133}$ Roczny cykl życia centrum handlowego nie był badany. 
nia ruchu klientów, największy jest w sobotę, w niedzielę stopniowo spada. W pozostałe dni tygodnia utrzymuje się na podobnym poziomie. Centrum handlowe najintensywniej żyje - „pulsuje” w dni weekendowe, kiedy to jest najliczniej frekwentowane przez odwiedzających (rys. 95).

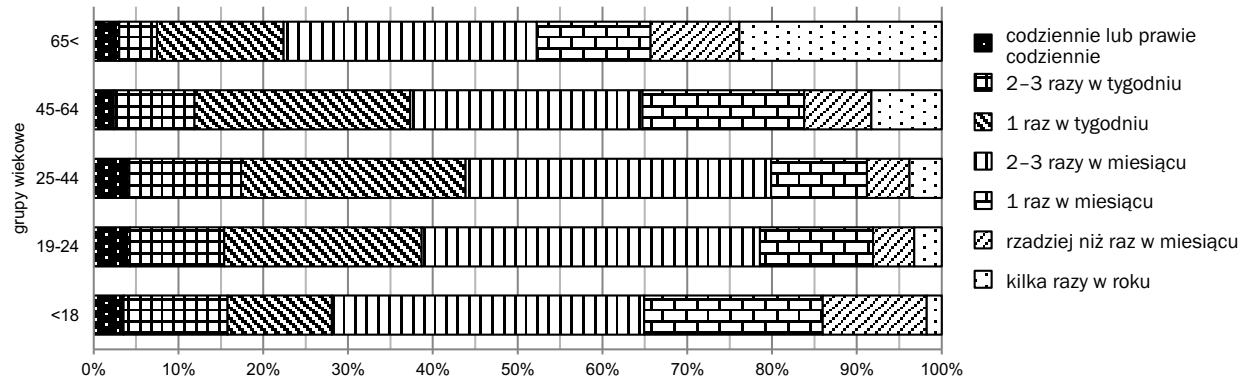

Rys. 94. Częstotliwość wizyt w centrach handlowych w zależności od kategorii wiekowej [N: 2411=100\%].

Źródło: Opracowanie własne na podstawie badań ankietowych.

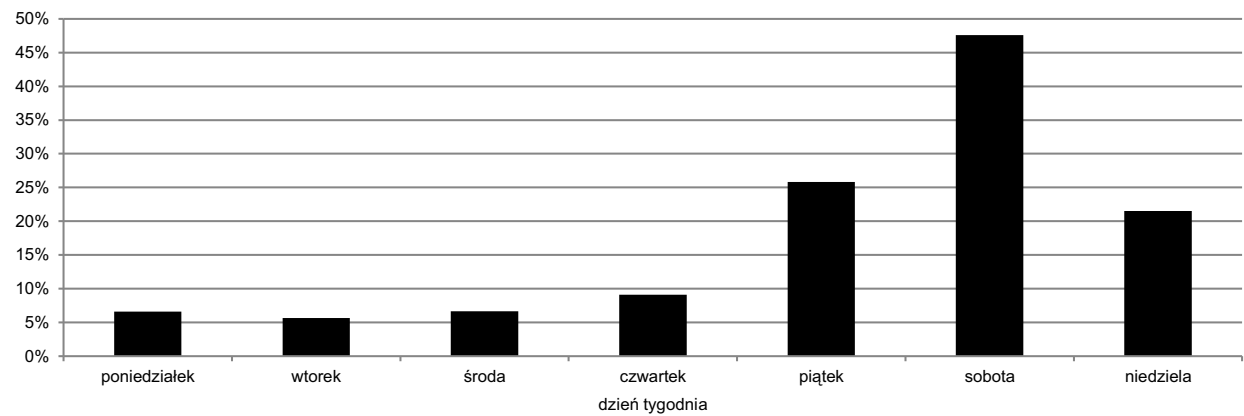

Rys. 95. Pobyty respondentów w centrach handlowych w zależności od dnia tygodnia.

Źródło: Opracowanie własne na podstawie badań ankietowych.

Należy zwrócić uwagę na fakt, że osoby powyżej 65. roku życia częściej odwiedzają takie centra handlowe w dni robocze, natomiast najrzadziej w niedzielę (tylko 1,4\%), natomiast młodzież szkolna (poniżej 18. roku życia) spędza czas w centrach handlowych głównie w soboty (70,2\%), piątki $(42,1 \%)$ i niedziele $(36,8 \%)$ (tab. 33). Osoby młodsze w dni weekendowe 
mają więcej czasu (są wolne od zajęć szkolnych), natomiast respondenci ze starszych grup wiekowych, szczególnie ci na emeryturze, dysponują czasem w dni robocze. Dla niektórych $\mathrm{z}$ tej drugiej grupy istotne jest unikanie tłumów podczas zakupów i dzięki temu większy komfort przy wykonywaniu tej czynności.

Tabela 33

Pobyty w centrach handlowych według dni tygodnia i wieku respondentów

\begin{tabular}{|l|c|c|c|c|c|c|}
\hline \multirow{2}{*}{$\begin{array}{c}\text { Dzień } \\
\text { tygodnia }\end{array}$} & \multicolumn{5}{|c|}{ Kategorie wiekowe } & \multirow{2}{*}{ Ogółem } \\
\cline { 2 - 6 } & $\mathbf{< 1 8}$ & $\mathbf{1 9 - 2 4}$ & $\mathbf{2 5 - 4 4}$ & $\mathbf{4 5 - 6 4}$ & $\mathbf{6 5}<$ & \\
\hline Poniedziatek & $\mathbf{1 , 8 \%}$ & $\mathbf{8 , 3 \%}$ & $\mathbf{6 , 8} \%$ & $5,0 \%$ & $8,7 \%$ & $6,6 \%$ \\
\hline Wtorek & $3,5 \%$ & $7,3 \%$ & $4,9 \%$ & $5,4 \%$ & $11,6 \%$ & $5,7 \%$ \\
\hline Środa & $7,0 \%$ & $8,1 \%$ & $6,0 \%$ & $5,9 \%$ & $14,5 \%$ & $6,7 \%$ \\
\hline Czwartek & $14,0 \%$ & $8,9 \%$ & $8,7 \%$ & $9,7 \%$ & $10,1 \%$ & $9,1 \%$ \\
\hline Piątek & $42,1 \%$ & $23,8 \%$ & $27,2 \%$ & $23,9 \%$ & $15,9 \%$ & $25,8 \%$ \\
\hline Sobota & $70,2 \%$ & $44,8 \%$ & $52,2 \%$ & $41,5 \%$ & $14,5 \%$ & $47,6 \%$ \\
\hline Niedziela & $36,8 \%$ & $21,6 \%$ & $24,3 \%$ & $16,2 \%$ & $1,4 \%$ & $21,5 \%$ \\
\hline
\end{tabular}

Źródło: Opracowanie własne na podstawie badań ankietowych.

Centra handlowe posiadają również swój dobowy rytm funkcjonowania. Wprawdzie 58,2\% respondentów stwierdziło, że w ich przypadku nie ma reguły co do godzin wizytowania tego typu kompleksów, ale część podało takie pory dnia, w których najczęściej korzystają z oferty dużych centrów handlowych. Klienci, którzy wskazali, w jakich porach dnia odwiedzają centra handlowe, najchętniej bywają w nich w godzinach popołudniowych między 16.00 a 20.00 (niedziela 51,7\%; piątek 66,8\%), co wiąże się między innymi z zakończeniem pracy, czy zajęć szkolnych. W sobotę i niedzielę częściej niż w pozostałe dni centra handlowe są odwiedzane również w godzinach południowych $12.00-16.00$ (w dni robocze - 19,8\%; w sobotę i niedzielę ponad 30\%) (rys. 96).

Ze względu na natężenie ruchu klientów w ciągu dnia możemy mówić o pewnych fazach w dobowym życiu centrum handlowego. Najczęściej tego typu kompleksy są otwarte w godzinach od 9.00, 10.00 do 21.00, 22.00. W godzinach przedpołudniowych budzą się ze snu, wtedy zaczynają pojawiać się pierwsi klienci, można więc określić ją jako „fazę porannej 


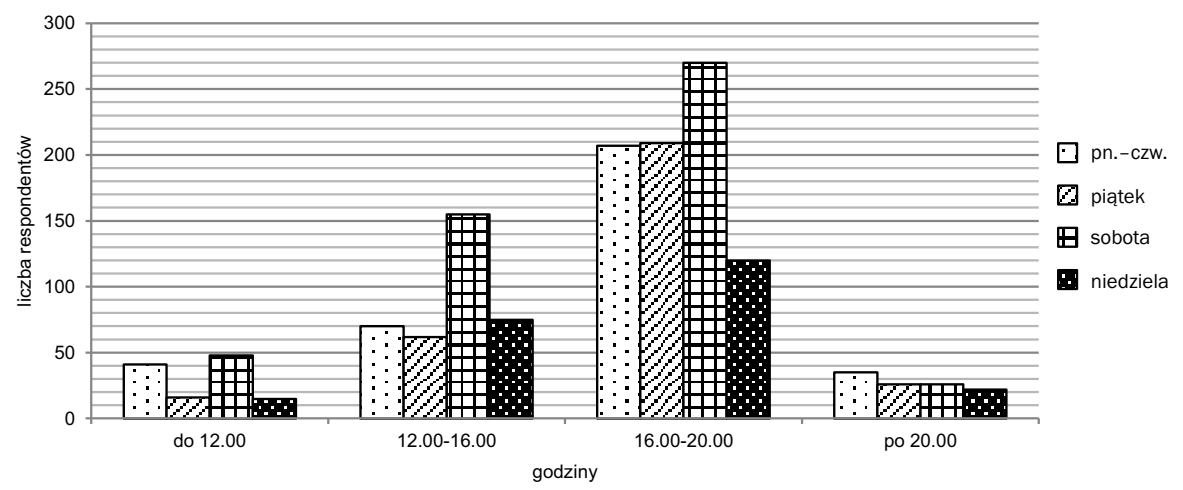

Rys. 96. Godziny pobytów w centrach handlowych według dni tygodnia.

Źródło: Opracowanie własne na podstawie badań ankietowych.

pobudki”. W godzinach popołudniowych zaczyna się wzmagać natężenie ruchu klientów i następuje wtedy faza „największej aktywności”. Pod koniec dnia stopniowo centrum handlowe przechodzi w fazę „powolnego spoczynku”, w której liczba odwiedzających zaczyna spadać. W godzinach nocnych w większości centra handlowe zapadają „w sen”134 (rys. 97).

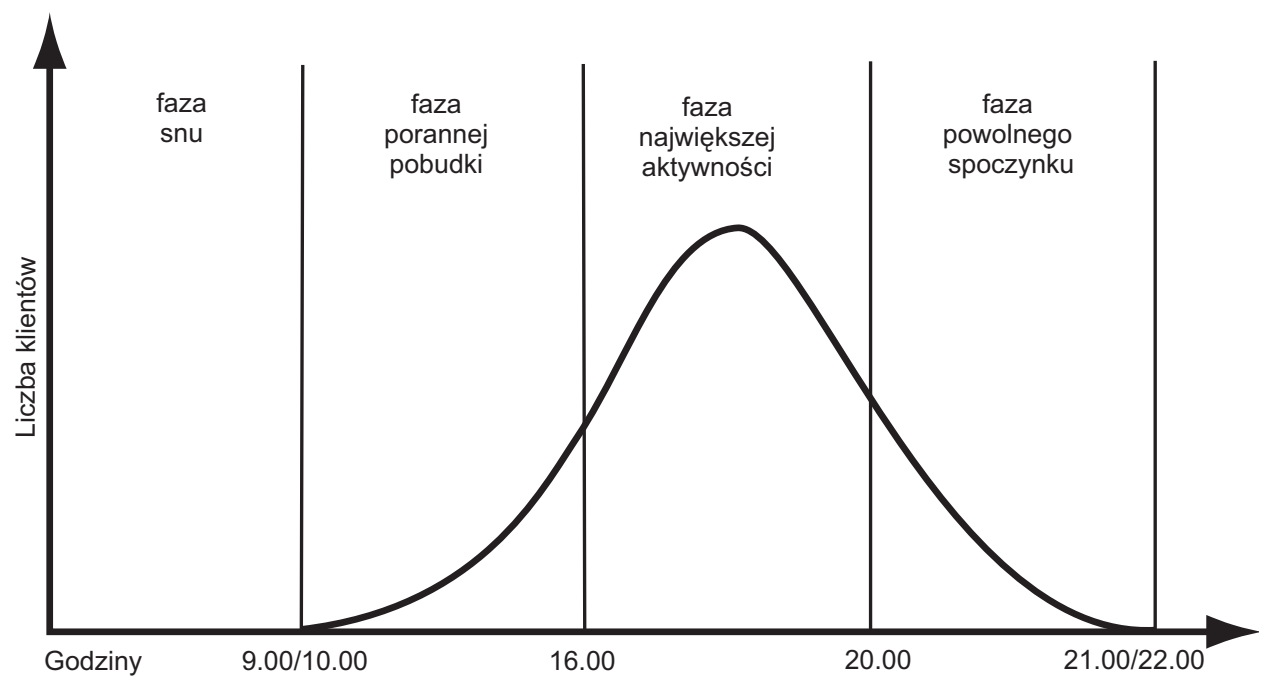

Rys. 97. Ogólny schemat dobowego cyklu życia centrum handlowego.

Źródło: Opracowanie własne na podstawie badań ankietowych.

${ }^{134}$ Niektóre centra handlowe mogą być otwarte przez całą dobę, na przykład Tesco W. 
Ta schematyczność życia centrum handlowego ma miejsce we wszystkie dni tygodnia. W zależności jednak od tego, czy to jest dzień roboczy, czy weekendowy przesunięciu ulegają godziny graniczne poszczególnych faz oraz różnicuje się ich długość. Wielkość natężenia ruchu klientów jest też różna w poszczególnych etapach w zależności od dnia tygodnia. Łódzkie centra handlowe są zróżnicowane pod względem ofertowym, co też ma swój wpływ na fazowość dobową (na przykład w Manufakturze wiele punktów rozrywkowych działa do późnych godzin nocnych, a nawet porannych, szczególnie w dni weekendowe).

\subsubsection{Korzystanie $\mathrm{z}$ oferty centrów handlowych}

Wyjazdy do centrów handlowych są często wyprawami z członkiem rodziny - mężem, żoną, dzieckiem (42,1\%) lub ze znajomymi, przyjaciółmi $(35,1 \%)$. Wiele osób lubi odwiedzać również te „świątynie konsumpcji” samemu (29,8\%). Sporadycznie jednak respondenci przyznają, że wyprawy tego typu są wyprawami rodzinnymi z „całą rodziną” $(9,3 \%)^{135}$. Pobyt w takim kompleksie trwa najczęściej 1-2 godziny (42,5\%) lub 2-3 godziny (28,5\%). Dość znaczna grupa respondentów odwiedza centra handlowe na dość krótko, bo do 1 godziny (18,9\%), a tylko co dziesiąta osoba spędza w nim powyżej 3 godzin.

Głównym powodem wizyt w centrach handlowych dla klientów jest robienie zakupów (93,2\%), dla co czwartej badanej osoby jest to sposób spędzania czasu wolnego (26,9\%), możliwość zapoznania się z nowymi towarami $(23,5 \%)$ lub/oraz możliwość korzystania z usług gastronomicznych (22,4\%). Tylko 201 (8,3\%) respondentów za jeden $z$ głównych powodów wskazało udział $\mathrm{w}$ imprezach i pokazach organizowanych na terenie centrów handlowych. Sporadycznie pojawiały się inne powody, z których najczęściej były wymieniane spotkania towarzyskie lub towarzyszenie innym osobom (rys. 98).

Należy zwrócić uwagę, że dla wielu z najmłodszej grupy respondentów (do 18. roku życia) obok robienia zakupów (najniższy wskaźnik 82,5\%) pobyty w centrach handlowych są również sposobem spędzania czasu wolnego (dla aż 61,4\%) oraz możliwością skorzystania z usług gastronomicznych

${ }^{135} \mathrm{~W}$ pytaniu można było zaznaczyć więcej niż jedną odpowiedź. 


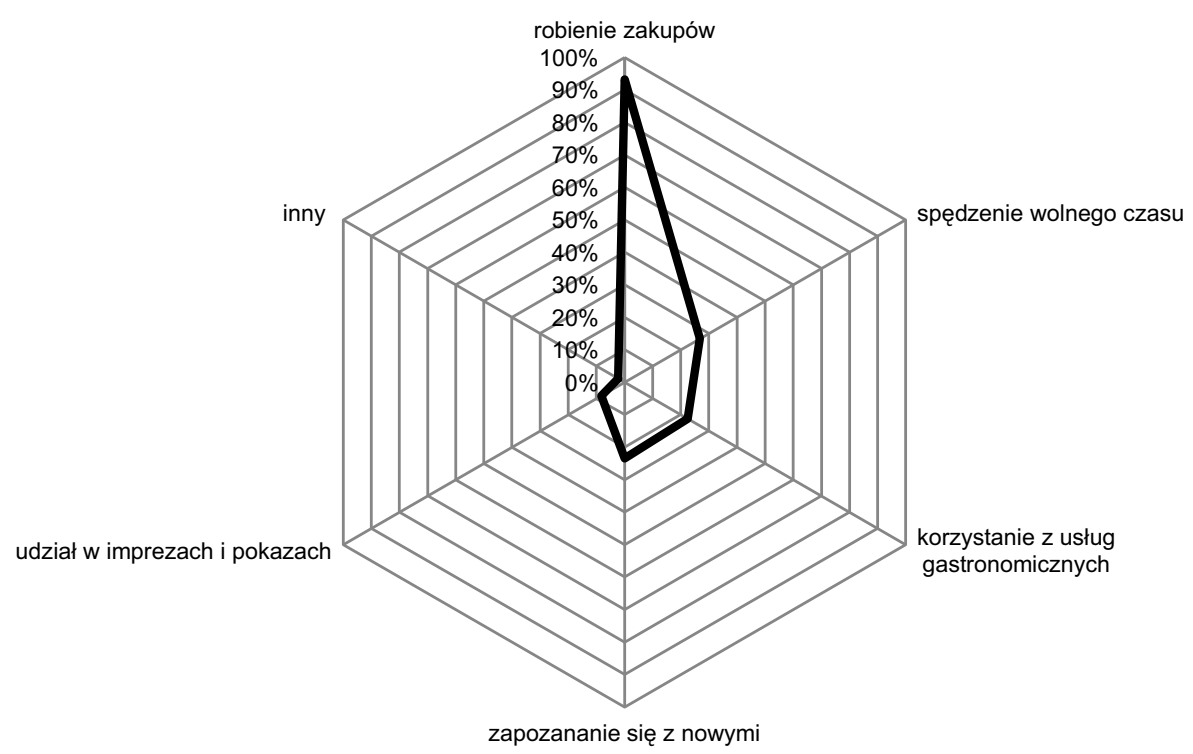

Rys. 98. Powody wizyt w centrach handlowych [N: $2420=100 \%$.

Źródło: Opracowanie własne na podstawie badań ankietowych.

$(42,1 \%)$ i wzięciu udziału w organizowanych imprezach i pokazach (dla $21,1 \%$ ). Dla osób powyżej 45 . roku życia wizyty w centrach handlowych są związane przede wszystkim z dokonywaniem zakupów (95,3\% - najwyższy wskaźnik). W tej kategorii wiekowej ewidentnie spada odsetek osób, korzystających z usług gastronomicznych (7-9\%) oraz tych, które biorą udział w imprezach i pokazach (niecałe 6\%). W grupie osób najstarszych jest najwyższy ze wszystkich kategorii wiekowych udział osób, dla których powodem odwiedzin takich centrów handlowych jest zapoznanie się z nowymi towarami (ok. 32\%) (rys. 99).

Głównym magnesem ofertowym przyciągającym klientów do centrów handlowych jest hipermarket $\mathrm{z}$ artykułami FMCG, ponad 80\% deklaruje, że korzysta $\mathrm{z}$ tego typu miejsc, robiąc zakupy. Prawie co drugi klient również odwiedza małe sklepy $(44,8 \%)$ zlokalizowane w galeriach handlowych oraz specjalistyczne hipermarkety (AGD, meblowy, budowlany, ogrodniczy) (40,1\%). Centra handlowe to nie tylko miejsca robienia zakupów dóbr materialnych, ale również możliwość skorzystania z węższej lub szerszej oferty usługowej i rozrywkowej. Co trzecia badana osoba przyznaje, że korzysta z punktów gastronomicznych (34,8\%), a co czwarta zaspokaja tu 


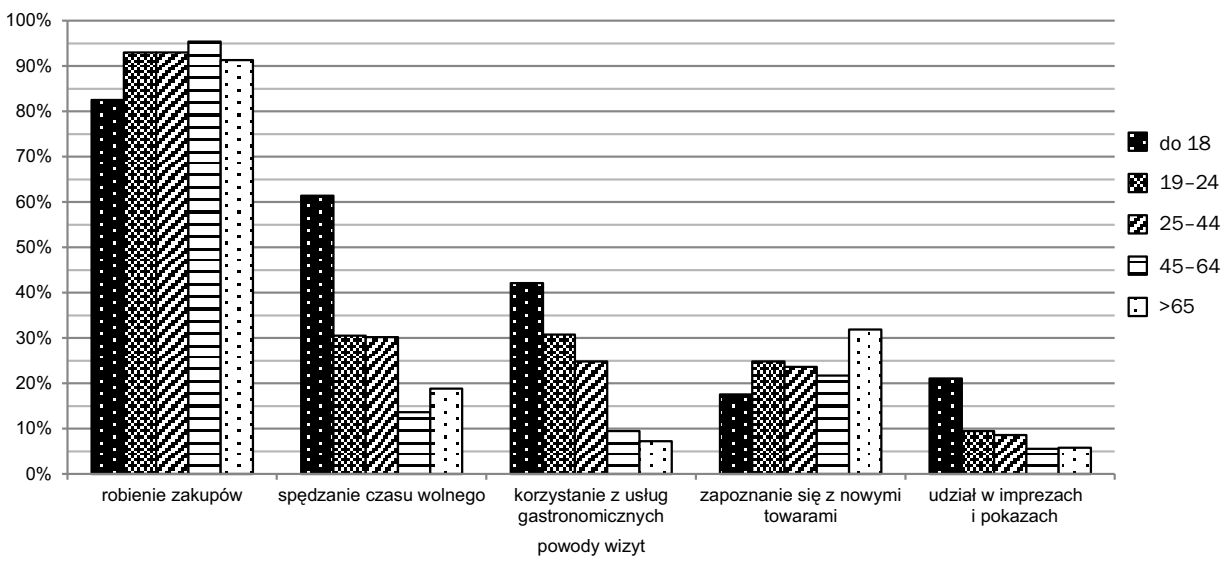

Rys. 99. Powody wizyt w centrach handlowych według wieku.

Źródło: Opracowanie własne na podstawie badań ankietowych.

swoje potrzeby rozrywkowe, odwiedzając działające tam kina czy teatry (oferta rozrywkowa dotyczy przede wszystkim klientów Manufaktury) (25,6\%). Oczywiście możliwość realizacji swoich potrzeb i zainteresowań jest uzależniona od typu ofertowego centrum. Z punktów usługowych, które mają swoje siedziby $\mathrm{w}$ tych kompleksach, największą popularnością cieszą się usługi finansowe (na przykład bankowe, ubezpieczeniowe $12 \%$ ) oraz kosmetyczne i fryzjerskie (8\%). Z innych punktów usługowych, na przykład pralniczych korzystają pojedyncze osoby (rys. 100).

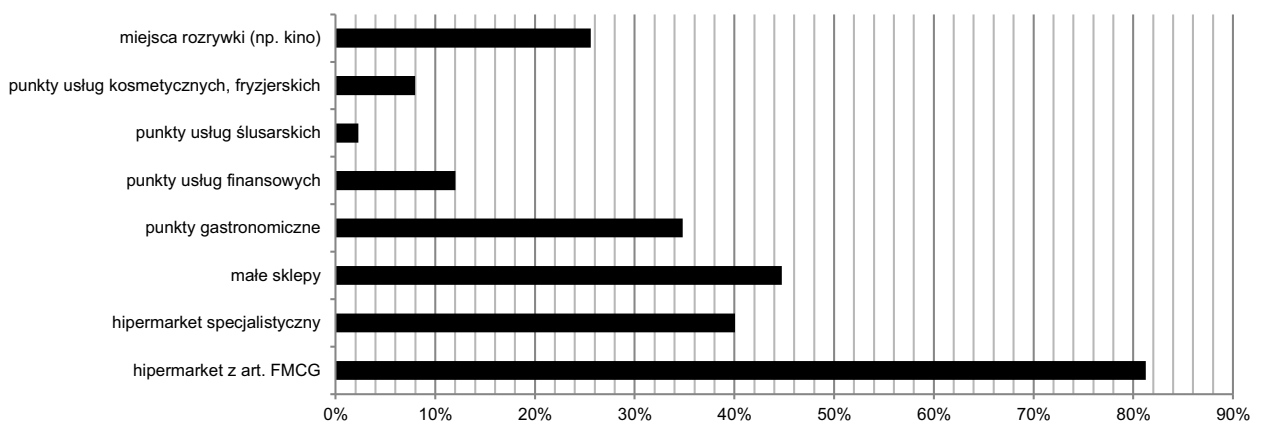

Rys. 100. Oferta, z jakiej respondenci korzystają w wybranych przez nich centrach handlowych.

Źródło: Opracowanie własne na podstawie badań ankietowych. 
Większy odsetek kobiet niż mężczyzn robi zakupy w hipermarkecie z FMCG $(82,7 \% ; 78,5 \%)$ i w małych sklepach $(46 \% ; 42,3 \%)$ oraz więcej $z$ nich korzysta $z$ oferty fryzjerskiej i kosmetycznej (9,9\%; 4,2\%). Mężczyźni natomiast $\mathrm{w}$ większym stopniu niż kobiety odwiedzają hipermarkety specjalistyczne $(43,1 \% ; 38,5 \%)$, punkty gastronomiczne $(36,6 \% ; 33,9 \%)$ i korzystają z usług ślusarskich $(3,2 \% ; 1,8 \%)$.

Różnice uwidaczniają się również między poszczególnymi kategoriami wiekowymi:

- hipermarket z FMCG - wraz z wiekiem odsetek korzystających z tych sklepów wzrasta (do 18. roku życia jest to 40,4\% osób; powyżej 64 . roku - 89,9\%),

- hipermarket specjalistyczny, ten typ sklepu odwiedzają głównie osoby w wieku 45-64 (49,8\%) oraz w wieku 25-44 (41,5\%),

- małe sklepy - im młodsze osoby, tym częściej wizytują te punkty, do 44. roku życia - od $48 \%$ do 54\%, w wieku 45-64, co trzecia osoba, a w wieku powyżej 64. roku życia już tylko co czwarta,

- punkty gastronomiczne $-\mathrm{z}$ ich oferty korzystają głównie ludzie młodzi i w średnim wieku poniżej 45. roku życia (40-50\%), najmniej zainteresowani tą ofertą są ludzie najstarsi $(11,6 \%)$,

- usługi kosmetyczne i fryzjerskie - leżą głównie w centrum zainteresowań ludzi młodych do 24. roku życia (około 10\%), im starsze osoby, tym odsetek osób poddających się zabiegom upiększającym w tego typu placówkach spada (2,9\%).

W hipermarketach i supermarketach z artykułami z FMCG głównie są kupowane artykuły chemiczne, środki czystości, kosmetyczne $(75,4 \%)$ i spożywcze $(65,7 \%)$. Asortyment odzieżowy, obuwniczy, sportowy (30,7\%) oraz papierniczy - książki, czasopisma (44,6\%) - przez dużą część klientów nabywana jest w małych i średnich sklepach zlokalizowanych w galeriach handlowych. W dużych specjalistycznych marketach nabywcy często zakupują natomiast sprzęt RTV (37,5\%) i AGD (33,6\%) oraz towary służące do wyposażenia wnętrz mieszkań na przykład meble, dywany, firanki (37,6\%) (rys. 101).

Asortyment nabywany przez klientów w centrach handlowych jest bardzo zróżnicowany. Nie wszystkie towary kupowane przez klientów są nabywane we wskazanych przez respondentów kompleksach. Najwięcej osób nie kupuje w wybranych centrach handlowych artykułów szkolnych i zabawek (44,4\%), elementów wyposażenia wnętrz mieszkań (44,4\%). 


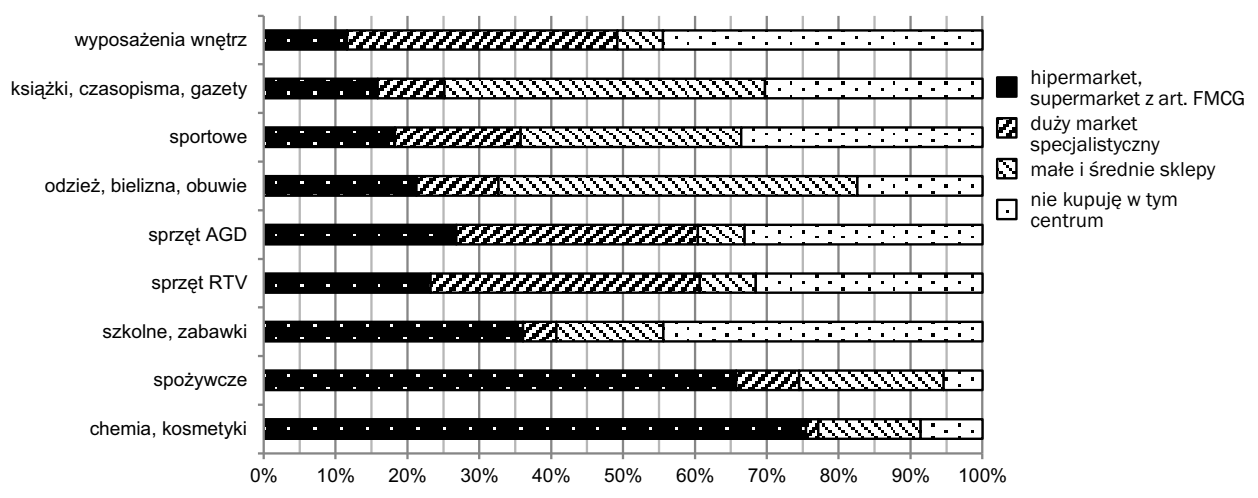

Rys. 101. Miejsca zakupu w centrach handlowych ze względu na rodzaj asortymentu.

Źródło: Opracowanie własne na podstawie badań ankietowych.

Ponad 30\% klientów we wskazanym przez siebie centrum handlowym nie kupuje również artykułów sportowych, sprzętu AGD i RTV oraz książek, czasopism i gazet.

\subsubsection{Postrzeganie łódzkich centrów handlowych i ich lokalizacji}

W Łodzi funkcjonuje dwanaście centrów handlowych zlokalizowanych w różnych częściach miasta. Okazuje się, że klienci w zdecydowanej większości (prawie 95\%) tego typu kompleksów mają listę wybranych obiektów, które najczęściej odwiedzają. Tylko 123 osoby $(5,1 \%)$ stwierdziły, że w zależności od potrzeb korzystają $\mathrm{z}$ oferty w różnych centrach handlowych i nie są do żadnego $z$ nich przywiązani. Najczęściej frekwentowanym kompleksem jest wizytówka Łodzi, czyli Manufaktura (ponad 57\%), natomiast na drugim miejscu znajduje się Galeria Łódzka odwiedzana przez około 43\% osób. Prawie co czwarty klient bywa również w Porcie Łódź (22,1\%). Przynajmniej co 10 respondent wizytuje inne duże centra handlowe: C.H. Pasaż Łódzki, C.H. Tulipan, Tesco na Pojezierskiej oraz C.H. M1 i Tesco na Widzewie. Najmniej osób odwiedza C.H. Guliwer (8,4\%), Carrefour Sz. (7,2\%), Carrefour P. (6,8\%) i E. Leclerc (6\%) (rys. 102).

W przypadku wskazania najbardziej ulubionego łódzkiego centrum handlowego kolejność jest zbliżona. Należy jednak w tym momencie podkreślić, że dla ponad 39\% ankietowanych nie ma faworyzowanego kom- 


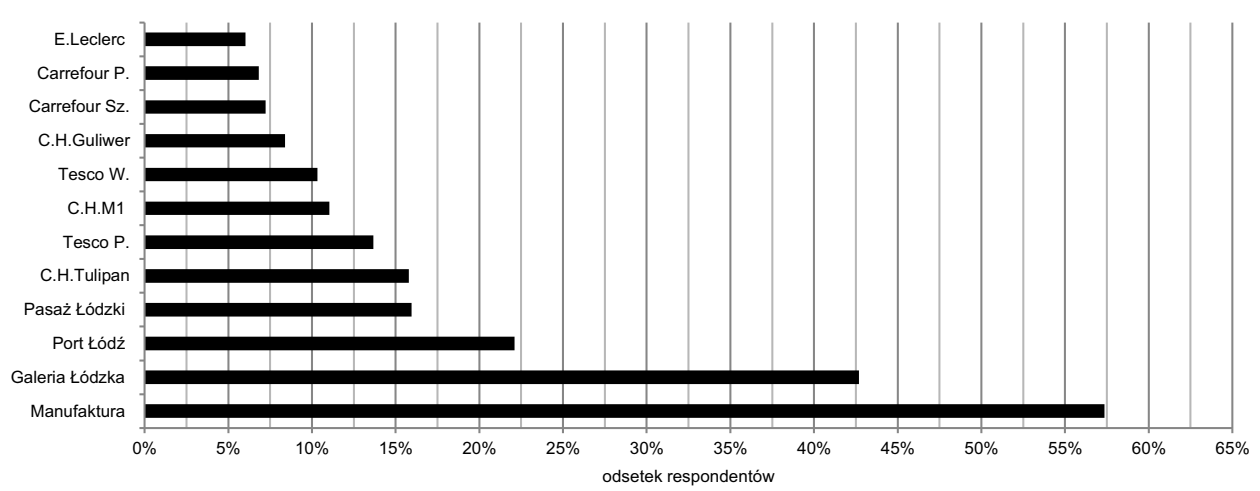

Rys. 102. Najczęściej odwiedzane łódzkie centra handlowe.

Źródło: Opracowanie własne na podstawie badań ankietowych.

pleksu. Z osób, które mają ulubione centrum handlowe, to co dla czwartego respondenta takim kompleksem jest Manufaktura (25,1\%; 607 osób). Dość dużą sympatią cieszą się również Galeria Łódzka (10,3\%; 248 osób) i Port Łódź (7,9\%; 190 osób). Pozostałe centra handlowe są uznawane za ulubione przez kilka procent osób od 3,6\% (86 osób) C.H. Tulipan do 0,8\% (19 osób) Carrefour Sz.

Łódzkie centra handlowe są dobrze postrzegane przez ich klientów, o czym może świadczyć fakt, że $85 \%$ respondentów nie wskazało nielubianego centrum handlowego. $Z$ tych osób, które są negatywnie nastawione do któregoś z kompleksów, to najwięcej wskazań otrzymał Port Łódź 67 osób (2,8\%), Manufaktura 47 (1,7\%), Galeria Łódzka 38 (1,6\%) oraz C.H. M1 37 (1,5\%). Pozostałe badane centra handlowe były wskazywane jako nielubiane przez jeden lub mniej procent ankietowanych (po mniej niż 25 osób). Negatywne postrzeganie niektórych centrów handlowych nie wpływa zasadniczo na zachowania przestrzenne nabywców, ponieważ odsetek osób wskazujących na nielubiane kompleksy jest niewielki.

W dalszej kolejności należy zastanowić się nad lokalizacją centrów handlowych względem miejsc zamieszkania respondentów. $Z$ badań ankietowych wynika, że 50,6\% [N=2392] osób wybiera najczęściej centrum handlowe położone najbliżej miejsca zamieszkania, ale aż 40,8\% ankietowanych nie kieruje się tym czynnikiem i wybiera kompleksy dalej położone od miejsca zamieszkania. Warto też zaznaczyć, że 8,6\% respondentów nie orientuje się, czy wskazane przez nich centrum handlowe jest najbliżej położone względem miejsca zamieszkania. 
Ankietowani zostali poproszeni również o wskazanie miejsca najkorzystniejszej względem ich miejsca zamieszkania lokalizacji nowego centrum handlowego. Z 2401 respondentów, którzy odpowiedzieli na to pytanie, 8,5\% (204 osoby) uważało, że nie jest potrzebny następny obiekt tego typu w mieście. Z tych, którzy jednak wypowiedzieli się w kwestii lokalizacji nowego centrum handlowego [ $\mathrm{N}=2197$; 90,8\%], najwięcej klientów widziałoby taki obiekt w zamieszkiwanej dzielnicy, w odległości od 10 do 30 minut dojścia pieszego (około 41\%) lub bliżej od 5 do 10 minut (około 34\%). W sumie aż trzy czwarte respondentów zlokalizowałaby taki obiekt stosunkowo blisko własnego miejsca zamieszkania. Dość znaczna grupa ankietowanych wskazała jednak na lokalizację na obrzeżach miasta (około 15\%). Niewiele osób okazało się zwolennikami lokalizacji w bezpośrednim sąsiedztwie domu (około 6\%) lub poza miastem na terenach niezamieszkanych (4,2\%) (rys. 103).

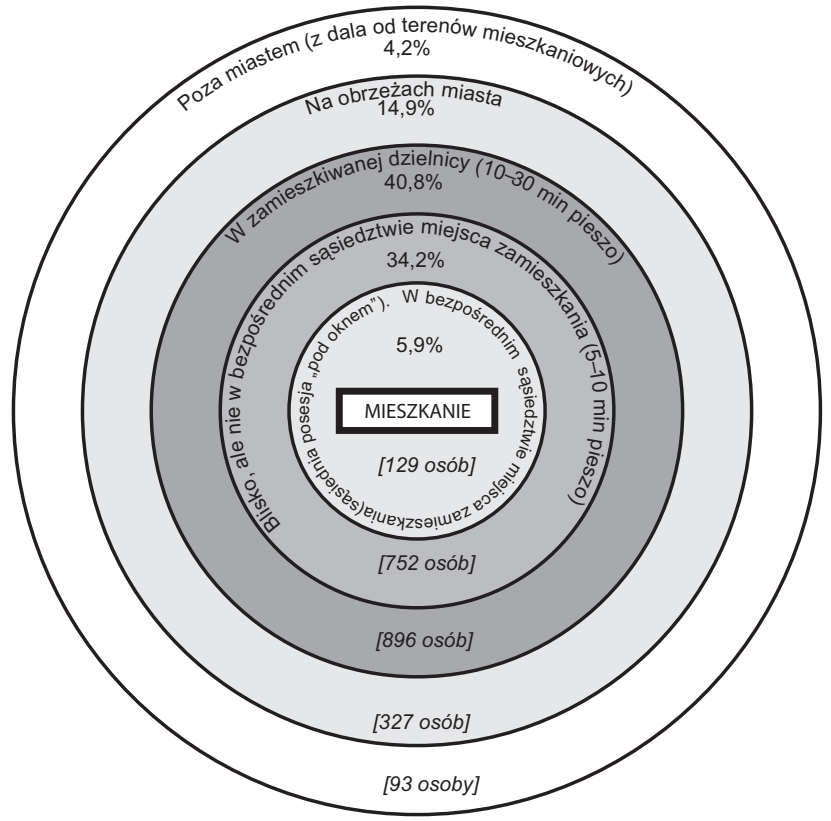

Rys. 103. Miejsca lokalizacji dużego obiektu handlowego w stosunku do miejsca zamieszkania według opinii respondentów [N: 2197=100\%].

Źródło: Opracowanie własne na podstawie badań ankietowych. 
Decyzja o przyszłej lokalizacji centrum handlowego w dużej mierze zależy od tego, czy dana osoba dysponuje samochodem, czy też nie. Klienci zmotoryzowani bardziej są skłonni wskazywać dalsze odległości lokalizacji od miejsca zamieszkania niż osoby niezmotoryzowane, dla których bliższa odległość jest bardziej korzystna. Na umiejscowienie nowego centrum handlowego na obrzeżach miasta lub poza miastem zgadza się około $80 \%$ respondentów zmotoryzowanych (rys. 104). Oczywiście należy pamiętać, że niektóre osoby nieposiadające samochodu wyjeżdżają do tego typu obiektów w towarzystwie osoby dysponującej autem.

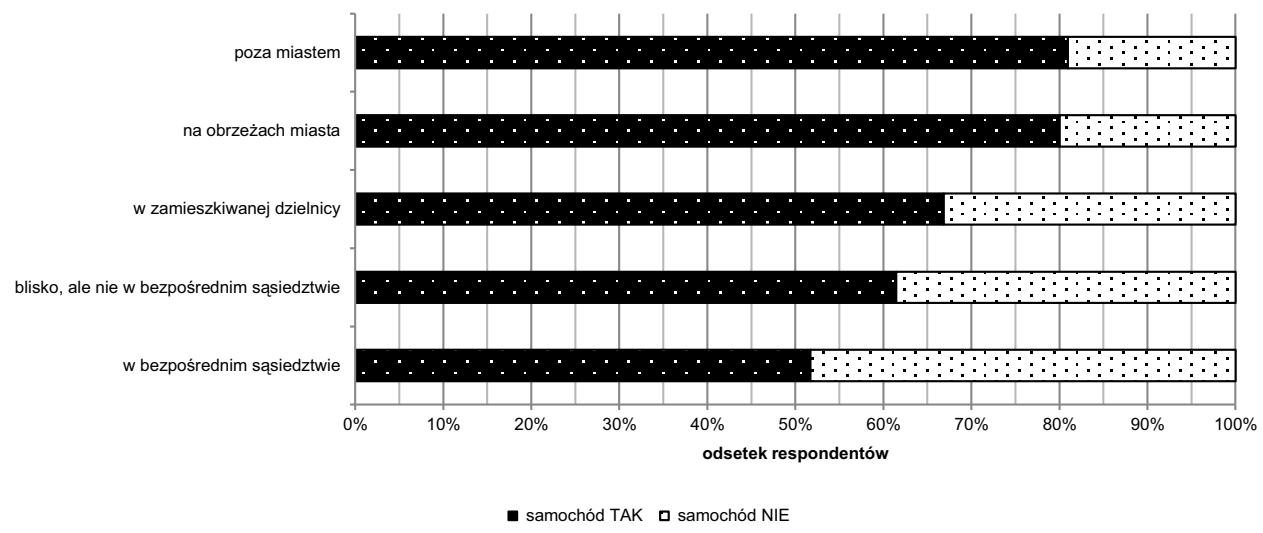

Rys. 104. Opinie o lokalizacji centrum handlowego w stosunku do miejsca zamieszkania w zależności od dysponowania samochodem [N: 2014=100\%].

Źródło: Opracowanie własne na podstawie badań ankietowych.

Wielu respondentów podawało argumenty przeciwko lokalizacji centrum handlowego $\mathrm{w}$ bezpośrednim sąsiedztwie ich miejsca zamieszkania „pod oknem”. Taki obiekt ich zdaniem przyczyniłby się do powstania utrudnień oraz wpłynąłby na zaistnienie różnych negatywnych zjawisk. Ponad $60 \%$ ankietowanych przewiduje pojawienie się $\mathrm{w}$ takiej sytuacji licznych uciążliwości, które związane byłby z wzrostem natężenia ruchu samochodowego i pieszego. Osoby te szczególnie obawiają się utrudnień komunikacyjnych, na przykład zatłoczenia dróg dojazdowych (korki), zajmowania osiedlowych miejsc parkingowych. Duża grupa ankietowanych utożsamia miejsca zamieszkania z azylem, w którym odpoczywają po 
pracy i dlatego obawiają się zakłócenia ich domowego spokoju w wyniku wzmożonego hałasu komunikacyjnego czy też przez imprezy odbywające się na terenie tego typu kompleksów (tab. 34).

Niektóre $z$ badanych osób widzą w takiej lokalizacji jeszcze inne zagrożenia, związane między innymi z pogorszeniem się jakości stanu środowiska przyrodniczego, będącym skutkiem systematycznego niszczenia zieleni, zatruwania powietrza przez wzmożoną emisję spalin czy też powstające nielegalne wysypiska śmieci (3,5\%). Ten ostatni argument znajduje swoje potwierdzenie przy obserwacjach poczynionych $\mathrm{w}$ otoczeniu już funkcjonujących niektórych łódzkich centrów handlowych, na przykład Carrefour P. czy w pobliżu C.H. Guliwer. Wygląd centrum handlowego, jego architektura, którą można przewidzieć (obiekty tego typu pod względem architektonicznym budowane są według przyjętych wzorów), jest dla pewnej grupy osób nie do przyjęcia. Nie podoba im się taka nowoczesna wielkogabarytowa forma, która dodatkowo może zasłaniać widok z okna lub go pogorszyć, czyli po prostu zepsuje ładny widok z okna, który najczęściej utożsamiany jest z zielenią (tab. 34).

Wśród ankietowanych znalazły się też osoby, dla których budowa takiego centrum handlowego łączy się ze zmniejszeniem poczucia bezpieczeństwa. Wpływ na taki stan rzeczy z jednej strony mogą mieć osoby z marginesu społecznego (żebracy, bezdomni, pijacy), z drugiej strony wzmożony ruch samochodowy może generować większą wypadkowość. Osoby te obawiają się głównie wzrostu przestępczości - częstszych bójek, czy też wzrostu kradzieży (tab. 34).

Niewielka grupa osób lubiących robić zakupy uważa, że tak blisko usytuowany kompleks w stosunku do ich miejsca zamieszkania będzie bardzo poważną pokusą w związku z czym obawiają się, że wzrośnie ich częstotliwość wizyt oraz/lub długość czasu spędzanego w takim centrum handlowym, co spowoduje stratę czasu i pieniędzy, a także kupowanie zupełnie niepotrzebnych rzeczy. Inni wzięli w obronę lokalne - osiedlowe sklepiki, które w pobliżu konkurencyjnego cenowo i asortymentowo kompleksu (większa liczba i zróżnicowanie towaru) mogłyby zbankrutować. Część respondentów (53 osoby) nie podała konkretnego zagrożenia, wynikającego z budowy takiego budynku „pod ich oknami”, ale jako argument przeciwko takiej budowie podali ich zbyt dużą liczbę w mieście lub fakt, że już taki obiekt $\mathrm{w}$ ich bezpośrednim sąsiedztwie istnieje i nie potrzebują następnego (tab. 34). 
Tabela 34

Argumenty przeciwko budowie centrum handlowego w bezpośrednim sąsiedztwie miejsca zamieszkania (,pod oknami”)

\begin{tabular}{|c|c|c|c|c|}
\hline Lp. & $\begin{array}{c}\text { Negatywne } \\
\text { zjawiska }\end{array}$ & Argumenty & $\begin{array}{l}\text { Liczba } \\
\text { wskazań }\end{array}$ & [\%] \\
\hline 1. & $\begin{array}{l}\text { Utrudnienia związane } \\
\text { ze wzrostem } \\
\text { natężenia ruchu } \\
\text { samochodowego } \\
\text { i pieszego }\end{array}$ & $\begin{array}{l}\text { - utrudnienia komunikacyjne (wzmożony ruch } \\
\text { uliczny - korki, hałas, spaliny, zajmowanie miejsc } \\
\text { parkingowych, niszczenie dróg) } \\
\text { - organizowanie imprez - hałas, zamieszanie, tłok } \\
\text { - zakłócenie spokoju - cenienie spokoju, ciszy, } \\
\text { prywatności }\end{array}$ & 1503 & 62,1 \\
\hline 2. & $\begin{array}{l}\text { Negatywny wpływ } \\
\text { na środowisko } \\
\text { przyrodnicze } \\
\text { otoczenia }\end{array}$ & $\begin{array}{l}\text { - zanieczyszczenie powietrza } \\
\text { - niszczenie zieleni } \\
\text { - pojawianie się nielegalnych wysypisk śmieci } \\
\text { (śmietnik pod oknami) }\end{array}$ & 85 & 3,5 \\
\hline 3. & $\begin{array}{l}\text { Negatywny wpływ na } \\
\text { estetykę krajobrazu }\end{array}$ & $\begin{array}{l}\text { - } \text { szpeci i zasłania widok, rażące neony } \\
\text { - pragnienie posiadania ładnego widoku z okna } \\
\text { (gtównie na zieleń) }\end{array}$ & 76 & 3,2 \\
\hline 4. & $\begin{array}{l}\text { Zmniejszenie } \\
\text { poczucia } \\
\text { bezpieczeństwa }\end{array}$ & $\begin{array}{l}\text { - wzrost przestępczości (kradzieże, bójki) } \\
\text { - } \text { pojawienie się bezdomnych, żebrzących, osób } \\
\text { nietrzeźwych } \\
\text { - zagrożenia związane z ruchem samochodowym, } \\
\text { wzrost liczby wypadków (szczególnie zagrożenia dla } \\
\text { bawiących się dzieci) }\end{array}$ & 34 & 1,4 \\
\hline 5. & $\begin{array}{l}\text { Wpływ na stratę } \\
\text { czasu i pieniędzy }\end{array}$ & $\begin{array}{l}\text { - } \text { częstsze zakupy } \\
\text { - } \text { spędzanie więcej czasu na zakupach } \\
\text { - } \text { pokusa robienia niepotrzebnych zakupów } \\
\text { (wydawanie pieniędzy) }\end{array}$ & 15 & 0,6 \\
\hline 6. & $\begin{array}{l}\text { Negatywny wpływ } \\
\text { na funkcjonowanie } \\
\text { sklepików } \\
\text { osiedlowych }\end{array}$ & $\begin{array}{l}\text { - duża konkurencja cenowa oraz asortymentowa } \\
\text { - doprowadzenie do bankructwa }\end{array}$ & 15 & 0,6 \\
\hline 7. & Inny & $\begin{array}{l}\text { - jest zbyt dużo w mieście } \\
\text { - } \text { istnieje już taki obiekt w sąsiedztwie } \\
\text { - } \text { spadek cen nieruchomości i tym podobne }\end{array}$ & 147 & 6,1 \\
\hline
\end{tabular}

Źródło: Opracowanie własne na podstawie badań ankietowych [N: 2420=100\%].

Wśród wszystkich ankietowanych znalazła się też grupa osób (zdecydowanie mniejsza od przeciwników takiej budowy), która byłaby zadowolona $\mathrm{z}$ lokalizacji centrum handlowego $\mathrm{w}$ bezpośrednim sąsiedztwie zamieszkania. Podkreślali oni przede wszystkim bliską odległość do kompleksu, w którym można nabywać towary taniej, szybciej, bardziej komfortowo 
oraz w którym dzięki odległości można bywać częściej, korzystając z licznych promocji (11,7\%). Taka lokalizacja jest postrzegana jako korzystna nie tylko przez osoby niezmotoryzowane (mogą dotrzeć na pieszo), ale również przez niektóre osoby posiadające samochody (oszczędność paliwa i czasu) (tab. 35).

\section{Tabela 35}

Argumenty za budową centrum handlowego w bezpośrednim sąsiedztwie miejsca zamieszkania (,pod oknami”)

\begin{tabular}{|c|c|c|c|c|}
\hline Lp. & Powody & Argumenty & $\begin{array}{c}\text { Liczba } \\
\text { wskazań }\end{array}$ & [\%] \\
\hline 1. & $\begin{array}{l}\text { Odległość } \\
\text { - blisko na } \\
\text { zakupy }\end{array}$ & $\begin{array}{l}\text { - duży wybór tanich artykułów (oszczędność pieniędzy) } \\
\text { - możliwość bywania częściej, częstsze korzystanie } \\
\text { z promocji } \\
\text { - można szybko zrobić zakupy } \\
\text { - } \text { wygoda (dla osób starszych, inwalidów) }\end{array}$ & 284 & 11,7 \\
\hline 2. & $\begin{array}{l}\text { Oszczędność } \\
\text { czasu }\end{array}$ & $\begin{array}{l}\text { - szybsze dotarcie do sklepu (nie stoi się w korkach, } \\
\text { nie trzeba robić specjalnej wyprawy) } \\
\text { - można robić zakupy w dogodnym momencie, } \\
\text { o każdej porze dnia (długo otwarty) }\end{array}$ & 118 & 4,9 \\
\hline 3. & $\begin{array}{l}\text { Możliwość } \\
\text { dotarcia pieszo }\end{array}$ & $\begin{array}{l}\text { - latwo dotrzeć (nawet przy braku samochodu) } \\
\text { - jest blisko, kiedy trzeba przynieść ciężkie zakupy } \\
\text { - oszczędność pieniędzy (mniejsze wydatki na paliwo) }\end{array}$ & 49 & 2,0 \\
\hline 4. & Inne & $\begin{array}{l}\text { - } \text { potencjalne miejsce pracy } \\
\text { - wzrost wartości nieruchomości } \\
\text { - lepsza komunikacja (nowe drogi, MPK - częstsze kursy) } \\
\text { - zwiększenie prestiżu okolicy, osiedla } \\
\text { - } z \text { większenie możliwości spędzania czasu wolnego, itp. }\end{array}$ & 17 & 0,7 \\
\hline
\end{tabular}

Źródło: Opracowanie własne na podstawie badań ankietowych.

Z badań wynika, że u większości klientów centra handlowe nie budzą złych lub dobrych konotacji i nie to decyduje o ich zachowaniach przestrzennych (dokonywanie wyboru konkretnego centrum handlowego). Istotne z punktu widzenia lokalizacji jest położenie w stosunku do miejsca zamieszkania. Zdecydowana większość osób (75\%) chce, by taki obiekt znajdował się dość blisko jego miejsca zamieszkania (do 30 minut pieszo), ale nie chcą mieć go w bezpośrednim sąsiedztwie „pod oknem”, obawiając się głównie problemów związanych ze wzrostem natężenia ruchu samochodowego i wynikającymi z tego faktu konsekwencjami. 


\subsection{Profile klientów $i$ ich zachowania nabywcze w zależności od typu centrum handlowego}

\subsubsection{Profile klientów}

Łódzkie centra handlowe, jak już wcześniej napisano, różnią się między sobą, między innymi ofertą, wielkością i lokalizacją, w związku z tym jednym z problemów badawczych, nad którym należy się zastanowić, jest odpowiedź na pytanie, „,zy istnieją różnice w strukturze klientów poszczególnych typów centrów handlowych?”. Pod rozwagę wzięto do analizy kilka cech demograficznych, społecznych i ekonomicznych - wiek, płeć, wykształcenie, stan cywilny, liczbę posiadanych dzieci, źródła utrzymania i ocenę statusu materialnego.

$\mathrm{Na}$ dwanaście centrów handlowych wybranych do analizy zachowań nabywczych i przestrzennych wskazało 2335 osób ${ }^{136}$. Najwięcej respondentów wybrało typ I (Manufaktura) - 810 osób, po ponad 500 osób było klientami centrów handlowych typu II (Galeria Łódzka, Port Łódź) i IV (C.H. M1, Pasaż Łódzki, Carrefour P., Carrefour Sz., Tesco W., E. Leclerc). Najmniej respondentów wskazało na centra handlowe III typu - 390 osób (Tesco P., C.H. Guliwer, C.H. Tulipan). Struktura ankietowanych według płci była podobna we wszystkich typach. Zdecydowaną większość stanowiły kobiety (około 66\%), co trzeci respondent był mężczyzną (około 34\%) (tab. 36).

Tabela 36

Struktura klientów według płci i typów centrów handlowych

\begin{tabular}{|l|c|c|c|c|c|}
\hline \multirow{2}{*}{ Typy } & \multicolumn{2}{|c|}{ Kobiety } & \multicolumn{2}{c|}{ Mężczyźni } & \multirow{2}{*}{ Razem } \\
\cline { 2 - 5 } & Liczba & {$[\%]$} & Liczba & {$[\%]$} & \\
\hline Typ I & 537 & 66,3 & 273 & 33,7 & 810 \\
\hline Typ II & 389 & 65,2 & 208 & 34,8 & 597 \\
\hline Typ III & 267 & 68,5 & 123 & 31,5 & 390 \\
\hline Typ IV & 360 & 66,9 & 178 & 33,1 & 538 \\
\hline Razem & 1553 & 66,5 & 782 & 33,5 & 2335 \\
\hline
\end{tabular}

Źródło: Opracowanie własne na podstawie badań ankietowych [N: 2335=100\%].

${ }^{136} \mathrm{~W}$ sumie 85 osób opisało szczegółowo swoje zachowania nabywcze i przestrzenne w Makro Cash \& Carry (ul. Kasprzaka i Rzgów), Selgros Cash \& Carry (ul. Rokicińska i ul. 3 Maja) oraz Carrefour (ul. Bandurskiego). Tych kwestionariuszy ankiet nie wzięto pod uwagę w tej części pracy. 
Pod względem wieku zauważalna jest różnica między klientami I i II typu a III i IV. W pierwszym przypadku dominują ludzie młodzi, gdzie ponad $80 \%$ są to osoby poniżej 44. roku życia, natomiast $\mathrm{w}$ drugim spada udział tych osób do około $60 \%$, a wzrasta liczba osób starszych powyżej 45. roku życia (rys. 105). Średni wiek klienta centrum handlowego I typu wynosi 31,6 lat i jest zbliżony do średniego wieku klienta centrum II typu - 31,9 lat. W dwóch pozostałych kategoriach centrów handlowych przeciętny klient jest o 8 lat starszy (III - 39,1; IV typ - 39,8).

Zauważalne są również różnice w wykształceniu klientów. W typie I i II klienci są lepiej wykształceni, większy jest udział osób z wykształceniem wyż-

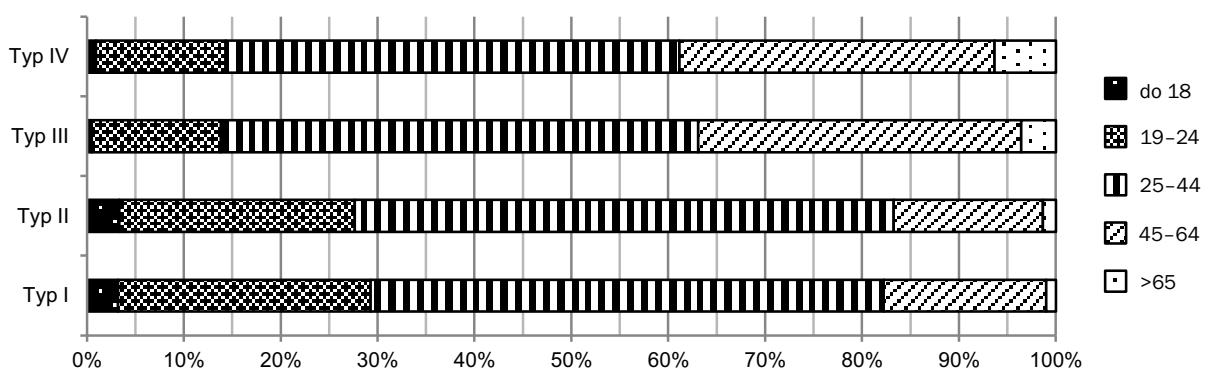

Rys. 105. Struktura klientów według wieku i typów centrów handlowych [N: $2335=100 \%]$.

Źródło: Opracowanie własne na podstawie badań ankietowych.

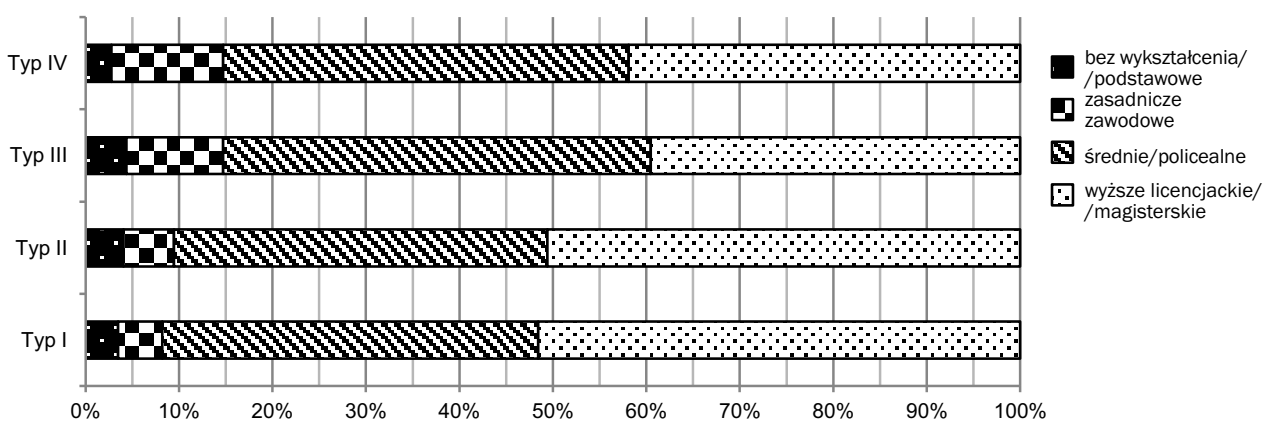

Rys. 106. Struktura klientów według wykształcenia i typów centrów handlowych [N: 2318=100\%].

Źródło: Opracowanie własne na podstawie badań ankietowych. 
szym (około 50\%), natomiast w centrach handlowych typu III i IV ich odsetek spada do blisko $40 \%$, natomiast wzrasta udział osób z wykształceniem zawodowym (I i II - po około 5\%; III i IV - po około 10\%) (rys. 106). Na jedną osobę z wyższym wykształceniem (licencjackim i magisterskim) przypada 0,94 (I typ) i 0,98 (II typ) osoby z innym wykształceniem, wskaźnik ten wzrasta znacznie w przypadku III typu - 1,53 i IV typu - 1,39, co świadczy o większym udziale osób z wykształceniem wyższym wśród klientów typu I i II.

Wcześniej już wspomniano, że w typie I i II klientami są głównie ludzie młodzi, $w$ związku $\mathrm{z}$ tym przeważają $\mathrm{w}$ nich osoby będące $\mathrm{w}$ stanie wolnym - panny i kawalerowie stanowią tu około $60 \%$ klientów. W pozostałych typach ten udział spada o połowę do około 30\%, natomiast wzrasta ewidentnie udział osób pozostających w związkach małżeńskich, którzy w III i IV typie stanowią około 60\% klientów (I, II - około 30\%). W tych dwóch kategoriach wzrasta też udział osób w stanie wdowim oraz rozwiedzionych i separowanych (I, II - około 6\%; III, IV - około 13\%) (rys. 107). Na jedną osobę w związku małżeńskim w I typie przypada 2,1 osoby w stanie wolnym, w II typie 1,8 . W pozostałych typach ten wskaźnik przyjmuje wartość dużo niższą i wynosi 0,8 , co świadczy o przewadze w tym wypadku osób pozostających w związkach małżeńskich.

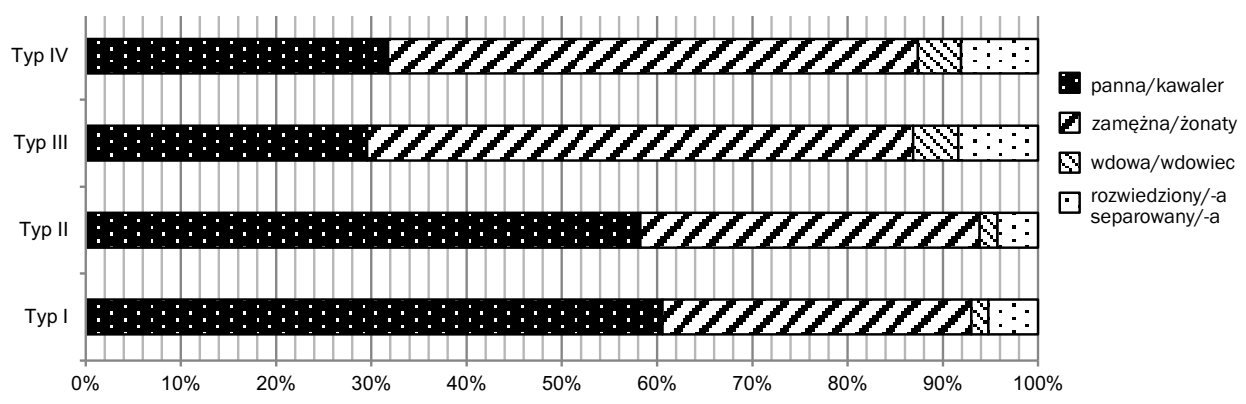

Rys. 107. Struktura klientów według stanu cywilnego i typów centrów handlowych

[N: $2289=100 \%]$.

Źródło: Opracowanie własne na podstawie badań ankietowych.

Pomimo że w typie III i IV dominują osoby pozostające w związku małżeńskim, to ten fakt nie przekłada się na liczbę dzieci. Praktycznie klienci wszystkich typów centrów handlowych w większości (ponad 65\%) nie mają potomstwa. Te osoby, które zadeklarowały ich posiadanie, najczęściej mają jedno lub dwójkę dzieci (rys. 108). 


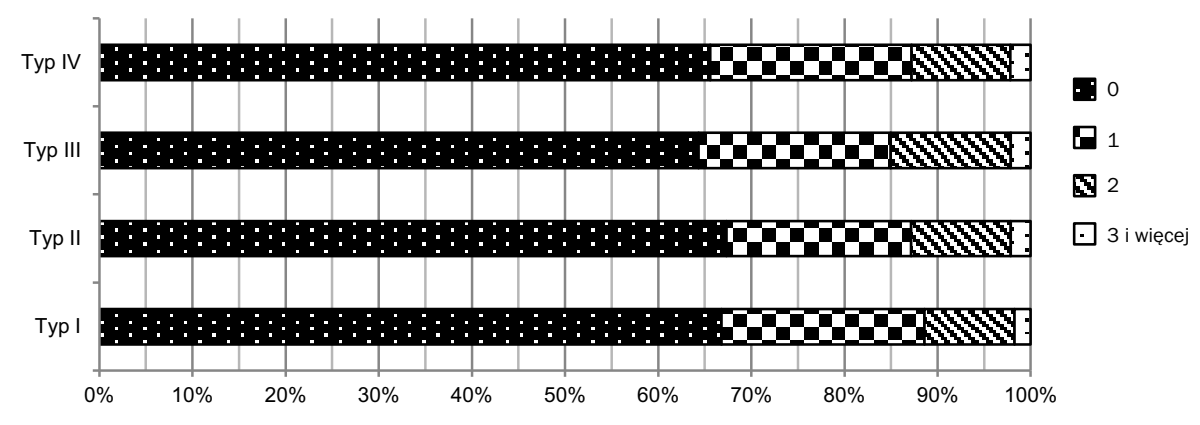

Rys. 108. Struktura klientów według liczby posiadanych dzieci i typów centrów handlowych [N: 2197=100\%].

Źródło: Opracowanie własne na podstawie badań ankietowych.

Klienci łódzkich centrów handlowych w głównej mierze utrzymują się z pracy najemnej (ponad 60\%). Nieznacznie większy odsetek takich osób jest w typie III $(72,4 \%)$ i typie IV $(67,9 \%)$ niż w typie I $(65,4 \%)$ i II $(62,6 \%)$. Największy udział osób prowadzących własną firmę (około 10\%) jest zwolennikami zakupów w Galerii Łódzkiej i Porcie Łódź (typ II), a najniższy w typie III (5,7\%). Około 10\% wizytujących centra handlowe III i IV typu utrzymuje się z niezarobkowych źródeł, na przykład emerytury, renty, zasiłki (w tym dla osób bezrobotnych), w pozostałych typach ten odsetek jest dwa razy niższy i wynosi około 5\%. W największych centrach handlowych (typ I i II) duży udział posiadają również ludzie młodzi, którzy często pozostają na utrzymaniu innych, stąd ponad $20 \%$ takich osób wśród odwiedzających te kompleksy (rys. 109).

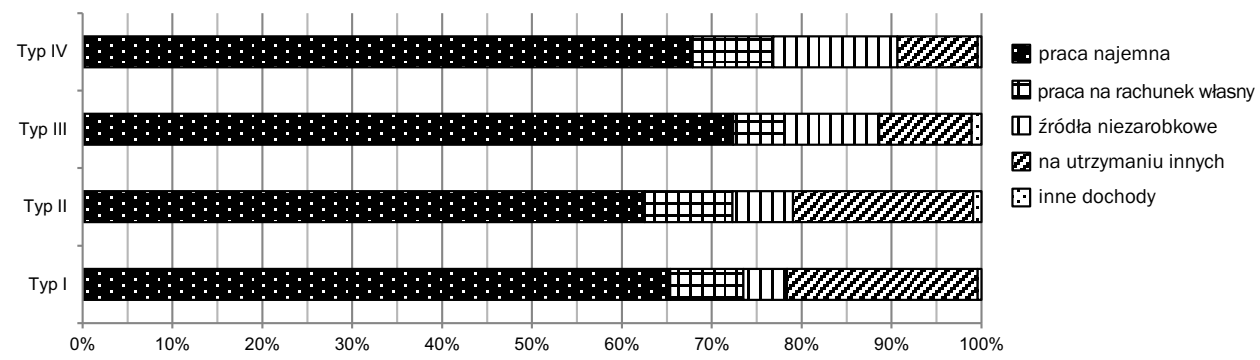

Rys. 109. Struktura klientów według źródła utrzymania i typów centrów handlowych [N: 2097=100\%].

Źródło: Opracowanie własne na podstawie badań ankietowych. 
Zdecydowana większość respondentów wszystkich typów centrów handlowych ocenia swój status materialny jako średnio zadowalający lub dobry (około 85-89 \%). Największy odsetek osób postrzegających swój status materialny jako zły lub bardzo zły jest klientami centrów handlowych z III i IV typu (13\%, 12,4\%), w typie I i II takie osoby stanowią około 6,5\%. Natomiast największym udziałem klientów zadowolonych ze swojego statusu materialnego (ocena dobra i bardzo dobra) charakteryzują się największe centra handlowe Manufaktura (40,4\%), Port Łódź i Galeria Łódzka (42,9\%). Odsetek osób najlepiej oceniających swój status jest o około $10 \%$ niższy w pozostałych typach (rys. 110). Średnia ocena statusu materialnego najwyższa jest wśród klientów II typu - 3,4 oraz w przypadku I typu 3,36. Trochę niżej wypada średnia nota dla pozostałych dwóch typów, i tak klienci IV typu oceniają swój status materialny na 3,21, a najniżej klienci III typu na 3,15.

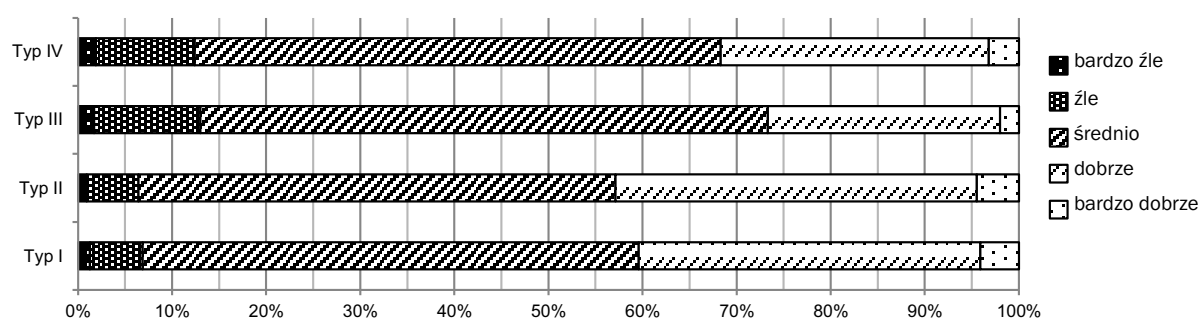

Rys. 110. Ocena własnego statusu materialnego przez klientów według typów centrów handlowych [N: 2322=100\%].

Źródło: Opracowanie własne na podstawie badań ankietowych.

Podsumowując, należy zauważyć, że w centrach handlowych I i II typu większy jest udział osób z wykształceniem wyższym (o około 10\%), ludzi młodszych do 24. roku życia (o około 15\%), będących w stanie wolnym (o około 30\%), pozostających na utrzymaniu innych (o około 10\%). Odsetek osób oceniających lepiej swój status materialny jest również wyższywśród klientów największych łódzkich centrów handlowych z typu I i II (o około 10\%) (rys. 111).

Z powyższej analizy wynika, że profile klientów centrów handlowych I i II typu są zbliżone do siebie - tak jak w przypadku nabywców $z$ typów III i IV. Statystycznie przeciętny klient tych pierwszych dwóch kategorii jest osobą młodszą, lepiej wykształconą, najczęściej w stanie wolnym, oceniającą lepiej swój status materialny (tab. 37). 


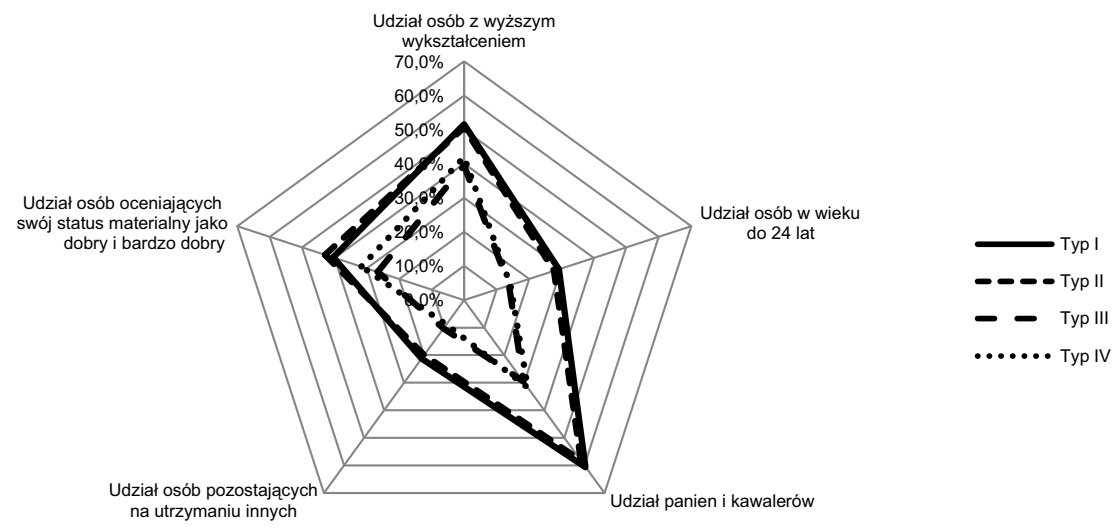

Rys. 111. Charakterystyka klientów centrów handlowych według ich typów.

Źródło: Opracowanie własne na podstawie badań ankietowych.

Tabela 37

Profile klientów według typów centrów handlowych (różnice i podobieństwa)

\begin{tabular}{|c|c|c|c|}
\hline Lp. & Kategoria & $\begin{array}{c}\text { Typ I i II } \\
\text { duże centra } \\
\text { handlowo-usługowo- } \\
\text {-rozrywkowe }\end{array}$ & $\begin{array}{l}\text { Typ III i IV } \\
\text { małe i średnie centra } \\
\text { handlowo-usługowe }\end{array}$ \\
\hline 1. & Wiek & $\begin{array}{l}\text { - osoba młoda - średni wiek około } \\
30 \text { lat (statystyczny klient jest } \\
\text { młodszy niż w pozostałych typach) }\end{array}$ & $\begin{array}{l}\text { - osoba w średnim wieku - średni wiek } \\
\text { około } 40 \text { lat (statystyczny klient jest } \\
\text { starszy niż w pozostałych typach) }\end{array}$ \\
\hline 2. & Wykształcenie & $\begin{array}{l}\text { osoba dobrze wykształcona } \\
\text { (większy udział osób z wyższym } \\
\text { wykształceniem) }\end{array}$ & $\begin{array}{l}\text { - osoba średnio wykształcona } \\
\text { (niższy udział osób z wyższym } \\
\text { wykształceniem, a większy } \\
\text { na przykład z zawodowym) }\end{array}$ \\
\hline 3. & Stan cywilny & $\begin{array}{l}\text { - osoba w stanie wolnym (większy } \\
\text { odsetek panien i kawalerów) }\end{array}$ & $\begin{array}{l}\text { - osoba pozostająca w związku } \\
\text { małżeńskim (większy odsetek } \\
\text { osób w związkach oraz wdowców, } \\
\text { rozwiedzionych i separowanych) }\end{array}$ \\
\hline 4. & $\begin{array}{l}\text { Źródło } \\
\text { utrzymania }\end{array}$ & $\begin{array}{l}\text { - osoba utrzymująca się z pracy } \\
\text { najemnej lub będąca na utrzymaniu } \\
\text { innych (osoby uczące się) }\end{array}$ & $\begin{array}{l}\text { - osoba utrzymująca się z pracy } \\
\text { najemnej, lub osoba utrzymująca się } \\
\text { z niezarobkowych źródeł (emeryci, } \\
\text { renciści, bezrobotni) }\end{array}$ \\
\hline 5. & $\begin{array}{l}\text { Ocena statusu } \\
\text { materialnego }\end{array}$ & $\begin{array}{l}\text { - osoba oceniająca dobrze swój status } \\
\text { materialny (większy odsetek ocenia } \\
\text { go jako dobry lub bardzo dobry) }\end{array}$ & $\begin{array}{l}\text { - osoba oceniająca średnio swój status } \\
\text { materialny (większy odsetek ocenia } \\
\text { go jako średni, zły lub bardzo zły) }\end{array}$ \\
\hline
\end{tabular}

Źródło: Opracowanie własne. 


\subsubsection{Zachowania nabywcze}

Identyfikacji zachowań nabywczych klientów łódzkich centrów handlowych w zależności od ich typu dokonano dzięki analizie między innymi takich elementów jak: osoby towarzyszące podczas wizyt, długość czasu pobytu, dni i godziny odwiedzin, oferta, z jakiej korzystają. Dokonano również oceny powodów, które zadecydowały o wyborze danego typu centrum handlowego. Zachowania nabywcze klientów centrów handlowych zależą między innymi od oferty (bogactwa, stopnia jej dywersyfikacji), jaka jest do dyspozycji w poszczególnych typach kompleksów. Można zauważyć, iż do kompleksów typu III i IV wyjścia/wyjazdy mają, dla większości osób, charakter rodzinny (ponad 50\%) lub/i indywidualny (dla ponad 30\%). Tylko co dziesiąty klient deklaruje, że odbywa takie wizyty w towarzystwie znajomych i przyjaciól. Do Manufaktury (typ I), Portu Łódź, czy Galerii Łódzkiej (typ II) odsetek osób przybywających w gronie rodziny jest znacznie niższy (około 35\%), natomiast wzrasta odsetek klientów odwiedzających te kompleksy z przyjaciółmi i znajomymi - w typie I (Manufaktura), aż 39,8\% respondentów tak zaznaczyło, a w typie II - 34,6\% (rys. 112).

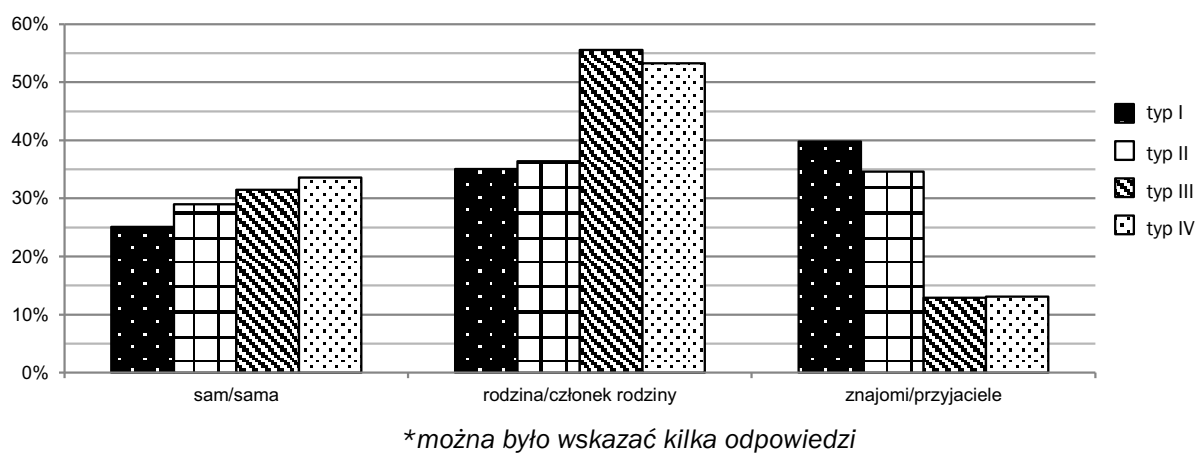

Rys. 112. Z kim klienci odwiedzają poszczególne typy centrów handlowych.

Źródło: Opracowanie własne na podstawie badań ankietowych.

W centrach handlowych III i IV typu wizyty dla zdecydowanej większości klientów (około 80\%) to krótkie wypady trwające do 2 godzin, których celem jest głównie robienie zakupów. Znaczny odsetek stanowią w nich również osoby, dla których pobyty trwają tylko do 1 godziny (około $30 \%$ ). 
W centrach handlowych kategorii I i II obok bardziej zróżnicowanej i bogatej oferty materialnej występuje również pakiet rozrywkowy, szczególnie w Manufakturze, dlatego czas przebywania na terenie tych kompleksów dla wielu klientów znacznie się wydłuża i trwa powyżej 2 godzin (typ I - około 55\%; typ II - około 46\%), a odsetek osób przebywających na jej terenie do 1 godziny jest najniższy (tylko dla około 10\%) (rys. 113).

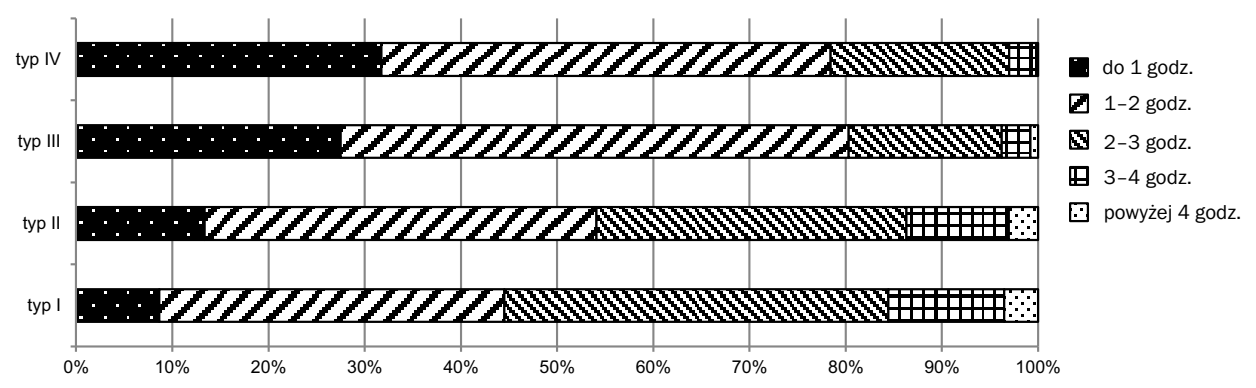

Rys. 113. Długość pobytu w centrach handlowych według ich typów [N: 2198=100\%].

Źródło: Opracowanie własne na podstawie badań ankietowych.

Respondenci w większości odwiedzają centra handlowe 1-3 razy w miesiącu (około 50\%), raz w tygodniu (około 18\%) lub 2 razy w tygodniu (około $15 \%$ ). Pod tym względem nie zaznaczają się istotne różnice w strukturach odpowiedzi klientów poszczególnych typów centrów handlowych. Mniej więcej co trzeci klient twierdzi, iż nie istnieją reguły w tygodniowym korzystaniu $\mathrm{z}$ oferty tych kompleksów (w II typie jest to 33\%, w III $22,6 \%$, w IV 26\%, w I 22,9\%,), zgodnie $\mathrm{z}$ ich deklaracjami nie działają schematycznie, a ich odwiedziny mają miejsce w rozmaitych dniach tygodnia i z różną częstotliwością.

Pozostali respondenci wskazali dni tygodnia, w których najczęściej bywają w tego typu ,świątyniach konsumpcji”. Dzięki tego rodzaju wskazaniom można zaobserwować pewne prawidłowości i odmienności między typami centrów handlowych. $Z$ osób, które posiadają preferowane dni tygodnia, w których odwiedzają centra handlowe, najwięcej wskazało na pobyty w sobotę (od 33,7\% w I typie do 39,9\% w IV) i piątki (od 18,2\% w II typie do $27,3 \%$ w III). Ciekawie wygląda również sytuacja w niedzielę. W ten świąteczny - katolicki - dzień największy odsetek klientów Manufaktury przebywa na jej terenie (około 22,8\%) oraz w Galerii Łódzkiej 
i Porcie Łódź (średni wskaźnik dla obydwu 18,8\%), stosunkowo niewiele osób wskazuje centra handlowe jako miejsca niedzielnych zakupów wśród klientów centrów handlowych III i IV typu (9,7\%; 11\%). W typowe dni robocze (poniedziałek-czwartek) we wskazanych kompleksach z tych, co regularnie w nich bywają odsetek waha się od $4 \%$ do $10 \%$ (rys. 114).

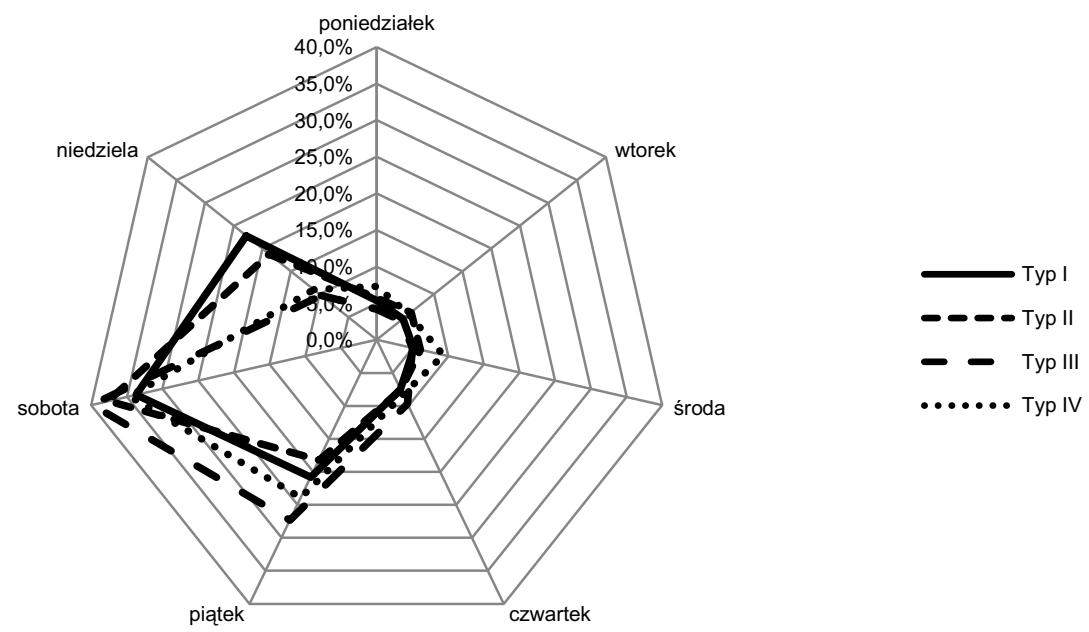

Rys. 114. Korzystanie z oferty w poszczególnych dniach tygodnia według typów centrów handlowych.

Źródło: Opracowanie własne na podstawie badań ankietowych.

Obok tygodniowego schematu robienia zakupów również istotne wydaje się przyjrzenie się dobowym preferencjom klientów. I tak jak w poprzednim układzie, tak i tu można zaobserwować pewne zależności i różnice. Wynikają one między innymi z dnia tygodnia oraz typu centrum handlowego, należy też pamiętać, że istotne jest tu też miejsce i charakter pracy klientów oraz inne zmienne wynikające, na przykład $z$ ich cech osobowościowych, rodzinnych, kulturowych.

Preferencje godzinowe zależą w dużej mierze od dnia tygodnia, którego charakter jest zdeterminowany między innymi godzinami pracy (oczywiście dotyczy to osób pracujących). Innymi kryteriami sugerują się osoby niepracujące, czyli emeryci, renciści, bezrobotni, czy osoby młode uczące się, pozostające na utrzymaniu innych (uczniowie, studenci), a innymi ludzie aktywni zawodowo. W związku z tym, że w społeczeństwie, tak jak wśród ankietowanych, zdecydowanie przeważają osoby pracujące, dlate- 
go ich schemat zachowań czasowych w dużej części zależy od ustalonego tygodniowego i dziennego rytmu pracy. Jak wiadomo, większość osób pracuje od poniedziałku do piątku około ośmiu godzin dziennie. Sobota dla wielu osób jest dniem wolnym od pracy, a jeżeli nie, to od popołudnia mają czas wolny od obowiązków związanych $z$ pracą zawodową i dodatkowo $\mathrm{z}$ perspektywą dnia spędzonego w sposób nienarzucony, ale zaplanowany, często na łonie rodziny (niedziela). W związku z powyższym we wszystkie dni tygodnia największy odsetek osób korzysta $z$ oferty centrów handlowych w godzinach popołudniowych, po godzinie 16.00, czyli w dni robocze jest to czas po pracy, a w sobotę najlepszy czas na robienie zakupów, korzystanie $z$ oferty rozrywkowej czy kulturowej.

Łódzkie centra handlowe są otwierane od poniedziałku do soboty w godzinach porannych najczęściej o godz. 9.00 (ale Carrefoury już od 8.00), a zamykane najczęściej o godzinie 21.00 (ale Carrefoury o 22.00). W niedzielę czas ich pracy ulega skróceniu, otwierane są często godzinę później, czyli o 10.00, a zamykane przynajmniej godzinę wcześniej, czyli o godzinie 20.00. W największych centrach handlowych zdarza się, że niektóre sklepy zlokalizowane na ich terenie mają inne godziny otwarcia niż ogólnie przyjęte dla pozostałych placówek usługowych. Takim przykładem może być hipermarket Tesco oraz Pasaż w Galerii Łódzkiej, sklepy Leroy Merlin, Piotr i Paweł w Porcie Łódź czy hipermarket Real w C.H. Tulipan. Oczywiście duże nagromadzenie różnych punktów handlowych, gastronomicznych w Manufakturze oraz rozbudowana oferta rozrywkowa i kulturowa, w tym kina, teatr, muzea zlokalizowane niezależnie w kilku budynkach, wpływają na zróżnicowanie godzin otwarcia. Z niektórych punktów można korzystać do późnych godzin nocnych, a nawet porannych (dyskoteki).

Jeżeli, przyjrzymy się godzinom odwiedzin klientów poszczególnych typów centrów handlowych w zależności od dnia tygodnia (chodzi tu oczywiście o osoby, które zadeklarowały, w jakich dniach tygodnia i w jakich godzinach wizytują je najczęściej), to można zauważyć pewne prawidłowości. Klienci centrów handlowych III i IV typu bardziej chętnie odwiedzają te kompleksy w godzinach przedpołudniowych i południowych, szczególnie ta różnica uwidacznia się w dni robocze (poniedziałek-czwartek) ${ }^{137}$, kiedy

${ }^{137}$ Dniem roboczym jest oczywiście również piątek, ale w związku z tym, że uwidaczniają się różnice w porównaniu $z$ innymi dniami, w udziale klientów według godzin korzystania $z$ oferty przedstawiono go oddzielnie. 
to prawie $50 \%$ osób robiących wtedy zakupy uczęszcza do nich przed godziną 16.00. W tego typu dniach odsetek klientów „przedpołudniowych” i „południowych” w centrach handlowych I i II typu jest zdecydowanie mniejszy i wynosi około $35 \%$. Najniższy odsetek osób robiących zakupy do 16.00 we wszystkie dni tygodnia występuje w Manufakturze (około 8\%), ale $z$ drugiej strony to właśnie w tym kompleksie najwięcej osób przebywa do najpóźniejszych godzin, bo aż około $20 \%$ bywa w tym centrum handlowym w godzinach wieczornych po 20.00 (odsetek waha się w zależności od dnia tygodnia) (rys. 113), co związane jest $z$ korzystaniem przez wiele osób nie tylko $\mathrm{z}$ oferty handlowej, ale też/lub z gastronomicznej, rozrywkowej czy kulturowej.

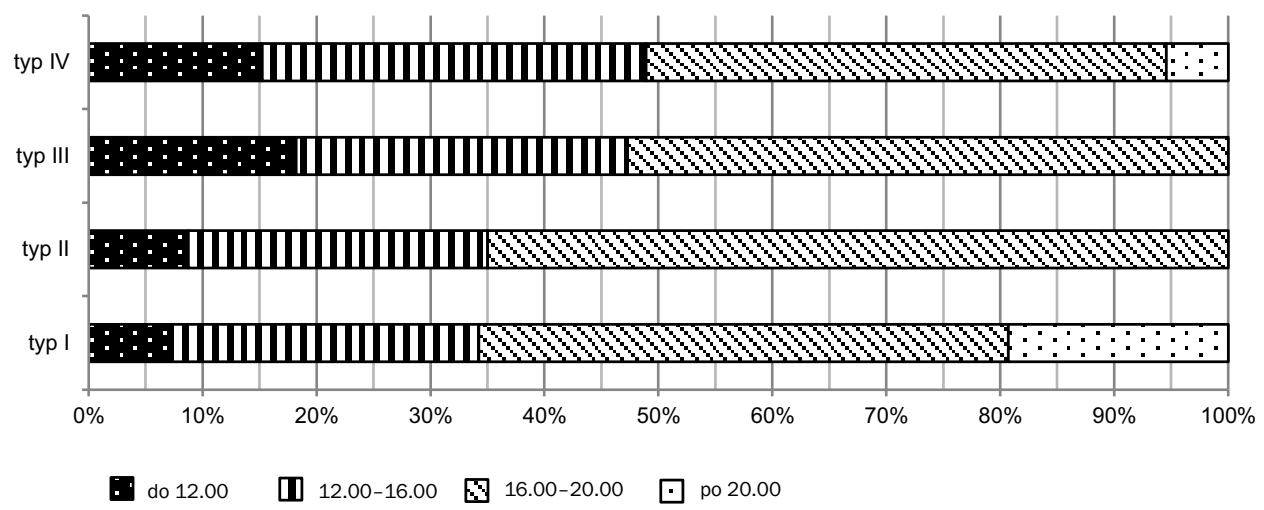

Rys. 115. Godziny korzystania z oferty od poniedziałku do czwartku w centrach handlowych według ich typów [N: 341=100\%].

Źródło: Opracowanie własne na podstawie badań ankietowych.

Ze wszystkich przeankietowanych osób 299 wskazało piątek jako dzień regularnych wizyt w centrach handlowych. W porównaniu $z$ innymi dniami roboczymi można zauważyć, że spada odsetek osób korzystających z oferty centrów handlowych do godziny 16.00 , a wzrasta tych, którzy wizytują te kompleksy w godzinach popołudniowych i wieczornych. W centrach typu III i IV tak jak w typowy dzień powszedni jest duży udział klientów odwiedzających je przed godziną 16.00 (niecałe 30\%). Natomiast szczególnie Manufaktura w piątki cieszy się dużą popularnością wśród klientów „popołudniowych” (ponad 60\%) i „wieczornych” (około 18\%) (rys. 116). 


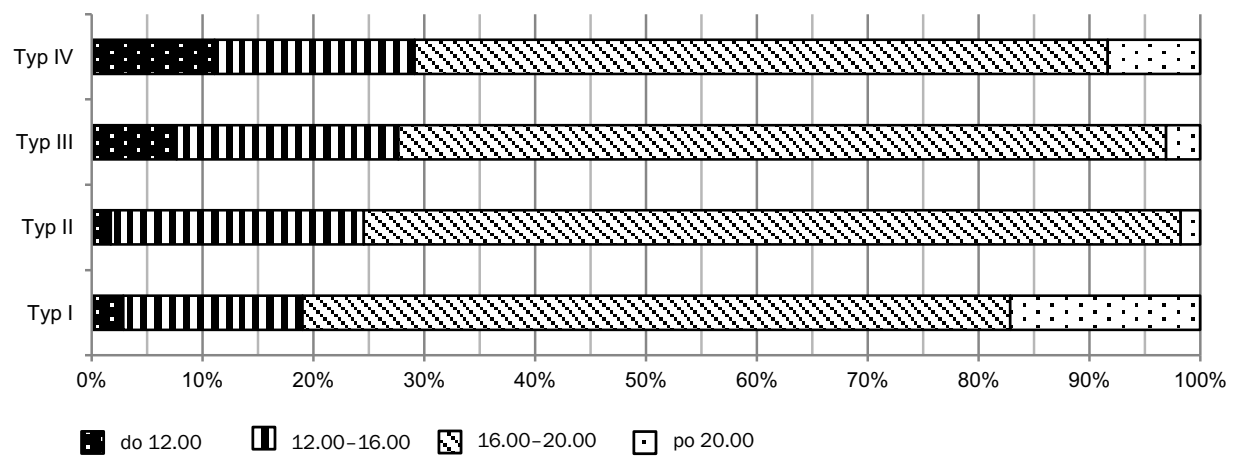

Rys. 116. Godziny korzystania z oferty w piątek w centrach handlowych według ich typów [N: 299=100\%].

Źródło: Opracowanie własne na podstawie badań ankietowych.

$\mathrm{Z}$ dni weekendowych najbardziej popularnym dniem odwiedzin centrów handlowych jest sobota, to wtedy wielu nabywców dokonuje zakupów (często na cały tydzień), i/lub korzysta $z$ innej oferty. To właśnie na sobotę wskazało najwięcej osób jako najczęstszy dzień wizyt w centrach handlowych (487). W tym dniu znacznie większy odsetek „porannych” klientów posiadają centra handlowe mniejsze IV typu (około 30\%) i III (około 20\%), niż większe II typu (około 10\%) i I (około 5\%). Natomiast Manufaktura oraz Galeria Łódzka i Port Łódź są przez większość (około $70 \%$ ) odwiedzane w godzinach popołudniowych (rys. 117).

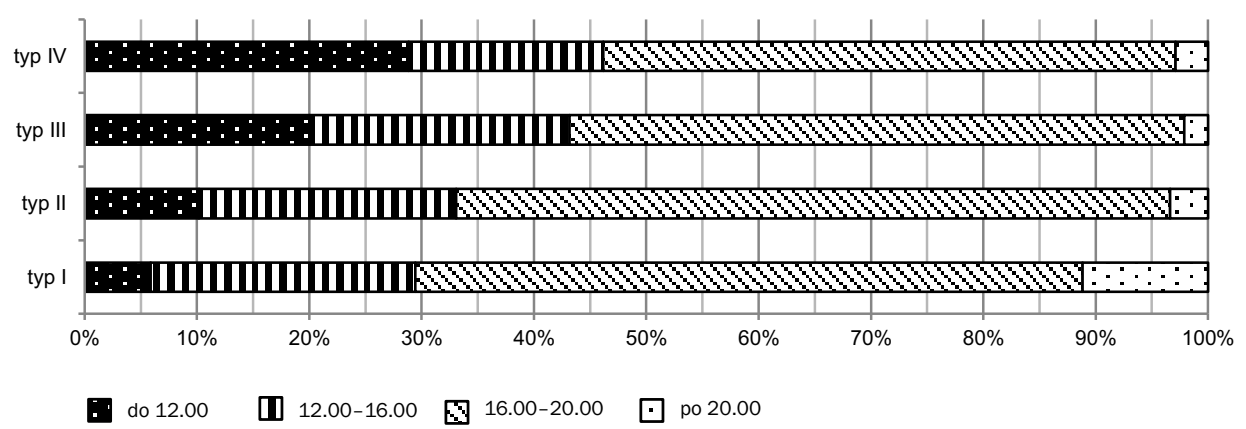

Rys. 117. Godziny korzystania z oferty w sobotę $w$ centrach handlowych według ich typów [N: 487=100\%].

Źródło: Opracowanie własne na podstawie badań ankietowych. 
Wśród respondentów najmniejszą popularnością z dni weekendowych cieszy się niedziela, najmniej osób wskazało na regularne wizyty (230 osób). W porównaniu z sobotą można zauważyć, że spada znacząco odsetek klientów do godziny 12.00, szczególnie w typie IV (o około 20\%) i w III (o około 10\%). Natomiast w tym dniu wzrasta odsetek osób, którzy wizytują te kompleksy po godzinie 20.00 (rys. 118).

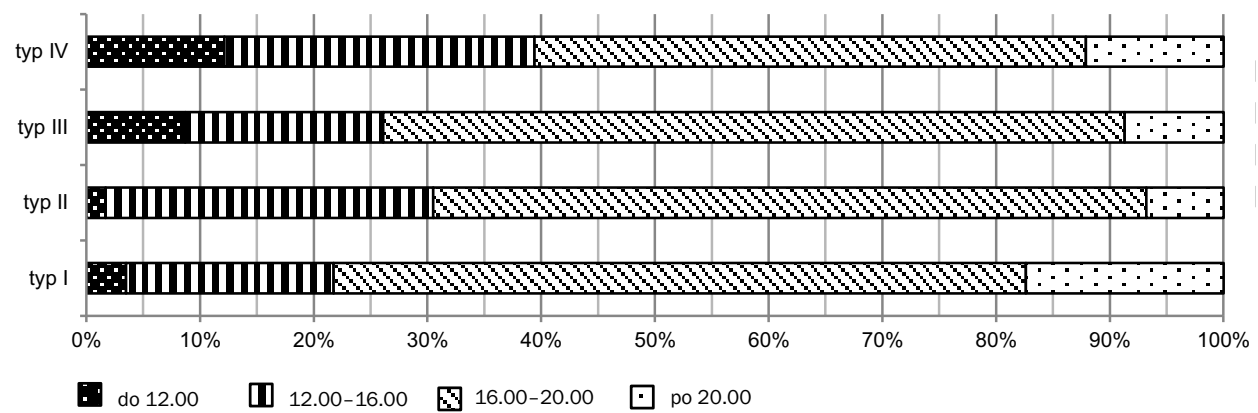

Rys. 118. Godziny korzystania z oferty w niedzielę w centrach handlowych według ich typów [N: 230=100\%].

Źródło: Opracowanie własne na podstawie badań ankietowych.

Istotne różnice zaznaczają się w traktowaniu pobytów w poszczególnych kategoriach centrów handlowych. W typie III i IV wizyty klientów są przede wszystkim koniecznością zrobienia zakupów (dla około 90\%), obowiązkiem połączonym z przyjemnością (dla około 45\%) lub/i czasem załatwiania koniecznych spraw innych niż zakupy (dla około 30\%). Bardziej zróżnicowane jest postrzeganie pobytów w największych centrach handlowych. W typie I i II pobyt kojarzy się mniejszej liczbie respondentów z koniecznością robienia zakupów (około 60\%), natomiast dla zdecydowanie większego odsetka odwiedzających wizyty są również przyjemnością w ramach czasu wolnego (około 50-60\%), a wręcz dla niektórych sposobem spędzania czasu wolnego (40-50\%), są też miejscami rozrywki czy też miejscem spotkań towarzyskich (40-55\%). Szczególnie w tych dwóch ostatnich kategoriach uwidacznia się różnica między postrzeganiem pobytu przez klientów I typu, a tych z II typu. Większy odsetek klientów Manufaktury niż Portu Łódź i Galerii Łódzkiej kojarzy wizyty w tym kompleksie z miejscem spotkań i rozrywki (o około 15\%) oraz z przyjemnością w ramach czasu wolnego (o około 10\%) i sposobem jego spędzania (o około 7\%) (rys. 119). 


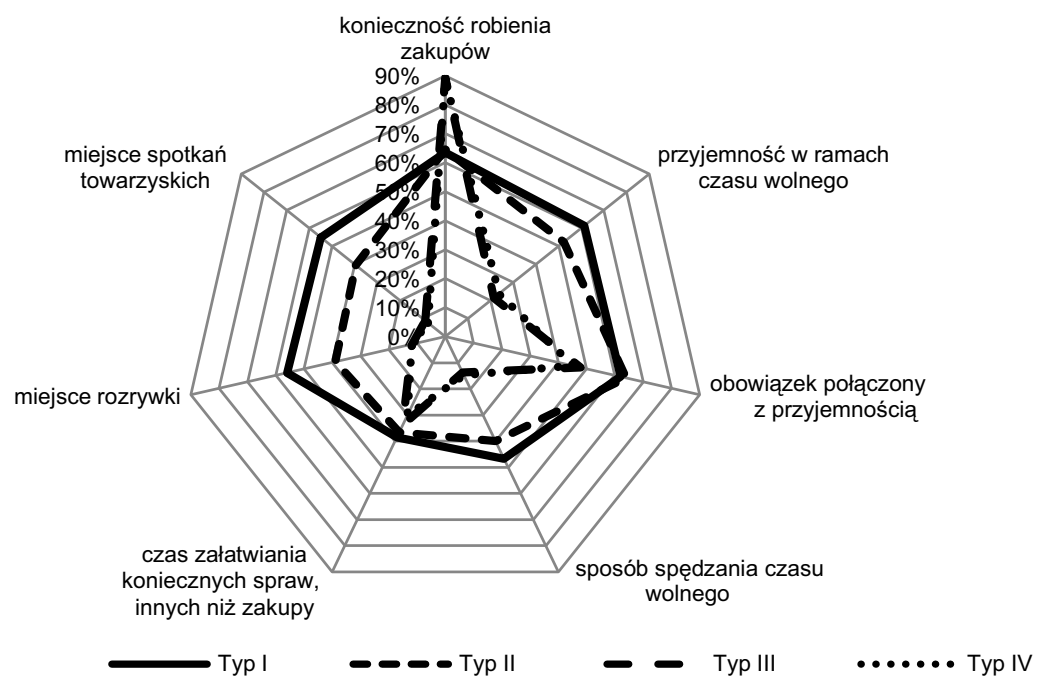

Rys. 119. Czym jest dla klientów pobyt w centrum handlowym (według typów centrów handlowych.

Źródło: Opracowanie własne na podstawie badań ankietowych.

Należy się zastanowić, jakie są główne motywy przyciągające klientów do danych centrów handlowych, co jest największym magnesem w zależności od ich typu. Niezależnie od rodzaju centrum handlowego prawie dla wszystkich respondentów (ponad 95\%) najważniejsze znaczenie przy wyjazdach do tego typu kompleksów ma bogata oferta asortymentowa (oceniane na notę od 3,77 - IV typ do 4,15 w I typie), odpowiednia jakość towarów (nota od 3,79 IV typ do 3,96 w I typie) oraz liczne promocje i niskie ceny (nota około 3,5). Natomiast dla klientów wszystkich centrów handlowych niewielkie znaczenie odgrywają karty lojalnościowe (oceniane na około 2).

Dodatkowo dla klientów Manufaktury (4,02), Galerii Łódzkiej i Portu Łódź $(3,89)$ istotne przy wyborze wskazanego kompleksu było istniejące na jego terenie zróżnicowanie sklepów różnych firm oraz funkcjonujące liczne punkty usługowe (3,38 - I typ, 3,0 - II typ). Różnica między I typem a II polega na wyższym znaczeniu dla klientów Manufaktury jako miejsca rozrywki - 3,4 (II typ - 2,53) oraz miejsca miłego spędzania czasu wolnego - 3,37 (II typ - 2,92) i zagospodarowania czasu wolnego - 2,9 (II typ - 2,35). Klienci centrów handlowych typu III i IV przy ich wyborze nie kierują się ofertą rozrywkową (około 1,3), ani tą zapewniającą możliwość zagospodarowania czasu wolnego (około 1,3) lub jego miłego spędzenia (ok. 1,7) (rys. 120). 


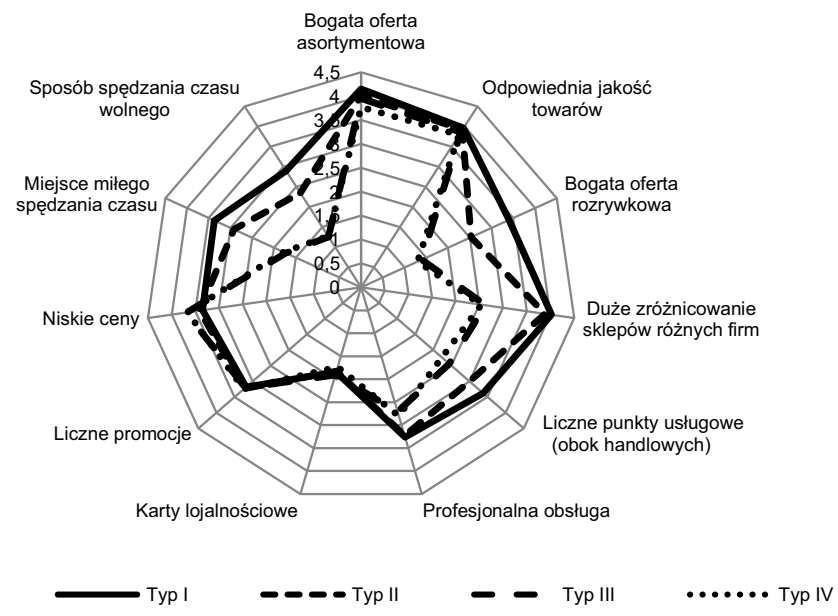

w skali od 0 - brak znaczenia do 5 - bardzo duże znaczenie.

Rys. 120. Średnia ocena znaczenia motywów w wyborze centrum handlowego danego typu.

Źródło: Opracowanie własne na podstawie badań ankietowych.

W zależności od kategorii zmiennej okazało się, że dla niektórych osób nie mają one znaczenia (0) przy wyborze danego centrum handlowego. Sprawdzono więc, na jakich poziomach kształtują się oceny tych kategorii dla osób, które wskazały znaczenie poszczególnych motywów wyboru danego kompleksu. Najwyższe oceny uzyskała Manufaktura ze względu na bogatą ofertę $(4,15)$, odpowiednią jakość towarów $(4,09)$, duże zróżnicowanie sklepów różnych firm $(4,1)$, liczne punkty usługowe $(3,59)$, niskie ceny $(3,65)$ i liczne promocje $(3,51)$. W przypadku tego typu centrum handlowego podkreślono jednak również duże znaczenie bogatej oferty rozrywkowej $(3,72)$ oraz że jest to miejsce miłego spędzenia czasu $(3,66)$. W przypadku Portu Łódź i Galerii Łódzkiej o ich atrakcyjności świadczą te same powody, główna różnica polega na dużo niższej ocenie oferty rozrywkowej $(3,17)$ oraz oferty miłego spędzania czasu $(3,42)$. Przy wyborze centrum handlowego z III lub IV typu najważniejsze znaczenie miała ich bogata oferta asortymentowa (odpowiednio 4,05; 3,94), jakość towarów $(3,98$; $3,95)$, liczne promocje $(3,6 ; 3,59)$ oraz niskie ceny $(3,88 ; 3,85)$. Klienci, którzy postrzegają te centra handlowe jako miejsca spędzania czasu wolnego i rozrywkowe, uważali, że w tym zakresie znaczenie tego typu oferty jest niewielkie i kształtuje się poniżej oceny 2 (tab. 38). 


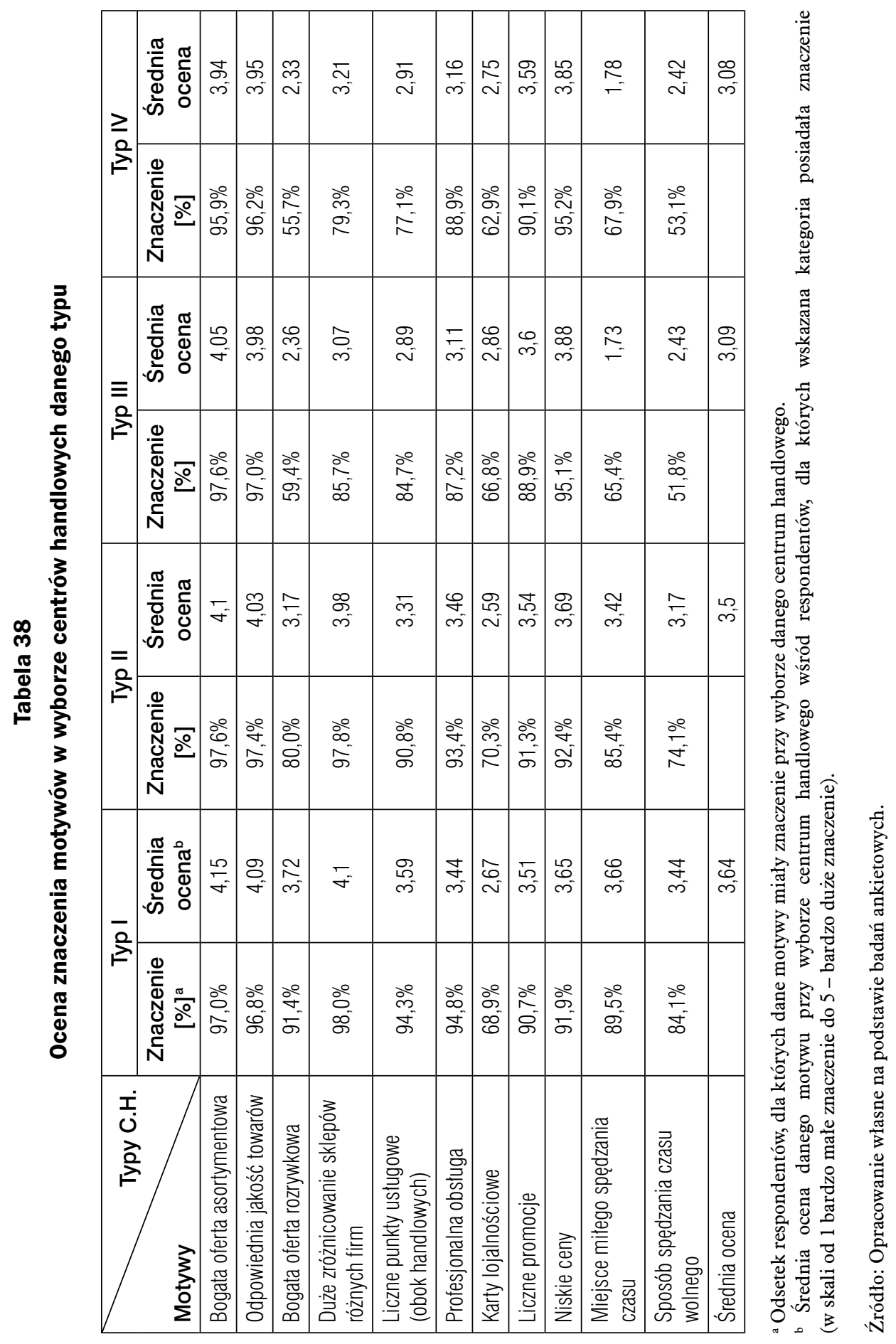


Klienci łódzkich centrów handlowych korzystają z oferty różnych placówek w nich zlokalizowanych, pod tym względem też widać podobieństwa w zachowaniach nabywców z typu I i II oraz między klientami typu III i IV. W tych dwóch pierwszych typach zdecydowanie większy odsetek klientów robi zakupy $\mathrm{w}$ małych sklepach znajdujących się $\mathrm{w}$ galeriach handlowych (ponad 50\%) oraz korzysta $z$ usług gastronomicznych (około 40\%). Zdecydowanie największy odsetek klientów jest konsumentami usług rozrywkowych w Manufakturze (około 50\%), co wyróżnia ją na tle pozostałych kompleksów. W centrach handlowych typu III i IV więcej klientów dokonuje zakupów w hipermarkecie $\mathrm{z}$ artykułami spożywczymi (o około 20\%) (rys. 121).

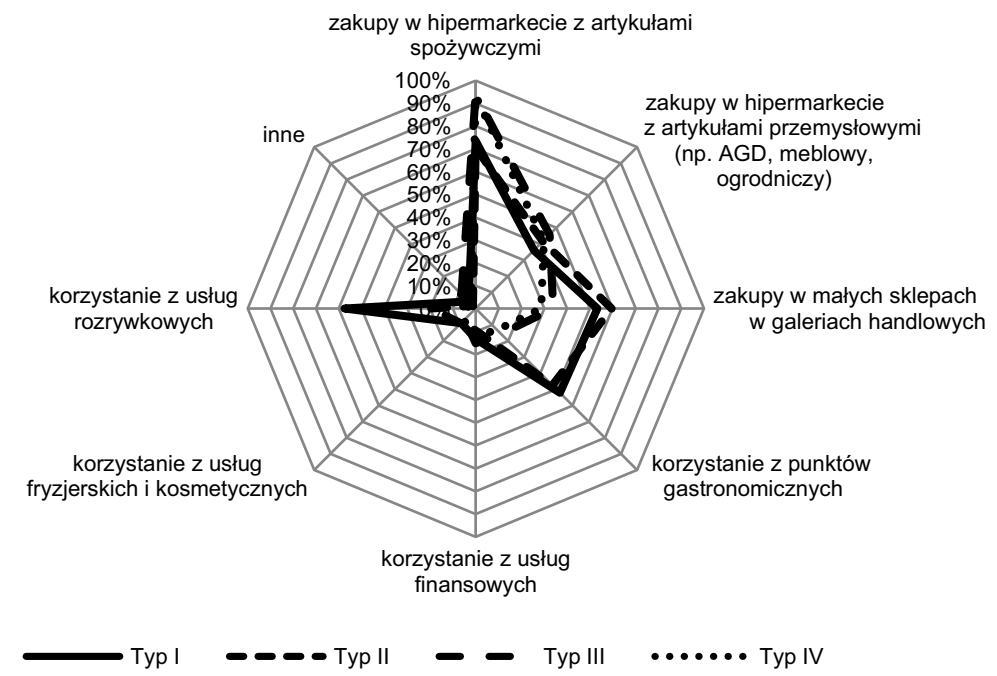

Rys. 121. Oferta, z jakiej korzystają klienci poszczególnych typów centrów handlowych.

Źródło: Opracowanie własne na podstawie badań ankietowych.

Głównym celem wizyt w centrach handlowych jest dokonywanie zakupów różnych dóbr materialnych. Nie każdy rodzaj towaru jednak jest nabywany przez respondentów we wskazanych kompleksach. We wszystkich typach duży odsetek stanowią klienci nienabywający w nich artykułów wyposażenia wnętrz (około 40\%), sprzętu RTV (około 25,6\% - II typ do $30,5 \%$ w III) i AGD (25,8\% w IV typie do $31,9 \%$ w I typie). Większy odsetek klientów centrów handlowych typu III i IV nie kupuje w nich odzieży, 
bielizny i obuwia $(33,6 \% ; 25,7 \%)$ niż w typach I i II (7,3\%; 9,2\%), artykułów sportowych (w III i IV około 35\%; około 25\% w I i II typie) oraz książek, czasopism, gazet (około 25\% III i IV typ; w I i II około 35\%). Natomiast w I i II typie większy odsetek jest osób które nie nabywają w nich artykułów spożywczych i artykułów dla dzieci (o około 10\%) oraz środków czystości i kosmetyków (o około 5\%) (rys. 122).

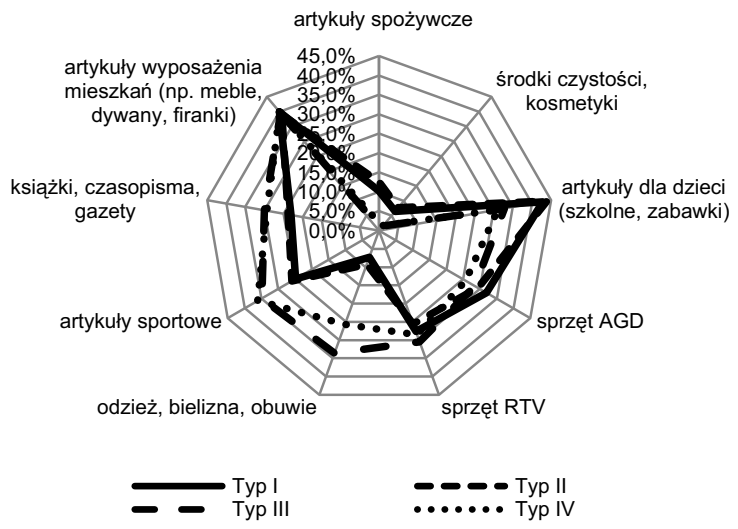

Rys. 122. Oferta, jakiej klienci nie nabywają w poszczególnych typach centrów handlowych.

Źródło: Opracowanie własne na podstawie badań ankietowych.

Zakupy towarów w centrach handlowych można zrobić w hipermarkecie, supermarkecie, dużym sklepie specjalistycznym lub w małych i średniej wielkości placówkach zlokalizowanych w galeriach handlowych. W wyborze miejsca zakupów na terenie centrów handlowych w zależności od nabywanego asortymentu również można zauważyć pewne podobieństwa i różnice między poszczególnymi typami centrów handlowych (tab. 39).

Artykuły spożywcze nabywane są przez klientów głównie w hipermarketach i supermarketach znajdujących się na terenie kompleksów handlowych (od $57 \%$ klientów w typie II do $70,5 \%$ w typie III). W II typie występuje najniższy odsetek kupujących w hipermarkecie, wartość ta jest zaniżana przez klientów Portu Łódź, na terenie którego znajduje się hipermarket Piotr i Paweł postrzegany jako placówka dla osób dysponujących większą gotówką. Artykuły spożywcze przez większy odsetek klientów centrów handlowych I i II typu jest też nabywany w małych i średnich sklepach (o około 3\%). 


\section{Tabela 39}

Rodzaje artykułów nabywane w różnych placówkach zlokalizowanych na terenie poszczególnych typów centrów handlowych

\begin{tabular}{|c|c|c|c|c|c|}
\hline $\begin{array}{l}\text { Rodzaj } \\
\text { artykułów }\end{array}$ & $\begin{array}{c}\text { Rodzaje sklepów } \\
\text { w centrum handlowym }\end{array}$ & Typ la & Typ II & Typ III & Typ IV \\
\hline \multirow[t]{3}{*}{ Artykuły spożywcze } & hipermarket, supermarket z art. FMCG & $60,1 \%$ & $57,0 \%$ & $70,5 \%$ & $66,9 \%$ \\
\hline & duży sklep specjalistyczny & $2,0 \%$ & $1,2 \%$ & $1,3 \%$ & $1,1 \%$ \\
\hline & małe i średnie sklepy & $13,1 \%$ & $13,4 \%$ & $10,7 \%$ & $10,2 \%$ \\
\hline \multirow{3}{*}{$\begin{array}{l}\text { Środki czystości, } \\
\text { kosmetyki }\end{array}$} & hipermarket, supermarket z art. FMCG & $47,8 \%$ & $48,9 \%$ & $73,1 \%$ & $72,7 \%$ \\
\hline & duży sklep specjalistyczny & $9,5 \%$ & $10,2 \%$ & $4,1 \%$ & $4,8 \%$ \\
\hline & małe i średnie sklepy & $24,2 \%$ & $23,6 \%$ & $11,0 \%$ & $8,9 \%$ \\
\hline \multirow[t]{3}{*}{ Sprzęt AGD } & hipermarket, supermarket z art. FMCG & $20,1 \%$ & $21,6 \%$ & $25,4 \%$ & $30,3 \%$ \\
\hline & duży sklep specjalistyczny & $32,8 \%$ & $31,3 \%$ & $29,0 \%$ & $25,5 \%$ \\
\hline & małe i średnie sklepy & $6,3 \%$ & $8,0 \%$ & $4,9 \%$ & $4,1 \%$ \\
\hline \multirow[t]{3}{*}{ Sprzęt RTV } & hipermarket, supermarket z art. FMCG & $19,3 \%$ & $20,6 \%$ & $22,1 \%$ & $21,2 \%$ \\
\hline & duży sklep specjalistyczny & $36,1 \%$ & $35,0 \%$ & $29,2 \%$ & $31,4 \%$ \\
\hline & małe i średnie sklepy & $7,7 \%$ & $9,7 \%$ & $4,6 \%$ & $4,6 \%$ \\
\hline \multirow{3}{*}{$\begin{array}{l}\text { Odzież, bielizna, } \\
\text { obuwie }\end{array}$} & hipermarket, supermarket z art. FMCG & $19,5 \%$ & $17,4 \%$ & $20,3 \%$ & $19,7 \%$ \\
\hline & duży sklep specjalistyczny & $10,9 \%$ & $11,6 \%$ & $7,7 \%$ & $9,7 \%$ \\
\hline & małe i średnie sklepy & $54,1 \%$ & $53,9 \%$ & $35,9 \%$ & $31,6 \%$ \\
\hline \multirow[t]{3}{*}{ Artykuły sportowe } & hipermarket, supermarket z art. FMCG & $15,9 \%$ & $16,9 \%$ & $16,9 \%$ & $15,1 \%$ \\
\hline & duży sklep specjalistyczny & $15,6 \%$ & $15,9 \%$ & $14,6 \%$ & $16,5 \%$ \\
\hline & małe i średnie sklepy & $34,4 \%$ & $33,7 \%$ & $19,0 \%$ & $16,9 \%$ \\
\hline \multirow{3}{*}{$\begin{array}{l}\text { Artykuły dla dzieci } \\
\text { (szkolne, zabawki) }\end{array}$} & hipermarket, supermarket z art. FMCG & $25,6 \%$ & $25,6 \%$ & $41,3 \%$ & $40,9 \%$ \\
\hline & duży sklep specjalistyczny & $4,9 \%$ & $4,4 \%$ & $3,3 \%$ & $3,0 \%$ \\
\hline & małe i średnie sklepy & $14,6 \%$ & $17,1 \%$ & $8,2 \%$ & $9,9 \%$ \\
\hline \multirow{4}{*}{$\begin{array}{l}\text { Książki, czasopisma, } \\
\text { gazety }\end{array}$} & hipermarket, supermarket z art. FMCG & $12,7 \%$ & $13,2 \%$ & $15,9 \%$ & $15,1 \%$ \\
\hline & duży sklep specjalistyczny & $7,5 \%$ & $16,6 \%$ & $5,4 \%$ & $7,4 \%$ \\
\hline & małe i średnie sklepy & $45,1 \%$ & $42,9 \%$ & $33,3 \%$ & $31,4 \%$ \\
\hline & nie kupuję w tym centrum handlowym & $23,1 \%$ & $23,8 \%$ & $30,0 \%$ & $29,4 \%$ \\
\hline \multirow{3}{*}{$\begin{array}{l}\text { Artykuły wyposażenia } \\
\text { mieszkań }\end{array}$} & hipermarket, supermarket z art. FMCG & $10,7 \%$ & $11,4 \%$ & $11,3 \%$ & $8,7 \%$ \\
\hline & duży sklep specjalistyczny & $34,4 \%$ & $36,2 \%$ & $32,1 \%$ & $32,0 \%$ \\
\hline & małe i średnie sklepy & $5,7 \%$ & $6,2 \%$ & $5,9 \%$ & $5,6 \%$ \\
\hline
\end{tabular}

a Typ I 810=100\%; Typ II 597=100\%; Typ III 390=100\%; Typ IV 538=100\%. Można było zaznaczać kilka wariantów, dlatego nie sumuje się do $100 \%$. Wskazywano sporadycznie też inne rodzaje artykułów.

Źródło: Opracowanie własne na podstawie badań ankietowych. 
Artykuły kosmetyczne i środki czystości, przez większy odsetek klientów, nabywane są w hipermarketach i supermarketach ogólnoprzemysłowych w centrach handlowych III i IV (około 70\%), niż typu I i II (około 50\%). Natomiast w sklepach specjalistycznych (o około 6\%) i małych i średnich sklepach (o około 13\%) większy odsetek nabywców zaopatruje się w taki asortyment w kompleksach typu I i II.

Sprzęt AGD i RTV - we wszystkich centrach handlowych nabywany jest głównie w dużych specjalistycznych sklepach (około 30\% nabywców - o kilka procent jest większy w typie I i II). Sprzęt RTV przez około $20 \%$ klientów jest kupowany w placówkach z artykułami FMCG. W przypadku urządzeń AGD najmniejszy odsetek nabywców nabywa go w sklepach specjalistycznych (25,5\%) w typie IV, a największy w Manufakturze (32,8\%). Zakupów artykułów dla dzieci (na przykład szkolne, zabawki) większy odsetek klientów centrów handlowych III i IV typu dokonuje w hipermarketach z artykułami FMCG (około 40\%) niż w typach I i II (około 25\%). Odzież, obuwie i tym podobne klienci centrów handlowych typu I i II nabywają w małych i średnich sklepach zlokalizowanych w galeriach (ponad 50\%), w przypadku klientów kompleksów typu III i IV ich odsetek jest mniejszy o około 20\%. Artykuły sportowe w Manufakturze, Galerii Łódzkiej i Porcie Łódź są kupowane w małych i średnich sklepach przez ponad $30 \%$, natomiast w pozostałych centrach handlowych przez około $18 \%$ klientów. Książki, czasopisma, gazety większy odsetek klientów typu I i II kupuje we wskazanych centrach handlowych w małych i średnich sklepach (ponad 40\%), w typie III i IV ponad 30\%. Natomiast artykuły wyposażenia mieszkań około 30\% nabywców dokonuje zakupów w dużych specjalistycznych sklepach zlokalizowanych na terenie badanych kompleksów.

Łódzkie centra handlowe oceniono również pod względem ich atrakcyjności w oczach ich klientów. Do oceny wzięto pod uwagę ocenę respondentów oferty poszczególnych centrów handlowych, odsetek osób, które wskazały na odwiedzanie poszczególnych kompleksów, wskazujących dane centrum handlowe jako najczęściej odwiedzane, ulubione i nielubiane (tab. 40). Oceniając ofertę, obliczono średnią ocenę w skali 0-5 dla następujących kategorii: bogata oferta asortymentowa, odpowiednia jakość towarów, bogata oferta rozrywkowa, duże zróżnicowanie sklepów różnych firm, liczne punkty usługowe, profesjonalna obsługa, karty lojalnościowe, liczne promocje, niskie ceny oraz miejsce spędzania czasu wolnego. 
Tabela 40

Elementy wzięte pod uwagę przy ocenie atrakcyjności łódzkich centrów handlowych

\begin{tabular}{|l|c|c|c|c|c|}
\hline \multirow{2}{*}{$\begin{array}{c}\text { Centrum } \\
\text { handlowe }\end{array}$} & \multicolumn{5}{|c|}{ Wskaźniki dotyczące centrów handlowych } \\
\cline { 2 - 6 } & $\begin{array}{c}\text { Ocena } \\
\text { oferty }\end{array}$ & Wizytowane & $\begin{array}{c}\text { Najczęściej } \\
\text { odwiedzane }\end{array}$ & Ulubione & Nielubiane \\
\hline Manufaktura & 3,34 & $57,4 \%$ & $34,7 \%$ & $25,1 \%$ & $1,7 \%$ \\
\hline Galeria Łódzka & 3,06 & $42,7 \%$ & $16,6 \%$ & $10,2 \%$ & $1,6 \%$ \\
\hline Port Łódź & 3,23 & $22,1 \%$ & $9,0 \%$ & $7,9 \%$ & $2,8 \%$ \\
\hline C. H. Tulipan & 2,76 & $15,8 \%$ & $6,6 \%$ & $3,6 \%$ & $1,0 \%$ \\
\hline C.H. Guliwer & 2,5 & $8,4 \%$ & $4,8 \%$ & $1,2 \%$ & $0,3 \%$ \\
\hline Tesco P. & 2,55 & $13,7 \%$ & $5,2 \%$ & $2,0 \%$ & $0,7 \%$ \\
\hline C.H. M1 & 2,81 & $11 \%$ & $4,7 \%$ & $2,6 \%$ & $1,5 \%$ \\
\hline Pasaż Łódzki & 2,55 & $16 \%$ & $5,2 \%$ & $2,2 \%$ & $0,4 \%$ \\
\hline Carrefour P. & 2,59 & $6,8 \%$ & $2,5 \%$ & $1,0 \%$ & $0,6 \%$ \\
\hline Carrefour Sz. & 2,23 & $7,2 \%$ & $3,8 \%$ & $0,8 \%$ & $0,4 \%$ \\
\hline Tesco W. & 2,59 & $10,3 \%$ & $4,7 \%$ & $1,7 \%$ & $0,4 \%$ \\
\hline E. Leclerc & 2,44 & $6,0 \%$ & $2,2 \%$ & $1,0 \%$ & $1,0 \%$ \\
\hline & w skali & $\mathbf{2 4 2 0 = 1 0 0 \%}$ & $\mathbf{2 3 3 5 = 1 0 0 \%}$ & $\mathbf{2 4 2 0 = 1 0 0 \%}$ & $\mathbf{2 4 2 0 = 1 0 0 \%}$ \\
\hline
\end{tabular}

Źródło: Opracowanie własne na podstawie badań ankietowych.

W pierwszej kolejności zmienne poddano standaryzacji „Z”. Następnie wartości zestandaryzowane zsumowano i dzięki temu otrzymano wskaźnik syntetyczny. Wskaźnik ten poddano ocenie na podstawie wskaźnika jednorodności (rzetelności) skali $\alpha$-Cronbacha, który w tym wypadku osiągnął wartość 0,946 . W oczach klientów najbardziej atrakcyjnymi centrami handlowymi są: Manufaktura (10,98), Galeria Łódzka (4,97) i Port Łódź (4,63). Natomiast C.H. M1 (-0,29) i C.H. Tulipan $(-0,45)$ mimo kilkakrotnej mniejszej atrakcyjności zlokalizowały się najbliżej przeciętnej atrakcyjności. Pozostałe centra handlowe odbiegają znacząco od najatrakcyjniejszych kompleksów, gdzie wskaźnik syntetyczny osiąga wartości poniżej -2. Najgorzej oceniony został Carrefour Sz. $(-4,09)$ oraz C.H. Guliwer $(-3,17)$ (tab. 41). 
Tabela 41

Atrakcyjność łódzkich centrów handlowych w oczach klientów

\begin{tabular}{|l|c|c|c|c|c|c|}
\hline $\begin{array}{c}\text { Centrum } \\
\text { handlowe }\end{array}$ & $\begin{array}{c}\mathbf{Z} \text { - ocena } \\
\text { oferty }\end{array}$ & $\begin{array}{c}\mathbf{Z}- \\
\text { wizytowane }\end{array}$ & $\begin{array}{c}\mathbf{Z}-\text { najcze- } \\
\text { ściej } \\
\text { odwiedzane }\end{array}$ & $\begin{array}{c}\mathbf{Z} \text { - ulubio- } \\
\text { ne }\end{array}$ & $\begin{array}{c}\mathbf{Z}- \\
\text { nielubiane }\end{array}$ & $\begin{array}{c}\text { Wskaźnik } \\
\text { syntetyczny }\end{array}$ \\
\hline Manufaktura & 1,85291 & 2,46532 & 2,88669 & 2,87990 & 0,89184 & 10,98 \\
\hline Galeria Łódzka & 1,01498 & 1,54278 & 0,90505 & 0,75123 & 0,75806 & 4,97 \\
\hline Port Łódź & 1,52372 & 0,24998 & 0,07299 & 0,42264 & 2,36337 & 4,63 \\
\hline C.H. M1 & 0,26684 & $-0,44662$ & $-0,39779$ & $-0,33454$ & 0,62429 & $-0,29$ \\
\hline C.H. Tulipan & 0,11721 & $-0,14539$ & $-0,18977$ & $-0,19168$ & $-0,04459$ & $-0,45$ \\
\hline Tesco P. & $-0,51123$ & $-0,27718$ & $-0,34304$ & $-0,42026$ & $-0,44592$ & $-2,00$ \\
\hline Pasaż Łódzki & $-0,51123$ & $-0,13284$ & $-0,34304$ & $-0,39169$ & $-0,84724$ & $-2,23$ \\
\hline Tesco W. & $-0,39153$ & $-0,49055$ & $-0,39779$ & $-0,46312$ & $-0,84724$ & $-2,59$ \\
\hline Carrefour P. & $-0,39153$ & $-0,71020$ & $-0,63865$ & $-0,56312$ & $-0,57969$ & $-2,88$ \\
\hline E.Leclerc & $-0,84042$ & $-0,76041$ & $-0,67149$ & $-0,56312$ & $-0,04459$ & $-2,88$ \\
\hline C.H. Guliwer & $-0,66086$ & $-0,60979$ & $-0,38684$ & $-0,53455$ & $-0,98102$ & $-3,17$ \\
\hline Carrefour Sz. & $-1,46886$ & $-0,68510$ & $-0,49632$ & $-0,59169$ & $-0,84724$ & $-4,09$ \\
\hline
\end{tabular}

Źródło: Opracowanie własne na podstawie badań ankietowych.

Porównując obiektywną atrakcyjność ofertową centrów handlowych $\mathrm{z}$ oceną ich atrakcyjności w opinii ich klientów (subiektywną), można zauważyć pewne podobieństwa i różnice. Najatrakcyjniejsze w obydwóch ocenach są Manufaktura (1 lokata), Galeria Łódzka (2. miejsce) i Port Łódź (3. miejsce). Niektóre kompleksy są słabiej oceniane przez klientów niż wynika to $\mathrm{z}$ ich obiektywnej atrakcyjności: C.H. Guliwer (7. lokata w ocenie obiektywnej - 11. w subiektywnej), Tesco P. (4.; 6.), Carrefour Sz. (11.; 12.). Natomiast inne wybrane centra handlowe postrzegane są lepiej w oczach klientów niż wynika to $\mathrm{z}$ ich obiektywnej oceny atrakcyjności ofertowej: C.H. M1 (4. miejsce; 6.), Carrefour P. (10.; 12.), Pasaż Łódzki (7.; 8.), Tesco W. (8.; 9.), E. Leclerc (9.; 10.). Generalnie można zauważyć, że obydwie oceny są względem siebie zbieżne, poszczególne centra handlowe posiadają podobną atrakcyjność w ocenie obiektywnej i subiektywnej. Największa różnica w ocenie dotyczy C.H. Guliwer, którego oferta lokuje ten kompleks na siódmym miejscu, ale w oczach klientów jest bardzo słabo ceniony, dopiero na jedenastym. 
Tabela 42

Cechy zachowań nabywczych klientów według typów centrów handlowych

\begin{tabular}{|c|c|c|c|c|}
\hline Lp. & Kategoria & $\begin{array}{l}\text { Typ I - duże } \\
\text { centra } \\
\text { usługowo- } \\
\text {-rozrywkowo- } \\
\text {-kulturowe }\end{array}$ & $\begin{array}{l}\text { Typ II - duże } \\
\text { centra } \\
\text { usługowo- } \\
\text {-rozrywkowe }\end{array}$ & $\begin{array}{l}\text { Typ III i IV - małe i średnie } \\
\text { centra usługowe }\end{array}$ \\
\hline 1. & Towarzystwo & \multicolumn{2}{|c|}{$\begin{array}{l}\text { odwiedziny w gronie rodzinnym lub } \\
\text { indywidualnie, ale duże znaczenie odgrywają } \\
\text { pobyty w towarzystwie znajomych i przyjaciót }\end{array}$} & $\begin{array}{l}\text { - wizyty mają głównie charakter } \\
\text { rodzinny i indywidualny }\end{array}$ \\
\hline 2. & Długość pobytu & \multicolumn{2}{|c|}{ • długie wizyty najczęściej powyżej 2 godzin } & - krótkie wypady często do 2 godzin \\
\hline 3. & $\begin{array}{l}\text { Tygodniowy } \\
\text { cykl życia }\end{array}$ & \multicolumn{2}{|c|}{$\begin{array}{l}\text { - gtównie odwiedzane w piątek po południu } \\
\text { oraz w dni weekendowe (sobota i niedziela) }\end{array}$} & $\begin{array}{l}\text { - głównie odwiedzane w piątek } \\
\text { popołudniu i w sobotę }\end{array}$ \\
\hline 4. & $\begin{array}{l}\text { Dobowy cykl } \\
\text { życia }\end{array}$ & \multicolumn{2}{|c|}{$\begin{array}{l}\text { - głównie wizytowane w godzinach } \\
\text { popołudniowych i wieczornych }\end{array}$} & $\begin{array}{l}\text { - głównie wizytowane w godzinach } \\
\text { popołudniowych, ale } \\
\text { równocześnie duży odsetek } \\
\text { osób odwiedzających tego typu } \\
\text { kompleksy w godzinach rannych } \\
\text { i południowych }\end{array}$ \\
\hline 5. & $\begin{array}{l}\text { Postrzeganie } \\
\text { wizyt }\end{array}$ & $\begin{array}{l}\text { - miejsce robienia } \\
\text { zakupów, } \\
\text { ale również } \\
\text { spędzania czasu } \\
\text { wolnego, spotkań } \\
\text { towarzyskich } \\
\text { i korzystania } \\
\text { z oferty rozrywkowej }\end{array}$ & $\begin{array}{l}\text { - miejsce robienia } \\
\text { zakupów, } \\
\text { ale również } \\
\text { spędzania czasu } \\
\text { wolnego }\end{array}$ & $\begin{array}{l}\text { - gtównie miejsce robienia } \\
\text { zakupów }\end{array}$ \\
\hline 6. & Motywy wizyt & \multicolumn{2}{|c|}{$\begin{array}{l}\text { - bogata oferta asortymentowa, jakość } \\
\text { towarów, promocje, niskie ceny } \\
\text { zróżnicowanie sklepów, punkty usługowe }\end{array}$} & $\begin{array}{l}\text { - bogata oferta asortymentowa, } \\
\text { jakość towarów, promocje, niskie } \\
\text { ceny }\end{array}$ \\
\hline 7. & $\begin{array}{l}\text { Miejsca } \\
\text { zakupów }\end{array}$ & \multicolumn{2}{|c|}{$\begin{array}{l}\text { - hipermarkety z FMCG, markety } \\
\text { specjalistyczne, częste zakupy w małych } \\
\text { i średnich sklepach w galeriach handlowych }\end{array}$} & $\begin{array}{l}\text { - zakupy głównie w hipermarketach } \\
\text { i supermarketach z artykułami } \\
\text { FMCG }\end{array}$ \\
\hline 8. & $\begin{array}{l}\text { Asortyment } \\
\text { nabywany }\end{array}$ & \multicolumn{2}{|c|}{$\begin{array}{l}\text { - nabywane są artykuły spożywcze, środki } \\
\text { czystości, kosmetyczne oraz odzież i obuwie }\end{array}$} & $\begin{array}{l}\text { - nabywane są artykuły spożywcze, } \\
\text { środki czystości, kosmetyczne }\end{array}$ \\
\hline 9. & $\begin{array}{l}\text { Asortyment } \\
\text { nienabywany }\end{array}$ & \multicolumn{2}{|c|}{$\begin{array}{l}\text { - w mniejszym stopniu nabywane są artykuły } \\
\text { wyposażenia wnętrz, RTV i AGD }\end{array}$} & $\begin{array}{l}\text { - w mniejszym stopniu nabywają } \\
\text { artykuły wyposażenia wnętrz, } \\
\text { artykuły dla dzieci, RTV i AGD } \\
\text { - wiele osób nie kupuje tu odzieży, } \\
\text { obuwia, artykułów sportowych } \\
\text { oraz książek i czzsopism }\end{array}$ \\
\hline
\end{tabular}

Źródło: Opracowanie własne. 
Wśród klientów łódzkich centrów handlowych można wyróżnić trzy typy zachowań nabywczych. Pierwszy typ jest charakterystyczny dla Manufaktury jako dużego centrum usługowo-rozrywkowo-kulturowego, drugi bardzo podobny występuje na terenie dużych centrów usługowo-rozrywkowych (Galeria Łódzka i Port Łódź). Między zachowaniami nabywczymi klientów tych dwóch typów uwidacznia się główna różnica, wynikająca $z$ zakresu oferty rozrywkowo-kulturowej. Na terenie kompleksu Manufaktury wizytujące ją osoby zdecydowanie częściej korzystają z oferty rozrywkowej, a pobyty na jego terenie traktują jako sposób spędzania czasu wolnego. W przypadku klientów III i IV typu centrów handlowych ich zachowania są bardzo do siebie podobne, w związku z tym można mówić o jednym typie zachowań nabywczych na terenie tego typu kompleksów (tab. 42).

Z przeprowadzonych badań widać, że zachowania nabywcze zależą w dużej mierze od oferty centrów handlowych, szczególnie wpływ na nie ma ta część rozrywkowa i kulturowa oraz liczba i zróżnicowanie punktów usługowych (w tym głównie handlowych). Im oferta bogatsza, tym pobyty dłuższe, a powody wizyt bardziej zróżnicowane. W małych i średnich centrach handlowych (III i IV typ) głównym motywem ich odwiedzin dla klientów jest dokonanie zakupów dóbr materialnych. W tych największych duże znaczenie obok tego posiada możliwość skorzystania $\mathrm{z}$ oferty niematerialnej - miłego spędzenia czasu, skorzystanie $z$ oferty rozrywkowej czy „spotkanie się" z kulturą.

\subsection{Zasięg oddziaływania centrów handlowych oraz zachowania przestrzenne ich klientów}

\subsubsection{Zasięg oddziaływania}

Klienci łódzkich centrów handlowych w większości zamieszkują w mieście Łodzi (83,6\% z N=2390), pozostali pochodzą z innych gmin, głównie położonych w aglomeracji łódzkiej. Szczególnie w przypadku kompleksów zlokalizowanych na obrzeżach miasta C.H. M1 i Port Łódź to ponad 30\% ich klientów pochodzi spoza Łodzi (rys. 123), przede wszystkim z okolicznych gmin. Do Portu Łódź najwięcej osób dojeżdża z gmin: Pabianice (47,6\% osób mieszkających poza Łodzią) i Ksawerów (9,5\%). 
W przypadku C.H. M1 klienci legitymują się zamieszkaniem w gminach Brzeziny (30,3\%) i Nowosolna (30,3\%). Duży udział klientów spoza Łodzi ma również peryferyjnie położony, w stosunku do centrum Łodzi, Carrefour na ulicy Szparagowej (około 20\%). Do tego kompleksu dojeżdżają obok łodzian również mieszkańcy gmin: Aleksandrów Łódzki (66,5\%) oraz Zgierz (31,3\%).

Obok centrów handlowych położonych peryferyjnie w stosunku do centrum miasta, należy zwrócić uwagę na „śródmiejsko” położone ponadlokalne centra handlowe Galerię Łódzką i Manufakturę. W przypadku obydwu tych kompleksów zasięg ich oddziaływania jest ponadmiejski, ponieważ około $20 \%$ ich klientów mieszka poza Łodzią. Do Manufaktury ${ }^{138}$ dojeżdżają szczególnie osoby z wielu gmin położonych w niedalekiej odległości od Łodzi, w tym najwięcej osób pochodziło z gmin: Zgierz (18,3\%), Aleksandrów Łódzki (8,4\%), Pabianice (7,6\%), Łęczyca (4,6\%) i Konstantynów Łódzki (3,8\%). Galeria Łódzka stanowi cel wyjazdów między innymi dla mieszkańców gmin: Pabianice (17,2\%), Andrespol (8,6\%), Koluszki (8,6\%), Brzeziny (7,2\%).

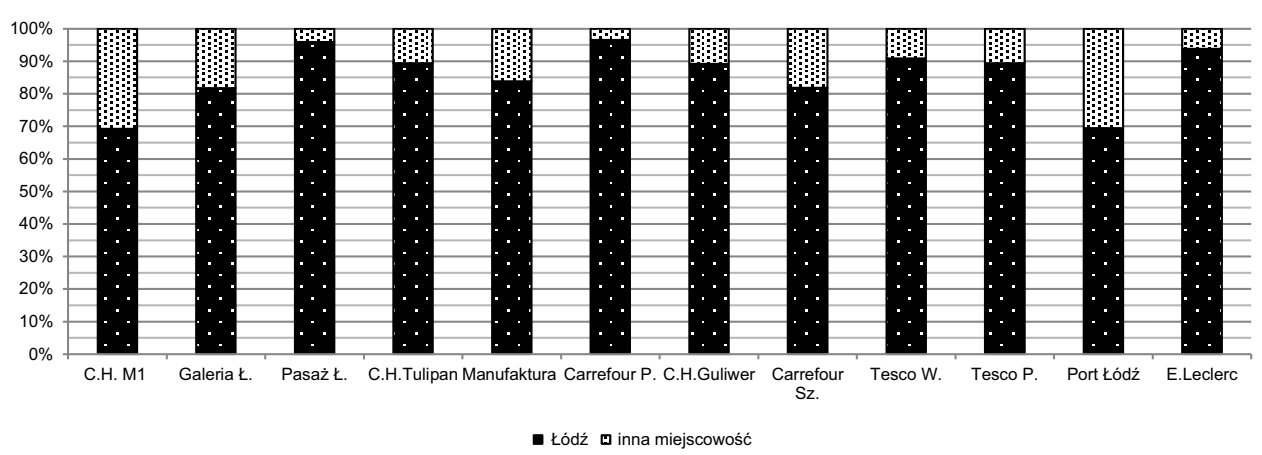

Rys. 123. Struktura klientów według miejsca zamieszkania [N: 2390=100\%].

Źródło: Opracowanie własne na podstawie badań ankietowych.

\footnotetext{
${ }^{138}$ W 2008 roku pod kierunkiem E. Szafrańskiej i T. Napierały studenci dokonali identyfikacji zasięgu oddziaływania Manufaktury na podstawie numerów rejestracyjnych pojazdów. Wyniki wykazały, że większość samochodów została zarejestrowana w Łodzi (około 71\%), z województwa łódzkiego najwięcej klientów było z powiatów ościennych, szczególnie ze zgierskiego. Wśród samochodów zarejestrowanych poza województwem lódzkim dominowały te z województwa mazowieckiego i wielkopolskiego (Studium przypadku. Centrum Handlowo-Ustugowe Manufaktura, 2010, s. 61-64).
} 
Można więc zauważyć pewną prawidłowość - peryferyjnie położone centra handlowe przyciągają osoby z sąsiednich gmin (wyraziście są zarysowane kierunki ciążenia), natomiast położone „śródmiejsko” o ponadlokalnym charakterze ściągają klientów $\mathrm{z}$ różnych kierunków (bez konkretnej prawidłowości). Pozostałe centra handlowe posiadają bardziej lokalny charakter, a ich klienci pochodzą głównie z Łodzi (90\% i więcej).

W Łodzi ankietowani klienci łódzkich centrów handlowych zamieszkują w 45 jednostkach osiedlowych (spośród 56), w których odsetek ankietowanych był podobny (0,2-0,5\% mieszkańców). Największy odsetek respondentów zamieszkiwał w jednostkach: Akademicka, Chocianowice (1,1-2,3\%), Nowe Miasto, Teofilów Przemysłowy oraz Łaskowice (0,6-1\%). $\mathrm{Z}$ jednostek bardziej zurbanizowanych, z zabudową wielorodzinną, o dużej gęstości zaludnienia pochodzi większa liczba klientów niż z innych rejonów miasta. Najwięcej ankietowanych (po 90 i więcej) zamieszkuje jednostki osiedlowe: Akademicka, Nowe Miasto, Zielona, Stare Miasto-Bałuty, Teofilów, Widzew Wschód, Retkinia (rys. 124 i 125).

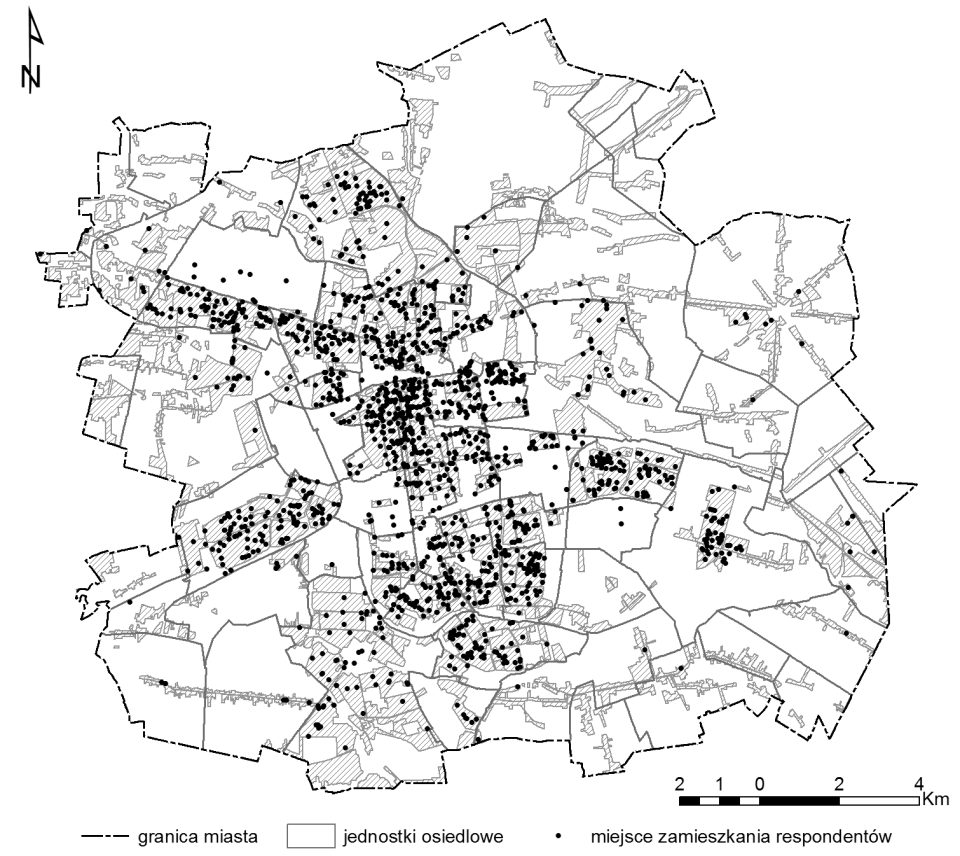

Rys. 124. Miejsca zamieszkania respondentów w Łodzi według jednostek osiedlowych.

Źródło: Opracowanie własne na podstawie badań ankietowych. 


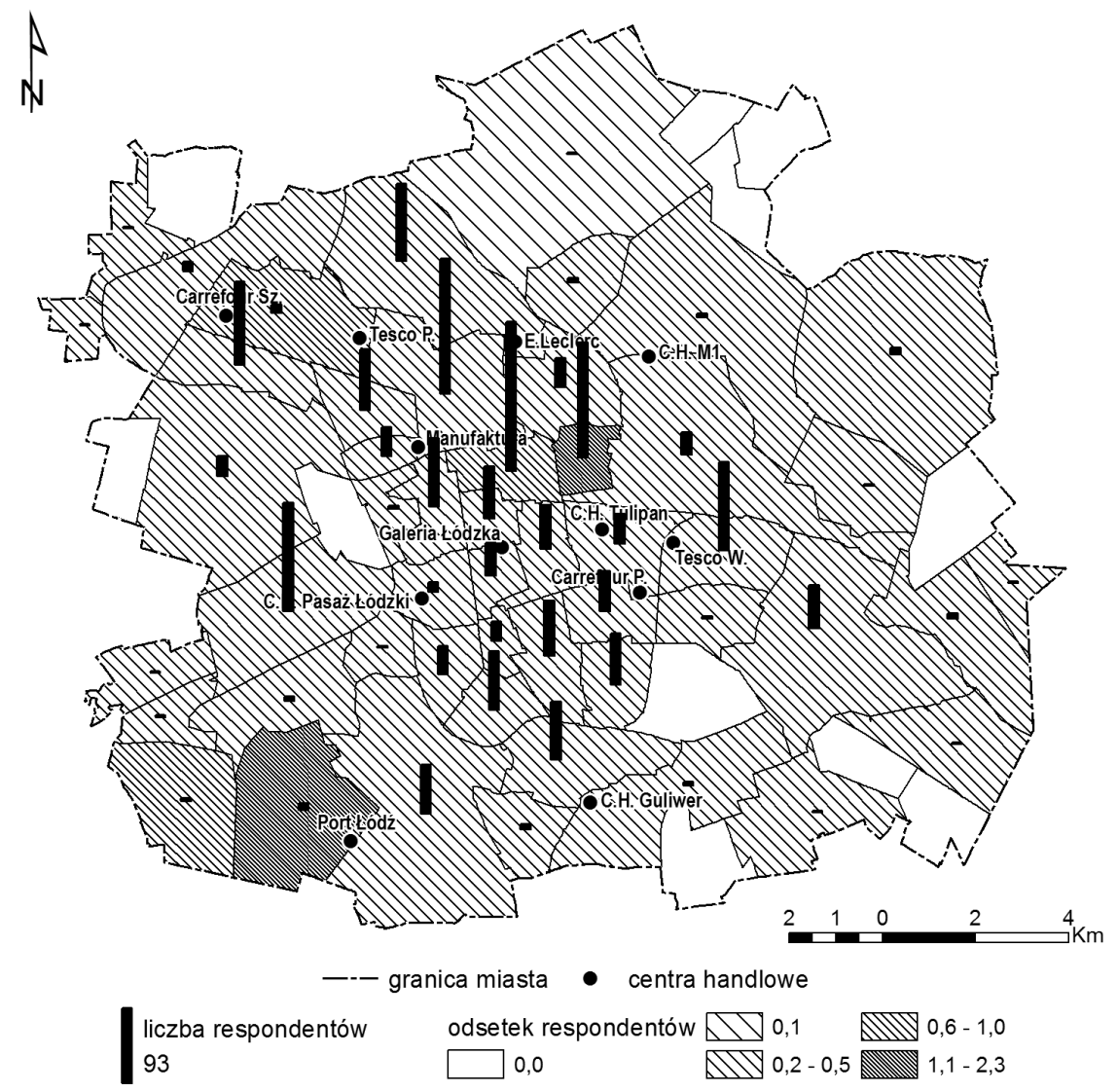

Rys. 125. Liczba i odsetek respondentów według miejsca zamieszkania w jednostkach osiedlowych Łodzi.

Źródło: Opracowanie własne na podstawie badań ankietowych.

Większość osób podróż do centrum handlowego rozpoczyna $\mathrm{z}$ domu (57,7\%), część odwiedza tego typu kompleksy po drodze z pracy/szkoły do domu (21,3\%), a pewna grupa respondentów wybiera, wskazane przez siebie centrum handlowe, w momencie gdy znajduje się $\mathrm{w}$ jego pobliżu (17,3\%). Odwiedzając wybrane kompleksy, najczęściej ankietowani przemieszczają się do nich samochodem (52,9\%), środkami komunikacji miejskiej - tramwaj, autobus (27,2\%) lub pieszo (14,9\%). Z bezpłatnych autobusów poszczególnych centrów handlowych w celu dojechania do nich korzysta 4,2\% ankietowanych. Czas jaki przeznaczają respondenci na do- 
tarcie do wybranego kompleksu handlowego wynosi najczęściej do $15 \mathrm{~min}$ (44,3\%; $\mathrm{N}=2409), 15-30$ minut (35,9\%) lub 30-45 minut (12,5\%) - dłuższy czas wskazuje tylko 7,3\% respondentów (rys. 126).

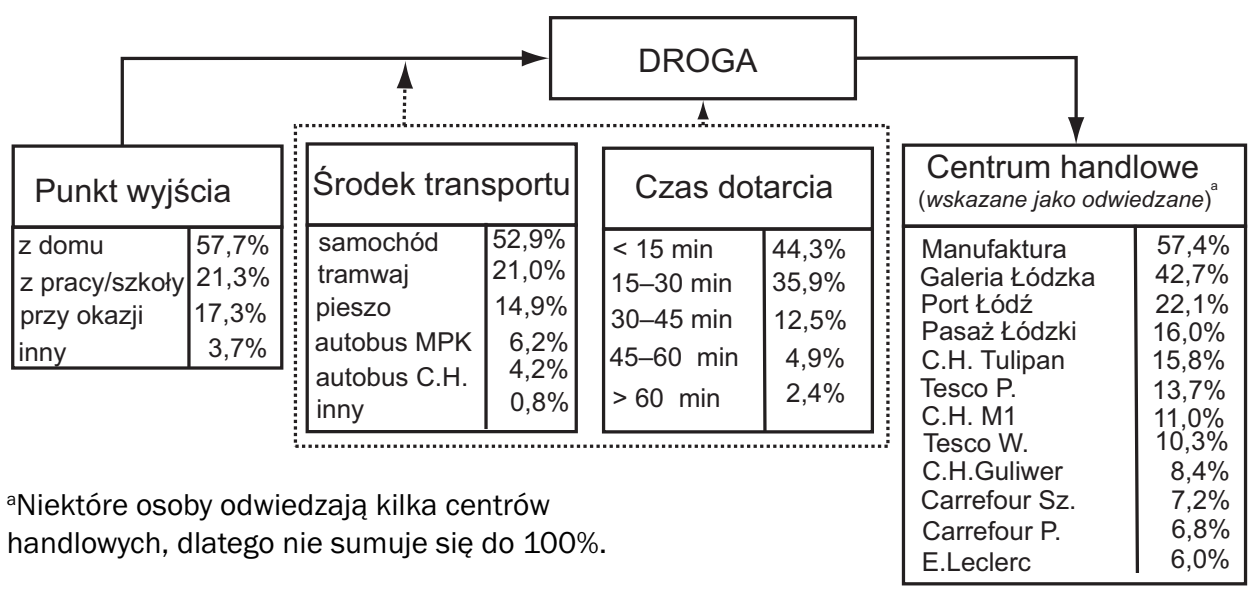

Rys. 126. Droga do łódzkich centrów handlowych.

Źródło: Opracowanie własne na podstawie badań ankietowych.

Czas poświęcany na dotarcie do wybranego centrum handlowego jest dla zdecydowanej większości respondentów satysfakcjonujący (64,2\%) lub nie ma znaczenia (23,8\%), tylko dla 12\% (282 osób) jest zbyt długi. Z lokalizacji wskazywanych centrów handlowych respondenci są zadowoleni i uważają, że są one zlokalizowane w odpowiedniej odległości od ich miejsca zamieszkania (84,5\%), tylko 14,7\% uważa, że są położone zbyt daleko, a 0,8\% (20 osób) twierdzi, że zbyt blisko ich mieszkania. Ogólnie należy podkreślić, że lokalizacja wybranych centrów handlowych jest oceniana jako korzystna $(65,4 \%)$, a nawet bardzo korzystna (17,7\%). Tak dobra ocena może wynikać $\mathrm{z}$ faktu, że osoby wskazywały te centra handlowe, do których udają się najczęściej, które lubią i do których lokalizacji są już przyzwyczajeni.

Ocenę powyższą potwierdzają również odpowiedzi na pytanie o problemy, na które napotykają podczas pokonywania drogi do wybranego przez nich centrum handlowego. Na utrudnienia wskazała prawie co dziesiąta osoba ankietowa, która uważa że: jest ono zbyt daleko położone od miejsca zamieszkania (9,3\%), brak bezpłatnego autobusu $(9,1 \%)$, czas dojazdu jest zbyt długi (8,8\%), są problemy ze znalezieniem miejsca parkingowego 
(8,6\%), jest zbyt mało połączeń komunikacją miejską (7,7\%). Najpoważniejszym problemem utrudniającym przybycie do wskazanego centrum handlowego okazały się zatłoczone drogi dojazdowe, na te utrudnienia zwróciło uwagę aż 23,4\% respondentów.

Największe obszarowo oddziaływanie w Łodzi posiadają centra handlowe I i II typu (rys. 127 i 128), mniejsze zasięgi natomiast mają centra handlowe III i IV typu (rys. 129 i 130). Do Manufaktury i do Galerii Łódzkiej przyjeżdżają osoby praktycznie ze wszystkich rejonów miasta (rys. 127 i 128), w przypadku Portu Łódź, mimo że ten kompleks ma również charakter ponadlokalny, to jednak klientami łódzkimi są głównie mieszkańcy z jednostek położonych na południu miasta w sąsiedztwie ulicy Rzgowskiej (Ruda, Nowe Rokicie, Kurak, Górny Rynek, Dąbrowa Zachodnia, Chojny Zatorze) (rys. 128).

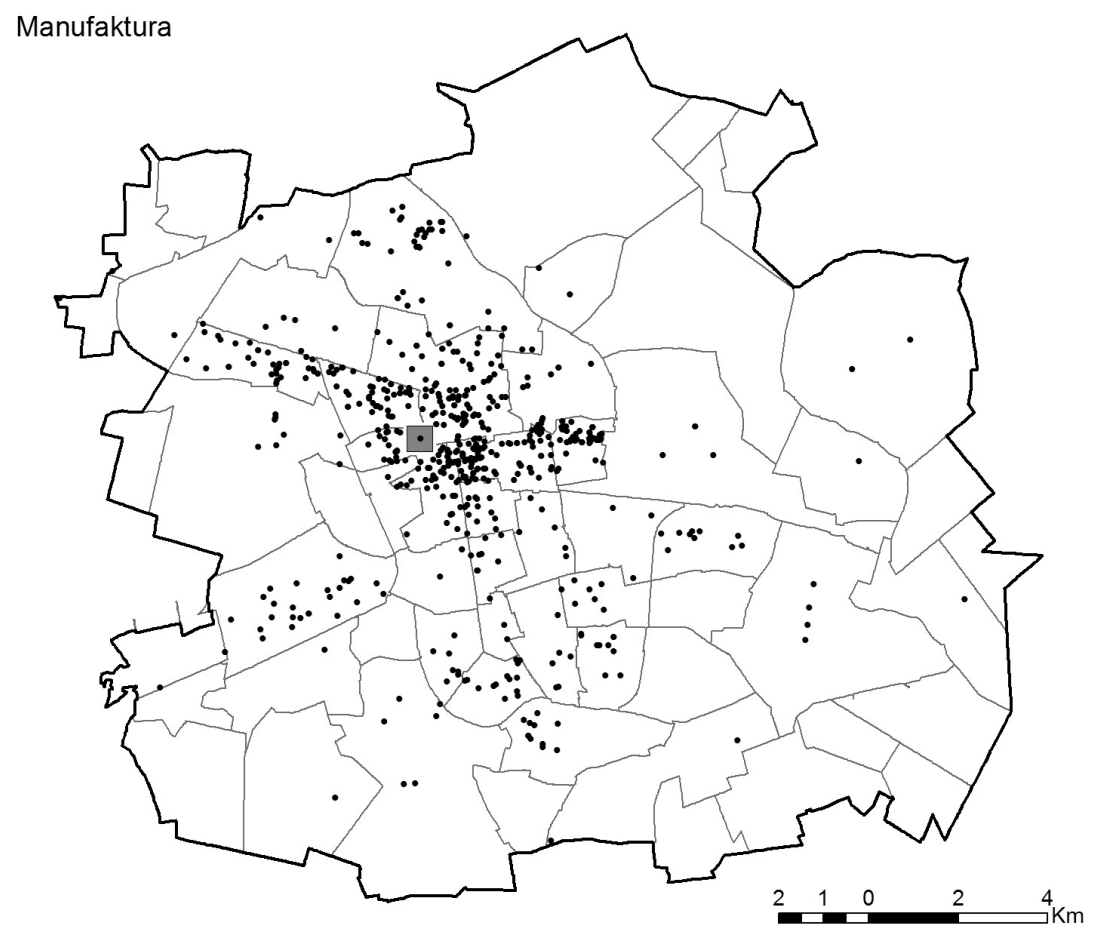

Rys. 127. Miejsca zamieszkania w Łodzi klientów centrum handlowego I typu $[\mathrm{N}: 676=100 \%]$.

Źródło: Opracowanie własne na podstawie badań ankietowych. 

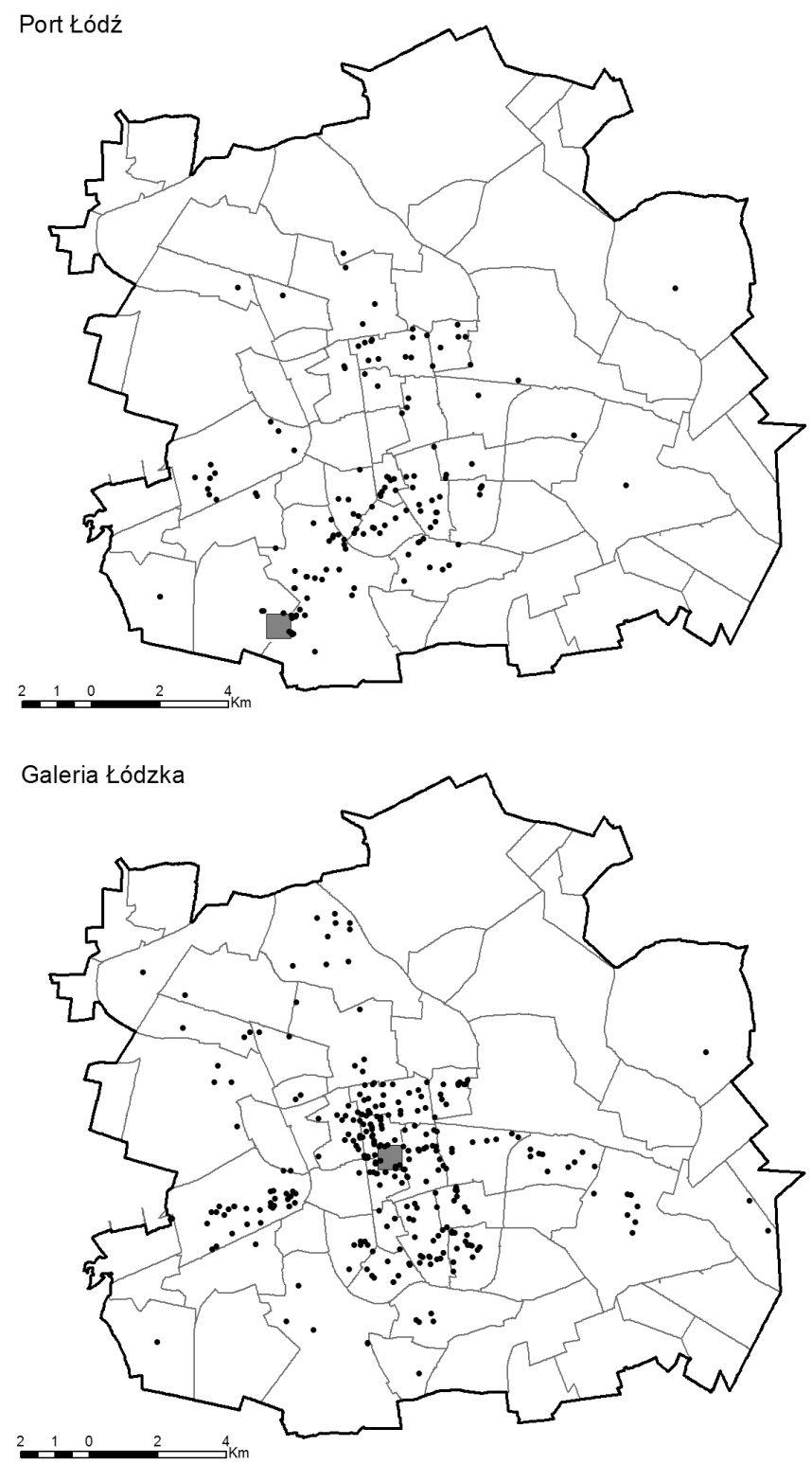

Rys. 128. Miejsca zamieszkania w Łodzi klientów centrów handlowych II typu [N: 455=100\%].

Źródło: Opracowanie własne na podstawie badań ankietowych. 

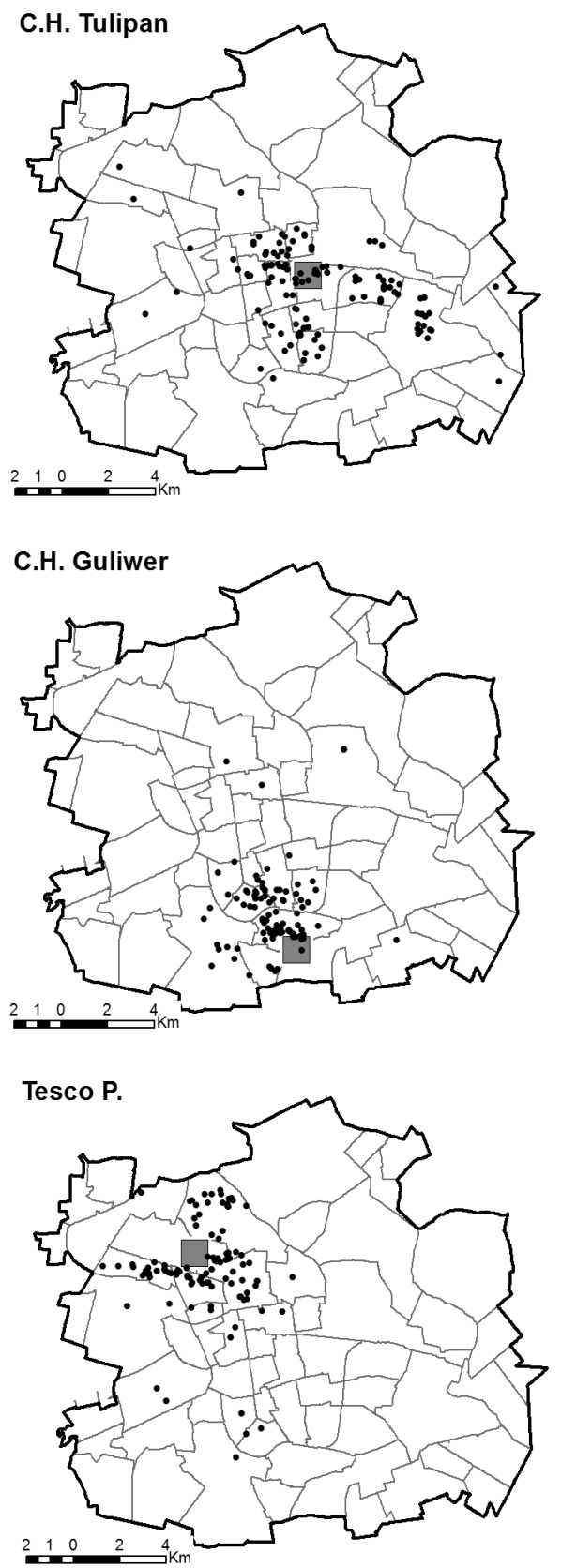

Rys. 129. Miejsca zamieszkania w Łodzi klientów centrów handlowych III typu [N: $343=100 \%]$.

Źródło: Opracowanie własne na podstawie badań ankietowych. 

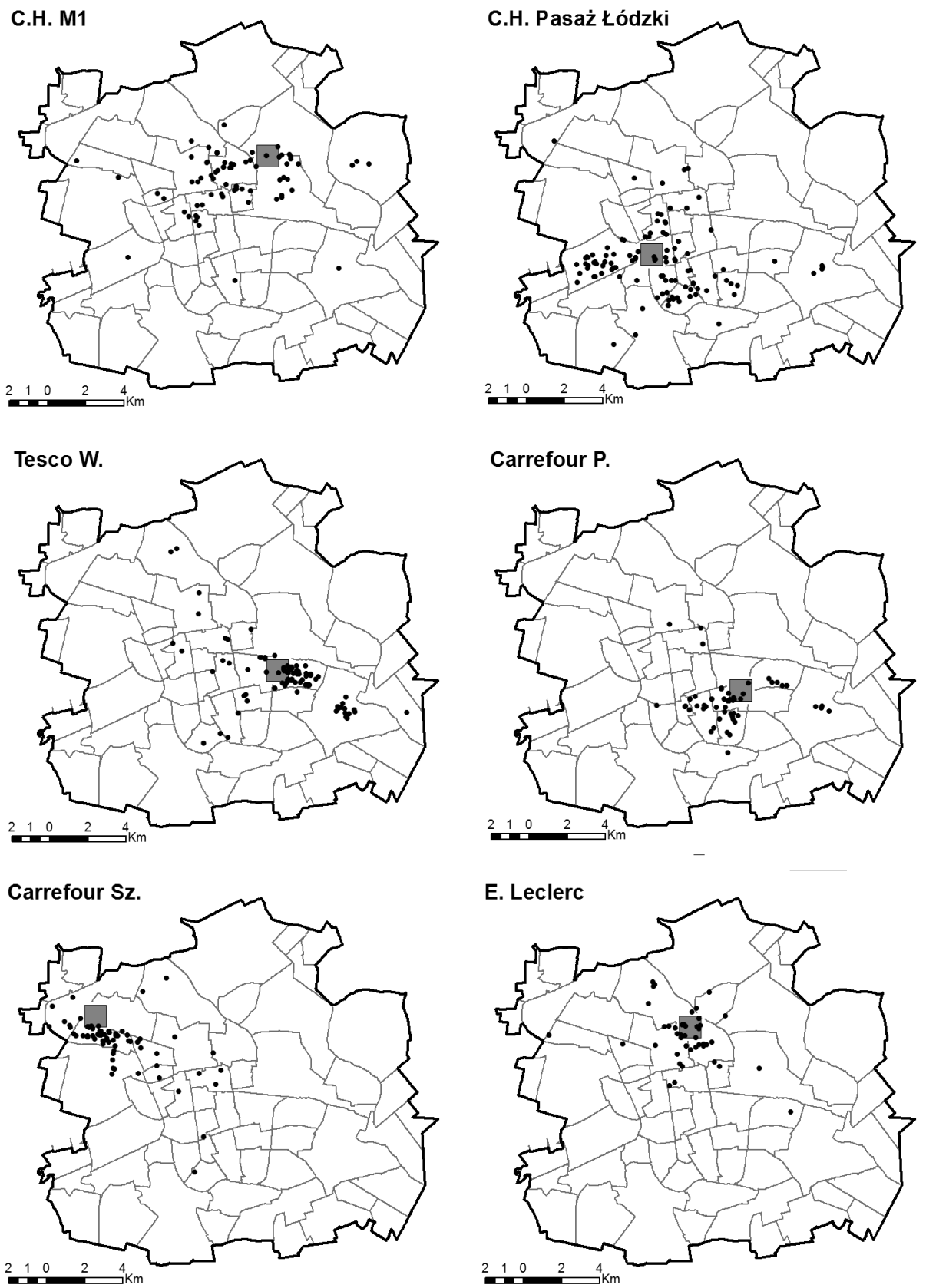

Rys. 130. Miejsca zamieszkania w Łodzi klientów centrów handlowych IV typu [N: $460=100 \%$.

Źródło: Opracowanie własne na podstawie badań ankietowych. 
We wszystkich przypadkach najwięcej klientów pochodzi z terenów sąsiadujących $\mathrm{z}$ danym centrum handlowym. W dużej mierze na wielkość obszaru oddziaływania poszczególnych centrów handlowych wpływ ma wielkość centrum handlowego, zróżnicowanie i bogactwo jego oferty, położenie w stosunku do centrum miasta, głównych arterii komunikacyjnych oraz w stosunku do terenów mieszkaniowych. W przypadku rozmieszczenia klientów niektórych centrów handlowych wręcz można orientacyjnie wyznaczyć przebieg głównych arterii komunikacyjnych, np. Galeria Łódź - aleja Marszałka Józefa Piłsudskiego, aleja Tadeusza Kościuszki, ulica Kilińskiego; Port Łódź - ulica Pabianicka; C.H. Tulipan - aleja Marszałka Józefa Piłsudskiego, ul. Stefana Kopcińskiego.

Dla poszczególnych centrów handlowych za pomocą narzędzi analiz przestrzennych GIS w aplikacji ArcMap wyznaczono strefy zasięgu. W pierwszym etapie poszukiwano promienia koła (środek stanowiło centrum handlowe), w którym znalazłaby się odpowiednia liczba respondentów (obliczona dla zadanych odsetków 50\%, 70\% i 90\%). Do tego celu zastosowano narzędzie selekcji obiektów na podstawie relacji przestrzennych. W drugim etapie wykreślono ekwidystanty o znalezionych promieniach. Pod uwagę wzięto tylko klientów, którzy posiadają łódzki adres zamieszkania, w związku z czym wyznaczone promienie określają strefy zasięgów centrów handlowych w Łodzi.

Największy zasięg oddziaływania ${ }^{139} \mathrm{w}$ Łodzi posiadają peryferyjnie położone: Port Łódź (90\% klientów dojeżdża do niego z odległości do $9 \mathrm{~km}$ ) oraz C.H. M1 $(5,9 \mathrm{~km})$. Duży zasięg oddziaływania posiadają również centralnie położone Manufaktura (około 5,6 km), Galeria Łódzka (około $5,7 \mathrm{~km}$ ) oraz C.H. Tulipan (około 5,4 km). Niektóre centra handlowe posiadają wybitnie lokalny charakter, ponieważ 50\% ich klientów zamieszkuje obszar w promieniu do 2 kilometrów od wskazanego centrum handlowego: Carrefour P., Carrefour Sz., Tesco W., E. Leclerc (tab. 43, rys. 131).

$\mathrm{Z}$ analizy zasięgu oddziaływania widać, że centra handlowe $\mathrm{z}$ bogatszą ofertą posiadają większy zasięg oddziaływania od tych z zawężoną ofertą. Na zasięg oddziaływania wpływ ma również lokalizacja centrum handlowego. W przypadku kompleksów zlokalizowanych na peryferiach miasta zasięg ten się rozszerza, ponieważ do nich przyjeżdżają osoby z dalszych odległości. Kompleksy o przeciętnej atrakcyjności

${ }^{139}$ Pod uwagę wzięto tylko klientów, którzy posiadają łódzki adres zamieszkania. 
oferty, zlokalizowane w pobliżu osiedli mieszkaniowych posiadają bliższy zasięg oddziaływania. Często klientami tego typu centrów handlowych są osoby mieszkające w pobliżu w odległości do 2-3 km od niego (typ III i IV) (rys. 131).

Tabela 43

Zasięg stref odległościowych wokół łódzkich centrów handlowych w zależności od odsetka klientów

\begin{tabular}{|l|c|c|c|}
\hline \multirow{2}{*}{ Centrum handlowe } & \multicolumn{3}{|c|}{ Zasięg strefy ze względu na udział klientów [w kilometrach] } \\
\cline { 2 - 4 } & $\begin{array}{c}\text { strefa I } \\
\mathbf{( 5 0 \% ~ k l i e n t o ́ w ) ~}\end{array}$ & $\begin{array}{c}\text { strefa II } \\
\text { (70\% klientów) }\end{array}$ & $\begin{array}{c}\text { strefa III } \\
\mathbf{9 0 \%} \text { klientów) }\end{array}$ \\
\hline Port Łódź & 4,95 & 6,1 & 8,85 \\
\hline Manufaktura & 2,7 & 3,82 & 5,57 \\
\hline C.H. M1 & 2,66 & 3,9 & 5,9 \\
\hline Galeria Łódzka & 2,62 & 3,46 & 5,65 \\
\hline C.H. Tulipan & 2,56 & 3,3 & 5,35 \\
\hline Pasaż Łódzki & 2,55 & 3,25 & 4,8 \\
\hline Tesco P. & 2,15 & 2,7 & 3,7 \\
\hline C.H. Guliwer & 2,1 & 2,89 & 3,8 \\
\hline Carrefour P. & 1,7 & 2,42 & 3,5 \\
\hline Carrefour Sz. & 1,54 & 2,5 & 4,7 \\
\hline Tesco W. & 1,4 & 2,59 & 4,52 \\
\hline E. Leclerc & 1,2 & 2,1 & 3,2 \\
\hline
\end{tabular}

Źródło: Opracowanie własne na podstawie badań ankietowych [N: 1925=100\%].

W celu lepszego zobrazowania zależności między miejscem zamieszkania a wyborem konkretnego centrum handlowego wokół poszczególnych badanych kompleksów wyznaczono strefy 15-minutowej dostępności samochodem (mapa pokazuje już zgeneralizowaną jej formę). Najwięcej respondentów wybranych centrów handlowych, powyżej 200, pochodziło ze stref wskazanych przez siebie kompleksów wokół Galerii Łódzkiej (253), Manufaktury (252), C.H. Tulipan (246) i Tesco P. (205). Najmniej nabywców zamieszkiwało w strefach w otoczeniu C.H. M1 (52), E. Leclerc (97) oraz Portu Łódź (102) (rys. 132). 

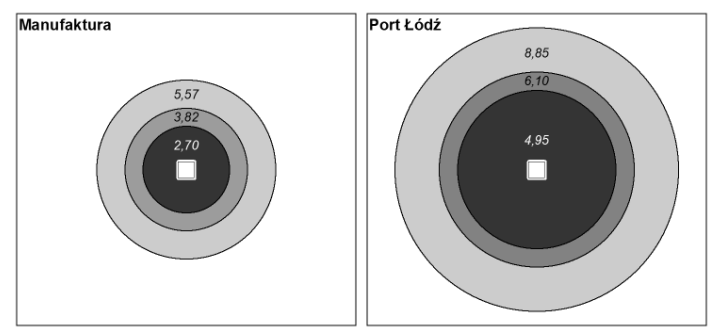

Rys. 131. Zasięg oddziaływania centrów handlowych według typów.

Źródło: Opracowanie własne na podstawie badań ankietowych.
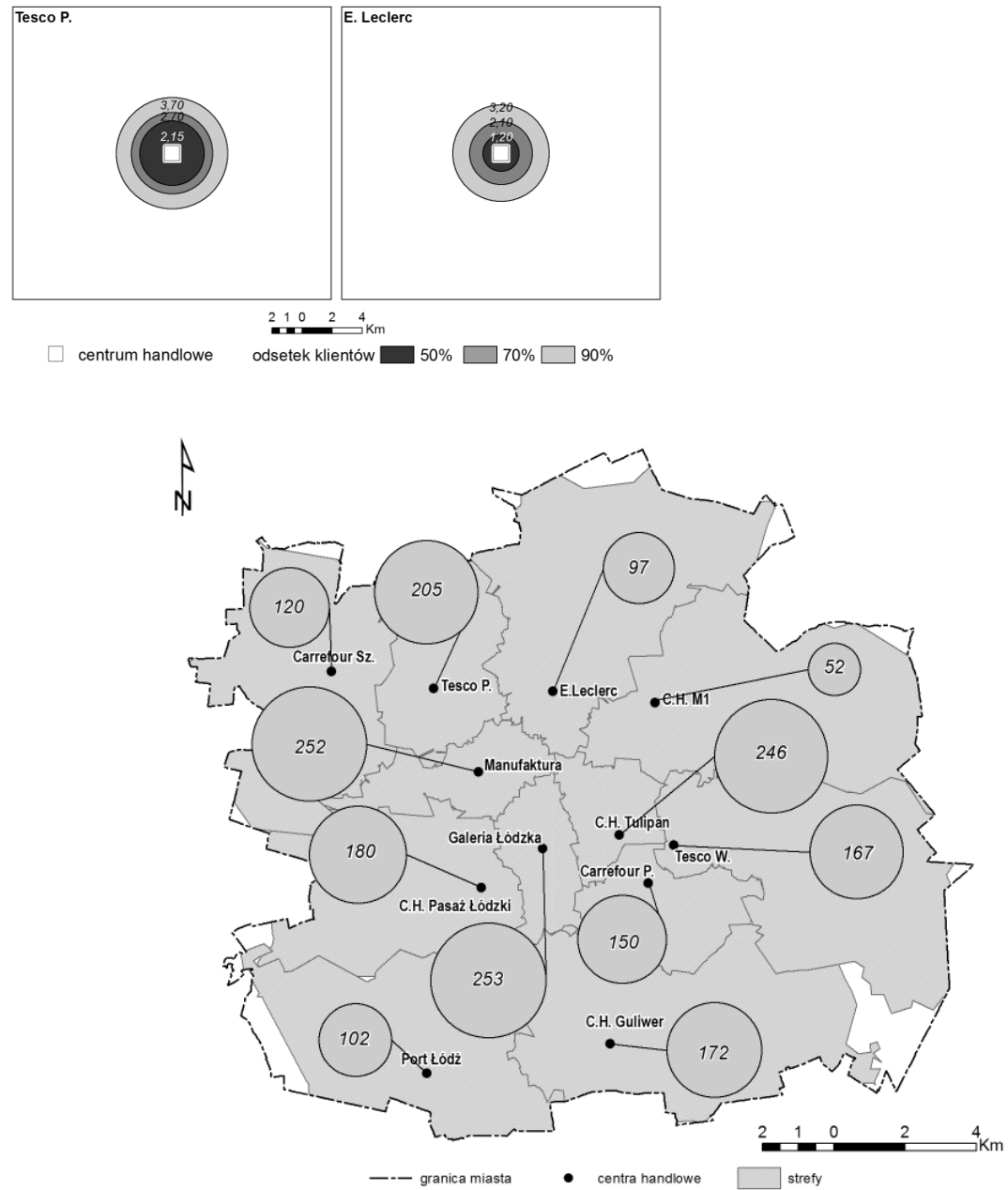

(kartodiagram kołowy - pokazujące liczbę respondentów z wyznaczonej strefy, którzy wskazali na centrum handlowe zlokalizowane $w$ tej strefie).

Rys. 132. Zgeneralizowane strefy dostępności 15 minut samochodem z liczbą respondentów z danej strefy.

Źródło: Opracowanie własne na podstawie badań ankietowych. 
Klienci mieszkający w strefie 15-minutowej dostępności samochodowej danego centrum handlowego nie zawsze wskazywali je jako najczęściej odwiedzane lub/i najbardziej ulubione, niektórzy wybrali kompleks inny, dalej położony. Największy odsetek klientów zamieszkujących w wyznaczonych strefach, którzy wybrali najbliżej zlokalizowane centrum handlowe względem miejsca zamieszkania, mieszka w rejonie: Manufaktury (około 68\%), C.H. M1 (52\%) i Portu Łódź (około 50\%). Najmniejszy odsetek respondentów wskazało na najbliżej położone centrum handlowego ze stref wokół C.H. Tulipan (około 16,3\%), Carrefour P. (22\%), E. Leclerc (około 28,9\%) oraz Pasażu Łódzkiego (około 29,4\%) (tab. 44, rys. 133).

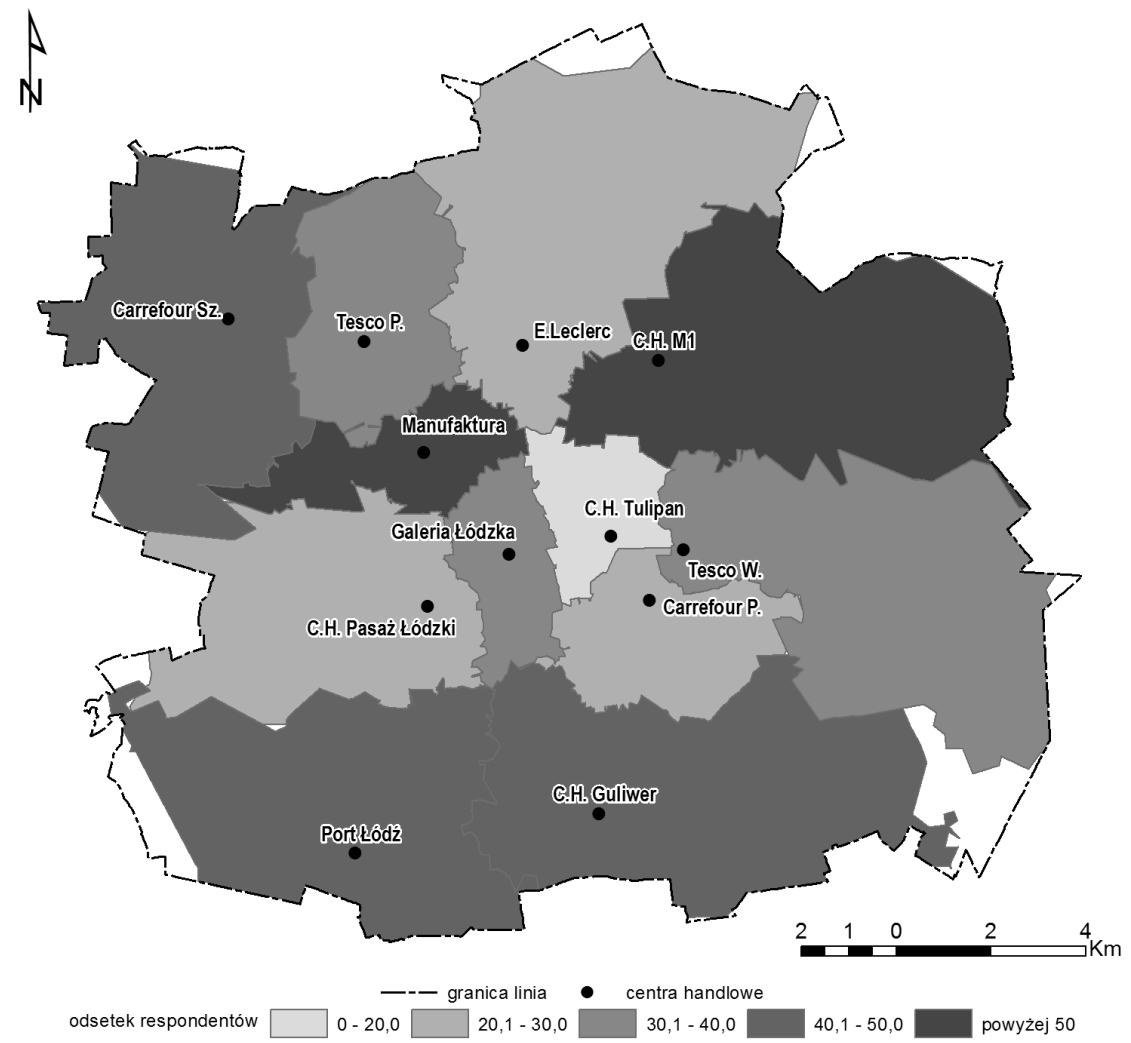

Rys. 133. Odsetek respondentów korzystających z oferty wskazanego centrum handlowego i mieszkających w jego strefie 15-minutowej dostępności samochodem.

Źródło: Opracowanie własne na podstawie badań ankietowych. 


\section{Tabela 44}

Zamieszkanie w wybranej strefie dostępności 15 minut samochodem a wskazanie konkretnego centrum handlowego jako najczęściej odwiedzanego

\begin{tabular}{|l|c|c|c|}
\hline $\begin{array}{c}\text { Centrum } \\
\text { handlowe }\end{array}$ & $\begin{array}{c}\text { Liczba respondentów } \\
\text { mieszkających } \\
\text { w danej strefie, którzy } \\
\text { wybrali centrum } \\
\text { handlowe położone } \\
\text { w tej strefie }\end{array}$ & $\begin{array}{c}\text { Liczba respondentów } \\
\text { mieszkających } \\
\text { w danej strefie } \\
\text { (ogółem) }\end{array}$ & $\begin{array}{c}\text { Odsetek } \\
\text { respondentów, którzy } \\
\text { mieszkają w danej } \\
\text { strefie i wybrali } \\
\text { centrum handlowe } \\
\text { zlokalizowane w tej } \\
\text { strefie [\%] }\end{array}$ \\
\hline Manufaktura & 171 & 252 & 67,9 \\
\hline C.H. M1 & 27 & 52 & 51,9 \\
\hline Port Łódź & 51 & 102 & 50,0 \\
\hline C.H. Guliwer & 78 & 172 & 45,4 \\
\hline Carrefour Sz. & 50 & 120 & 41,7 \\
\hline Galeria Łódzka & 99 & 253 & 39,1 \\
\hline Tesco W. & 61 & 167 & 36,5 \\
\hline Tesco P. & 64 & 205 & 31,2 \\
\hline Pasaż Łódzki & 53 & 180 & 29,4 \\
\hline E. Leclerc & 28 & 97 & 28,9 \\
\hline Carrefour P. & 33 & 150 & 22,0 \\
\hline C.H. Tulipan & 40 & 246 & 16,3 \\
\hline
\end{tabular}

Źródło: Opracowanie własne na podstawie badań ankietowych.

Można więc zauważyć pewną prawidłowość. Jeżeli centrum handlowe o charakterze lokalnym jest położone w pobliżu śródmiejskiego obszaru miasta, niedaleko innych kompleksów o bogatszej ofercie, to wtedy mieszkańcy ich stref są bardziej skłonni wskazywać je jako to, z którego najczęściej korzystają lub/i jest najbardziej ulubionym (jest on innym kompleksem handlowym niż ten najbliżej położonym miejsca zamieszkania). Natomiast mieszkańcy stref peryferyjnych miasta są klientami najczęściej centrów handlowych zlokalizowanych w pobliżu ich miejsc zamieszkania. W strefach centralnych miasta odbywa się więc konkurencja między centrami handlowymi o pozyskanie klientów, ponieważ ich strefy oddziaływania nakładają się wzajemnie na siebie. 


\subsubsection{Zachowania przestrzenne klientów}

Zachowania przestrzenne klientów centrów handlowych zależą między innymi od lokalizacji danego centrum i jego oferty oraz od miejsca zamieszkania lub pracy nabywców. W związku $\mathrm{z}$ tym należy przeanalizować tego typu zachowania nie tylko w ramach wcześniej wydzielonych typów centrów handlowych, ale również oddzielnie dla każdego badanego centrum handlowego oraz w zależności od jego typu lokalizacyjnego. Przeprowadzając badania nad zachowaniami przestrzennymi klientów należy ustalić, gdzie oni mieszkają, skąd najczęściej wyruszają w swoją podróż do wybranego kompleksu, jak długo zajmuje im dojazd oraz jaki środek transportu wybierają.

Ważną kwestią w badaniach nad zachowaniami przestrzennymi klientów jest ustalenie, skąd rozpoczynają swoją podróż do wskazanego centrum. $Z$ przeprowadzonych badań wynika, że większość rozpoczyna swoją wyprawę $\mathrm{z}$ własnego domu, dlatego istotne jest położenie kompleksów handlowych względem ich miejsc zamieszkania. Największy odsetek nabywców rozpoczyna swój wyjazd do centrum handlowego z domu w przypadku klientów: C.H. Guliwer (80\%), E. Leclerc (78\%), Port Łódź (74\%), Pasaż Łódzki (74\%) i Tesco W. (72\%). Część respondentów przyznaje jednak, że odwiedziny tego typu kompleksów mają miejsce po drodze z pracy, ze szkoły lub wizytują je przy okazji pobytu w jego pobliżu. Duży odsetek tych ostatnich jest klientami Manufaktury (22\%), Galerii Łódzkiej (21\%), C.H. M1 i Carrefour Sz. (18\%) (rys. 134).

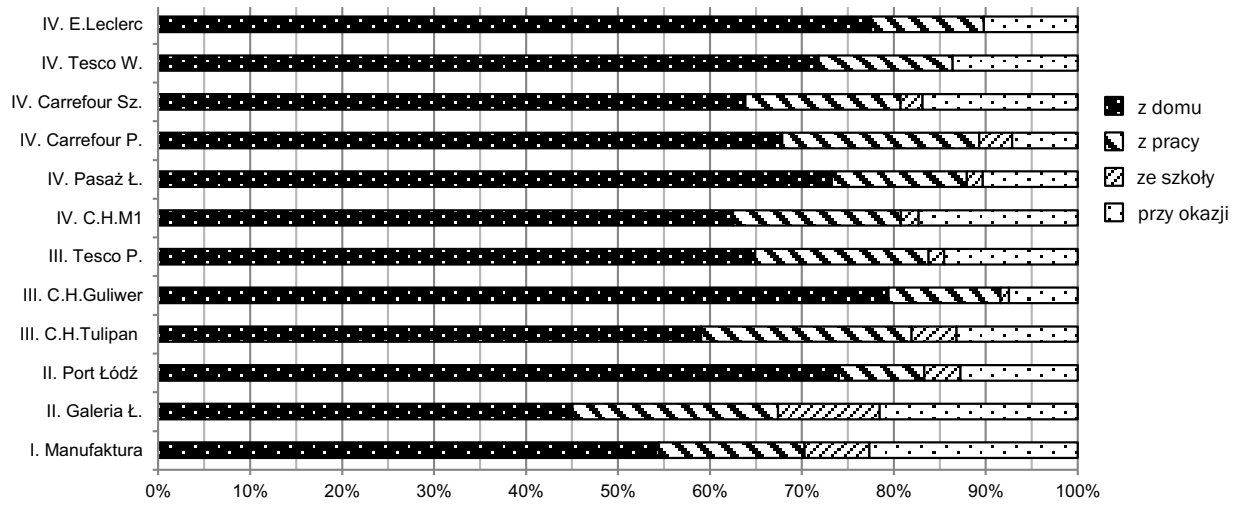

Rys. 134. Miejsce, z którego respondenci najczęściej rozpoczynają swoją podróż do centrum handlowego [N: $2187=100 \%]$.

Źródło: Opracowanie własne na podstawie badań ankietowych. 
Jeżeli spojrzymy na zestawienie według typów ofertowych centrów handlowych, to w przypadku I i II typu mniejszy odsetek osób wybiera się do tego typu kompleksów z domu (około 55\%), niż w pozostałych typach (około 68\%). Natomiast w obydwu kategoriach większy udział posiadają osoby odwiedzające te kompleksy, będąc w ich pobliżu (około 20\%) (rys. 135). W II typie obok Galerii Łódzkiej znalazł się Port Łódź, oba kompleksy posiadają różne położenie względem śródmieścia Łodzi, co wpływa na odmienne zachowania przestrzenne, w związku z tym wskaźniki w tym przypadku są zaburzone. Klienci Galerii Łódzkiej odwiedzają ją nie tylko wyruszając $z$ domu (około 45\%), ale często po drodze z pracy/szkoły (około $33 \%$ ) lub będąc okazjonalnie w jej pobliżu (około 22\%), natomiast klienci Portu Łódź przede wszystkim wyjeżdżaja/wychodzą do niego z domu (72\%), a około $12 \%$ bywa w nim przy okazji.

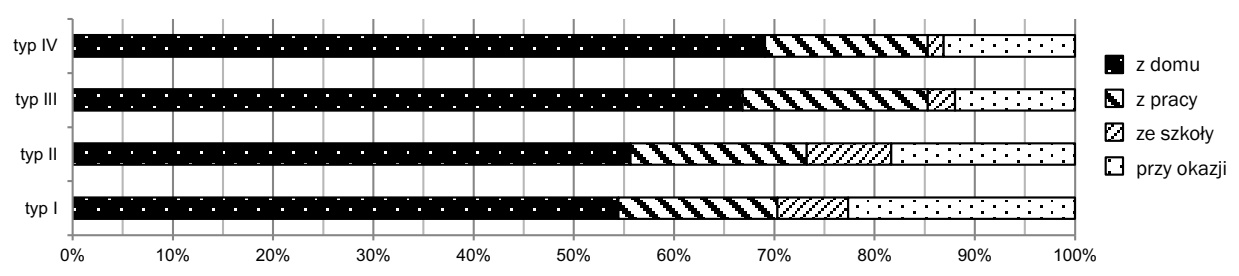

Rys. 135. Miejsce, z którego respondenci najczęściej rozpoczynają swoją podróż do danego ofertowego typu centrum handlowego [N: 2187=100\%].

Źródło: Opracowanie własne na podstawie badań ankietowych.

Położenie badanych kompleksów handlowych w przestrzeni miasta w zależności od odległości od jego centrum jest zróżnicowane, dlatego ze względu na to kryterium wyodrębniono trzy jego typy lokalizacyjne: śródmiejski - o charakterze ponadlokalnym (Manufaktura i Galeria Łódzka), peryferyjny (Port Łódź, C.H. M1, C.H. Guliwer i Carrefour Sz.). Pozostałe centra handlowe zaliczono do typu trzeciego, tak zwanego osiedlowego: Tesco W., Tesco P., Carrefour P., Pasaż Łódzki, C.H. Tulipan, E. Leclerc ${ }^{140}$.

${ }^{140}$ Wydzielono te typy, ponieważ zauważono, że zachowania przestrzenne klientów zależą bardziej od położenia badanych kompleksów względem centrum miasta niż od ich typu ofertowego. 
Ewidentnie specyficzny jest w tym wypadku typ śródmiejski (ponadlokalny), gdzie około $50 \%$ klientów wyrusza do niego z domu, ale ponad $20 \%$, odwiedza te centra handlowe będąc $w$ ich pobliżu, a około $30 \%$ po drodze ze szkoły lub pracy (rys. 136).

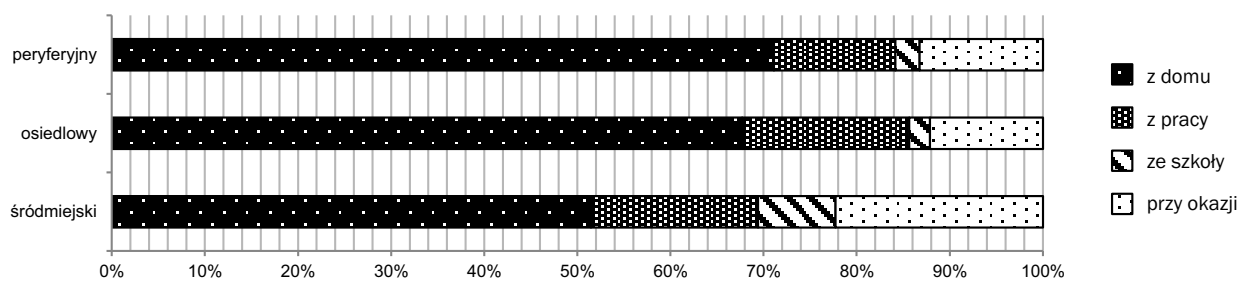

Rys. 136. Miejsce, z którego respondenci najczęściej rozpoczynają swoją podróż do danego lokalizacyjnego typu centrum handlowego [N: 2187=100\%].

Źródło: Opracowanie własne na podstawie badań ankietowych.

Sąsiedztwo oraz zasięg oddziaływania poszczególnych centrów handlowych wpływają również na strukturę zabudowy, w jakiej zamieszkują klienci. Ponad 70\% klientów - mieszkańców bloków posiada Tesco W. (najwięcej, bo ponad 80\%), Tesco P., Carrefour P., Pasaż Łódzki i C.H. Guliwer. Natomiast zdecydowanie najmniej mieszka w blokach nabywców wizytujących C.H. M1 (około 38\%) oraz Port Łódź (około 50\%). Znaczny odsetek klientów tych centrów handlowych zamieszkuje w domu jednorodzinnym lub w zabudowie szeregowej (odpowiednio około 45\% i 38\%). $\mathrm{Z}$ kamienic najwięcej klientów (około 20\%) ma: Manufaktura, Galeria Łódzka, Pasaż Łódzki, C.H. Tulipan oraz Carrefour P. (rys. 137).

Centra handlowe przyciągają głównie klientów zmotoryzowanych, jednak część respondentów korzysta ze środków Miejskiego Przedsiębiorstwa Komunikacyjnego - MPK (tramwaj, autobus), przybywa pieszo lub korzysta $z$ innych form dojazdu ${ }^{141}$, na przykład $z$ bezpłatnych linii autobusowych organizowanych przez poszczególne centra handlowe.

${ }^{141} \mathrm{~W}$ kategorii inny zdecydowanie dominują osoby korzystające $\mathrm{z}$ linii bezpłatnych autobusów, inne środki komunikacji, na przykład rower wskazywały pojedyncze osoby, w związku $\mathrm{z}$ tym można kategorię inny w tym wypadku utożsamiać z liniami bezpłatnych autobusów. Wyjątek stanowi Manufaktura, gdzie dwie osoby dojeżdżają liniami bezpłatnymi, a siedem innymi środkami lokomocji, oraz Portu Łódź, do którego nikt nie dojeżdżał bezpłatnym autobusem, natomiast trzy osoby wskazały na inny środek lokomocji. 


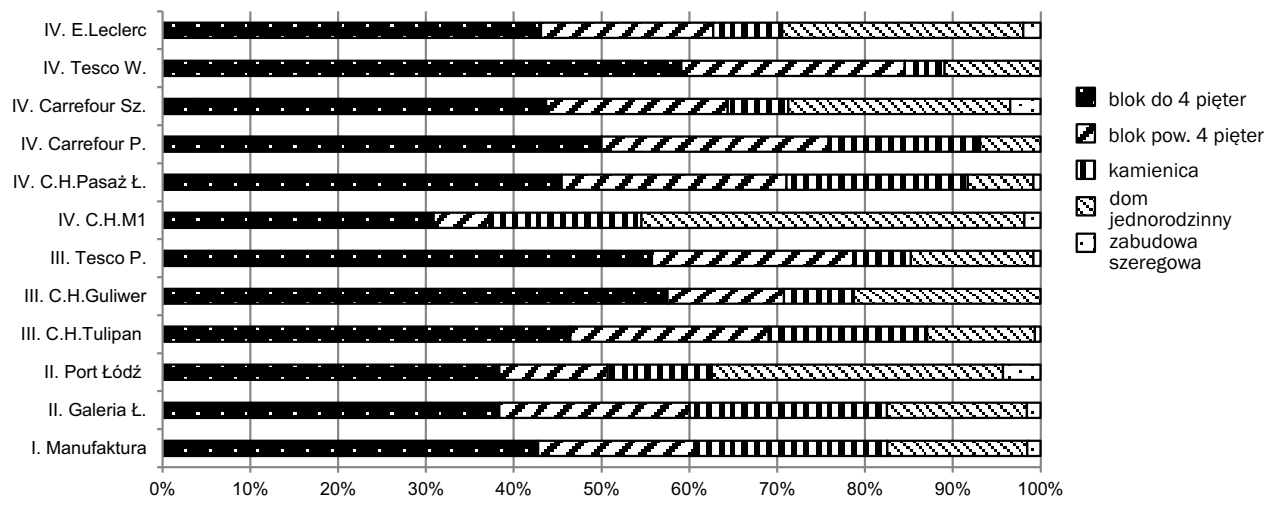

Rys. 137. Struktura klientów wg miejsca zamieszkania - typu zabudowy [N: 2323=100\%].

Źródło: Opracowanie własne na podstawie badań ankietowych.

Największy odsetek klientów przybywających samochodami (prywatnymi, lub służbowymi) posiada C.H. M1 (około 83\%), Tesco P. (około 76\%), Port Łódź (około 72\%) oraz Pasaż Łódzki (około 63\%), natomiast najmniejszy Galeria Łódzka (około 32\%), Manufaktura (około 45\%) i E. Leclerc (około 46\%). Z komunikacji miejskiej korzystają głównie klienci Galerii Łódzkiej (około 45\%), Manufaktury (około 40\%) i Portu Łódź (około 23\%). „Pieszych” klientów największy udział posiadają E. Leclerc i Tesco W. (około 30\%) (rys. 138).

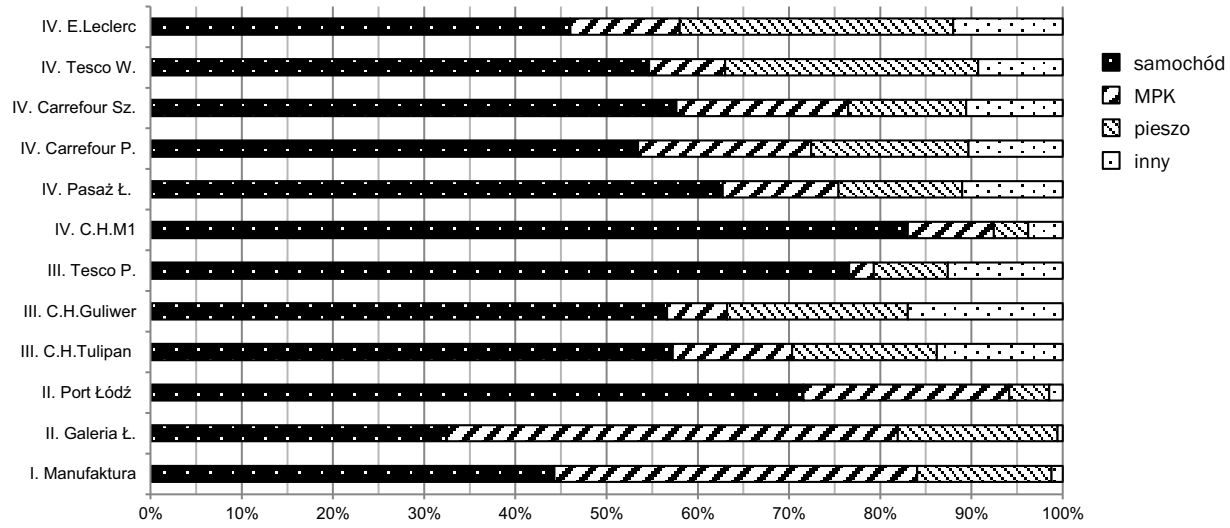

Rys. 138. Środki transportu, z których korzystają klienci centrów handlowych w celu dotarcia do nich [N: 2184=100\%].

Źródło: Opracowanie własne na podstawie badań ankietowych. 
W typie I i II obok samochodu (około 45\% klientów), wykorzystywane są do przemieszczania przez wielu klientów tramwaje i autobusy miejskie (wskaźnik dla drugiego typu jest wypadkową centralnie położonej Galerii Łódź i peryferyjnego Portu Łódź). W typie III i IV ponad $60 \%$ dojeżdża samochodem, mniejszy odsetek osób korzysta ze środków MPK (III około 8\%; IV - około 13\%), natomiast wzrasta udział osób korzystających z bezpłatnych linii autobusowych tzw. frikobusów (III - prawie $15 \%$, IV - około 9\%) (rys. 139).

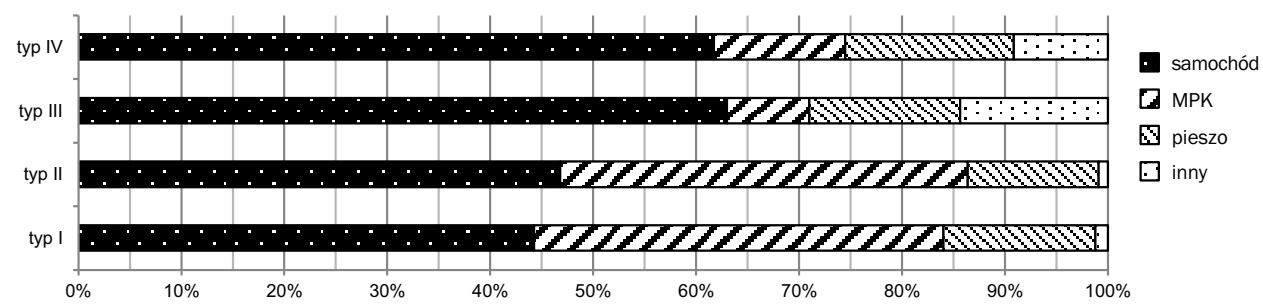

Rys. 139. Rodzaje środków komunikacji wykorzystywane przez respondentów według typów ofertowych centrów handlowych [N: 2184=100\%].

Źródło: Opracowanie własne na podstawie badań ankietowych.

Posiadanie własnych linii bezpłatnych autobusów podnosi atrakcyjność poszczególnych centrów handlowych. Można więc zauważyć pewną prawidłowość. Centra handlowe o bogatej ofercie $z$ typu I i II oferują tego typu usługi w ograniczonym zakresie. Galeria Łódzka nie posiada własnej linii autobusowej, Manufaktura tylko tramwaj o niewielkim zasięgu przestrzennym, a Port Łódź oferuje jedną linię, ale za opłatnością 1 zł. Najbardziej rozbudowaną sieć linii bezpłatnych autobusów posiadają mniejsze centra handlowe typu III i IV, w związku z czym to właśnie one posiadają największy odsetek klientów korzystających z tych linii (rys. 139-140).

Analizując sposób pokonywania drogi do centrum handlowego według jego typu lokalizacyjnego, należy zwrócić uwagę, że w typie śródmiejskim najmniej osób dociera do niego prywatnym samochodem (około 40\%), natomiast najwięcej przybywa dzięki miejskim środkom komunikacji (ponad 40\%). W typie osiedlowym z samochodu korzysta około $60 \%$ klientów, duży jest też odsetek osób dojeżdżających frikobusami (około 10\%) oraz odwiedzających je pieszo (około 18\%). Największy udział klientów przemieszczających się samochodem jest w typie peryferyjnym (około 70\%), do którego przybywa natomiast najmniejszy odsetek nabywców pieszo (około 10\%) (rys. 141). 

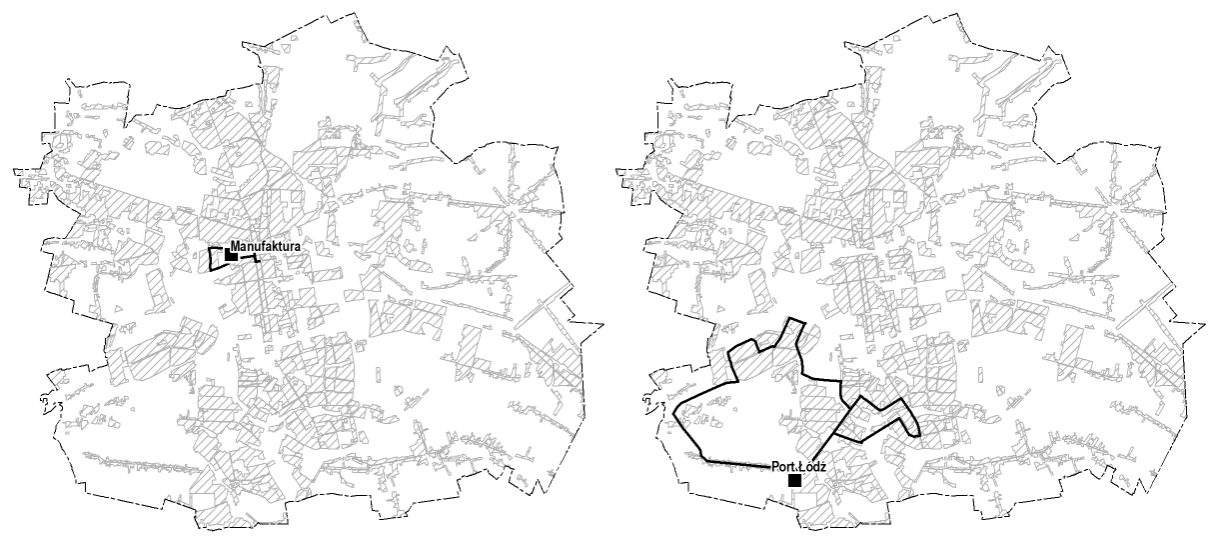

TYP III

TYP IV

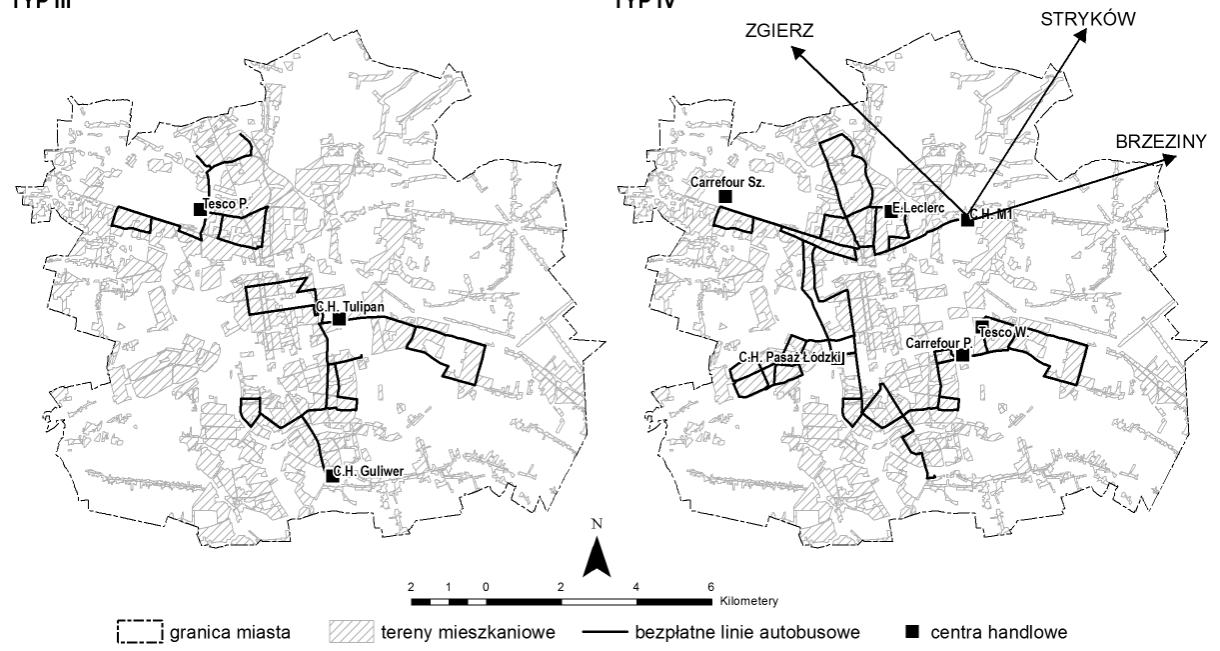

Rys. 140. Przebieg linii bezpłatnych autobusów według typów ofertowych centrów handlowych.

Źródło: Opracowanie własne.

W przypadku klientów centrów handlowych, do których większość osób dociera samochodem, większy jest też stopień zmotoryzowania. Ponad 80\% klientów C.H. M1, Portu Łódź i Tesco na Pojezierskiej deklaruje posiadanie samochodu. Najmniejszym odsetkiem nabywców dysponujących własnym autem charakteryzują się klienci Galerii Łódzkiej, Carrefoura P., Manufaktury i Tesco W. (po około 60\%) (rys. 142). 


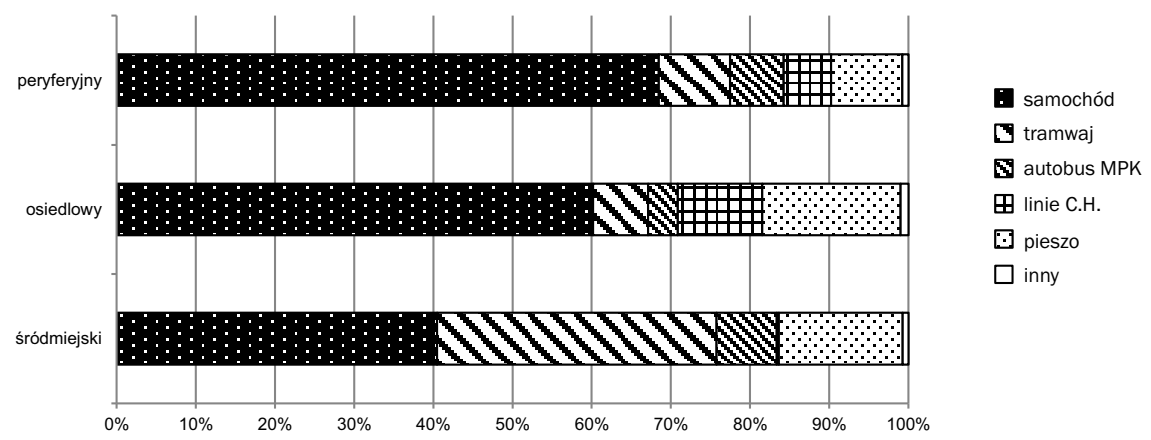

Rys. 141. Rodzaje środków komunikacji wykorzystywanych przez respondentów według typów lokalizacyjnych centrów handlowych [N: 2184=100\%].

Źródło: Opracowanie własne na podstawie badań ankietowych.

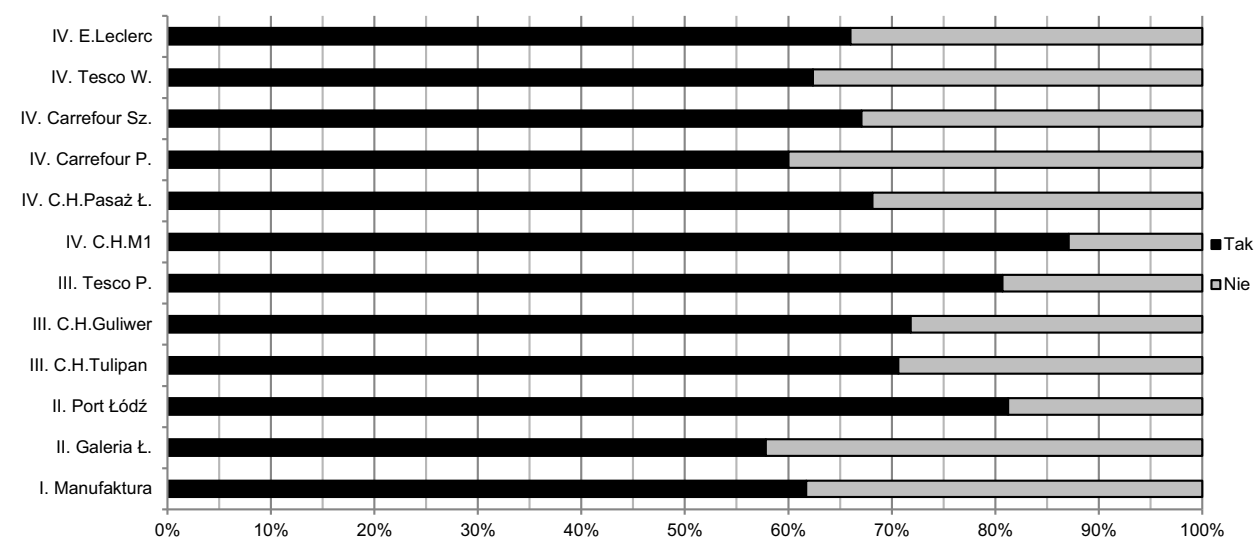

Rys. 142. Stopień zmotoryzowania klientów według centrów handlowych

$$
\text { [N: } 2138=100 \%] \text {. }
$$

Źródło: Opracowanie własne na podstawie badań ankietowych.

Zdecydowana większość klientów łódzkich centrów handlowych, poświęca na dotarcie do wybranego kompleksu do 30 minut. Największy odsetek respondentów, którym droga zajmuje więcej czasu ma Port Łódź, chcąc się do tego kompleksu dostać, około 35\% osób przeznacza więcej niż pół godziny, również duży odsetek klientów Manufaktury i Galerii Łódzkiej jest skłonnych również poświęcić więcej niż 30 minut na drogę (około 25\%) (rys. 143). 


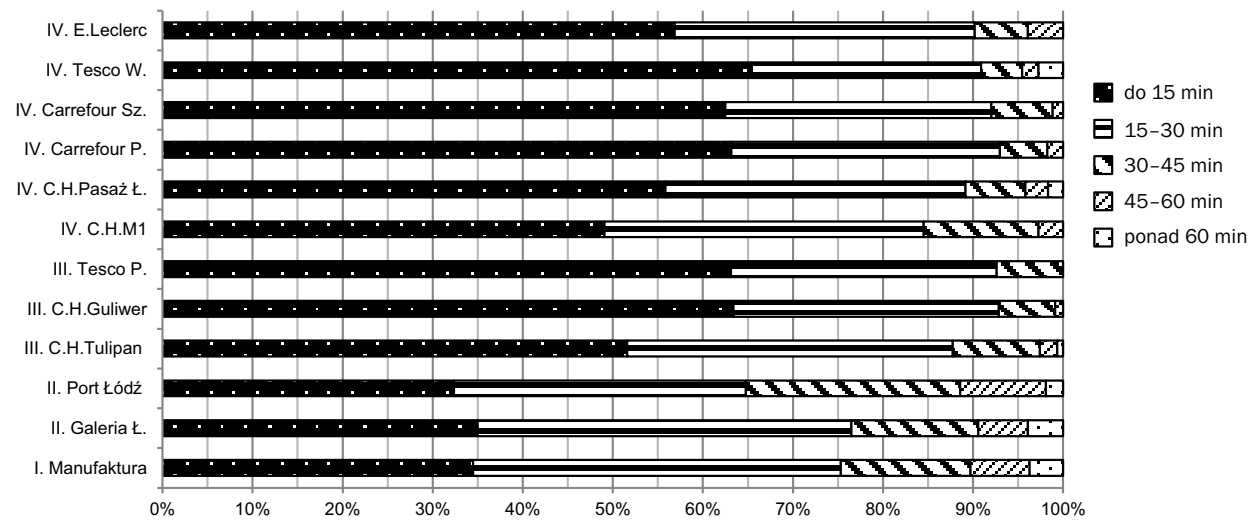

Rys. 143. Czas poświęcony na dojazd do wybranego centrum handlowego

[N: 2324=100\%].

Źródło: Opracowanie własne na podstawie badań ankietowych.

Centra handlowe III i IV typu posiadające mniejszy zasięg oddziaływania, przyciągają klientów głównie zamieszkałych w promieniu do 30 minut. Prawie $60 \%$ osób przybywa do celu w czasie do 15 minut, co potwierdza ich lokalny charakter. Inaczej wygląda sytuacja w przypadku centrów handlowych typu I i II, które są kompleksami ponadlokalnymi. Udział osób, które docierają do tych centrów w czasie do 15 minut spada o prawie połowę i wynosi około 35\%, natomiast ewidentnie wzrasta udział klientów, którzy przeznaczają na pokonanie drogi ponad 30 minut (około 25\%) (rys. 144).

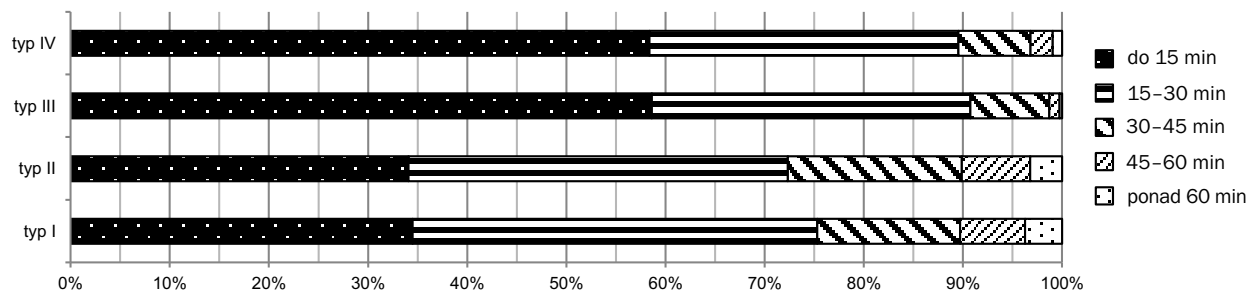

Rys. 144. Czas poświęcony na dojazd do centrów handlowych według ich typów ofertowych [N: 2324=100\%].

Źródło: Opracowanie własne na podstawie badań ankietowych.

Czas dojazdu do wybranego centrum handlowego zależy nie tylko od położenia jego w mieście, ale w dużej mierze od jego charakteru. W przypadku śródmiejskich kompleksów o ponadlokalnym znaczeniu klienci są 
skłonni poświęcić więcej czasu niż 15 minut na dojazd do niego (około $65 \%$ ). Klienci centrów handlowych osiedlowych i peryferyjnych głównie zamieszkują ich okolice stąd dla większego odsetka $\mathrm{z}$ nich czas dojazdu jest krótszy. Klienci centrów handlowych peryferyjnych w przeważającej części poświęcają na pokonanie drogi nie więcej niż 30 minut (około 90\%). Wynika to nie tylko z bliskiego miejsca zamieszkania, ale też $\mathrm{z}$ faktu, że te centra handlowe położone są przy drogach wylotowych, więc czas dojazdu jest krótszy (mniejsze natężenie ruchu). W typie śródmiejskim występuje najmniejszy udział osób, którzy dostają się do nich w czasie krótszym niż 15 minut (około 35\%) (rys. 145).

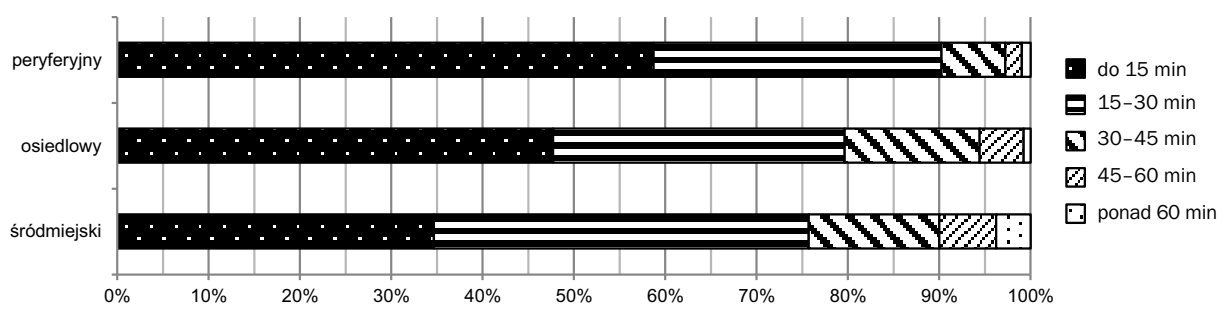

Rys. 145. Czas poświęcony na dojazd do centrów handlowych według ich typów lokalizacyjnych [N: 2324=100\%].

Źródło: Opracowanie własne na podstawie badań ankietowych.

Zachowania przestrzenne klientów I i II typu oraz III i IV są do siebie zbliżone (w typie II Port Łódź zaburza wartości). Klienci centrów handlowych typu III i IV są przede wszystkim mieszkańcami Łodzi (około 90\%; I, II - około 80\%), w większym stopniu dojeżdżają na zakupy samochodem (około 67\%; I, II - około 45\%),), częściej wyruszają do nich z własnego domu (około 70\%; I, II - około 55\%), wybierając centrum handlowe zlokalizowane w promieniu do 15 minut dojścia lub dojazdu (około 60\%; I, II - około 35\%) (rys. 146).

Klienci peryferyjnie położonych centrów handlowych częściej docierają do nich w czasie do 15 minut (około 60\%), przybywają do tych kompleksów głównie samochodem (około 70\%), większy ich odsetek mieszka poza granicami administracyjnymi Łodzi (około 24\%) i najczęściej wyruszają do centrów handlowych $\mathrm{z}$ domu (około 72\%). W centrach handlowych o charakterze śródmiejskim wydłuża się znacznie czas dojazdu klientów do nich (do 15 minut - około 35\%), częściej klienci korzystają ze środków komunikacji miejskiej (najmniejszy odsetek osób przybywających samo- 


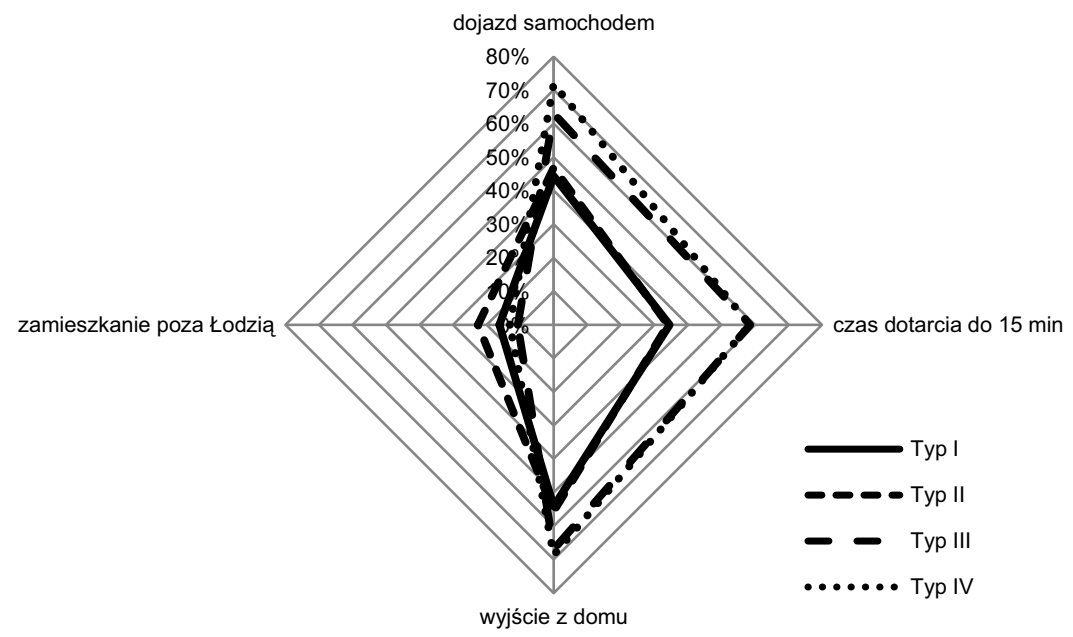

Rys. 146. Wybrane cechy zachowań przestrzennych klientów centrów handlowych według ich typów ofertowych.

Źródło: Opracowanie własne na podstawie badań ankietowych.

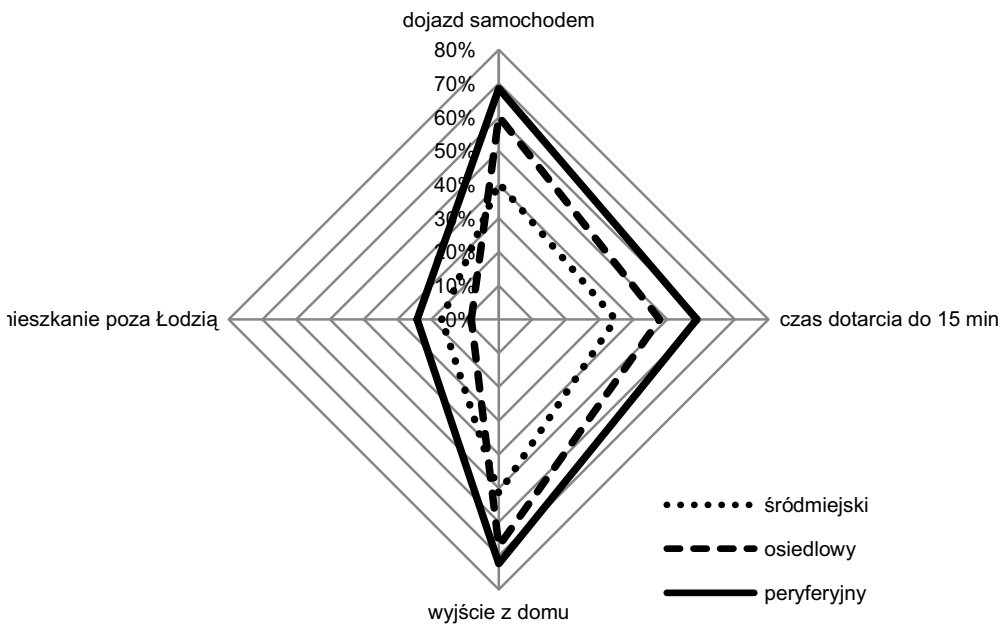

Rys. 147. Wybrane cechy zachowań przestrzennych klientów centrów handlowych według ich typów lokalizacyjnych.

Źródło: Opracowanie własne na podstawie badań ankietowych. 


\section{Tabela 45}

Odsetek osób, dla których w wyborze centrum handlowego poszczególne kategorie związane z dostępnością posiadają znaczenie

\begin{tabular}{|c|c|c|c|c|c|c|}
\hline $\begin{array}{c}\text { Centra } \\
\text { handlowe }\end{array}$ & $\begin{array}{c}\text { Bliskość } \\
\text { miejsca } \\
\text { zamiesz- } \\
\text { kania }\end{array}$ & $\begin{array}{c}\text { Bliskość } \\
\text { miejsca } \\
\text { pracy }\end{array}$ & $\begin{array}{l}\text { Łatwy do- } \\
\text { jazd samo- } \\
\text { chodem }\end{array}$ & $\begin{array}{c}\text { Łatwość } \\
\text { parkowa- } \\
\text { nia }\end{array}$ & $\begin{array}{l}\text { Łatwy } \\
\text { dojazd } \\
\text { MPK }\end{array}$ & $\begin{array}{c}\text { Połączenia } \\
\text { liniami bez- } \\
\text { płatnego } \\
\text { autobusu }\end{array}$ \\
\hline I. Manufaktura & $87,4 \%$ & $55,9 \%$ & $73,5 \%$ & $74,2 \%$ & $81,8 \%$ & $50,3 \%$ \\
\hline $\begin{array}{l}\text { II. Galeria } \\
\text { Łódzka }\end{array}$ & $86,0 \%$ & $63,6 \%$ & $69,6 \%$ & $69,6 \%$ & $84,5 \%$ & $44,5 \%$ \\
\hline II. Port Łódź & $84,1 \%$ & $49,5 \%$ & $86,2 \%$ & $88,0 \%$ & $70,2 \%$ & $40,4 \%$ \\
\hline III. C.H. Tulipan & $91,3 \%$ & $56,5 \%$ & $83,1 \%$ & $80,8 \%$ & $74,8 \%$ & $68,1 \%$ \\
\hline III. C.H. Guliwer & $95,5 \%$ & $45,5 \%$ & $85,0 \%$ & $79,4 \%$ & $66,3 \%$ & $70,9 \%$ \\
\hline III. Tesco P. & $96,6 \%$ & $51,4 \%$ & $92,2 \%$ & $91,2 \%$ & $60,3 \%$ & $64,6 \%$ \\
\hline IV. C.H. M1 & $94,4 \%$ & $51,0 \%$ & $92,6 \%$ & $90,7 \%$ & $61,4 \%$ & $57,7 \%$ \\
\hline $\begin{array}{l}\text { IV. C.H. Pasaż } \\
\text { Łódzki }\end{array}$ & $86,3 \%$ & $48,7 \%$ & $78,3 \%$ & $76,3 \%$ & $60,2 \%$ & $57,1 \%$ \\
\hline IV. Carrefour P. & $94,8 \%$ & $45,1 \%$ & $74,5 \%$ & $73,6 \%$ & $77,8 \%$ & $69,8 \%$ \\
\hline IV. Carrefour Sz. & $97,7 \%$ & $47,6 \%$ & $70,6 \%$ & $68,7 \%$ & $73,3 \%$ & $60,7 \%$ \\
\hline IV. Tesco W. & $93,5 \%$ & $48,4 \%$ & $75,2 \%$ & $72,9 \%$ & $64,9 \%$ & $53,6 \%$ \\
\hline IV. E. Leclerc & $92,2 \%$ & $50,0 \%$ & $69,4 \%$ & $71,1 \%$ & $69,8 \%$ & $59,1 \%$ \\
\hline
\end{tabular}

Źródło: Opracowanie własne na podstawie ankiet.

chodem - około 40\%), spory udział mają też osoby mieszkające poza Łodzią (około 17\%), natomiast wyjazdy dla co drugiego klienta są celowymi wyprawami z domu. W centrach osiedlowych zwraca głównie uwagę fakt, że niewielu ich klientów mieszka poza Łodzią (około 8\%) (rys. 147).

Istotne było również sprawdzenie, jakie elementy „dostępnościowe” posiadały znaczenie przy wyborze konkretnego badanego kompleksu. Dla klientów centrów handlowych znaczenie przy ich wyborze odgrywa odległość od miejsca zamieszkania oraz możliwość dotarcia środkami komunikacji (w tym samochodem). Zdecydowana większość respondentów uznała za znaczące szczególnie bliskość miejsca zamieszkania (ma znaczenie dla od 84,1\% klientów Portu Łódź, do 97,7\% Carrefour Sz.), łatwy dojazd samochodem (dla 69,6\% odwiedzających Galerię Łódzką, do 92,6\% C.H. M1) oraz łatwość parkowania (dla 68,7\% klientów Carrefour Sz., do 91,2\% Tesco P.). Łatwy dojazd środkami MPK ma znaczenie głównie w przy- 


\section{Tabela 46}

Średnia ocena kategorii związanych z dostępnością w wyborze centrów handlowych (w skali 1-5)

\begin{tabular}{|c|c|c|c|c|c|c|}
\hline $\begin{array}{c}\text { Typy } \\
\text { ofertowe C.H. }\end{array}$ & $\begin{array}{c}\text { Bliskość } \\
\text { miejsca } \\
\text { zamiesz- } \\
\text { kania }\end{array}$ & $\begin{array}{c}\text { Bliskość } \\
\text { miejsca } \\
\text { pracy }\end{array}$ & $\begin{array}{c}\text { Łatwy } \\
\text { dojazd } \\
\text { samocho- } \\
\text { dem }\end{array}$ & $\begin{array}{c}\text { Łatwość } \\
\text { parkowa- } \\
\text { nia }\end{array}$ & $\begin{array}{l}\text { Łatwy } \\
\text { dojazd } \\
\text { MPK }\end{array}$ & $\begin{array}{c}\text { Połączenia } \\
\text { liniami bez- } \\
\text { płatnego } \\
\text { autobusu }\end{array}$ \\
\hline I. Manufaktura & 3,43 & 2,91 & 3,41 & 3,48 & 3,6 & 2,66 \\
\hline $\begin{array}{l}\text { II. Galeria } \\
\text { Łódzka }\end{array}$ & 3,31 & 3,08 & 3,26 & 3,41 & 3,76 & 2,81 \\
\hline II. Port Łódź & 3,34 & 2,52 & 3,69 & 3,86 & 3,4 & 2,37 \\
\hline III. C.H. Tulipan & 3,68 & 3,23 & 3,7 & 3,76 & 3,33 & 3,47 \\
\hline III. C.H. Guliwer & 4,1 & 2,67 & 3,67 & 3,8 & 3,42 & 3,41 \\
\hline III. Tesco P. & 3,78 & 2,79 & 3,94 & 3,87 & 3,14 & 3,33 \\
\hline IV. C.H. M1 & 3,72 & 2,64 & 3,79 & 3,75 & 3 & 3,08 \\
\hline $\begin{array}{l}\text { IV. C.H. Pasaż } \\
\text { Łódzki }\end{array}$ & 3,89 & 3 & 3,86 & 3,85 & 3,37 & 3,52 \\
\hline IV. Carrefour P. & 3,93 & 3,3 & 3,98 & 3,92 & 3,69 & 3,86 \\
\hline IV. Carrefour Sz. & 3,94 & 3,3 & 3,93 & 4,07 & 3,49 & 3,35 \\
\hline IV. Tesco W. & 4,06 & 2,91 & 3,82 & 4,2 & 3,29 & 3,38 \\
\hline IV. E. Leclerc & 4,21 & 2,61 & 3,76 & 3,86 & 3,53 & 3,42 \\
\hline
\end{tabular}

Źródło: Opracowanie własne na podstawie ankiet.

padku klientów śródmiejsko położonych Galerii Łódzkiej i Manufaktury, natomiast połączenia bezpłatnymi liniami autobusów jest istotne dla wielu klientów C.H. Guliwer (70,9\%), Carrefour P. (69,8\%) i C.H. Tulipan $(68,1 \%)$. Nie dla wszystkich respondentów poszczególne zmienne posiadają znaczenie przy wyborze danego centrum handlowego, szczególnie dla wielu nie liczy się położenie ich względem miejsc pracy oraz możliwość dojazdu frikobusami (tab. 45).

Ważną kwestią do ustalenia była ocena poszczególnych zmiennych dla osób, które widzą znaczenie poszczególnych kategorii. Okazało się że największe znaczenie dla tych klientów posiada bliskość miejsca zamieszkania, łatwość dojazdu samochodem i możliwość parkowania te kategorie były oceniane często na ocenę około 3,5, a czasami wręcz zbliżoną do 4 . Nie są to jednak wysokie noty w porównaniu $z$ oceną ofertową centrów handlowych (tab. 46). 
W zależności od miejsca lokalizacji centrum handlowego można zauważyć jednak pewne różnice $\mathrm{w}$ ocenie znaczenia poszczególnych kategorii. Dla klientów śródmiejskich centrów handlowych większe znaczenie niż dla pozostałych typów posiada łatwy dojazd środkami komunikacji MPK (około 3,1, w pozostałych około 2,3), oraz bliskość miejsca pracy (1,8 w pozostałych ok. 1,4). Natomiast słabiej zostały w tym typie ocenione: bliskość miejsca zamieszkania (około 2,9), łatwy dojazd samochodem (około $2,4)$ oraz łatwość parkowania (około 2,5). Dla klientów osiedlowych kompleksów większe znaczenie niż w pozostałych typach odgrywają dogodne połączenia liniami bezpłatnego autobusu 2,2 (w peryferyjnym 1,8; w śródmiejskim 1,3) (rys. 148).

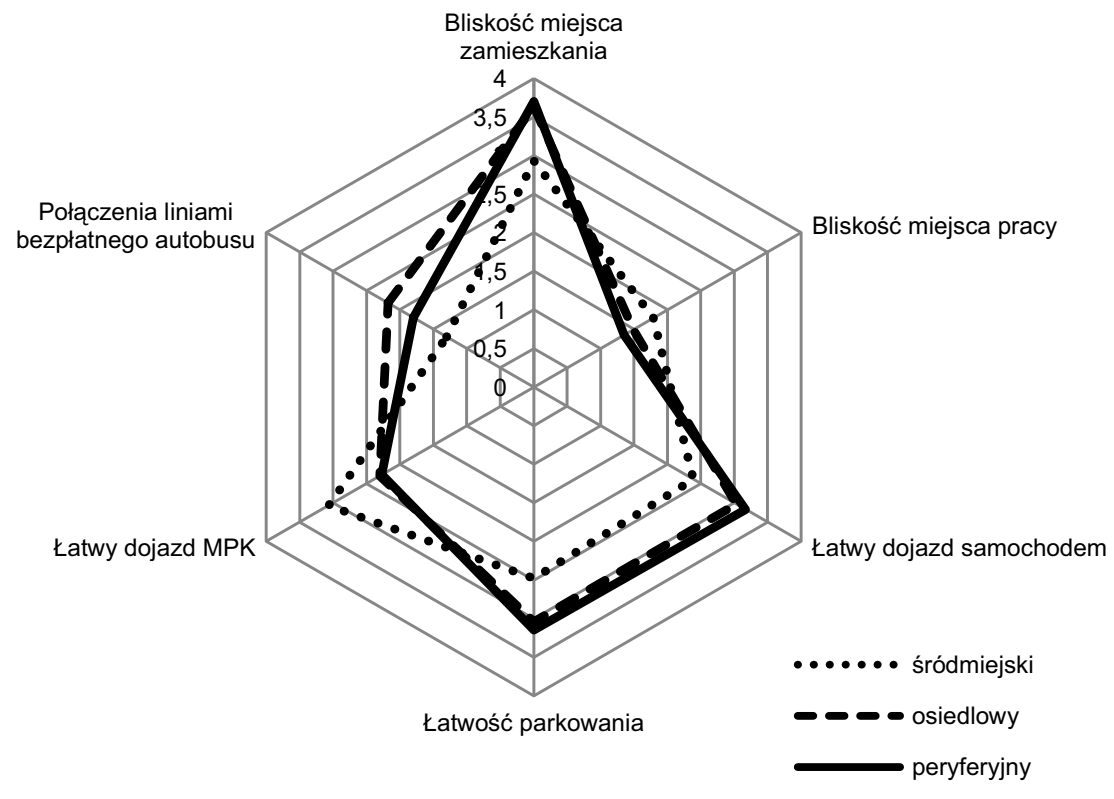

- w skali od 0 - brak znaczenia do 5 - bardzo duże znaczenie

Rys. 148. Średnia ocena kategorii związanych z dostępnością w wyborze centrów handlowych danego typu lokalizacyjnego.

Źródło: Opracowanie własne na podstawie badań ankietowych.

Ze względu na typy lokalizacyjne centrów handlowych można mówić o różnych zachowaniach przestrzennych ich klientów. 
- Typ śródmiejski (ponadlokalny) - klientami są głównie mieszkańcy Łodzi, ale spory odsetek stanowią również osoby spoza miasta. Klienci tych centrów handlowych korzystają często ze środków komunikacji miejskiej, częściej niż w pozostałych typach frekwentują je nie bezpośrednio $\mathrm{z}$ domu, ale po drodze $\mathrm{z}$ pracy/szkoły lub przy okazji, jak są w ich pobliżu. Są bardziej skłonni do przeznaczenia dłuższego czasu na pokonanie drogi do nich.

- Typ II osiedlowy - klienci tego typu centrów handlowych są głównie mieszkańcami Łodzi, przybywający do nich samochodem, ale dla niektórych z nich znaczenie odgrywa również możliwość skorzystania z autobusów bezpłatnych linii. Najczęściej wizytują te centra handlowe, bezpośrednio wyprawiając się do nich $\mathrm{z}$ domu, a dla większości czas dotarcia do nich zajmuje do 30 minut.

- Typ III peryferyjny - klientami tego typu centrów handlowych są głównie mieszkańcy okolicznych terenów, ponieważ zlokalizowane są przy granicy administracyjnej miasta (przy jej drogach wylotowych), to niektórzy klienci pochodzą z sąsiednich miejscowości. Osoby je odwiedzające najczęściej są zmotoryzowane i przybywają do nich samochodem, ale jest też pewna grupa osób korzystająca $z$ frikobusów. Ze względu na miejsce zamieszkania klientów oraz lokalizację kompleksów handlowych czas dotarcia do nich zajmuje stosunkowo mało czasu - dla większości do 15 minut. 



\section{ZAKOŃCZENIE}

W Łodzi funkcjonuje już dwanaście centrów handlowych, a dalsze są $\mathrm{w}$ realizacji lub w sferze projektowej. Te nowoczesne kompleksy handlowo-usługowe są zróżnicowane pod względem ofertowym, w sumie można wyróżnić ich cztery typy, od tych o najbardziej rozbudowanej ofercie handlowo-usługowo-rozrywkowej (typ I) do najmniejszych o ofercie praktycznie tylko handlowej (typ IV). Centra handlowe są rozmieszczone w różnych rejonach Łodzi, a o ich lokalizacji zadecydowały, między innymi wolne tereny inwestycyjne (w tym poprzemysłowe), układ komunikacyjny i sąsiedztwo osiedli mieszkaniowych. Zwraca uwagę szczególnie wykorzystanie terenów poprzemysłowych i magazynowych przy budowie tych nowoczesnych kompleksów oraz lokalizacja kilku $\mathrm{z}$ nich w niedalekiej odległości od centrum miasta (Manufaktura, Galeria Łódzka C.H. Tulipan, Pasaż Łódzki). Takie ich rozmieszczenie powoduje, że są dobrze skomunikowane $\mathrm{z}$ poszczególnymi rejonami miasta, a w piętnastominutowych strefach dojścia pieszego mieszka 13,4\% łodzian.

Jednokilometrowe strefy wokół centrów handlowych posiadają różny charakter. Pod względem struktury użytkowania terenu możemy mówić o otoczeniu: rolniczym, przemysłowym z dużym udziałem terenów komunikacyjnych, mieszkaniowo-usługowym, usługowym oraz wielofunkcyjnym. Lokalizacja poszczególnych kompleksów determinuje również rodzaj zabudowy znajdujący się w ich pobliżu. W tym wypadku możemy mówić o otoczeniu z przewagą zabudowy śródmiejskiej, zabudowy wielorodzinnej, jednorodzinnej, oraz zabudowy wiejskiej, której towarzyszy zabudowa wielorodzinna i jednorodzinna.

Centra handlowe wywierają wpływ na otaczającą ją przestrzeń, kreując zalążki, tak zwane bieguny nowoczesnej przestrzeni usługowo-handlowej, 
wpływ ten jest różny w zależności od miejsca lokalizacji danego centrum handlowego i „zastanego" zagospodarowania terenu. Generalnie można mówić o czterech głównych typach tego rodzaju produktu miejskiego, jakim są wyżej wymienione bieguny. Szczególnie należy zwrócić uwagę na wpływ, jaki wywierają na strukturę podmiotów usługowych w ich bezpośrednim otoczeniu. Wprawdzie nie uchwycono zmian jakie się dokonały w otoczeniu pod wpływem lokalizacji centrów handlowych (to powinno być dalszym kierunkiem badań), ale zwrócono uwagę na tendencję przyciągania w rejon badanych obiektów, innych o charakterze specjalistycznym (tzw. lokalizacja przyrostowa), np. Praktiker, Castorama, Obi. W związku z tym wydzielono typy zależności lokalizacyjnych między centrami handlowymi, a innymi placówkami usługowymi (w tym głównie handlowymi).

Pojawienie się w strukturze miasta tych kompleksów handlowo-usługowych wpłynęło na zmiany zachowań nabywczych i przestrzennych głównie mieszkańców Łodzi, ale nie tylko. Centra handlowe są bardzo atrakcyjne dla klientów nie tylko w wymiarze oferowanych produktów materialnych, ale również tych niematerialnych (duchowych), więc przyciągają do siebie dużą liczbę klientów. Skala atrakcyjności, jak wykazały badania, zależy w głównej mierze od wielkości centrum handlowego, które determinuje bogactwo oferty. Zarówno w ocenie obiektywnej, jak i subiektywnej, poszczególne kompleksy uzyskały podobne lokaty przy czym okazało się, że najatrakcyjniejszymi są Manufaktura, Galeria Łódzka i Port Łódź.

Szczególnie wpływ na zachowania nabywcze posiada oferta poszczególnych centrów handlowych, im jest ona bogatsza tym pobyty dłuższe, a powody wizyt bardziej różnorodne. W małych i średnich centrach handlowych pobyty mają głównie charakter zakupowy (III, IV typ), w tych największych (I i II) duże znaczenie odgrywa zakup dóbr i usług, ale bardzo istotny, a dla wielu najważniejszy jest wymiar niematerialny - możliwość miłego spędzenia czasu, rozrywki czy „spotkania się” z kulturą.

Ostatecznie, w wyniku przeprowadzonych badań, w zależności od typu ofertowego centrum handlowego, zidentyfikowano dwa profile klientów. Pierwszy jest charakterystyczny dla dużych kompleksów handlowych (I i II typ), a drugi dla pozostałych centrów handlowych (III i IV typ). Klienci największych łódzkich kompleksów handlowych, w porównaniu do pozostałych są osobami młodszymi, lepiej wykształconymi, będący najczęściej w stanie wolnym, osobami oceniającymi lepiej swój status materialny. Okazało się również, że zachowania nabywcze klientów centrów 
handlowych zależą $\mathrm{w}$ głównej mierze od typu ofertowego kompleksu. Pierwszy typ jest charakterystyczny dla Manufaktury, jako dużego centrum handlowo-usługowo-rozrywkowego, drugi bardzo podobny występuje na terenie dużych centrów handlowo-usługowych (Galeria Łódzka i Port Łódź). Między zachowaniami nabywczymi klientów tych dwóch typów główna różnica wynika z zakresu oferty rozrywkowo-kulturowej (najbogatsza w Manufakturze). W przypadku klientów III i IV typu centrów handlowych, ich zachowania są bardzo do siebie podobne, w związku z tym można mówić o jednym typie zachowań nabywczych na terenie tego typu kompleksów. Ogólnie można zauważyć, że w typie I i II w porównaniu z pozostałymi typami centrów handlowych (III i IV) wizyty są dłuższe, częściej odbywają się w gronie przyjaciół i znajomych, w weekendy i w godzinach popołudniowych. $\mathrm{O}$ wyborze ich decyduje nie tylko bogata oferta asortymentowa, jakość towarów, promocje i niskie ceny, ale również klientów przyciąga do nich duże zróżnicowanie sklepów i liczne punkty usługowe, stąd częściej korzystają z oferty placówek zlokalizowanych w galeriach handlowych.

Zachowania przestrzenne klientów centrów handlowych zależą w głównej mierze od: położenia danego centrum handlowego względem centrum miasta, głównych osi komunikacyjnych i terenów mieszkaniowych. W celu lepszego uchwycenia uwarunkowań zachowań przestrzennych dokonano dodatkowej klasyfikacji centrów handlowych pod względem lokalizacyjnym na typ śródmiejski (ponadlokalny), peryferyjny i osiedlowy. Okazało się, że w dwóch pierwszych typach wielu klientów pochodzi spoza Łodzi, czyli o przyciąganiu klientów z innych miejscowości decyduje ponadlokalny charakter lub położenie blisko granic administracyjnych miasta. Zauważono również, że peryferyjnie położone centra handlowe w sumie posiadają zasięg lokalny, ponieważ nawet te osoby, które nie mieszkają w Łodzi, to legitymują się miejscem zamieszkania w niedalekiej odległości od centrum handlowego. W typie osiedlowym klientami głównie są osoby mieszkające na pobliskich, względem danego centrum handlowego, osiedlach mieszkaniowych. Odwiedzający te nowoczesne kompleksy najczęściej wyruszają bezpośrednio $\mathrm{z}$ domu (w typie śródmiejskim spory odsetek osób bywa w nich przy okazji), dociera do nich własnym samochodem (w typie śródmiejskim często korzystają z komunikacji miejskiej), a droga zajmuje im często tylko około 15 min (w typie śródmiejskim dla wielu osób czas jest zdecydowanie dłuższy). 
Ważny ze względów praktycznych temat nowoczesnych kompleksów handlowych jest ciągle zbyt rzadko podejmowany przez geografów. W niektórych opracowaniach badawczych pojawiają się różne sugestie co do dalszych rozważań nad handlem w tym nad centrami handlowymi, lub wręcz wskazywane są nowe kierunki geograficznych badań.

W. Wilk (2003) zauważa, że „szczególnie silniejsze akcentowanie roli czasu wolnego i wypoczynku w życiu jednostek i grup powoduje coraz pilniejszą potrzebę także geograficznych badań nad wzajemnymi relacjami między zakupami w ich tradycyjnym rozumieniu i wyjściem na zakupy jako formą wypoczynku”. Według tego samego autora opracowania wymagają przede wszystkim następujące tematy: oddziaływanie handlowych kompleksów wielkopowierzchniowych na otoczenie w skali lokalnej i regionalnej, identyfikacja ich wpływu na rozwój struktury przestrzennej i funkcji miejskich oraz ocena ich roli w procesie suburbanizacji i rozlewaniu się miast (urban sprawl). Natomiast A. Szromnik (2009) uważa, że istnieje potrzeba, a nawet konieczność kontynuowania studiów i analiz z zakresu lokalizacji obiektów handlowo-usługowych.

Geograficzne pole badawcze w zakresie badań nad nowoczesnymi kompleksami handlowo-usługowymi można rozszerzyć o nowe kierunki badań. Tym bardziej że dotychczasowe nieliczne badania posiadają głównie charakter rejestrujący. Szczególnie ważne jest podjęcie rozważań metodologiczno-teoretycznych.

Badania wpływu na otoczenie są prowadzone głównie w kontekście ich roli w gospodarce lokalnej, regionalnej, czy krajowej. Badacze powinni większą uwagę zwrócić na wpływ centrów handlowych na ich bezpośrednie otoczenie, m.in. na zmiany funkcjonalne, społeczne, krajobrazowe, zmianę w strukturze podmiotów gospodarczych (w tym głównie usługowych) - powstawanie, likwidacja relokacja placówek. W związku z tym ważne wydaje się prowadzenie pogłębionych badań w ramach produktu jakim są pulsujące bieguny nowoczesnej przestrzeni usługowo - handlowej i wyznaczenie ich zasięgu tzw. obszarów handlowych (opracowanie metod wyznaczania) i ich segmentacja oraz identyfikacja czynników i barier determinujących zasięg oddziaływania. Tego typu badania pozwolą zrozumieć i przewidzieć zmiany w przemieszczeniach potencjalnych klientów i zapobiegać uciążliwościom powstającym w ich konsekwencji. Badania K. Dmochowskiej-Dudek (2008, 2011) nad syndromem NIMBY wykazały, że przy „budowie centrów handlowych dochodzi lub może dochodzić 
do konfliktów lokalizacyjnych". Mieszkańcy obawiają się wielu negatywnych zjawisk, które mogą mieć miejsce przy zbyt bliskiej lokalizacji tego typu kompleksów w stosunku do ich miejsc zamieszkania. W związku $\mathrm{z}$ tym istotne wydają się badania nad postrzeganiem centrów handlowych i ich lokalizacji przez mieszkańców.

Centra handlowe stają się miejscami coraz dłuższego czasu przebywania ludzi, dla których są alternatywą nie tylko spędzania czasu wolnego, ale stają się oazą bezpieczeństwa, substytutem przestrzeni publicznej. Ważne więc jest podjęcie badań nad relacjami między typową przestrzenią publiczną, a tą w kompleksach handlowych, tak zwaną „pseudopubliczną”. Często pisze się o „zamieraniu” tradycyjnych centrów miast w wyniku pojawienia się atrakcyjnych obiektów handlowo-usługowych przyciaggających dużą liczbę klientów. Badania relacji między postrzeganiem centrów handlowych i ich roli, a zmianami funkcjonalnymi i pozycją centrów miast powinny być kontynuowane i rozszerzane.

Praca dotycząca atrakcyjności łódzkich centrów handlowych oraz zachowań nabywczych i przestrzennych ich klientów posiada zarówno walor poznawczy jak i aplikacyjny. Pogłębione badania inwentaryzacyjne kompleksów handlowych oraz ich otoczenia pozwoliły na dokonanie wydzielenia ich typów i ocenę atrakcyjności centrów handlowych. Przeprowadzone badania ankietowe $z$ nabywcami dały możliwość określenia profili klientów oraz identyfikacji determinant zachowań nabywczych i przestrzennych. Do zrealizowania celi badawczych zaproponowano wskaźniki syntetyczne oceny ofertowej centrów handlowych oraz wydzielenia typów zagospodarowania otoczenia i atrakcyjności centrów handlowych. Badania tego typu są pierwszymi tak kompleksowymi badaniami w Polsce nad wszystkimi centrami handlowymi (ich otoczeniem i klientami), zlokalizowanymi w dużym mieście. Zaproponowane podejście i metodologia badań mogą zostać wykorzystane do kontynuacji ich w innych miastach, co da możliwość prowadzenia studiów porównawczych, między innymi nad wpływem centrów handlowych na szeroko pojęte funkcjonowanie miasta (rys. 149). Szczegółowy przegląd dorobku badawczego szczególnie tego geograficznego i ekonomicznego pozwolił na wyznaczenie nowych kierunków badań, co może być inspiracją dla wielu badaczy interesujących się tą problematyką.

Praca stanowi również cenne źródło informacji, dla władz miasta i zarządców kompleksów handlowych, np. o postrzeganiu lokalizacji centrów handlowych przez mieszkańców, o elementach wpływających na ich atrak- 


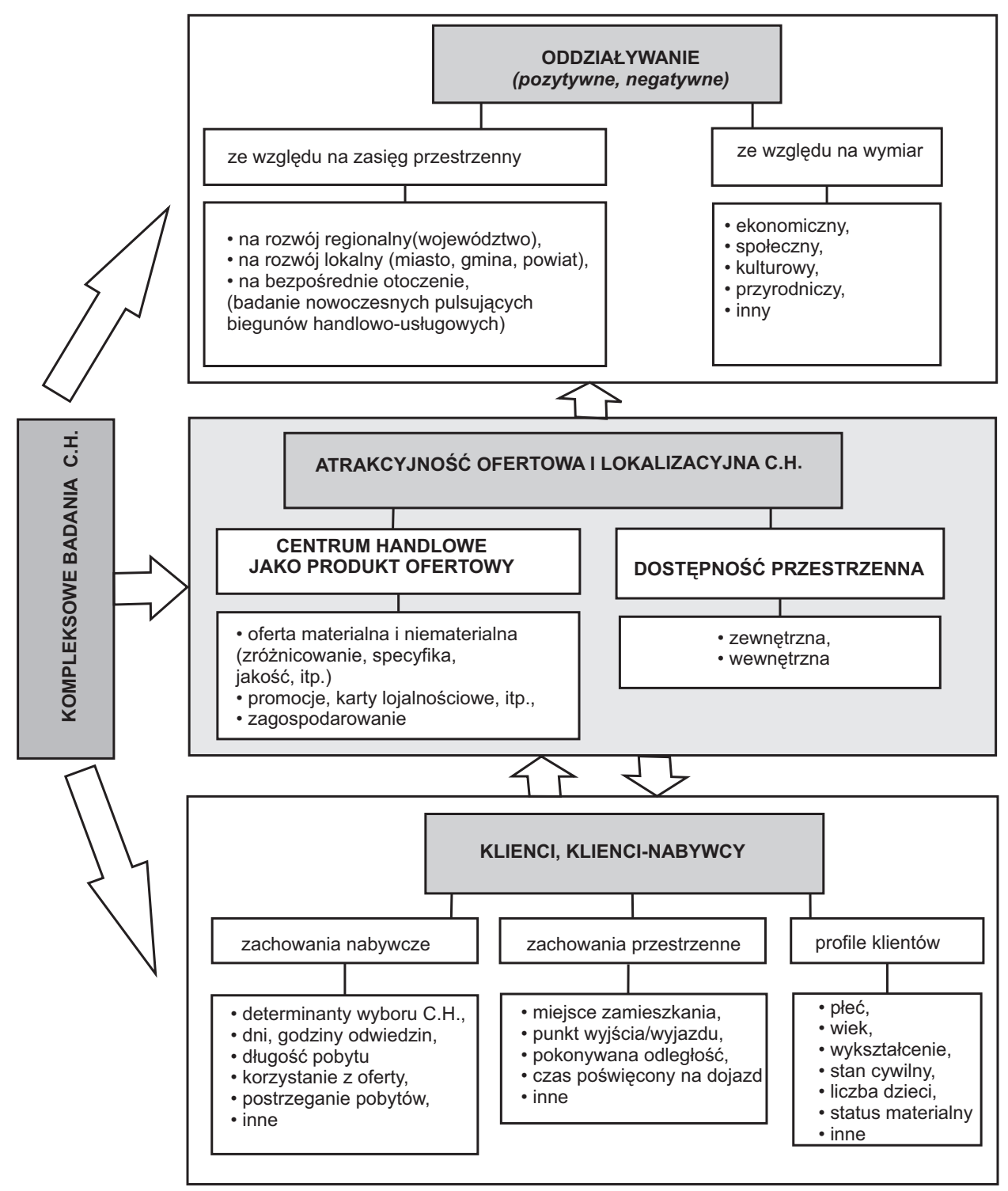

Rys. 149. Schemat kompleksowych badań nad centrami handlowymi. Źródło: Opracowanie własne.

cyjność, o determinantach zachowań nabywczych i przestrzennych klientów. W związku z tym władze miast, gmin mogą wskazywać najbardziej dogodne (najlepsze) miejsca na lokalizacje tego typu kompleksów i lepiej rozwiązywać problemy komunikacyjne, pojawiające się przy zmianach po- 
toków przemieszczeń klientów. Zarządcy centrów handlowych mogą dzięki tym badaniom lepiej dostosować ofertę do oczekiwań klientów, aby być bardziej konkurencyjnym na rynku.

Z powyższych rozważań widać, że temat centrów handlowych nie został jeszcze wyczerpany, wiele wyzwań w tym zakresie stoi jeszcze przed naukowcami w tym przed geografami. Jednym z zadań autorki, piszącej tą pracę, było zainspirowanie i zachęcenie geografów do podjęcia dalszych badań nad tymi nowymi przestrzeniami, które pojawiły się i nadal pojawiają się w strukturach funkcjonalno-przestrzennych głównie miast, ale i w strefach podmiejskich. 



\section{BIBLIOGRAFIA}

Abdallat M.M.A., Emam H.S., 2001, Consumer behavior models in tourism. Analysis study, Department of Tourism and Hospitality, King Saud University, http://www.scribd.com/doc/19523031/ Consumer-Behavior-Models-and-Consumer-Behavior-in-Tourism, (dostęp 1 maja 2012).

Aldskogius H., 1977, A conceptual framework and swedish case study of recreational behavior and environmental cognition, "Economic Geography", vol. 53, nr 2, s. 163-183.

Altkorn J., 1994, Marketing w turystyce, PWN, Warszawa.

Babbie E., 2007, Badania spoteczne w praktyce, PWN, Warszawa.

Bauman Z., 2000, Globalizacja, PIW, Warszawa.

Bednarek R., Kaczmarek T., Kaczmarek U., 2004, Sieć handlowa miasta Poznania i jej ocena z punktu widzenia zaspokojenia potrzeb konsumentów i lokalizacji nowych obiektów handlowych, Dedal Invest-Eko, Wydział Rozwoju Urzędu Miasta Poznania, Poznań.

Berman B., Evans J.R., 2010, Retail management: a strategic approach, (11 ${ }^{\text {th }}$ Edition), http://wps. prenhall.com/bp_berman_retail_9/42/10855/2778982.cw/-/2779044/index.html, (dostęp 23 marca 2012).

Bierwiaczonek K., 2010, Między galeria handlowq, ratuszem i bazylika. Miejsca charakterystyczne centrów ślaskich miast w percepcji spotecznej, [w:] Bukowska-Floreńska I., Problemy społeczne $i$ kulturowe wspótczesnego miasta, „Studia Etnologiczne i Antropologiczne”, t. 10, Uniwersytet Śląski, Katowice, s. 177-190.

Bińczyk A., 2006, Od Manufaktury do „Manufaktury”-nowa przestrzeń w Łodzi, [w:] Jażdżewska I. (red.), Nowe przestrzenie w miastach. Ich organizacja i funkcje, XIX Konwersatorium Wiedzy o Mieście, Uniwersytet Łódzki, s. 211-219.

Bombol M., 2003, Czas wolny w naukach spotecznych, [w:] Bombol M., Dąbrowska A., Czas wolny. Konsument, Rynek. Marketing, K.E. Liber, Warszawa, s. 2-38.

Bombol M., Dąbrowska A., 2003, Czas wolny. Konsument, Rynek. Marketing, K.E. Liber, Warszawa.

Bon J., Pras B., 2001, Rozdziat ról nabywcy, ptacacego i konsumenta, [w:] Lambkin M., Foxall G., Raaij van F., Heilbrunn B. (red.), Zachowanie konsumenta. Koncepcje $i$ badania europejskie, PWN, Warszawa, s. 150-162.

Borusiak B., 2008, Modele wzrostu przedsiębiorstw handlu detalicznego, AE, Poznań.

Borusiak B., 2008a, Zarządzanie przedsiębiorstwem handlowym, [w:] Sławińska M., Kompendium wiedzy o handlu, PWN, Warszawa, s. 48-77.

Bosiacki S., Rydlewski P., 2009, Wielkomiejskie centra i galerie handlowe jako miejsca rekreacji $i$ atrakcje turystyczne, „Zeszyty Naukowe”, nr 16, WSHiU, Poznań, s. 35-44. 
Bratkowski J., Klima E., Rochmińska A., 2005, Rozwój sklepów wielkopowierzchniowych i ustug gastronomicznych w Eodzi, [w:] Marszał T. (red.), Gospodarka w przestrzeni polskich miast, „Biuletyn KPZK PAN”, z. 216, Warszawa, s. 227-240.

Bray J., 2008, Consumer behavior theory: approaches and models, http://eprints.bournemouth.ac. uk/10107/1/Consumer_Behaviour_Theory_-_Approaches_\%26_Models.pdf, (dostęp 9 października 2011).

Brezdeń P., Spallek W., 2010, Przestrzenne zróżnicowanie wielkopowierzchniowych sieci handlowych w województwie dolnoślaskim i jego uwarunkowania, [w:] Zioło Z., Rachwał T. (red.), Przedsiębiorczość w warunkach integracji europejskiej, Warszawa-Kraków, Nowa Era, Zakład Przedsiębiorczości i Gospodarki Przestrzennej IG UP w Krakowie, „Przedsiębiorczość-Edukacja”, nr 6, s. 294-307.

Budner W., 2003, Lokalizacja przedsiębiorstw. Aspekty ekonomiczno-przestrzenne $i$ środowiskowe, AE, Poznań.

Budner W., 2011, Wspótczesne tendencje $i$ determinanty lokalizacji handlu w miastach, „Zeszyty Naukowe”, nr 21, WSHiU, Poznań, s. 52-60.

Budner W., 2011a, Skutki oddziatywania sklepów wielkopowierzchniowych na istniejąca sieć handlowa i rynek pracy w Lesznie, „Zeszyty Naukowe”, nr 22, WSHiU, Poznań, s. 43-57.

Burbidge S.K., Goulias G., 2009, Active travel behavior, "Annual Meeting of the Journal of the Transportation Research Board”, no 88, http://www.uctc.net/papers/873.pdf, (dostęp 2 maja 2011).

Centrum handlowo-rozrywkowe Sukcesja Łódź, http://scf2012.retailnet.pl/projekty/centrum-handlowo-rozrywkowe-sukcesja-lodz/, (dostęp 24 sierpnia 2012).

Chan E.S.K., 2003, New educational service products: tertiary EC/EB education - the Asia Pacific Region, School of Information System, Deakin University, Victoria, Australia, http://dlibrary.acu.edu.au/staffhome/elchan/thesis/tindex.htm, (dostęp 20 lutego 2012).

Chmielak G., 1999, Centra handlowe - analiza lokalizacji, „Nieruchomości”, nr 6, C.H. Beck, http://www.nieruchomosci.beck.pl/index.php?mod=m_artykuly\&cid=16\&id=291, (dostęp 10 listopada 2012).

Chmielewski J.M., 2004, Rola miejskich przestrzeni publicznych, „Urbanista”, nr 4, Warszawa, s. 12.

Chrzanowska A., 2011, Centrum handlowo-ustugowe Galeria Lódzka w Lodzi-funkcjonowanie $i$ wptyw na otaczajaca przestrzeń, praca magisterska napisana w Katedrze Gospodarki Przestrzennej i Planowania Przestrzennego, Wydz. Nauk Geograficznych, UŁ, Łódź, promotor dr A. Rochmińska.

Chrzanowska A., Rochmińska A., 2012, Zachowania nabywcze i przestrzenne klientów Galerii Łódzkiej w Łodzi, „Acta Univesritatis Lodziensis. Folia Oeconomica” nr 12, Wyd. UŁ, Łódź, s. 204-219.

Chwałek J., 2008, Handel detaliczny, [w:] Szulce H., Chwałek J., Ciechomski W., Mielczarczyk Z., Ekonomika handlu. Podręcznik, cz. 1, WSiP, Warszawa, s. 18-186.

Ciechomski W., 2006, Koncentracja w handlu detalicznym - przestanki, miary i skutki, [w:] Mikołajczyk J. (red.), Handel. Znaczenie we wspótczesnej gospodarce, WSHiU, Poznań, s. 89-99.

Ciechomski W., 2010, Koncentracja handlu w Polsce $i$ jej implikacje dla strategii konkurowania przedsiębiorstw handlowych, Wydawnictwo Uniwersytetu Ekonomicznego, Poznań.

Ciok S., Ilnicki D., 2011, Handel detaliczny w przestrzeni dużego miasta na przyktadzie Wroctawia, [w:] Koncepcje i Problemy Badawcze Geografii, Wyższa Szkoła Gospodarki, Bydgoszcz, s. 219-237.

Cohen L., 1996, From town center to shopping center: The reconfiguration of community marketplaces in postwar America, “The American Historical Review”, vol. 101, no 4, s. 1050-1081.

Cowell W.D., 1984, The Marketing of services, Williame Heinemanu Ltd., London.

Dalgakiran A., 2008, Interpreting the spatial preferences of retail firms in the post-1980 period: case of Izmir, Turkey, [w:] Theoretical and empirical researches on services turing socio-economic changes, Rochmińska A. (red.), “Space-Societ-Economy”, nr 8, s. 47-58. 
Daszkowska M., 1998, Ustugi. Produkcja, rynek, marketing, PWN, Warszawa.

Dąbrowska A., 2003, Rynki ustugowe zwiazane z czasem wolnym, [w:] Bombol M., Dąbrowska A., Czas wolny. Konsument. Rynek. Marketing, K.E. Liber, Warszawa, s. 93-169.

DeLisle J.R., 2005, The evolution of shopping center research: a 12-year retrospective, "Journal of Shopping Center Research", vol. 12, no 2, s. 1-83.

DeLisle J.R., 2009, Towards global classification of shopping centers, http://www.icsc.org/srch/ rsrch/wp/GlobalRetailClass_Feb2009.pdf, (dostęp 1 grudnia 2011).

Dietl J., 1991, Handel we wspótczesnej gospodarce, PWE, Warszawa.

Dmochowska-Dudek K., 2008, Ustugowe obiekty NIMBY woczach mieszkańców Eodzi, [w:] Theoretical and empirical researches on services during Socio-Economic changes, Rochmińska A. (red.), "Space-Societ-Economy", nr 8, s. 189-196.

Dmochowska-Dudek K., 2011, Obiekty NIMBY jako przyktad konfliktowych inwestycji na terenach mieszkaniowych - teoretyczny zarys problemu, [w:] Dzieciuchowicz J. (red.), Wspótczesne przemiany środowiska mieszkaniowego - wybrane problemy, UŁ, Łódź, s. 29-58.

Dołhun A., 2011, Regulacje czy nadregulacje w kwestii wielkopowierzchniowych obiektów handlowych (WOH), TUP, Katowice, http://www.spatialplanning.info/tup/AnnaDolhunWOH.pdf, (dostęp 23 lutego 2012).

Domański T., 2001, Strategie marketingowe dużych sieci handlowych, PWN, Warszawa.

Domański T., 2005, Strategie rozwoju handlu, PWE, Warszawa.

Domański T., 2006, Proces internacjonalizacji polskiego handlu. Wyzwania i zagrożenia dla polskich firm, [w:] Mikołajczyk J. (red.), Handel. Znaczenie we wspótczesnej gospodarce, WSHiU, Poznań, s. $29-36$.

Dryś M., 2011, Centra handlowe - architektoniczne ruiny?, „Akademia Sztuki”, http://www.akademiasztuki.org/Centra-handlowe-architektoniczne, (dostęp 12 grudnia 2012).

DTZ Research, 2009, Rynek powierzchni handlowych Polska, www.detaldzisiaj.com.pl.

Dudek-Mańkowska S., 2006, Funkcje wybranych centrów handlowych w Warszawie, [w:] Jażdżewska I. (red.), Nowe przestrzenie w miastach. Ich organizacja i funkcje, XIX Konwersatorium Wiedzy o Mieście, Uniwersytet Łódzki, s. 245-254.

Dudek-Mańkowska S., 2010, Shopping centres in the Warsaw metropolitan area, „Acta Universitatis Carolinae. Geographica", No 1-2, s. 35-47, http://web.natur.cuni.cz/ksgrrsek/ acta/2010/2010_dudek.pdf, (dostęp 15 grudnia 2011).

Dudek-Mańkowska S., Fuhrmann M., 2009, Centra handlowe trzeciej generacji w Warszawie jako nowe produkty turystyczne, [w:] Stasiak A. (red.), 2009, Kultura i Turystyka-wspólnie zyskać, WSTiH Łódź, s. 269-282.

Dune G., 2009, Motivation and decision making in city break travel. The case of Dublin, VDM Publishing, Saarbrucken, Germany.

Dybicz T., 2001, Modelowanie ruchu generowanego przez centra ustugowo-handlowe, XLVII Konferencja Naukowa Komitetu Inżynierii Lądowej i Wodnej PAN i Komitetu Nauki PZITB, Krynica, http://www.transeko.pl/publik/Referat_Krynica_2001.pdf, (dostęp 2 października 2011).

Dzieciuchowicz J., 1984, Problemy demograficzne śródmieścia Lodzi, „Acta Universitatis Lodziensis. Folia Geographica", nr 3, Łódź, s. 37-67.

Dzieciuchowicz J., 2002, Zasoby mieszkaniowe Łodzi: Rozwój, struktura przedmiotowa i przestrzen$n a$, ,Acta Universitatis Lodziensis. Folia Geographica Socio-Oeconomica”, nr 4, UŁ, Łódź, s. $47-65$.

Dzieciuchowicz J., 2011, Społeczne budownictwo mieszkaniowe w Łodzi - rozwój, zasoby mieszkaniowe $i$ ich użytkownicy, [w:] Dzieciuchowicz J. (red.), Wspótczesne przemiany środowiska mieszkaniowego - wybrane problemy, UŁ, Łódź, s. 115-144.

Dzieciuchowicz J., 2012, Nowa geografia handlu, „Acta Univesritatis Lodziensis. Folia Oeconomica" nr 12, UŁ, Łódź, s. 37-53. 
Dzieciuchowicz J., 2012a, Wielkie centrum handlowe w przestrzeni miejskiej i podmiejskiej: Manufaktura w Łodzi i Ptak w Rzgowie, UŁ, Łódź.

Fatyga B., 2009, Czas wolny, [w:] Raport o stanie i zróżnicowaniach kultury miejskiej w Polsce, Ministerstwo Kultury i Dziedzictwa Narodowego, s. 26-37.

Feinberg R.A., Meoli J., 1991, A brief history of the mall, "Advances in Consumer Research", vol. 18 , p. $426-427$.

Felisiak M., 2008, Zachowania konsumenckie, Komunikat z badań CBOS, BS/117/2008, Warszawa.

Fertal'ova J., 2006, Evaluation of attendance in selected hypermarkets and shopping stores in the towns of Prešov and Košice, "Acta Univ. Palacki, Geographica", no 39, Olomuc, s. 19-29.

Fuhrmann M., 2006a, Miasto w mieście - przestrzeń centrum handlowego jako substytut przestrzeni miejskiej, [w:] Dynamika przestrzeni miejskiej, Wydawnictwo Poznańskie, s. 71-76.

Fuhrmann M., 2006b, Rola centrum handlowego Sadyba Best Mall w życiu mieszkańców Osiedla Sadyba, [w:] Górecki J. (red.), Przestrzeń społeczno-ekonomiczna Europy Środkowej $i$ Wschodniej, Koło Geografów Uniwersytetu Jagiellońskiego, Kraków, s. 47-55.

Fuhrmann M., 2007, Centrum handlowe a jakość życia, „Genius Loci”, nr 4 (maj 2007), s. 1 i 3-4.

Fuhrmann M., 2009, Znaczenie turystyczne centrów handlowych nowej generacji w Warszawie, [w:] Stasiak A. (red.), „Turystyka i Hotelarstwo”, nr 14/2008, WSTH w Łodzi, s. 47-56.

Fuhrmann M., Dudek-Mańkowska S., 2010, Wpływ lokalizacji centrów handlowych w Warszawie na organizacje czasu wolnego mtodzieży, [w:] Madurowicz M. (red.), Wartościowanie wspótczesnej przestrzeni miejskiej, Instytut Geografii Społeczno-Ekonomicznej i Gospodarki Przestrzennej, Urząd Miasta Stołecznego Warszawy, s. 367-377.

Fularz A., 2004, Rozwój podmiejskich centrów dystrybucji detalicznej w ujęciu ekonomiki transportu, „Studia Regionalne i Lokalne”, nr 4, s. 145-158.

Gajewski S., 1994, Zachowanie się konsumenta a wspótczesny marketing, UŁ, Łódź.

Garbarski L., 1994, Zrozumieć nabywce, PWE, Warszawa.

Ghirardo D., 1999, Architektura po modernizmie, VIA, Toruń.

Godlewska H., 2001, Lokalizacja działalności gospodarczej. Wybrane zagadnienia, WSHiFM, Warszawa.

Golledge R.G., Stimson R.J., 1997, Spatial behavior: a geographic perspective, The Guilford Press, New York.

Gołembski G., 1998, Przedsiębiorstwo turystyczne w gospodarce wolnorynkowej, AE, Poznań.

Goss J., 1993, The "Magic of the mall": an analysis of form, function, and meaning in the contemporary retail built environment, "Annals of the Association of American Geographers", vol. 83, no 1 , s. $18-47$.

Groeger 1., 2011, Wspótczesna zabudowa rezydencjonalna. Przykład Łodzi, [w:] Dzieciuchowicz J. (red.), Wspótczesne przemiany środowiska mieszkaniowego - wybrane problemy, UŁ, Łódź, s. 83-98.

Grzelońska U., 1997, Roczniki Kolegium Analiz Ekonomicznych, Warszawa.

Grzesiuk A., 2011, Handel detaliczny a rytualizacja konsumpcji, [w:] Borusiak B. (red.), Orientacja rynkowa we wspótczesnym handlu detalicznym, „Zeszyty Naukowe”, $\mathrm{nr}$ 177, AE, Poznań, s. 138-147.

Grzeszczak J., 1999, Bieguny wzrostu a formy przestrzeni spolaryzowanej, „Prace Geograficzne”, nr 173, PAN, IGiPZ, Continuo, Wrocław.

Guzik R., 2003, Przestrzenna dostępność szkolnictwa ponadpodstawowego, Instytut Geografii i Gospodarki Przestrzennej UJ, Kraków.

Gwosdz K., Sobala-Gwosdz A., 2008, Geografia hipermarketów w Polsce: strategie lokalizacyjne firm $i$ ich skutki przestrzenne, „Przegląd Geograficzny”, IGiPZ PAN, t. 80, z. 4, s. 515-539.

Gwynn D., 2008, The history of the american shopping center, http://www.otherstream.com/wp-content/uploads/2008/12/bibliography.pdf, (dostęp 24 marca 2012).

Holloway J.Ch., Robinson Ch., 1997, Marketing w turystyce, PWE, Warszawa. 
http://baza.archiwa.gov.pl, (dostęp 24.01.2010).

http://capitalpark.pl/news/169/87/lodz-Street-Mall-Vis-a-Vis.htm, (dostęp 12 września 2012).

http://gastrowiedza.pl (13.02.2012) - Profesjonalne zarzqdzanie gastronomiq.

http://prch.org.pl/PL/BazaWiedzy/Definicje/Default.aspx.

http://prch.org.pl/PL/StronaGlowna/Default.aspx.

http://www.boig.pl/projekt/38, The Blue Ocean Investment Group, (dostęp 24 sierpnia 2012).

Huff D., McCallum B.M., 2008, Calibrating the huff model using ArcGis business analyst, An ESRI White Paper, United States of America.

Hungarian council of shopping centers, http://www.mbsz.hu/2011_08_06/MBSZ_eves_jenetes_ A4_2010_FINAL.pdf.

ICSC - International council of shopping centers, http://www.icsc.org/.

ICSC shopping center definitions. Basic configurations and types for the United States, 2004, International Council of Shopping Centers (ICSC), http://www.icsc.org/srch/lib/USDefinitions.pdf, (dostęp 12 lipca 2012).

ICSC shopping center definitions. Basic configurations and types, 1999, International Council of Shopping Centers, USA.

Ira V., Matlovič R., Sýkora L., Szczyrba Z., 2001, Procesy transformacyjne struktury przestrzennej miast postkomunistycznych na tle koncentracji w handlu detalicznym w Republice Czeskiej $i$ Stowackiej (przyktad Pragi, Bratystawy, Otomunca i Preszowa), [w:] Jażdżewska I. (red.), Miasto postsocjalistyczne - organizacja przestrzeni miejskiej i jej przemiany (cz. II), XIV Konserwatorium Wiedzy o Mieście, UŁ, Łódź, s. 243-251.

Iwan B., 2007, Oddziatywanie hipermarketów na rozwój spoteczności lokalnych, „Prace Naukowe”, nr 39, SGGW, Warszawa s. 113-122.

Iwińska-Knop K., 2011, Techniki wywierania wplywu na decyzje nabywcze klientów hipermarketów, [w:] Borusiak B. (red.), Orientacja rynkowa we wspótczesnym handlu detalicznym, „Zeszyty Naukowe", nr 177, AE, Poznań, s. 65-74.

Jachnis A., 2007, Psychologia konsumenta. Psychologiczne i socjologiczne uwarunkowania zachowań konsumenckich, Oficyna wydawnicza Branta, Bydgoszcz-Warszawa.

Jakovčić M., Rebernik D., 2008, Comparative analysis of development of retail and shopping centres after 1990 in Ljubljana and Zagreb, "Hrvatski Geografski Glasnik", 70/2, s. 33-48.

Jakóbczyk-Gryszkiewicz J., 2008, Centrum targowo-bazarowe w strefie podmiejskiej Łodzi i jego funkcjonowanie po wejściu Polski do Unii Europejskiej, „Czasopismo Geograficzne”, t. 78, z. 4, s. 305-323.

Jałowiecki B., 2011, Studia miejskie - między historiq a teoriq, „Studia Regionalne i Lokalne”, nr 2 (44), s. 26-40.

Janiszewska A., Klima E., Rochmińska A., 2011, Centra handlowe w Łodzi-zawtaszczona, przestrzeń publiczna?, [w:] Jażdżewska I. (red.), Człowiek w przestrzeni publicznej miasta, XXIV Konwersatorium Wiedzy o Mieście, UŁ, Łódź, s. 157-165.

Janiszewska A., Klima E., Rochmińska A., 2011, Fakość życia na tódzkich osiedlach, [w:] Dzieciuchowicz J. (red.), Wspótczesne przemiany środowiska mieszkaniowego - wybrane problemy, UŁ, Łódź, s. 145-180.

Janiszewska A., Rochmińska A., 2009, Rozwój i funkcjonowanie handlu hurtowego w Łodzi, [w:] Dzieciuchowicz J. (red.), Ustugi dla producentów i biznesu w przestrzeni wielkomiejskiej. Przykład Łodzi, UŁ, Łódź, s. 61-79.

Janoś-Kresło M., 2006, Cechy konsumentów i gospodarstw domowych jako podmiotów konsumpcji, [w:] Janoś-Kresło M., Mróz B., Konsument i konsumpcja we wspótczesnej gospodarce, SGH, Warszawa, s. 13-40.

Jarosz A., 2001, Miejsce hipermarketów w przestrzeni miejskiej aglomeracji, [w:] Warszawa jako przedmiot badań w geografii spoteczno-ekonomicznej, „Prace Geograficzne”, nr 184, s. 253-264. 
Jezierski A., Leszczyńska C., 2001, Historia gospodarcza Polski, Key Text, Warszawa.

Jonas A., 2006, Fakość ustug, [w:] Czubała A., Jonas A., Smoleń T., Wiktor J.W., Marketing ustug, Wolters Kluwer Polska, Kraków, s. 115-149.

Jung B., 1989, Ekonomia czasu wolnego. Zarys problematyki, PWN, Warszawa.

Kaczmarek J., 1996, Dzienna ścieżka życia mieszkańców Łodzi a warunki życia w mieście, „Szlakami Nauki”, nr 22, ŁTN, Łódź.

Kaczmarek J., 2001, Miejsce - w poszukiwaniu wtaściwej miary, [w:] Rogacki H. (red.), Koncepcje teoretyczne i metody badan geografii spoteczno-ekonomicznej i gospodarki przestrzennej, Wydawnictwo Naukowe Bogucki, Poznań, s. 73-81.

Kaczmarek J., 2003, feżeli... to - interpretacja wyników badań przestrzennej cztowieka, [w:] Rogacki H. (red.), Problemy interpretacji wyników metod badawczych stosowanych w geografi spoteczno-ekonomicznej i gospodarce przestrzennej, Wydawnictwo Naukowe Bogucki, Poznań, s. 31-42.

Kaczmarek J., 2005, Podejście geobiograficzne w geografii spotecznej. Zarys teorii i podstawy metodyczne, Uł, Łódź.

Kaczmarek J., Stasiak A., Włodarczyk B., 2005, Produkt turystyczny, PWE, Warszawa.

Kaczmarek T., 2010, Struktura przestrzenna handlu detalicznego. Od skali globalnej do lokalnej, Wydawnictwo Naukowe Bogucki, Poznań.

Kaczmarek T., 2011, Handel detaliczny $w$ rozwoju funkcjonalnym i przestrzennym miast w Polsce, [w:] Wdowicka M., Mierzejewska L. (red.), Problemy rozwoju lokalnego i regionalnego na poczqtku XXI wieku, „Biuletyn Instytutu Geografii Społeczno Ekonomicznej i Gospodarki Przestrzennej Uniwersytetu im. Adama Mickiewicza", Poznań, s. 67-84.

Kaczmarek T., Kaczmarek U., 2006, Stara i nowa przestrzeń handlowa Poznania, [w:] Jażdżewska I. (red.), Nowe przestrzenie w miastach. Ich organizacja i funkcje, XIX Konwersatorium Wiedzy o Mieście, UŁ, s. 221-231.

Kaczmarek T., Szafrański T., 2008, Poziom rozwoju i struktura przestrzenna handlu detalicznego w Poznaniu, [w:] Rochmińska A. (red.), Theoretical and empirical reserches on services during socio-economic changes, „Space-Society-Economy“, No 8, Katedra Gospodarki Przestrzennej i Planowania Przestrzennego, UŁ, Łódź, s. 95-110.

Kaczorek A., Kowalczyk A., 2003, Modele lokalizacji ustug gastronomicznych na obszarach miejskich, „Prace i Studia Geograficzne”, nr 32, s. 191-203.

Kajdanek K., 2006, Nowe przestrzenie centrum? O znaczeniu galerii handlowych w obrazie przestrzenno-funkcjonalnym centrum miasta Wroctawia, [w:] Jażdżewska I. (red.), Nowe przestrzenie w miastach. Ich organizacja i funkcje, XIX Konwersatorium Wiedzy o Mieście, UŁ, s. 255-264.

Kamiński A., 1965, Czas wolny i jego problematyka społeczno-wychowawcza, Zakład Narodowy im. Ossolińskich, Wrocław.

Karta Przestrzeni Publicznej, 2009, www.tup.org.pl, (dostęp 12 czerwca 2011).

Kavanagh M, 2000, A brief history of shopping centers, http://www.icsc.org/srch/about/impactofshoppingcenters/01_briefhistory.pdf, (dostęp 24 marca 2012).

Kiel G., Haberkern G., 1998, Issues in shopping centre trade areas, Paper presented at the inaugural Australia New Zealand Academy of Marketing Conference, s. 1138-1154, http://anzmac. info/conference/1998/Cd_rom/Kiel146.pdf, (dostęp 2 maja 2011).

Kienzler I., Romanowski R., 2009, Leksykon handlowy, C.H. Beck, Warszawa.

Kieżel E., 1998, Konsument, przedsiębiorstwo, przestrzeń, Centrum Badań i Ekspertyz Akademii Ekonomicznej im. Karola Adamieckiego, Katowice.

Kinley T., Kim Y-K., Forney J., 2002, Tourist - destination shopping center: an importance - performance analysis of attributes, "Journal of Shopping Center Research", 9 (1), s. 51-72.

Kłosiewicz-Górecka U., 2006, Globalizacja w sektorze handlu w Polsce - wyzwania dla krajowych przedsiębiorstw handlowych, [w:] Mikołajczyk J. (red.), Handel znaczenie we wspótczesnej gospodarce, WSHiU, Poznań, s. 51-68. 
Kłosiewicz-Górecka U., 2009, Zmiany w handlu detalicznym, [w:] Sławińska M. (red.), Handel wewnętrzny w Polsce 1989-2009, IBRKiK, Warszawa, s. 117-143.

Kłosiewicz-Górecka U., 2010, Zmiany w sieci handlu detalicznego, „Wiadomości Statystyczne”, nr 9, s. 36-48.

Kłosiewicz-Górecka U., Słomińska B., 2001, Samorzq̨d terytorialny, a rozwój nowoczesnego han$d l u$, Difin, Warszawa.

Kłosowski F., 2002, Hipermarkety w przestrzeni handlowej miast aglomeracji katowickiej, [w:] Słodczyk J. (red.), Przemiany bazy ekonomicznej i struktury przestrzennej miast, Uniwersytet Opolski, Opole, s. 373-381.

Knecht-Tarczewska M., 2011, Centrum handlowe jako nowoczesny produkt handlowo-ustugowy, „Zeszyty Naukowe”, nr 175, Uniwersytet Ekonomiczny, Poznań, s. 293-303.

Kochaniec A., 2011, Rola centrów handlowych w kreowaniu wizerunku miast, [w:] Grzegorczyk A., Kochaniec A. (red.), Kreowanie wizerunku miasta, Wyższa Szkoła Promocji, Warszawa, s. 238-247.

Kociuba D., 2006, Nowe przestrzenie handlowe Lublina, [w:] Jażdżewska I. (red.), Nowe przestrzenie w miastach. Ich organizacja i funkcje, XIX Konwersatorium Wiedzy o Mieście, UŁ, s. 231-244.

Komor M., 2011, Internacjonalizacja handlu w Europie, [w:] Sławińska M. (red.), Handel we wspótczesnej gospodarce. Źródta i przejawy innowacyjności, „Zeszyty Naukowe”, nr 175, Wyd. UE, Poznań, s. 73-82.

Kompendium wiedzy o handlu, 2008, Sławińska M. (red.), PWN, Warszawa.

Kompil M., Çelik H.M., 2006, Analyzing the retail structure change of Izmir - Tukey: integrative and disintegrative aspects of large-scale retail developments, $42^{\text {nd }}$ ISOCARP Congress.

Kopaliński W., 1994, Stownik wyrazów obcych $i$ zwrotów obcojezyycznych, Wiedza Powszechna, Warszawa.

Koter M., 1969, Geneza uktadu przestrzennego Łodzi przemystowej, „Prace Geograficzne”, nr 79, Instytut Geografii PAN, PWN, Warszawa.

Kotler P., 1994, Marketing. Analiza, planowanie, wdrażanie, kontrola, Gebethner \& Ska, Warszawa.

Kowalski S., Sowier-Kasprzyk I., 2008, Zarzqdzanie produktem sportowo-rekreacyjnym w warunkach spoteczeństwa konsumpcyjnego, [w:] J. Kall, B. Sojkin (red.), Zarzadzanie produktem - teoria, praktyka, perspektywy, Wyd. AE, Poznań, s. 140-147.

Kowrygo B., Levytska G., 2006, Zmiany na rynku ustug gastronomicznych (na przyktadzie restauracji Quick E Casual), „Handel Wewnętrzny”, numer specjalny, czerwiec, s. 378-383.

Krause K., 2010, Przestrzeń publiczna jako przestrzeń handlu, [w:] Lorens P., Martyniuk-Pęczek J., Problemy kształtowania przestrzeni publicznej, Urbanista, Gdańsk, s. 100-106.

Kucharska B., Twardzik M., 2007, Koncentracja i integracja w handlu. Aspekt teoretyczny, Wyższa Szkoła Biznesu, Dąbrowa Górnicza.

Kufel J., Mruk H., 1998, Konsument jako instytucja ekonomiczna i prawna, [w:] Kufel J. (red.), Ochrona konsumenta w uregulowaniach publicznoprawnych, AE, Poznań.

Kwiatkowski K., 2010, Przestrzeń publiczna i jej uzurpatorskie zawtaszczanie, „Czasopismo Techniczne”, z. 2-A, Politechnika Krakowska, s. 277-284.

Lambert J., 2005, One step closer to a pan-european shopping center standard, http://prch.org.pl.

Ledwoń S., 2009, Przeksztatcenia obszarów śródmiejskich z udziatem funkcji handlowej, [w:] Wybrane zagadnienia z rewitalizacji miast, Lorens P., Martyniuk-Pęczek J. (red), Urbanista, Gdańsk, s. 36-58.

Leksykon sfery spożycia. Terminologia i metodyka badań, 1988, PTE, Poznań.

Levitt T., 1980, Marketing success through differentiation of anything, "Harvard Business Review", s. 83-91, cte.jhu.edu/courses/pii/marketing success through differentiation.pdf, (dostęp 3 marca 2012).

Levytska G., 2011, Ustugi gastronomiczne - znaczenie i tendencje rozwoju, SGGW, Warszawa. 
Lewandowska J., 2006, Co Polacy robia w czasie wolnym, Komunikat z badań CBOS, BS/124/2006, Warszawa.

Liszewski S., 1978, Tereny miejskie. Podziat i klasyfikacja, „Acta Universitatis Lodziensis. Zeszyty Naukowe UŁ”, z. 15, s. 3-33.

Loudon D.L., Della Bitta A.J., 1993, Consumer behavior: concepts and applications by hardcover, McGraw-Hill College, Columbus.

Lukić A., Jakovčić M., 2004, Location and function of hypermarkets and shopping center in Zagreb, "Razprave", dela 22, s. 39-54, www.dlib.si/stream/URN:NBN:SI:doc-ZYYX3QHW/...3655.../ PDF, (dostęp 2 maja 2011).

Łódzki rynek nieruchomości 2011/2012, 2012, Urząd Miasta Łodzi, Łódź.

Łódź: jest miejsce na nowe centra handlowe, (http://www.bankier.pl/wiadomosc/Lodz-jest-miejsce-na-nowe-centra-handlowe-2181089.html), (dostęp 21 lipca 2010).

Łukasik P., 2008, Marketing w handlu detalicznym produktami spożywczymi: wybrane aspekty zachowań nabywców, UMCS, Lublin.

Łukasik P., 2010, Lokalizacja miejsca sprzedaży, [w:] Sobczyk G., Zarzadzanie sprzedażq w przedsiębiorstwie handlowym, PWE, Warszawa, s. 60-67.

Majchrzak K., 2007, Centrum handlowe jako atrakcja turystyczna ery postturystyki na przykładzie Starego Browaru w Poznaniu, „Zeszyty Naukowe Uniwersytetu Szczecińskiego”, nr 466, Ekonomiczne Problemy Turystyki nr 9, s.181-185.

Makowski G., 2003, Świqtynia konsumpcji. Geneza i spoteczne znaczenie centrum handlowego, Trio, Warszawa.

Makowski G., 2010, Światynie handlu maja 15 lat, „Dziennik Gazeta Prawna” (z 1 października 2010 roku), http://www.e-leclerc.pl/pressf/799.pdf.

Maleszyk E., 1998, Zagraniczne sieci handlowe w Polsce, „Wiadomości Statystyczne”, XLIII, nr 8, s. $48-58$.

Maleszyk E., 1999, Rozwój hipermarketów, supermarketów i sklepów dyskontowych z kapitatem zagranicznym, „Wiadomości Statystyczne”, XLIV, nr 6, s. 44-52.

Maleszyk E., 2000, Ośrodki handlowe w Polsce, „Gospodarka Narodowa”, nr 11-12, s. 71-85.

Maleszyk E., 2001, Ośrodki handlowe w Polsce - uwarunkowania i kierunki rozwoju. Rynek $i$ konsumpcja, IRWiK, Warszawa.

Maleszyk E., 2001a, Kierunki rozwoju ośrodków handlowych w Polsce, „Handel Wewnętrzny”, nr 47, z. 4-5, s. 38-46.

Maleszyk E., 2002, Ocena procesu koncentracji w handlu i na rynku wewnętrznym, [w:] Pokorska B., Maleszyk E., Koncentracja $i$ integracja w handlu wewnętrznym, PWE, Warszawa, s. 77-126.

Maleszyk E., 2004, Rozwój sieci handlowych obstugi masowej w Polsce, „Wiadomości Statystyczne", XLIX, nr 1, s. 38-49.

Maleszyk E., 2009, Procesy koncentracji i integracji w handlu detalicznym, [w:] Sławińska M. (red.), Handel wewnętrzny w Polsce 1989-2009, IBRKiK, Warszawa, s. 144-157.

Maleszyk E., 2011, Nowe trendy w procesach koncentracji i integracji handlu w Polsce, [w:] Sławińska M. (red.), Handel we wspótczesnej gospodarce. Źródta i przejawy innowacyjności, „Zeszyty Naukowe", nr 175, UE, Poznań, s. 40-51.

Malina A., 2004, Wielowymiarowa analiza przestrzennego zróżnicowania struktury gospodarki Polski wedtug województw, AE, Kraków.

Marketing w handlu, 2007, Białoń L. (red.), WSM, Warszawa.

Marketing w handlu, 2009, Rosa G. (red.), Wydawnictwo Naukowe Uniwersytetu Szczecińskiego, Szczecin.

Matlovič R., Ira V., Sýkora L., Szczyrba Z., 2001, Procesy transformacyjne struktury przestrzennej miast postkomunistycznych (na przyktadzie Pragi, Bratystawy, Otomuńca oraz Preszowa), 
[w:] Jażdżewska I. (red.), Miasto postsocjalistyczne - organizacja przestrzeni miejskiej i jej przemiany (cz. II), XIV Konserwatorium Wiedzy o Mieście, UŁ, Łódź, s. 9-21.

Matysiak N., 2009, Wspótczesne centra handlowe w Polsce, „Handel Wewnętrzny - rynek, przedsiębiorstwo, konsumpcja, marketing”, nr 6, IBRKiK, Warszawa, s. 26-31.

Mazurek-Łopacińska K., 1997, Zachowania nabywców jako postawa strategii marketingowej, AE, Wrocław.

Mazurkiewicz L., 2002, Planowanie marketingowe w przedsiębiorstwie turystycznym, PWE, Warszawa.

Mazurkiewicz L., 2007, Model przestrzennego zachowania turystów, „Przegląd Geograficzny”, nr 79, s. 99-113.

Medlik S., 1995, Leksykon podróży, turystyki, hotelarstwa, PWN, Warszawa.

Middleton V.T.C, 1996, Marketing w turystyce, Polska Agencja Promocji Turystyki, Warszawa.

Mikołajczyk J., 2008, Instrumenty marketingu w handlu, [w:] Sławińska M., Kompendium wiedzy o handlu, PWN, Warszawa, s. 119-159.

Mikołajczyk J., 2008a, Wybór formatu sklepu, [w:] Sławińska M., Kompendium wiedzy o handlu, PWN, Warszawa, s. 119-127.

Mikołajczyk J., 2008b, Przestrzenne aspekty funkcjonowania handlu, [w:] Sławińska M., Kompendium wiedzy o handlu, PWN, Warszawa, s. 288-299.

Milewska M., Prączko A., Stasiak A., 2010, Podstawy gastronomii, PWE, Warszawa.

Milewska-Osiecka K., 2011, Fizjonomia i uktady urbanistyczne nowego budownictwa mieszkaniowego jako element ksztattowania warunków mieszkaniowych (na wybranych przyktadach), [w:] Dzieciuchowicz J. (red.), Wspótczesne przemiany środowiska mieszkaniowego - wybrane problemy, UŁ, Łódź, s. 59-82.

Mironowicz I., 2010, Wspótczesne dylematy przestrzeni publicznej, [w:] Lorens P., Martyniuk-Pęczek J., Problemy ksztattowania przestrzeni publicznej, Urbanista, Gdańsk, s. 36-48.

Mordwa S., 2012, Poczucie bezpieczeństwa w centrach handlowych. Przyktad badań opinii klientów Galerii Łódzkiej i Manufaktury w Łodzi, [w:] Dzieciuchowicz J. (red.), Zróźnicowanie przestrzeni społeczno-ekonomicznej - wybrane problemy, „Acta Universitatis Lodziensis. Folia Geographica Socio-Oeconomica”, nr 12, UŁ, Łódź, s. 163-185.

Mruk H., Pilarczyk B., Sojkin H., Szulce H., 1996, Podstawy marketingu, AE, Poznań.

Mruk H., Rutkowski I.P., 1999, Strategia produktu, PWE, Warszawa.

Mudie P., Cottam A., 1998, Ustugi. Zarzqdzanie i marketing, PWN, Warszawa.

Namyślak B., 2006, Rozwój wielkopowierzchniowych obiektów handlowych we Wroctawiu, [w:] Jażdżewska I. (red.), Nowe przestrzenie w mieście, ich organizacja i funkcje, XVIII Konwersatorium Wiedzy o Mieście, UŁ, s. 265-276.

National council of shopping centers of France (CNCC), http://www.cncc.com/index.php?ru$\mathrm{b}=18$ \&srub $=28$, (dostęp 21 kwiecień 2010).

Nawrocki T., 2010, Od rynku do mallu. Zmiany centrów miast ślaskich i ich spoteczna percepcja, [w:] Bukowska-Floreńska I., Problemy spoteczne i kulturowe wspótczesnego miasta, [w:] „Studia Etnologiczne i Antropologiczne", t. 10, Uniwersytet Śląski, Katowice, s. 164-176.

Nordic council of shopping centers (NCSC), http://www.ncsc.se/index.php?option=com_conten$\mathrm{t} \&$ task $=$ section\&id $=15 \& \mathrm{Itemid}=66,($ dostęp $21 \mathrm{kwiecień} 2010)$.

Nowakowska A., 2002, Produkt turystyczny, [w:] Gołembski G. (red.), Kompendium wiedzy o turystyce, PWN, Warszawa, s. 24-43.

Nowe wcielenie Uniwersalu. Na górze biura, na dole sklepy, pod ziemia parking, „Express Ilustrowany”, (28.02.2009), http://lodz.naszemiasto.pl/wydarzenia/967436.html, (dostęp 24 stycznia 2010).

Olearczyk A., 1979, Ośrodki handlowe, Biblioteka IHWiU, Warszawa. 
Ooi J.T.L., Sim L-L., 2007, The magnetism of suburban shopping centers: do size and Cineplex matter, "Journal of Property Investment \& Finance", vol. 25, no 2, s. 111-135.

Otto J., Olczak A., 2007, Marketing w handlu i ustugach, Politechnika Łódzka, Łódź.

Panasiuk A., 2010, Organizacja multiustugowa, [w:] K. Rogoziński, A. Panasiuk, Zarzadzanie organizacjami ustugowymi, „Zeszyty Naukowe” nr 145, Uniwersytet Ekonomiczny, Poznań, s. 73-82.

Pancewicz Ł., 2010, Prywatyzacja przestrzeni publicznych, [w:] Lorens P., Martyniuk-Pęczek J., Problemy ksztattowania przestrzeni publicznej, Urbanista, Gdańsk, s. 80-90.

Parczewski W., Tauszyński K., 2005, Projektowanie obiektów użyteczności publicznej, WSiP, s. 71-84.

Parysek J.J., 2008, Aglomeracje miejskie w Polsce oraz problemy ich funkcjonowania i rozwoju, [w:] Parysek J.J., Tölle A. (red.), Wybrane problemy rozwoju i rewitalizacji miast: aspekty poznawcze i praktyczne, „Biuletyn Instytutu Geografii Społeczno-Ekonomicznej i Gospodarki Przestrzennej UAM. Seria Rozwój Regionalny i Polityka Regionalna”, nr 5, Wydawnictwo Naukowe Bogucki, Poznań, s. 30-48.

Pawlak A., 1999, Mapa pokrycia terenu opracowana wedtug propozycji czwartego poziomu legendy CORINE Land Cover a zróżnicowanie środowiska dla arkusza N-34-106-D, „Fotointerpretacja w geografii. Problemy Telegeoinformacij”, nr 30, Uniwersytet Warszawski, Warszawa.

Payne A., 1996, Marketing ustug, PWE, Warszawa.

Perenc J., Rak A., 2009, Przeobrażenia handlu w Polsce po 1989 roku, [w:] Rosa G. (red.), Marketing whandlu, Wydawnictwo Naukowe Uniwersytetu Szczecińskiego, Szczecin, s. 29-56.

Pietraszewski M., 2000, Organizacja gospodarki w Polsce, eMPi², Poznań.

Pilarczyk B., 2001, Kompozycja elementów marketingu-mix w handlu, [w:] Pilarczyk B., Sławińska M., Mruk H., Strategie marketingowe przedsiębiorstw handlowych, PWE, Warszawa, s. 143-180.

Pilarczyk B., Sławińska M., Mruk H., 2001, Strategie marketingowe przedsiębiorstw handlowych, PWE, Warszawa.

Plesińska A., 2003, Zmiany w zagospodarowaniu tódzkich wielkopowierzchniowych obiektów handlowych z lat 60-tych i 70-tych, praca magisterska, Katedra GPiPP UŁ, promotor dr A. Rochmińska.

Pokorska B., Maleszyk E., 2002, Koncentracja $i$ integracja na rynku wewnętrznym w optyce sieci handlowych - koncepcja badań, [w:] Pokorska B., Maleszyk E., Koncentracja i integracja w handlu wewnętrznym, PWE, Warszawa, s. 13-26.

Pokorska B., Maleszyk E., 2006, Integracja przedsiębiorstw a procesy konkurencji, PWE, Warszawa.

Portuguese Association of Shopping Centres (A.P.C.C.), http://www.apcc.pt/tipologia.php, (dostęp 11 maja 2011).

Prymon M., 2008, Marka w dynamicznej koncepcji produktu, [w:] J. Kall, B. Sojkin (red.), Zarzqdzanie produktem - teoria, praktyka, perspektywy, AE, Poznań, s. 489-495.

Ptáček P., Szczyrba Z., 2007, Current suburbanisation trends in the Czech Republic and spatial transformation of retail, "Revija za geografijo", 1-2, s. 55-65.

Racoń-Leja K., 2007, Przestrzeń publiczna zagrożona, „Czasopismo Techniczne” z. 2-A, Politechnika Krakowska, s. 215-220.

Rapacz A., 1994, Przedsiębiorstwo turystyczne. Podstawy i zasady dziatania, PWN, Warszawa.

Raport - rynek powierzchni handlowych, 2012, Cushman \& Wakefield, http://cdn11.muratorplus. smcloud.net/t/myfile/Rynek-powierzchni-handlowych-w-Polsce_raport-Cushman.pdf, (dostęp 5 maja 2013).

Rawski M., 2008, Profil dziatalności przedsiębiorstw a wykorzystanie procesu pozycjonowania, [w:] Kall J., B. Sojkin (red.), Zarzqdzanie produktem - teoria, praktyka, perspektywy, AE, Poznań, s. 217-231. 
Rebernik D., Jakovčić M., 2006, Development of retail and shopping centres in Ljubljana, "Razprave" dela 26, s. 5-26, www.dlib.si/stream/URN:NBN:SI:DOC-TIRWAZA0/...8d97.../PDF, (dostęp 2 maja 2011).

Rembowska K., 2000, Spoteczna percepcja funkcjonowania nowych instytucji masowej konsumpcji w Lodzi. Supermarkety i Fast foody, „Urbánne a krajinné štúdie”, nr 3, Inštitút Turizmu a Hotelovového Manažmentu, Prešov, s. 174-179.

Rochmińska A., 2005, Rozwój sieci handlowych z udziałem kapitału zagranicznego, [w:] Dzieciuchowicz J. (red.), Ustugi rynkowe w dobie transformacji, UŁ, Łódź, s. 65-92.

Rochmińska A., 2008, Zachowania konsumenckie w handlu internetowym na przyktadzie mieszkańców jednostki osiedlowej Łodzi (Olechów), [w:] Theoretical and empirical researches on services during socio-economic changes, UŁ, Łódź, s. 155-164.

Rochmińska A., 2010, Sieci handlowe z kapitatem zagranicznym jako nowy element w strukturze miasta, [w:] Jażdżewska I. (red.), Duże $i$ średnie miasta polskie w okresie transformacji, „XXII Konwersatorium Wiedzy o Mieście”, z. 1, UŁ, Łódź, s. 161-172.

Rochmińska A., 2011, Zakupy a czas wolny Łodzian, „Acta Univesritatis Lodziensis. Folia Oeconomica", nr 11, UŁ, Łódź, s. 207-217.

Rozporządzenie Ministra Infrastruktury z 12 kwietnia 2002 roku w sprawie warunków technicznych, jakim powinny odpowiadać budynki i ich usytuowanie, Dz.U., Nr 75, poz. 690, z późn. zm.

Rozporządzenie Ministra Rozwoju Regionalnego i Budownictwa w sprawie ewidencji gruntów i budynków z 29 marca 2001 roku, Dz.U., Nr 38, poz. 454.

Rozwój sieci handlowych z udziatem kapitatu zagranicznego, 2005, [w:] Dzieciuchowicz J. (red.), Ustugi rynkowe w dobie transformacji, UŁ, Łódź, s. 65-92.

Rudnicki L., 2000, 2012, Zachowania konsumentów na rynku, PWE, Warszawa.

Rutkowski I.P., 2011, Strategie produktu. Koncepcje i metody zarzqdzania oferta produktowa, PWE, Warszawa.

Rynek wewnętrzny w 2011 roku. Informacje i opracowania statystyczne, 2012, GUS, Warszawa.

Rynkowe zachowania konsumentów, 1999, 2000, E.Kieżel (red.), AE, Katowice.

Sagan A., 2003, Analiza rzetelności skal satysfakcji i lojalności, StatSoft Polska, s. 39-52.

Shiboleth A., 2009, W Polsce powstanq centra V generacji, http://gospodarka.gazeta.pl/firma /1,31560,6993593,W_Polsce_powstana_centra_handlowe_V_generacji.html (dostęp 2 września 2009).

Shostack G.L., 1982, How to design a service, "European Journal of Marketing”, vol. 16(1), s. 49-64.

Sikos T., Hoffmann M., 2005, Typology of shopping centres in Budapest, Research Institute, J. Selye University, Komárno.

Sławińska M., 2008, Handel we wspótczesnej gospodarce, [w:] Sławińska M. (red.), Kompendium wiedzy o handlu, PWN, Warszawa, s. 11-31.

Słodczyk J., 2001, Przestrzeń miasta i jej przeobrażenia, „Studia i Monografie”, nr 298, Uniwersytet Opolski, Opole.

Słomińska B., 2009, Handel na rynkach regionalnych i lokalnych, [w:] Sławińska M. (red.), Handel wewnętrzny w Polsce 1989-2009, IBRKiK, Warszawa, s. 58-70.

Stownik języka polskiego, 1979, Szymczak M. (red.), t. I i II, PWN, Warszawa.

Smagacz M., 2007, Młodzież w centrum handlowo-rozrywkowym. Raport z badań socjologicznych na zlecenie Miejskiego Programu Przeciwdziatania Przestępczości Mtodzieży, Instytut Socjologii UJ, Kraków.

Smoleń T., 2006, Produkt ustugowy, [w:] Czubała A., Jonas A., Smoleń T., Wiktor J.W., Marketing ustug, Wolters Kluwer, Kraków, s. 90-114. 
Smolová I., Szczyrba Z., 2000, Large commercial centers in the Czech Republic - landscape and regionally aspects of development (Contribution to the study of the problematic), "Acta Univ. Palacki, Geographica", no 36, Olomuc, s. 81-87.

Smyczek S., 2005, Konsument indywidualny jako podmiot rynku, [w:] Smyczek S., Sowa I. (red.), Konsument na rynku: zachowania, modele, aplikacje, Difin, Warszawa, s. 15-58.

Smyczek S., 2005, Modele zachowań konsumentów na rynku, [w:] Smyczek S., Sowa I., Konsument na rynku. Zachowania, modele, aplikacje, Difin, Warszawa, s. 115-202.

Smyczek S., 2005, Zachowania konsumentów indywidualnych na rynku, [w:] Smyczek S., Sowa I., Konsument na rynku. Zachowania, modele, aplikacje, Difin, Warszawa, s. 15-57.

Smyczek S., Sowa I., 2005, Konsument na rynku. Zachowania, modele, aplikacje, Difin, Warszawa.

Sobala-Gwosdz A., Gwosdz K., 2011, Polska wschodnia w strategiach lokalizacji sieci hipermarketów, [w:] Nierówności spoteczne a wzrost gospodarczy. Uwarunkowania sprawnego działania w przedsiębiorstwie i regionie, z. 20, Uniwersytet Rzeszowski, s. 276-290.

Sobocińska M., 2011, Konkurowanie przedsiębiorstw handlowych w warunkach rozwoju nowej konsumpcji, [w:] Borusiak B. (red.), Orientacja rynkowa we wspótczesnym handlu detalicznym, „Zeszyty Naukowe", nr 177, UE, Poznań, s. 11-19.

Sojkin B., 2003, Produkt w strategii marketingowej przedsiębiorstwa, [w:] B. Sojkin (red.), Zarzqdzanie produktem, PWE, Warszawa, s. 17-53.

Sondej T., 2009, Handel we wspótczesnej gospodarce, [w:] Rosa G. (red.), Marketing w handlu, Wydawnictwo Naukowe Uniwersytetu Szczecińskiego, Szczecin, s. 13-28.

Stasik A., 2010, Czas wolny Polaków, Komunikat z badań CBOS, BS/133/2010, Warszawa.

Storey Ch., Easingwood Ch.J., 1998, The augmented service offering: a conceptualization and study of its impact on new service success, J Prod Innov Managvol. 15(1998): 335-351, http://www.iei. liu.se/program/smio/722a26/readings/1.101700/9Theaugmentedserviceoffering.pdf, (dostęp 20 lutego 2012).

Studium przypadku. Centrum Handlowo-Ustugowe Manufaktura, 2010, [w:] S. Liszewski (red.), Ruch turystyczny w Łodzi i województwie tódzkim w 2009 r., ŁTN, Łódź, s. 61-64.

Studium uwarunkowań $i$ kierunków zagospodarowania przestrzennego miasta Łodzi, 2010, Uchwała nr XCIX/1826/10, Rada Miejska w Łodzi, Łódź.Styś A. 2003, Marketing ustug, PWE, Warszawa.

Suchecki B., Lewandowska-Gwarda K., 2010, Klasyfikacja, wizualizacja i grupowanie danych przestrzennych, [w:] Suchecki B. (red.), Ekonometria przestrzenna, C.H. Beck, Warszawa, s. 37-69.

Sullivan M., Adcock D., 2003, Marketing w handlu detalicznym, Oficyna Wydawnicza, Kraków.

Szafrańska E., 2012, Przemiany struktury spotecznej, przestrzennej i funkcjonalnej wielkich osiedli mieszkaniowych na przyktadzie osiedla Widzew Wschód w Łodzi, [w:] Dzieciuchowicz J., Groeger L. (red.), Ksztattowanie przestrzeni mieszkaniowej miast, UŁ, Łódź, s. 179-196.

Szczyrba Z., 2002, Shopping gravity of large-scale stores - example of Terno Olomouc hypermarket (Contribution to the study of the problematic), "Acta Univ. Palacki, Geographica”, no 37, Olomuc, s. 91-96.

Szczyrba Z. 2005, Changes of shopping behaviour of the Czech population in the period of economic transformation, [w:] Michalski, T. (red.), Geographical aspects of transformation process in central and east-central Europe, Bernardinum, Gdynia, s. 188-196.

Szczyrba Z., 2000, Large commercial centers in the Czech Republic - new dimension of the regional structure, [w:] Ilnicki D. (red), Przeksztatcenia regionalnych struktur funkcjonalno-przestrzennych 5, Uniwersytet Wrocławski, Wrocław, s. 411-418.

Szromnik A., 2009, Makroekonomiczne przestanki lokalizacji obiektów handlowych, „Samorząd terytorialny", nr 10, Wolters Kluwer, Warszawa, s. 16-39.

Szulce H., 1998, Struktury $i$ strategie w handlu, PWE, Warszawa. 
Szumilak J., 2004, Miejsce i rola handlu detalicznego w procesie gospodarowania, [w:] Szumilak J. (red.), Handel detaliczny funkcjonowanie i kierunki rozwoju, Oficyna Ekonomiczna, Kraków, s. 11-46.

Śmigielska G., 2004, Oferta ustugowa handlu detalicznego, [w:] Szumilak J. (red.), Handel detaliczny funkcjonowanie i kierunki rozwoju, Oficyna Ekonomiczna, Kraków, s. 47-86.

Światowy G., 2006, Zachowania konsumentów. Determinanty oraz metody poznania i ksztattowania, PWE, Warszawa.

Tarondeau J., Xardel D., 1999, Dystrybucja, Assimi Polska, Kraków.

Taylor Z., 2000, Przeksztatcenia sieci handlu detalicznego i gastronomii w okresie transformacji spoteczno-gospodarczej Polski, „Prace Geograficzne”, nr 175, Continuo, Wrocław.

Teoria handlu socjalistycznego, 1966, Wakar A. (red.), PWN, Warszawa.

The Finnish Council of Shopping Centers, http://www.ncsc.se/images/finnishshoppingcenters. pdf, (dostęp 15 czerwca 2011).

Tobiasz-Lis P. 2011, Osiedla grodzone w Łodzi. Przyczyny i konsekwencje zjawiska, [w:] Dzieciuchowicz J. (red.), Wspótczesne przemiany środowiska mieszkaniowego - wybrane problemy, UŁ, Łódź, s. 99-114.

Toffler A., 1974, Szok przysztości, PIW, Warszawa.

Tul-Krzyszczuk A., 2011, Tendencje rozwojowe w handlu detalicznym w Polsce, [w:] Kosicka-Gębska M., Tul-Krzyszczuk A., Gębski J., Handel detaliczny żywnościq w Polsce, SGGW, Warszawa, s. 32-64.

Tuncer D., Alkibay S., Hoşgör S., 2008, Turkisch shopping centers and a research on the reasons for their attraction, www.escp-eap.net/conferences/.../2008.../Tuncer_Alkibay_Hosgor.pdf, (dostęp 25 czerwca 2011).

Twardzik M., 2007, Determinanty wyboru lokalizacji centrów handlowych w województwie Ślaskim, [w:] Szumilak J., Rola handlu w tworzeniu wartości dla nabywcy, Fundacja UE, Kraków, s. 191-201.

Ustawa o ochronie zabytków i opiece nad zabytkami z 23 lipca 2003 roku, Dz.U., Nr 162, poz. 1568 , ze zm.

Ustawa o planowaniu i zagospodarowaniu przestrzennym z 27 marca 2003 roku, Dz.U., Nr 80, poz. 717 , ze. zm.

Ustawa o tworzeniu i działaniu wielkopowierzchniowych obiektów handlowych z 11 maja 2007 roku, Dz.U., Nr 127, poz. 880.

Ustawa o zmianie ustawy o zagospodarowaniu przestrzennym z dnia 13 lipca 2000 roku, Dz.U., $\mathrm{Nr} 14$, poz. 124, ze zm.

Ustawa z dnia 23 kwietnia 1964 roku Kodeks cywilny, Dz.U., Nr 16 poz. 93 ze zm. tekst jednolity. Walmsley D.J., Lewis G.J., 1997, Geografia cztowieka. Podejście behawioralne, PWN, Warszawa.

Werwicki A., 2000, Handel targowiskowy w aglomeracji tódzkiej na tle jego znaczenia ogólnopolskiego w latach 1994-1997, „Szlakami Nauki” nr 31, ŁTN, Łódź.

Werwicki A., 2001, Targowiska, [w:] Liszewski S. (red.), Funkcja regionalna Łodzi i jej rola w kształtowaniu województwa. Zarys monografi województwa tódzkiego, ŁTN, Łódź, s. 360-368.

Więcław J., 2000, Nowe centra handlowe w strukturze przestrzenno-funkcjonalnej Krakowa, [w:] Jażdżewska I. (red.), Miasto postsocjalistyczne. Organizacja przestrzeni miejskiej i jej przemiany, XIII Konserwatorium Wiedzy o Mieście, Katedra Geografii Miast i Turyzmu, Łódź, s. 175-177.

Więcław J., 2003, Hipermarkety, jako nowy element w strukturze przestrzennej miast Polski na przykładzie Krakowa, [w:] Górka Z., Więcław J. (red.), Badania i podróże naukowe krakowskich geografów, PTG Oddział w Krakowie, Kraków, s. 137-146.

Więcław-Michniewska J., 2006, Nowe przestrzenie handlowe w aspekcie realizacji zadań samorzqdu terytorialnego, [w:] Jażdżewska I. (red.), Nowe przestrzenie w miastach. Ich organizacja i funkcje, XIX Konwersatorium Wiedzy o Mieście, Wyd. Uniwersytet Łódzki, s. 277-286. 
Wilk W., 2003, Między zakupami a rozrywka - nowe znaczenie centrum handlowego, „Prace i Studia Geograficzne", t. 32, s. 205-224.

Wilk W., 2004, Zachodnioeuropejskie sieci handlowe w Czechach, w Polsce i na Stowacji: podobieństwa i różnice, [w:] Przeksztatcania regionalnych struktur funkcjonalno-przestrzennych. Regionalny wymiar integracji europejskiej, t. VIII/2, Zakład Geografii Społecznej i Ekonomicznej, Zakład Zagospodarowania Przestrzennego, IGiRR Uniwersytet Wrocławski, s. 231-240.

Wilk W., 2005, Miejsce miast w sieciach handlowych - przyktad Polski, [w:] Lisowski A. (red.), Zmiany przestrzenne i funkcjonalne obszarów miejskich, „Prace i Studia Geograficzne”, t. 35, Warszawa, s. 129-153.

Winiarczyk-Raźniak A., 2007, Kompleksowe zaopatrzenie w ustugi w regionie miejskim Krakowa (na przyktadzie wybranych centrów handlowych), [w:] Przeksztatcenia regionalnych struktur funkcjonalno-przestrzennych. Od lokalnego do globalnego wymiaru gospodarowania przestrzeniq - nowe jakości przestrzeni spoteczno-ekonomicznej, Brezdeń P., Grykień S. (red.), Wydawnictwo Uniwersytetu Wrocławskiego, Wrocław, s. 351-357.

Włodarczyk B., 2009, Przestrzeń turystyczna. Istota, koncepcje, determinanty rozwoju, UŁ, Łódź.

Wnuk-Lipiński E., 1981, Budżet czasu, struktura spoteczna, polityka spoteczna, PAN, Zakład Narodowy im. Ossolińskich, Wrocław.

Wojnowski W., 2012, Plaza Centers: otwarcie Łódź Plaza nastąpi w 2014 roku, http://www.retailnet.pl/Wspolna/Wiadomosci/2012/Maj/22/Plaza-Centers--otwarcie--odz-Plaza-nastapi-w-2014-.aspx, (dostęp 24 sierpnia 2012).

Wolaniuk A., 1994, Przemieszczanie centrum wielkiego miasta - przykład Łodzi, [w:] Region miejski. Centrum a peryferia w okresie transformacji politycznej, gospodarczej i spotecznej, VII Konwersatorium Wiedzy o Mieście, Katedra GMiT UŁ, Komisja Geografii Osadnictwa i Ludności PTG, s.69-76.

Wójcik M., 2009, Centrum handlowo-rozrywkowe jako „miejsce” w przestrzeni spotecznej Łodzi. Przyktad „Manufaktury”, [w:] Klima E. (red.), Czynniki spoteczne w gospodarce przestrzennej i planowaniu przestrzennym, „Space-Society-Economy”, nr 9, s. 133-142.

Wrzesińska J., 2008, Rozwój wielkopowierzchniowych obiektów handlowych w Polsce, [w:] Kiryjow J. (red.), Ekonomika i organizacja gospodarki żywnościowej, „Zeszyty Naukowe SGGW”, nr 72, SGGW, Warszawa, s. 161-170.

www.stat.gov.pl.

Wyrok Trybunału Konstytucyjnego z 8 lipca 2008 roku, Dz.U., Nr 123, poz.803, sygn. Akt K 46/07.

Yrigoyen C.C., Otero J.V., 1997, Spatial interaction models applied to the design of retail trade areas, http://www.uam.es/personal_pdi/economicas/coro/investigacion/viena98.PDF, (dostęp 12 marca 2012).

Zabrocki R., 2008, Dostosowanie portfela produktów gastronomii polskiej do potrzeb i oczekiwań konsumentów, [w:] Kall J., Sojkin B. (red.), Zarzqdzanie produktem - teoria, praktyka, perspektywy, AE, Poznań, s. 289-295.

Zagraniczne inwestycje w handlu na rynkach lokalnych, 2007, Kłosiewicz-Górecka U. (red.), PWE Warszawa.

Zatwarnicka-Madura B., 2011, Preferencje nabywców (w szczególności kobiet) wobec instrumentów marketingowego oddziatywania w miejscu sprzedaży, [w:] Borusiak B. (red.), Orientacja rynkowa we wspótczesnym handlu detalicznym, „Zeszyty Naukowe”, nr 177, AE, Poznań, s. 96-105.

Zipser W., 2006, Ustugi wielkopowierzchniowe a zachowania przestrzenne mieszkańców duzych miast (na podstawie wroctawskich obserwacji), [w:] Słodczyk J., Klimek R. (red.), Przemiany przestrzeni miast i stref podmiejskich, Uniwersytet Opolski, Opole, s. 63-79. 


\title{
ALFABETYCZNY SPIS RYSUNKÓW
}

\author{
C
}

Charakterystyka klientów centrów handlowych według ich typów (rys. 111), 232

Czas poświęcony na dojazd do centrów handlowych według ich typów ofertowych (rys. 144), 271

Czas poświęcony na dojazd do centrów handlowych według ich typów lokalizacyjnych (rys. 145), 272

Czas poświęcony na dojazd do wybranego centrum handlowego (rys. 143), 271

Częstotliwość wizyt w centrach handlowych w zależności od kategorii wiekowej (rys. 94), 213

Czym jest dla klientów pobyt w centrum handlowym (według typów centrów handlowych) (rys. 119), 240

Czym jest pobyt w centrum handlowym (rys. 93), 211

Czynniki lokalizacji ogólnej i szczegółowej placówek handlowych (rys. 5), 41

$\mathbf{D}$

Długość pobytu w centrach handlowych według ich typów (rys. 113), 234

Droga do łódzkich centrów handlowych (rys. 126), 254

$\mathbf{E}$

Etapy badań ankietowych dotyczące łódzkiego handlu (rys. 80), 196

$\mathbf{G}$

Gęstość zaludnienia w strefach wokół centrów handlowych w 2009 roku (rys. 68), 172

Główne determinanty atrakcyjności centrum handlowego (rys. 12), 62

Główne ograniczenia eliminujące centra handlowe jako przestrzeń publiczną (rys. 2), 22

Główni uczestnicy „gry o przestrzeń” przy lokalizacji obiektów handlowych (rys. 4), 37

Godziny korzystania z oferty od poniedziałku do czwartku w centrach handlowych według ich typów (rys. 115), 237

Godziny korzystania $\mathrm{z}$ oferty w niedzielę w centrach handlowych według ich typów (rys. 118), 239 
Godziny korzystania $\mathrm{z}$ oferty w piątek w centrach handlowych według ich typów (rys. 116), 238

Godziny korzystania $\mathrm{z}$ oferty w sobotę w centrach handlowych według ich typów (rys. 117), 238

Godziny pobytów w centrach handlowych według dni tygodnia (rys. 96), 215

\section{$\mathbf{J}$}

Jednokilometrowe strefy badań wokół łódzkich centrów handlowych (rys. 40), 147

$\mathbf{K}$

Korzystanie $\mathrm{z}$ oferty w poszczególnych dniach tygodnia według typów centrów handlowych (rys. 114), 235

\section{$\mathbf{L}$}

Liczba dzieci w gospodarstwie domowym (rys. 84), 201

Liczba i odsetek respondentów według miejsca zamieszkania w jednostkach osiedlowych Łodzi (rys. 125), 253

Liczba ludności i gęstość zaludnienia w strefach piętnastominutowej dostępności pieszej (rys. 32), 116

Liczba ludności według płci w strefach wokół centrów handlowych w 2009 roku (rys. 67), 172

Liczba osób w gospodarstwie domowym (rys. 83), 201

Liczba placówek handlowych zlokalizowanych w bezpośrednim sąsiedztwie centrów handlowych (rys. 73), 178

Liczba placówek usługowych zlokalizowanych w bezpośrednim sąsiedztwie centrów handlowych (rys. 72), 178

Liczba respondentów wedługg łódzkich centrów handlowych (rys. 81), 199

Liniowy pięcioetapowy model turystycznych podróży według. A. Mathieson, G. Wall (1982) (rys. 20), 83

Lokalizacja centrów handlowych w Łodzi w 2012 roku na tle sieci drogowej (rys. 28), 108

Lokalizacja łódzkich centrów handlowych na tle jednostek osiedlowych (rys. 29), 109

Lokalizacja placówek gastronomicznych w centrum handlowym (rys. 39), 138

\section{$\mathbf{M}$}

Miejsca lokalizacji dużego obiektu handlowego w stosunku do miejsca zamieszkania według opinii respondentów (rys. 103), 222

Miejsca zakupu w centrach handlowych ze względu na rodzaj asortymentu (rys. 101), 220

Miejsca zamieszkania respondentów w Łodzi według jednostek osiedlowych (rys. 124), 252

Miejsca zamieszkania w Łodzi klientów centrów handlowych II typu (rys. 128), 256

Miejsca zamieszkania w Łodzi klientów centrów handlowych III typu (rys. 129), 257

Miejsca zamieszkania w Łodzi klientów centrów handlowych IV typu (rys. 130), 258

Miejsca zamieszkania w Łodzi klientów centrum handlowego I typu (rys. 127), 255

Miejsce, z którego respondenci najczęściej rozpoczynają swoją podróż do centrum handlowego (rys. 134), 264

Miejsce, z którego respondenci najczęściej rozpoczynają swoją podróż do danego ofertowego typu centrum handlowego (rys. 135), 265 
Miejsce, z którego respondenci najczęściej rozpoczynają swoją podróż do danego lokalizacyjnego typu centrum handlowego (rys. 136), 266

Model oddziaływania hipermarketu na sklepy zlokalizowane w jego sąsiedztwie (rys. 71), 176

Model systemów atrakcyjności turystycznej [G. Richards 2002] (rys. 24), 88

Model wyboru miejsc docelowych w turystyce [P.K. Ankomah i inni, 1996] (rys. 23), 88

Model zachowań konsumenckich D.L. Loudon, A.J. Della Bitta (1993) (rys. 18), 76

Model zachowań konsumenckich Engel-Blackwell-Miniard (1995) (rys. 17), 74

Model zachowań przestrzennych klientów centrów handlowych (rys. 25), 90

\section{$\mathbf{N}$}

Najczęściej odwiedzane łódzkie centra handlowe (rys. 102), 221

$\mathbf{0}$

Ocena statusu materialnego ze względu na miejsce zamieszkania (rys. 86), 203

Ocena statusu materialnego ze względu na źródło dochodów (rys. 85), 202

Ocena własnego statusu materialnego przez klientów według typów centrów handlowych (rys. 110), 231

Odsetek respondentów korzystających z oferty wskazanego centrum handlowego i mieszkających w jego strefie 15-minutowej dostępności samochodem (rys. 133), 262

Oferta nowoczesnych pulsujących miejskich biegunów handlowo-usługowych (rys. 14), 66

Oferta rdzenia centrum handlowego (rys. 13), 62

Oferta, jakiej klienci nie nabywają w poszczególnych typach centrów handlowych (rys. 122), 244

Oferta, z jakiej korzystają klienci poszczególnych typów centrów handlowych (rys. 121), 243

Oferta, $\mathrm{z}$ jakiej respondenci korzystają $\mathrm{w}$ wybranych przez nich centrach handlowych (rys. 100), 218

Ogólny schemat dobowego cyklu życia centrum handlowego (rys. 97), 215

Opinie o lokalizacji centrum handlowego w stosunku do miejsca zamieszkania w zależności od dysponowania samochodem (rys. 104), 223

$\mathbf{P}$

Piętnastominutowe strefy dostępności komunikacyjnej do łódzkich centrów handlowych (obraz szczegółowy) (rys. 34), 118

Piętnastominutowe strefy dostępności pieszej do łódzkich centrów handlowych (rys. 31), 115

Pobyty respondentów w centrach handlowych w zależności od dnia tygodnia (rys. 95), 213

Podstawowy podział nabywców indywidualnych (rys. 16), 71

Podział konsumentów na grupy (rys. 15), 70

Pola działań przestrzennych (rys. 22), 86

Postrzeganie czynności zakupu jako przyjemności lub sposobu spędzania czasu wolnego ze względu na miejsce ich realizacji (rys. 89), 207

Postrzeganie czynności zakupu w centrach handlowych (rys. 90), 209

Postrzeganie czynności zakupu w centrach handlowych według deklarowanego statusu materialnego (rys. 92), 210

Postrzeganie czynności zakupu w centrach handlowych według wieku (rys. 91), 209

Postrzeganie czynności zakupu ze względu na miejsce ich realizacji (rys. 88), 206

Powierzchnia terenów zajętych pod zabudowę mieszkaniową w strefach wokół łódzkich centrów handlowych (rys. 54), 161 
Powody wizyt w centrach handlowych (rys. 98), 217

Powody wizyt w centrach handlowych według wieku (rys. 99), 218

Poziomy (wymiary) produktu na przykładzie centrum handlowego (rys. 11), 58

Poziomy produktu (oferty) (rys. 10), 58

Poziomy produktu według T. Levitta (1980) i P. Kotlera (1994) (rys. 9), 56

Proces wyboru centrum handlowego (rys. 19), 78

Przebieg linii bezpłatnych autobusów według typów ofertowych centrów handlowych (rys. 140), 269

Przebieg linii bezpłatnych autobusów z poszczególnych centrów handlowych na terenie Łodzi (stan na maj 2011 roku) (rys. 30), 114

$\mathbf{R}$

Relacje między wypoczynkiem i zakupami a wielkością obiektów handlowych (rys. 87), 206

Rodzaje lokalizacji (rys. 6), 46

Rodzaje oferty rynkowej ze względu na jej strukturę (rys. 8), 55

Rodzaje środków komunikacji wykorzystywane przez respondentów według typów ofertowych centrów handlowych (rys. 139), 268

Rodzaje środków komunikacji wykorzystywanych przez respondentów według typów lokalizacyjnych centrów handlowych (rys. 141), 270

Rozmieszczenie punktów usługowych w pobliżu C.H. Guliwer (rys. 76), 183

Rozmieszczenie punktów usługowych w pobliżu C.H. Pasażu Łódzkiego (rys. 78), 186

Rozmieszczenie punktów usługowych w pobliżu C.H. Tulipan (rys. 77), 186

Rozmieszczenie punktów usługowych w pobliżu Portu Łódź (rys. 75), 183

Rozmieszczenie punktów usługowych w pobliżu Tesco Pojezierska (rys. 79), 187

\section{S}

Schemat badań (rys. 1), 9

Schemat kompleksowych badań nad centrami handlowymi (rys. 149), 284

Stopień zmotoryzowania klientów według centrów handlowych (rys. 142), 270

Strefy dostępności komunikacyjnej w promieniu 15 minut - generalizacja (rys. 36), 119

Strefy dostępności komunikacyinej w promieniu 15 minut (rys. 35), 119

Strefy dostępności komunikacyjnej w promieniu 30 minut - obraz szczegółowy (rys. 37), 120

Strefy dostępności pieszej do łódzkich centrów handlowych (do 60 minut) (rys. 33), 118

Struktura klientów według liczby posiadanych dzieci i typów centrów handlowych (rys. 108), 230

Struktura klientów według miejsca zamieszkania - typu zabudowy (rys. 137), 267

Struktura klientów według miejsca zamieszkania (rys. 123), 251

Struktura klientów według stanu cywilnego i typów centrów handlowych (rys. 107), 229

Struktura klientów według wieku i typów centrów handlowych (rys. 105), 228

Struktura klientów według wykształcenia i typów centrów handlowych (rys. 106), 228

Struktura klientów według źródła utrzymania i typów centrów handlowych (rys. 109), 230

Struktura ludności według wieku w strefach wokół centrów handlowych w 2009 roku (rys. 69), 173

Struktura respondentów według płci i wykształcenia (rys. 82), 200

Struktura sklepów wg grup PKD w łódzkich centrach handlowych w 2011 roku (rys. 38), 128

Struktura użytkowania terenu w strefie wokół C.H. Guliwer (rys. 42), 155

Struktura użytkowania terenu w strefie wokół C.H. M1 (rys. 43), 155 
Struktura użytkowania terenu w strefie wokół C.H. Tulipan (rys. 52), 160

Struktura użytkowania terenu w strefie wokół Carrefour Przybyszewskiego (rys. 53), 160

Struktura użytkowania terenu w strefie wokół Carrefour Szparagowa (rys. 45), 156

Struktura użytkowania terenu w strefie wokół E. Leclerc (rys. 49), 158

Struktura użytkowania terenu w strefie wokół Galerii Łódzkiej (rys. 47), 157

Struktura użytkowania terenu w strefie wokół Manufaktury (rys. 48), 158

Struktura użytkowania terenu w strefie wokół Pasażu Łódzkiego (rys. 51), 159

Struktura użytkowania terenu w strefie wokół Portu Łódź (rys. 44), 156

Struktura użytkowania terenu w strefie wokół Tesco Pojezierska (rys. 46), 157

Struktura użytkowania terenu w strefie wokół Tesco Widzewska (rys. 50), 159

Struktura zabudowy w strefie wokół C.H. Guliwer (rys. 66), 170

Struktura zabudowy w strefie wokół C.H. M1 (rys. 62), 168

Struktura zabudowy w strefie wokół C.H. Tulipan (rys. 58), 166

Struktura zabudowy w strefie wokół Carrefour Przybyszewskiego (rys. 59), 167

Struktura zabudowy w strefie wokół Carrefour Szparagowa (rys. 57), 166

Struktura zabudowy w strefie wokół E. Leclerc (rys. 61), 168

Struktura zabudowy w strefie wokół Galerii Łódzkiej (rys. 56), 165

Struktura zabudowy w strefie wokół Manufaktury (rys. 55), 165

Struktura zabudowy w strefie wokół Pasażu Łódzkiego (rys. 65), 170

Struktura zabudowy w strefie wokół Portu Łódź (rys. 64), 169

Struktura zabudowy w strefie wokół Tesco Pojezierska (rys. 63), 169

Struktura zabudowy w strefie wokół Tesco Widzewska (rys. 60), 167

Ś

Średnia ocena kategorii związanych z dostępnością w wyborze centrów handlowych danego typu lokalizacyjnego (rys. 148), 276

Średnia ocena znaczenia motywów w wyborze centrum handlowego danego typu (rys. 120), 241

Środki transportu, z których korzystają klienci centrów handlowych w celu dotarcia do nich

(rys. 138), 267

\section{$\mathbf{T}$}

Teoretyczny model zachowań przestrzennych klientów centrów handlowych (rys. 26), 91

Typy centrów handlowych ze względu na ich formę koncentracji i rozmieszczenie (rys. 3), 30

Typy zależności lokalizacyjnych między centrum handlowym a pobliskimi punktami usługowymi (rys. 74), 180-181

\section{$\mathbf{U}$}

Udział elementów materialnych i niematerialnych w ofercie rynkowej (rys. 7), 54

Uproszczony model zachowań przestrzennych klientów centrów handlowych (rys. 21), 85

W

Wartość współczynnika starości w strefach wokół centrów handlowych w 2009 roku (rys. 70), 174

Wybrane cechy zachowań przestrzennych klientów centrów handlowych według ich typów ofertowych (rys. 146), 273 
Wybrane cechy zachowań przestrzennych klientów centrów handlowych według ich typów lokalizacyjnych (rys. 147), 273

Wymiary „bliskości sieci wobec klienta” (rys. 27), 92

\section{$\mathbf{Z}$}

Z kim klienci odwiedzają poszczególne typy centrów handlowych (rys. 112), 233

Zasięg i powierzchnia jednokilometrowych stref handlowych wyznaczonych wokół poszczególnych łódzkich centrów handlowych (rys. 41), 148-149

Zasięg oddziaływania centrów handlowych według typów (rys. 131), 261

Zgeneralizowane strefy dostępności 15 minut samochodem z liczbą respondentów z danej strefy (rys. 132), 261 


\section{ALFABETYCZNY SPIS TABEL}

\section{A}

Argumenty przeciwko budowie centrum handlowego w bezpośrednim sąsiedztwie miejsca zamieszkania („pod oknami”) (tab. 34), 225

Argumenty za budową centrum handlowego w bezpośrednim sąsiedztwie miejsca zamieszkania („pod oknami”) (tab. 35), 226

Atrakcyjność łódzkich centrów handlowych w oczach klientów (tab. 41), 248

Atrakcyjność ofertowa łódzkich centrów handlowych (tab. 30), 191-192

B

Badania geograficzne centrów handlowych według ośrodków i zagadnień badawczych (tab. 1), 15-16

C

Cechy zachowań nabywczych klientów według typów centrów handlowych (tab. 42 ), 249

Czynniki i bariery rozwoju centrów handlowych w Polsce (tab. 13), 99

Czynniki lokalizacji dużych przedsiębiorstw (sieci handlowych) w zależności od skali przestrzennej (tab. 8), 43-44

D

Determinanty lokalizacji placówek handlowych (tab. 6), 39-40

Dostępność komunikacyjna łódzkich centrów handlowych (tab. 14), 112

$\mathbf{E}$

Elementy wzięte pod uwagę przy ocenie atrakcyjności łódzkich centrów handlowych (tab. 40), 247 


\section{$\mathbf{K}$}

Korzyści i zagrożenia wynikające z lokalizacji wielkopowierzchniowych obiektów handlowych (WOH) (tab. 9), 50

\section{$\mathbf{L}$}

Liczba placówek gastronomicznych w łódzkich centrach handlowych w 2011 roku (tab. 22), 140

Liczba placówek handlowych, w tym sklepów „kotwic”, w łódzkich centrach handlowych w 2011 roku (tab. 18), 130-131

Liczba placówek handlu detalicznego wg grup PKD w łódzkich centrach handlowych w 2011 roku (tab. 16), 126-127

Liczba wyspecjalizowanych sieciowych placówek handlu detalicznego w łódzkich centrach handlowych według grup PKD w 2011 roku (tab. 19), 132

\section{$\mathbf{N}$}

Niekorzystny i korzystny wpływ zagranicznych sieci handlowych na handel i lokalne rynki (tab. 10), 51

\section{$\mathbf{O}$}

Ocena znaczenia motywów w wyborze centrów handlowych danego typu (tab. 38), 242

Odsetek osób, dla których w wyborze centrum handlowego poszczególne kategorie związane $\mathrm{z}$ dostępnością posiadają znaczenie (tab. 45), 274

Ostateczne grupy biegunów nowoczesnej przestrzeni handlowo-usługowej (tab. 32), 193

Ostateczne grupy centrów handlowych (tab. 29), 190

\section{$\mathbf{P}$}

Pobyty w centrach handlowych według dni tygodnia i wieku respondentów (tab. 33), 214

Podstawowe rodzaje/formaty handlu detalicznego i ich lokalizacje (tab. 7), 42-43

Poziomy (wymiary) produktu na przykładzie centrum handlowego (tab. 11), 60-61

Profile klientów według typów centrów handlowych (różnice i podobieństwa) (tab. 37), 232

Przykłady możliwych zależności między uczestnikami procesu kupowania (tab. 12), 70-71

Przynależność do skupień łódzkich biegunów nowoczesnej przestrzeni usługowej (tab. 31), 193

Przynależność do skupień łódzkich centrów handlowych (tab. 28), 190

\section{$\mathbf{R}$}

Rodzaje (generacje) centrów handlowych ze względu na ich powierzchnię i funkcje (tab. 4), 32-33

Rodzaje artykułów nabywane w różnych placówkach zlokalizowanych na terenie poszczególnych typów centrów handlowych (tab. 39), 245

Rodzaje lokalizacji hipermarketów i centrów handlowych (tab. 5), 35 
Sieci placówek gastronomicznych w łódzkich centrach handlowych w 2011 roku (tab. 23), 141

Struktura klientów według płci i typów centrów handlowych (tab. 36), 227

Struktura placówek usługowych zlokalizowanych w bezpośrednim sąsiedztwie centrów handlowych według sekcji PKD (tab. 27), 177

Struktura placówek w łódzkich centrach handlowych w 2011 roku (tab. 15), 125

Struktura użytkowania terenu wokół łódzkich centrów handlowych (tab. 25), 152-153

Struktura wyspecjalizowanych placówek handlu detalicznego w łódzkich centrach handlowych w 2011 roku (tab. 17), 128-129

Struktura zabudowy w strefach wokół łódzkich centrów handlowych (tab. 26), 164

Ś

Średnia ocena kategorii związanych z dostępnością w wyborze centrów handlowych (w skali 1-5) (tab. 46), 275

\section{W}

Wybrane definicje centrum/ośrodka handlowego w literaturze naukowej (tab. 3), 28-29

Wybrane oficjalne krajowe definicje centrum handlowego (tab. 2), 27

\section{$\mathbf{Z}$}

Zamieszkanie w wybranej strefie dostępności 15 minut samochodem a wskazanie konkretnego centrum handlowego jako najczęściej odwiedzanego (tab. 44), 263

Zasięg komunikacyjny obszarów handlowych zależny od rodzaju centrum handlowego (tab. 24), 146

Zasięg stref odległościowych wokół łódzkich centrów handlowych w zależności od odsetka klientów (tab. 43), 260

Znane sieci handlowe posiadające swoje placówki w przynajmniej czterech centrach handlowych w 2011 roku (tab. 21), 134-135

Znane sieci handlowe $z$ odzieżą oraz sportowe posiadające swoje placówki w przynajmniej czterech centrach handlowych (tab. 20), 133 